UNIVERSIDADE DE SÃO PAULO

FFCLRP - DEPARTAMENTO DE PSICOLOGIA E EDUCAÇÃO

PROGRAMA EM PÓS-GRADUAÇÃO EM PSICOLOGIA

\title{
O BEM-ESTAR SUBJETIVO DE COMERCIANTES E COMERCIÁRIOS DE RIBEIRÃO PRETO E REGIÃO.
}

\author{
Airton Rodrigues \\ Orientador: Prof. Dr. José Aparecido da Silva \\ Dissertação apresentada à Faculdade de \\ Filosofia, Ciências e Letras de Ribeirão \\ Preto da USP, como parte das \\ exigências para a obtenção do título de \\ Mestre em Ciências, Área: Psicologia.
}


Rodrigues, Airton

Bem-estar subjetivo de comerciantes e comerciários de Ribeirão Preto e região, 2007.

283 pgs.

Dissertação, apresentada à Faculdade de Filosofia, Ciências e Letras de Ribeirão Preto / USP - Dep. de Psicologia e Educação.

Orientador: Da Silva, José Aparecido

1. Bem-estar subjetivo. 2. Felicidade. 3. Qualidade de vida 


\section{FOLHA DE APROVAÇÃO}

\section{Airton Rodrigues}

Dissertação apresentada à Faculdade de Psicologia da Universidade de São Paulo para obtenção do título de mestre em Psicologia.

Área de Concentração: Psicologia Orientador: Prof. Dr. José Aparecido da Silva

Aprovado em:

Banca Examinadora

Prof. Dr.

Instituição Assinatura:

Prof. Dr.

Instituição Assinatura:

Prof. Dr.

Instituição Assinatura:

Prof. Dr.

Instituição Assinatura:

Prof. Dr.

Instituição Assinatura: 
A quem tudo devo:

Pais (Airton e Rosmari)... Que semearam e hoje colho; Filhos (Tarso e Bernardo)... A minha vida, motivação e razão de meu esforço; Espírito (Rachel)... Esposa valorosa e alma gêmea. 


\section{AGRADECIMENTOS}

Ao Prof. Dr. José Aparecido da Silva, que me acolheu nesta empreitada, a gratidão ao meu mentor acadêmico.

À Profa. Dra. Adriana Backx Noronha Viana, pela grande didática, que me despertou o gosto pela estatística. .

Ao Prof. Dr. Elton H. Matsushima, pelas orientações preciosas 


\section{RESUMO}

O bem-estar subjetivo, ou felicidade, consiste na maneira como as pessoas avaliam suas próprias vidas, tanto de forma afetiva como cognitiva. Este juízo terá grande importância nas diversas esferas da vida, influenciando o desempenho social e profissional da pessoa. De forma agregada, níveis maiores, ou menores, de bem-estar subjetivo possuem impactos tanto no sistema político quanto na economia. Este estudo aplicou três diferentes questionários de mensuração de bem-estar subjetivo: o Oxford Happiness Questionnaire, com 29 itens; a Escala Geral de Felicidade, com 4 itens e uma escala única em uma amostra de 498 pessoas que trabalham no comércio de Ribeirão Preto e duas cidades vizinhas, e conduziu análises destes instrumentos. Além destas análises, foram estudadas as diferenças entre os diversos indivíduos que compõem a amostra, no intuito de investigar se idade, sexo, etnia, estado civil, escolaridade, número de filhos, atividade profissional (comerciantes / comerciários), emprego efetivo / temporário, renda, religião, atividade sócio política e saúde poderiam influenciar o nível de bem-estar subjetivo. Algumas destas características mostraram-se significativas. 


\begin{abstract}
The subjective well-being, or happiness, consists on the way people see their own lives, in affective or cognitive way. This judgment is very important in the different ambits of life, influencing the social and professional aspects of people. In different levels, the subjective well-being has impact on political and economical systems. This study used three different questionaries to measure the subjective well-being: Oxford Happiness Questionnaire with 29 items; Subjective Happiness Scale, with 4 items, and a single scale with 498 subjects who work in Ribeirão Preto commerce including two other cities. Structural analyses of Oxford Happiness Questionnaire and Subjective Happiness Scale were done. Besides these analyses, we assessed the difference among several subjects from the study group, aiming to investigate if age, gender, ethics, civil status, educational level, number of children, professional activity (salespeople), temporary job or regular job, income, religion, political participation, and health, could influence their level of subjective well-being. Some of these characteristics are significant.
\end{abstract}




\section{LISTA DE ILUSTRAÇÕES}

Figura 1- Renda e Felicidade nos Estados Unidos.......................................................19

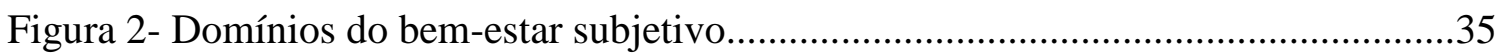

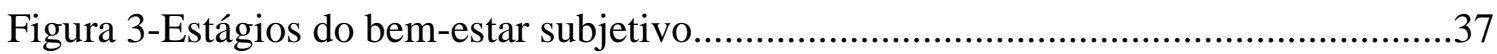

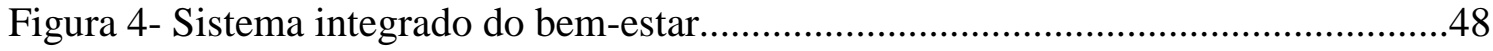

Figura 4- Satisfação com a vida e indicadores sociais de alguns países........................ 58

Figura 5- Felicidade e renda entre países................................................................6

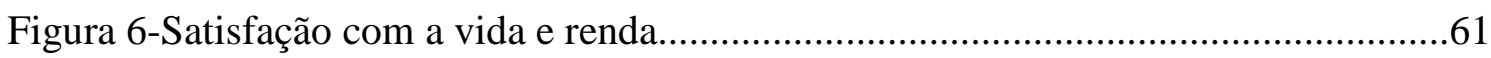

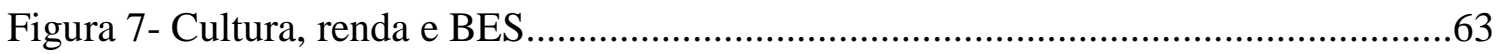

Figura 8- BES e liderança nas organizações................................................................75

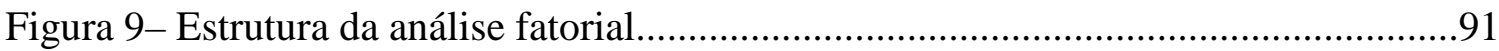

Figura 10- Distribuição da variância dos componentes..................................................92 


\section{LISTA DE TABELAS}

Tabela 1-Satisfação com a vida em vários grupos.......................................................22

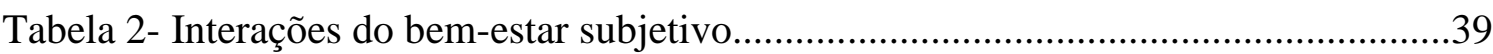

Tabela 3- Sub- significados dentro dos quadrantes de qualidade de vida........................41

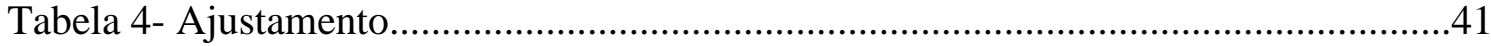

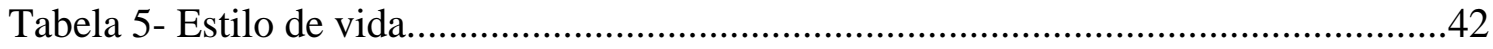

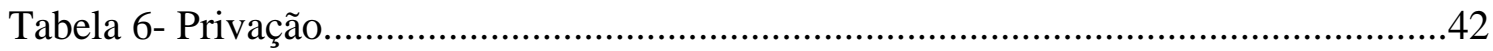

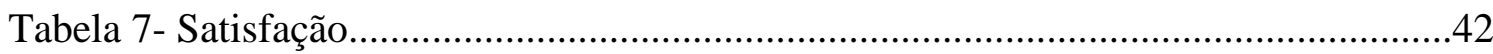

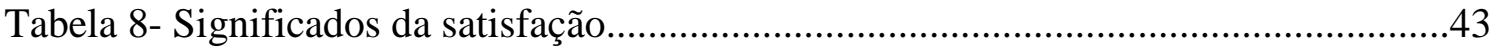

Tabela 9-Cidades fora de Ribeirão Preto onde foram coletados dados............................86

Tabela 10-Bairros de Ribeirão Preto onde foram coletados dados..................................87

Tabela 11-Exemplo da estrutura de variáveis dummy.................................................97

Tabela 12-Correlação entre os escores equiparados das escalas..................................108

Tabela 13-Alfa de Cronbach dos fatores do OHQ - Rotação ortogonal.........................111

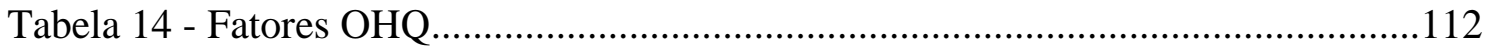

Tabela 15- Alfa de Cronbach dos fatores do OHQ - Rotação oblíqua............................113

Tabela 16-Análise discriminante stepwise realizada por Argyle \& Hills.......................118

Tabela 17- Função discriminante stepwise...........................................................119

Tabela 18- Carga fatorial análise 1 fator OHQ....................................................... 121

Tabela 19- Carga fatorial análise 2 fatores OHQ.....................................................122

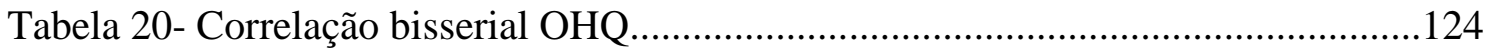

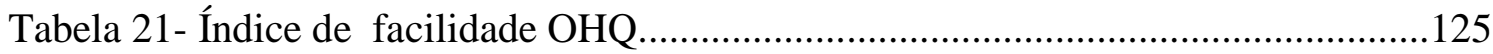

Tabela 22- Índices de fidedignidade e médias para a EGF.......................................128

Tabela 23- Valor de alfa caso item for deletado.....................................................129 
Tabela 24- Cargas fatoriais e percentual covariância - EGF.

Tabela 25- Análise fatorial grupo 1 - Idade de até 24 anos..........................................130

Tabela 26-Análise fatorial grupo 2 - Idade de 25 a 32 anos.......................................131

Tabela 27- Análise fatorial grupo 3- Idade de 33 a 66 anos.........................................132

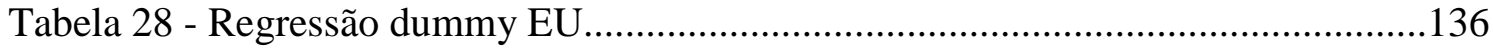

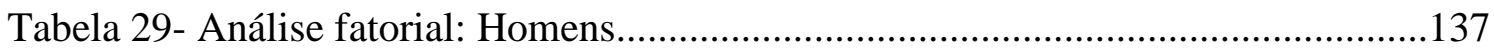

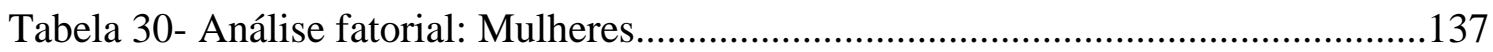

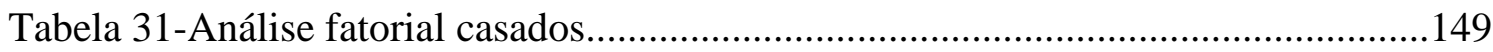

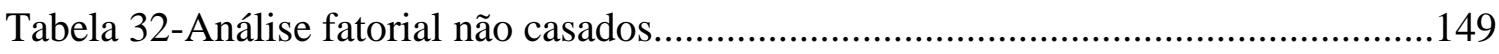

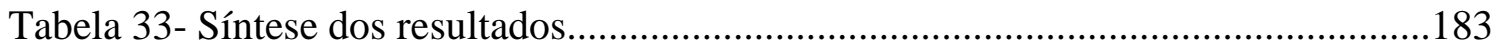




\section{LISTA DE GRÁFICOS}

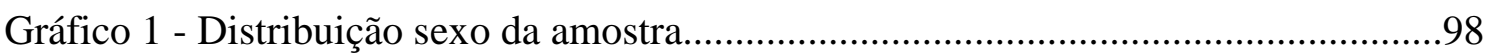

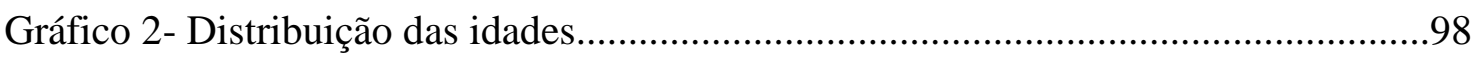

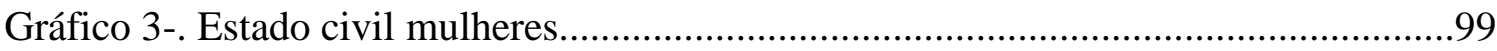

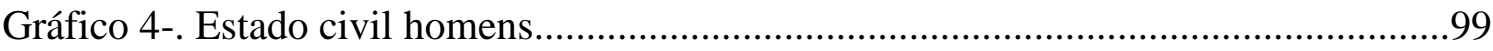

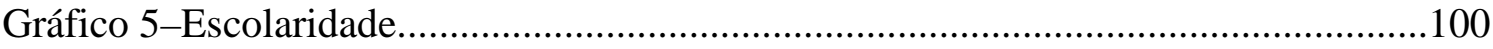

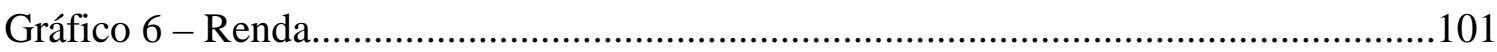

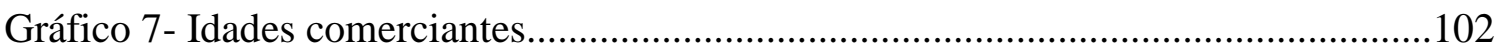

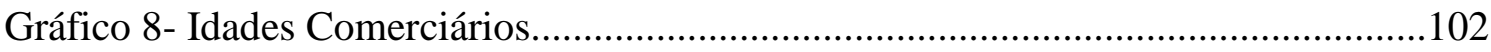

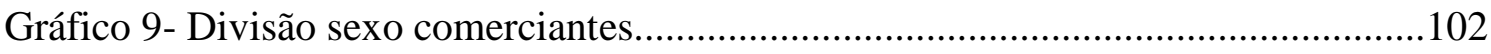

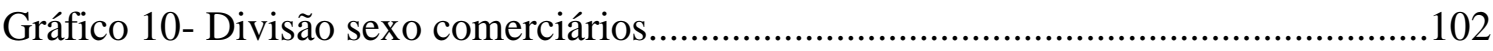

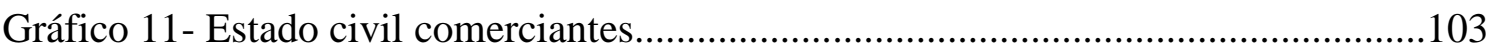

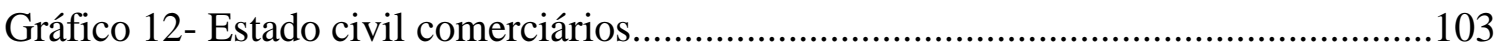

Gráfico 13- Tempo de comércio - comerciante.......................................................... 103

Gráfico 14- Tempo de comércio - comerciário...............................................................103

Gráfico 15- Distribuição renda comerciante................................................................103

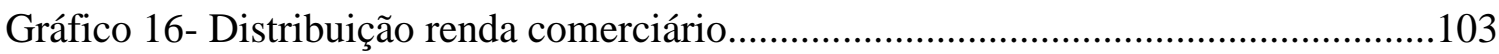

Gráfico 17- Escores equiparados das escalas nas categorias etárias.............................133

Gráfico 18- Escores médios equiparados - sexo.......................................................139

Gráfico 19- Escores médios equiparados - homens x idades........................................140

Gráfico 20- Escores médios equiparados - mulheres x idades.....................................141

Gráfico 21- Escores médios equiparados das escalas - etnia........................................144

Gráfico 22- Escores médios equiparados negros x sexo...........................................145

Gráfico 23 - Escores médios equiparados pardos x sexo..........................................145

Gráfico 24- Escores médios equiparados brancos x sexo.............................................146 
Gráfico 25- Escores médios equiparados índios x sexo

Gráfico 26- Escores médios equiparados para estado- civil 150

Gráfico 27- Escores médios equiparados para estado civil - homens.

Gráfico 28- Escores médios equiparados para estado civil - mulheres.

Gráfico 29- Escores médios equiparados por nível educacional. 156

Gráfico 30- - Escores médios equiparados por quantidade de filhos.

Gráfico 31- Escores médios equiparados nas escalas comerciantes e comerciários 161

Gráfico 32- Escores médios equiparados nas escalas entre comerciantes e comerciários homens.

Gráfico 33- Escores médios equiparados nas escalas entre comerciantes e comerciáriosmulheres. 162

Gráfico 34 Escores médios equiparados entre funcionários fixos e temporários 163

Gráfico 35- Escores médios equiparados de felicidade para níveis de renda 165

Gráfico 36- Escores médio equiparados de felicidade níveis de renda - homens 165

Gráfico 37- Escores médio equiparados de felicidade para níveis de renda- mulheres.166 Gráfico 38- Escores médios equiparados praticantes e não praticantes de religião 169

Gráfico 39- Escores médios equiparados para tipos de religião.

Gráfico 40- Escores médios equiparados praticantes e não praticantes de religiãohomens. 171

Gráfico 41- Escores médios equiparados praticantes e não praticantes de religião mulheres.

Gráfico 42- Escores médios equiparados para praticantes e não praticantes de atividades sócio políticas 173

Gráfico 43- Escores médios equiparados para saúde. .174

Gráfico 44- Escores médios equiparados indivíduos boa saúde separados por idades..175

Gráfico 45- Escores médios equiparados indivíduos que apresentam algum problema de saúde separados por idades 175

Gráfico 46- Escores médios equiparados separado por práticas desportivas 176 
SUMÁRIO

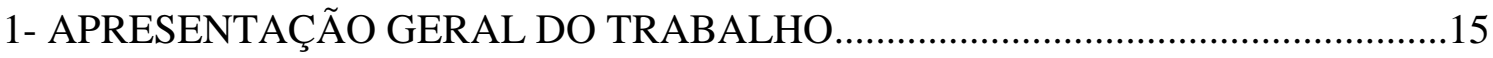

2- INTRODUÇÃ

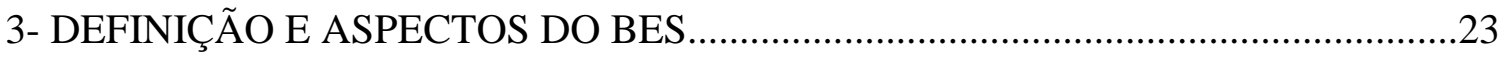

3.1 O BEM-ESTAR SUBJETIVO E FELICIDADE........................................23

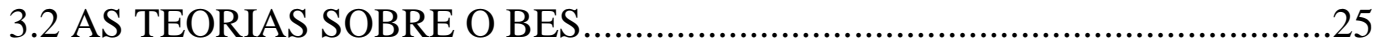

3.3 OS COMPONENTES DO BEM-ESTAR SUBJETIVO.................................30

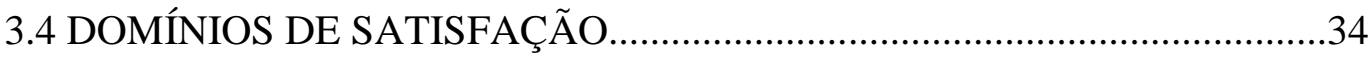

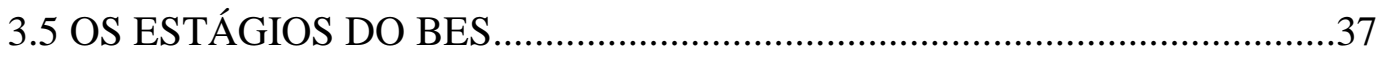

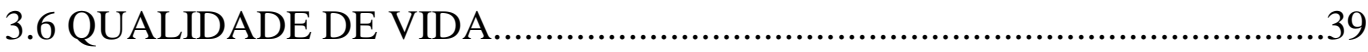

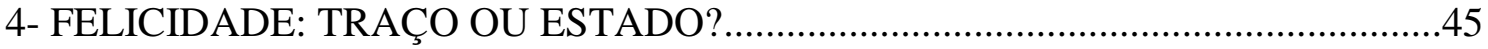

5- A FELICIDADE E OS FATORES ECONÔMICOS E POLÍTICOS...........................50

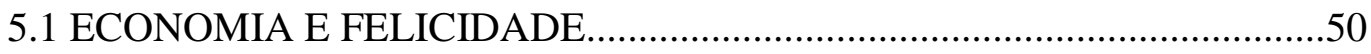

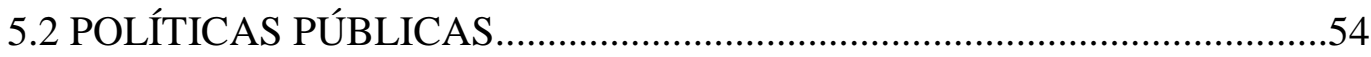

5.3 O BES COMO ÍNDICE SÓCIO- ECONÔMICO...........................................55

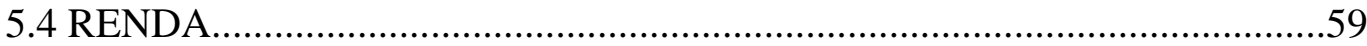

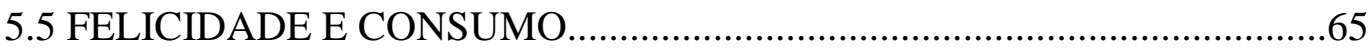

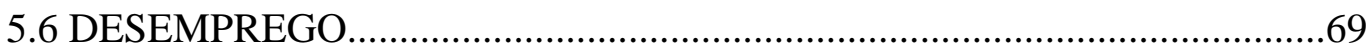

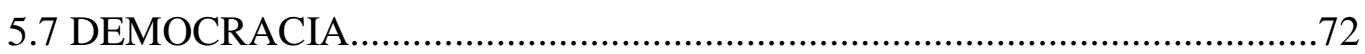

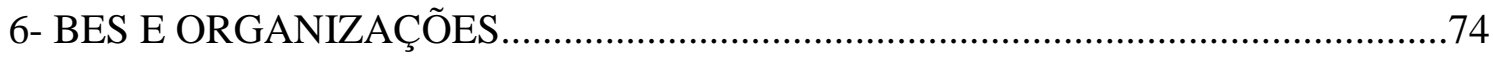

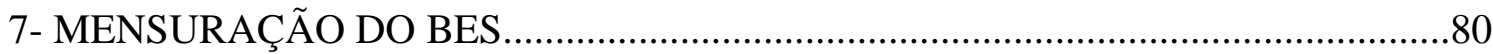

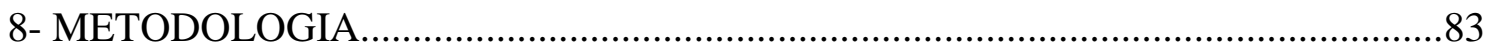

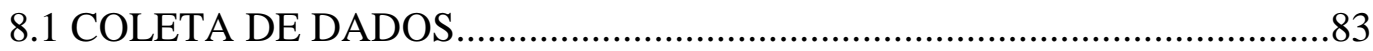

8.2 FERRAMENTAS ESTATÍSTICA UTILIZADAS NA ANÁLISE...............90

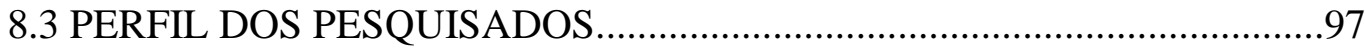


9- ANÁLISE DOS QUESTIONÁRIOS 105

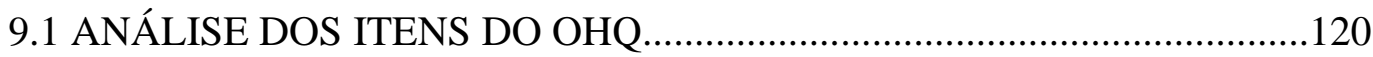

9.2 ESCALA GERAL DE FELICIDADE........................................................126

10- ANÁLISE DOS DADOS SÓCIO DEMOGRÁFICOS...............................................130

10.1 IDADE

10.2 SEXO

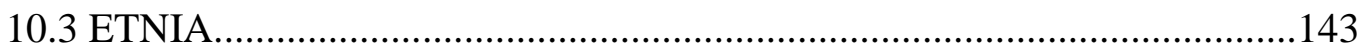

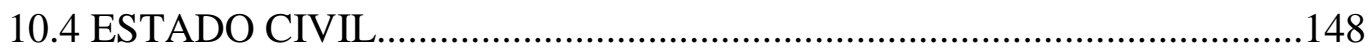

10.5 ESCOLARIDADE

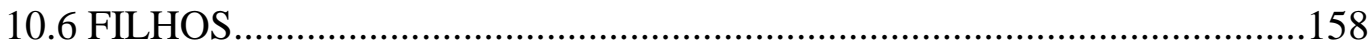

10.7 ATIVIDADE PROFISSIONAL...............................................................160

10.8 COMPARAÇÃO ENTRE EMPREGO EFETIVO E TEMPORÁRIO.......162

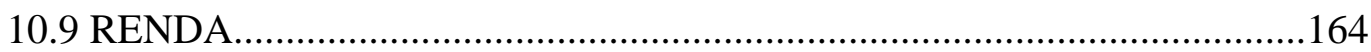

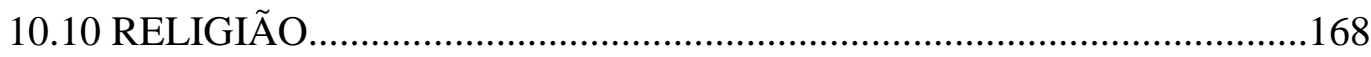

10.11 ATIVIDADE SÓCIO POLÍTICA...........................................................172

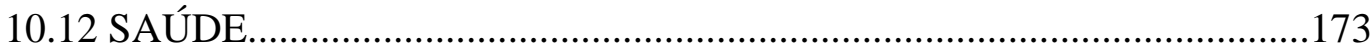

11- AS PESQUISAS SOBRE BES NO BRASIL.....................................................178

12- CONCLUSÃO

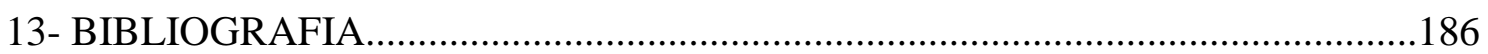

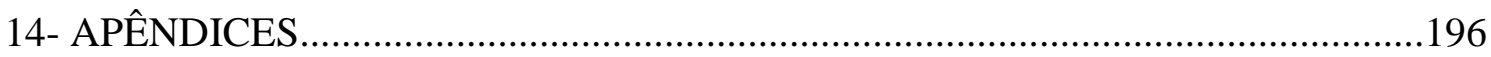

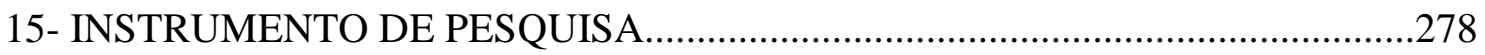




\section{1- Apresentação Geral do Trabalho}

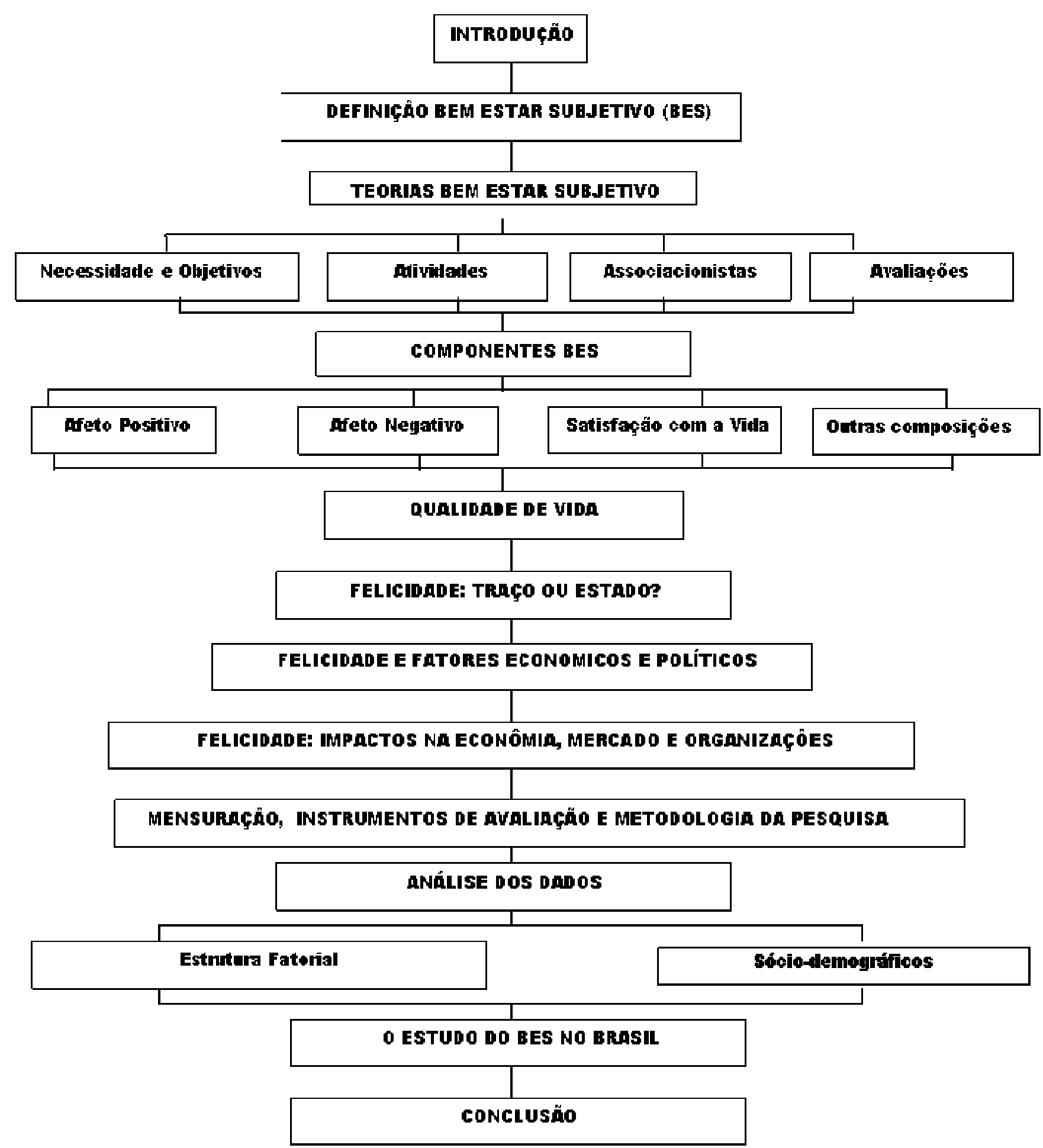




\section{2- INTRODUÇÃO}

Durante os últimos milênios, a felicidade tem sido foco de estudo por parte de diversas áreas do conhecimento. Há 2.300 anos, Epicuro definiu felicidade como a ausência de sofrimento e aconselhou seus discípulos a evitarem a corrida social e viverem em comunidades contemplativas (Veenhoven, 2006). Aristóteles cunhou o conceito eudemonista: a felicidade é vista como a satisfação derivada do caráter individual e suas ações, que leva a uma vida digna de ser vivida (Kingwell, 2006). A idéia de a felicidade conduzir a uma vida sem problemas é comum no pensamento religioso, em particular no pensamento de renúncia ao mundo, e vista como existente somente no Paraíso (Veenhoven, 2006). Problemas sociais estão ligados a condição de bem-estar dos indivíduos, uma vez que em situações desfavoráveis de vida há a redução do nível de felicidade destas pessoas, o que fornece legitimidade ao estado de bem-estar social (Veenhoven, 2006). Contudo, pessoas conseguem ser felizes, apesar de problemas sociais ou em sua vida particular, o que fornece forças para sustentar que a felicidade é um estado mental (Veenhoven, 2006).

A busca pela felicidade transcendeu os estudos comportamentais e filosóficos e entrou na farmacologia, que desenvolveu drogas que pretendem alterar estados mentais, como o Prozac, na busca de oferecer estados mais prazerosos na vida de seus usuários (Kingwell, 2006). Estudos mostram que há evidências neurológicas de que o processo de funcionamento cerebral de felizes e infelizes é diferente (Urry, Nitschke, Dolski, Jackson, Dalton, Kim Mueller, Rosenkranz, Ryff, Singer, \& Davidson, 2004).

A diferença entre as pessoas felizes e infelizes se faz além do escopo de saúde mental ou estado desejado: possuem diferenças no desempenho de suas vidas nas esferas pessoal, profissional, social, familiar e até mesmo sexual. Neste ultimo, revelou ter relações positivas com felicidade e ser estatisticamente relevante em regressões feitas, considerando a freqüência de relações (variável independente) e o desempenho em escala de avaliação 
(Blanchflower \& Oswald, 2004). O bem-estar subjetivo é mais do que um propósito em si; é condutor de valiosos resultados sociais e profissionais, uma vez que as pessoas felizes demonstraram ter resultados diferenciados em diversos domínios de suas vidas (Diener \& Seligman, 2002).

Pessoas felizes possuem benefícios tangíveis nos mais diversos domínios da vida, derivados deste estado mental positivo: maior tempo de casamento, mais amigos, maior suporte social e interações sociais mais enriquecedoras, resultados superiores no trabalho (como aumento de produtividade, qualidade do trabalho e maior renda), maior atividade, energia e envolvimento, maior autocontrole e autodomínio, maior habilidade em superar dificuldades, sistema imunológico mais eficiente e até mesmo maior longevidade, além de serem menos egoístas, mais cooperativas e caridosas (Lyubomirsky, Sheldon. \& Schkade, 2005). Diversos estudos mostram fortes correlações entre mensurações de felicidade e o desempenho diferenciado de indivíduos nas mais diversas atividades da vida: no trabalho, há correlação com avaliação de supervisores, 0,29 (Cropanzano \& Wright, 1999); desempenho no emprego, 0,22 (DeLuga \& Mason, 2000) e satisfação com o mesmo, 0,29 (Weiss, Nicholas\& Daus., 1999); melhor desempenho no clima organizacional, 0,32 (Foster „Hebl, West \& Dawson, 2004); avaliação positiva do serviço pelo consumidor, 0,41 (George, 1995); comprometimento interpessoal, 0,21 (Magen \& Aharoni, 1991); desempenho gerencial, 0,20 (Staw \& Barsade, 1993). Nas relações sociais, há registro de correlações com o comprometimento nas relações interpessoais, 0,27 (Berry \& Willingham, 1997); satisfação com amigos e atividades sociais, 0,31 e 37, respectivamente (Cooper, Okamura \& Gurka, 1992); apoio a amigos e vizinhos, 0,35 e 0,31 (Gladow \& Ray, 1986); satisfação com o casamento, 0,55 (Headey, Veenhoven \& Wearing 1991); solidão, -0,50 (Lee \& Ishii-Kuntz, 1987). Quanto à saúde, há correlações com depressão, -0,60 (Diener \& Seligman, 2002) e ansiedade, -0,34 (Kashdan \& Roberts, 2004). Aspectos que envolvem percepção individual, 
como auto-estima, 0,65 (Lucas, Diener \& Suh, 1996); avaliação de eventos passados, 0,41 (Lyubomirsky \& Tucker, 1998); auto- crítica, -0,39 (Mongrain \& Zuroff, 1995); crescimento pessoal, 0,38 (Ryff, 1989) e extroversão, 0,62 (Lucas, Diener, Grob, Suh, \& Shao, 2000).

Portanto, a felicidade deve ser melhor compreendida em sua estrutura e nas relações que possui nos mais diversos níveis. Consiste em estado ou traço? É estável e possível de se manter níveis elevados de felicidade? Quais são as características de pessoas felizes? O que influência a felicidade nas pessoas? Está relacionada com sexo, raça, idade, educação, renda, tipo de emprego ou estado civil? (Fuentes \& Rojas, 2001). Apesar de a felicidade proporcionar maior e melhor desenvolvimento humano, pouco suporte científico existe, sustentando a idéia de que a ela pode mudar para melhor. As técnicas propostas pelos livros de auto-ajuda geralmente possuem pequeno fundamento na literatura científica, e menos ainda confirmações empíricas de sua eficácia (Lyubomirsky, Sheldon \& Schkade, 2005).

A felicidade pode assumir diversos aspectos: passageira, traduzindo momentos hedônicos, que significa a preponderância do afeto positivo sobre o negativo, ou situações mais estáveis, que são avaliações positivas de determinados segmentos da vida, ou da vida como um todo (Veenhoven, 2000). Ela é reconhecida como importante fonte adicional de avaliação do desenvolvimento econômico e social, utilizado por economistas, sociólogos e gestores públicos no mundo, de maneira complementar aos indicadores objetivos, sendo a avaliação do bem-estar subjetivo uma medida de desempenho social de uma nação (Siegrist, 2003). De acordo com Brock (1993, conforme Diener \& Suh, 1997) existem três grandes abordagens para determinar a qualidade de vida: a primeira é através dos ideais normativos, isto é, o que é desejável para uma boa vida fundamentada em termos filosóficos e conceituais; a segunda é a satisfação de preferências, que representa os recursos e posses que os indivíduos adquirem para oferecer conforto, atendendo à satisfação de desejos; a terceira é a qualidade de vida em termos das experiências individuais, que representa o quanto a pessoa identifica sua 
vida como sendo boa e prazerosa. O bem-estar subjetivo (BES), ou felicidade, refere ao que as pessoas pensam e como se sentem sobre suas vidas, construindo conclusões em bases afetivas e cognitivas sobre sua existência (Seligman \& Csikszentmihalyi, 2000).

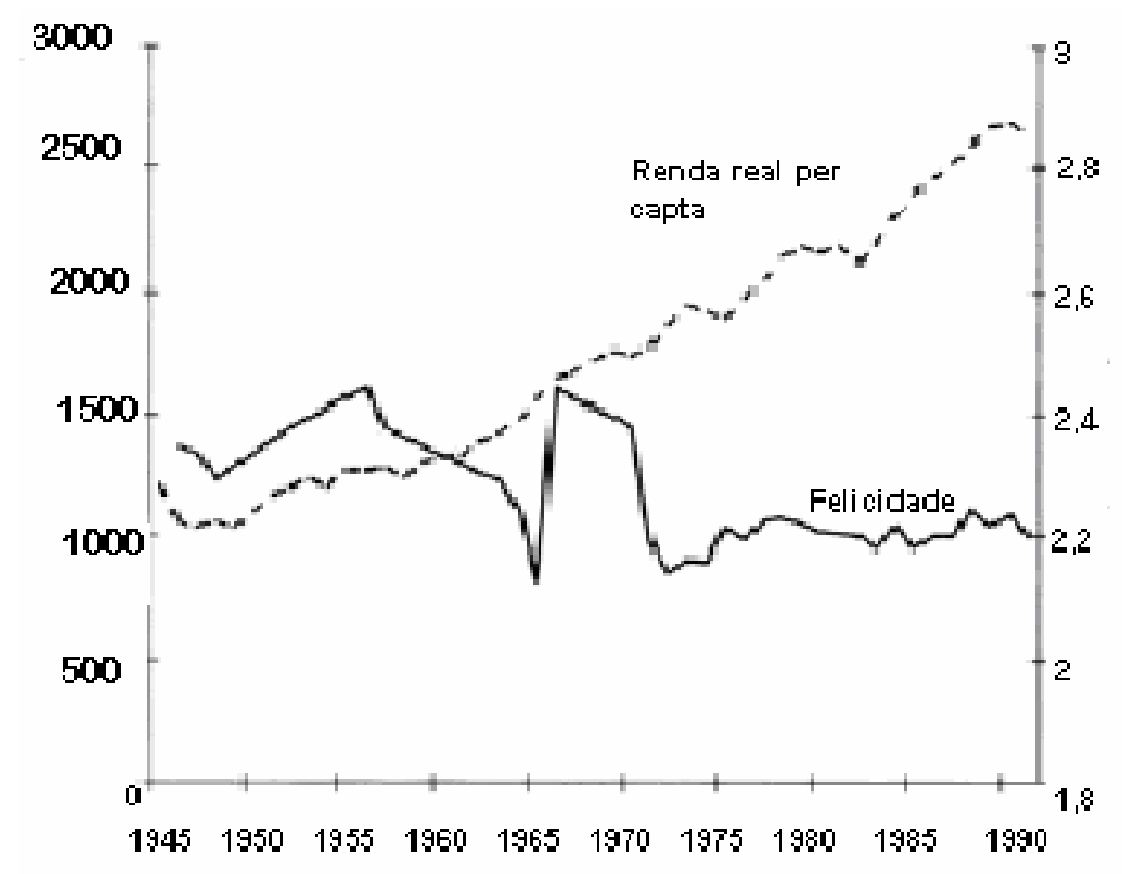

Figura 11- Renda e Felicidade nos Estados Unidos (Layard, 2003)

Comprovadamente o mundo está cada vez se tornando mais rico e produzindo mais e melhores bens e serviços. Porém, apesar do crescente aumento de poder de compra em muitos países, as pessoas não estão mais satisfeitas com suas vidas do que há cinco décadas (Layard, 2003). Entre 1946 e 1991, a renda nos Estados Unidos aumentou 2,5 vezes (Figura 1) sem haver impacto significativo no nível de felicidade registrado (Frey \& Stutzer, 2002). O Japão, que conseguiu o maior crescimento econômico pós-guerra, multiplicando sua renda por 6 entre 1958 e 1991, ao longo deste tempo permaneceu estável, em seu nível de felicidade (Frey \& Stutzer, 2002). Para outros países que também apresentaram crescimento em seu nível de renda houve também melhora na situação de felicidade, como na Dinamarca, Alemanha e Itália, porém pequeno e desproporcional ao ganho financeiro obtido (Frey \& Stutzer, 2002). 
Tabela 1-Satisfação com a vida em vários grupos (Diener, 2004).

\section{Satisfação com a vida em vários grupos}

\begin{tabular}{|l|l|}
\hline Os homens mais ricos da América, de acordo com a revista Forbes. & $\mathbf{5 , 8}$ \\
\hline Amish da Pensilvânia & $\mathbf{5 , 8}$ \\
\hline Inuit (tribo do norte da Groenlândia) & $\mathbf{5 . 8}$ \\
\hline Massai africanos & $\mathbf{5 . 7}$ \\
\hline Amostra probabilística de suecos & $\mathbf{5 . 6}$ \\
\hline Amostra de estudantes internacionais (47 nações em 2.000) & $\mathbf{4 . 9}$ \\
\hline Amish do Illinois & $\mathbf{4 . 9}$ \\
\hline Moradores de subúrbios em Calcutá & $\mathbf{4 . 6}$ \\
\hline Moradores de rua de Fresno, Califórnia & $\mathbf{2 , 9}$ \\
\hline Moradores de rua em Calcutá & $\mathbf{2 . 9}$ \\
\hline
\end{tabular}

Nota: os respondentes indicaram sua concordância com a afirmativa "Você está satisfeito com sua vida" utilizando uma escala de 1 (discordância completa) a 7 (concordância completa); 4 é um escore neutro.

Países do norte na Europa apresentam alta renda e alto nível de felicidade, seguidos por nações de língua inglesa (EUA, Inglaterra, Austrália e Irlanda), depois pelos latinoamericanos (incluindo o Brasil), o Oriente Médio, Europa Central e o leste europeu; porém existem países africanos que possuem níveis de felicidade maiores do que certos países europeus, como França, Itália e Espanha ( $\mathrm{Ng} \& \mathrm{Ng}$, 2000). Como exemplo da relação entre riqueza e felicidade entre as sociedades, os Amish norte-americanos, que vivem isolados dos avanços modernos em um modo de produção agrícola que data do século passado, registram o mesmo nível de satisfação com a vida do que os norte-americanos mais ricos, a tribo Maasai africana e uma amostra probabilística de suecos (Diener \& Seligman, 2004). Estes achados levam a perceber que continuar buscando avaliar a qualidade de vida, somente dentro dos padrões econômicos, atualmente estabelecidos, fundados em indicadores objetivos, é contar metade da história.

A economia não tem um fim em si e a política econômica, praticada pelas nações, deve objetivar levar o bem-estar à população. Duas abordagens têm sido utilizadas nas duas últimas décadas para retratar a qualidade de vida: indicadores objetivos e indicadores subjetivos (Diener \& Suh, 1997). Ao avaliarmos que a qualidade de vida se fundamenta em 
circunstâncias objetivas, as medidas econômicas nos dirão o que buscamos, porém se considerarmos que a qualidade de vida está na experiência de vida, então estes indicadores estão incompletos (Campbell, 1976).

Frey e Stutzer (2002) consideram três motivos de importância para que os economistas considerem a felicidade como indicador: o primeiro é quanto à política econômica: a percepção de utilidade do indivíduo, em nível micro, e a relação das variáveis econômicas, como inflação e desemprego, com o bem-estar subjetivo, em nível macro; a segunda por questões institucionais, traduz a qualidade de governança, pois em pesquisa mencionada por Frey e Stutzer (2002), realizada em 49 países, durante 10 anos, sugere que há benefícios no bem-estar que derivam da estabilidade e ordem institucional e o terceiro motivo é o mecanismo de construção da felicidade, que é análoga à utilidade entendida pelos economistas. Há forte correlação entre bem-estar e riqueza da nação (entre 0,5 e 0,7) onde as nações mais ricas possuem maiores escores nos registros de felicidade, contudo, com o crescimento da riqueza mundial, a renda necessária e a quantidade de riqueza produzida para manter este nível de bem-estar são cada vez maiores (Diener \& Seligman, 2004).

Existem diversos domínios de satisfação sobre os quais as pessoas avaliam suas vidas. Casamento, emprego, lazer, entre outros, são aspectos avaliados que levam a um determinado nível de satisfação. O bem-estar influi no trabalho, e este, por sua vez, também influência o bem-estar. Pessoas mais satisfeitas com a vida possuem desempenho profissional diferenciado das demais; contudo, a perda do emprego tem um impacto marcante no indivíduo (Diener, 2004). Funcionários felizes são mais cooperativos, mais pontuais, possuem menores ausências por doenças, permanecem empregados por períodos maiores, têm melhor avaliação de seus supervisores, entre outras características (Keyes, Hysom \& Lupo, 2000).

Quando avaliamos a felicidade das pessoas, devemos considerar os fatores de personalidade, assim como as características sócio-demográficas (Frey \& Stutzer, 2002). 
Diversos estudos citados em Hills e Argyle (2001) mostram as correlações de fatores de personalidade com a felicidade, enquanto Frey e Stutzer (2000) no livro Happiness and Economics mostram as relações das características sócio-demográficas com a felicidade. Lyubomirsky (2001) afirma que os indicadores objetivos conseguem explicar somente entre $8 \%$ a $15 \%$ da variância em felicidade.

A mensuração da felicidade, ou bem-estar subjetivo, normalmente é feita através de instrumentos de auto-avaliação e possui diversas escalas com diferentes estruturas, envolvendo desde múltiplos itens até escalas de item único. Esta pesquisa procura:

- Analisar três destas escalas que se propõem a mensurar o Bem-estar Subjetivo (BES), com estruturas diferentes, sendo a primeira a Escala de Felicidade de Oxford (OHQ), a segunda a Escala Geral de Felicidade (EGF) e a terceira uma escala de item único (EU). As análises são feitas mediante ferramentas estatísticas e critérios psicométricos, que buscam avaliar a estrutura fatorial do primeiro questionário e o desempenho dos três comparativamente no propósito de mensuração do BES, isto delimitado ao contexto da amostra.

- Utilizaram-se os instrumentos de medida para avaliar as características sóciodemográficas envolvidas na amostra, sua relação com a felicidade e compará-las com os resultados encontrados na literatura. Através de técnicas estatísticas, análises foram desenvolvidas buscando identificar a relação da idade, sexo, etnia, estado civil, escolaridade, número de filhos, atividade profissional (comerciantes / comerciários), emprego efetivo / temporário, renda, religião, atividade sócio política e saúde com o nível de felicidade registrado pelas escalas. 


\section{3 - DEFINIÇÃO E ASPECTOS DO BES}

\subsection{O BEM-ESTAR SUBJETIVO E FELICIDADE}

A avaliação da qualidade de vida é realizada individualmente, fundada em critérios estabelecidos pela própria pessoa, e o resultado desta avaliação leva à configuração do que é uma vida boa para a pessoa. Esta abordagem é chamada de bem-estar-subjetivo, e uma avaliação positiva destes parâmetros é denominada felicidade (Diener, 2000). A felicidade possui uma característica de longo prazo, o que não pode ser confundida com estados de espírito momentâneos e não pode também ser associada com saúde mental, pois é possível a pessoa se considerar feliz apesar de apresentar distúrbios mentais. Isto porque o BES é definido como a experiência vivida pela pessoa e mensurada pela perspectiva individual (Diener, Suh \& Oishi, 1997; Diener, 1984). Os termos felicidade e bem-estar subjetivo são empregados como sinônimos (Veenhoven, 1994).

Demócrito afirmou que uma vida feliz e prazerosa deve-se não ao que a pessoa possui, mas como ela reage às circunstâncias da vida. Esta definição fornecida pelo filósofo clássico, há milhares de anos, estabelece os princípios de disposição, prazer, satisfação e subjetividade do construto. Outros filósofos, como Sócrates, Platão e Aristóteles, defendiam a idéia de que a quantidade de bens materiais estaria ligada à felicidade, apesar de Aristóteles acrescentar que ainda está envolvida a necessidade de a pessoa realizar seu potencial individual. Epicuro propôs a maximização dos prazeres, originando o conceito hedônico de felicidade (Diener, Scollon \& Lucas, 2003). No século XVIII, o conceito de felicidade estava ligado aos propósitos de vida na época: a própria pessoa, o serviço ao rei e a Deus. No século XIX, surgiu a crença utilitarista fundada no pensamento econômico de que uma boa sociedade proporciona felicidade para o maior número de pessoas. No século XX, a felicidade foi inspiradora de grandes reformas e levou à criação do Estado de Bem-Estar Social (Veenhoven, 1994). 
As definições de bem-estar e felicidade podem ser compreendidas em três categorias (Diener, 1984). A primeira é um sentido de virtude, que possui um critério normativo, por definir um estado desejável. A segunda, normalmente utilizada por cientistas sociais, repousa nos padrões que levam as pessoas a avaliarem positivamente suas vidas, focadas uma vida boa e relacionada com qualidade de vida. Isto representa a satisfação com a vida que o indivíduo possui, avaliada com base em seus próprios critérios. A terceira está inserida no contexto do discurso diário em que a palavra felicidade é empregada, para demonstrar a preponderância do afeto positivo sobre o negativo, onde há mais momentos agradáveis do que desagradáveis. Corriqueiramente, utilizamos o termo felicidade no terceiro aspecto, porém o trabalho científico repousa no segundo.

O construto bem-estar subjetivo (BES), ou felicidade, possui três marcos (Diener, 1984). Primeiro, é subjetivo, reside na experiência individual de cada um. Segundo inclui mensurações positivas, o que representa mais do que a ausência de fatores negativos, como a maioria das medidas utilizadas em saúde mental, mas inclui também a presença de medidas positivas, mais especificamente um nível maior de afeto positivo em relação ao negativo. Terceiro, consiste na avaliação global de todos os aspectos de vida de uma pessoa.

A maneira como se desenrolam os fatos da vida influenciam a forma como a percebemos e avaliamos. Se um episódio acaba bem, este tende a ser lembrado de maneira positiva, independentemente do quanto desprazeroso foi anteriormente; em contrapartida, se acaba mal, este tende a ser lembrado de forma negativa, independentemente do quanto foi prazeroso anteriormente (Fredrickson \& Khaneman, 1993). As pessoas que vêem o mundo de forma derrotista, traço comum entre os indivíduos deprimidos, costumam atribuir eventos negativos a causas globais e de provável continuidade, mergulhadas em uma adversidade contínua, enquanto que as pessoas felizes tendem a avaliar de forma positiva os acontecimentos e interpretar eventos como bons: criam um mecanismo adaptativo mais 
eficiente do que as pessoas que lidam de maneira negativa com os eventos, sendo estas normalmente menos felizes. (Diener \& Suh, 1997).

Os fatores que envolvem a determinação do BES são fundados em duas bases: as condições externas e os processos internos. As condições externas são os contextos nos qual o indivíduo está inserido, enquanto que os processos internos são os mecanismos individuais pelo quais processam o nível de satisfação com a vida. Os entendimentos, tanto da sistemática mental quanto dos fatores conjunturais, oferecem condições de oferecer às pessoas maneira destas desfrutarem mais e melhor suas vidas (Veenhoven, 1994).

Em síntese, o bem-estar subjetivo, felicidade e satisfação com a vida compreendem uma mesma denominação por traduzirem uma avaliação positiva da vida em seu sentido mais amplo.

\subsection{AS TEORIAS SOBRE O BEM-ESTAR SUBJETIVO}

As teorias construídas sobre o BES não são excludentes e, normalmente, se completam. A felicidade pode derivar das situações descritas abaixo em diversas situações, porém alguns pesquisadores têm como preponderantes alguns destes conceitos.

\section{- NECESSIDADES}

Neste aspecto, a felicidade é obtida quando uma necessidade é suprida ou um objetivo alcançado. Veenhoven (1991) descreve necessidade como os pré-requisitos bio-psicológicos necessários para o funcionamento do indivíduo, que são inatos, inconscientes e universais. Isto significa que as necessidades estão localizadas nas demandas básicas do indivíduo.

O postulado de Wilson (1960, conforme Veenhoven, 1991) diz que a satisfação de necessidades causa felicidade e a persistência de necessidades causa infelicidade. A diferença entre as duas está na origem do esforço de satisfação. A pessoa pode estar, ou não, consciente da necessidade a ser satisfeita. Presumivelmente, uma sociedade feliz é aquela em que todas 
as necessidades humanas são cumpridas. Ao considerarmos que a condição fundamental de bem-estar é o atendimento das necessidades básicas das pessoas, as diferenças existentes entre os níveis de satisfação dos povos estão em função da eficiência dos governos em satisfazer estas necessidades individuais (Diener \& Lucas, 2000), oferecendo condições que atendam às demandas básicas da vida. As sociedades diferem em bem-estar subjetivo, e parte desta variação se dá graças a condições objetivas, como, nutrição, igualdade política, liberdade, educação e renda (Veenhoven, 1995). Neste aspecto, a renda possui relação direta, pois quanto maior for o nível desta, mais facilmente as necessidades serão satisfeitas (Fuentes \& Rojas, 2001).

\section{- OBJETIVOS}

Estes aspectos estão relacionados com os propósitos que possuímos em nossas vidas. Diferentes características destes objetivos são relacionadas a diferentes componentes do BES, oferecendo diferentes relações causais. Alguns objetivos podem ser mais benéficos do que outros, pois uns fundamentam-se em atividades mais intrínsecas, que são mais relacionados com o BES, enquanto outros buscam objetivos extrínsecos, com menor relação com o BES (Diener, 1984). Em outras palavras, podemos buscar realizações que satisfaçam, por exemplo, os nossos valores ou o nosso status.

Os objetivos são pautados em desejos determinados e conscientes e a relação com a felicidade está em sua concretização (Diener, 1984). Eles refletem aspirações individuais, provenientes de comparações feitas com outras pessoas (Diener, 1984). Os objetivos também guiam nossas escolhas e comportamentos, de maneira a servir de parâmetros, nas avaliações de satisfação com a vida (Diener, 1984). Alguns desses objetivos podem ser benéficos, enquanto outros podem agir em detrimento do bem-estar, pois não são compatíveis com as necessidades humanas intrínsecas (Diener \& Lucas, 2000). 


\section{- ATIVIDADES}

Esta teoria teve como principal patrono Aristóteles, para quem a felicidade vem através da realização virtuosa das atividades. Isto representa desempenhar o que se faz com maestria. De acordo com o filósofo, o homem possui habilidades e o emprego destas, para alcançar objetivos, proporciona a auto-realização (Diener, 1984). Csikszentmihalyi, em 1997, elaborou sua teoria Flow (fluir) (Csikszentmihalyi \& Csikszentmihalyi, 1988). Nela, quando as atividades forem vistas como prazerosas e, se os desafios forem equilibrados com as habilidades individuais, haverá um estado de imersão e o indivíduo envolver-se-á na atividade. Se estes desafios estiverem abaixo das habilidades, esta facilidade proporcionará desinteresse e, se estiver acima de suas habilidades, esta dificuldade poderá resultar em ansiedade. A convergência das habilidades com os desafios proporciona um estado de concentração intensa e prazerosa, desenhada pelo autor como uma sensação de fluir. Diferentemente da anterior, nesta teoria, a felicidade é alcançada pelo modo como as coisas são feitas, e não aonde se quer chegar. As duas, porém, não são incompatíveis, uma vez que a condução do processo pode ser prazerosa, tanto quanto à chegada ao objetivo proposto.

Quando o BES está ligado a atividades que são congruentes com os valores individuais, deixa de ser apenas uma forma de hedonismo, para, tendo em vista a realização individual de seus valores e objetivos, fornecerem à vida uma característica de propósito e significado (Diener, Suh \& Oishi, 1997). O indivíduo traça objetivos, frutos de comparações e quanto mais próximo destes objetivos estiver, maior felicidade irá registrar (Veenhoven, 1991).

\section{- ASSOCIACIONISTAS}

Há modelos que buscam explicar o porquê de alguns indivíduos possuírem um temperamento pré-disposto à felicidade. Muitas destas teorias são baseadas na memória, condicionamento ou cognição. A abordagem cognitiva da felicidade fundamenta-se nas redes 
associativas da memória. Os indivíduos tendem a se recordar de fatos que são congruentes com o estado emocional. Pesquisadores da memória afirmam que o indivíduo pode desenvolver uma rica rede de associações positivas e limitar as associações negativas, disparando idéias e afetos positivos, podendo estas pessoas ser mais felizes do que as demais (Diener, 1984). Isto significa dizer que uma pessoa que tenta evitar pensamentos infelizes e se concentrar em pensamentos felizes, pode aumentar o seu nível de felicidade (Diener, 1984).

\section{- AVALIAÇÕES}

Neste escopo, a felicidade resulta da comparação entre um determinado parâmetro e as condições atuais e está estreitamente ligada ao aspecto dos objetivos individuais mencionados anteriormente. Se esta comparação apresenta um saldo positivo para as condições atuais, irá resultar em felicidade. Estes parâmetros podem ser tanto situações sociais como financeiros. (Easterlin, 1974; Diener, 1984). Veenhoven (1991) relata que estas avaliações mentais consistem na percepção de como a vida é e de como deveria ser, sendo que, quanto menor a distância entre estas duas realidades, mais feliz a pessoa será. Existe uma sintonia fina entre os padrões percebidos da realidade e as condições de vida. Quando estas são melhoradas, os padrões de comparação são elevados e, quando há um decréscimo, estes padrões caem, porém não com o mesmo ritmo, pois existe a necessidade de adaptação a um estágio inferior ao anteriormente registrado. A eficiência com que o indivíduo se adapta ao novo contexto pode estar vinculada à sua capacidade de superar situações adversas (resiliencia) o que por sua vez envolve tanto o sistema individual, como o social, para que venham a auxiliar na eficiência de sua recuperação (Almeida, 2005).

A busca contínua por padrões mais elevados lê o indivíduo a uma armadilha hedônica, onde ambiciona determinado parâmetro, e ao alcançá-lo, adapta-se e volta a desejar um novo estágio acima do que alcançou, tornando transitória sua satisfação com a vida (Diener \& Lucas, 2000). Ao se registrar o progresso social, isto é, ganhos no padrão de vida para toda 
uma população, todos os parâmetros são elevados derivados dos ganhos generalizados, não proporcionando o aumento da felicidade (Veenhoven, 1991).

As pessoas algumas vezes desejam algo que poderiam ser ou fazer, diferente do que são ou fazem atualmente, como possuir um outro emprego, morar em outra cidade ou ter outro relacionamento, que pode levar à insatisfação caso, o indivíduo seja impulsionado por essas motivações (Sckade \& Kahnemann, 1998).

Os padrões de comparação são arbitrários e tendem a almejar indivíduos compatriotas, com idade similar e semelhante classe social, obedecendo a características socialmente valorizadas como prestígio e nível de vida material. São construtos mentais individuais os quais não se encaixam necessariamente em requisitos reais para uma boa vida; pessoas podem desejar coisas que não são boas para si, e transformá-las em necessidades e isto é algo que acontece através da sedução exercida pela propaganda e a moda (Veenhoven, 1991). Nesta abordagem, as condições objetivas afetam a satisfação com a vida de maneira indireta, uma vez que as condições em si não possuem significado. O que está em jogo são as avaliações subjetivas que são feitas relativamente a um determinado parâmetro.

O mecanismo de comparação pode não ser somente negativo. Quando nos comparamos às pessoas de níveis superiores ao nosso, estas podem servir de inspiração e motivação para um determinado objetivo ser alcançado (Diener \& Lucas, 2000; Diener e colaboradores, 2003).

As pessoas felizes e infelizes diferem da forma como se conduzem no processo de comparação social e como respondem a este processo; no caso das pessoas felizes, estas utilizam esta comparação para resguardarem seu bem-estar (Lyubomirsky, 2001). Isto significa dizer que as pessoas felizes tendem a se compararem às pessoas em situações inferiores, o que as leva a uma avaliação mais positiva de suas vidas (Lyubomirsky \& Ross, 1997). 
A dinâmica de comparação leva à mobilidade da situação do indivíduo, que resulta no princípio da adaptação. As pessoas reagem de forma intensa a certas circunstâncias ou eventos de vida, mas ao longo do tempo habituam-se e retornam ao ponto padrão de bemestar, o que pode ser tanto para eventos positivos como negativos. Assim, a adaptação é uma força que amortece o impacto dos eventos, que faz com que o indivíduo retorne a um ponto fixo ou patamar de bem-estar ao longo do tempo (Diener Suh, \& Oishi, 1997). Em face desta característica adaptativa, Veenhoven (1991) afirma que a felicidade não pode ser duradoura, uma vez que os padrões de avaliação sofrem um ajuste às circunstancias atuais. Em longo prazo, este padrão adaptativo provoca estabilidade nos níveis de BES e atribui uma característica neutra à avaliação do BES, visto que existe um balanceamento de momentos felizes e infelizes, porém, o nível onde estes patamares se encontram são diferentes entre os indivíduos e sofrem influência do meio externo.

Esta teoria do set point é questionada por Easterlin, que afirma que caso esta estiver correta, de nada serviriam as políticas públicas da busca por melhores condições de vida, pois seriam incapazes em elevar o nível de satisfação (Easterlin, 2003).

\subsection{OS COMPONENTES DO BEM-ESTAR SUBJETIVO}

A discussão sobre a estrutura básica do BES centra-se no balanço afetivo (afeto negativo e afeto positivo) e a satisfação com a vida (Diener, 1984). No afeto positivo, podem ser considerados fatores, como alegria, afeição e orgulho, e o afeto negativo pode compreender emoções e estados de espírito, como raiva, ansiedade, tristeza. (Diener, Suh, \& Oishi, 1997). Esta estrutura foi decorrente do trabalho realizado em 1969 por Bradburn que mostrou a independência entre os afetos positivo e negativo. Um exemplo para ilustrar a relação desta independência de afeto positivo e afeto negativo seria uma briga com nossos filhos. É claro que os pais gostam deles, mas isso não impede que se zanguem com suas travessuras. 
$\mathrm{O}$ aspecto afetivo possui duas características distintas: a primeira é a freqüência e a segunda é a intensidade (Diener, 1984). Em termos de freqüência, o afeto positivo é inversamente relacionado com o negativo. Quanto mais freqüente uma pessoa sente um, menos freqüente sente o outro; contudo podem variar quanto a sua intensidade, porém o mecanismo como se opera este balanceamento e as alterações de afeto ainda não são claramente compreendidos (Diener e colaboradores, 2003).

O afeto negativo e o afeto positivo refletem experiências básicas dos eventos em curso na vida de uma pessoa. Portanto, muitos pesquisadores concordam que estes dois fatores são os que constituem a base do BES. Avaliações afetivas tomam a forma de estado de humor e emoções. Emoções são consideradas reações de curta duração que são ligadas a eventos específicos ou a estímulos externos, enquanto o humor é sentido afetivo mais difuso, que pode não estar vinculado a eventos específicos. Pelo estudo dos tipos de reações afetivas que os indivíduos experienciam, pesquisadores podem obter entendimento da forma como as pessoas avaliam as condições e eventos em suas vidas (Diener, Scollon \& Lucas, 2003).

As emoções possuem 5 características (Diener e colaboradores, 2003):

1. Envolvem afeto, significando que estão associadas a sentimentos de sofrimento ou prazer;

2. Emoções incluem avaliação de um objeto ou evento como bom ou mau;

3. A provocação de uma emoção está geralmente ligada com mudanças no comportamento através do ambiente;

4. Envolve ativação automática;

5. Envolve mudanças no comportamento cognitivo.

Os fatores de afeto estão alinhados com fatores de personalidade, sendo que o afeto positivo relaciona-se com extroversão, enquanto que o afeto negativo é ligado ao neuroticismo. Tellegen (1985, conforme Diener e colaboradores. 2003) afirma que tanto 
extroversão / afeto positivo quanto neuroticismo / afeto negativo refletem dois sistema de personalidade que são responsáveis por grande parte das diferenças individuais no afeto e comportamento.

Cada componente do BES, o afeto negativo e o afeto positivo, representam uma diferente forma de avaliação da vida. O AN (afeto negativo) e AP (afeto positivo) refletem a imediata reação dos indivíduos às condições de vida, boas ou más, enquanto os domínios de satisfação refletem a avaliação sob determinados aspectos da vida (Diener e colaboradores, 2003). Juntamente com o afeto positivo e negativo, a satisfação com a vida é o terceiro componente do BES. Ela resulta de avaliações cognitivas das condições de vida. Nem todas as pessoas julgam suas vidas da mesma forma, pois atribuem pesos a diferentes aspectos da vida e os avaliam em função do contexto imediato (Diener e colaboradores. 2003). Há a tendência de utilizar informações disponíveis no momento da avaliação para construir seu nível de satisfação, contudo, estas informações parecem ser fundamentadas sempre nas mesmas bases, o que deve produzir certa estabilidade na avaliação cognitiva, isto é, um determinado domínio que é valorizado pelo indivíduo para a avaliação, terá igual importância em outras avaliações (Diener e colaboradores. 2003).

A teoria da Múltipla Discrepância elaborada por Michalos (1985) afirma que a pessoa utiliza sete parâmetros para avaliarem suas vidas: 1) o que elas querem; 2) o que as outras pessoas possuem; 3) a melhor experiência no passado; 4) a expectativa para os próximos anos; 5) o progresso pessoal; 6) o que a pessoa acha que merece e 7) o que a pessoa avalia que necessita.

Para Veenhoven (1991), a felicidade é uma cognição do cérebro. Ela é insensível à qualidade de vida, se considerar que as pessoas exercem padrões de comparação, que são arbitrários, o que permite aos indivíduos sentirem-se subjetivamente bem em condições adversas, assim como em condições muito favoráveis de vida apresentar níveis de 
infelicidade. O autor ainda cita que a felicidade é construída na privação. Como os padrões de comparação não são exclusivamente externos, mas também ancorados nas experiências passadas, pois após tempos difíceis, ao se conseguir melhoras na situação as avaliações de vida da pessoa serão mais favoráveis, em termos comparativos.

A satisfação com a vida, de acordo com Argyle (1987, pág. 142) “... é um dos principais componentes da felicidade. Satisfação é uma espécie de avaliação reflexiva agradável do quão bem as coisas estão correndo e como têm estado. Há a satisfação da vida como um todo, com trabalho, lazer, casamento e outros domínios". O mesmo autor cita que possuímos três grandes fatores de avaliação da vida - outras pessoas, trabalho e lazer - que são grandes domínios de satisfação e possuem relação com a satisfação total; como possuem maior importância, causam impacto maior no nível geral de satisfação.

Há outras formas de composição do BES. A estrutura fundamentada no balanço afetivo, conforme dito, derivou do trabalho de Bradburn (1969), contudo, existem pesquisas que fornecem fundamentos para construção de uma estrutura diferenciada do BES. Em Ryff (1989), são citados os conceitos de Maslow'(1968), Rogers (1961), Jung (1933) e Allport (1961). Neste contexto, são considerados os seguintes fatores integrantes ao BES:

Auto aceitação: característica central de saúde mental, assim como auto atualização, funcionamento ótimo e maturidade. O indivíduo, mantendo atitudes positivas em relação a si mesmo, emerge características centrais de funcionamento positivo psicológico.

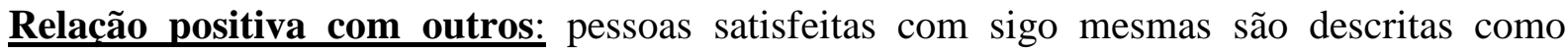
possuidoras de profundo senso de empatia e afeição pelas pessoas. O elo social com outras pessoas é uma importante fonte de felicidade (Argyle \& Handerson, 1985). Fordyce (1983) sugere como método de aumento da felicidade o convívio social. 
Autonomia: qualidades como autodeterminação, independência e domínio interno são características desta dimensão. O indivíduo não procura a aprovação de outros, mas se avalia pelos padrões individuais e se vê livre de convenções, medo e crenças alheias.

Superioridade ambiental: a habilidade do indivíduo em criar ambientes sustentáveis para sua condição psíquica é definida como característica de saúde mental. Enfatiza a habilidade de avançar-se ao mundo e mudá-lo criativamente, através de atividades psíquicas ou mentais. O envelhecimento sadio enfatiza a extensão com que o indivíduo toma vantagem das oportunidades do ambiente.

Propósito na vida: a saúde mental é definida em incluir crenças que fornecem o sentimento que dá um propósito e significado à vida. A definição de maturidade também enfatiza uma clara compreensão de propósito de vida, senso de direcionamento e intencionalidade. O indivíduo que possui um funcionamento positivo possui objetivos, intenções e senso de direcionamento, os quais contribuem para o sentimento de que a vida é significativa.

Crescimento Pessoal: Um ótimo funcionamento psicológico requer não somente as características anteriores, como também o contínuo desenvolvimento e expansão do potencial individual.

\subsection{DOMÍNIOS DE SATISFAÇÃO}

Diener, Scollon e Lucas (2003) afirmam que o BES é um fenômeno multifacetado e deve ser estudado sob diversos ângulos. Os autores oferecem um modelo o qual ilustra a estrutura do construto e os níveis acessados. Conforme a Figura 2, diversos níveis são especificados em uma hierarquia. No topo se encontra o bem-estar subjetivo, que reflete a avaliação geral da pessoa; pesquisadores que trabalham neste nível devem mensurar vários componentes de níveis menores da hierarquia para se obter um quadro completo do indivíduo. Este nível possui 4 componentes: emoções prazerosas, emoções desprazerosas, julgamentos globais e domínios de satisfação, que são moderadamente correlacionados um com outro. $\mathrm{Na}$ 
primeira coluna são exemplificadas as emoções positivas, assim como, na segunda, que mostra algumas das emoções negativas. Na terceira existe o aspecto cognitivo, que constituem as bases sob as quais são realizadas as avaliações da vida. Na quarta coluna se encontram domínios definidos que são avaliados emocional e cognitivamente.

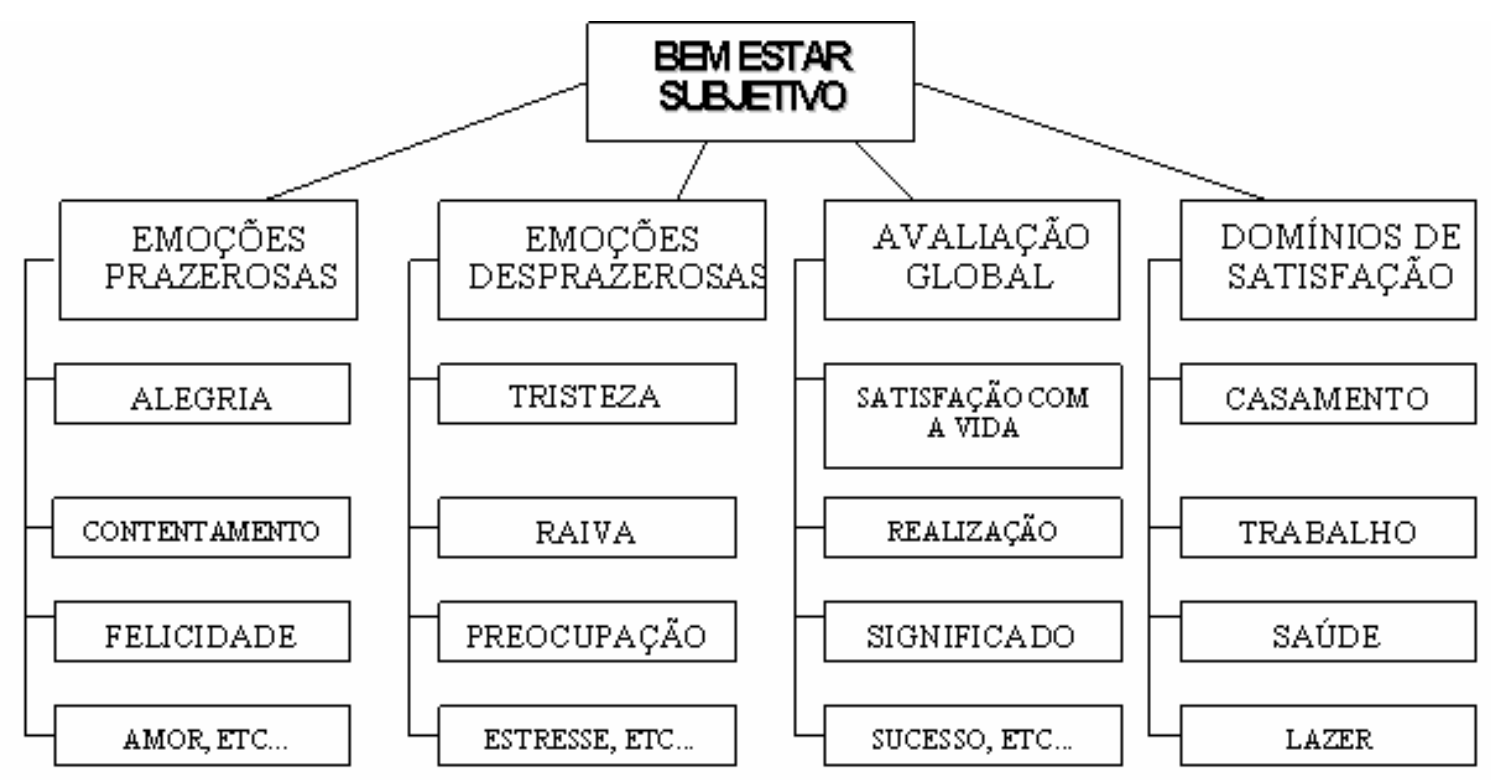

Figura 12- Domínios do bem-estar subjetivo (Diener Scollon \& Lucas, 2003)

Domínios de satisfação refletem a avaliação individual de aspectos específicos da vida, valorizados de diferentes maneiras entre os indivíduos. Para obter esta mensuração, o pesquisador deve construir mecanismos de avaliação que reflitam determinada área, como, por exemplo, satisfação com o trabalho. O estudo de cada área é importante a fim de entender a configuração e as maneiras como as pessoas se relacionam com cada domínio. (Diener e colaboradores, 2003). Domínios que são mais próximos e imediatos da vida pessoal possuem maior influência na construção do BES (Diener, 1984). Cada domínio de satisfação está sujeito às características sócio-demográficas que exercem diferentes níveis de influências: Casamento: O casamento é um dos eventos mais importantes que afetam a vida e o bem-estar de uma pessoa (Stutzer \& Frey, 2004). Como os autores explicam, com o casamento, as pessoas se engajam em um comprometimento mútuo e de longo prazo, do qual se espera 
recompensas afetivas e materiais, isto porque, além da relação emocional, existe o papel econômico com que se obtém o ganho de escala, proveniente da união de rendas. A renda média domiciliar e os custos mensais do lar possuem um forte efeito positivo na satisfação domiciliar, apesar de pessoas com maiores níveis de educação serem mais críticas em suas condições domiciliares e possuírem maior expectativa, às vezes não satisfeitas (Vaan Prag, 2003).

Trabalho: passamos grande parte de nossa vida exercendo uma determinada atividade profissional e a relação que possuímos com nosso trabalho nos identifica como indivíduo e constrói nossos parâmetros sociais (Myers, 1992). A felicidade é um recurso que aprimora tanto o desempenho pessoal, como profissional, possuindo impacto positivo no ambiente de trabalho e relacionamento entre colegas (Wright \& Cropanzano, 2004). Quick e Quick (2004) relatam uma relação direta entre a saúde da empresa e do funcionário, afirmando que ambas são interdependentes. Este domínio pressupõe existência de relação com a idade, tendo-se uma relação em forma de U, sendo o ponto mínimo por volta dos 50 anos (Wright, 2003), quando o indivíduo retira-se do mercado de trabalho através da aposentadoria. A satisfação financeira pode ser um subdomínio do trabalho ou um domínio isolado (Van Praag, 2003).

Saúde: Saúde e felicidade estão altamente correlacionadas (Stutzer \& Frey, 2002), sendo a primeira um importante recurso para a segunda (Argyle, 1987). A satisfação com a saúde cai com o aumento da idade e cresce com o aumento de renda, apesar de ser em pequena escala (Van Praag, 2003).

Lazer: Estas são atividades que os indivíduos realizam nas horas vagas e o fazem simplesmente porque o desejam, por diversão, entretenimento e que revertam em bem-estar próprio (Argyle, 1987). Para algumas pessoas é uma grande fonte de satisfação, para outras possui prioridades menores do que o trabalho, família ou casamento (Argyle, 1987). A importância deste domínio, em relação à idade, registra uma curva em U com mínimo em 35 
anos, sendo que a renda domiciliar não é um forte indicador para satisfação no lazer (Van Praag, 2003). Pessoas com maiores níveis de educação tendem a ter menos satisfação com o lazer e os homens possuem maior satisfação do que as mulheres (Van Praag, 2003).

Em linhas gerais, para cada domínio da vida são realizadas avaliações afetivas e cognitivas, com deferentes níveis de importância, o que leva determinados aspectos a terem um peso maior na avaliação do que outros, de acordo com os valores e características individuais.

\subsection{OS ESTÁGIOS DO BES}

Considerando o aspecto multifacetado do BES, este pode ser desdobrado em diferentes estágios ao longo do tempo. Diener Scollon e Lucas (2003) formataram um modelo que segue duas premissas básicas. Primeira, o BES é visto em estágios temporais, que não são idênticos entre si. Segunda, em nenhum dos estágios está refletida a verdadeira felicidade. Neste modelo, os afetos momentâneos (AP e AN) e a memória são importantes para o BES.

\section{EVENTO EXTERNO}

Avaliação (atençã̃o, percepção, interpretação)

REAÇÃO EMOCIONAL ON LINE

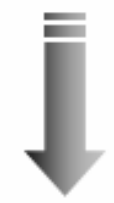

Codificação, repetição, ruminaçã̃o,

MEMÓRIA PARA EMOĢÃo

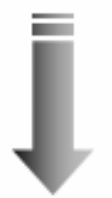

Avaliaçã̃o da relevância das emoções, auto conceito, teorias implícitas, valores e crenças atuais, normas culturais, padrões, informações salientes/ disponiveis.

\section{AVALIAĢÃo GERAL DO BES}

Figura 13-Estágios do bem-estar subjetivo (Diener, Scollon \& Lucas, 2003) 
No primeiro estágio do modelo acima, eventos ocorrem às pessoas, mas seus efeitos no BES de longo prazo são fracos. Por haver muitas ocorrências entre um evento e a construção do julgamento total de satisfação, estes podem possuir uma característica pontual de afastamento no nível normal de BES (média), porém podem ocasionar uma grande importância nas emoções correntes (on line) dos indivíduos. O impacto emocional dos eventos irá depender em grande parte da avaliação individual, baseada nas diferenças particulares existentes em percepção, atenção e interpretação destes eventos. $\mathrm{O}$ estágio seguinte é a reação emocional imediata, em si complexa e multifacetada, que envolve diversos aspectos relacionados, como expressões não-verbais e comportamentais, codificadas na memória por inúmeros processos, incluindo a repetição de informações emocionais, reminiscências e ruminações as quais podem influenciar o grau de relação entre as experiências on line e a recordação de experiências similares. A memória é tratada, no modelo, como uma experiência separada das emoções on line. Alguns fatores envolvidos no processo de transição entre emoções e memórias são o auto-conceito que o indivíduo possui, as crenças correntes, teorias implícitas e normas culturais. Finalmente se erguem as construções globais de satisfação com a vida. Este estágio é influenciado pelos estágios anteriores e as experiências imediatas podem agir sobre a configuração da satisfação como um todo. Contudo, a extensão de como estas emoções irá influenciar a avaliação global depende da memória individual para emoções. Em adição, estes julgamentos de satisfação incorporam outros conceitos, como normas culturais e as informações disponíveis no momento da avaliação, que podem variar entre indivíduos e culturas (Diener e colaboradores, 2003).

Estados emocionais positivos são desejados, contudo, as emoções negativas como medo, raiva ou repudio, foram necessárias dentro do processo evolucionário para a autopreservação, pois serviam como um guia para nosso comportamento (Fredrickson, 2003). Buss (2000) mostra que a evolução, através da seleção natural, produziu mecanismos 
competitivos que favorecem uns em detrimento de outros, o que dificulta a felicidade. Em contrapartida, possui mecanismo de envolvimento que a favorece. As emoções são como um sinal automático que nos avisa sobre se demandas mínimas para o bom funcionamento biopsicológico estão sendo supridas (Veenhoven, 1991). Emoções negativas são apropriadas em diversas circunstâncias, e o permanente estado de emoções positivas pode refletir um problema de desvio de comportamento (Diener e colaboradores, 2003).

O curso dos acontecimentos da vida também opera de maneira a influenciar a satisfação com a vida. Considerando o balanceamento entre os eventos positivos e negativos, quanto melhor for a satisfação resultante, maior o nível de felicidade. Estes acontecimentos vitais explicam cerca de $25 \%$ da variância na felicidade registrada (Veenhoven, 1994b).

\subsection{QUALIDADE DE VIDA}

Veenhoven (2004) procurou demonstrar as interações de fatores pessoais e ambientais a fim de ilustrar os campos de estudos e significados derivados destas relações.

Tabela 2- Interações do bem-estar subjetivo (Veenhoven, 2000)

\begin{tabular}{|l|c|c|}
\cline { 2 - 3 } \multicolumn{1}{l|}{$\begin{array}{l}\text { OPORTUNIDADES DE } \\
\text { VIDA }\end{array}$} & $\begin{array}{c}\text { QUALIDADES EXTERNAS } \\
\text { Qondes de vida do ambiente } \\
\text { (campo 1) }\end{array}$ & $\begin{array}{c}\text { Habilidade de vida da pessoa } \\
\text { (campo 2) }\end{array}$ \\
\hline RESULTADOS DE VIDA & $\begin{array}{c}\text { Utilidade de vida } \\
\text { (campo 3) }\end{array}$ & $\begin{array}{c}\text { Satisfação } \\
\text { (campo 4) }\end{array}$ \\
\hline
\end{tabular}

Na horizontal, estão as oportunidades fornecidas pelos eventos de vida e o resultado de vida. Oportunidades e resultados não são o mesmo. As oportunidades são oferecidas pelo contexto macro, como, por exemplo, a riqueza de uma nação, a igualdade social, oportunidades de educação. Os resultados de vida compreendem o impacto micro, ao nível individual, envolvendo as oportunidades aproveitadas pelos indivíduos (Veenhoven, 2000). 
$\mathrm{Na}$ vertical, estão as qualidades que o ambiente e o indivíduo possuem, respectivamente. A interação destes fatores resulta em quatro diferentes tipos de qualidade de vida, conforme pode ser visto na Tabela 3. Isto explica em parte o resultado positivo de algumas pessoas que, apesar das poucas oportunidades que possuem, conseguem muito de suas vidas.

Condições de vida do ambiente: o bem-estar é visto em função do contexto e condições externas. Sociólogos e ecologistas direcionam seus estudos neste aspecto.

Habilidade de vida da pessoa: são as oportunidades internas ao indivíduo, mostrando o quanto este está equipado para lidar com os problemas da vida, utilizado por médicos e psicólogos, referenciando como qualidade de vida ou bem-estar. Os biólogos entendem este aspecto como potencial adaptativo.

Utilidade da vida: Representa o propósito de vida. Neste quadrante, estão valores maiores com os quais a vida é avaliada, ou, em outras palavras, o sentido da vida. Pastores, padres e conselheiros morais atuam neste campo.

Satisfação com a vida: Esta consiste na qualidade de vida aos olhos do contemplador, caracterizada por uma avaliação subjetiva. Aqui normalmente termos como bem-estar subjetivo e felicidade são empregados.

Assim, em síntese pode-se apresentar o quadro a seguir: 
Tabela 3- Subsignificados dentro dos quadrantes de qualidade de vida (Veenhoven, 2000)

\begin{tabular}{|c|c|c|}
\hline & QUALIDADES EXTERNAS & QUALIDADES INTERNAS \\
\hline $\begin{array}{l}\text { OPORTUNIDADES DE } \\
\text { VIDA }\end{array}$ & $\begin{array}{l}\text { Condições de vida do ambiente } \\
\text { - Ecológico (ex: clima moderado, } \\
\text { ar limpo) } \\
\text { - Social (ex: liberdade política, } \\
\text { igualdade social) } \\
\text { - Econômica (desenvolvimento } \\
\text { econômico, seguridade social) } \\
\text { - Cultural (ex: produção artística, } \\
\text { educação em massa) }\end{array}$ & $\begin{array}{l}\text { Habilidade de vida da pessoa } \\
\text { - Saúde física (negativo: } \\
\text { ausência de doença; positivo: } \\
\text { resiliência) } \\
\text { - Saúde mental (negativo: } \\
\text { ausência de problemas mentais; } \\
\text { positivo: autonomia, } \\
\text { criatividade) } \\
\text { - Conhecimento (ex: } \\
\text { escolaridade, domínio de } \\
\text { tecnologia) } \\
\text { - Habilidades (ex: inteligência, } \\
\text { relacionamento) } \\
\text { - Arte de viver (ex: estilo de vida } \\
\text { variado, gosto diferenciado) } \\
\text { - Etc... }\end{array}$ \\
\hline RESULTADOS DE VIDA & $\begin{array}{l}\text { Utilidade de vida } \\
\text { - Utilidade externa (Para íntimos - } \\
\text { ex: cuidar de amigos, crianças. } \\
\text { Para a sociedade - ex: ser um } \\
\text { bom cidadão. Para a humanidade } \\
\text { - ex: deixar uma invenção). } \\
\text { Retidão moral (ex: compaixão, } \\
\text { valores). } \\
\text { - Etc... }\end{array}$ & $\begin{array}{l}\text { Satisfação } \\
\text { - Avaliação com domínios da } \\
\text { vida (ex: trabalho, casamento). } \\
\text { - Estado predominante (ex: } \\
\text { deprimido, alegre). } \\
\text { - Avaliações globais (afetiva: } \\
\text { nível geral de humor; } \\
\text { cognitiva: contentamento com } \\
\text { a vida). }\end{array}$ \\
\hline
\end{tabular}

Considerando a matriz acima, abordar-se-ão alguns aspectos que se caracterizam quanto as interação destes elementos (Veenhoven, 2000):

- Ajustamento

Tabela 4- Ajustamento(Veenhoven, 2000)

\begin{tabular}{|l|l|l|}
\cline { 2 - 3 } \multicolumn{1}{c|}{} & QUALIDADES EXTERNAS & QUALIDADES INTERNAS \\
\hline $\begin{array}{l}\text { OPORTUNIDADES DE } \\
\text { RIDA }\end{array}$ & $\begin{array}{l}\text { Condições de vida do ambiente } \\
\text { (campo 1) }\end{array}$ & $\begin{array}{l}\text { Habilidade de vida da pessoa } \\
\text { (campo 2) }\end{array}$ \\
\hline RESULTADOS DE VIDA & $\begin{array}{l}\text { Utilidade de vida } \\
\text { (campo 3) }\end{array}$ & $\begin{array}{l}\text { Satisfação } \\
\text { (campo 4) }\end{array}$ \\
\hline
\end{tabular}

Considerando as áreas assinaladas, as habilidades de vida de uma pessoa, acrescida de sua satisfação com a vida, oferecem o quão bem esta lida com a vida e se ajusta aos eventos. 
- Estilo de vida

Tabela 5- Estilo de vida (Veenhoven, 2000)

\begin{tabular}{|l|l|l|}
\cline { 2 - 3 } \multicolumn{1}{l|}{} & QUALIDADES EXTERNAS & QUALIDADES INTERNAS \\
OPORTUNIDADES DE & Condições de vida do ambiente & Pabilidade de vida da pessoa \\
\hline RESULTADOS DE VIDA & Utilidade de vida & Satisfação \\
\hline
\end{tabular}

Este aspecto está ligado ao lado hedônico da felicidade, associada a uma gratificação sensorial.

- $\quad$ Privação

Tabela 6- Privação (Veenhoven, 2000)

\begin{tabular}{|c|c|c|}
\hline 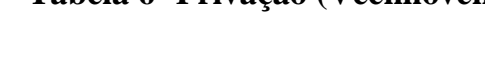 & QUALIDADES EXTERNAS & QUALIDADES INTERNAS \\
\hline $\begin{array}{l}\text { OPORTUNIDADES DE } \\
\text { VIDA }\end{array}$ & Condições de vida do ambiente & Habilidade de vida da pessoa \\
\hline RESULTADOS DE VIDA & Utilidade de vida & Satisfação \\
\hline
\end{tabular}

O déficit de recursos neste campo pode implicar na privação e, conseqüentemente, na falha em suprir as necessidades humanas básicas. Aqui estão temas como pobreza e exclusão social.

- Felicidade

Tabela 7- Satisfação (Veenhoven, 2000)

\begin{tabular}{|l|l|l|}
\cline { 2 - 3 } \multicolumn{1}{l|}{} & QUALIDADES EXTERNAS & QUALIDADES INTERNAS \\
OPORTUNIDADES DE & Condições de vida do ambiente & Habilidade de vida da pessoa \\
\hline RESULTADOS DE VIDA & Utilidade de vida & Satisfação \\
\hline
\end{tabular}

Este campo representa a felicidade, que, de acordo com Kcewicz (1997, conforme Veenhoven, 2000): uma justificada satisfação com a vida. Justificada porque a felicidade é fundada nos critérios individuais e dificilmente poderia ocorrer em condições abjetas de vida. 
Esta matriz mostra que um foco em determinado campo pode não resultar necessariamente na melhoria de outro. Por exemplo, governantes acreditam que se fornecerem moradia ou educação (campo 1) podem estar atingindo a satisfação com a vida (campo 4), o não necessariamente pode ocorrer. Existe necessidade para se fixar um critério entre as muitas oportunidades de melhoria que são possibilitadas pelos gestores públicos. Estes critérios podem partir do campo quatro, detectando níveis de satisfação e a partir daí elaborar planos de ações que atinjam pontos valorizados pelos indivíduos.

A satisfação com a vida, de acordo com o Veenhoven (2000), é um ótimo mecanismo de avaliação do quanto às condições de vida se ajustam com as habilidades individuais, desde que mensurada apropriadamente. As condições avaliadas podem ser estudadas em dois níveis; o primeiro, macro, procurando entender o tipo de sociedade onde as pessoas podem possuir maior felicidade e o micro, onde se procura entender as posições e diferenças individuais na sociedade. Pode-se considerar também o nível meso, que consiste no estudo da relação de felicidade e organizações, de trabalho, por exemplo.

Ainda no mesmo texto, Veenhoven mostra que a satisfação é também possuidora de múltiplos significados, que estão representados na Tabela 8 .

Tabela 8- Significados da satisfação (Veenhoven, 2000)

\begin{tabular}{|l|l|l|}
\cline { 2 - 3 } \multicolumn{1}{c|}{} & PASSAGEIRO & DURADOURO \\
\hline PARTE DA VIDA & Prazer & Satisfação parcial \\
\hline A VIDA COMO UM TODO & Experiência Maior & Satisfação com a vida \\
\hline
\end{tabular}

Prazeres: São satisfações passageiras, que podem ser sensoriais, como apreciações de um bom vinho, ou mental, como um bom filme. A idéia de que podemos maximizar estas sensações é chamada de hedonismo. 
Satisfação Parcial: Esta é a satisfação referente a determinados domínios da vida. Algumas vezes a palavra felicidade é utilizada para avaliar estes segmentos em particular, como a carreira profissional.

Experiência Maior: A satisfação com a vida pode assumir um aspecto intenso e "oceânico", em uma conotação mística onde a experiência assume um caráter profundo. Escritores e religiosos empregam a palavra felicidade em tal sentido.

Satisfação com a vida: Esta é uma satisfação duradoura e vista de maneira global na avaliação da vida. É este campo em que se encontra o escopo desta pesquisa, pois reflete um estado da mente que não pode ser alcançado objetivamente, da mesma forma que a pressão sanguínea ou temperatura corporal (Veenhoven, 2000). Estados de felicidade pode se manifestar externamente, como através de sorrisos ou postura corporal, porém não são freqüentemente visíveis. Por isso se utiliza instrumento de auto-avaliação para acessar o construto.

A felicidade reflete duas condições importantes. A primeira depende do quanto às necessidades humanas encontram as condições de vida. A segunda indica o quão bem as habilidades individuais de uma pessoa combinam com as condições nas quais as pessoas vivem. (Veenhoven, 2004). Portanto, a mensuração do bem-estar subjetivo é uma medida tanto de contexto quanto de desempenho, relacionando as qualidades individuais e ambientais. 


\section{4 - FELICIDADE: TRAÇO OU ESTADO?}

Traço, na definição de Veenhoven (1991), consiste em uma característica durável de uma pessoa ou sociedade, normalmente utilizada em contraponto a estados, que consiste em algo essencialmente variável. Traços são tipicamente vistos como causas, enquanto os estados como resultados. O autor utiliza três características para diferenciar o traço do estado: 1) estabilidade temporal; 2) consistência entre situações e 3) causa interna (mais do que externa). As habilidades individuais são importantes na configuração da felicidade uma vez que operam para a solução dos problemas da vida (Veenhoven, 1994b).

Para Diener (1984), a felicidade pode ser considerada tanto um traço, como um estado emocional. Fatores ambientais estáveis contribuem em alguma extensão pela estabilidade do BES, porém uma porção da variância do construto é devida a fatores de personalidade, e outra porção, devida a circunstâncias de vida das pessoas.

A importância e a contribuição das características genéticas são reconhecidas por diversos autores, uma vez que fatores de personalidade, geneticamente construídos, respondem por grande parte da configuração do BES. Tellegen, Lykken, e Bouchard (1988) encontraram que $50 \%$ do bem-estar subjetivo podem ser atribuídos a fatores genéticos. A extroversão é um traço de personalidade e os extrovertidos são mais felizes (Wilson, 1967), isto em função do convívio social que estes possuem, pois o relacionamento social é um promotor de bem-estar. Fordyce (1983) sugere o convívio social como forma de aumentar o bem-estar subjetivo. Em adultos, otimismo, auto-estima e extroversão são muitos dos traços pessoais possuídos por pessoas felizes. As duas formas afetivas do bem-estar subjetivo parecem estar, de acordo com pesquisas, relacionadas com fatores de personalidade, mais especificamente com extroversão e neuroticismo (Diener, Suh, E. \& Oishi, 1997). Kasser e Ryan (1996) ponderam este papel dos traços herdados ao considerar que, ainda que uma 
pessoa esteja limitada por fatores genéticos a um determinado limiar de bem-estar, esta pode se sentir mais feliz através da busca de objetivos mais intrínsecos.

Veenhoven (1994) aborda a possibilidade de haver uma personalidade feliz e analisa algumas hipóteses. A primeira é que a pessoa nasce feliz ou infeliz, sendo uma disposição temperamental baseada na estrutura neurofisiológica dos centros de prazer do cérebro, capazes de sentirem-se alegres e propensas a avaliações positivas quanto a suas vidas. Uma segunda hipótese é que a felicidade é uma disposição adquirida. As pessoas podem desenvolver atitudes positivas ao longo da vida, enquanto outras podem ter uma postura malhumorada e crítica das condições em que vive (Veenhoven, 1994). A própria estrutura e configuração do BES descrita, construída através da memória e da maneira como são interpretados os eventos da vida, demonstra parte deste mecanismo. Independentemente da origem, a felicidade, sendo um traço individual, implica que o indivíduo tenderá a ter maiores ou menores níveis de satisfação ao longo da vida, em função de suas características individuais.

Um grande defensor do papel genético na construção da felicidade é o pesquisador David Lykken. Ele afirma que a hereditariedade da avaliação de BES é de 50\%, enquanto que a média do BES vinculada ao set point é de $80 \%$ (Lykken, 1990). Em pesquisa realizada junto a gêmeos monozigóticos e dizigóticos $(\mathrm{n}=79$ e $\mathrm{n}=48$ respectivamente) (Lykken \& Tellegen, 1996), com média de idade de 20 anos na primeira mensuração e 30 anos na segunda mensuração, para os gêmeos criados juntos, a correlação entre os níveis de BES registrado entre os dizigóticos foi próxima a zero $(0,07)$, enquanto que a correlação para os monozigóticos foi de 0,40. Quando se consideram gêmeos criados separados e pesquisados já em idade adulta, para os dizigóticos a correlação continuou próxima a zero, enquanto que para os monozigóticos foi de 0,48 (Lykken \& Tellegen, 1996). Sabemos que os gêmeos monozigóticos são clones naturais e carregam a mesma carga genética e a forte correlação 
existente mostra que o que mais influenciou seus níveis de BES foram suas características natas semelhantes entre eles.

A inteligência é em grande parte resultado de traços genéticos (Da Silva, 2005). Desempenho profissional e renda, por exemplo, estão relacionados com o nível de inteligência das pessoas. Contudo, se a capacidade de processamento intelectual é uma característica de desempenho individual, a felicidade é uma medida da qualidade deste desempenho. Lykken e Tellegen (1996) mostram que pessoas inteligentes conseguem bons desempenhos naquilo que fazem, mas pessoas felizes o fazem com mais prazer e dedicação, independentemente de seu nível de inteligência. Contudo, os dois fatores não estão relacionados, ao menos como até agora são mensurados (Veenhoven, 1994b).

O fato de haver características genéticas envolvidas no BES não significa que este apresenta resultados homogêneos ao longo do tempo, o que significa dizer que existe um ponto para qual o indivíduo converge mediante a adaptação aos eventos (Lykken, 1999). Há uma variação ao longo desta média e a amplitude desta variação é configurada particularmente a cada indivíduo (Veenhoven, 1994).

A felicidade parece ser mais constante do que a infelicidade. Pesquisa de Brachtel e Zapf (1984, conforme Veenhoven, 1984), que acompanhou indivíduos ao longo de dois anos, mostrou que cerca de $40 \%$ tornaram a se classificar como felizes em duas medidas de tempo diferentes, enquanto os infelizes, que se classificaram da mesma maneira, foram $12 \%$. $\mathrm{O}$ mesmo autor cita que outras características pessoais, como boa saúde ou habilidade em lidar com problemas pode interagir de modo a elevar o nível de BES. As correlações de longo prazo podem ser devido às condições de vida. Uma boa renda, matrimônio estável, bons relacionamentos interpessoais atuam favoravelmente na felicidade individual.

Apesar da possibilidade da felicidade ter um caráter genético em sua configuração do ponto de estabilidade, para onde o indivíduo converge, as condições externas influenciam à 
medida que proporcionam ao indivíduo chegar a este ponto. Dessa maneira, fatores contextuais irão atuar de forma a proporcionar maior ou menor variação ao longo deste ponto (Veenhoven, 1994). Em uma teoria homeostátisca, autores (Cummins, 2000; Tatzel, 2002) sugerem que o bem-estar subjetivo é composto por um sistema integrado que compreende a estrutura genética acompanhada por uma estrutura de segunda ordem.

\section{FATORES DE PRIMEIRA ORDEM DETERMINANTES - PERSONALIDADE}

\section{FATORES DE SEGUNDA ORDEM DETERMINANTES - HABILIDADES INTERNAS}

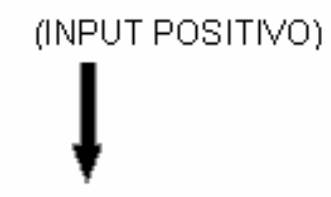

EXTROVERSÄO

NEUROTICISMO

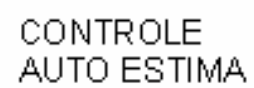

OTIMISMO

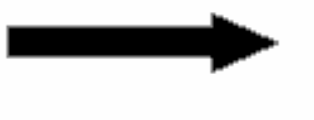

\section{RESULTADO}

BEM ESTAR

SUB.JETIVO

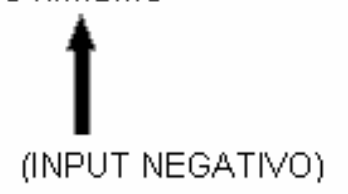

Figura 14- Sistema integrado do bem-estar (Cummins, 2000)

Os fatores primários envolvem dois fatores de personalidade que fornecerão uma determinada amplitude para a qualidade de vida subjetiva. Os fatores de segunda ordem são as habilidades internas dos indivíduos. Fatores como renda irá influenciar o segundo nível do modelo, que possui uma correlação com o controle primário, a auto-estima e o otimismo. O autor menciona que é intuitivo perceber que, havendo uma baixa renda, é reduzida a possibilidade de se conseguir exercer controle sobre o ambiente, sentir-se bem consigo ou ter uma perspectiva otimista sobre o futuro (Cummins, 2000). A educação se encaixa neste modelo. Estatisticamente, níveis altos de educação estão relacionados com altas rendas e níveis baixos de educação com baixas rendas, e, por sua vez, a educação reforça os mecanismos internos de segunda ordem. Atuando os mecanismos de segunda ordem sem 
limitações, serão os fatores de primeira ordem os responsáveis pela definição do balanceamento do BES (Cummins, 2000). 


\section{5- A FELICIDADE E OS FATORES ECONÔMICOS E POLÍTICOS}

\subsection{ECONOMIA E FELICIDADE}

O escopo econômico se estende além das dimensões objetivas avaliadas pelos economistas e a avaliação subjetiva se faz necessária para compreensão de questões, envolvendo renda, trabalho, expectativas (a forma como as pessoas interagem com seu contexto), entre outros aspectos (Hamermesh, 2004). Frank (1997) orienta que a percepção de felicidade dos psicólogos é diferente daquela que os economistas possuem. Economistas falam de utilidade individual, o que em um modelo econômico tradicional representa o crescente consumo de bens e serviços que as pessoas têm como desejados, porém, como os recursos são escassos, os indivíduos irão escolher entre as alternativas de mercado aquelas que maximizam sua utilidade. A definição econômica de bem-estar está relacionada com níveis de renda que podem oferecer de maneira crescente a satisfação de necessidade e melhor padrão de vida, enquanto que a psicologia procura entender e explicar as fontes que proporcionam felicidade ou a falta dela (Fuentes \& Rojas, 2001).

A economia não possui um fim em si, mas tem um valor que leva a contribuir para a felicidade humana (Stutzer \& Frey, 2003). Para Oswald (1997), o desempenho econômico é um meio para um determinado fim: fazer as pessoas mais felizes. Diversos esforços ao longo da história buscaram criar mecanismos de obtenção de uma sociedade que possuísse qualidade de vida, combatendo males como enfermidades, ignorância e pobreza. No século XVIII, Jeremy Benthan propôs que o objetivo da política pública deva ser aumentar a soma de felicidade de uma sociedade e que a utilidade marginal de renda era maior para pessoas pobres sendo, pois, necessária a distribuição de renda (Layard, 2003). Um novo princípio moral foi sugerido: o bem de uma nação não deve ser avaliado pela decência de suas 
intenções, mas pela utilidade de suas conseqüências (Veenhoven, 2004). Ele considerou que a utilidade reflete os prazeres e dores dos indivíduos.

À medida que o progresso ofereceu sucesso na solução destes problemas, mensurados objetivamente, nos dias atuais, a busca por esta sociedade que oferece satisfação a seus integrantes demanda uma mensuração mais subjetiva a fim de fornecer referenciais de qualidade de vida (Veenhoven, 1994b). O próprio crescimento econômico está colocando em xeque o bem-estar das pessoas ( $\mathrm{Ng} \& \mathrm{Ng}, 2000)$. As Nações Unidas, universidades e diversos pesquisadores buscaram a partir da década de 70 mecanismos de indicadores subjetivos, como o Eurobarômetro da União Européia, as Informes Sócio Culturais nos Países Baixos e o GSOEP (German Socio Economic Panel) na Alemanha.

A relação entre economia e felicidade, que orienta diversas pesquisas no mundo, tem oferecido alguns achados muito pertinentes. Em Oswald (1997), a felicidade aparenta ter melhorado levemente nos EUA, porém o aumento é muito pequeno. O crescimento da renda real registrado no país nas ultimas décadas não tem contribuído significativamente para a qualidade de vida das pessoas. A relação entre desempenho econômico e bem-estar possui um impacto muito maior em relação à infelicidade do que a felicidade. Um exemplo é o período da Grande Depressão Americana, quando o suicídio alcançou seu nível recorde na história (Oswald, 1997), o que mostra que níveis extremos de crise econômica podem provocar atos extremos originários de estados mentais de depressão; contudo, em cenário inverso, onde exista progresso econômico, a elevação generalizada da riqueza em uma nação não oferece o mesmo impacto em proporcionar níveis maiores de bem-estar, não registrando significativo aumento de felicidade.

Os economistas sempre se valeram de medidas objetivas para mensurar a felicidade, chamada por eles de utilidade. A estrutura clássica do pensamento econômico se fundamentou nas condições de eficiência econômica, abordando um aspecto analítico das condições 
objetivas dos recursos disponíveis (Steele, 2004). Contudo, atualmente, o pensamento econômico tradicional vem cedendo lugar a novos desafios e aceitando a possibilidade da mensuração subjetiva da utilidade (Stutzer \& Frey, 2002 e 2003), confrontando a teoria econômica clássica na qual, para um indivíduo ter determinadas vantagens, é necessário que outro(s) tenha(m) determinadas desvantagens (Steele, 2004). A necessidade da distribuição de renda surgiu através do estudo de Pareto, pelo qual $20 \%$ da população detinham $80 \%$ das riquezas e o aumento de renda de parte significativa da população proporcionaria aumento de utilidade, isto é, felicidade às pessoas (Kenny, 2005). A abordagem subjetiva da utilidade permite um conceito mais amplo, envolvendo o processo de decisão e a experiência utilitária do indivíduo (Stutzer \& Frey, 2002).

O utilitarismo teve seu berço no iluminismo, onde havia a crença de que o crescente aumento das riquezas impactaria a qualidade de vida das pessoas e, por conseqüente, o nível de felicidade do indivíduo (Giannetti, 2002). Seus filósofos entendiam (entre eles Jeremy Bentham) que a felicidade consistia em desfrutar de prazeres e na proteção contra dores (Kingwell, 2006), o que ajudou a estabelecer o elo entre riqueza e felicidade.

A qualidade de vida pode possuir dois significados: 1) a presença de condições necessárias para uma boa vida; 2)e a prática do viver bem. O primeiro representa um indicador social. O segundo representa uma atitude individual quanto à qualidade de vida. $\mathrm{A}$ satisfação com a vida deriva destes dois fatores. O monitoramento do nível de bem-estar subjetivo proporciona inferir o parâmetro de qualidade de vida existente, e sua variação é um indicador de melhora ou queda nos padrões existentes, devendo, portanto ser bem compreendido (Veenhoven, 1994b).

Ao considerar que a economia tem por sua finalidade gerar o bem-estar, a política econômica deve perseguir os mecanismos que possam viabilizá-lo, porém o impacto deste desenho macroeconômico na felicidade das pessoas quer seja em seu período presente ou nas 
perspectivas quanto ao rumo da economia do país, é visto de diferentes formas. Para alguns pesquisadores, quanto melhor for a avaliação do estado atual da economia, melhor o bemestar registrado (Hayo \& Serfert, 2003), enquanto que para outros o progresso econômico representa o aumento de apenas uma pequena quantidade de felicidade (Oswald, 1997). A perspectiva de alteração da situação atual da conjuntura econômica pode influenciar o BES, quer para melhor ou pior (Frey \& Stutzer, 2000).

Um dos indicadores de qualidade de vida em um aspecto objetivo é o índice de bens materiais, que pode ser interpretado como uma medida de riqueza material das residências. Este índice é baseado na posse de telefones, TVs e/ ou carros, oferecendo uma relação de quanto maior a riqueza, maior o bem-estar esperado (Hayo \& Seifert, 2003).

O PIB tem demonstrado ser uma sofrível mensuração de bem-estar das sociedades. Desde a Segunda Grande Guerra, seus indicadores vêm registrando crescimento, contudo os níveis de felicidade obtidos estão estagnados. Apesar do crescimento econômico registrado no Ocidente, a felicidade não cresceu nos últimos 50 anos (Layard, 2003). Conforme podemos atestar pela observação da Figura 1 as rendas individuais, aumentaram ao longo do meio século considerado, porém o nível de felicidade registrou aumento no período pós-guerra, declínio em seguida e após a oscilação significativa, mostra relativa estabilidade após a década de 70. Ao longo do meio século demonstrado, houve oscilações no nível de felicidade, porém parece não ter saído de um determinado nível, em oposição à renda, que apresentou uma evolução constante. Com esta evidência, podemos considerar alguns aspectos para buscar sua explicação. Isto parece sustentar o conceito de que existe um nível de felicidade para o qual o indivíduo converge, fruto da adaptação a novas circunstâncias. Outra possibilidade é que a crescente produção de riquezas ofuscou buscas igualmente importantes ao indivíduo, como lazer, relacionamento e valores intrínsecos. 
Em síntese, a procura pelo bem-estar através do aumento de riqueza e melhoria das condições objetivas de vida, fundamentada nos princípios utilitaristas de três séculos atrás está em xeque. Os dados históricos apresentados de geração de riqueza têm demonstrado que esta relação apresentou-se falha. Portanto, se faz necessário valorizar a abordagem subjetiva, uma vez que são os valores individuais que irão orientar as atitudes das pessoas (Fry, 2005), resultando na prática do viver bem, contudo, sem desconsiderar a importância dos indicadores objetivos, que de forma conjunta aos subjetivos poderão retratar de forma mais precisa e extensa o nível de qualidade de vida das pessoas.

\subsection{POLÍTICAS PÚBLICAS}

Veenhoven (1991) afirma que a satisfação com a vida está ligada à comparação com condições anteriores de vida do indivíduo. Considerando seu caráter subjetivo, esta não está relacionada somente com condições objetivas de vida, mas também com otimismo e pessimismo. Perspectivas de mudanças podem traduzir-se em um aumento de felicidade. Isto faz com que aspirações de progresso transmitidas pelo meio políticos podem resultar em uma inflação de expectativas, e por consequiência do BES, assim também como sua queda.

A gestão pública tem com objetivo oferecer meios de desenvolvimento para que a sociedade se aprimore. Se esta conseguir prover condições que possam levar seus integrantes a satisfazerem seus objetivos individuais de progresso, o resultado será atingir maior coesão social, o que leva a também a reduzir os níveis de conflitos interpessoais e ansiedade, fornecendo um contexto que leva à maior satisfação com a vida (felicidade) e, por consequiência, maior capital social (Ho, 2005). Esta ligação entre evolução social e felicidade é polêmica entre os pesquisadores. Veenhoven (1991) sustenta uma posição diferente. Isto por dois motivos. O primeiro, porque a felicidade é relativa. Qualquer melhoria nas condições de vida acarreta a elevação dos padrões de comparação. A segunda é que a felicidade é um traço 
mais fixo do que variável, determinado por mecanismo de disposição interno à pessoa (Veenhoven, 1991). Richard A. Easterlin conclui que caso exista este traço fixo, qualquer esforço movido pelo poder público em melhorar as condições de vida das pessoas seria totalmente infrutífero (Easterlin, 2004).

Se o desenvolvimento econômico não oferece muita contribuição para o nível de felicidade das pessoas, a falta de condições aceitáveis de vida é fonte de infelicidade. Em diversas sociedades, o serviço de assistência social está a cargo do governo, viabilizado com recursos públicos, de forma a buscar amparar os desempregados, os doentes e os idosos. A assistência a estas pessoas, distribuída de forma mais eqüitativa, permite que se mantenha um nível de bem-estar social. Países como a Suécia, onde existe um avançado sistema de assistência social, apresenta um elevado nível de felicidade. Para os alemães, a seguridade social é um mecanismo de tornar a vida das pessoas que dependem deste sistema mais feliz (Veenhoven, 2000).

\subsection{O BES COMO ÍNDICE SÓCIO-ECONÔMICO}

Ao se avaliar a qualidade de vida focada no bem-estar subjetivo das pessoas, o resultado obtido significa o quanto o sistema social está funcionando bem (Veenhoven, 2000). Isto representa o quão bem seus cidadãos vivem e o quanto são providas condições demandadas por eles para uma boa vida (Veenhoven, 2005).

Existe uma contribuição de fatores de personalidade na construção da felicidade, conforme já mencionado, contudo o contexto externo pode atuar de maneira a não proporcionar que a pessoa atinja o seu potencial de bem-estar. Fatores econômicos possuem impacto na felicidade do indivíduo, agindo através dos seguintes elementos: renda, desemprego e inflação (Stutzer \& Frey, 2002). Esta atuação do contexto macro para o contexto micro recebe uma resposta no sentido micro para macro. Em outras palavras, a ação do contexto econômico no indivíduo oferece a resposta deste ao meio, pois a felicidade da 
pessoa e seu nível de satisfação com a vida o guiarão em sua conduta como agente econômico. Pesquisas a serem demonstradas mais adiante mostram que a felicidade e, particularmente a satisfação com o domínio trabalho, proporciona ao indivíduo ser mais produtivo, participativo e comprometido em sua organização. O consumo é outro aspecto importante, que deriva do nível de satisfação com a vida. As pessoas comparam-se em relação a seus pares quanto a posses e padrões de vida. Aspiração a estágios diferentes de riqueza resulta em consumo de bens ou serviços. Portanto, a felicidade é muito mais do que um indicador de saúde e bem-estar, mas consiste em uma métrica estratégica dos diversos agentes da economia.

A necessidade pela adoção de um indicador subjetivo como complementar aos indicadores objetivos passa pelas características particulares de cada um (Veenhoven, 2002). Os indicadores objetivos focam os aspectos materiais e situacionais, independentes da consciência subjetiva, isto é, da percepção que as pessoas têm deste contexto. Um segundo aspecto é que os indicadores objetivos são interpretados por observadores externos, isto é, a informação é proveniente de analistas e não das próprias pessoas. Terceiro, os indicadores objetivos são valorizados de diferente maneira pelas pessoas, refletindo como estas avaliam o contexto que as cerca. Considerando o estudo de Becken e colaboradores (1987, conforme Diener \& Suh, 1997), 329 áreas metropolitanas norte americanas foram avaliadas quanto à qualidade de vida de seus moradores, mediante indicadores objetivos e conferido-se diferente pesos aos indicadores; 134 diferentes cidades poderiam ser classificadas como as melhores e 150 poderiam ser classificadas como as piores, tendo como resultado os diferentes aspectos valorizados dos indicadores objetivos. Os indicadores subjetivos conseguem informações de como os indivíduos percebem o seu meio, e a relação entre ambos pode ser tanto de causa como de efeito (Diener \& Suh, 1997), pois os dois estão relacionados e interagem entre si. 
Os indicadores subjetivos tornam-se elemento importante para traçar políticas sociais, tanto quanto para avaliar os objetivos e sucessos políticos. Redução da pobreza ou melhoria nas condições de moradia é percebida subjetivamente pelos indivíduos. A saúde pública é outro exemplo (Veenhoven, 2002). Diversos registros são realizados quanto ao consumo médico ou à reincidência de doenças, porém a longevidade não pode ser mensurada, pois seu efeito é de longo prazo. De acordo com Seligman (2002), existe uma estreita relação entre felicidade e longevidade. O sucesso de políticas sociais depende de seu direcionamento que, por sua vez, depende da qualidade de informações existentes, sendo necessários tanto os dados objetivos quanto os subjetivos, para se obter uma avaliação completa.

A política social também necessita de informações para planejar decisões futuras. Empreendedores públicos devem possuir e monitorar as informações objetivas, mas também as subjetivas, a fim de traçar, verificar e corrigir as ações tomadas através da percepção que os indivíduos possuem, detectada subjetivamente. Isto impacta o sistema político e a maneira como se processam as relações eleitorais. O marketing político requer a opinião do público sobre suas preocupações, aspirações e satisfações, que são mensuradas subjetivamente (Veenhoven, 2002).

Uma acurada mensuração e avaliação de qualidade de vida podem responder a questões como: a sociedade progrediu ao longo do tempo? As políticas executadas têm sido adequadas com os objetivos e ideais da sociedade? Os investimentos têm trazido os resultados desejados? (Diener \& Suh, 1997).

Um paralelo entre os indicadores subjetivos e objetivos é importante. A riqueza de informações dos dois tipos de mensuração não é as mesmas e oferecem visões distintas sobre a qualidade de vida de uma sociedade, sendo estas mensurações afetadas por diferentes tipos de erros (Diener \& Suh, 1997). 


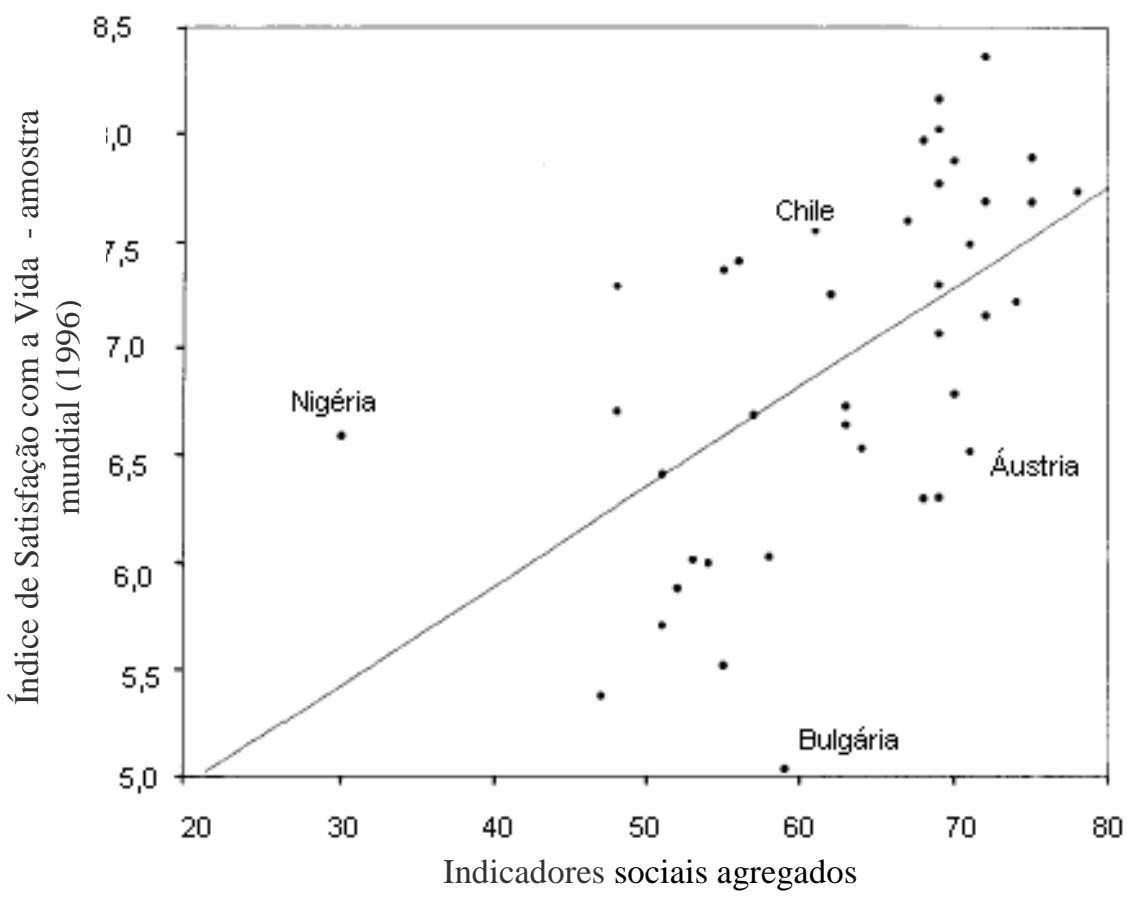

Figura 15- Satisfação com a vida e indicadores sociais de alguns países (Diener \& Suh, 1997)

Na figura acima, a Nigéria possui o mesmo nível de satisfação do que a Áustria, porém com diferenças acentuadas nos indicadores sociais. O Chile tem indicadores sociais similares aos da Bulgária, porém com grandes diferenças nos níveis de satisfação com a vida. Esta diferente caracterização dos países leva à necessidade de compreensão do mecanismo de interação entre os dois indicadores. Curiosamente, por vezes os indicadores objetivos se tornam subjetivos, à medida que se devem decidir quais dados entrarão e quais dados serão excluídos na avaliação de condições de vida, enquanto os indicadores subjetivos podem ser mais objetivos, pois as pessoas manifestam, sobre o seu ponto de vista, o que sentem em relação à vida (Diener \& Suh, 1997).

A preocupação em detectar subjetivamente o que ocorre com as pessoas surge através de evidências de que, apesar do enorme crescimento econômico registrado nos últimos 50 anos, as sociedades vêm apresentando sérios e crescentes problemas não solucionados pelo desenvolvimento (Layard, 2003): 
- Na década de 50, apenas $2 \%$ dos norte americanos apresentavam depressão aos 35 anos. Hoje, cerca de $14 \%$ registram o distúrbio, e este montante elevou-se em período de rápido crescimento econômico.

- O crescimento do uso do álcool é um indicador de infelicidade. Foi registrado na maioria dos países, o aumento do uso da bebida e cerca de $25 \%$ dos jovens norteamericanos afirmam ter experimentado problemas com o álcool. As mortes por cirrose aumentaram muito nos últimos 50 anos.

- O uso de drogas sofreu uma escalada vertiginosa e a disponibilidade crescente de novas drogas e toxinas mais potentes no mercado vêm sendo registradas em muitos países. Tudo isso no propósito de alterar o estado mental para buscar sensações de bem-estar (Kingwell, 2006).

- Estudos mundiais retratam o aumento da depressão clínica atestada. Alguns países envolvidos no estudo, apresentaram cerca de $15 \%$ da população com o quadro clínico.

Para Diener e Suh (1997) o desenvolvimento econômico é inversamente relacionado com aspectos da qualidade de vida, como tempo para o lazer ou a saúde do meio ambiente. Portanto, quanto maior a quantidade de riquezas que nossa sociedade esteja apta a produzir, isto não implicará necessariamente em qualidade de vida. A avaliação do próprio indivíduo de seu meio, fundamentado na satisfação que possui com a vida, oferece um indicador mais preciso da percepção da pessoa, de seu contexto, e, por conseqüência, um mecanismo mais preciso de avaliação, diferentemente da forma econômica, que através de inferência fundamentada nos recursos externos, classifica o padrão e qualidade de vida das pessoas.

\subsection{RENDA}

Os economistas vêem como evidente o fato de que o aumento de renda e o consumo prevêem maior utilidade, sendo que a satisfação da pessoa depende do nível absoluto de suas posses. Pesquisas na área de felicidade e bem-estar apontam para outra direção, mostrando 
que apesar do desenvolvimento econômico e aumento da renda real não houve aumento do nível de satisfação registrada (Stutzer, 2004).

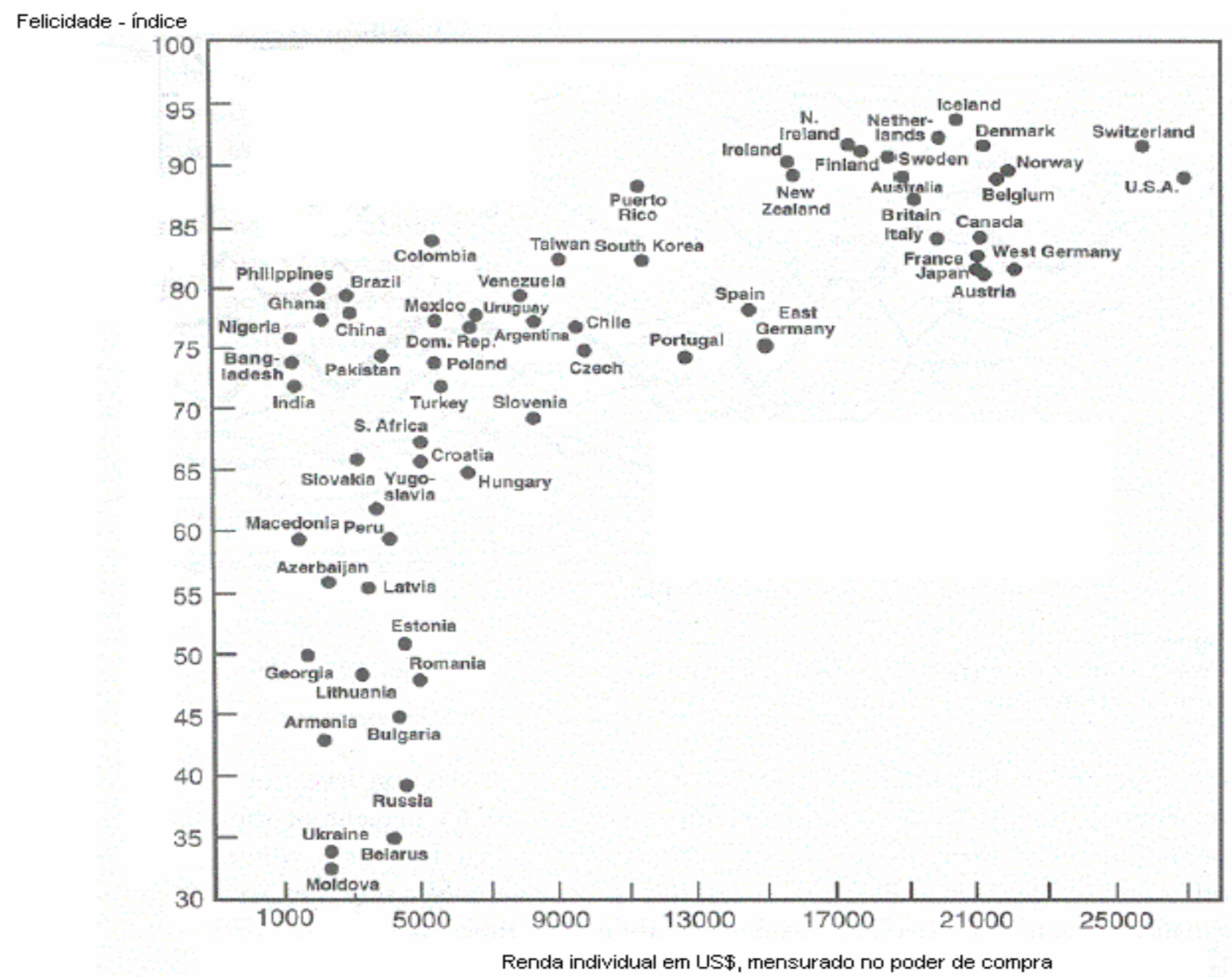

Fonte: World Values Survey. Indice de felicidade equivale ao percentual de pessoas satisfeitas com a vida

Figura 16- Felicidade e renda entre países (Layard, 2003)

Existe uma relação positiva entre renda e felicidade em países. Apesar de pessoas em países ricos reportarem maiores escores de BES do que os países pobres, e do aumento de renda real em alguns países, seus moradores não tiveram ganhos de felicidade (Diener, 1984). A influência da renda no BES pode ser relativa. O nível de felicidade mão está ligado ao nível absoluto de bens e serviços de que uma pessoa pode usufruir, mas à comodidade e benefícios que representam. Pessoas que são mais ricas do que outras tendem a serem mais felizes, 
porém, quando o nível total de renda aumenta, o nível de felicidade não sofre a mesma alteração.

A relação entre renda e felicidade parece ter uma relação próxima por uma razão muito lógica: o poder de compra oferece a satisfação de desejos. Os economistas ajudaram a popularizar este conceito à medida que relacionaram diretamente, e, de forma crescente, o consumo e a utilidade. Utilizando os dados obtidos através do GSOEP, a renda e a felicidade oferecem uma relação direta e crescente, mas este aumento na felicidade tende à estabilização, conforme na Figura 7 (Stutzer \& Frey, 2003).

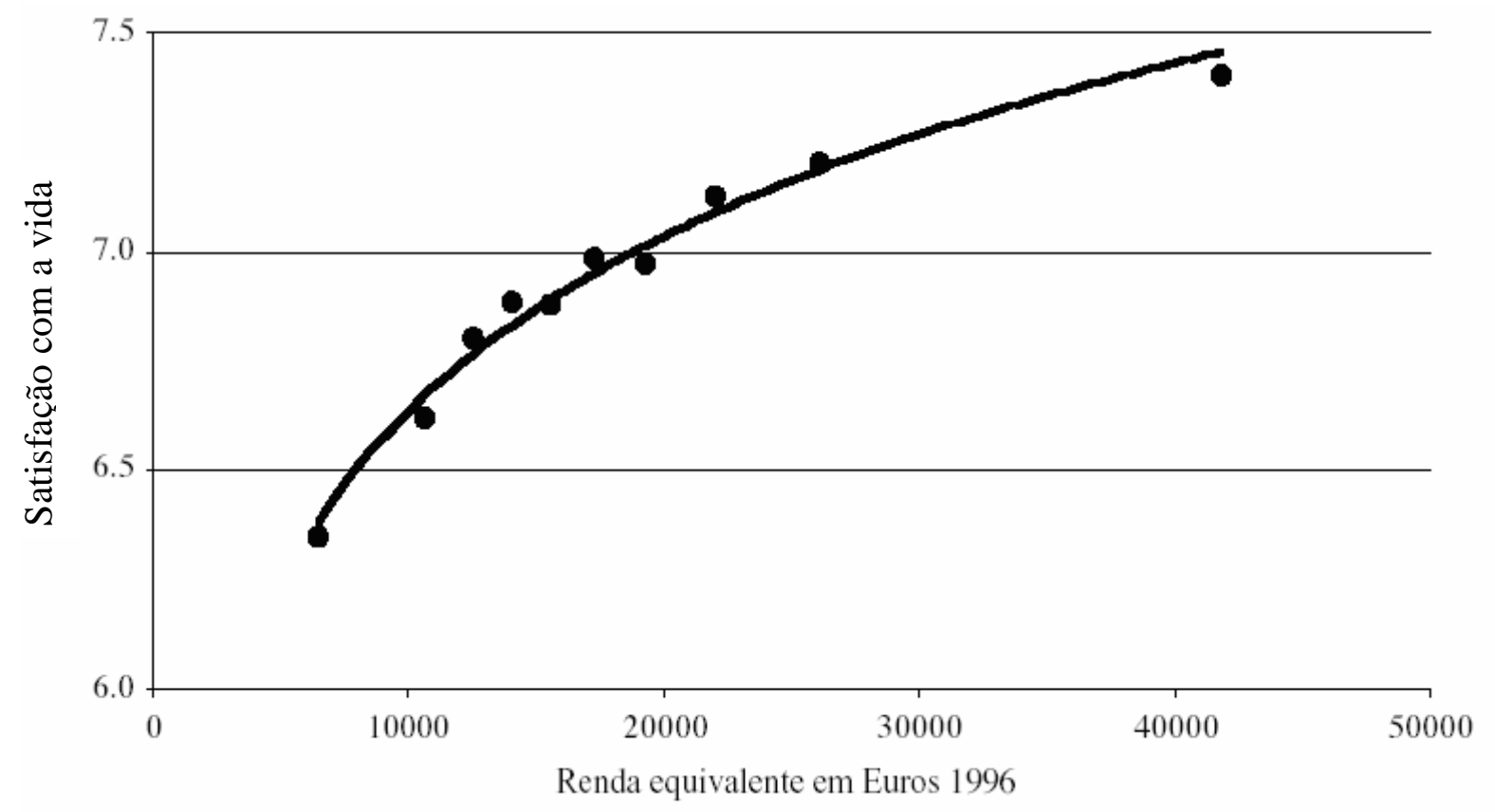

Figura 17-Satisfação com a vida e renda (Stutzer \& Frey, 2003)

Foi descrito em capítulo anterior sobre as comparações existentes entre os indivíduos, e as comparações de renda são forte parâmetro. As aspirações por renda oferecem maior nível de utilidade ${ }^{1}$ ao indivíduo e influência em sua capacidade de adaptação. Aspirações maiores, com relação à renda reduzem o ganho de felicidade obtido quando esta aumenta, reprimindo o nível de satisfação (Stutzer \& Frey, 2003). Dito de outra forma, isto representa uma

\footnotetext{
${ }^{1}$ No conceito econômico, a satisfação do indivíduo é se dá quando se consegue maximizar os escassos recursos existentes, partindo daí a aproximação entre o conceito de satisfação proveniente desta otimização e felicidade.
} 
insatisfação crônica da pessoa, que almeja novos estágios de renda, sem valorizar o bem-estar conquistado. Existem dois processos de construção destas aspirações individuais. Primeiro, não é o nível absoluto de renda que importa, mas a posição relativa em relação a outros indivíduos. Segundo, as pessoas adaptam-se ao seu novo nível de consumo ou renda. Acréscimos de bens provocam maior utilidade / felicidade, mas este efeito se estabiliza. Existe uma dinâmica entre o processo de comparação hedônica, a comparação e competição sociais e a comparação de consumo; que juntos levam os indivíduos a terem aspirações crescentes. (Stutzer \& Frey, 2003).

O mecanismo de comparação entre os indivíduos é um processo dinâmico, no qual as pessoas avaliam não somente a distância existente entre seus parâmetros, mas também a velocidade da mudança e criam expectativas com relação a esta mudança. Esta sistemática de comparações leva a pessoa a se sentir vencedora ou perdedora (Hayo \& Seifert, 2002).

Arthaud-Dar e Near (2005) propuseram um modelo que envolve a cultura e os diferentes papéis da renda para o indivíduo e o impacto no BES. Há quatro níveis de riqueza os quais se pode considerar, e em cada um os parâmetros de avaliação são guiados pelos parâmetros culturais em questão: no primeiro, a renda de subsistência, na qual a satisfação das necessidades básicas leva ao bem-estar através do atendimento de demandas fundamentais como comida e vestimenta. Em um segundo estágio, na alteração da renda para níveis maiores, leva a uma adaptação, impactando o BES em um primeiro momento, mas ao longo do tempo este ganho de felicidade é perdido, fruto deste processo de adaptação. O que leva ao terceiro estágio, que consiste na renda relativa, oriunda da comparação social, que pode ter um efeito depressor no BES. A renda desejada, quando alcançada, proporciona a satisfação derivada do objetivo cumprido, que no modelo existe a indicação de uma retro alimentação (Figura 8), isto é, o bem-estar relaciona-se com o desempenho em alcançar objetivos, que por sua vez produz um impacto no nível de felicidade. 


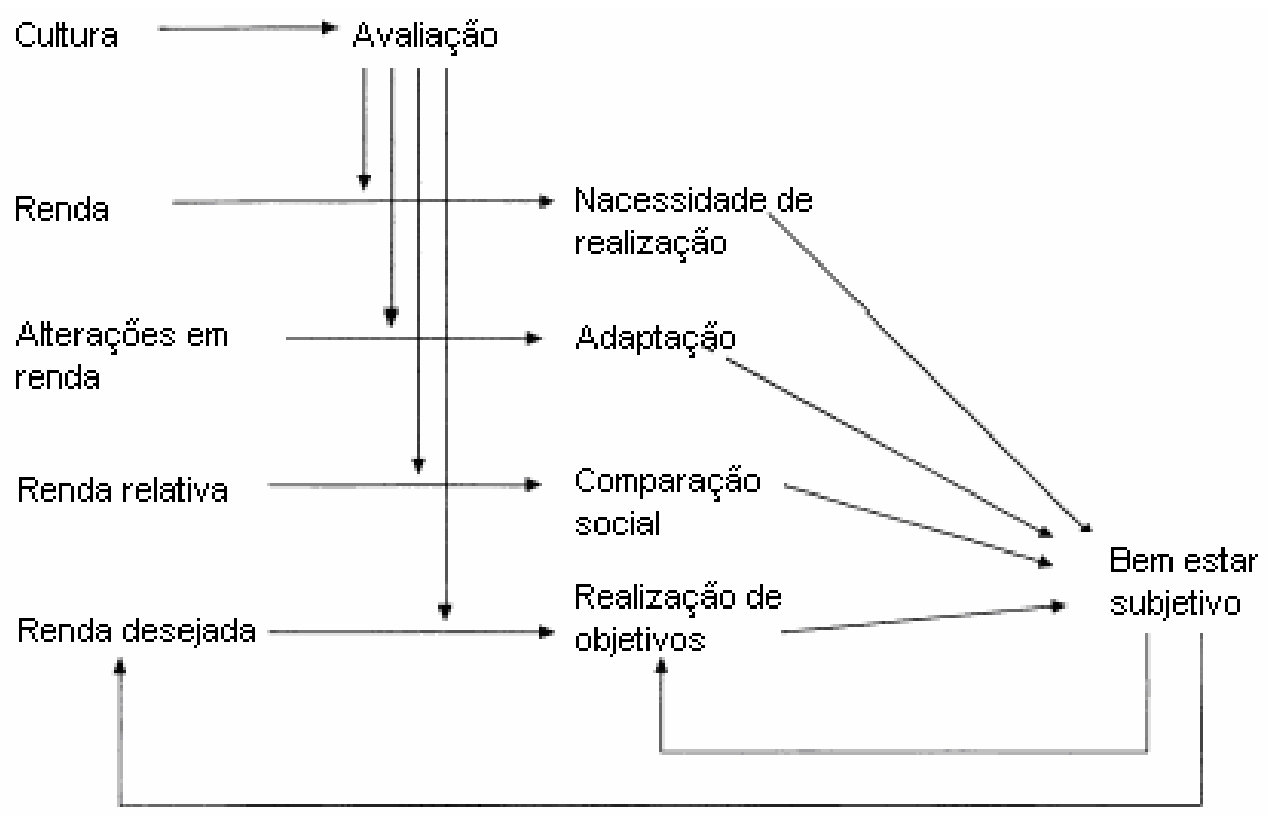

Figura 18- Cultura, renda e BES (Arthaud-Dar \& Near, 2005)

Esta relação existente entre felicidade e aspirações individuais são objetos de estudo entre economistas e psicólogos, a fim de compreender o impacto existente na felicidade individual. Os bens e serviços extras conseguidos com o diferencial de renda, ao longo do tempo, têm seus benefícios atenuados a ponto de desaparecerem por completo. Isto leva a um novo processo de comparação, via estímulos de consumo, levando às novas aspirações (Stutzer, 2004), criando um ciclo. Stutzer (2004) afirma que as pessoas não são capazes de fazer avaliações absolutas. Elas necessitam de referenciais, como outras pessoas, situações passadas ou expectativas de futuro, para construir seus níveis de aspirações.

Stutzer (2004) descreve um paradoxo da felicidade: enquanto pessoas com maiores rendas apresentam, na média, maior satisfação com a vida, o aumento generalizado de renda não oferece o aumento do nível de felicidade. As aspirações também sofrem um incremento conjugado a esta elevação real de renda, de modo que estas comparações são realizadas em patamares mais elevados. 
As aspirações por renda podem ser um mecanismo depreciador da felicidade. Quanto maior a distância existente entre o nível presente e a aspiração desejada, tanto menor será o nível de satisfação com a vida da pessoa (Stutzer, 2004). Nickerson, Scwarz, Diener e Kahneman (2003) mostram o lado sombrio do sonho americano. As aspirações e os objetivos possuem consequiências negativas psicológicas como depressão, ansiedade, queda de autoestima, insatisfação com a vida, pois o ter, ao invés do ser, distancia o indivíduo de aspectos significativos da vida. Os autores afirmam que, quanto maior o desejo por sucesso financeiro, menor o total de satisfação com a vida registrada.

A renda em si pode ser um fator limitador do BES, enquanto fonte externa de viabilização. Isto significa dizer que um indivíduo que não tenha recursos para participar do convívio social ou quaisquer atividades que lhe proporcionem satisfação, sem poder arcarem com os gastos necessários, ainda que mínimos como transportes ou qualquer outra despesa podem infringir uma queda em seu nível de satisfação com a vida (Cummins, 2000). Assim, a pobreza pode produzir vulnerabilidade direta ou indireta com prejuízo da realização pessoal. Privações de alimentação adequada ou serviços médicos influenciam diretamente o acesso às condições mínimas de qualidade de vida; indiretamente, age a distância existente entre as características internas do indivíduo (que define suas carências e necessidades) e os recursos externos disponíveis para lidar melhor com as dificuldades existentes, como doenças ou incapacidades (Smith, Langa, Kabeto, \& Ube, 2005). O dinheiro pode prejudicar a felicidade, quando considerados os fatores de segunda ordem, apresentados na Figura 2 do Capítulo 2: auto-estima, controle e otimismo. Indivíduos que não valorizam tanto o aspecto financeiro conseguem derivar um significado de vida diferente, diminuindo o impacto das circunstancias materiais, como por exemplo, os religiosos (Cummins, 2000), que conseguem imprimir em suas vidas significado mais intrínsecos. 
Apesar de a renda ter o aspecto proporcionar recursos para que os indivíduos operem com suas dificuldades cotidianas, ela estatisticamente explica uma pequena porção da variância existente nos níveis de felicidade (Stutzer, 2002).

\subsection{FELICIDADE E O CONSUMO}

Temos um senso que direciona nossas ações e nossas escolhas. Entre as diversas oportunidades existentes no mundo moderno, optamos por aquelas que achamos mais adequadas. Conforme citado por Layard (2003), se uma pessoa possui preferência por A a B, porém o custo de escolha de $\mathrm{A}$ aumenta em relação a $\mathrm{B}$, a tendência de escolher o primeiro é menor. Este é o mecanismo de processo de escolha no mercado.

O consumo é uma forma de identidade, que demarca classes sociais, forma subculturas que compartilham dada prática de consumo similar, define códigos culturais que são transmitidos através dele. Pela ideologia do consumo, que associa as posses materiais com felicidade, consumidores são dirigidos a acumular e organizar suas vidas em função de aquisição de bens materiais (Kilbourne, 2005).

O ciclo de formação de aspirações possui um forte aspecto no consumo. Aumento de renda se traduz em aumento de consumo, e este aspecto hedônico da felicidade conjugado com a capacidade adaptativa dos indivíduos, faz com que novas aspirações se configurem (Stutzer, 2004).

Os indicadores de felicidade, desde a década de 50, não apresentam nenhuma melhora no nível de felicidade, apesar da crescente riqueza registrada. A motivação, impulsionada pelas aspirações construídas por renda e consumo futuro, faz com que o indivíduo caia na armadilha hedônica, anteriormente citada, que move as pessoas neste mecanismo de comparação e desejos dos últimos 50 anos, porém sem obter resultado significativo em relação à satisfação com suas vidas. Layard (2003) oferece uma explicação para esta situação. Ele pergunta: qual foi o evento pós-guerra que levou as pessoas, apesar da crescente riqueza 
registrada, a terem os níveis de satisfação estáticos? A chegada da TV, para ele, teve um papel muito importante neste cenário. As pessoas, que até então realizavam suas comparações com seus pares, começaram a ter outros referenciais. A TV difere dos outros meios de comunicação nos seguintes sentidos: primeiro, sua forma imediata de exposição; segundo pelo longo tempo de exposição a que as pessoas se submetem (Layard, 2003). Pesquisas afirmam que a média de exposição das pessoas à televisão é de 25 horas semanais, isto é, mais do que um dia por semana se perde em frente ao televisor. Um Britânico típico passa mais tempo assistindo TV do que trabalhando. Na Europa, o tempo médio diário que se passa vendo-se TV é de cerca de 2 horas (Layard, 2003).

A TV foi introduzida nos EUA, em diversos estados, na década de 50, em diferentes épocas. Pesquisas atestam que no ano de chegada da TV, os furtos aumentaram em 5\% (Layard, 2003). A TV oferece comparação a todo o momento. Estudo de Kenrick (1993, conforme Layard, 2003) mostra experimentos junto a mulheres, às quais foram mostrados quadros de lindas modelos. O autor avaliou o humor, antes e depois disso, e constatou que o humor caiu após a exposição às figuras. Ele levou o mesmo experimento aos homens, que avaliados após um tempo de exposição às fotos, começaram a avaliar seus sentimentos com relação a suas esposas (Layard, 2003). De acordo com Buss (2000), os meios de comunicação em massa nos tornam grupos competitivos a ponto de destruir elos sociais íntimos.

O materialismo e suas implicações datam dos filósofos gregos, como Pitágoras, que exigia que seus estudantes renunciassem a seus bens pessoais, antes que entrassem em sua escola (Kilbourne, 2005). Existem relações entre o materialismo, o BES e a qualidade de vida das pessoas. Sirgy (1998, conforme Nickerson Schwarz, Diener, \& Kahneman 2003), define materialismo como a variável que reflete a importância maior dada na aquisição e posse de renda, riqueza e bens materiais. Esta característica é tida por alguns pesquisadores, como Belk (1984 e 1985, conforme Nickerson, Schwarz, Diener \& Kahneman, 2003), como um traço e, 
compreende três características: pocessividade, falta de generosidade e inveja, características inversamente relacionadas com felicidade. Para Tatzel (2001), o materialismo constitui valores culturais, que possuem três componentes: aquisição, como aspecto central de vida; aquisição, como caminho para a felicidade e o sucesso da vida, definido pelas posses.

As pessoas são movidas por comparações e estas comparações levam às aspirações, que por sua vez conduzem os indivíduos ao consumo. A relação da pessoa com o dinheiro e seu comportamento de gasto - consideradas variáveis de personalidade, cultura e prosperidade econômica - possui implicações tanto para a saúde mental, quanto para o nível de bem-estar e satisfação com a vida. Atitudes com o dinheiro, valores materiais e comportamentos com preços abrangem respectivamente os aspectos cognitivos, emocionais e comportamentais da experiência da pessoa com o consumo (Tatzel, 2001). Estas experiências estão pautadas em relações de abundância e escassez de recursos e gastos.

O materialismo possui uma orientação externa e nem todas as pessoas valorizam este aspecto. A busca pelo status e a visibilidade social são elementos que orientam o consumo de pessoas materialistas, optando estas por produtos/ serviços que possam fornecer esta diferenciação social. A situação de compra é a junção da razão e dos valores materiais individuais, resultando em determinados comportamentos com relação a preços. Indivíduos cautelosos, quanto a seus recursos, possuem uma relação negativa com preços, e valores altos podem ser um inibidor de compra. Para pessoas gastadoras o alto valor pode ser um indutor a gastos, tendo uma relação positiva com relação ao preço (Tatzel, 2001).

As pessoas materialistas tendem a possuir menores níveis de suporte social, pois têm menos relacionamentos, se comparados aos menos materialistas, o que tende a influenciar os níveis de satisfação com a vida (Christopher, Kuo, Abraham, Leonard \& Linz, 2004). Conforme dito, existem dois objetivos para os quais se podem dirigir: intrínsecos ou extrínsecos. A felicidade está ligada à busca dos valores intrínsecos, e estudos afirmam que 
os materialistas são psicologicamente menos saudáveis, em face das motivações extrínsecas (Kasser, 2000). Prioridades traçadas em função da expectativa de quanto iremos nos adaptar a determinadas experiências ou bens irão orientar nossas opções de consumo. Um indivíduo pode optar por trabalhar todos os sábados a fim de comprar um carro $30 \%$ mais caro, em detrimento de estar com a família ou amigos, atribuindo mais satisfação ao bem do que ao suporte social fornecido pelos entes próximos, construindo dessa forma alternativas as quais espera potencializarem seu bem-estar (Frank, 1997). As necessidades intrínsecas, como o crescimento pessoal, relacionamentos satisfatórios e participação comunitária são mais satisfatórios para os indivíduos do que as necessidades extrínsecas, como reconhecimento social (Oishi, Diener, \& Suh, 1999). A satisfação global do indivíduo está relacionada com os valores adotados por ele, influenciado pela cultura onde vive. Estes valores que se encontram salientes no momento da avaliação contribuem para a configuração do nível total de satisfação com a vida (Oishi, Diener, \& Suh, 1999).

Os fatores descritos que movem as pessoas a entrarem em uma dinâmica de consumo, na busca do bem-estar perdido pelas diferenças sociais e resultantes das comparações e aspirações, leva a um mecanismo perverso na economia que pode ser um depressor ainda maior dos níveis de satisfação com a vida. A competitividade econômica, sustentada pelo consumo e pela produção necessária para atendê-lo, impõe custos substanciais à sociedade, como o comprometimento ambiental, fazendo com que este crescimento econômico seja um fator que leva à redução da felicidade das pessoas $(\mathrm{Ng}, 1997)$. A avaliação e monitoramentos dos níveis de felicidade podem oferecer o quão rápido a satisfação com a vida das pessoas é consumida por esta escalada de consumo e produção.

Para Ott (2001), o desenvolvimento da economia de mercado tem colocado os relacionamentos pessoais sob pressão, através da competitividade, individualismo e resultando na menor coesão familiar; assim levam os contatos sociais a serem mais 
instrumentais, racionais e comerciais. Considerando que altos níveis de suporte social são associados com altos níveis de satisfação com a vida (Lyubomirsky, 2001), esta configuração das relações leva à depressão e a perdas no nível de felicidade, tornando as pessoas mais vulneráveis ao estresse e a condições psicológicas adversas. A economia de mercado está deprimindo o nível de felicidade em vários países do mundo (Ott, 2001), e o conceito cultural de que a riqueza e o crescimento econômico oferecem maiores níveis de felicidade, propagados pelos modelos econômicos até agora vigentes, levam o indivíduo a procurar pela riqueza material em detrimento de outros aspectos importantes da vida.

\subsection{DESEMPREGO}

O afeto positivo, afeto negativo e satisfação com a vida são variáveis moderadamente estáveis, oscilando levemente, alterando somente mediante eventos maiores de vida. Isto leva a crer que o BES possui um patamar que é determinado por fatores de personalidade, porém este nível pode sofrer pressões que o levam a oscilar. Mediante um mecanismo de adaptação, o indivíduo tende a retornar aos níveis anteriormente registrados (Lucas, Clark, Georgellis \& Diener, 2004).

O desemprego possui um forte impacto na felicidade dos indivíduos. Os desempregados demonstram um nível menor de felicidade do que os empregados. Pessoas que em algum período de suas vidas sofreram o desemprego tendem a ter menor satisfação com a vida, do que aqueles que nunca foram desempregados (Lucas, Clark, Georgellis \& Diener 2004).

Em estudo longitudinal, conduzido junto a 24.000 respondentes que participaram de pelo menos 1 das 15 "ondas" do GSEP (German Socio - Economic Panel Study), 5.184 afirmaram estar desempregados em pelo menos 1 das 15 coletas consideradas (Lucas e colaboradores, 2004). Neste estudo, indivíduos com maiores renda registraram maiores níveis de satisfação do que aqueles com menores rendas. Pessoas que, em algum momento, 
experenciaram o desemprego registraram menores níveis de satisfação do que aqueles que nunca estiveram desempregados, o que leva a crer que a adaptação ao desemprego é um acontecimento que ocorre com certa dificuldade. As pessoas que, no início do estudo, apresentaram menores níveis de satisfação com a vida, ao estarem desempregadas, mostraram-se menos ativas no combate à situação. As mulheres, no estudo, registraram reações negativas menores do que os homens. Nesta pesquisa, contrária à teoria do ponto-fixo de felicidade, as pessoas não retornaram aos seus níveis anteriores de felicidade, após um longo período de desemprego. Este fato permanece mesmo após o controle da renda, o que demonstra que a falta de adaptação não se deve apenas a problemas econômicos. Esta pesquisa demonstrou que o desemprego parece criar um novo patamar de satisfação, inferior aos níveis registrados anteriormente em que indivíduos com rendas maiores tendem a possuir um padrão de adaptação menos negativo do que pessoas com rendas menores. A reincidência ao desemprego mostrou uma capacidade de adaptação ainda mais difícil. Os indivíduos com maiores níveis de satisfação, no início da pesquisa, reagiram de forma mais positiva a momentos de desemprego e estiveram mais propensos a retornar aos níveis anteriores de satisfação do que aqueles que possuíam menores níveis de BES.

Pessoas com diferentes características sócio-demográficas são atingidas de diferentes maneiras pelo desemprego. Jovens e velhos registram menores queda no bem-estar do que pessoas de meia idade. Indivíduos com maior educação sofrem uma maior redução do nível de BES do que empregados com baixa educação (Frey, 2002).

Frey e Stutzer (2002) afirmam que, apesar de haver correlação entre desemprego e BES, talvez as causas ocorram em sentido contrário: pessoas infelizes não possuem um bom desempenho e tendem a desistir, enquanto as pessoas felizes procuram ser mais ajustadas à vida profissional, o que as torna menos sujeitas a perderem seus empregos. Esta é uma relação que deve ser vista com certa cautela. A renda não possui um papel importante no BES, porém 
o desemprego, sim. Um estudo sobre saúde mental, junto a desempregados, mostrou que o estresse mental destes é duas vezes maior do que alguém que possui emprego (Oswald, 1997).

Em estudo em 12 países europeus, encontrou-se que - mantendo-se todas as influências constantes - a cada ponto de aumento na taxa geral de desemprego, há uma queda de 0,028 unidades no escore geral de felicidade, em uma escala de 4 pontos. Isto implica em $2 \%$ da população rever seu conceito de "não muito satisfeito com a vida" para "totalmente insatisfeito com a vida" (Frey \& Stutzer, 2002). Desempregados tendem a se associar com indivíduos em iguais situações, devido ao tempo disponível existente. Há o risco do rompimento de relacionamentos, sobretudo o casamento, quando um dos parceiros está desempregado.

Os estados de infelicidade derivados do desemprego devem-se aos seguintes fatores (Stutzer \& Frey, 2003):

- A perda do emprego pode produzir depressão e ansiedade, assim como a perda de controle pessoal.

- O desemprego leva à redução da auto-estima.

- O emprego regular leva a um trabalho diário estruturado e proporciona contatos externos e suporte social complementar ao familiar. Em contraste, estar desempregado acompanha um estigma social em uma sociedade onde o trabalho define a posição e o status social.

O nível de queda do BES em situações de desemprego está relacionado com a norma social para o trabalho. A interação com outros membros da sociedade e o não conformismo em face da situação possui o efeito de um estímulo à ação, levando o desempregado a enfrentar a situação (Stutzer \& Frey, 2003). Isto significa dizer que algumas sociedades possuem menor aceitação da condição de desemprego, o que faz com que nestes casos a pessoa desempregada sinta-se mais desconfortável e procure a reversão desta condição o mais 
rápido possível. Em outras sociedades existe maior aceitação, muitas vezes fruto de cenário macroeconômico onde esta situação assola uma grande quantidade de pessoas.

Existe um fator a ser considerado com relação ao desemprego: deve haver um contingente regulador de mão de obra, pois o pleno emprego é inflacionário. A falta de oferta de mão de obra eleva o valor deste recurso, que por sua vez é repassado aos preços. Por sua vez, a inflação também possui impacto no nível de satisfação com a vida de maneira negativa. Em estudo realizado, o aumento de 1 ponto no desemprego resulta na queda de 0,01 unidade no escore de felicidade e o aumento da inflação em 5 pontos percentuais (fato com que historicamente o Brasil conviveu durante muito tempo), há uma queda em 0,05 unidades nos escores de felicidade (Stutzer \& Frey, 2003). Isto é um efeito substancial, pois leva a 5\% da população a alterar sua classificação de "muito satisfeito" para "razoavelmente satisfeito", isto em uma escala de 4 pontos, classificam-se 1 ponto abaixo. $\mathrm{O}$ estudo conduz a uma questão: o quanto um país deve reduzir sua inflação a ponto de permitir o aumento de um ponto percentual em sua taxa de desemprego? Os economistas normalmente tendem a operar estas duas variáveis sem considerarem o impacto que possuem em uma terceira variável igualmente importante: a felicidade, que possui relação com os dois fatores. Pode-se, portanto, considerar que a mensuração do nível do BES das pessoas demonstra o bom ajuste entre as duas variáveis, em um cenário macroeconômico.

\subsection{DEMOCRACIA}

A pessoa é influenciada pelo sistema político em que vive, e aquelas que vivem em uma democracia mostram ser mais felizes (Frey \& Stutzer, 2004). Três fatores importantes na democracia levam a esta afirmação:

- Liberdade política: a possibilidade dos cidadãos engajarem-se no processo democrático, através da participação política; 
- Liberdade econômica: a oportunidade de indivíduos realizarem livre troca de bens, serviços e trabalho;

- Liberdade pessoal: a liberdade de uma pessoa em sua vida privada.

Os fatores acima listados são relacionados estatisticamente com a felicidade (Veenhoven 2000, conforme Frey \& Stutzer, 2003). O processo participativo das pessoas, através de eleições, referendos e consultas populares, proporciona a interação destas com os destinos públicos (Frey \& Stutzer, 2000), de forma a orientar o caminho desejado, pela maioria, para o país. Uma pesquisa realizada na Suíça, entre cidadãos votantes e estrangeiros, sem direito a voto, mostrou que o processo participativo ofereceu maior satisfação ao primeiro grupo do que ao segundo (Frey \& Stutzer, 2004).

Ao considerarmos que variáveis econômicas possuem impacto na felicidade (inflação e desemprego), o bem-estar proveniente destas variáveis irá influenciar na aceitação do governante. De acordo com pesquisas, o aumento do desemprego em um ponto percentual resulta na queda de popularidade do governo entre 0,4 a 0,8 pontos percentuais (Frey e Stutzer, 2000), tendo também impacto no nível de felicidade, conforme descrito, levando as pessoas a terem avaliações com a vida menos favoráveis e esta insatisfação possui influências em um processo eleitoral. 


\section{6- BES E ORGANIZAÇÕES}

A maioria dos homens e mulheres passa grande parte de suas vidas no trabalho. Considerando 7 a 8 horas por dia, 5 dias por semana, dos 18 aos 65 anos, totalizamos cerca de 100.000 horas no trabalho (Argyle, 1985). Esta relação que possuímos com nossa vida profissional pode ser uma grande fonte de felicidade ou de infelicidade, dependendo de como esta relação for estabelecida. Em outras palavras, é através dele que definimos quem somos e quem identificamos como comunidade; formatamos nosso senso de relações sociais, muitas vezes fundamentado pelos elos profissionais de parceiros que integram uma mesma equipe, direcionada a objetivos comuns e em profissões convergentes, configurando, assim, o senso de orgulho e a forma de se pertencer a um grupo, que auxilia a construir a identidade social de cada um (Myers, 1992).

Wrzesniewski, McCauley, Rozin, \& Schwartz (1997) mostraram a relação que as pessoas possuem com seus trabalhos, que foram divididas em empregos, carreiras e vocações. Aqueles que vêem seus trabalhos como empregos estão apenas interessadas no benefício material do trabalho e não procuram e nem recebem qualquer recompensa dele. $\mathrm{O}$ trabalho não é um fim, mas um meio de ter prazeres fora do emprego. Quando existe o foco na carreira, as pessoas realizam um profundo investimento em suas profissões e os resultados são aferidos pelo retorno financeiro, assim como pelo sucesso no avanço na estrutura organizacional. Por fim, há a vocação. Neste contexto as pessoas acham seus trabalhos inseparáveis de suas vidas, envolvendo-se de forma prazerosa em suas atividades.

Em um estudo (Wright \& Burnett, 1993 conforme Wright e colaboradores 2004) objetivando avaliar a relação entre bem-estar subjetivo e desempenho no trabalho, realizou-se junto ao pessoal de nível gerencial sênior de uma organização a avaliação de desempenho de seus subordinados, pautados em duas dimensões: ênfase nos objetivos e facilitação do trabalho. Foi também acrescido um item de desempenho total. Foram ministrados também 
instrumentos psicológicos de avaliação de afeto positivo, afeto negativo e o Índice de Bemestar Psicológico. As análises demonstraram relações positivas tanto do bem-estar como do afeto negativo no desempenho, sendo o primeiro relacionado positivamente e o segundo negativamente. As emoções positivas nos ajudam a construir recursos sociais e materiais, e nos auxiliam a aprender comportamentos para o futuro. Elas acontecem quando tudo está indo bem e quando temos tempo para nos engajar em ações que nos beneficiarão mais tarde. (Diener, Scollon \& Lucas, 2003).

O bem-estar subjetivo dos funcionários é mais do que uma questão de saúde, que ocasionam faltas e prejuízos a empresas e ao sistema de saúde. O BES possui um impacto positivo na organização e sobre tudo no botton line (resultado final) das organizações. Empresas onde existem níveis maiores de bem-estar entre seus integrantes, apresentam maior lucratividade, satisfação e lealdade do cliente, maiores taxas de retenção, melhor assistência a funcionários e maiores níveis de produtividade (Keyes, Hysom \& Lupo, 2000). Quando existe uma liderança legitima, apta a exercer uma influência competente e confiante, criando relações que resultem em sentimentos positivos, os resultados citados são melhor alcançados, conforme modelo representado na Figura 9 (Keyes, Hysom \& Lupo, 2000).

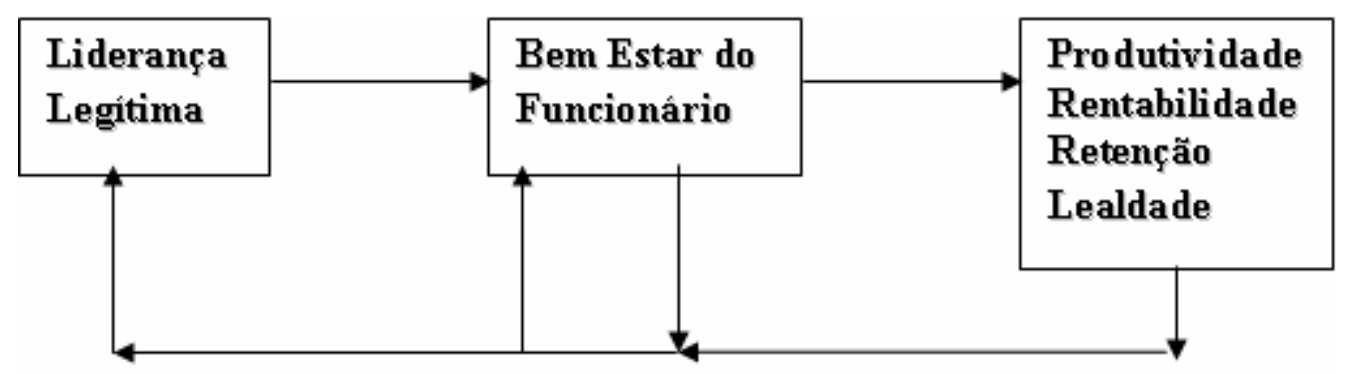

Figura 19- BES e liderança nas organizações ( Keyes, Hysom \& Lupo, 2000)

As emoções positivas induzem um sentimento solidário. Pessoas que trabalham em um departamento comercial, por exemplo, acabam por atuar de maneira mais conjunta com seus clientes, quando estão guiados por este tipo de afeto (Fredrickson, 2004). As emoções 
positivas conseguem "reverberar", contagiando outras pessoas, uma vez que as expressões e feedback faciais podem transmitir emoções positivas com quem estamos interagindo (Fredrickson, 2004).

A psicologia nos últimos anos tem focado seus estudos nos aspectos negativos da vida, conforme mencionado. A psicologia organizacional acompanhou o mesmo caminho. A união dos negócios com a psicologia data da década de 20. Nesta ocasião foram desenvolvidos estudos sobre o aumento de vendas decorrente de uma "melhor" propaganda. Para divulgar um determinado medicamento, foram realizados 5 anúncios diferentes, sendo que alguns relatavam a importância da boa saúde e faziam apelos à sua preservação, enquanto que outras amedrontavam as pessoas quanto às tristes e onerosas conseqüências das doenças. As primeiras "peças publicitárias", com conotação mais positiva quase não trouxeram retorno de vendas, mas as segundas, apresentando um aspecto mais negativo, registraram o aumento de vendas em $171 \%$ (Wright \& Cropanzano, 2004). As avaliações funcionais seguem também um critério negativo do comportamento do funcionário, focando mais suas faltas do que suas qualidades e virtudes. (Wright \& Cropanzano, 2004). Com o surgimento da Psicologia Positiva, novas fronteiras na área da gestão estão se abrindo, em que os estudiosos de forma multidisciplinar procuram compreender a relação das qualidades e virtudes humanas com seu desempenho profissional.

Recentemente, na Universidade de Michigan, surgiu uma linha de estudo denominada Positive Organizational Scholarship (POS), que tem por objetivo compreender de uma forma diferenciada a dinâmica que existe em uma organização que produz resultados através das emoções positivas (uma das bases da felicidade) de seus integrantes, como alegria, contentamento, orgulho, gratidão, entre outras (Fredrickson, 2003). Em outras palavras, como as organizações podem ser desenvolvidas baseadas nas características positivas das pessoas, suas forças e virtudes. As emoções positivas oferecem um funcionamento ótimo do indivíduo 
(Fredrickson, 2003), o que fornece uma calibragem comportamental muito importante aos processos existentes na organização. POS investiga a maneira pela qual a organização e seus membros florescem e prosperam em uma forma favorável, estudando os resultados positivos e a maneira de a eles chegar (Cameron, 2004).

A felicidade, em seu aspecto de satisfação geral com a vida, é um indicador de desempenho na empresa. Em pesquisa realizada junto a alunos de MBA, os participantes com maior nível de BES demonstraram ser superiores em tomadas de decisões, apresentaram melhor comportamento interpessoal e foram mais bem avaliados em seus desempenhos e performances, além de terem melhores salários (Wright \& Cropanzano, 2004). Em outro estudo longitudinal, o BES foi prognóstico de desempenho de supervisores com alguns anos de antecedência (Wright, Cropanzano \& Meyer, 2004). A correlação entre felicidade e desempenho no trabalho é de 0,3 a 0,50, o que significa que existe um percentual entre $10 \%$ a 20\% do bom desempenho explicados pelo nível de BES do indivíduo (Wright \& Cropanzano, 2004)

Os comportamentos baseados no afeto positivo conduzem a uma melhor clareza e compreensão dos objetivos da organização. Isto leva a uma melhor utilização dos recursos de forma congruente a estes objetivos e o resultado é o maior contentamento do indivíduo no trabalho, o fortalecimento do senso de solidariedade e o aprendizado de que existe uma missão compartilhada entre as pessoas da organização (Harter, 2003). Isto eleva o bem-estar a uma importância estratégica dentro das empresas.

Existem diferenças individuais que são fatores que podem resultar em níveis diferentes de felicidade, e por vezes devemos buscar não deprimir o nível existente de bem-estar, se não for possível promovê-lo. Portanto, as características individuais marcadas pelos traços pessoais devem ser respeitadas e bem aproveitadas, através da convergência destas com a função a ser desempenhada. A felicidade não deve ser um critério de discriminação, mas de 
alocação eficiente dos recursos humanos. Seligman (2002) mostrou que os advogados possuem níveis menores de felicidade, em virtude da necessidade de suas profissões de prevenirem aspectos negativos potencialmente prejudiciais. Pessoas mais críticas com relação à vida podem exercer atividades de controle, como tesouraria ou jurídico, enquanto que indivíduos mais extrovertidos devem integrar áreas como comercial ou atendimento ao cliente da organização.

É possível então procurar difundir felicidade a toda a organização, de maneira que se tenham funcionários dispostos e felizes e os problemas de produtividade e rotatividade acabem? Não é bem assim. De um lado, onde grande parte dos trabalhos é repetitiva e existem prazos e metas a ser cumpridos, há problemas de supervisões inaptas, tanto no campo estratégico como interpessoal. De outro lado, as bases em que é construída a satisfação são particulares a cada um e para uma organização gerenciar este mecanismo é algo, por vezes, fora de seu escopo. Portanto, gerenciar a insatisfação e procurar minimizá-la é por vezes mais viável do que buscar promover a satisfação no trabalho (Crow, 1995).

Conforme visto, a felicidade possui em grande parte sua variância explicada por fatores disposicionais. E estes fatores levam à satisfação com o emprego. Diversos estudos, citados em Lounsbury, Loveland, Sundstrom, Gibson, Drost e Hamrick (2003), mostram que fatores de personalidade estão relacionados com a satisfação com a carreira do indivíduo, sendo que a extroversão relacionada positivamente e o neuroticismo relacionado inversamente.

Em um estudo de atitudes com o dinheiro e satisfação salarial, encontrou-se que aqueles que colocam uma alta prioridade no sucesso financeiro tendem a ser insatisfeitos com seu salário e seu emprego (Tatzel, 2003). Dessa maneira, o trabalho demonstra ser muito mais do que uma fonte de recursos, mas a aplicação de talentos e habilidades individuais em tarefas profissionais. A convergência das habilidades e competências individuais com a atividade 
profissional exercida possui importante papel na condução do BES, pois se o desafio está aquém destas habilidades, o indivíduo apresenta tédio, devido à sua facilidade; se está além de suas capacidades, se faz presente a frustração e o desânimo pela dificuldade da empreitada; porém, existindo a sintonia entre a atividade e capacidade, o indivíduo mergulha em um estado de absorção, envolvido pela tarefa (Csikszentmihalyi \& Csikszentmihalyi, 1988).

O trabalho pode ser uma fonte de felicidade, se considerar que, em uma primeira instância, ele proporciona a satisfação de demandas fundamentais da vida, como alimentação e abrigo. À medida que se registra evolução, ele oferece novos objetivos a serem alcançados, através do exercício de habilidades e competências individuais, o que leva à felicidade. Dessa forma, o trabalho passa a transitar por todas as características vistas anteriormente que envolvem a felicidade. 


\section{7- MENSURAÇÃO DO BES}

Há uma questão que ecoa em diversas pesquisas: pode a felicidade ser mensurada? Se novamente verificarmos o Quadro 2, devemos observar que estamos tratando de felicidade, enquanto satisfação global quanto à vida. Neste contexto a felicidade é tanto um estado como traço mental e como tal pode ser mensurado. Existem, contudo, suas limitações. A primeira é quanto à utilização do auto-relato como forma de medida. Algumas pessoas podem não ser capazes de enxergar suas vidas em um sentido mais amplo, ou manifestarem mais um estado desejado do que real, o que pode distorcer os escores fornecidos. Por isso, acessar o BES através de mecanismos indiretos pode oferecer uma maior validade ao instrumento (Veenhoven, 2004).

Há diversas pesquisas que utilizam diferentes tipos de escalas para a mensuração da felicidade. Existem escalam mais extensas, mais compactas e escalas de um único item. Para Diener, (1984) apesar da brevidade e da funcionalidade desta última, não é possível estimar sua consistência interna. Para ele, a fidedignidade que pode ser calculada é a estabilidade temporal, através do re-teste, verificando a confiabilidade da medida. As escalas de itens únicos tendem a ser menos confiáveis, ao longo do tempo, do que as escalas múltiplas; apesar disso, sua fidedignidade temporal tende a ser relativamente alta. O tipo de escala a ser utilizada deve, então, ser em função do tempo disponível para a coleta (Diener 1984).

Em estudo realizado por Diener e colaboradores (2003), foram encontradas correlações entre 0,73 a 0,89 com escalas de múltiplos itens, acessados por diversas vezes em um período de três meses, que demonstra ser a escala de item único relativamente estável ao longo do tempo. Este tipo de escala oferece mensurações rápidas e fáceis, sendo também sensíveis em captar de maneira geral a satisfação com a vida do respondente, com níveis aceitáveis de validade e fidedignidade. Contudo não fornece um quadro completo, e quando possível devem ser acompanhadas de mensurações adicionais (Diener e colaboradores, 2003). 
Se considerarmos que o bem-estar subjetivo possui mais do que uma dimensão, o problema com o item único, de acordo com Diener (1984), é sua inabilidade em acessar separadamente as várias dimensões do bem-estar subjetivo.

A utilização de escalas com múltiplos itens oferece algumas vantagens. A primeira é a redução dos erros quanto a interpretações diferentes de palavras-chaves. A segunda é que acessar de forma indireta, ignorando o respondente o assunto a ser acessado, pode oferecer menor influência de tendências nas avaliações, apesar de que a felicidade é um conceito bem definido para algumas pessoas, e acessar o construto de maneira direta pode oferecer uma maior precisão na avaliação (Veenhoven, 2004).

A fidedignidade registrada em pesquisas tem demonstrado que as respostas são afetadas por variações menores na composição das frases, ordem das questões e por fatores situacionais, como a velocidade da entrevista e o tempo. Como resultado pode haver pequenos desvios, podendo uma pessoa ter escore 6, em uma investigação, e escore, 7 em uma segunda investigação. Há também objeções quanto à comparabilidade das respostas, pois um determinado escore pode não significar o mesmo para diferentes indivíduos.

As variáveis que incorporam a mensuração do BES (afeto positivo, afeto negativo e satisfação com a vida) são utilizadas para refletirem as condições atuais de vida de uma pessoa. Havendo alteração nestas condições, espera-se que o BES sofra mudança também. Contudo, como existe uma tendência de estabilidade destas variáveis, é de se esperar que o BES também seja estável ao longo do tempo. Esta estabilidade é reforçada pelo fato de que existem fatores de personalidade envolvidos na construção do BES e estes fatores também são estáveis em pessoas adultas (Diener e colaboradores, 2003). Diener e Larsen (1984) estudaram a possibilidade de mudança dos escores de BES pela variação de fatores situacionais e concluíram que existe uma estabilidade do BES, ao longo do tempo, mesmo sob mudanças contextuais. 
Diener e colaboradores (2003) relatam a discussão existente sobre o afeto e a cognição e sua relação na mensuração do BES, onde afirma que, além do aprofundamento dos estudos, é necessária a mensuração separada dos dois sistemas, ainda que não haja independência destes dois fatores, obtendo-se assim um quadro mais completo do construto.

A auto-avaliação pode não representar uma maneira totalmente confiável de aferição do BES. Cognitivamente, existem estados desejados os quais os indivíduos querem configurar, podendo o questionário refletir mais uma condição desejada do que a sua condição presente. Algumas pessoas tendem a se avaliar de forma positiva, querendo se retratar mais felizes do que realmente são (Diener e colaboradores, 2003). A ordem das questões, a sua grafia, o tipo de escalas aplicadas, o estado de espírito em que se encontra o respondente no ato da avaliação, e a seleção das informações processadas podem ser também outros fatores de erros (Stutzer e Frey, 2003). 


\section{8 - METODOLOGIA}

\subsection{COLETA DE DADOS}

A pesquisa foi realizada junto ao setor comercial de Ribeirão Preto e Região, sendo utilizadas 3 escalas de auto-avaliação: o Oxford Happiness Questionnaire (OHQ), a Escala Geral de Felicidade (EGF) e uma Escala de Item Único (EU), juntamente com informações sócio demográficas do pesquisado.

Dentro da área da empresarial, escolheu-se este segmento. A coleta de dados poderia ser dirigida a diversos tipos de organizações, mas alguns aspectos foram considerados para optar por esse segmento. Primeiro, há uma distribuição heterogênea de diversos perfis de indivíduos. O setor comercial abrange desde organizações pequenas e com estruturas familiares até magazines de origem multinacional. O segundo aspecto é a possibilidade de contar com bancos de dados onde houvesse informações que servissem de guia para a coleta de dados. Isto levou a procurar a ACIRP (Associação Comercial e Industrial de Ribeirão Preto). O terceiro motivo para a escolha do comércio foi a acessibilidade que este segmento oferece. Empresas comerciais de qualquer tamanho possuem suas portas abertas em virtude da própria atividade, facilitando o contato com os entrevistados.

Foi adquirida da Associação sua base de dados do setor comercial, contendo 3.556 empresas associadas. Estes endereços forneceram a base para o sorteio dos locais a serem percorridos para a coleta de dados, não envolvendo nenhuma informação com relação às empresas. Sua utilização foi eminentemente geográfica, a fim de seguir uma distribuição mais probabilística possível. A quantidade de questionários totais para a análise deve ser representativa, portanto foi fixada a quantia de 500 .

Para a seleção dos locais onde aplicar o questionário, foram sorteadas inicialmente 204 empresas. Este sorteio se procedeu da seguinte forma: a listagem era composta por 68 páginas, cada página com 52 empresas; de cada página foram selecionadas três empresas. Esta 
seleção se deu através de uma planilha Excel com 68 linhas e três colunas, preenchidas através de números aleatórios de 1 a 52, o que totaliza as 204 empresas inicialmente selecionadas.

Estas empresas contribuiriam de 1 a 4 indivíduos, conforme o interesse e a disponibilidade de participação das pessoas que lá trabalhavam. Uma exceção a este número foram algumas poucas empresas comerciais de grande porte, como o caso de um hipermercado de matérias de construção; um grande magazine do setor de eletrodomésticos; uma grande loja de confecções e um supermercado de grande porte, enfim, empresas que possuem grande quantidade de funcionários. Para estas, foram deixados 10 questionários. São empresas que possuem um padrão diferenciado de política de recursos humanos, tanto em relação à carga horária quanto ao padrão de remuneração e benefícios. Se fosse coletada uma quantidade muito grande de respondentes nestes locais, poderíamos ter viés; tentou-se então equilibrar não somente a distribuição das empresas, mas também a representatividade dos tipos de funcionários envolvidos.

O instrumento foi elaborado com as escalas mencionadas e dados sócio-demográficos do pesquisado, além do termo de consentimento. Neste, explicava-se o objetivo da pesquisa, a voluntariedade da participação, o comprometimento de apoio caso necessário e a segurança de sigilo das informações. No termo de consentimento havia também uma explicação do como se procedia a coleta: o instrumento era deixado para o respondente por um período de quatro dias, sendo coletado após este período. Isto por um motivo simples: a atividade comercial, como qualquer outra profissional, muitas vezes não oferece o tempo necessário para que a pesquisa seja feita em local de trabalho. A fim de não atrapalhar o andamento do estabelecimento nem comprometer o profissional, o questionário foi deixado para que fosse preenchido em horário compatível ao de serviço, ou na residência do trabalhador, conforme este achasse oportuno. 
Foram tiradas cópias inicialmente de 300 questionários e visitadas as localidades sorteadas. Iniciou-se um primeiro problema: algumas das empresas que constavam na listagem não mais existiam. Este problema foi solucionado de duas maneiras: caso no endereço estivesse sido instalada outra empresa, ou houvesse alguma nas proximidades, isto é, no mesmo quarteirão, os dados seriam coletados naquele estabelecimento, uma vez que não havia foco em empresas, mas a preocupação de respeitar uma distribuição geográfica; caso não fosse possível, o endereço era desconsiderado.

Um segundo problema surgiu: este um pouco mais dificultoso. Ao entregar o questionário, combinava-se a data de retorno para coletar o instrumento, instrução que também constava no termo de consentimento e, em grande parte dos casos, o questionário não estava preenchido nesta data. Surgiu um problema de teor ético: tinha-se a necessidade dos dados e a disposição de coletá-los em situação favorável ao respondente, mas não se podia coagi-lo a responder, insistindo e passando no local diversas vezes a fim de verificar se havia sido preenchido o questionário após a data acertada verbalmente e no Termo e Consentimento. Procedeu-se da seguinte forma: após os quatro dias corridos, na data marcada, passava-se para coletar o questionário. Caso este não estivesse preenchido, muitas vezes por situação de esquecimento, então se questionava a disponibilidade do respondente, na participação na pesquisa. Caso a resposta fosse negativa, recolhia-se o instrumento em branco, que seria utilizado para outro indivíduo. Caso se concordasse em participar, marcar-se-ia uma outra data, anotada na planilha de controle dos questionários pendentes para sua restituição.

Nesta segunda data marcada, se estivesse preenchido, recolher-se-ia o questionário. Caso não estivesse pronto, voltava-se a confirmar a disponibilidade de participação e se acaso a pessoa não tivesse tempo disponível para respondê-lo, poderia restituí-lo sem problemas. Se esta optasse pela devolução, era baixado no controle de questionários pendentes e reutilizado para outro respondente. Caso se quisesse participar, nesta segunda oportunidade, era marcada 
uma nova data, apontada no controle e nesta retornava-se para coletar o questionário. Caso estivesse preenchido, dava-se baixa na relação de visitas. Caso não estivesse preenchido, respeitosamente solicitava o questionário de volta. Na possibilidade de não se conseguisse falar com a pessoa com quem havia sido deixado o questionário, ou se por qualquer motivo não estivesse disponível o instrumento de pesquisa, o impresso era perdido.

Este foi um problema freqüente ao longo da coleta de dados. Muitos questionários foram perdidos e foi necessário passar-se por mesmo local, em muitas ocasiões 4 vezes, sendo a primeira para deixar o questionário, a segunda para realizar a primeira coleta, a terceira para tentar novamente ter o questionário restituído e uma quarta vez para realizar uma última tentativa para obter-se o instrumento de pesquisa. A quantidade resultante de questionários nesta primeira pesquisa foi praticamente a metade do que seria o objetivo original, sendo necessário um novo sorteio, utilizando-se a mesma metodologia de obtenção dos endereços das empresas.

Novamente, neste segundo sorteio foram seguidos os mesmo procedimentos na sistemática de coleta de dados. As listagens possuíam diversas empresas da região, como Serrana, Jardinópolis, Bonfim Paulista e outras. Procurou-se respeitar a inclusão dos dados das localidades fora de Ribeirão Preto.

Finalmente, no segundo sorteio, chegou-se próximo ao total pretendido de 500 questionários. Estes tiveram a seguinte distribuição por bairros, em alguns casos por cidades vizinhas, para as quais não foram referenciados os bairros:

Tabela 9-Cidades fora de Ribeirão Preto onde foram coletados dados

\begin{tabular}{|l|c|}
\hline Cidades & Questionários \\
\hline BONFIM PAULISTA & 5 \\
\hline JARDINÓPOLIS & 22 \\
\hline Total & 27 \\
\hline
\end{tabular}


Tabela 10- Bairros de Ribeirão Preto onde foram coletados dados

\begin{tabular}{|c|c|}
\hline Bairro & Questionários \\
\hline ADELINO SIMIONI & 3 \\
\hline ALTO BOA VISTA & 13 \\
\hline ALTO IPIRANGA & 1 \\
\hline ANTONIO MARINCEK & 1 \\
\hline AVELINO ALVES PALMA & 1 \\
\hline CAMPOS ELISEOS & 60 \\
\hline CENTRO & 88 \\
\hline INDEPENDENCIA & 3 \\
\hline IPIRANGA & 40 \\
\hline JD AEROPORTO & 3 \\
\hline JD ALEXANDRE BALBO & 2 \\
\hline JD AMERICA & 27 \\
\hline JD ANTARTICA & 1 \\
\hline JD CALIFORNIA & 1 \\
\hline JD IRAJA & 1 \\
\hline JD MACEDO & 2 \\
\hline JD MOSTEIRO & 2 \\
\hline JD PALMA TRAVASSOS & 7 \\
\hline JD PAULISTA & 12 \\
\hline JD PAULISTANO & 2 \\
\hline JD SALGADO FILHO & 1 \\
\hline JD SUMARE & 11 \\
\hline JD TREVO & 2 \\
\hline JD ZARA & 1 \\
\hline NOVA RIBEIRANIA & 16 \\
\hline PLANALTO VERDE & 2 \\
\hline PRQ ANDORINHAS & 1 \\
\hline PRQ I LAGOINHA & 5 \\
\hline PRQ I TANQUINHO & 9 \\
\hline PRQ RIBEIRAO PRETO & 8 \\
\hline QUINTINO FACCI II & 3 \\
\hline REPUBLICA & 3 \\
\hline RES PRQ SERVIDORES & 1 \\
\hline RIBEIRANIA & 6 \\
\hline SUMAREZINHO & 16 \\
\hline VL AMELIA & 7 \\
\hline VL BRASIL & 9 \\
\hline VL CARVALHO & 8 \\
\hline VL ELISA & 8 \\
\hline VL MARIANA & 5 \\
\hline VL SEIXAS & 1 \\
\hline VL TAMANDARE & 2 \\
\hline VL TIBERIO & 30 \\
\hline VL VIRGINIA & 4 \\
\hline 刜/D & 27 \\
\hline Total & 456 \\
\hline
\end{tabular}


Pode-se verificar que grandes partes dos bairros de Ribeirão Preto estão representados na relação acima. Na linha final existe a denominação "\#N/D Total” que significa a quantidade de endereços que foram coletados, porém não identificados por bairro. Esta foi uma falha detectada no início da pesquisa e reparada. Os 485 questionários obtidos (458 em Ribeirão Preto e 27 em cidades vizinhas - Tabelas 9 e 10) envolvem cerca de 200 empresas, ou endereços visitados, sendo a média de questionários foram de 2,42 por empresa.

A diversidade de bairros marca a riqueza de informações da base de dados obtida. Existe a coleta de amostras em localidades que possuem um perfil mais comercial, como o Centro da cidade, Ipiranga e Campos Elíseos, que correspondem a 38,7\% do total dos respondentes e locais mais afastados, tidos como comércio de bairro. Os shoppings centers também foram representados. Ribeirão Preto possui 3 destes centros de compras e lazer e o sorteio contemplou lojas dentro destes locais. Temos locais mais populares, com menor faixa de renda como Jardim Aeroporto, Adelino Palma, Salgado Filho ou Parque Ribeirão, assim como há a representação de bairros classe média como Pq. Das Andorinhas, Jd. América, Sumarezinho e locais nobres da cidade, como Jd.Irajá, Alto da Boa Vista e Ribeirania.

Como esta pesquisa não utiliza nenhuma informação da empresa, mantendo o sigilo dos locais onde foram coletados, não foi relacionado o local de coleta de dados e o respondente, mas em pesquisas futuras saber sobre as diferenças de BES existente entre trabalhadores que atuem em shopping centers e aqueles que trabalham em lojas de rua são informações interessantes a serem obtidas ${ }^{2}$.

A diversidade dos tipos de estabelecimentos comerciais visitados foi muito grande: butiques, borracheiros, magazines, farmácias, hipermercados, lojas de sapatos, lojas de roupas, funileiros, mecânicos, joalherias, floriculturas, padarias, mercados, supermercados, lojas de computadores e periféricos, academias, açougues, varejões, locadoras de vídeo,

\footnotetext{
${ }^{2}$ Considerando a diferença de carga de trabalho, conforto das instalações, entre outras variáveis.
} 
papelarias, revendedoras de automóveis, lojas de materiais para construção, bares, restaurantes, escolas de informática e línguas, auto centers, produtos metalúrgicos, produtos químicos e para piscinas, madeireiras, postos de gasolina, produtos odontológicos, sex shop, artigos para presentes, seguradora, planos médicos, TV por assinatura, tapeçaria, auto escola, despachantes, entre outras. A quantidade total de questionários obtidos foi de 519, contudo 35 foram preenchidos indevidamente, pois não compreenderam a escala e escreveram somente "sim" ou "não", nas afirmações, totalizando os 485 descritos. A coleta de dados teve a duração de 5 meses.

Para a análise estatística foi utilizado o software SPSS. Os itens que deveriam sofrer inversão foram feitos através da fórmula matemática: $\mathrm{X}=\mathrm{k}-(\mathrm{x}-1)$, onde $\mathrm{X}$ é o escore invertido, $\mathrm{k}$ a quantidade de pontos da escala, sendo para o OHQ seis pontos e para a EGF sete pontos e $\mathrm{x}$ o escore assinalado no instrumento. Portanto, se um respondente marcasse para o OHQ o escore 5, em uma escala de 6 pontos, $X=6-(5-1)=2$. As afirmativas, contudo, não sofreram inversão, por questão de consistência e validade do questionário.

Para a análise das escalas, quanto a sua estrutura e às correlações existentes, as seguintes técnicas estatísticas foram utilizadas para avaliar a estrutura interna dos questionários, técnicas estas que serão explicadas mais adiante:

1. Correlação de Pearson

2. Teste de médias (Teste t)

3. Análise fatorial

4. Análise discriminante

5. Alfa de Cronbach

6. Correlação bisserial

7. Índice de facilidade 
Tanto para o OHQ (Oxford Happiness Questionnaire) quanto para a EGF (Escala Geral de Felicidade) se procurou seguir os mesmos passos definidos pelos autores a fim de obter as convergências e divergências quanto às suas estruturas, considerando as versões originais comparadas com o que foi encontrado em nossa análise.

Após a avaliação dos questionários, foram feitas as análises para determinados segmentos sócio-demográficos, a fim de observar o comportamento das características individuais, consideradas na pesquisa e os achados na literatura. Nestas análises foram empregadas as seguintes técnicas estatísticas:

1. Análise fatorial

2. Análise de regressão linear multivariada com variáveis binárias

3. Análise de variância

4. Testes não paramétricos

Foram considerados na análise, somente os questionários que estivessem corretamente preenchidos e para as análises estatísticas foi solicitado ao software que desconsiderasse os casos perdidos. Quanto aos dados sócio-demográficos, praticamente não houve dados perdidos.

Foi utilizado o método de grupos critérios, segmentados em função do desempenho nos teste, a fim de avaliar a discriminação dos itens no teste (Pasquali, 2003).

\section{2 - FERRAMENTAS ESTATÍSTICAS UTILIZADAS NA ANÁLISE}

\section{Análise Fatorial}

A análise fatorial consiste em técnica estatística que tem por objetivo a redução das variáveis em um número menor, constituindo variáveis hipotéticas (Kim e Mueller, 1978). Esta é uma importante técnica usada em psicometria, sobretudo para avaliação, tanto da fidedignidade como da validade do instrumento (Pasquali, 2003). 
As variáveis fornecidas pela análise fatorial, também denominadas de fatores, podem exprimir não somente uma síntese das variáveis envolvidas na análise, traduzindo um resumo, mas também pode fornecer dimensões latentes existentes, através de sua estrutura de correlação entre as variáveis (Hair, Anderson, Tatham \& Black, 2005).

O exame de uma determinada estrutura matricial, envolvendo variáveis métricas, pode fornecer as relações entre as variáveis que integram a matriz e, através desta covariância a construção de uma estrutura de análise que venha a fornecer indícios da razão deste comportamento (Kim \& Muller, 1978).

$\mathrm{Na}$ análise fatorial as variáveis em uma determinada estrutura matricial possuem dois componentes: o primeiro é a variância em comum que possui com outras variáveis, e o segundo é a variação exclusiva a si. Dessa forma, podemos observar que as variáveis que são observáveis integram dois componentes, um comum à estrutura matricial (variável fonte) e o outro, particular e exclusivo (Kim \& Muller, 1978).

De uma maneira gráfica, podemos expressar a análise fatorial da seguinte maneira, considerando-se duas variáveis $\mathrm{X}_{1}$ e $\mathrm{X}_{2}$ observadas:

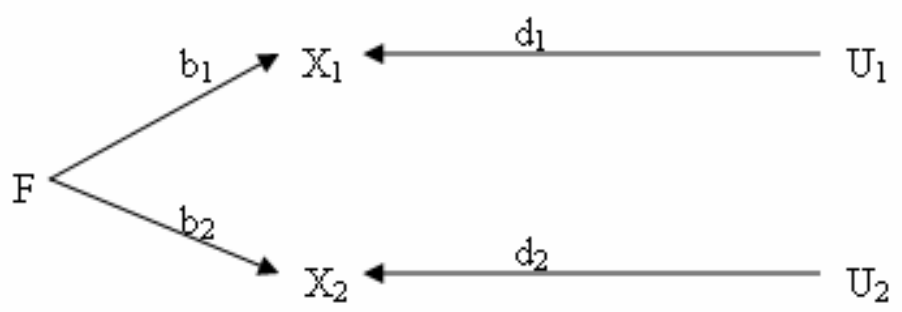

Figura 20- Estrutura da análise fatorial (Kim \& Muller,1978 )

Onde:

$\mathrm{X}_{1}$ e $\mathrm{X}_{2}$ : variável observada

$\mathrm{U}_{1}$ : variável única, ou específica, a variável $\mathrm{X}_{1}$

$\mathrm{U}_{2}$ : variável única, ou específica, a variável $\mathrm{X}_{2}$

$\mathrm{b}_{1}, \mathrm{~b}_{2}$ : pesos (ou cargas) da variável fonte $\mathrm{F}$ 
$\mathrm{d}_{1}, \mathrm{~d}_{2}:$ pesos (ou cargas) da variável única $\mathrm{U}$

Portanto:

$X_{1}=b_{1} F+d_{1} U_{1}$

$X_{2}=b_{2} F+d_{2} U_{2}$

A análise fatorial consiste em traçar as relações existentes entre as partes em comum das variáveis observáveis que integram um fator, chamado de comunalidade. Em outras palavras, na análise fatorial, as variáveis se agregam em função de suas partes em comum, constituindo daí fatores. Através desta comunalidade, podemos extrair a validade do teste (Pasquali, 2003).

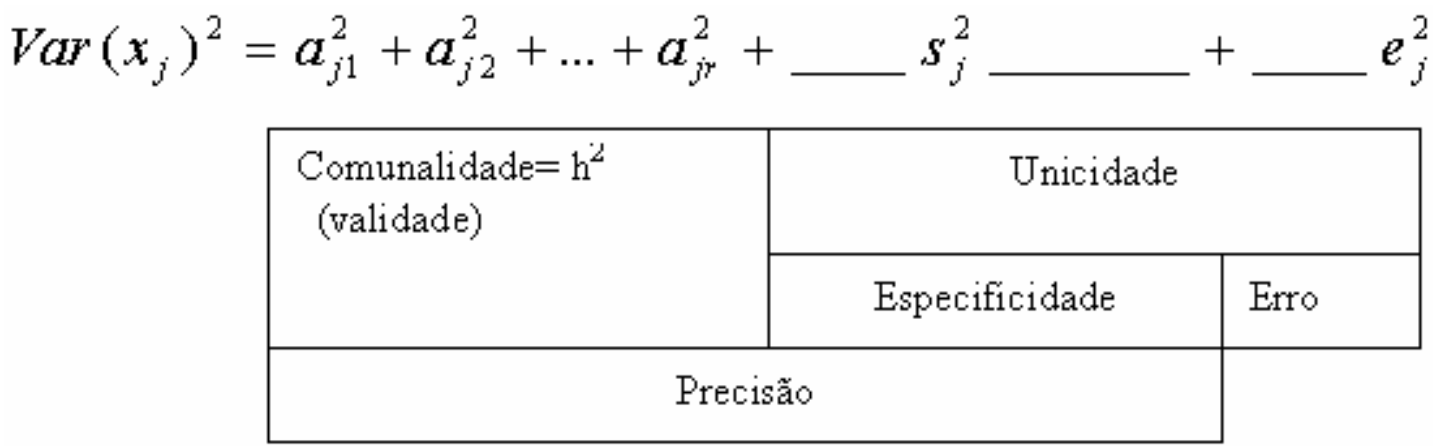

Figura 21- Distribuição da variância dos componentes (Pasquali, 2003).

A validade do teste é especificada pela soma da variância das cargas comuns. Isto significa dizer que as comunalidades das variáveis, que integram um fator, agem de forma conjunta explicando aquele fator. Quanto maior for esta comunalidade, maior será a convergência entre as variáveis que integram o fator, fornecendo maior validade à mensuração, pois estas variáveis estarão medindo o mesmo elemento. Isto significa dizer que os fatores são agrupados pela busca da minimização da variância interna em relação à externa. Quanto menor for esta variância existente entre as variáveis que integram o fator, mais robusto este será (Hair e colaboradores, 2005). Dito de outra maneira, a comunalidade traduz o sucesso de se medir o que se propõe, pois as variáveis convergem neste propósito através de suas covariâncias (Kim \& Mueller, 1978). Com estabilidade da especificidade das variáveis 
do teste, mais a segurança de se estar medindo o que se propõe, obtemos a precisão de medida do teste.

Quando se considera, além da variância das comunalidades, a variância da carga específica da variável, isto é, a parte que não possui comunalidade e é exclusiva à variável, temos a precisão do teste, pois se há baixa variabilidade desta parte única da variável, podemos verificar a consistência da medida (Pasquali, 2003).

Vale ressaltar que a análise fatorial é vista de forma conjunta à técnica de Extração de Componentes Principais. Contudo, estas técnicas são técnicas distintas e denominações independentes. A técnica de Extração de Componentes Principais possui como objetivo a extração de uma quantidade menor de variáveis, em que os fatores encontrados mantêm sua ortogonalidade, isto é, as variáveis que mais se correlacionam integram um mesmo fator, mantendo sua independência das variáveis com as quais possui uma menor correlação (Kim e Mueller, 1978b). Isto é normalmente usado para a redução de dados matriciais, onde se obtém novas variáveis estatísticas hipotéticas. Este rearranjo das variáveis é feito na rotação dos eixos. Isto quer dizer que, quando a análise fatorial realiza seus cálculos matriciais para a configuração dos fatores, esta se inicia no primeiro fator e a partir deste a distribuição de cargas para os demais fatores. Isto faz com que se tenham, neste primeiro fator, cargas mais elevadas do que as demais, o que não invalida os cálculos, mas é importante que os fatores tenham uma melhor distribuição de suas cargas, de maneira a apresentar um resultado mais homogêneo, assim é feita a rotação dos eixos cartesianos para uma melhor acomodação das cargas (Kim \& Muller, 1978).

Na técnica de Componentes Principais, conforme foi dito, há a preocupação de permanecer uma alta correlação dentro do fator, através de técnicas de rotação como a Varimax, utilizada neste trabalho, obtendo-se fatores independentes, os quais poderão ser utilizados em outras técnicas estatísticas. Contudo, na concepção da análise fatorial, busca-se 
o fator latente que está por detrás das variáveis envolvidas: a força subjacente que venha a explicar o comportamento das variáveis observadas. Neste contexto, as variáveis devem estar relacionadas dentro dos fatores e estes, por sua vez, devem manter o relacionamento entre si, sustentando um sistema de covariações. Em outras palavras, procura-se manter uma forte relação dentro do fator, mas o ângulo de rotação dos fatores sofre ajustamentos de maneira que as relações externas a este também sejam preservadas. Isto se obtém através de outro tipo de rotação: a oblíqua. Ela consiste em variar o ângulo dos eixos que envolvem as variáveis de maneira a se obter uma melhor correlação entre as variáveis, e por conseqüência um ajustamento mais harmônico, tanto dentro como entre os fatores. Através deste ajustamento, conseguimos chegar a um ou mais fatores que venham explicar a variância observada.

As técnicas de análises multivariadas de dependência possuem algumas suposições estatísticas a ser observadas. São estas: multicolinearidade, homoscedasticidade e linearidade. A análise fatorial é melhor desempenhada se estes conceitos são observados, porém, de acordo com Hair e colaboradores. (2005) “as suposições criticas na análise fatorial são mais conceituais do que estatísticas. De um ponto de vista estatístico, os desvios da normalidade, da homoscedasticidade e da linearidade aplicam-se apenas no nível em que elas diminuem as correlações observadas" (pg. 98). Artes (1998) afirma que as escalas de avaliação psicológica são compostas por itens cujas respostas não podem ser modeladas por meio de uma distribuição normal e sugere a aplicação do método de análise de componentes principais, que não requer a pressuposição de normalidade, por obter os fatores através da decomposição da matriz de correlação.

Hair e colaboradores (2005) afirmam que se as variáveis não sustentam uma correlação maior do que 0,30 entre elas, a análise provavelmente será inapropriada. Uma maneira de estar verificando a estrutura das variáveis, com relação à análise é a medida de análise de mensuração do sistema (MSA). Esta medida é fornecida pelo programa 
computacional pela qual se demonstra a previsão da variável em relação às outras variáveis. O autor apresenta uma escala de valores que é utilizada nas análises das variáveis apresentadas na análise fatorial, sendo que aquelas com MSA de 0,8 acima são consideradas admiráveis; 0,80 a 0,70 medianas; 0,70 a 0,60 razoáveis; de 0,60 a 0,50 medíocres e abaixo de 0,50 inaceitáveis. Este é um forte critério para exclusão de variáveis, juntamente quando no resultado da análise uma variável integra um único fator.

\section{Análise Discriminante}

Consideramos aqui dois tipos de análises discriminantes. Uma é a análise discriminante múltipla, técnica estatística multivariada de dependência que envolve uma variável dependente categórica (nominal ou não métrica) e variáveis independentes métricas. Outra que consiste na análise dos itens quanto ao seu poder discriminante, é determinada através da análise bisserial de pontos. Esta ultima é uma correlação de variável dicotômica (obtida através da criação de grupos critério) e uma variável contínua (escore geral do teste) (Bunchaft \& Cavas, 2002).

A análise discriminante multivariada envolve a combinação linear entre a variável dependente e variáveis independentes, resultando em uma função discriminante (Hair e colaboradores, 2005). Esta forma é parecida com a análise de regressão, à medida que possui como resultado uma equação linear que busca prever o comportamento da variável dependente, através da independente, porém na regressão esta relação é dada através de variáveis métricas, ou não métricas categorizadas, através de matrizes binárias.

Neste caso, cada variável discriminante também possui um escore, semelhante à regressão, o qual indica a carga que a variável possui na equação. Esta carga é calculada a partir de uma média do grupo, que consiste no centróide (Hair e colaboradores, 2005).

A análise discriminante possui uma particularidade em relação à regressão: ao invés de fornecer uma única equação como o caso desta ultima, ela irá fornecer n- 1 equações, sendo 
$n$ a quantidade de categorias envolvidas na análise discriminante. Por exemplo, suponhamos que a pesquisa estivesse envolvida em saber a auto-avaliação dos respondentes com relação a alguns domínios da vida, como trabalho, lazer ou família; o avaliado se classificaria como muito feliz, feliz, pouco feliz ou infeliz (4 categorias). Em uma análise discriminante teríamos 3 funções diferentes, face à propriedade da técnica estatística.

Citando Hair e colaboradores. (2005): “A análise discriminante é aplicável a qualquer questão de pesquisa que tenha o objetivo de entender a pertinências de grupos que possam ser avaliados em uma série de variáveis independentes" (pg. 210). O autor ainda menciona que “como uma análise de perfil, a análise discriminante fornece uma avaliação objetiva das diferenças entre grupos em um conjunto de variáveis independentes... Para entender as diferenças entre os grupos, a análise discriminante permite discernir o papel das variáveis individuais, bem como definir combinações dessas variáveis individuais que representam dimensões de discriminação entre os grupos" (pg. 210).

\section{Análise de Regressão}

O objetivo de utilização desta técnica é estabelecer a relação estatística entre uma variável dependente, representada pelos escores equiparados das escalas de mensuração ${ }^{3}$ e variáveis independentes, representadas pelas características sócio-demográficas.

Para a realização da regressão, como a maioria dos dados são qualitativos, matrizes binárias (variáveis dummy) foram criadas para esta análise e foram adotadas como variáveis independentes. O objetivo desta categorização foi conhecer o impacto de cada categoria dos dados demográficos representados na pesquisa, de forma a investigar as diferenças existentes entre os indivíduos, e as escalas, na mensuração do BES. Como exemplo, considere a Tabela 11:

\footnotetext{
${ }^{3}$ Foram realizados os cálculos tanto com os escores equiparados como os escores totais das escalas, não apresentando diferença entre os resultados obtidos (somente foram incluídos no trabalho os resultados do primeiro caso).
} 
Tabela 11 - Exemplo da estrutura de variáveis dummy

\begin{tabular}{|l|c|c|c|c|c|} 
& Casados & Solteiro & Divorciado & Viúvo & Outros \\
\hline Referencia Casados & 0 & 0 & 0 & 0 & 0 \\
\hline dummy Solteiros & 0 & 1 & 0 & 0 & 0 \\
\hline dummy Divorciados & 0 & 0 & 1 & 0 & 0 \\
\hline dummy Viúvos & 0 & 0 & 0 & 1 & 0 \\
\hline dummy Outros & 0 & 0 & 0 & 0 & 1 \\
\hline
\end{tabular}

$\mathrm{Na}$ análise com a matriz binária $^{4}$, a quantidade resultante de variáveis é n-1, sendo n o total de categorias existentes, isto porque a análise fundamenta-se em uma característica e fornece os resultados em função de um parâmetro estabelecido, escolhido pelo pesquisador; portanto, as cargas e sinais de regressão são em função da variável que recebeu zero para todas as categorias, a qual é a categoria de referência da regressão.

Para a estimação do modelo geral de regressão e ajuste deste são, examinadas as significâncias práticas e estatísticas da análise, através do coeficiente de determinação, seu índice ajustado, erro de estimativa e significância estatística. Havendo relação estatística entre os dois competentes avalia-se a magnitude desta relação e o direcionamento (direto ou inverso), podendo-se identificar os comportamento das características individuais e a felicidade.

\section{3 - PERFIL DOS PESQUISADOS}

A caracterização da amostra define um perfil dos indivíduos que trabalham no comercio atualmente, servindo também para qualificar o material humano presente na pesquisa.

\footnotetext{
${ }^{4}$ Esta representa a presença ou ausência do atributo em questão.
} 


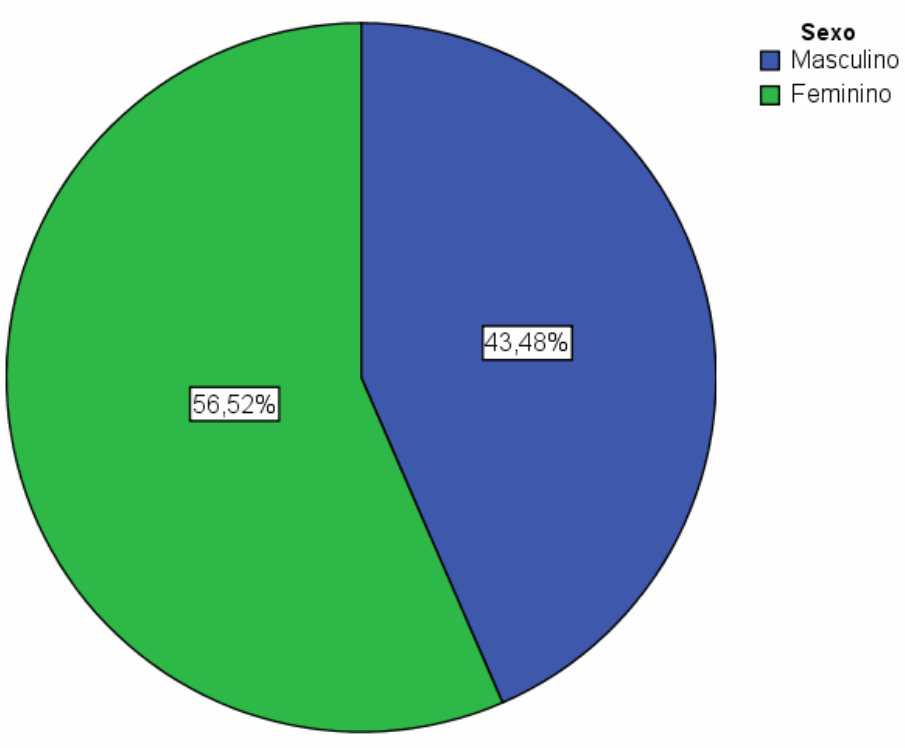

Gráfico 1 - Distribuição sexo da amostra

A amostra é composta de $43,5 \%$ do sexo masculino e $56,5 \%$ do sexo feminino (Gráfico 1); sendo que 50,5\% são casados, 42,4\% solteiros, 3,8\% divorciados, 1,4\% viúvos e $1,9 \%$ possuem outros tipos de relacionamentos. A idade dos entrevistados compreende entre 15 a 66 anos, com idade média de 30,85 anos; as mulheres com média de 29,3 anos, e 32,27 para os homens. O Gráfico 2 mostra a distribuição etária dos pesquisados.

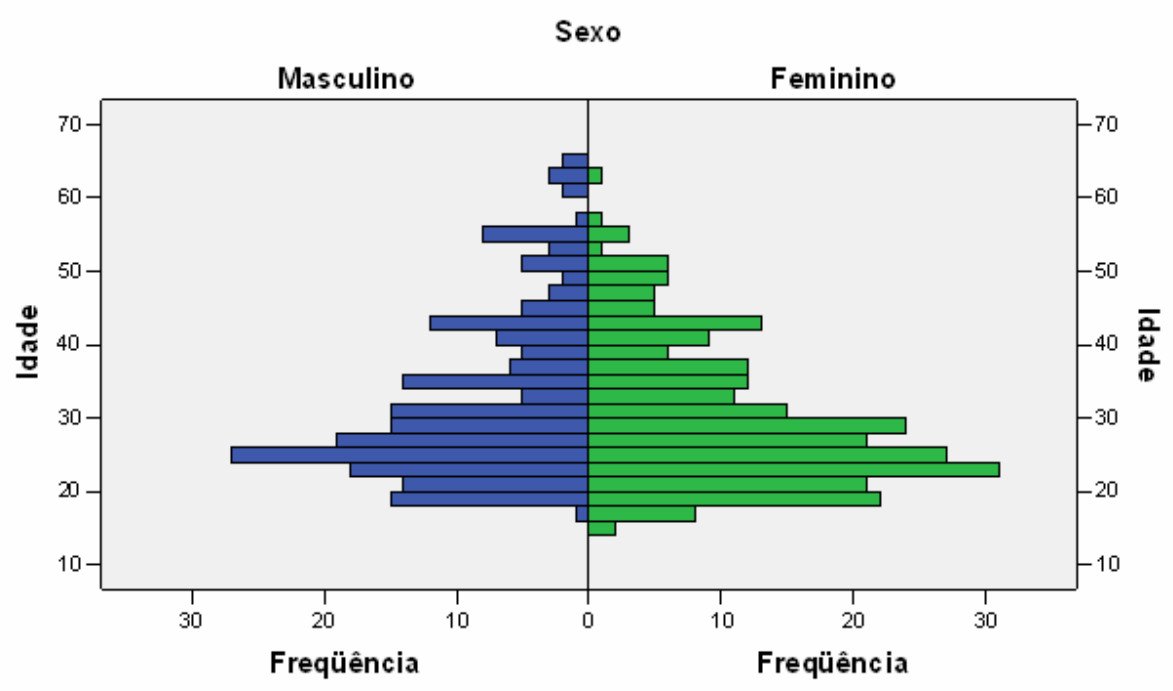

Gráfico 2- Distribuição das idades 


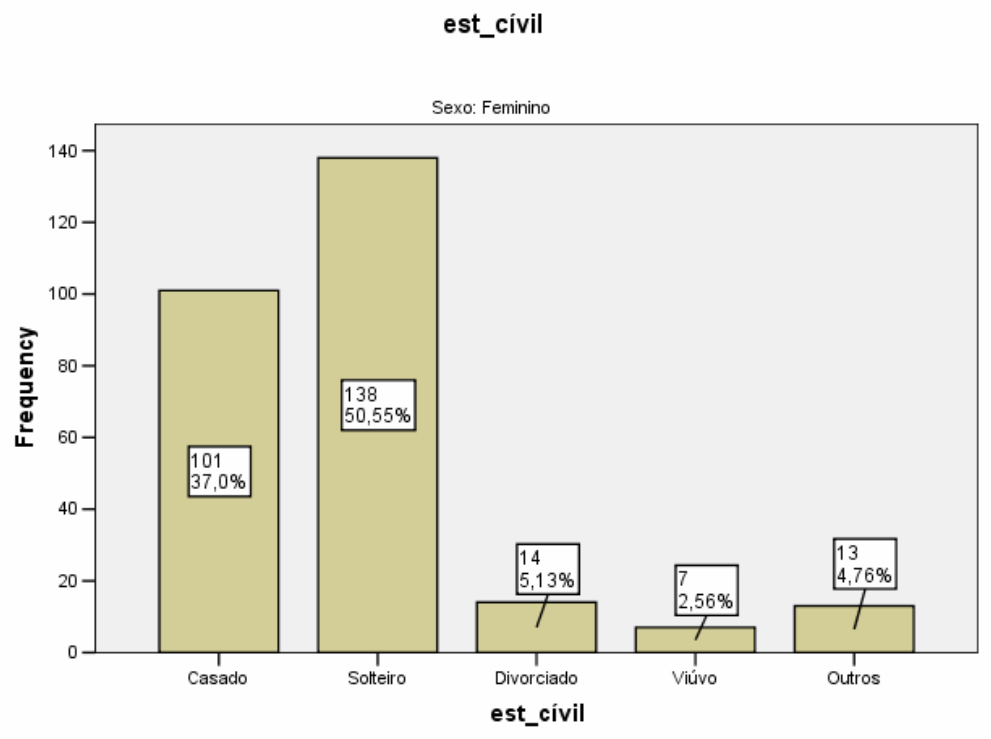

Gráfico 3- Estado civil mulheres

Para as mulheres, $37 \%$ delas são casadas, $50,5 \%$ solteiras, $5,1 \%$ divorciadas, $2,6 \%$ viúvas e 4,8\% possuem outros relacionamentos não relacionados na pesquisa. O Gráfico 3 mostra a distribuição destes indivíduos. Considerando a idade média das mulheres, a metade delas não é casada. Elas também possuem quantidade maior de divorciados, viúvos e que possuem outros relacionamentos. Para os homens, 50,48\% são casados, 42,38\% solteiros, $3,81 \%$ divorciados, $1,43 \%$ viúvos e $1,9 \%$ possuem tipos de relacionamentos não relacionados, conforme o Gráfico 4. 


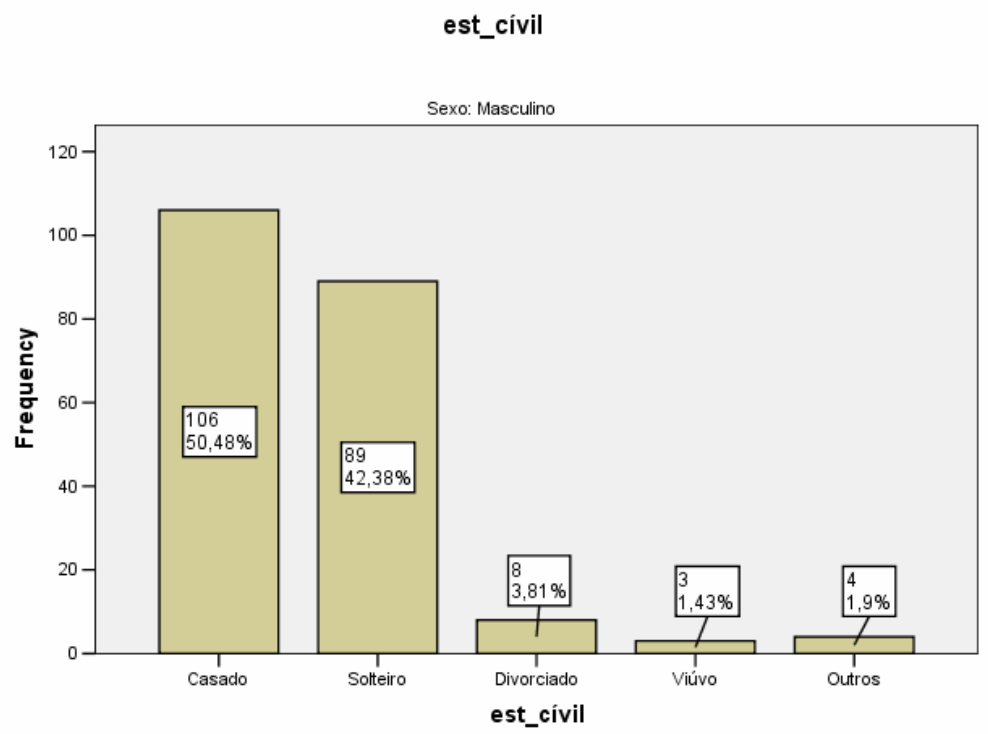

Gráfico 4- Estado civil homens

A quantidade composta por solteiros sem filhos é de $42 \%$ da amostra. Os casados possuem em sua grande maioria até dois filhos, sendo poucos os casos de casais que possuem acima desta quantidade (30 casos, sendo 23 para três filhos e 7 para mais do que três filhos).

Quanto à escolaridade, a maioria possui o ensino médio completo $(47,5 \%)$, seguido por aqueles que possuem superior incompleto $(15,4 \%)$, superior completo $(13,3 \%)$, ensino médio incompleto $(12,9 \%)$, ensino fundamental incompleto $(7,3 \%)$ e ensino fundamental completo $(3,7 \%)$ (Gráfico 5). Se considerarmos a classificação por sexo, freqüência de mulheres que possuem o superior completo é um pouco maior do que os homens (15\% para elas contra $11 \%$ para eles). Pode-se considerar também que o setor possui perfil de profissionais especializados, considerando que a maioria, cerca de $70 \%$, está há mais de 4 anos no comércio. 


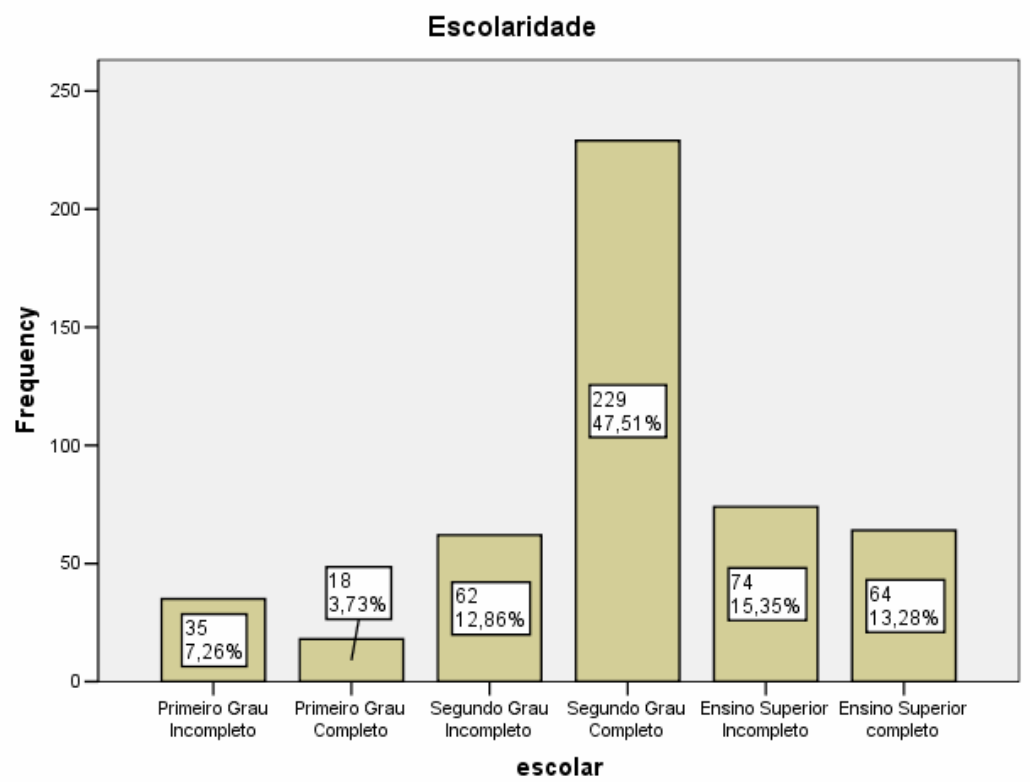

\section{Gráfico 5-Escolaridade}

Foram encontradas diversas faixas de renda, não havendo uma concentração acentuada em uma determinada categoria. Os que possuem renda familiar entre 501-1.000 reais correspondem a 28,3\%, seguidos por renda na faixa de 1.001-1.500 reais, 20,5\%; três categorias possuem igual representação: até 500 reais, $1.501-2.00$ e 2.501-3.000, com 14,5\% e por último o percentual de 7,76\% para a faixa de renda entre 2.001-2.500, conforme apresentação do Gráfico 6.

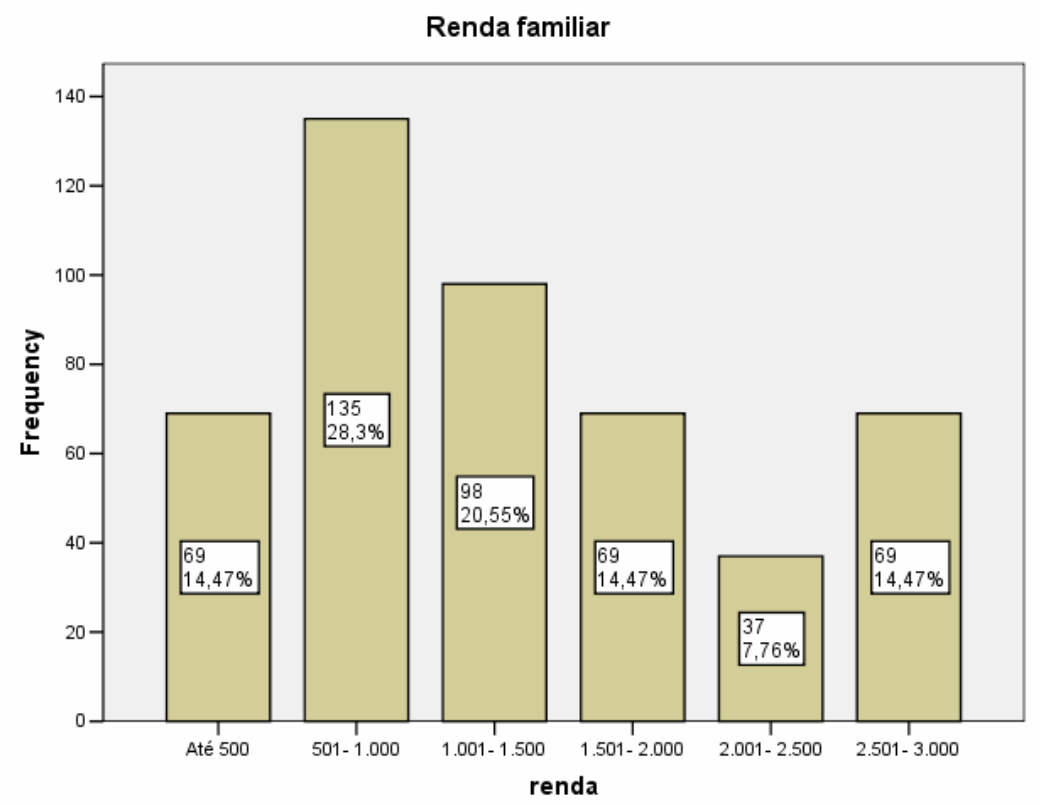


Entre os respondentes, $98 \%$ possuem geladeira; $97,7 \%$, televisão; $86,4 \%$, telefone; 74,7\%, automóvel; 43,9\%, computador; 34,8\%, Internet; 84,9\% ,celular; 52,2\%, DVD; $57,1 \%$, microondas; apenas $26 \%$ possuem casa própria e 40,5\% têm plano de saúde. Grande parte dos entrevistados, $98,6 \%$, possui bom relacionamento no trabalho e $62 \%$ praticam atividade esportiva. Os fumantes correspondem a 17,2\%; os hipertensos a 7,2\%; os diabéticos a 2,3\%; problemas de visão $2,3 \%$ e de audição $1,4 \%$ e apenas 2 deficientes físicos foram entrevistados. Quanto à religião, 21,7\% não praticam religião; 60,5\% são católicos; 19,3\%, evangélicos; $8,1 \%$,espíritas e 11,6\% praticam religiões não incluídas na pesquisa.

Os indivíduos entrevistados enquadraram-se em quatro tipos de etnias, sendo que $79,4 \%$ avaliaram-se como brancos; $16,3 \%$, pardos; $3,8 \%$, negros e $0,6 \%$, índios. Segmentada por sexo, entre os homens a pesquisa apresentou 5,3\% de negros; $15,8 \%$, pardos; $78,0 \%$ de brancos e 1,0\% de índios. Para as mulheres, $2,6 \%$ responderam pertencer à raça negra; $16,6 \%$, pardas; $80,4 \%$, brancas e $0,4 \%$, índia (apenas uma pessoa).

Ao considerarmos as diferenças entre comerciantes e comerciários, a comparação entre as idades mostra que a metade dos comerciários está na faixa etária de 21 a 30 anos, enquanto que, entre os comerciantes, mais da metade se encontra entre 31 e 50 anos. A presença das mulheres como funcionárias no comércio são ligeiramente mais elevadas do que a proporção entre mulheres empresárias. Mais da metade dos comerciários é solteiro enquanto que cerca de $60 \%$ dos comerciantes são casados. 

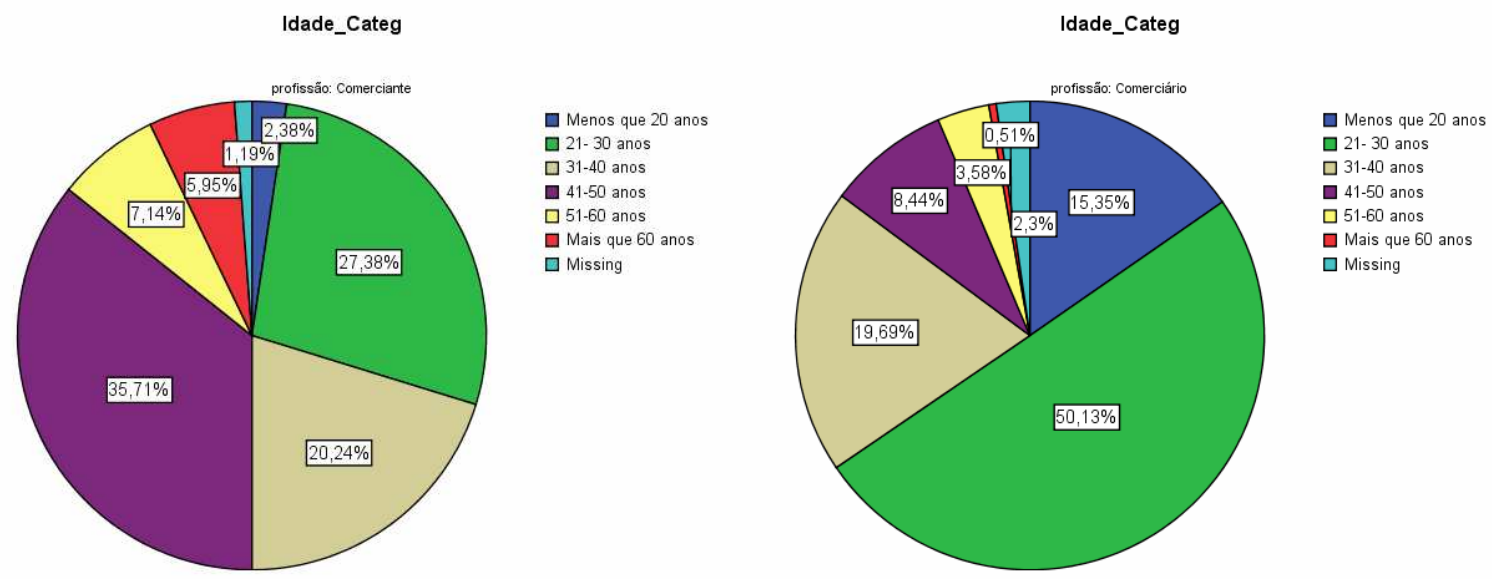

Gráfico 7- Idades comerciantes

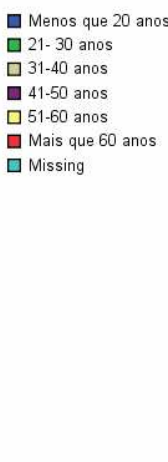

Gráfico 8- Idades Comerciários
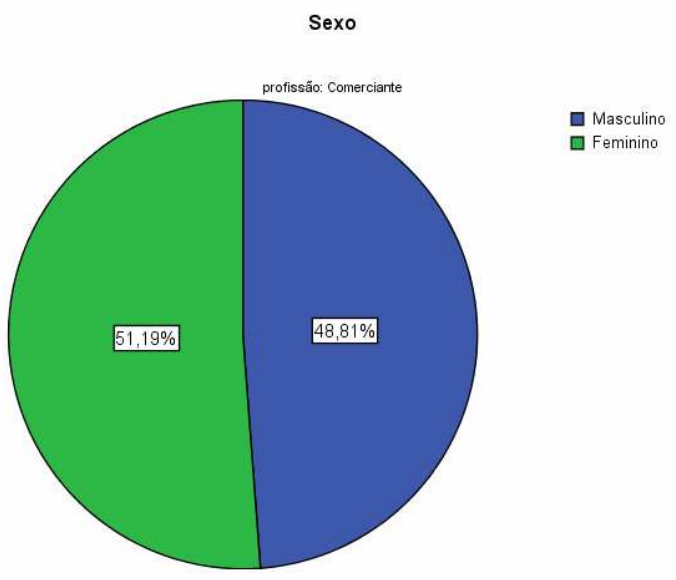

Gráfico 9- Divisão sexo comerciantes

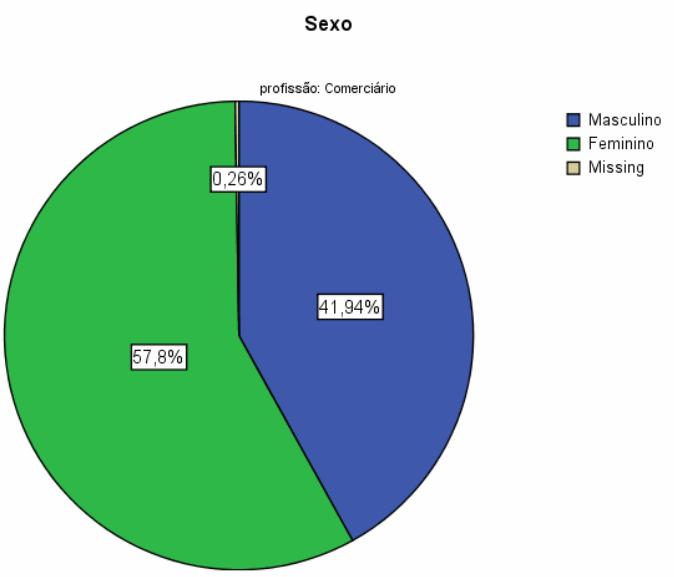

Gráfico 10- Divisão sexo comerciários
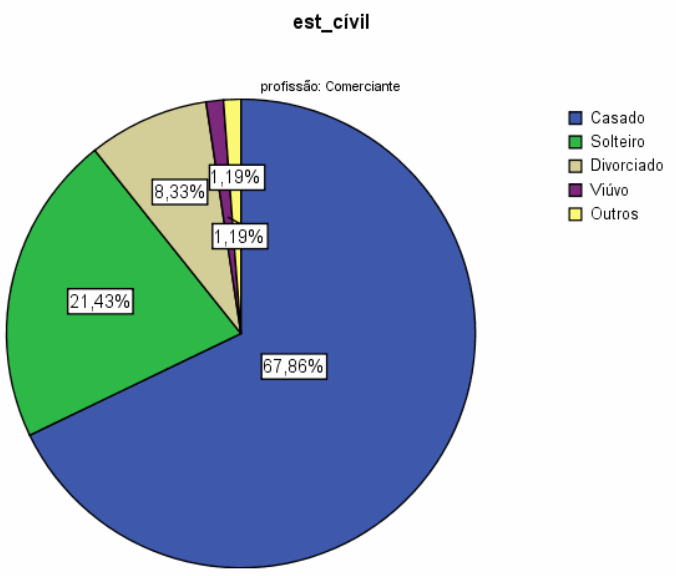

Gráfico 11- Estado civil comerciantes

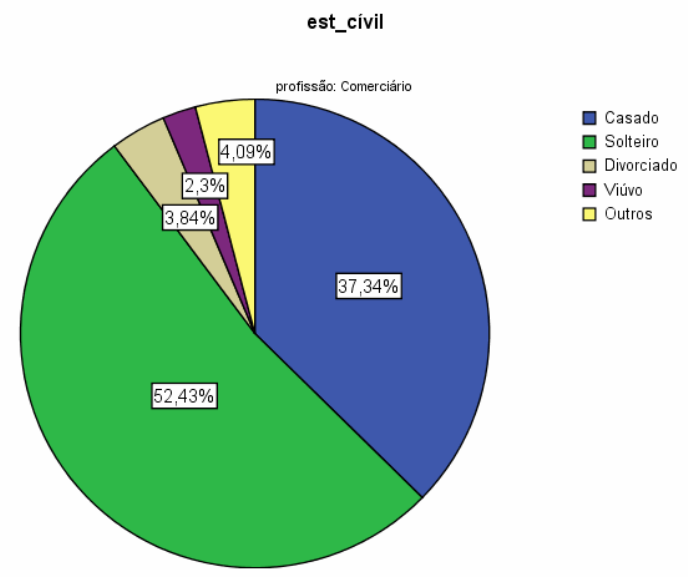

Gráfico 12- Estado civil comerciários 


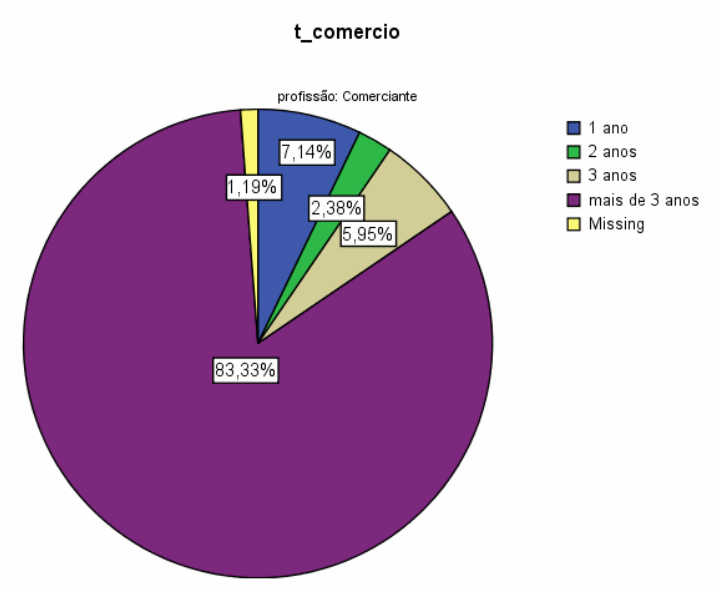

Gráfico 13- Tempo de comércio - comerciante

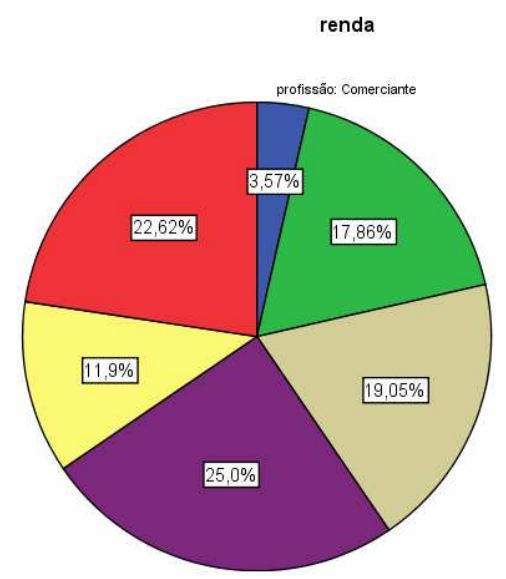

Gráfico 15- Distribuição renda comerciante

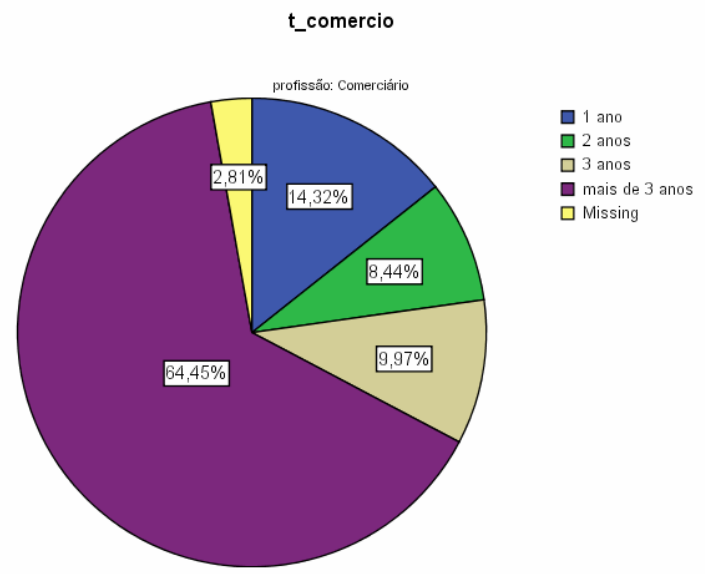

Gráfico 14- Tempo de comércio - comerciário

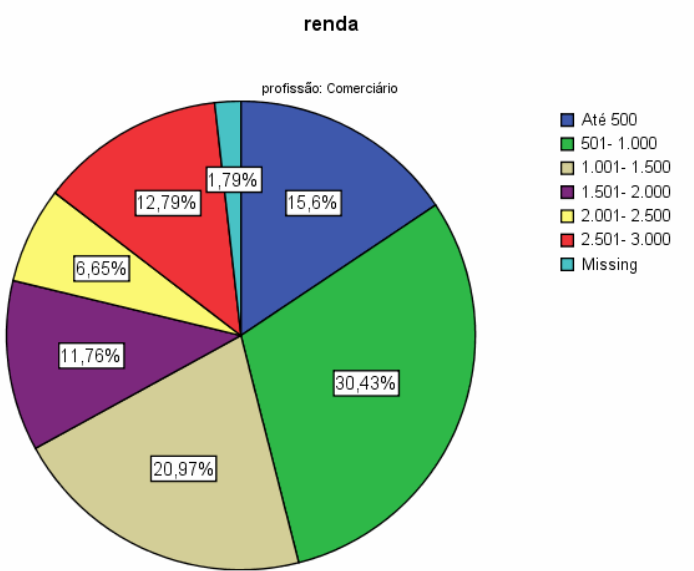

Gráfico 16- Distribuição renda comerciário

Os Gráficos 13 e 14 mostram a especialização do setor, com grande parte dos entrevistados com mais de 3 anos de atuação no segmento comercial. As faixas de rendas mostram estar distribuídas tanto nos empresários, quanto nos funcionários.

Estes são resultados de amostras coletadas aleatoriamente e que não tiveram por objetivo obter representatividade de respondentes em todas as categorias. Isto dificulta algumas análises estatísticas, devido à falta de quantidade necessária de observações para serem realizadas estas análises, e em outros casos, os resultados obtidos junto a poucos pesquisados oferecem conclusões restritas ao universo desta amostra. Porém a aleatoriedade fornece uma distribuição amostral mais próxima da população. 


\section{9- ANÁLISE DOS QUESTIONÁRIOS}

O Oxford Happiness Questionnaire foi elaborado para ser uma versão mais curta do Oxford Happiness Inventory (Argyle, Martin \& Crossland, 1989, conforme Hills \& Argyle, 2002), formatado a partir da inversão do Inventário de Depressão de Beck (1961). Em uma perspectiva teórica, Argyle e Crossland (1987, conforme Francis, Ziebertz, \& Lewis, 2003) sugerem que a felicidade compreende três componentes: frequiência de afeto positivo, a média de satisfação em determinado período e a ausência de sentimentos negativos, como ansiedade ou depressão. Através desta perspectiva, foram utilizados os 21 itens do instrumento de Beck, acrescido de 11 itens para formatar o Inventário de Felicidade de Oxford. Posteriormente 3 itens foram desconsiderados, totalizando 29 , utilizando-se originalmente com uma escala de 4 pontos.

A análise da escala de origem, Argyle (1989, conforme Francis, 1999) mostra a confiabilidade interna do questionário de 0,90, avaliada através do alfa de Cronbach e testere-teste com 7 semanas de espaçamento, com um índice de 0,78 , o que mostra o alto grau de fidedignidade da escala OHI. A validade de construto foi obtida através de relação com os principais componentes da escala (afeto positivo, negativo e satisfação com a vida): correlação de $+0,32$ com a escala de afeto positivo do Balanço de Afeto de Badburn; + 0,57 com o Índice de Satisfação com a Vida de Argyle e correlação de -0,52 com o inventário de depressão de Beck (Francis, 1999). Vários estudos citados em Francis e colaboradores (2003), empregando o OHI, relacionaram-se com a definição operacional de felicidade.

Em Hills e Argyle (2002) mostra-se a utilização da escala OHI em diversos países como Estados Unidos, Grã Bretanha, Canadá, Austrália, havendo traduções em hebraico e chinês. Em sua versão original, cada item era apresentado em 4 níveis incrementais seguindose a configuração da escala de Beck. O OHI foi revisto na publicação mencionada, sendo adotada então uma escala de Linkert de 6 pontos, que expressa níveis de concordância e 
discordância das afirmativas, que deu origem ao Oxford Happiness Questionnaire (OHQ). O instrumento consta no Apêndice II. A escala apresenta 8 questões invertidas, que foram revertidas para análise dos dados, através da fórmula citada.

Bunchaft e Canvas (2002) afirmam que entre as estratégias mais adequadas para a tradução está a avaliação por especialistas quanto à adequação da tradução. O orientador deste trabalho é notório especialista no tema e fluente na língua original do questionário (inglês), portando, habilitado em avaliar não somente a tradução do questionário como também sua estrutura de mensuração.

A fim de melhor avaliação do leitor, estão incluídas as Tabelas dos resultados conseguidos, as quais estarão relacionadas em Apêndices. Vale lembrar que os itens invertidos foram posicionados matematicamente no mesmo sentido dos demais, porém as afirmativas continuam no sentido original, por uma questão de validade.

A média geral dos respondentes foi de 4,464, sendo o valor mínimo de 3,240 e o máximo de 5,59 em uma escala de 6 pontos.

Deve-se haver uma correlação entre variáveis com certa robustez para que a análise fatorial seja bem sucedida (Hair e colaboradores, 2005). A primeira Tabela, fornecida pelo software, obteve a correlação dois a dois entre as 29 questões o total de 841 correlações. Se descontarmos as correlações existentes entre as variáveis semelhantes, há uma matriz de 812 correlações, dentre as quais apenas 31 estão com valores acima de 0,30, e nenhuma delas acima de 0,49 . Isto pode representar certa fragilidade nos fatores obtidos.

O valor de alfa de Cronbach $\alpha=0,797$ calculado para esta escala não obteve desempenho tão bom quanto o resultado dos autores em sua versão de validação do questionário, que foi $\alpha=0,91$, e menor também do que o valor do questionário que deu origem a este, o OHI, que foi $\alpha=0,92$. 
Observando Pasquali (2003, pg. 200) “... um coeficiente de fidedignidade abaixo de 0,80 já é fraco e um de 0,70 é inaceitável”. O valor obtido representa uma covariância entre os itens do questionário de $62,41 \%$ e este montante é considerado fraco, mediante o critério citado.

A elaboração de grupos critérios, dentro da amostra, proporciona a avaliação do poder discriminante dos itens do questionário. Para verificar a discriminação do teste, isto é, se os itens que o compõem são capazes de identificar grupos distintos, o autor estabeleceu a média dos respondentes e classificou a amostra acima e abaixo desta medida; então realizou o teste $t$ para amostras independentes, a fim de avaliar a capacidade de identificar as diferenças existentes. O resultado pode ser verificado na Tabela 1 nos Apêndices.

O teste serve também para discutir a homoscedasticidade. Esta propriedade garante que a variância utilizada na explicação e previsão garanta um teste justo, segundo Hair e colaboradores (2005). Em termos de discriminação dos grupos, a grande maioria dos itens do questionário apresentou no teste estatístico $p<0,05$ e, isto considerando-se um nível de confiança adotado para a pesquisa de $95 \%$, indica que os grupos possuem diferenças entre si. Em outras palavras, ao considerar a maioria dos itens do questionário, estes podem discriminar em dois grupos diferentes: os felizes e os não tão felizes. Não me refiro à infelicidade por esta remeter a um quadro patológico e o objetivo do teste não é detectar esta característica. Quando menciono quase a totalidade do teste é porque uma variável não conseguiu significância estatística no teste de médias: o item 25 - Encontro belezas em algumas coisas.

Esta variável apresentara ser comum para os dois grupos, e como poderá ser visto na Tabela 1, em Apêndices em que a diferença entre as médias é muito baixa, tal fato representa que não conseguem contribuir para distinção entre os indivíduos. Portanto, a fim de fornecer maior validade interna ao teste, proporcionando-lhe maior homogeneidade, este item foi 
desconsiderado em todas as análises. Ao se extrair esta variável, o alfa do teste elevou-se para 0,803 , passando a um nível mais apropriado.

Uma nova diferença se estabelece entre nossa análise e a realizado pelo autor. Enquanto identificamos uma variável que não contribuiu para a medida, na escala original todas as variáveis foram significantes na separação dos grupos.

É oportuna a discussão de outra validade: a de construto. Uma das maneiras como pode ser feita é através da correlação deste questionário com outros questionários que se proponham a medir o mesmo construto (Pasquali, 2003). A validade de conceito pode ser obtida através da correlação com outros testes designados com o mesmo nome (Anastasi, 1965). Como o instrumento foi composto de três testes, todos os três designados como testes de felicidade, espera-se que haja uma correlação significativa entre eles, pois todos propõem de alguma maneira a mensuração do mesmo construto. As correlações são bem substantivas, onde a EU possui uma correlação de 0,635 com a EGF e de 0,556 com a OHQ e a EGF possui correlação de 0,632 com o OHQ (Tabela 12).

Tabela 12- Correlação entre os escores equiparados das escalas

\begin{tabular}{llccc}
\hline \hline & & EU & Total_OHQ & TOTAL_EGF \\
\hline \hline EU & Pearson Correlation & 1 &, $556\left(^{* *}\right)$ &, $635\left({ }^{* *}\right)$ \\
& Sig. (2-tailed) & &, 000 &, 000 \\
& $\mathrm{~N}$ & 482 & 482 & 480 \\
Total_OHQ & Pearson Correlation &, $556\left(^{* *}\right)$ & 1 &, $632\left(^{* *}\right)$ \\
& Sig. (2-tailed) &, 000 & &, 000 \\
& $\mathrm{~N}$ & 482 & 484 & 482 \\
TOTAL_EGF & Pearson Correlation &, $635\left(^{* *}\right)$ &, $632\left({ }^{* *}\right)$ & 1 \\
& Sig. (2-tailed) &, 000 &, 000 & \\
& $\mathrm{~N}$ & 480 & 482 & 482 \\
\hline \hline
\end{tabular}

** Correlação significante em 0.01

Seguindo os passos de Hills e Argyle (2002), foi realizada inicialmente uma análise fatorial com rotação ortogonal, a fim de que os fatores obtidos tivessem maior interpretabilidade. Vale lembrar que a variável anteriormente descrita (item 25) que não colaborou com a medida foi descartada da análise. Para melhor visualização dos fatores rotacionados foi solicitado ao software que não fosse demonstrada as cargas abaixo de 0,10 . 
Nesta análise, a variável 15 foi excluída por apresentar uma baixa comunalidade: 0,345. Após sua exclusão, pôde-se verificar que a explicação da variância aumentou $(52,76 \%)$, permanecendo estáveis os demais indicadores de qualidade da análise (KMO de 0,837 e resíduos de 38\%). A Tabela 2 em Apêndices mostra as cargas fatoriais e os fatores obtidos e na Tabela 3 as comunalidades.

Houve dois artigos publicados que envolveram a análise fatorial do instrumento antecessor ao utilizado, o OHI, onde foram obtidos sete fatores, os quais foram "frouxamente nomeados": cognição positiva, comprometimento social, afeto positivo, senso de controle, disposição física, auto satisfação e prontidão mental (Hills \& Argyle, 2002), quantidade também obtida no trabalho Hills e Argyle (2001), que também encontraram igualmente sete fatores para o OHI, nomeados como: satisfação com a vida, eficácia, sociabilidade/ empatia, resultado positivo, bem-estar físico, jovialidade e auto-estima. O critério para identificação dos fatores, para os autores, foi do eigenvalue acima de 1, critério que também foi utilizado ao longo deste trabalho. Os fatores obtidos seguem abaixo, os quais são nomeados de forma interpretativa, conforme o agrupamento das variáveis obtidas e observada a parte teórica estruturada em capítulos anteriores.

\section{FATOR 1 - Satisfação com a vida}

- A vida é boa.

- Eu sinto que a vida é muito recompensada.

- Eu sou muito feliz.

- Estou muito satisfeito com tudo em minha vida.

- Eu acho a maioria das coisas agradáveis.

- Eu não acho que o mundo que o mundo é um bom lugar.

\section{FATOR 2 - Controle}

- Existe uma diferença entre o que gostaria de fazer e o que faço.

- Não acho fácil tomar decisões.

- Sinto que não estou, sobretudo, no controle de minha vida.

- Eu raramente me sinto descansado.

- Não me sinto particularmente satisfeito com a maneira que sou. 


\section{FATOR 3 - Disposição mental}

- Sinto-me alegre e exaltado.

- Sinto minha mente completamente alerta.

- Sinto que possuo muita energia.

\section{FATOR 4 - Superioridade ambiental}

- Eu não me acho atraente.

- Não me divirto com outras pessoas.

- Sempre contagio de alegria outras pessoas.

- Eu sorrio muito.

\section{FATOR 5 - Autonomia}

- Estou sempre comprometido e envolvido.

- Sinto-me capaz de conseguir qualquer coisa.

- Sempre me saio bem em tudo o que quero.

\section{FATOR 6 - Relação positiva com outros}

- Eu tenho sentimentos calorosos com quase todos.

- Eu sou intensamente interessado em outras pessoas.

\section{FATOR 7 - Propósito}

- Não tenho particularmente senso de significado e propósito para minha vida.

- Eu particularmente não sou otimista sobre o futuro.

\section{FATOR 8 - Aceitação}

- Sempre tenho boa influência nos acontecimentos

- Não me sinto particularmente saudável

- Não tenho particularmente memórias felizes do passado

Neste ponto houve convergência com a quantidade de fatores obtida pelo autor e a encontrada pela nossa análise. Contudo, o artigo de Argyle (2002), que menciona os fatores obtidos pela escala $\mathrm{OHI}$, não nomeia os fatores para a análise do $\mathrm{OHQ}$, porque os pesquisadores afirmam que os fatores não são consistentes para nomeá-los. De acordo com a metodologia adotada, Hair e colaboradores (2005), a nomeação dos fatores consiste em etapa integrante e necessária à análise. Para a designação dos fatores acima, observou-se também a estrutura do BES sugerida por Ryff (1989) e as nomeações dos fatores realizadas pelos autores (Hills \& Argyle, 2001 e 2002). 
Não houve menção no artigo de referência quanto à explicação da variância, mas a quantidade obtida por nós é um montante considerável, se avaliarmos que estes oito explicam mais da metade da variação de felicidade das pessoas envolvidas na amostra. A quantidade de fatores obtida em nossa análise e no artigo que serve de suporte para este trabalho também foi encontrada por Campbell (1976), há 30 anos, quando realizou estudo, envolvendo elementos afetivos e cognitivos como componentes do BES.

As variáveis que integram um fator, juntas, possuem uma determinada consistência interna, isto é, uma coerência. Esta medida é fornecida pelo alfa de Cronbach, que foi calculado para cada fator obtido.

Tabela 13 - Alfa de Cronbach dos fatores do OHQ - Rotação ortogonal

\begin{tabular}{lc}
\hline \hline FATOR & ALFA DE CRONBACH \\
\hline \hline SATISFAÇÃO COM A VIDA & $\mathbf{0 , 6 8 9}$ \\
CONTROLE & $\mathbf{0 , 5 7 3}$ \\
DISPOSIÇÃO MENTAL & $\mathbf{0 , 4 8 1}$ \\
SUPERIORIDADE AMBIENTAL & $\mathbf{0 , 5 6 9}$ \\
AUTONOMIA & $\mathbf{0 , 5 2 4}$ \\
RELAÇÃO POSITIVA COM OUTROS & $\mathbf{0 , 4 7 8}$ \\
PROPÓSITO & $\mathbf{0 , 2 1 8}$ \\
ACEITAÇÃO & $\mathbf{0 , 1 1 4}$ \\
\hline \hline
\end{tabular}

Observa-se que os fatores Satisfação com a vida, Controle, Superioridade ambiental e Autonomia possuem valores de alfa acima de 0,5 (quanto mais próximo a 1, mais consistência interna o fator possui), que mostra a coerência existente dentro do fator, diferente dos fatores Disposição mental, Relação positiva com outros, Propósito e Aceitação, de baixo valor.

$\mathrm{O}$ autor conclui sobre a falta de interpretabilidade para os fatores obtidos, tanto em função das cargas muito próximas de algumas variáveis em alguns fatores, como também pela baixa correlação existente entre os fatores do questionário original $(\mathrm{OHI})$ e sua versão posterior e reduzida (OHQ). Obtivemos também uma variável que está indeterminada entre dois fatores: Não tenho particularmente memórias felizes do passado possui cargas próximas 
entre o sétimo e oitavo fator. Optou-se por permanecer no fator em que havia a carga ligeiramente superior.

$\mathrm{Na}$ busca de obter uma estrutura fatorial que observasse não somente as relações das variáveis internas ao fator, mas como também preservar as correlações entre os fatores, foi utilizado outro tipo de rotação, a oblíqua.

O resultado da rotação oblíqua forneceu algumas mudanças nas variáveis e a estrutura resultante mostrou-se mais consistente (Tabela 14). O valor de KMO e explicação da variância permaneceram, porém os resíduos aumentaram um pouco, $41 \%$.

Tabela 14 - Fatores OHQ

\section{Fatores obtidos OHQ}

Explicação

da

variância

FATOR 1- Satisfação com a vida

- A vida é boa.

- Eu sinto que a vida é muito recompensada.

- Eu sou muito feliz.

- Estou muito satisfeito com tudo em minha vida.

- Eu acho a maioria das coisas agradáveis

\section{FATOR 2 - Controle}

- Existe uma diferença entre o que gostaria de fazer e o que faço.

- Não acho fácil tomar decisões.

- Sinto que não estou, sobretudo, no controle de minha vida.

- Eu raramente me sinto descansado.

- Não me sinto particularmente satisfeito com a maneira que sou.

\section{FATOR 3 - Relação positiva com outros}

- Eu tenho sentimentos calorosos com quase todos.

- Eu sou intensamente interessado em outras pessoas.

- Sinto que possuo muita energia.

\section{FATOR 4 - Autonomia}

- Estou sempre comprometido e envolvido.

- Sinto-me capaz de conseguir qualquer coisa.

- Sempre me saio bem em tudo o que quero

FATOR 5 - Superioridade ambiental

- Eu não me acho atraente.

- Não me divirto com outras pessoas.

- Sempre contagio de alegria outras pessoas.

- Eu sorrio muito.

\section{FATOR 6 - Aceitação}

- Sempre tenho boa influência nos acontecimentos.

- Não me sinto particularmente saudável.

- Eu não acho que o mundo é um bom lugar. 


\section{FATOR 7 - Propósito}

- Não tenho particularmente senso de significado e propósito para minha vida.

- Eu particularmente não sou otimista sobre o futuro.

- Não tenho particularmente memórias felizes do passado.

\section{FATOR 8 - Disposição mental}

- Sinto-me alegre e exaltado.

- Sinto minha mente completamente alerta.

Conforme pode ser observado, a rotação oblíqua ofereceu uma distribuição diferente para alguns fatores. No fator Satisfação com a vida, a variável Eu acho que o mundo é um bom lugar deixou de integrar o fator; em Controle, Autonomia e Superioridade Ambiental não houve mudanças; Relação positiva com os outros recebeu a variável Sinto que possuo muita energia, originária do fator Disposição Mental; Aceitação recebeu a variável Eu acho que o mundo é um bom lugar e perdeu Não tenho particularmente memórias felizes do passado, que passou a integrar o fator Propósito.

Tabela 35- Alfa de Cronbach dos fatores do OHQ - Rotação oblíqua

\begin{tabular}{lc}
\hline \hline FATOR & $\underline{\text { ALFA DE CRONBACH }}$ \\
\hline \hline SATISFAÇÃO COM A VIDA & $\mathbf{0 , 7 0 0}$ \\
CONTROLE & $\mathbf{0 , 5 7 3}$ \\
DISPOSIÇÃO MENTAL & $\mathbf{0 , 3 9 9}$ \\
SUPERIORIDADE AMBIENTAL & $\mathbf{0 , 5 6 9}$ \\
AUTONOMIA & $\mathbf{0 , 5 2 4}$ \\
RELAÇÃO POSITIVA COM OUTROS & $\mathbf{0 , 4 8 5}$ \\
PROPÓSITO & $\mathbf{0 , 3 3 1}$ \\
ACEITAÇÃO & $\mathbf{0 , 1 1 7}$ \\
\hline \hline
\end{tabular}

O novo arranjo, obtido com a rotação oblíqua elevou ligeiramente a consistência interna do primeiro fator; Controle, Autonomia e Superioridade ambiental não sofreram alteração no valor de alfa (uma vez que não foi alterada sua estrutura interna); Disposição mental teve o valor decrescido, porém Relação positiva com os outros, Propósito e Aceitação tiveram leve aumento dos escores (Tabela 15). Como a rotação oblíqua considera a relação entre os fatores, será esta a estrutura fatorial a ser considerada na análise a fim de investigar a 
estabilidade estrutural do questionário quanto à estabilidade das variáveis que compõem os fatores.

As comunalidades representam a variância explicada pela solução fatorial encontrada para cada variável. Estas devem ser observadas a fim de verificar se atendem a um nível mínimo de explicação aceitável, isto é, 0,5 (Hair e colaboradores, 2005). Os itens Não me sinto particularmente satisfeito com a maneira que sou; Não tenho particularmente senso de significado e propósito para minha vida; Eu particularmente não sou otimista sobre o futuro; Sinto minha mente completamente alerta; Eu sinto que a vida é muito recompensada; Eu raramente me sinto descansado; Eu acho a maioria das coisas agradáveis; Eu acho que o mundo que o mundo é um bom lugar; Sempre me saio bem em tudo o que quero; Eu não me acho atraente não obtiveram valor aceitável de explicação, conforme podem ser verificados os escores na Tabela 5, em Apêndices. Para estas variáveis, há duas soluções possíveis. A primeira é a interpretação fatorial da forma como se encontra, ignorando a informação das comunalidades; a segunda é a eliminação destas variáveis para buscar aumentar a quantia de variância explicada (Hair e colaboradores, 2005). A eliminação de 10 variáveis comprometeria muito a análise do questionário, optando-se pela primeira alternativa.

No trabalho de referência, os oito fatores obtidos pelo autor na análise fatorial foram novamente fatorados, a fim de avaliar se haveria algum fator de segunda ordem envolvido no questionário. Através desta nova análise, Hills e Argyle (2002) obtiveram um único fator, levando o autor à conclusão sobre a unidimensionalidade do questionário.

Seguimos o mesmo procedimento, porém não foi possível obter o mesmo resultado. A nova análise fatorial, considerando-se os fatores rotacionados obliquamente, resultou em dois fatores subjacentes ao questionário. Na Tabela 6 de Apêndices, constam as cargas fatoriais para os dois fatores obtidos, cuja composição foi: 


\section{FATOR 1}

- Satisfação com a vida

- Controle

- Relação positiva com outros

- Autonomia

- Superioridade ambiental

\section{FATOR 2}

- Aceitação

- Propósito

- Disposição mental

O KMO para a análise foi de 0,722 ; o menor MSA foi de 0,554 e o total de variância explicada pelos dois fatores foi de 44,08\%. Os dois fatores obtidos praticamente não são correlacionados entre si, apresentando um valor de 0,040 .

As correlações internas entre as variáveis são de grande importância para a sustentabilidade da análise fatorial. A matriz de correlações obtida pela análise do autor possuiu um valor menor de $-0,04$ e maior de 0,65 , com média de 0,28 . Nossa matriz de correlações obteve menor valor de $-0,087$ e maior valor de 0,494 e média entre as correlações de 0,153 . Isto significa praticamente metade da força das correlações. Existe uma diferença significativa na quantidade de pesquisados, envolvidos em ambos os questionários, sendo de 167 no artigo de referência, contra 485 utilizados por esta pesquisa. Portanto, para descartar a hipótese de correlações indesejadas tenham surgido da grande amostra estudada, ou que a quantidade diminuiu a força das correlações, foi investigada a matriz de correlações com a metade dos respondentes, selecionados de forma aleatória. As correlações médias permaneceram similares. O valor obtido foi de 0,147 , com valor mínimo de $-0,130$ a 0,558 . A amplitude aumentou se compararmos com o resultado anterior. Na Tabela 7, em Apêndices, há a análise fatorial realizada com esta metade da amostra selecionada, que acabou por resultar em 7 fatores. Esta estrutura de correlações, portanto, fragiliza a análise fatorial. 
Os autores, para endossarem a unidimensionalidade do teste, se apoiaram na realização de técnica multivariada denominada análise discriminante. Para esta análise temos como variável dependente uma variável categórica, e para isso foi adotado o recurso de grupos-critério, que categoriza os pesquisados em função do posicionamento em relação à média geral do questionário. A soma dos escores do teste, considerado os itens em sentido contrario revertidos, representa o nível de BES (Hills \& Argyle, 2002). O ponto central, obtido pela média geral do questionário, estabelece o ponto de corte entre os grupos e a conseqüente classificação destes, em um ou outro grupo, isto é, aqueles acima ou abaixo da média. Esta, portanto, é a variável dependente. Como variáveis independentes métricas estão as variáveis que os itens do questionário, com exceção da que foi descartada pelo teste de médias.

Para construção do modelo, foram utilizados 342 respondentes aleatórios, 70,7\% da amostra, e para a validação do modelo obtido, 141 respondentes, ou $29,1 \%$. A diferença dos dois percentuais corresponde a dois casos que foram excluídos da análise. A relação entre as variáveis dependentes e independentes é fornecida através de função matemática, na qual os escores representam pesos das variáveis para a composição do modelo.

Para a análise das médias, em um teste de hipóteses, temos:

$\mathrm{H}_{0}=$ as médias dos grupos são iguais

$\mathrm{H}_{1}=$ as médias dos grupos são diferentes.

O resultado do teste nos levou a rejeitar a hipótese nula e aceitamos a hipótese alternativa, pela qual as médias são diferentes, podendo então os grupos criados ser discriminados.

A análise das matrizes de covariância, que é importante para a análise discriminante, é através do resultado do Box M. Em um teste de hipóteses, obtemos:

$\mathrm{H}_{0}=$ igualdade de covariância 
$\mathrm{H}_{1}=$ as matrizes não possuem igualdade de covariância.

O resultado para este teste foi de $\operatorname{sig}=0,000<0,05$. A aceitação da falta de igualdade entre as matrizes desfavorece a realização da análise discriminante, uma vez que pode afetar negativamente o processo de classificação. A existência ou não deste problema não foi mencionada no artigo e consiste em uma propriedade a ser observada para este tipo de análise.

A análise discriminante oferece n-1 equações, resultando neste caso apenas 1 equação graças ao delineamento estabelecido. Para melhor compreensão: a adoção dos grupos critério dividiu a escala em duas categorias (n): acima e abaixo da média. $\mathrm{O}$ autor se apoiou nesta propriedade para sustentar a unidimensionalidade, encontrada na análise fatorial. Este é um raciocínio tendencioso, uma vez que foram criadas duas categorias voluntariamente. Poderíamos, ao invés de duas categorias, nomear três categorias e então classificar o sujeito entre "feliz", "relativamente feliz" e "não tão feliz". Isto faria com que a análise discriminante retornasse duas equações, sustentando os dois fatores de segunda ordem que foram encontrados por nossa pesquisa. Portanto, a unidimensionalidade obtida pelos autores, através da análise discriminante, é fruto de um artifício metodológico.

Resta saber se este modelo conseguiu uma boa discriminação dos respondentes. Com relação ao acerto na discriminação obtida neste trabalho, houve um percentual $94,2 \%$ de classificação correta na construção do modelo e 92,7\% na validação da função. Estes valores estão muito próximos aos $90 \%$ mencionado pelos autores do questionário.

Conclusivamente, fortes divergências surgiram entre os resultados originais existentes no artigo e nossa análise. Primeiro, na estrutura das correlações entre as variáveis, sendo mais fortes quando realizadas no país de origem do questionário do que em versão adaptada ao Brasil. Daí pode-se refletir sobre a influência do aspecto cultural no questionário. Segundo, quanto à dimensionalidade do teste, a qual os autores apresentaram uma única e neste trabalho há a presença de duas dimensões, atestadas pela análise fatorial realizada e pela análise dos 
itens, presente mais adiante. Terceiro, quanto à propriedade em adoção da análise discriminante, uma vez que um pré-suposto necessário para sua realização, neste trabalho, não se mostrou válido. O ponto de convergência foi a quantidade de fatores de primeira ordem, coincidindo em 8 .

Hills e Argyle avaliaram que o número de itens, envolvidos no questionário (29), era grande e não propiciava uma análise consistente dos fatores obtidos. Então, 1) através de outra análise discriminante, agora pelo método stepwise (que consiste na inclusão das variáveis uma a uma, montando um elenco das que conseguem maior discriminação), formaram uma escala com um conjunto menor de itens, e então 2) realizaram a análise fatorial com estes itens que resultaram da stepwise para avaliar as dimensões envolvidas.

Após feita a primeira parte, encontramos a existência de uma forte divergência entre as duas pesquisas. Ambas conseguiram um grande percentual de discriminação dos grupos, contudo, as variáveis e a quantidade de variáveis discriminantes foram bem diferentes. Enquanto o autor encontrou 8 variáveis discriminantes, na análise deste trabalho, através do método stepwise, foram encontradas 15 variáveis. A escala reduzida obtida pelo autor compreende os seguintes itens:

Tabela 16- Análise discriminante stepwise realizada por Argyle e Hills (2002)

\begin{tabular}{llcc}
\hline \hline & Variável "entered” & Wilks $\boldsymbol{\lambda}$ & $\boldsymbol{F}$ \\
\hline \hline 1 & Sinto que a vida é recompensada. & 0,63 & 99,3 \\
2 & Sinto minha mente completamente alerta & 0,50 & 81,1 \\
3 & Não me sinto particularmente satisfeito com a maneira que sou & 0,45 & 66,1 \\
4 & Encontro belezas em algumas coisas. & 0,41 & 57,7 \\
5 & Estou muito satisfeito com tudo em minha vida. & 0,39 & 50,7 \\
6 & Sempre me saio bem em tudo o que quero & 0,37 & 45,1 \\
7 & Eu não me acho atraente & 0,36 & 40,3 \\
8 & Não tenho particularmente memórias felizes do passado. & 0,35 & 36,7 \\
\hline \hline
\end{tabular}

A diferença não foi significativa apenas na quantidade, uma vez que 7 afirmativas a mais foram significantes. Entre as 15 variáveis envolvidas, apenas 3 coincidem com a escala reduzida de 8 itens originais de Hills e Argyle (2002): Não tenho particularmente memórias felizes do passado; Sempre me saio bem em tudo o que quero; Sinto minha mente 
completamente alerta. Esta significativa diferença também pode ser graças a aspectos culturais. O item que mais discriminou os grupos no questionário original foi Eu sinto que a vida é recompensada, enquanto em nosso estudo, a variável Eu acho a maioria das coisas agradáveis foi a mais responsável pela separação dos grupos. Outra diferença entre as escalas foi que a variável Encontro beleza em algumas coisas que foi considerada significante para discriminar os grupos em Hills e Argyle (2002) e, neste trabalho, desconsiderada. As variáveis que obtidas na stepwise foram:

Tabela 17- Função discriminante stepwise

\begin{tabular}{lc}
\hline \hline Itens & $\begin{array}{c}\text { Coeficientes Função } \\
\text { Discriminante }\end{array}$ \\
\hline \hline Eu acho a maioria das coisas agradáveis & 0,237 \\
Existe uma distância entre o que eu gostaria de fazer e o que faço & 0,210 \\
Eu sou muito feliz & 0,209 \\
Eu particularmente não sou otimista sobre o futuro & 0,193 \\
Não me divirto com outras pessoas & 0,190 \\
Sinto minha mente completamente alerta & 0,182 \\
Sempre me saio bem em tudo o que quero & 0,172 \\
Sinto que não estou, sobretudo, no controle de minha vida & 0,163 \\
Estou muito satisfeito com tudo em minha vida & 0,142 \\
Eu tenho sentimentos calorosos com quase todos & 0,134 \\
Eu não me acho atraente & 0,131 \\
Não me sinto particularmente saudável & 0,110 \\
Não tenho particularmente senso de significado e propósito para minha vida & 0,104 \\
Eu não me sinto particularmente satisfeito com a maneira que sou & 0,103 \\
Não tenho particularmente memórias felizes do passado & 0,098 \\
\hline \hline
\end{tabular}

Há, portanto, duas escalas reduzidas, uma produzida pelos autores originais e outra encontrada neste trabalho. Para avaliar os resultados obtidos na literatura de referência, quanto à dimensionalidade, foram realizadas análises fatoriais para os dois casos, pois:

1- A escala com 15 itens possui sua própria estrutura de correlações e deve ser avaliada.

2- Por outro lado, a escala reduzida do autor pode oferecer uma estrutura mais harmônica e convergente com os resultados obtidos originalmente.

Na primeira análise, o valor de KMO foi de 0,787 , o menor MSA de 0,629 . Os quatro fatores obtidos foram responsáveis por 47,206\% da explicação da variância e resíduos de 59\%. Este valor consiste nas correlações reproduzidas, que é o resíduo obtido pela 
substituição das variáveis pelos fatores. A composição dos fatores está demonstrada nas Tabelas 9 e 10, em Apêndices. Ao fatorar-se novamente estes quatro fatores, encontrou-se 2 fatores de segunda ordem, com KMO de 0,571 (que mostra a má adequação da análise) e explicação da variância de 60,23\%.

Considerando as variáveis da escala reduzida do autor, correlações médias foram iguais, 0,130. O KMO de 0,700 foi inferior e o menor MSA de 0,421 (referente à variável 25, Encontro belezas em algumas coisas) e a explicação da variância de 40,95\%, com 82\% de resíduos. O resultado, contudo é o grande diferencial. Enquanto, para esta análise, o autor encontrou somente um fator, foram encontrados dois fatores, consistentes com as análises anteriores.

Esta escala reduzida de oito itens foi utilizada por Maltby e Babrer (2005), para avaliar a diferença entre felicidade hedônica e eudamônica, pautada na dimensão única do construto.

\subsection{ANÁLISE DE ITENS DO OHQ}

Apesar das diferenças entre o questionário original e os resultados obtidos até agora neste trabalho, deve-se avaliar a capacidade de mensuração da escala. A escala possui uma consistência interna aceitável e alta correlação com outros testes que buscam mensurar o BES. O desempenho total do teste está ligado ao desempenho de cada item, assim, é necessário proceder às análises destes.

Para avaliação dos itens é necessário avaliar as dimensões do questionário. Para podermos avaliar este aspecto é necessário examinar o desempenho das cargas fatoriais. Uma observação se faz importante: até agora as análises fatoriais feitas tinham por objetivo maximizar a explicação da variância com a menor quantidade possível de fatores. Para análise da(s) dimensão(ões) do teste temos de avaliar a correlação expressa pela carga 
fatorial com o fator, ou dimensão em que se encontra. Em outras palavras, devemos procurar obter a melhor distribuição possível de cargas aceitáveis para as variáveis em análise. Para isso é necessário solicitar a quantidade de fatores a serem extraídos, iniciando em 1 (que determina a unidimensionalidade) e verificar as cargas existentes. Aquela que se apresentar abaixo de 0,30 , para o item, mostra ser inapropriada porque não integra um mesmo propósito de mensuração, e novas análises fatoriais devem ser feitas até que haja distribuição compatível das cargas fatoriais (Pasquali, 2003). Na Tabela 18, estão os resultados obtidos pela fatoração, avaliando a unidimensionalidade do teste.

Tabela 18- Carga fatorial análise 1 fator OHQ

\begin{tabular}{lcc}
\hline \hline & & \\
\hline & $\begin{array}{c}\text { Carga } \\
\text { Fatorial }\end{array}$ & $\begin{array}{c}\text { Percentual } \\
\text { Covariância }\end{array}$ \\
\hline \hline Fator 1 & & \\
Eu sou muito feliz & 0,697 & $49 \%$ \\
Sinto-me alegre e exaltado & 0,603 & $36 \%$ \\
Estou muito satisfeito com tudo em minha vida & 0,593 & $35 \%$ \\
Eu sinto que a vida é muito recompensada & 0,579 & $34 \%$ \\
Sempre contagio de alegria outras pessoas & 0,556 & $31 \%$ \\
Eu sorrio muito & 0,548 & $30 \%$ \\
Sempre me saio bem em tudo o que quero & 0,517 & $27 \%$ \\
A vida é boa & 0,516 & $27 \%$ \\
Eu particularmente não sou otimista sobre o futuro & 0,512 & $26 \%$ \\
Sinto-me capaz de conseguir qualquer coisa & 0,506 & $26 \%$ \\
Sinto que possuo muita energia & 0,473 & $22 \%$ \\
Eu acho a maioria das coisas agradáveis & 0,470 & $22 \%$ \\
Eu não me sinto particularmente satisfeito com a maneira que sou & 0,432 & $19 \%$ \\
Sinto minha mente completamente alerta & 0,401 & $16 \%$ \\
Eu acho que o mundo que o mundo é um bom lugar & 0,392 & $15 \%$ \\
Sempre tenho boas influências nos acontecimentos & 0,390 & $15 \%$ \\
Não me divirto com outras pessoas & 0,364 & $13 \%$ \\
Eu não me acho atraente & 0,356 & $13 \%$ \\
Sinto que não estou, sobretudo, no controle de minha vida. & 0,356 & $13 \%$ \\
Não me sinto particularmente saudável & 0,347 & $12 \%$ \\
Não tenho particularmente memórias felizes do passado & 0,326 & $11 \%$ \\
Existe uma diferença entre o que gostaria de fazer e o que faço & 0,290 & $8 \%$ \\
Não é fácil tomar decisões & 0,287 & $8 \%$ \\
Eu tenho sentimentos calorosos com quase todos & 0,267 & $7 \%$ \\
Eu sou intensamente interessado em outras pessoas & 0,260 & $7 \%$ \\
Estou sempre comprometido e envolvido & 0,234 & $5 \%$ \\
Eu raramente me sinto descansado & 0,208 & $4 \%$ \\
Não tenho particularmente senso de significado e propósito para minha & & $3 \%$ \\
vida & 0,174 & $3 \%$ \\
\hline \hline
\end{tabular}


O KMO para a análise foi de 0,837 e total da variância explicada de $19,077 \%$. Os itens assinalados em amarelo mostram aqueles com escore abaixo do indicado. Ao elevarmos ao quadrado o valor da carga fatorial, é obtido o percentual de covariância entre o item e o fator. Esta é uma medida de validade de construto do item, uma vez que, quanto maior for esta relação, mais o item conseguirá traduzir o traço mensurado (Pasquali, 2003). Face a este resultado, não podemos atestar a unidimensionalidade do questionário, pois várias variáveis possuem escores abaixo do indicado. Deve-se, então, continuar a realizar a fatoração dos itens, até que haja a distribuição conveniente das cargas fatoriais (Pasquali, 2003). A Tabela 19 abaixo mostra os resultados para extração de dois fatores.

Tabela 19- Carga fatorial análise 2 fatores OHQ

\begin{tabular}{lcc}
\hline \hline & $\begin{array}{c}\text { Carga } \\
\text { Fatorial }\end{array}$ & $\begin{array}{c}\text { Percentual } \\
\text { Covariância }\end{array}$ \\
\hline \hline Fator 1 & & \\
Eu sou muito feliz & 0,646 & $41,7 \%$ \\
Sempre contagio de alegria outras pessoas & 0,635 & $40,4 \%$ \\
Sinto-me alegre e exaltado & 0,622 & $38,7 \%$ \\
Eu sorrio muito & 0,585 & $34,2 \%$ \\
Eu sinto que a vida é muito recompensada & 0,568 & $32,3 \%$ \\
Sempre me saio bem em tudo o que quero & 0,548 & $30,0 \%$ \\
Sinto-me capaz de conseguir qualquer coisa & 0,529 & $28,0 \%$ \\
Estou muito satisfeito com tudo em minha vida & 0,517 & $26,7 \%$ \\
Sempre tenho boas influências nos acontecimentos & 0,508 & $25,8 \%$ \\
Eu acho a maioria das coisas agradáveis & 0,503 & $25,3 \%$ \\
Sinto que possuo muita energia & 0,478 & $22,9 \%$ \\
Sinto minha mente completamente alerta & 0,474 & $22,4 \%$ \\
A vida é boa & 0,451 & $20,3 \%$ \\
Eu tenho sentimentos calorosos com quase todos & 0,387 & $15,0 \%$ \\
Estou sempre comprometido e envolvido & 0,328 & $10,8 \%$ \\
Eu sou intensamente interessado em outras pessoas & 0,324 & $10,5 \%$ \\
Fator 2 & & \\
Eu não me sinto particularmente satisfeito com a maneira que sou & 0,560 & $31,4 \%$ \\
Não me sinto particularmente saudável & 0,550 & $30,3 \%$ \\
Não é fácil tomar decisões & 0,515 & $26,6 \%$ \\
Sinto que não estou, sobretudo, no controle de minha vida. & 0,503 & $25,4 \%$ \\
Existe uma diferença entre o que gostaria de fazer e o que faço & & \\
Não tenho particularmente memórias felizes do passado & 0,486 & $23,6 \%$ \\
Eu raramente me sinto descansado & 0,483 & $23,4 \%$ \\
Eu particularmente não sou otimista sobre o futuro & 0,481 & $23,1 \%$ \\
Eu não acho que o mundo que o mundo é um bom lugar & 0,478 & $22,8 \%$ \\
Eu não me acho atraente & 0,391 & $15,3 \%$ \\
Não me divirto com outras pessoas & 0,387 & $15,0 \%$ \\
Não tenho particularmente senso de significado e propósito para minha vida & 0,272 & $7,4 \%$ \\
\hline \hline
\end{tabular}


A variável Não tenho senso de significado e propósito para a vida está assinalada devido à baixa relação com o fator em que está inserida, que a torna passível de exclusão. Porém optou-se por mantê-la, a fim de preservar a composição das variáveis, até agora analisadas, uma vez que a carga fatorial apresenta estar um pouco abaixo do ponto de corte definido. O valor do KMO da análise foi de 0,837 e explicação da variância de $26,57 \%$

Diener e colaboradores (2003) já afirmaram que, em função da independência do afeto positivo e afeto negativo, fundamentos do bem-estar subjetivo, este construto não poderia ser unidimensional e que possuiria, ao menos, duas dimensões. Obtidos dois fatores, Pasquali (2003) instrui que sejam tratados como se fossem testes diferentes para análise dos itens, portanto, esta análise será feita em função de cada fator.

A análise de itens envolve variáveis dicotômicas para acerto ou erro nos itens. De acordo com Bunchaft e Cavas (2002) “... consideramos que um item discrimina entre os escores altos e baixos, funcionando como preditor do resultado global no teste, desde que os sujeitos com escores altos no teste acertem esse item com maior frequiência do que os sujeitos com escores baixos no teste" (pg. 41). O acerto ou erro em questão está relacionado à magnitude do traço latente necessário para que o pesquisado venha a aceitar ou rejeitar o item (Pasquali, 2003). Este tipo de cálculo está ligado a Teoria de Resposta ao Item, técnica que está além dos conhecimentos adquiridos para condução deste trabalho. Dessa forma é necessário estabelecer o ponto de corte para classificar os indivíduos que possuem maior e menor escore para o item avaliado. Neste critério, foi utilizada a mediana de cada item para classificar cada respondente, acima ou abaixo deste ponto (Tabela 199) e através de uma matriz binária realizar os cálculos de correlação (Pasquali, 2003).

Os resultados da Tabela 20 oferecem a correlação de Pearson do item com o resultado total do teste, relativo a cada fator. Considerando uma correlação mínima de 0,3 (Pasquali, 2003), os itens foram classificados em ordem decrescente de correlação, onde no primeiro 
fator, 3 itens se mostraram com baixa correlação, portanto inapropriados (Eu tenho sentimentos calorosos com quase todos; Estou sempre comprometido e envolvido; Eu sou intensamente interessado em outras pessoas) e no segundo fator acontece o mesmo com 3 itens (Eu raramente me sinto descansado; Existe uma diferença entre o que gostaria de fazer e o que faço; Não é fácil tomar decisões).

Tabela 20- Correlação bisserial OHQ

\begin{tabular}{lc}
\hline \hline & $\begin{array}{c}\text { Correlação } \\
\text { Bisserial }\end{array}$ \\
\hline \hline Fator 1 & \\
Sempre contagio de alegria outras pessoas & 0,496 \\
Sinto-me alegre e exaltado & 0,479 \\
Estou muito satisfeito com tudo em minha vida & 0,476 \\
Eu sou muito feliz & 0,471 \\
Eu sinto que a vida é muito recompensada & 0,466 \\
Eu acho a maioria das coisas agradáveis & 0,440 \\
Sempre me saio bem em tudo o que quero & 0,431 \\
A vida é boa & 0,389 \\
Eu sorrio muito & 0,387 \\
Sinto-me capaz de conseguir qualquer coisa & 0,384 \\
Sinto que possuo muita energia & 0,378 \\
Sempre tenho boas influências nos acontecimentos & 0,376 \\
Sinto minha mente completamente alerta & 0,334 \\
Eu tenho sentimentos calorosos com quase todos & 0,274 \\
Estou sempre comprometido e envolvido & 0,235 \\
Eu sou intensamente interessado em outras pessoas & 0,145 \\
Fator 2 & \\
Não tenho particularmente senso de significado e propósito para minha & 0,426 \\
vida & 0,397 \\
Não me sinto particularmente satisfeito com a maneira que sou & 0,383 \\
Eu particularmente não sou otimista sobre o futuro & 0,362 \\
Não me divirto com outras pessoas & 0,322 \\
Sinto que não estou, sobretudo, no controle de minha vida. & 0,321 \\
Não me sinto particularmente saudável & 0,315 \\
Eu não me acho atraente & 0,312 \\
Eu não acho que o mundo que o mundo é um bom lugar & 0,304 \\
Não tenho particularmente memórias felizes do passado & 0,277 \\
Eu raramente me sinto descansado & 0,275 \\
Existe uma diferença entre o que gostaria de fazer e o que faço & 0,224 \\
Não é fácil tomar decisões & \\
\hline \hline
\end{tabular}

Outro aspecto da análise de itens a ser considerado é o índice de facilidade. Este é obtido através da razão entre a quantidade de acertos no questionário ${ }^{5}$, através das pessoas que apresentaram maior escore na avaliação (mais convergentes com o comportamento

\footnotetext{
${ }^{5}$ Considerar a definição fornecida para acerto e erro.
} 
esperado) e daquelas com menor escore (mais distantes do comportamento esperado na avaliação do item).

Tabela 21- Índice de facilidade OHQ

Índice Facilidade

\section{Fator 1}

Eu sou muito feliz

Sinto que possuo muita energia

0,814

Eu sorrio muito

0,795

Estou sempre comprometido e envolvido

0,756

A vida é boa

0,750

Sinto minha mente completamente alerta

0,705

Sinto-me capaz de conseguir qualquer coisa

0,700

Eu sinto que a vida é muito recompensada

0,692

Sempre contagio de alegria outras pessoas

0,671

Eu acho a maioria das coisas agradáveis

0,640

Estou muito satisfeito com tudo em minha vida

0,616

Eu tenho sentimentos calorosos com quase todos

0,612

Eu sou intensamente interessado em outras pessoas

0,603

Sempre tenho boas influências nos acontecimentos

0,601

Sinto-me alegre e exaltado

0,574

Sempre me saio bem em tudo o que quero

\section{Fator 2}

Não tenho particularmente memórias felizes do passado

0,620

Eu raramente me sinto descansado

0,620

Não acho fácil tomar decisões

0,595

Não me divirto com outras pessoas

0,585

Eu não acho que o mundo que o mundo é um bom lugar

0,583

Eu não me acho atraente

0,570

Não me sinto particularmente saudável

Não me sinto particularmente satisfeito com a maneira que sou

Sinto que não estou, sobretudo, no controle de minha vida.

Não tenho particularmente senso de significado e propósito para minha

vida

Existe uma diferença entre o que gostaria de fazer e o que faço

O primeiro fator possui índices mais altos de facilidade do que o segundo. O item que mostrou maior facilidade de avaliação foi Eu sou muito feliz. As sentenças que apresentam sentido negativo e foram agrupadas em um único fator, possuem índice de facilidade um pouco menor, o que leva a considerar a possibilidade de uma dificuldade maior na resposta a estes itens. O item Não tenho particularmente memórias felizes do passado foi o de avaliação mais fácil para o segundo fator. 
Em síntese, o OHQ mostra ser uma escala bidimensional que, no primeiro fator, possui 3 itens que discriminam sofrivelmente os indivíduos, assim como no segundo fator. Os valores ligeiramente abaixo do estipulado na correlação bisserial, com exceção do escore de 0,145 para a variável Eu sou intensamente interessado em outras pessoas, que mostra ser um item potencialmente descartável, fragilizam a escala, porém a sua estrutura conceitual é diferenciada das demais, à medida que se procura avaliar uma quantidade maior de aspectos que envolvem o BES. Assim, seu desempenho será avaliado conforme se encontra, pareado às outras duas escalas, porém em trabalhos futuros será necessária a observação destas precariedades, para que a escala adquira maior eficácia em seu objetivo de mensuração.

Kashdan (2004), que realizou uma avaliação do questionário, concluiu que a presente estrutura do questionário desfavorece o estudo do BES se comparado a outras medidas. O desempenho do questionário será avaliado ao longo do trabalho para que, na conclusão deste, se observem as convergências quanto às críticas apontadas, falhas estas que dizem respeito à formação dos itens e ao foco em determinados construtos, como auto-estima, que pode inflar determinadas relações do BES e assim apresentar alto nível de multicolinearidade.

\subsection{ESCALA GERAL DE FELICIDADE}

Esta escala foi elaborada por Lyubomirsky e Lepper (1999), a fim de obter uma medida diferenciada das existentes. De acordo com a autora "As mensurações atuais acessam um dos dois componentes (do BES) ou são itens únicos de avaliação global. O que falta é uma mensuração total da felicidade subjetiva - que consiste em uma avaliação global e subjetiva do quanto uma pessoa é feliz ou infeliz...”. (pg. 139). Sua abordagem baseia-se na característica subjetiva do respondente em avaliar sua felicidade em sua própria perspectiva. A escala é composta por 4 itens, sendo que dois iniciais procuram caracterizar o pesquisado de forma absoluta, isto é, o quanto se considera feliz; e relativa, comparando-se a outros, em o 
quanto se sente feliz. Os outros dois itens descrevem indivíduos felizes e infelizes, respectivamente e solicita aos respondentes que quantifique o grau em que as afirmações convergem com sua forma de ser. As autoras deste questionário afirmam que seu benefício é não "ameaçar a unidimensionalidade do construto com numerosos itens" (pg. 140) e a existência de 4 itens proporciona o cálculo de sua consistência interna, construindo uma escala mais curta. A escala se encontra no capítulo 15- Instrumento de Pesquisa. Observa-se no questionário que o último item está em sentido inverso, que foi revertido de forma matemática para as análises que seguem.

Neste questionário podemos observar correlações mais fortes (Tabela $11 \mathrm{em}$ Apêndices). O valor da menor correlação entre as variáveis do questionário é de 0,246 e o maior de 0,681, com média de 0,39. Isto significa dizer que este questionário possui uma estrutura interna de correlações muito mais favorável à análise fatorial do que o questionário anterior. A variável de melhor correlação é Em geral eu me considero... está bem correlacionada com a variável Comparando com a maioria dos meus amigos, eu me considero... $(0,681)$. Em outras palavras, um indivíduo que se considera de maneira absoluta mais ou menos feliz, o faz também relativamente, comparando-se a outras pessoas. A segunda maior correlação está entre o primeiro e o terceiro item $(0,433)$, que representa a relação entre a avaliação em forma geral da própria felicidade e o referencial de pessoas felizes fornecido.

A média obtida para o questionário foi de 5,390 e desvio de 1,52. O questionário foi aplicado em diversas amostras de colegiais, comunidade feminina e em aposentados nos EUA; e em amostras de adultos na Rússia. A Tabela 22 mostra uma comparação entre os resultados obtidos para o cálculo do alfa de Cronbach, a quantidade destas amostras, suas médias e desvio padrão presentes na literatura; na última linha estão os valores obtidos pela análise realizada neste trabalho, que se apresenta assinalada. Vale lembrar que, no caso da 
Rússia, este país passou por transformações culturais e econômicas marcantes, afetando o BES, conforme pode ser verificado na Figura 6.

Tabela 22- Índices de fidedignidade e médias para a EGF (Lyubomirsky e Lepper, 1999)

\begin{tabular}{lccc}
\hline \hline Amostra & Alfa de Cronbach & Média & Desvio Padrão \\
\hline \hline Amostra 1 de universitários - EUA $(\mathrm{n}=551)$ & 0,85 & 4,89 & 1,11 \\
Amostra 2 de universitários - EUA $(\mathrm{n}=372)$ & 0,88 & 4,99 & 1,07 \\
Amostra 3 de universitários - EUA $(\mathrm{n}=156)$ & 0,86 & 5,07 & 1,14 \\
Amostra 4 de universitários - EUA (n= 242) & 0,89 & 4,94 & 1,18 \\
Amostra 5 de universitários - EUA (n=74) & 0,91 & 4,79 & 1,21 \\
Amostra 6 de universitários - EUA (n= 551) & 0,94 & 4,63 & 1,72 \\
Amostra 7 de universitários - EUA (n= 135) & 0,92 & 4,96 & 1,19 \\
Amostra 8 de universitários - EUA (n= 43) & 0,84 & 4,88 & 1,04 \\
Amostra universitários russos (n=67) & 0,84 & 4,84 & 1,13 \\
Colegiais EUA (n=36) & 0,81 & 5,62 & 0,96 \\
Comunidade adulta urbana - EUA (n=198) & 0,86 & 5,62 & 0,96 \\
Comunidade adulta urbana - Rússia (n=63) & 0,79 & 4,02 & 0,93 \\
Comunidade feminina - EUA (n= 92) & 0,85 & 4,80 & 1,12 \\
Aposentados urbanos - EUA (n= 622) & 0,86 & 5,62 & 0,96 \\
Comerciantes e comerciários - Brasil (n= 485) & $\mathbf{0 , 7 0}$ & $\mathbf{5 , 3 9}$ & $\mathbf{1 , 5 4}$ \\
\hline \hline
\end{tabular}

Entre as análises realizadas, os representantes brasileiros mostraram estar entre os mais felizes, com escores inferiores apenas aos aposentados, colegiais e amostra de mulheres dos Estados Unidos da América. Possuímos também uma das maiores variações, representada pelo desvio padrão da escala. Tanto nos EUA quanto na Rússia, os valores do alfa estiveram entre bons e aceitáveis, porém o desempenho da escala aplicada no Brasil quanto ao índice de consistência apresentou valor fraco. A Tabela 23 mostra o valor da consistência interna do questionário caso o item fosse deletado. Apesar de haver a indicação de que a exclusão do último item aumentaria a consistência interna do questionário, esta não atingiria o valor tido como ideal. Assim, foi mantida sua permanência e a consistência interna em nível tido como tolerável. 
Tabela 23- Valor de alfa caso item for deletado

\begin{tabular}{|c|c|c|c|c|c|}
\hline & $\begin{array}{l}\text { Média da } \\
\text { escala se o } \\
\text { item for } \\
\text { deletado }\end{array}$ & $\begin{array}{l}\text { Variância da } \\
\text { escala se o } \\
\text { item for } \\
\text { deletado }\end{array}$ & $\begin{array}{l}\text { Correlação } \\
\text { item total }\end{array}$ & $\begin{array}{l}\text { Quadrado } \\
\text { da } \\
\text { correlação }\end{array}$ & $\begin{array}{l}\text { Alpha de } \\
\text { Cronbach se } \\
\text { o item for } \\
\text { deletado }\end{array}$ \\
\hline Em geral me considero & 15,8631 & 12,347 & 0,628 & 0,509 & 0,550 \\
\hline $\begin{array}{l}\text { Comparando com a maioria de } \\
\text { meus amigos, eu me } \\
\text { considero. }\end{array}$ & 15,7531 & 12,698 & 0,575 & 0,478 & 0,579 \\
\hline $\begin{array}{l}\text { Algumas pessoas geralmente } \\
\text { são muito felizes }\end{array}$ & 16,4834 & 12,329 & 0,441 & 0,217 & 0,650 \\
\hline $\begin{array}{l}\text { Algumas pessoas geralmente } \\
\text { não são muito felizes }\end{array}$ & 16,5747 & 11,692 & 0,348 & 0,126 & 0,739 \\
\hline
\end{tabular}

Com o propósito de verificar a capacidade de discriminação da escala, o escore médio

da dos pesquisados é utilizado para classificá-los acima e abaixo da média geral do teste (grupos critério) e, então, realizado o teste t para amostras independentes. Estabelecidos os grupos, os quatro itens apresentaram significância estatística para o teste, mostrando diferenças entre as médias (Tabela 12 em Apêndices).

Para a análise fatorial, os indicadores de qualidade da análise mostram KMO de 0,694, menor MSA de 0,639 e comunalidades aceitáveis, com menor valor de 0,317 para a variável 4. Como foi obtido um único fator, que explica $55,56 \%$ da variância, portanto, unidimensional.

Tabela 24- Cargas fatoriais e percentual covariância - Escala Geral de Felicidade

\begin{tabular}{lcc}
\hline \hline & Carga & $\begin{array}{c}\text { Percentual } \\
\text { Covariância }\end{array}$ \\
\hline \hline Em geral me considero... & 0,860 & $74 \%$ \\
Comparando com a maioria de meus amigos, eu me considero... & 0,832 & $69 \%$ \\
Algumas pessoas geralmente são muito felizes... & 0,688 & $47 \%$ \\
Algumas pessoas geralmente não são muito felizes... & 0,563 & $32 \%$ \\
\hline \hline
\end{tabular}

Conforme as autoras definiram, esta é uma escala mais rápida e simples de ser empregada, porém também apresenta alguns problemas, detectados neste trabalho para a amostra em questão. Primeiro é quanto à proporção da variância que pode ser explicada por causas subjacentes (Teste KMO), que apresenta valor abaixo das análises fatoriais feitas anteriormente. Segundo, o último item mostra estar bem próximo do limite de 0,3 , pois em níveis inferiores a este a questão passa a comprometer sua função de discriminação dos respondentes 


\section{0- ANÁLISE DOS DADOS SÓCIO-DEMOGRÁFICOS}

\subsection{IDADE}

Com o propósito de verificar a estabilidade dos fatores obtidos, a amostra foi dividida em faixas etárias. Diversos agrupamentos etários foram encontrados na literatura, mas acredito que a melhor forma seja uma distribuição válida em função dos dados disponíveis, a fim de que o resultado seja estatisticamente significante. Portanto, se considerarmos que, para se fazer uma análise fatorial minimamente confiável, são necessárias 5 observações por item do questionário (Hair e colaboradores, 2005) e o OHQ possui 29 itens, o que totaliza 145 afirmações necessárias. Como temos 484, menos 15 respostas omissas, totalizam 469 dividindo-se por 145, obtemos, em valores redondos, 3 grupos etários. Estes grupos foram divididos através de sua ordenação crescente e corte a cada 145 sujeitos, com a tolerância necessária da quantidade de sujeitos para que todo o grupo etário estivesse incorporado na análise. Dessa forma, os grupos criados para as análises podem variar ligeiramente na quantidade de indivíduos considerados na análise. O primeiro grupo consiste em idades até 24 anos, com 152 sujeitos. O segundo grupo é de 25 anos a 32 anos, constituindo 149 sujeitos, e o terceiro grupo é a partir de 33 anos acima, até 66 anos, com 168 pesquisados. Talvez não seja a divisão etária ideal, mas a opção foi pela consistência estatística, que prejudica o ultimo grupo que possui grande amplitude de idade.

Tabela 25 Análise fatorial grupo 1 - Idade de até 24 anos

\begin{tabular}{ccccccccc}
\hline \hline \multirow{2}{*}{ Análise } & $\begin{array}{l}\text { Número } \\
\text { Variáveis }\end{array}$ & KMO & Bartlett & Fatores & Explicação & Resíduos & < MSA & Exclusão \\
\hline \hline 1 & 28 & 0,709 & 0,000 & 9 & $60,34 \%$ & $42 \%$ & 0,402 & 17 \\
2 & 27 & 0,724 & 0,000 & 9 & $61,38 \%$ & $41 \%$ & 0,435 & 15 \\
3 & 26 & 0,737 & 0,000 & 8 & $58,92 \%$ & $44 \%$ & 0,503 & - \\
\hline \hline
\end{tabular}

A Tabela 25 mostra a síntese da análise feita. Como resultado, a variável 17 foi excluída devido ao índice de MSA abaixo do indicado, 0,50 (Hair e colaboradores, 2005), enquanto que a 15 apresentou fator com uma única variável. A Tabela completa com os 
fatores e respectivas cargas resultantes se encontra na Tabela 15 em Apêndices (somente não aparecem as cargas abaixo de 0,1 , pois foi solicitado ao software que não apresentasse tais valores) e as comunalidades na Tabela 16, também em Apêndices.

Temos como referência a fatoração total da amostra (em sua rotação oblíqua), portanto, um parâmetro de comparação para os resultados a serem obtidos. É importante observar que em todas as comparações a serem feitas entre as duas estruturas obtidas, a análise inicial e a segmentada por determinada característica, tiveram rotação através da técnica Oblimin.

As variáveis para a análise fatorial, nesta faixa etária, os 8 fatores obtidos sofreram novo arranjo de sua composição, se comparada com a formação original (Tabela 17 em Apêndices). O primeiro fator, que podemos designar para ambas as análises de Satisfação com a vida, possui maior semelhança com a estrutura original, assim como o fator Propósito. Observa-se que Superioridade ambiental foi dividida em dois fatores: o 6 e 5 da análise por idades.

Para a faixa etária de 25 a 32 anos, os resultados para a análise fatorial e comunalidades estão na Tabela 18 e 19, respectivamente, em Apêndices. As duas variáveis mencionadas na Tabela 26 a seguir foram excluídas porque constituíram um único fator. $\mathrm{O}$ valor de alfa de Cronbach foi de 0,832 .

Tabela 26-Análise fatorial grupo 2 - Idade de 25 a 32 anos

\begin{tabular}{ccccccccc}
\hline \hline Análise & $\begin{array}{c}\text { Número } \\
\text { Variáveis }\end{array}$ & KMO & Bartlett & Fatores & Explicação & Resíduos & < MSA & Exclusão \\
\hline \hline 1 & 28 & 0,785 & 0,000 & 8 & $59,09 \%$ & $39 \%$ & 0,479 & 29 \\
2 & 27 & 0,798 & 0,000 & 8 & $60,25 \%$ & $41 \%$ & 0,608 & 18 \\
3 & 26 & 0,801 & 0,000 & 7 & $57,61 \%$ & $39 \%$ & 0,711 & - \\
\hline \hline
\end{tabular}

Nesta análise, somente o fator 5 manteve-se integralmente estável (Tabela 20, em Apêndices) e a quantidade total de fatores apresentou 1 a menos do que a quantia resultante da análise original (Tabela 26 acima). 
No último grupo considerado, as variáveis excluídas foram devido a constituírem um único fator e seus indicadores estão na Tabela 27 abaixo. $\mathrm{O}$ valor de alfa obtido foi de 0,841 . As comunalidades estão nas Tabelas 21 e 22, em Apêndices.

Tabela 27- Análise fatorial grupo 3 - Idade de 33 a 66 anos

\begin{tabular}{ccccccccc}
\hline \hline Análise & NV & KMO & Bartlett & Fatores & Explicação & Resíduos & < MSA & Exclusão \\
\hline \hline 1 & 28 & 0,792 & 0,000 & 9 & $61,43 \%$ & $39 \%$ & 0,607 & 6 \\
2 & 27 & 0,797 & 0,000 & 9 & $62,22 \%$ & $35 \%$ & 0,600 & 22 \\
3 & 26 & 0,807 & 0,000 & 8 & $59,71 \%$ & $38 \%$ & 0,606 & - \\
\hline \hline
\end{tabular}

A quantidade de fatores prosseguiu com a mesma quantia de 8, distribuídos relativamente de forma estável, com explicação maior da variância no primeiro fator (22,27\%), bem maior se comparada a análise inicial (9,45\%) (Tabela 23 em Apêndices).

Os fatores obtidos com relação à separação por idades possuem relativa estabilidade em suas composições. Por vezes, um fator é dividido em 2, mas parte dos fatores mantêm em sua estrutura interna parte de seu agrupamento original.

É igualmente importante buscar responder à seguinte questão: qual a relação entre idade e os escores de felicidade obtidos pela pesquisa? Para procurar compreender esta indagação, as faixas etárias receberam outra segmentação, sendo divididas em 6 categorias: até 20 anos; de 21 a 30 anos; de 31 a 40 anos; de 41 a 50 anos; de 51 a 60 anos; mais do que 60 anos. Esta categorização será utilizada para análises no restante deste trabalho.

As avaliação a seguir são realizadas, observando-se os escores da escala OHQ e da EGF equiparados para a EU, para todos os respondentes. O método utilizado para a equiparação foi o método linear, referenciado em Pasquali (2003). 


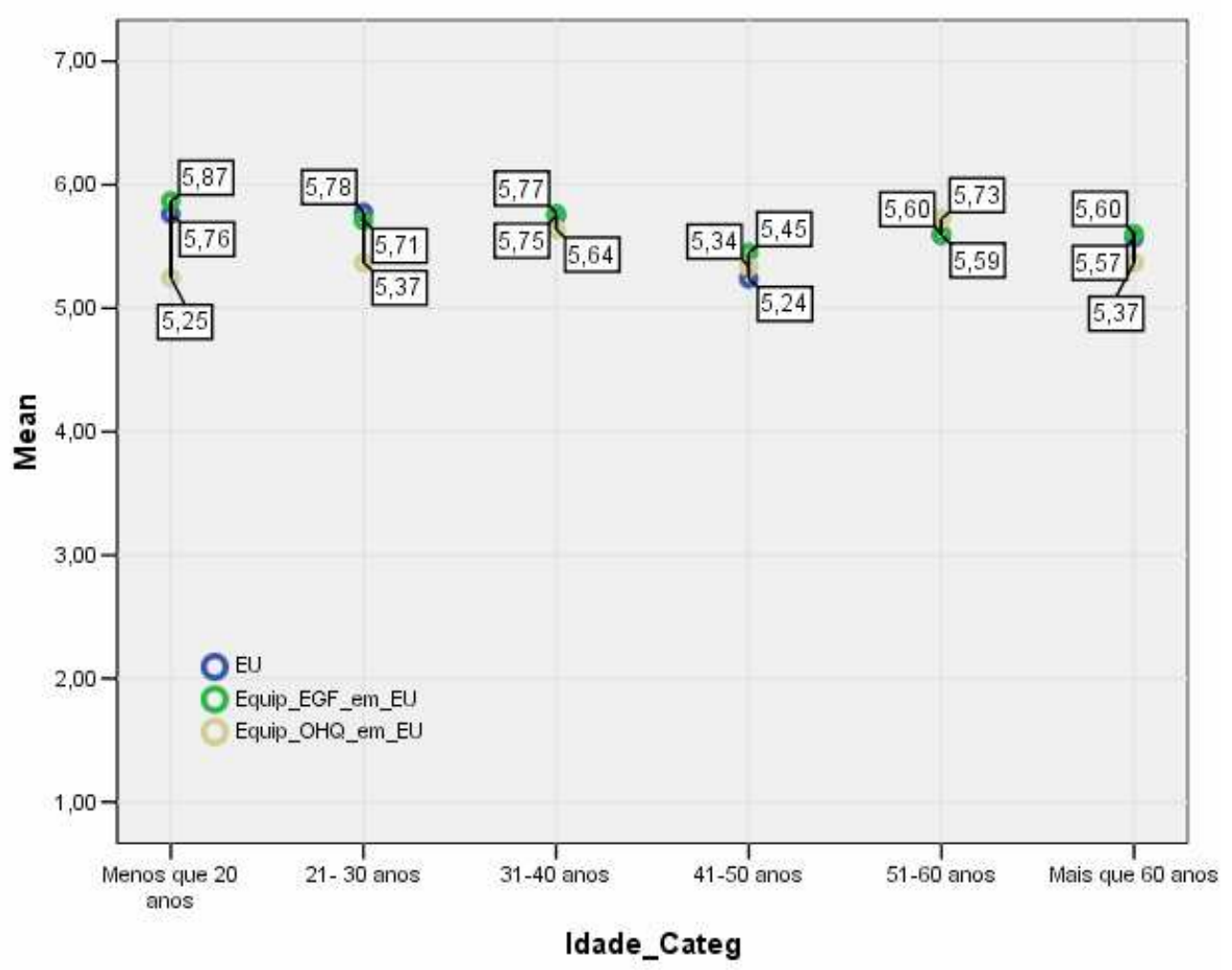

Gráfico 17- Escores equiparados das escalas nas categorias etárias

O Gráfico 17 mostra os escores médios obtidos pelos indivíduos das categorias etárias nas três escalas utilizadas. Ao considerarmos a mensuração de cada escala e avaliarmos as diferenças entre as médias etárias, a Tabela 24 em Apêndices nos mostra que não existe diferença entre estas medidas. É importante dizer que, não somente para este caso, mas como para todos que se seguem, envolvendo análise de variância é observada a homogeneidade das mesmas, pré-suposto necessário para realizar a análise e, apresentado o resultado caso este seja significativo, é adotado então um teste não paramétrico.

A avaliação das diferenças dos escores médios dentro das categorias, a Tabela $25 \mathrm{em}$ Apêndices, mostra que o escore médio equiparado do OHQ difere-se das outras duas escalas nas faixas etárias Menor de 20 anos e de 21 a 30 anos, apresentando níveis inferiores de desempenho.

Para investigar uma relação entre idade e felicidade, iremos nos valer de uma técnica estatística que relaciona duas variáveis métricas, no caso, primeiro a escala e, segundo, a 
idade, ambas discretas (para esta análise a idade não foi considerada de forma categorizada, mas sim, contínua). A variável dependente é cada escore total das escalas e como variável independente a idade. Em um teste de hipóteses, para verificar a possibilidade de regressão, temos:

$\mathrm{H}_{0}: \beta=0$ ( não havendo regressão)

$\mathrm{H}_{1}: \beta \# 0$ (há regressão)

As estalas EGF e OHQ não apresentaram significância para rejeitar a hipótese nula, acima descrita, contudo para a EU há evidência para rejeitarmos a hipótese nula e aceitar a alternativa (ver Tabela s 26 a 28 em Apêndices). Apesar de haver significância estatística e apresentar relação levemente inversa entre o nível de felicidade e a idade, esta relação tem uma explicação muito pequena $\left(R^{2}=0,010\right)$ da variância, o que a torna praticamente insignificante.

Com estudos iniciais, relacionando idade e felicidade, descobriu-se que os jovens eram mais felizes do que os velhos, contudo algumas pesquisas recentes não conseguiram relacionar idade com satisfação com a vida, e outras encontraram correlação positiva entre os dois fatores (Diener, 1984). A relação entre idade e felicidade é controversa, onde para alguns autores mostram uma relação positiva, outros em forma de U (DiTella \& MaCculloch, 2005). Para Clark e Oswald (2002b), esta conclusão é similar, tendo seu ponto mínimo na idade de 43 anos, e para Frey e Stutzer (2002) os menores escores são registrados na faixa dos 50 aos 59 anos. Esta diversidade de resultados pode mostrar a possibilidade de o BES variar ao longo do tempo (Easterlin, 2001). Em Helliwell (2003), os mais jovens e mais velhos apresentaram níveis maiores de felicidade. Myers (1992) não considera a existência de alterações no nível de felicidade em função da diferença etária entre as pessoas, e, se existe, não é significante (coincidente com nosso resultado). Argyle (1987) diz que a felicidade não varia muito em função da idade, contudo depende do sistema de mensuração que está sendo utilizado: se este 
sistema enfatiza a avaliação da satisfação do indivíduo mais ligada à parte cognitiva do bemestar, então haverá aumento em função da idade; isto porque as pessoas mais velhas são mais satisfeitas, mas experienciam menor frequiência e intensidade de sentimentos positivos e negativos. Este comportamento, contudo, possui certa diferença entre os sexos, havendo certas evidências de que os homens envelhecem mais felizes do que as mulheres, as quais possuem maior satisfação com a vida quando são jovens (Argyle, 1987). A atividade produtiva possui impacto positivo no BES, sobretudo para as idades mais avançadas, devido ao convívio social que estas proporcionam ao idoso e o exercício de atividade produtiva, como o voluntariado, por exemplo, oferece níveis maiores de satisfação com a vida, com a melhora da saúde, tanto física como mental (Baker, Cahalin, Gerst \& Burr, 2005).

Easterlin (2004) afirma que a felicidade possui efeito levemente crescente, dos 18 aos 45 anos, e depois começa a declinar suavemente. O aumento da satisfação até a meia idade relaciona-se com fatores como a família e o emprego; após a meia idade estes diminuem, acrescentando-se a menor satisfação com a saúde, o que ocasiona o decréscimo do nível registrado.

Em regressão utilizada por Fuentes e Rojas (2001), a idade de 40 anos apresentou significância estatística, quando avaliada em relação a uma escala de felicidade com item único. Com o propósito de testar a hipótese de que faixas etárias apresentam diferenças no BES, conforme citado na literatura, as categorias etárias definidas anteriormente foram transformadas em matrizes binárias, para averiguar a relação de cada categoria com o BES registrado em cada escala.

Nas Tabela s em Apêndices 29 e 30 mostram as Tabela s de coeficientes de regressão e coeficientes de determinação obtidas para as escalas OHQ e EGF. Observa-se que as faixas etárias 5 no OHQ e 4 na EGF se encontram muito próximas ao nível de significância $(p=0,51)$, considerado a margem de confiança de $95 \%$ mantido para a pesquisa. Estas 
categorias não consideradas como significantes, porém devem ser observadas em novos estudos com os questionários.

Tabela 28 - Regressão dummy EU

Coefficients $^{\mathrm{a}}$

\begin{tabular}{|c|c|c|c|c|c|c|}
\hline \multirow{2}{*}{\multicolumn{2}{|c|}{ Model }} & \multicolumn{2}{|c|}{$\begin{array}{c}\text { Unstandardized } \\
\text { Coefficients }\end{array}$} & \multirow{2}{*}{$\begin{array}{c}\text { Standardized } \\
\text { Coefficients }\end{array}$} & \multirow[b]{2}{*}{$t$} & \multirow[b]{2}{*}{ Sig. } \\
\hline & & $\mathrm{B}$ & Std. Error & & & \\
\hline & (Constant) & 5,794 &, 171 & & 33,960 &, 000 \\
\hline & Dummy_ldade_2 &,- 016 & ,194 &,- 006 &,- 082 & ,935 \\
\hline & Dummy_Idade_3 &,- 064 & 218 &,- 019 &,- 292 & ,770 \\
\hline & Dummy_Idade_4 &,- 480 & 238 &,- 123 & $-2,021$ & ,044 \\
\hline & Dummy_Idade_5 &,- 294 & ,308 &,- 051 &,- 955 & ,340 \\
\hline & Dummy_Idade_6 &,- 294 & ,508 &,- 028 &,- 578 & ,564 \\
\hline
\end{tabular}

a. Dependent Variable: unica

Assim como em Fuentes e Rojas (2001), o resultado da regressão para a EU foi que a faixa etária compreendida entre 41 e 50 anos é menos feliz do que grupo critério considerado (até 20 anos), em uma razão de $-0,480$ (Tabela 28). Este valor reflete a magnitude da distância para o critério adotado. Porém, ao observarmos a explicação da variância, este valor é de $1,5 \%$ e mostra que esta relação é muito pequena.

Observamos que alguns dos achados nos estudos citados, considerando-se a relação do BES e a idade, não se fizeram presentes nesta pesquisa. Pouca, ou nenhuma relação foi encontrada nos dados disponíveis. As diversas opiniões dos pesquisadores, estruturadas em diferentes resultados obtidos, utilizando-se diferentes tipos de escalas, que não levam a apontamentos convergentes, devendo-se explorar muito o assunto a fim de obter respostas mais consistentes. A satisfação com a vida é composta de diversos domínios, como emprego, família, lazer, entre outros, os quais possuem diferentes influências na idade, o que por sua vez pode ou não influenciar o BES, gerando um composto de fatores que devem ser mais bem investigados, a fim de que seja melhor compreendida esta relação. 


\subsection{SEXO}

Duas novas análises fatoriais foram realizadas para testar a estabilidade dos fatores e o arranjo obtido, isto tanto para os homens quanto para as mulheres. $\mathrm{O}$ resultado das análises realizadas será demonstrado nos quadro abaixo, sendo o primeiro para os homens e o segundo para as mulheres.

Tabela 29- Análise fatorial: Homens

\begin{tabular}{ccccccccc}
\hline \hline Análise & NV & KMO & Bartlett & Fatores & Explicação & Resíduos & < MSA & Exclusão \\
\hline \hline 1 & 28 & 0,819 & 0,000 & 8 & $56,62 \%$ & $38 \%$ & 0,615 & 29 \\
2 & 25 & 0,822 & 0,000 & 8 & $57,52 \%$ & $39 \%$ & 0,611 & - \\
\hline \hline
\end{tabular}

Permaneceu-se com a mesma quantidade de fatores, havendo estabilidade também na explicação da variância, por volta de 50\%; a variável excluída da análise foi por ter constituído um único fator. A Tabela 31 apresenta os fatores e suas respectivas cargas e a Tabela 32, as comunalidades, em Apêndices. A consistência interna do questionário, segmentado para o sexo masculino, foi de 0,837 e a comparação entre os fatores obtidos para a parte masculina da amostra com o resultado da análise fatorial para o questionário total pode, ser verificada na Tabela 33 (Apêndices). Observa-se que o primeiro fator, com uma estrutura similar ao originalmente obtido, possui uma explicação maior da variância e 3 fatores não encontraram nenhuma similaridade, no arranjo das variáveis da análise inicial.

A mesma comparação pode ser feita para somente as respondentes femininas da amostra (Tabela 30).

Tabela 30- Análise fatorial: Mulheres

\begin{tabular}{ccrrrrrrc}
\hline \hline Análise & NV & \multicolumn{1}{c}{ KMO } & Bartlett & Fatores & Explicação Resíduos & $<$ MSA & Exclusão \\
\hline \hline 1 & 28 & 0,802 & 0,000 & 8 & $53,66 \%$ & $41 \%$ & 0,573 & 10 \\
2 & 27 & 0,805 & 0,000 & 8 & $55,45 \%$ & $45 \%$ & 0,571 & - \\
\hline \hline
\end{tabular}

Para as mulheres, foram obtidos os resultados a seguir. As cargas fatoriais e comunalidades podem ser encontradas nas Tabelas 34 e 35, respectivamente, em Apêndices e, 
na Tabela 36, a comparação entre os fatores obtidos para o questionário total e para a fatoração segmentada para as mulheres.

Para a análise fatorial, considerada a estabilidade quanto à quantia dos fatores até agora obtidos, mostra ser bem constante em sua quantidade, visto que entre as 5 análises fatoriais realizadas, apenas 1 resultou em quantidade inferior aos 8 fatores. Os percentuais de explicação da variância dos fatores também estão próximos a 50\%. Já os arranjos das variáveis dentro dos fatores se mostram mais instáveis.

Para Argyle (1987), o gênero afeta de diferentes maneiras o BES das pessoas. As mulheres tendem a sentir afetos positivo e negativo com maior intensidade do que os homens, o que as leva a ter maior amplitude de variação de BES. Os papéis desenvolvidos pelo homem e pela mulher são distintos em nossa sociedade, pois elas possuem atribuições de cuidadora, tanto no lar (mãe, esposa), como no emprego (ex: professora, enfermeira); isto as posiciona emocionalmente de forma diferente do homem, pois a sociedade exige delas serem mais estável emocionalmente, o que pode levar as mulheres a apresentarem um BES maior do que o masculino, porém, este maior envolvimento emocional feminino, que as levam a expressar níveis mais extremos de BES, resulta para elas o ônus de serem as maiores sofredoras de distúrbios emocionais. (Wood, Rhodes \& Whelan., 1989). De uma forma geral, pesquisas mostram que mulheres relatam experimentar mais afeto positivo e grandes alegrias, registrando uma leve diferença, entre os sexos, a favor delas (Diener, 1984; Frey \& Stutzer, 2000; Stutzer \& Frey, 2002).

O estudo que se segue é voltado à compreensão do desempenho dos pesquisados em função de suas características individuais, quanto aos sexos. O teste estatístico, apresentado na Tabela 37 (Apêndices), mostra que, para nossa amostra, não há diferença entre os escores médios equiparados entre homens e mulheres, isto para as três escalas, cujos escores podem ser verificados no Gráfico 18. 


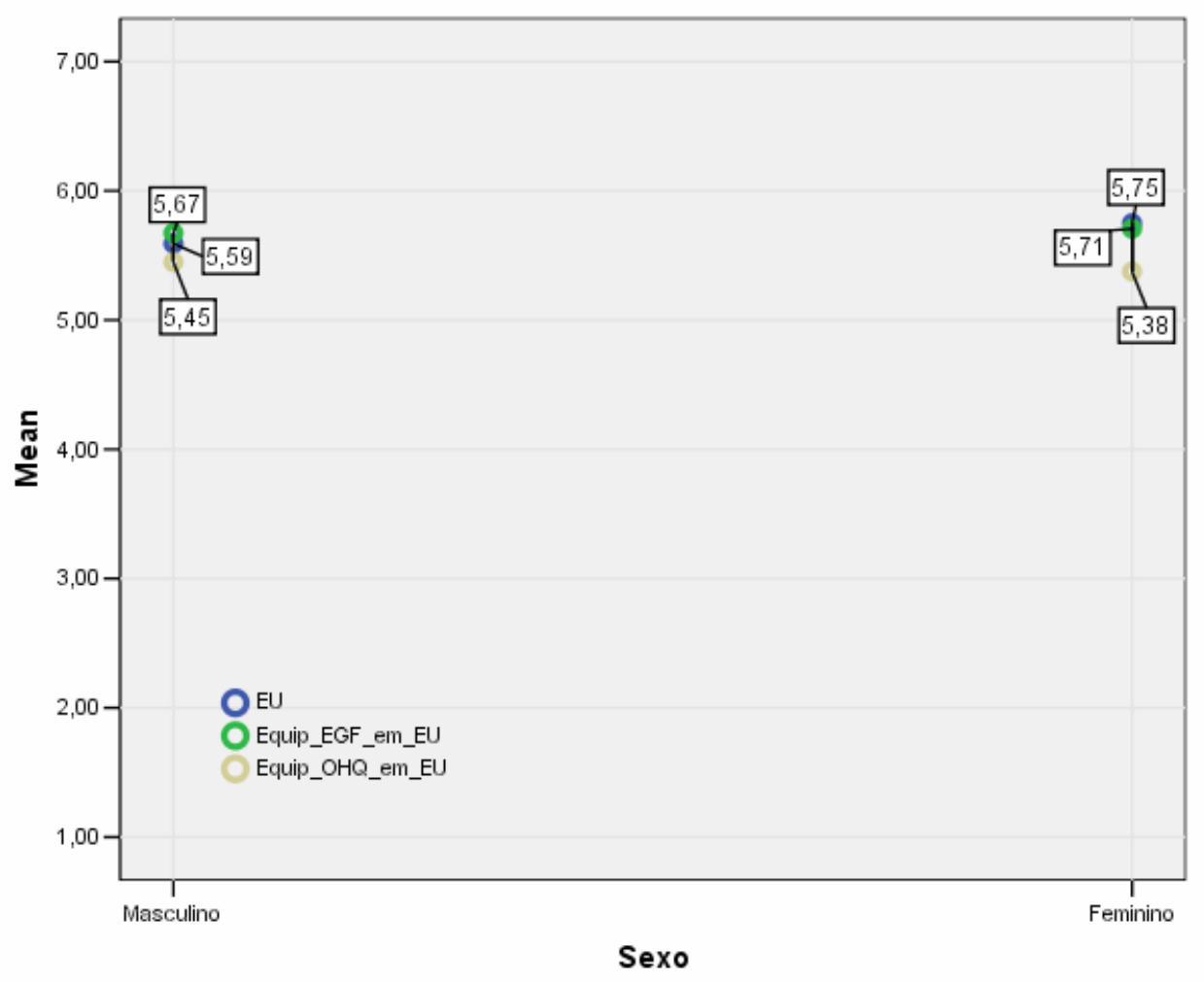

Gráfico 18- Escores médios equiparados nas escalas- sexo

Tendo em vista as categorias masculino e feminino, as Tabela s 38 e 39, em Apêndices, representam as análises dos escores das escalas dentro dos dois grupos considerados e mostram as correlações entre os escores das escalas e o teste t para amostras pareadas. Pode-se verificar a alta correlação entre os escores das escalas, na primeira tabela, e, na segunda, observa-se a significância estatística para a comparação entre as escalas EGF x OHQ para os homens e para as mulheres a diferença de médias entre EU x OHQ e EGF x OHQ. Dessa forma, atestada a igualdade de médias entre a EU e EGF, e verificando as diferenças citadas, podemos concluir que a OHQ se diferencia das outras duas medidas, relativo ao escore obtido. Em outras palavras, o escore equiparado menor (que pode ser verificado na representação gráfica acima) fornece indícios de que, na escala mais extensa e que investiga diversos aspectos do BES, níveis menores em termos de escore podem ser observados (para a mostra em questão).

De acordo com Argyle (1987), há outra variável a ser considerada que interage com o sexo, fornecendo um pouco mais de explicação às diferenças encontradas por ele: a idade. 
Para este autor, existe impacto diferente entre homens e mulheres, em função de suas idades; mulheres acima dos 45 tendem a ser mais felizes do que os homens, especialmente se não possuem filhos. No mesmo trabalho, há a referência a que os homens acima da idade de 55 anos tendem a ser mais felizes do que as mulheres. Outras pesquisas apontam que, nas faixas etárias mais novas, as mulheres são mais felizes que os homens, concordando que na velhice eles o são mais (Spreitzer \& Snyder, 1974).

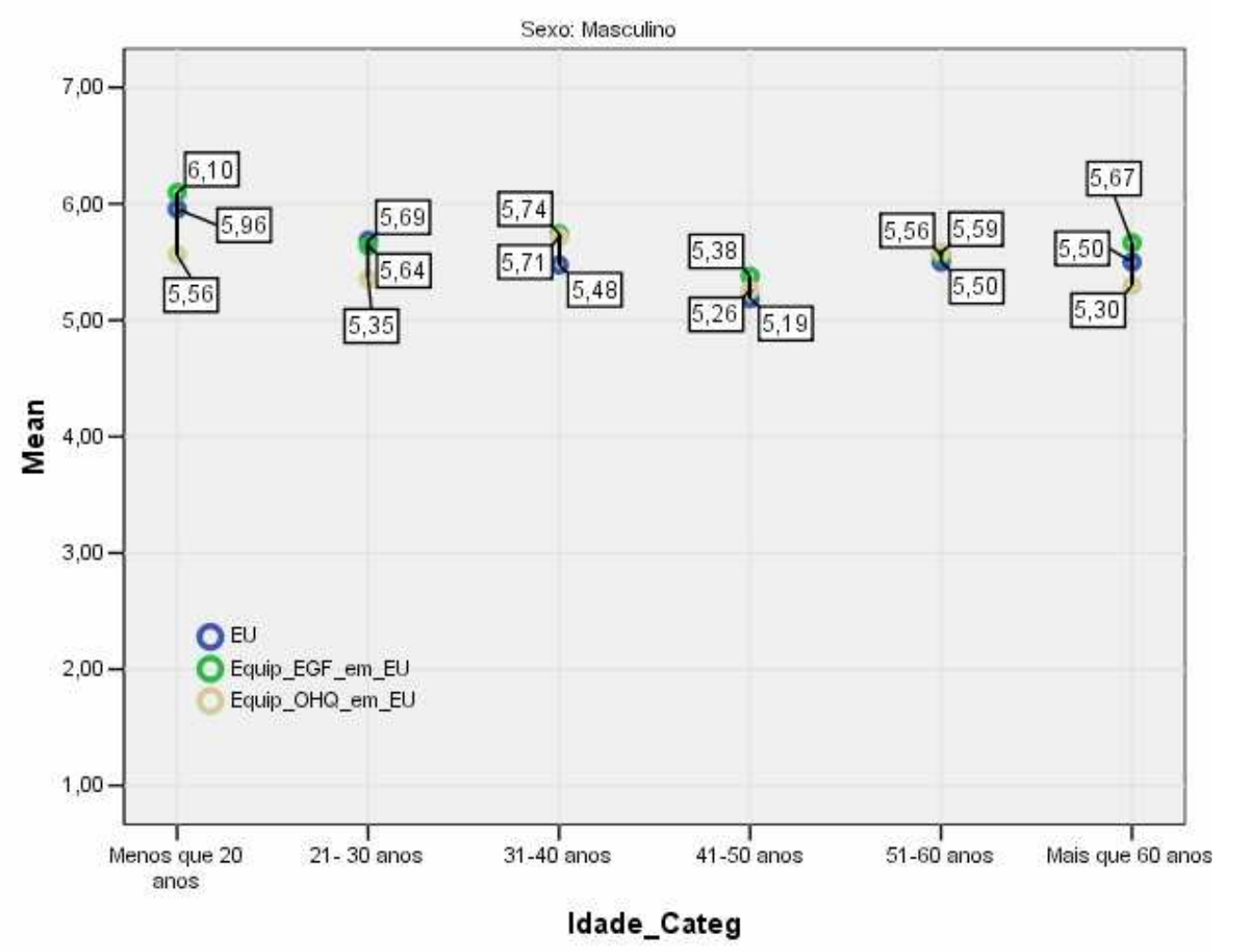

Gráfico 19- Escores médios equiparados nas escalas - homens x idades

Nos Gráficos 19 e 20, há o desempenho para as categorias etárias entre os homens e mulheres da amostra. O teste estatístico de homogeneidade das variâncias acusou diferenças para a EU, de maneira que especificamente para esta escala foi adotado um teste não paramétrico (Tabela 40). Para os dois testes realizados (Tabela s 41 e 42), não foram encontradas diferenças entre médias. Em outras palavras, mesmo consideradas as diferenças etárias entre os sexos, não houve diferenças entre o escore médio equiparado de felicidade, apresentado nas escalas utilizadas. 
$\mathrm{Na}$ avaliação das diferenças dos escores apresentados, dentro das categorias etárias, para os sexos, a EU apresentou diferença de escore com a EGF, apenas para os homens da faixa de 31 a 40 anos. O OHQ se diferenciou da EU em mulheres de 31 a 40 anos; da EGF em homens até 20 anos e para as duas escalas simultaneamente apresentou diferença em homens e mulheres entre 21 e 30 anos e mulheres até 20 anos (Tabela s 43 e 44, Apêndices). Esta análise procura demonstrar em quais categorias existe uma menor avaliação e em que escala esta se deu, fornecendo subsídio para uma melhor leitura dos gráficos apresentados.

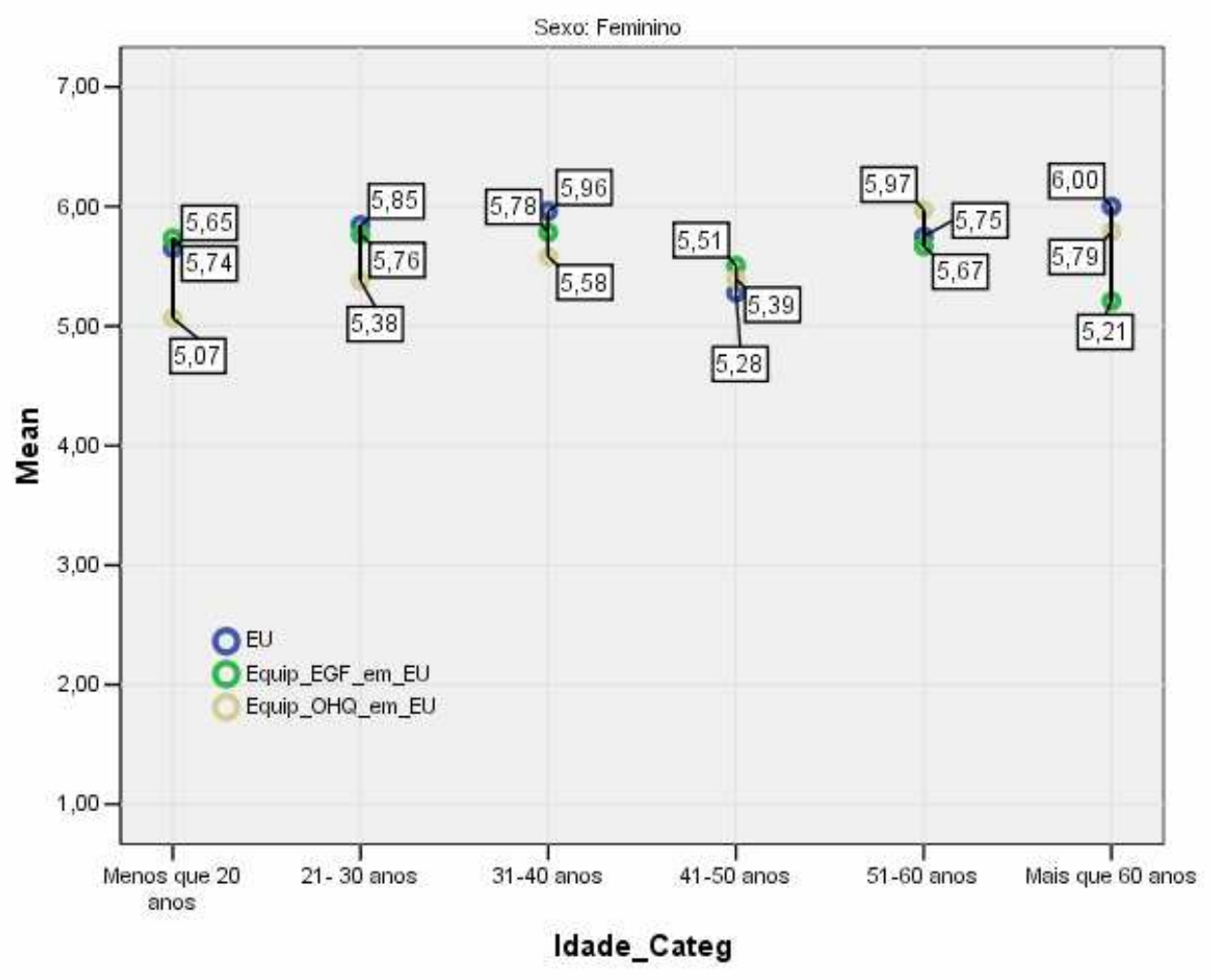

Gráfico 20- Escores médios equiparados nas escalas - mulheres x idades

Um estudo mais aprofundado pode ser realizado, considerando-se a idade e buscando-se a relação de casualidade entre níveis etários e sexo, para posterior comparação com a literatura. Para isto utilizam-se as variáveis dummies, controlada para homens e mulheres, tendo como variável dependente os escores totais das escalas utilizadas e categoria de referência a faixa etária Menor de 20 anos. 
Ao analisarmos as Tabelas compreendidas de 45 até 50, em Apêndices, podemos verificar que apresentaram significância estatística os homens entre 41 e 50 anos, para a EU ( $\beta=-0,848$ e $\left.R^{2}=0,023\right)$, e, para o OHQ, as mulheres entre 31 a 40 anos $\left(\beta=0,448\right.$ e $\left.R^{2}=0,027\right)$ e entre 51 a 60 anos $\left(\beta=1,019\right.$ e $\left.R^{2}=0,027\right)$. O resultado concordou com o que Argyle (1987) encontrou, pois o resultado mostra que mulheres com maior idade apresentam maior nível de felicidade. Quanto aos homens, houve significância para a faixa etária entre os 40 e 50 anos, obtida para a escala EU. A explicação da variância foi de $R^{2}=0,025$, ou 2,5\%.

Tendo em vista a afirmação de Argyle (1987) de que as mulheres sem filhos, na faixa etária de 45 anos, seriam mais felizes, a análise que segue foi obtida através da filtragem, considerando-se apenas o sexo feminino, controlada pelo número de filhos e, como fator, as categorias etárias. Para esta análise o grupo critério de idades foi alterado para a categoria 2, isto é, entre 21 e 30 anos, pois consiste em uma faixa etária mais apropriada para mulheres terem filhos, apesar de haver foco naquelas sem filhos. Entre os resultados obtidos para as três escalas (Tabelas 51 a 56), há significância estatística para mulheres na faixa etária entre 41 e 50 anos na escala EU, porém com uma diferença de sentido; esta relação é inversa ao grupo critério, $\beta=-0,941$, com explicação da variância de $R^{2}=0,038$. Isto mostra que a idade é significativa, tanto para Argyle (1997) quanto para este trabalho, porém, em sentidos opostos, uma vez que para o primeiro caso há uma relação direta, e no segundo, inversa. A quantidade da amostra (que em nosso caso não é muito expressiva) sugere que esta diferença seja vista com cautela. Assim, para melhor compreender os efeitos do tempo sobre a felicidade dos indivíduos, é necessário um projeto de pesquisa melhor delineado para este propósito, que venha a contemplar de forma proporcional uma ampla faixa de categorias etárias.

Além da idade, a literatura mostra que outros fatores possuem influência no BES entre os sexos: um é o estado civil: Wood e colaboradores (1989) afirmam que a mulher casada 
apresenta um nível de BES maior do que o homem; e outro se apresenta quanto à atividade profissional (Myers, 1992).

\subsection{ETNIA}

Para Frey e Stutzer (2002), os negros são menos felizes do que as demais etnias em várias pesquisas realizadas nos Estados Unidos. Estes autores citam que brancos e negros se diferenciam quanto à educação, renda, urbanidade; fatores importantes para serem controlados, a fim de verificar a existência de diferença entre as raças. Controlados estes fatores, registraram-se casos em que negros tiveram menores escores de bem-estar subjetivo, porém isto ocorreu apenas para certos grupos (Diener, 1984). É importante ressaltar que estas pesquisas se originam em país onde se registra uma desigualdade social diferente da presente em nosso país. Dessa maneira, os estudos que seguem buscam investigar indícios quanto à existência ou não de relação entre níveis de BES, para as etnias avaliadas na pesquisa. Algumas particularidades devem ser consideradas. Primeiramente, o pesquisado se autoavalia quanto à própria raça. Assim, a segmentação é pautada em uma avaliação individual de seu enquadramento étnico, configurando um aspecto subjetivo. Segundo, há a distribuição irregular entre as avaliações particulares, quanto ao grupo étnico pertencente: entre o total da amostra, 79,2\% se consideram brancos, o que representam 381 respondentes. Terceiro, é quanto à ausência da classificação de grupos como orientais, que não foram contemplados na pesquisa. Observadas estas particularidades e reservados os resultados para a amostra em questão, segue-se a média dos escores equiparados.

No Gráfico 21 há os escores equiparados obtidos em cada etnia. Para Índio há apenas três respondentes, o que consiste em uma representação muito baixa. A Tabela 57 (Apêndices) mostra a análise para a diferença entre os escores para as etnias, considerando cada escala. Esta análise não apresentou significância estatística para nenhuma categoria, portanto, os escores apresentados no gráfico a seguir são variações de uma mesma média. 


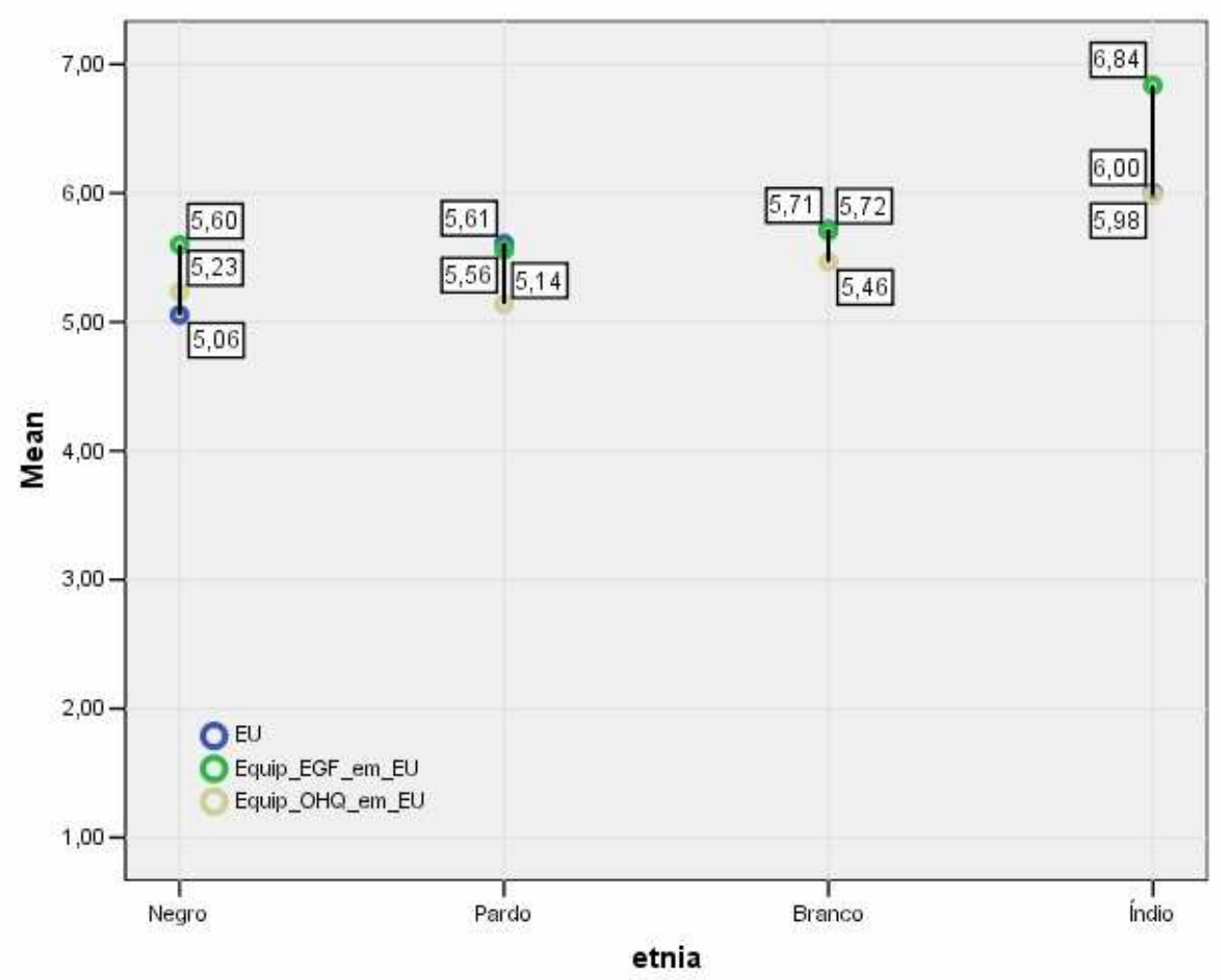

Gráfico 21- Escores médios equiparados das escalas - etnia

As Tabelas 58 e 59 presentes em Apêndices mostram as correlações e diferenças entre os valores para as médias em cada categoria étnica. Os escores EU e EGF apresentaram igualdade de média para todas as etnias, enquanto que o OHQ mostrou diferença na comparação com as duas escalas, para as categorias Branco e Pardo, e mostra ter escore menor, conforme pode ser verificado no gráfico acima.

No estudo, para procurar saber a relação de cada característica étnica e os escores de felicidade apresentados, a referência para as análises de regressão com variáveis dummies foi adotada a etnia Pardo. As Tabelas 60 a 65, em Apêndices, mostram os resultados das análises das regressões feitas, que demonstram a inexistência de relação, para todas as escalas avaliadas, entre etnia e BES.

Tendo em consideração as diferenças étnicas, foi realizada a análise para investigar as diferenças entre os sexos (Gráficos 21 a 24). 


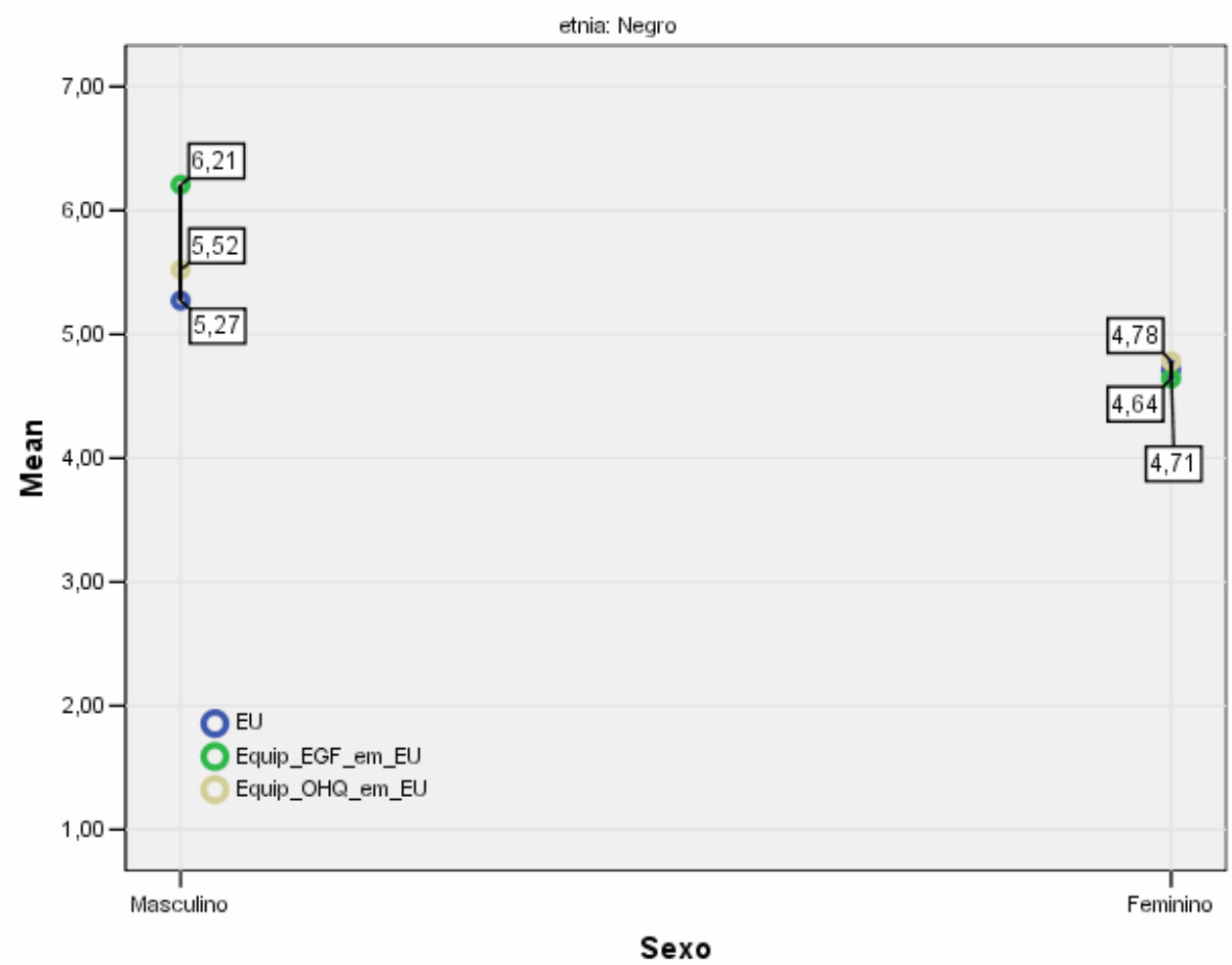

Gráfico 22- Escores médios equiparados negros x sexo

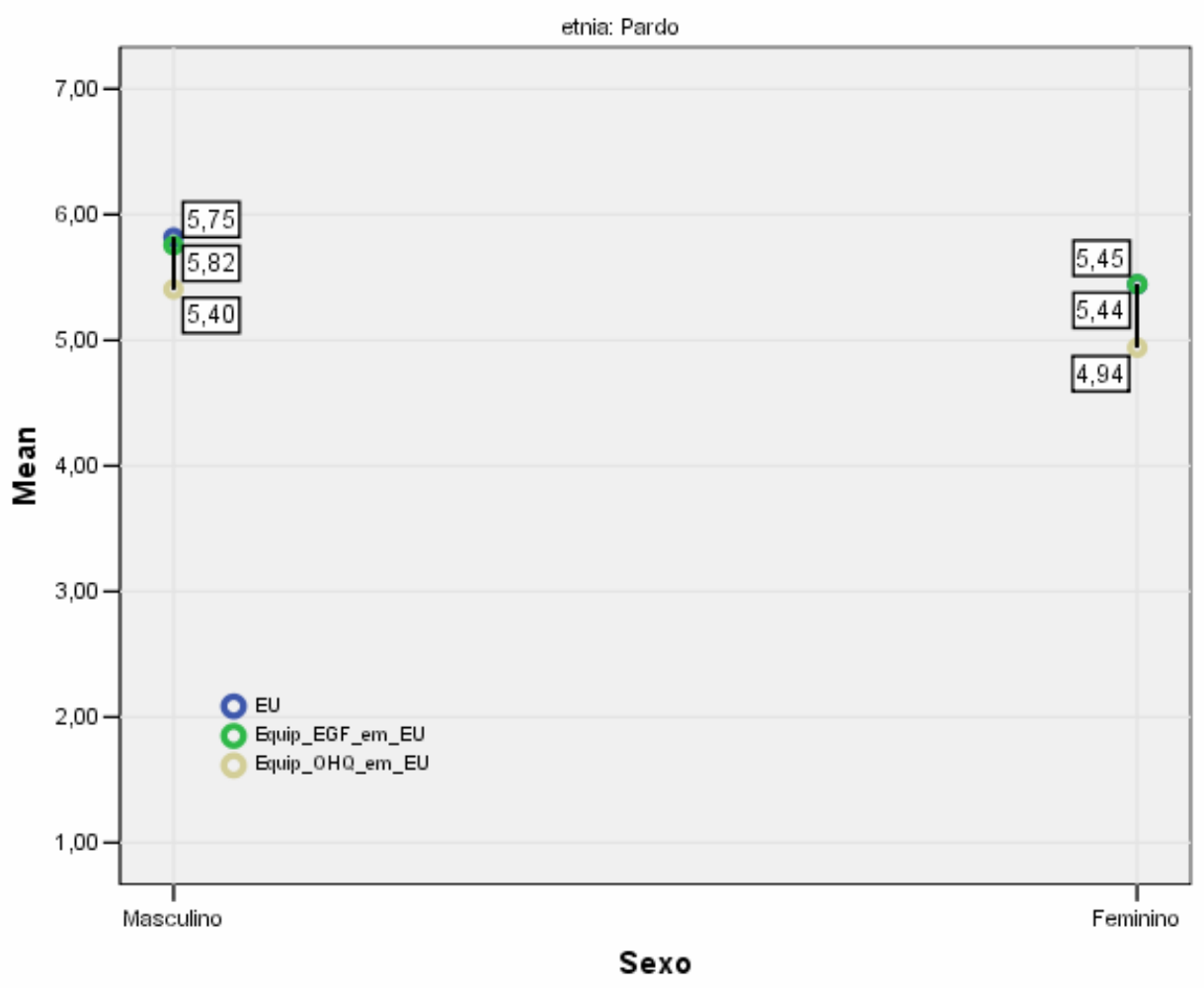

Gráfico 23 - Escores médios equiparados pardos x sexo 


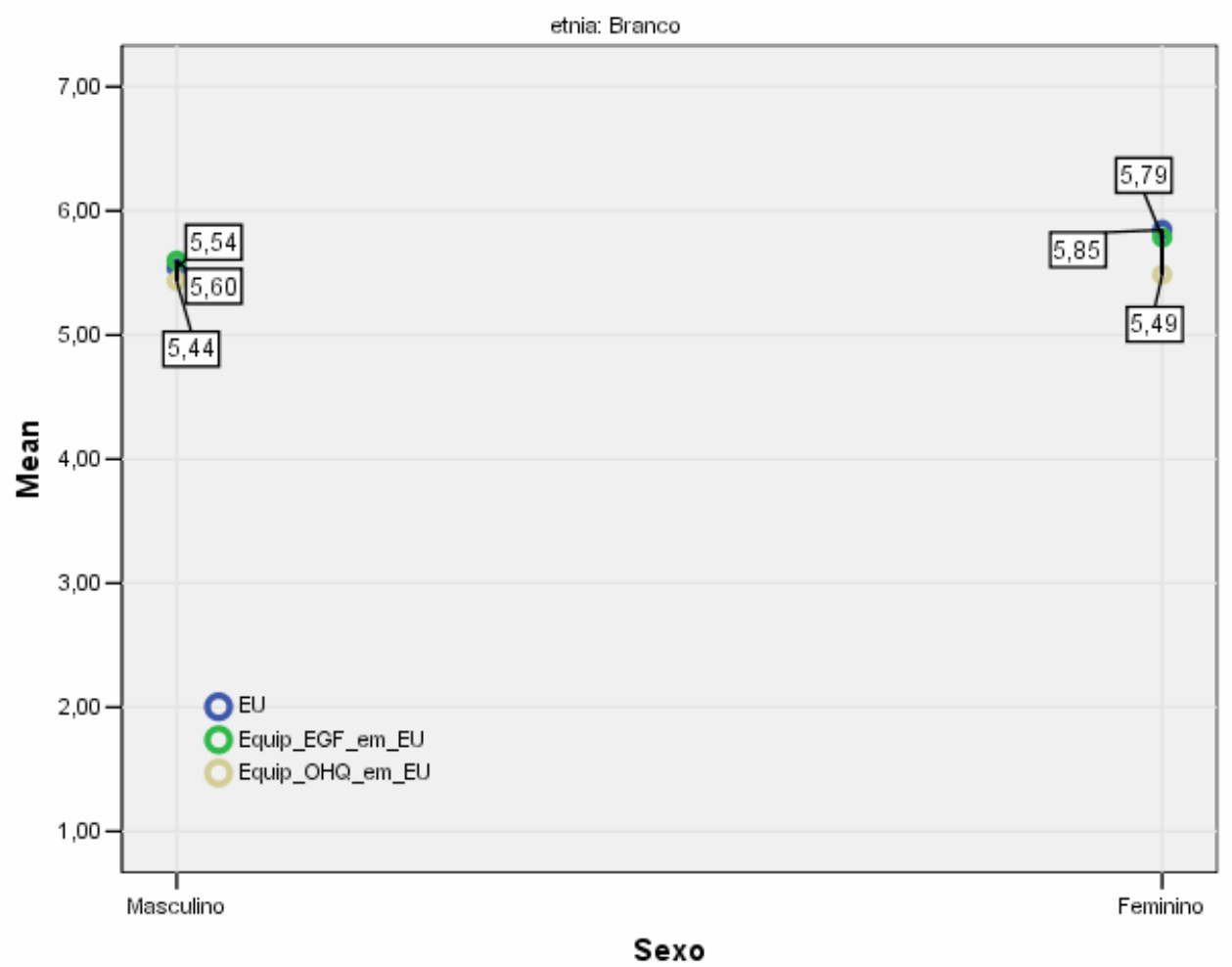

Gráfico 24- Escores médios equiparados brancos x sexo

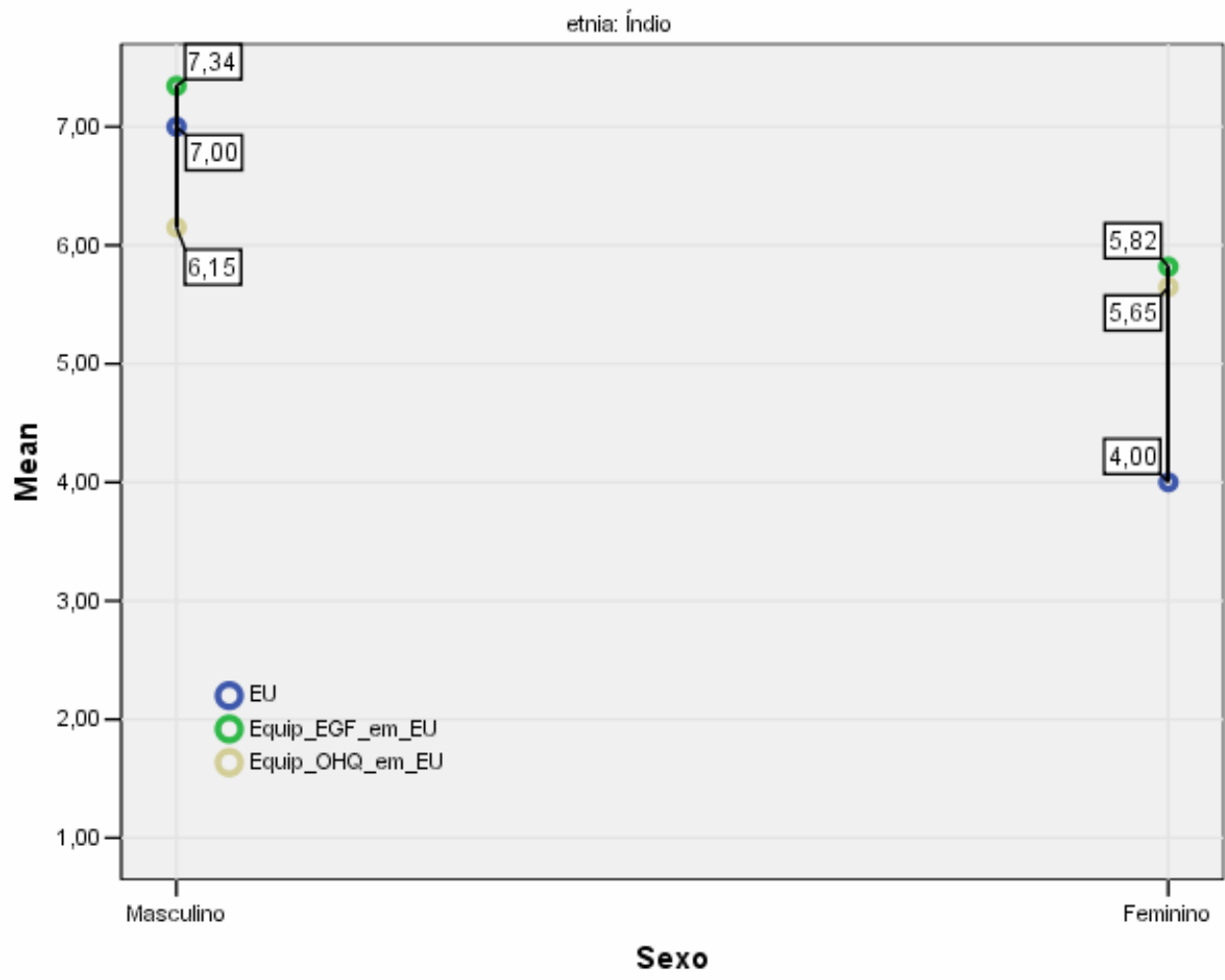

Gráfico 25- Escores médios equiparados índios x sexo 
Observa-se diferença entre os escores médios para homens e mulheres negros, na escala EGF, e para homens e mulheres brancos, na EU (Tabela 66, em Apêndices). No primeiro caso, o Gráfico 22 mostra níveis menores para elas, enquanto que, no Gráfico 24, elas possuem maiores escores do que eles. Uma observação a ser feita é que na Tabela mencionada existe uma categoria representada por um ponto, que consiste em 3 respondentes que não se classificaram.

As diferenças étnicas entre o sexo dos indivíduos são testadas em sua relação através do método de regressão, em que o grupo Masculino constitui o critério. As Tabelas de 67 a 72 mostram os resultados, nos quais se verifica a significância estatística para Branco na escala EU ( $\beta=0,295$ e $\left.R^{2}=0,012\right)$, e Negro na escala EGF ( $\beta=-1,565$ e $\left.R^{2}=0,371\right)$. No primeiro caso, as mulheres apresentaram ser mais felizes que os homens e no segundo deu-se o inverso. A explicação de 1,2\% da variância, no primeiro, caso é pequena, porém, para o segundo caso, o valor de $37,1 \%$ é alto e deve ser foco de melhor compreensão. O escore da regressão negativo $(\beta=-1,565)$ mostra a magnitude com que o grupo se posiciona abaixo do critério adotado (Homens). Deve-se atentar para a pequena distribuição de pesquisados nesta etnia, que leva a restringir esta informação aos limites da pesquisa. Porém, isto fornece indícios para novos estudos, sobretudo por ter convergência com o que Diener (1984) encontrou sobre menores níveis de bem-estar subjetivo, em determinados grupos de pesquisados negros.

Quando são consideradas as faixas etárias (Tabelas 74 a 79), a categoria Brancos com idade entre 41 e 50 anos, mostrou ser significativa para a $\mathrm{EU}\left(\beta=-0,698\right.$ e $\left.R^{2}=0,038\right)$, assim como os Pardos, que, por sua vez, mostraram significância para as faixas etárias entre 21 e 30 $\operatorname{anos}(\beta=0,820), 31$ a $40 \operatorname{anos}(\beta=1,022)$ e 41 e 50 anos $(\beta=1,052)$ para o OHQ $\left(R^{2}=0,10\right)$. Neste último caso, considerando que a variável critério é a faixa etária até 20 anos, os coeficientes da regressão mostram que à medida que a categoria etária aumenta maior é o valor da carga relativa ao critério adotado, com uma explicação da variância de $10 \%$. 
Conforme citado anteriormente, as diferenças econômicas entre negros e brancos, o que nos leva a ponderar a renda como fator de impacto no BES para as características étnicas (Frey \& Stutzer, 2002). Para esta análise, foi considerada a faixa inferior de renda familiar (até 500,00) como categoria de referência. A Tabela 73, em Apêndices, mostra a distribuição de renda entre os grupos étnicos e, nas Tabelas 80 a 85 em Apêndices, aparecem as regressões realizadas. A EU e a EGF não apresentaram significância estatística para nenhuma faixa de renda; o OHQ mostrou ser significante para a etnia Pardo, na faixa de renda $4(\beta=1,252)$, e etnia Branco, na faixa de renda $6(\beta=0,570)$. A explicação da variância para o último caso é 2,3\% e para o primeiro $14,3 \%$. A magnitude expressa pelo coeficiente de correlação fornece indícios que renda familiar maior (entre 1.501 a 2.000 reais) possui impacto positivo nos desempenho de felicidade, para a etnia Pardo, junto aos comerciantes e comerciários de Ribeirão Preto e Região. Os negros, que em trabalhos internacionais mostraram menores níveis de BES, não apresentaram significância em nenhuma escala utilizada neste trabalho.

Considerando que os trabalhos citados realizaram seus estudos em sociedades estrangeiras, sociedades estas que possuem distorções sociais, apontam o papel das condições de igualdade social na promoção do BES. Nesta pesquisa, um aspecto a ser considerado é quanto à etnia parda, que é uma designação comum em um país miscigenado como o Brasil; a qual apresentou relações neste trabalho, que devem ser mais bem compreendidas quanto às diferenças apresentadas.

\subsection{ESTADO CIVIL}

Stutzer e Frey (2004) fazem perguntas muito interessantes: o casamento torna as pessoas felizes ou as pessoas felizes se casam? Qual a relação causal entre casamento e felicidade?

Primeiramente será testada novamente a análise fatorial, sendo que a amostra foi dividida em dois grupos: o primeiro de casados e o segundo, de não casados. Esse último 
compreende os solteiros, divorciados, viúvos e outros, conforme indica o questionário. Esta divisão foi feita somente para a análise fatorial, a fim de verificar a estabilidade, para este grupo, da quantidade de fatores encontrados anteriormente. Na fatoração para casados a variável (18) foi excluída por apresentar uma comunalidade muito baixa em relação às demais $(0,268)$.

Tabela 31-Análise fatorial casados

\begin{tabular}{|c|c|c|c|c|c|c|c|c|}
\hline Análise & $\overline{\mathrm{NV}}$ & KMO & $\overline{\text { Bartlett }}$ & $\overline{\text { Fatores }}$ & Explicação & Resíduos & 2 <MSA & $\overline{\text { Exclusão }}$ \\
\hline 1 & 28 & 0,753 & $\overline{0,000}$ & 9 & $59,08 \%$ & $42 \%$ & 0,547 & 18 \\
\hline 2 & 27 & 0,752 & 0,000 & 9 & $60,71 \%$ & $43 \%$ & 0,531 & - \\
\hline
\end{tabular}

As cargas fatoriais e comunalidades para a análise dos casados estão nas Tabelas 86 e 87, estando na Tabela 88 a comparação entre os fatores obtidos originalmente e o resultado da análise para os casados (todas em Apêndices). Para os não casados, cujo resumo da análise está na Tabela 32 abaixo, as cargas fatoriais, comunalidades e comparação dos fatores obtidos estão nas Tabelas 89, 90 e 91, em Apêndices, respectivamente.

Tabela 32 - Análise fatorial não casados

\begin{tabular}{ccccccccc}
\hline \hline Análise & NV & KMO & Bartlett & Fatores & Explicação Resíduos & < MSA & Exclusão \\
\hline \hline 1 & 28 & 0,820 & 0,000 & 9 & $58,49 \%$ & $39 \%$ & 0,572 & - \\
\hline \hline
\end{tabular}

Tanto para os casados quanto os não casados, a quantidade de fatores obtidos foram 9 , com o arranjo de suas variáveis para o primeiro caso mais convergente com a análise original, nos 5 primeiros fatores e, para o segundo caso, 2 fatores da análise original não encontraram nenhuma simetria na análise realizada para não casados (ver Tabela 91, Apêndices). Observadas as análises anteriores, é de se esperar que os fatores não venham a integrar a mesma composição, porém este remanejamento é até agora feito em uma quantidade relativamente fixa de oito fatores, sendo estes dois grupos de análise uma exceção. Pouco se pode concluir deste resultado, uma vez que a estrutura pode realmente diferir das encontradas anteriormente, como pode ser uma particularidade da matriz fatorial, obtida como resultado 
da amostra, porém julga-se válida esta observação, para que esta particularidade seja observada em outros estudos.

O Gráfico 26 mostra os escores equiparados para cada estado civil considerado na pesquisa. A Tabela 92 (Apêndices) mostra o teste estatístico quanto à homogeneidade da variância, que apresentou desigualdade para as escalas EU e EGF. Dessa forma é necessário realizar um teste não paramétrico. O teste de Kruskal Wallis (Tabela 93) mostrou que para a EGF não existem diferenças entre os escores, porém para a EU há diferença entre as médias. Isto nos leva a afirmar que os viúvos possuem menor nível de felicidade do que os demais (conforme gráfico abaixo). Para o OHQ, as médias em questão são iguais (Tabela 94).

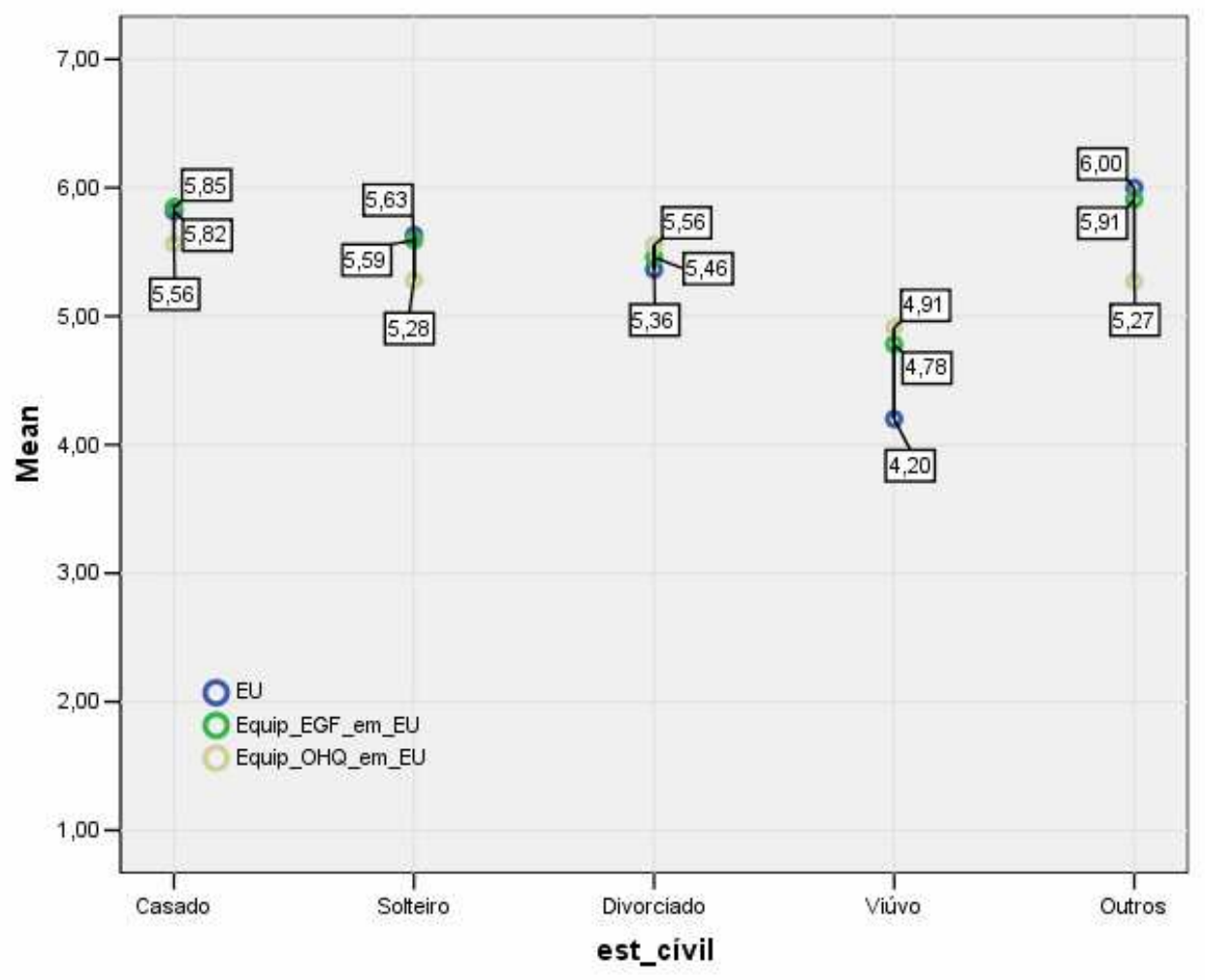

Gráfico 26- Escores médios equiparados para estado-civil nas três escalas

Em avaliação dos escores equiparados das escalas internos às categorias (Tabela s $95 \mathrm{e}$ 96), observa-se em todas a igualdade de médias entre a EU e a EGF. Já em relação ao OHQ, este registrou significância para as categorias casado, solteiro e outros relacionamentos, 
diferença esta tanto com a escala EU quanto EGF. No gráfico, anterior pode se verificar que os escores equiparados para o OHQ nesses casos são menores.

Para avaliarmos as diferenças entre homens e mulheres, posto o estado civil, foram analisadas as médias dos escores, inicialmente quanto a sua homocedasticidade (Tabela 97, em Apêndices). $\mathrm{O}$ resultado mostrou que a EU não apresenta igualdade de variância para o sexo feminino (Tabela 98). Nas escalas EGF e OHQ, os homens não apresentaram diferenças entre as médias das categorias de estado civil, porém para as mulheres houve significância estatística para as duas escalas (Tabela 99). Isto significa dizer que existe para as mulheres diferenças no BES em função do estado civil.

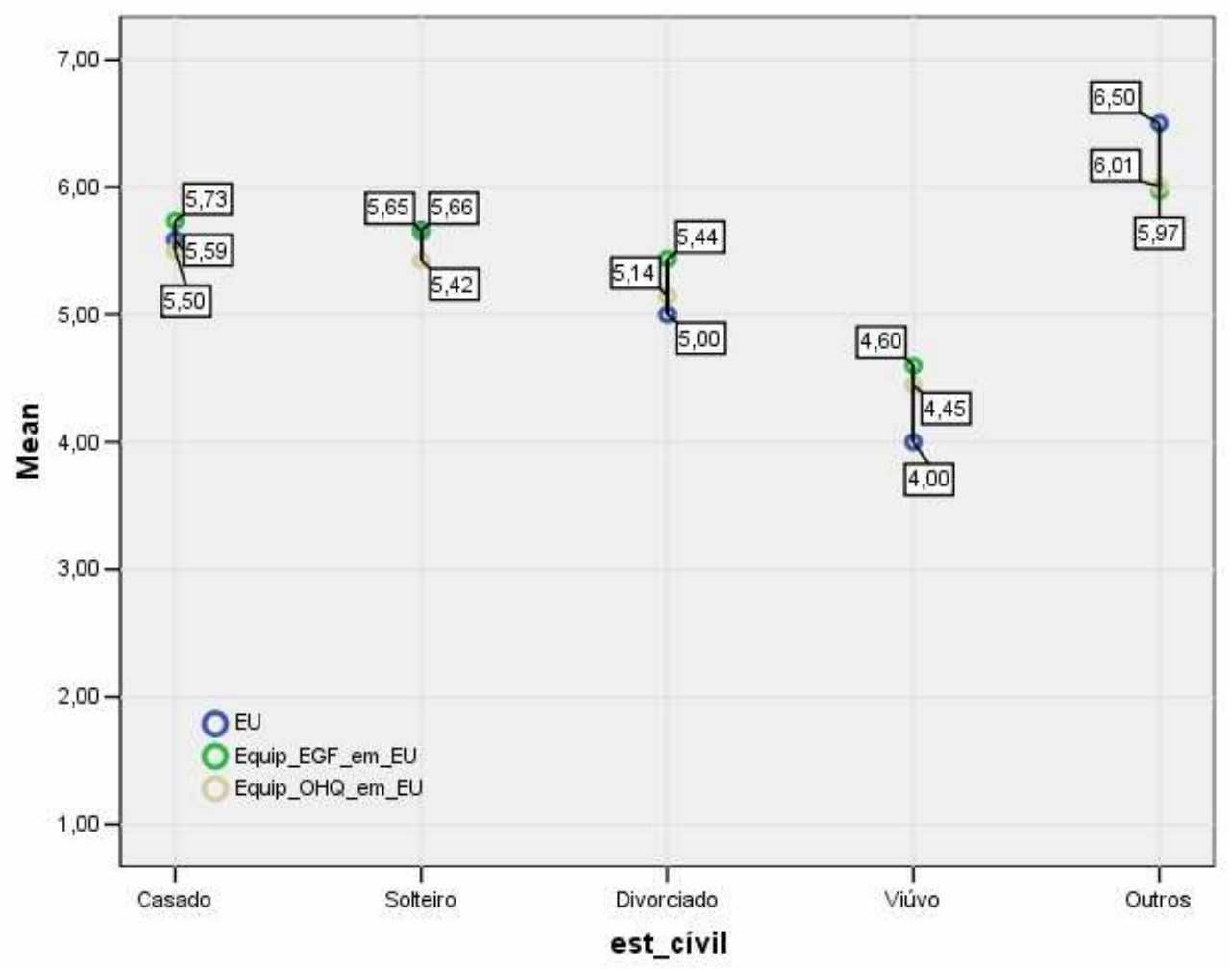

Gráfico 27- Escores médios equiparados para estado civil - homens 


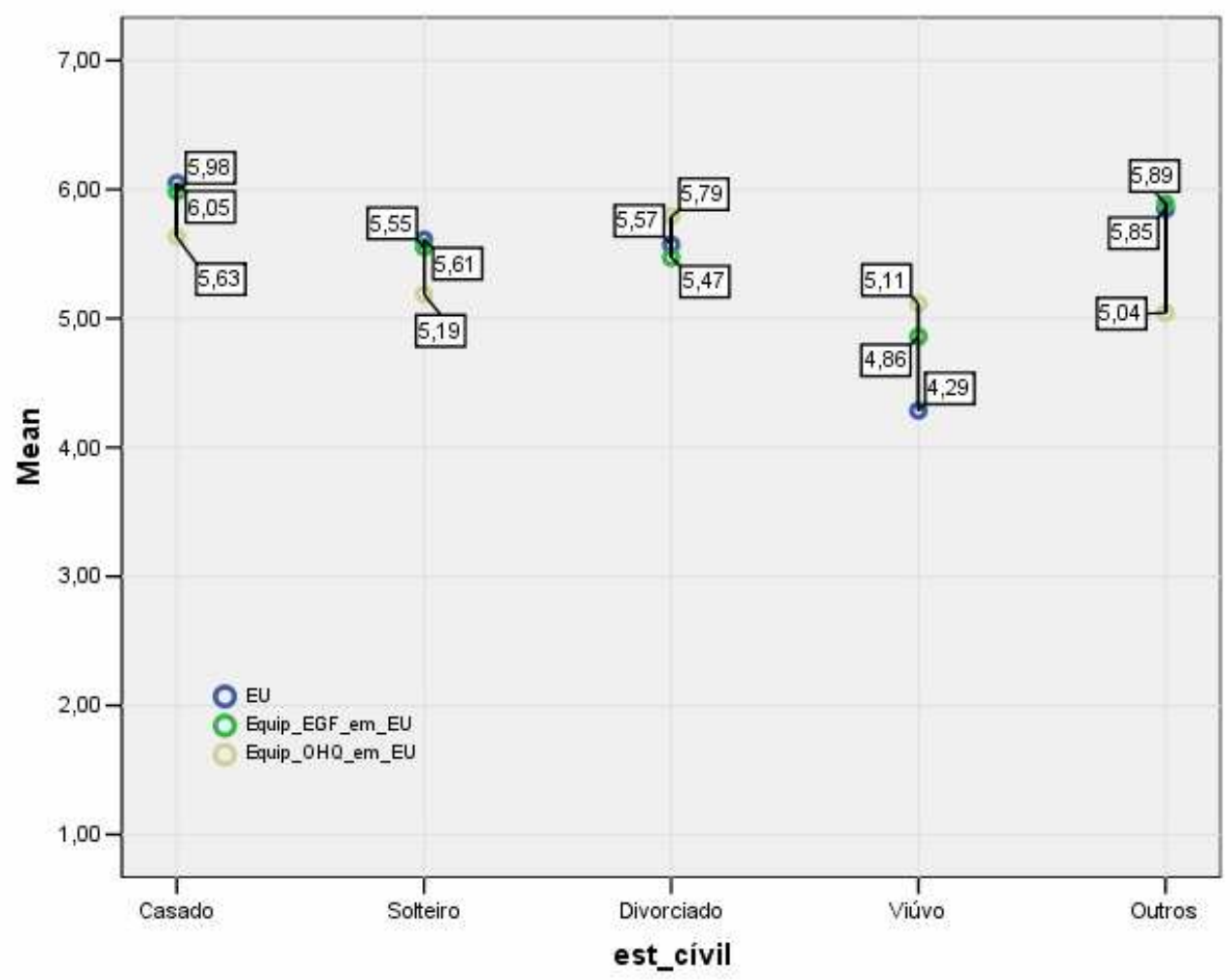

Gráfico 28- Escores médios equiparados para estado civil - mulheres

Assim, os escores apresentados para cada escala no Gráfico 27 são variações de uma mesma média, enquanto que os valores apresentados no Gráfico 28 possuem diferenças, o que indica que as mulheres casadas são mais felizes do que as solteiras e as viúvas possuem níveis inferiores de felicidade. As Tabelas 100 e 101 em Apêndices mostram as correlações e teste estatístico para os escores de medidas equiparadas internos às categorias. Para os homens não houve diferenças entre os valores entre o desempenho das escalas, enquanto que para as mulheres, o OHQ mostrou diferença tanto da EU como a EGF para Solteiro, que apresenta menor escore e Outros, onde o OHQ apresentou escore diferente somente à EGF. Novamente é observado que para estas categorias, o OHQ possui menor desempenho em alguns casos, em termos de valor de escore equiparado.

As diferenças acima mencionadas foram analisadas através de regressão com matrizes binárias. A variável escolhida para ser referência é a categoria Solteiro e o resultado será verificado por sexo, visto a diferença entre as médias dos escores para as mulheres. As 
Tabelas compreendidas entre 102 e 107, em Apêndices, mostram as regressões realizadas, tendo como variável dependente o escore total de cada escala utilizada (para o OHQ e EGF, equiparados) e independentes as categorias de estado civil. Apresentaram significância estatística os viúvos $\left(\beta=-1,663\right.$ e $\left.R^{2}=0,056\right)$ e viúvas $\left(\beta=-1,325\right.$ e $\left.R^{2}=0,056\right)$ para a EU; as mulheres casadas para a EU $\left(\beta=0,439\right.$ e $\left.R^{2}=0,056\right)$, EGF $\left(\beta=0,446\right.$ e $\left.R^{2}=0,037\right)$ e para o OHQ ( $\beta=0,453$ e $\left.R^{2}=0,035\right)$. Apesar da explicação da variância não ser elevada, a significância nas três escalas para as mulheres casadas reforça que o casamento possui maior benéfico para as mulheres, ao menos na amostra coletada.

Tendo em vista que outros aspectos sócio-demográficos idade, podem oferecer diferenças no BES, observando o tipo de relacionamento, foi considerada a análise para estes casos, onde as Tabela s 108 a 111, em Apêndices, apresentam regressão dummy por faixa etária, separado por estado civil. Na construção da matriz binária necessária para a regressão, a categoria de referência foi alterada para a faixa etária 2, entre 21 e 30 anos, onde o tipo de relacionamento está mais maduro do que na categoria anterior. Somente para a EU houve significância para a faixa etária entre 41 a 50 anos, entre os casados $\left(\beta=-0,671\right.$ e $\left.R^{2}=0,057\right)$, na EGF os casados com idade inferior a 20 anos $\left(\beta=1,117\right.$ e $\left.R^{2}=0,060\right)$. As demais significâncias estatísticas não foram consideradas porque se tratam de apenas 2 sujeitos na categoria. Resguardadas as devidas cautelas na interpretação destas informações, pois houve significâncias em escalas diferentes e com limitado número de indivíduos, pode-se imaginar que aqueles que possuem menor tempo de casado são mais felizes do que aqueles com idade mais avançada.

Em uma análise longitudinal, foi encontrado que os casados possuem maior nível de bem-estar psicológico e que os solteiros possuem um nível de bem-estar similar ao que as pessoas que coabitam (Kim \& McKenry, 2002). Esta relação não formalizada está inserida na denominação Outros de nossa pesquisa. Este grupo indefinido pode envolver diversos tipos 
de relações, como amasiados, ou até mesmo a relação entre mesmo sexo, que não configura em nenhuma categoria da pesquisa, podendo ser trabalho em pesquisas futuras. Em Argyle e Handerson (1985), os autores afirmam que casamento inevitavelmente envolve conflitos e este embate emocional acaba por deprimir o nível de satisfação. Portanto, parece natural não encontrar níveis muito baixos para indivíduos divorciados, considerando-se a possibilidade de que estes tenham deixado uma relação tumultuada.

A literatura mostra que a dissolução do casamento pode ser derivada de fatores, como a viuvez ou a separação. A primeira se origina de ordem natural do casamento, pois, mais cedo ou tarde, haverá a ruptura pela falta de um dos cônjuges. Muitos indivíduos que se tornam viúvos, assim o permanecem, não tornando ao nível tradicional de satisfação com a vida, mesmo oito anos após o evento (Lucas e colaboradores, 2003), enquanto que a separação é o rompimento voluntário da relação (Clark e Oswald, 2002). Em virtude desta diferença na natureza do rompimento, com a viuvez, o nível de felicidade cai significativamente, pois em um caso é opcional, enquanto que no outro, não. Holmer e Rachel (1967, conforme Lucas e colaboradores, 2003) mostram que a viuvez e o divórcio são os dois eventos mais estressantes da vida adulta, até mesmo maior do que ir para a cadeia. Na mesma obra, o casamento foi listado como o $7^{\circ}$ entre os 50 eventos mais estressantes. Em contrapartida, o casamento pode ser altamente compensador com forte impacto no BES (Luca e colaboradores, 2003). Para Stutzer e Frey (2002), as pessoas felizes tendem a permanecer mais tempo em seus relacionamentos. Easterlin (2003) questiona esta posição de que o casamento é um promotor de felicidade, fato de difícil compreensão porque existem diferenças entre a felicidade de pessoas casadas e porque a felicidade no primeiro casamento é maior, se comparada em indivíduos com mais de um matrimônio. De acordo com Helliwell (2003), tanto para o homem quanto para a mulher, o casamento não oferece diferenças, sendo positivo ao BES em ambos os casos. 
Neste trabalho, foram conduzidas investigações que servissem de parâmetro para compararmos com o que foi achado entre as pesquisas realizadas, referentes às diferenças individuais quanto à relação do bem-estar subjetivo e o estado civil. De uma forma geral, o casamento aparenta ter impacto maior para as mulheres do que para os homens, considerada a análise feita, porém isto somente poderia ser observado com a correta propriedade, se pudéssemos avaliar dois momentos de vida distintos dos indivíduos, isto é, pré e pós-nupcial. Em outras palavras, procurou-se quantificar as diferenças entre os níveis de BES entre as diferentes situações de estado civil dos pesquisados, porém uma construção mais apropriada de pesquisa, feita através de um delineamento que ofereça o estudo dos indivíduos em aspecto longitudinal, poderá oferecer informações mais substanciosas.

\subsection{ESCOLARIDADE}

Muitos estudos descobriram que não há efeitos significantes entre os níveis educacionais e felicidade e outros tantos indicam efeitos positivos, em especial para as mulheres (Diener, 1984). Campbell (1981) sugere que a educação pode servir ao indivíduo como recurso pelo qual aumente suas aspirações. Para Veenhoven (1984), há uma correlação alta nas nações pobres e correlações baixas nas nações ricas. Frey e Stutzer (2003) encontraram que a educação possui relações estatísticas significantes com o BES. Para Helliwell (2003), a educação oferece atributos para se participar de atividades e conexões sociais, que estão ligadas ao BES, porém os efeitos no BES são insignificantes. Para Easterlin (2001), a educação, juntamente com o desemprego, afeta a felicidade através da renda, se considerar que esta é um resultado de inter-relações de circunstâncias sócio-culturais. 


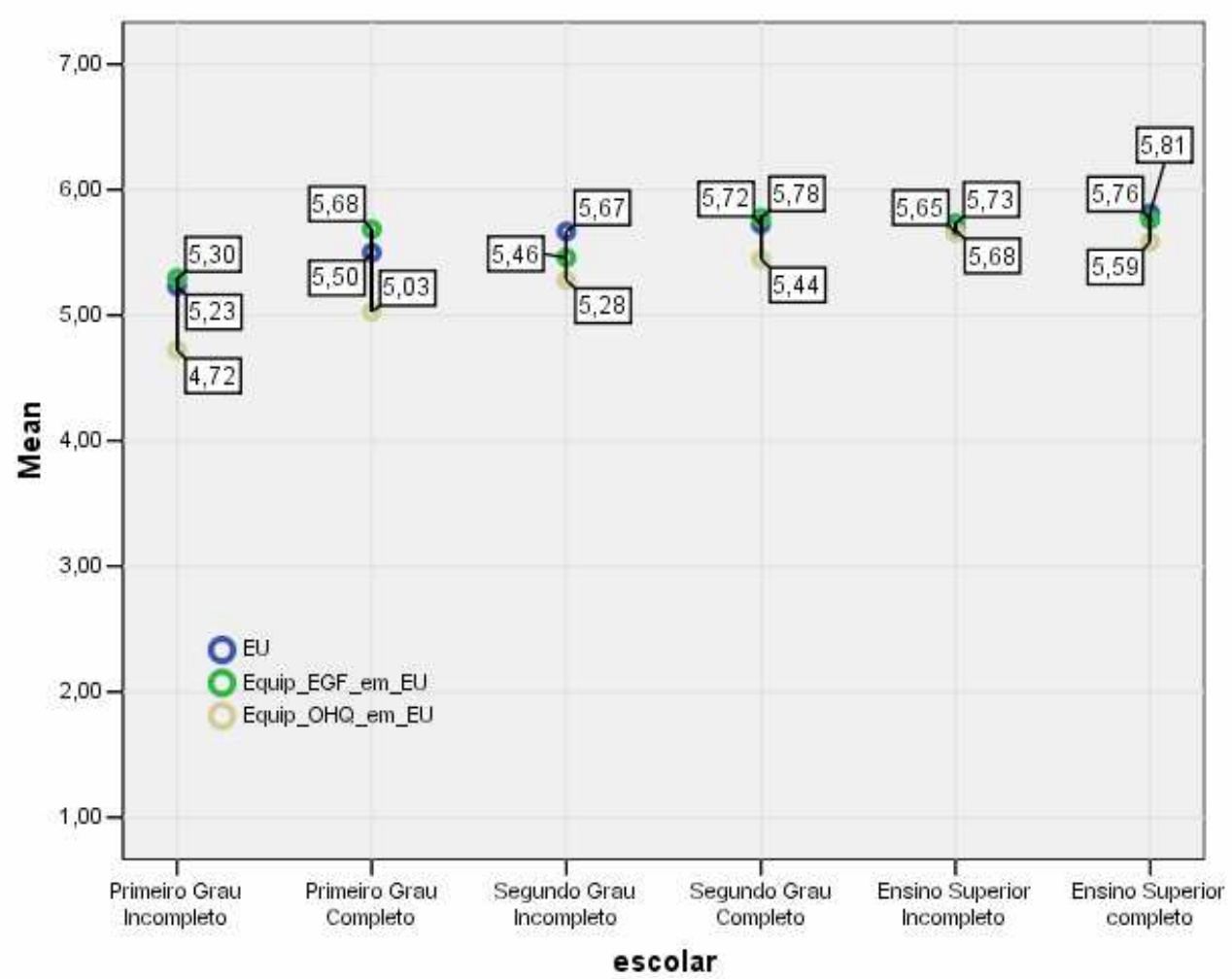

Gráfico 29- Escores médios equiparados por nível educacional

No Gráfico 29 há os escores médios de BES e na Tabela 114 (Apêndices) mostra que para a EU e EGF os escores médios indicados são variações de uma mesma média, mas para o OHQ houve significância estatística, de maneira que existem diferenças entre as médias. Isto representa que, de acordo com os escores do gráfico acima, indivíduos com menor escolaridade possuem menor nível de BES. Quanto ao desempenho das escalas dentro das categorias (Tabelas 115 e 116, em Apêndices), a EU com a EGF mostraram igualdade para todos os níveis escolares, porém o OHQ apresentou diferença para Primeiro grau incompleto (diferença para a EU e EGF), Primeiro grau completo (diferença EGF), Segundo grau incompleto (EU) e Segundo grau completo (EU e EGF). Nestes casos, podese verificar graficamente o menor valor relativo ao OHQ.

Ao se buscar uma relação linear entre o nível educacional do pesquisado e o BES (Tabelas 117 a 122, Apêndices), através do mesmo método de regressão realizado até agora e tendo-se como critério o Primeiro Grau Incompleto, mostraram-se significantes os três 
maiores níveis educacionais, apenas para a escala OHQ (Segundo Grau completo, $\beta=0,691$; Terceiro Grau Incompleto, $\beta=0,893$; Terceiro Grau Completo, $\beta=0,825$ ). Esta relação mostra que níveis maiores de escolaridade entre os pesquisados estão relacionados com maior felicidade, e o percentual de explicação da variância é de 3,2\%.

Tendo em vista as diferenças educacionais em relação ao sexo, ainda com o mesmo grupo critério para a regressão, as Tabela s 123 a 128 mostram o estudo de relação entre o nível escolar dos pesquisados. Para as mulheres com terceiro grau completo houve significância para a escala EU $(\beta=0,709)$ e OHQ, sendo que nesta última escala os níveis escolares Segundo Grau Completo $(\beta=0,761)$, Terceiro Grau Incompleto $(\beta=1,029)$ e Terceiro Grau Completo $(\beta=0,916)$, mostraram relevância no estudo, somente para elas, com níveis de explicação de $R^{2}=0,021$ para EU e $R^{2}=0,065$ para o OHQ. Isto significa dizer que a escolaridade pode possuir um pequeno impacto positivo no bem-estar subjetivo para as mulheres. Não são valores muito expressivos, porém é positivo considerar que o nível maior de escolaridade representa uma maneira para elas tornarem-se ligeiramente mais felizes. Em uma investigação de relação considerando-se o estágio escolar e a etnia (Tabela s 129 a 134), houve significâncias estatísticas somente para a escala OHQ, na classificação de etnia Branco $(\beta=0,975)$. Os indivíduos com o Segundo Grau Completo $(\beta=0,732)$, Terceiro Grau Incompleto $(\beta=0,975)$ e Terceiro Grau Completo $(\beta=0,846)$ mostraram maior carga para a regressão, tendo como critério Primeiro grau incompleto. A explicação da variância é de $2,9 \%$.

Para Campbell (1981), a escolaridade, a princípio, mostra não ter muito impacto no BES, pois esta relação baixa e deve ser mais bem compreendida à medida que, conforme apontou, esta pode vir a constituir recursos do indivíduo que o auxiliam no desempenho de suas atividades. Assim, é conveniente que esta característica seja estudada em associação 
com outras variáveis, como desempenho profissional, por exemplo, uma vez que esta capacita os indivíduos à medida que a educação alcança níveis mais altos.

\subsection{FILHOS}

Dalgas-Pelish (1993) afirma que a felicidade conjugal, a partir da gestação, sofre decréscimo e Myers (1992) mostra que na fase do "ninho vazio" existe um sensível acréscimo de bem-estar no casamento. A dificuldade da família moderna e sua instabilidade possuem grande impacto nos filhos (Sund \& Smyrnios, 2005). Estes, entre outros estudos, mostram sua na felicidade individual e conjugal.

Argyle e Henderson (1985, pg. 130) mostram a evolução da satisfação com a vida, em função do estágio de vida dos filhos. Quando o casamento não possui crianças, apresenta-se o maior nível de satisfação. À medida que a idade dos filhos vai avançando, o nível de satisfação vai caindo, até chegar a seu patamar mínimo, quando os filhos possuem idades entre 12 e 16 anos, isto é, alcançarem a adolescência. Na proporção em que os filhos envelhecem e se encaminham na vida, deixando o lar, a satisfação do casal aumenta, até chegar a níveis similares ao período inicial do casamento em que não havia crianças, denominado "ninho vazio". 


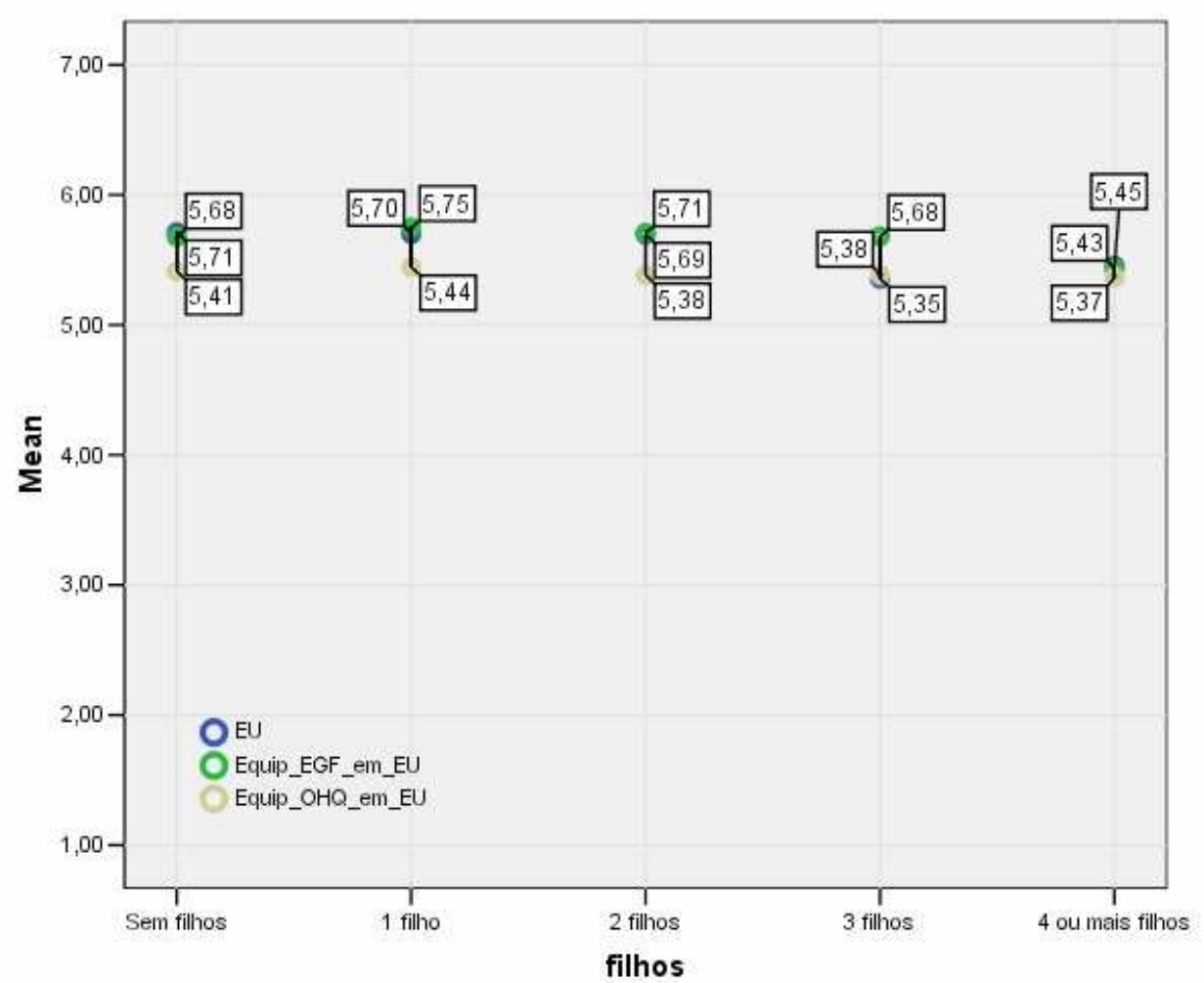

Gráfico 30- Escores médios equiparados por quantidade de filhos

O Gráfico 30 mostra as médias para as escalas, tendo em seu eixo a quantidade de filhos. Os escores não diferenciaram os indivíduos em função do número de filhos, sendo para cada valor uma variação da mesma média (Tabela 135, Apêndices). Quanto às diferenças de mensuração das escalas nas categorias, a EU apresentou diferença com a EGF na categoria 3 filhos, enquanto que o OHQ apresentou ter escores menores na primeira, segunda e terceira categorias (sem, um e dois filhos) (Tabela 136 e 137). No gráfico acima, podemos verificar que estes escores equiparados são inferiores aos das duas outras escalas.

Conforme dito anteriormente, existem deferentes níveis de felicidade para os casais, em função dos estágios de vida. Para testar esta hipótese, a amostra é filtrada para considerar somente a parte casada dos trabalhadores e empresários do comércio e analisada para cada categoria de quantidade de filhos, tendo como variável independente as faixas etárias consideradas e dependente, cada uma das escalas utilizadas. A variável-critério para idades não pode permanecer a mesma, pois a faixa considerada até 20 anos torna-se inapropriada para análise, pois poucas pessoas possuem filhos nesta idade. Dessa forma, o critério de 
análise foi a categoria imediatamente superior, de 21 a 30 anos. Para nenhum caso foi encontrada significância estatística (Tabelas 138 até 143), considerando-se a margem de confiança de $95 \%$ até agora adotada ${ }^{6}$. Não foi possível, assim, comprovar o que a literatura mencionada afirmou. A Tabela 144, em Apêndices, mostra a correlação negativa entre números de filhos e escolaridade.

\subsection{ATIVIDADE PROFISSIONAL}

O tema desta pesquisa é avaliar as diferenças individuais entre os comerciantes e comerciários de Ribeirão Preto e Região. Uma dessas diferenças é a ocupação desempenhada dentro das organizações, pela qual podemos avaliar se o empresário possui níveis diferenciados de bem-estar subjetivo, se comparados aos seus funcionários.

O Gráfico 31 mostra os escores médios de BES para comerciantes e comerciários. A análise das médias, presente na Tabela 145, mostra que não existe diferenças entre os escores apresentados de comerciantes e comerciários. Quanto ao desempenho interno à categoria, para os comerciários, o OHQ mostrou diferença com as duas escalas EGF e EU (Tabela 147) e, conforme representação gráfica, com escore menor.

Os Gráficos 31 e 32 a seguir mostram os escores individualizados para o sexo, no propósito de investigar se a atividade comercial pode representar maior nível de satisfação, a um ou a outro grupo. Através do teste estatístico (Tabela 148), para nenhuma das escalas foi detectada diferença nas médias, isto é, não existem diferenças entre os escores apresentados nos gráficos. As diferenças de médias das escalas internas às categorias são testadas na Tabela 149 (Apêndices), onde a EGF e a EU possuem igualdade em seus escores equiparados, porém o OHQ apresenta diferenças com ambas as escalas.

\footnotetext{
${ }^{6}$ Porém devemos observar o resultado para a categoria acima de 60 anos sem filhos, na EU, que está muito próxima ao nível de significância e o coeficiente apresenta carga negativa ao critério adotado
} 


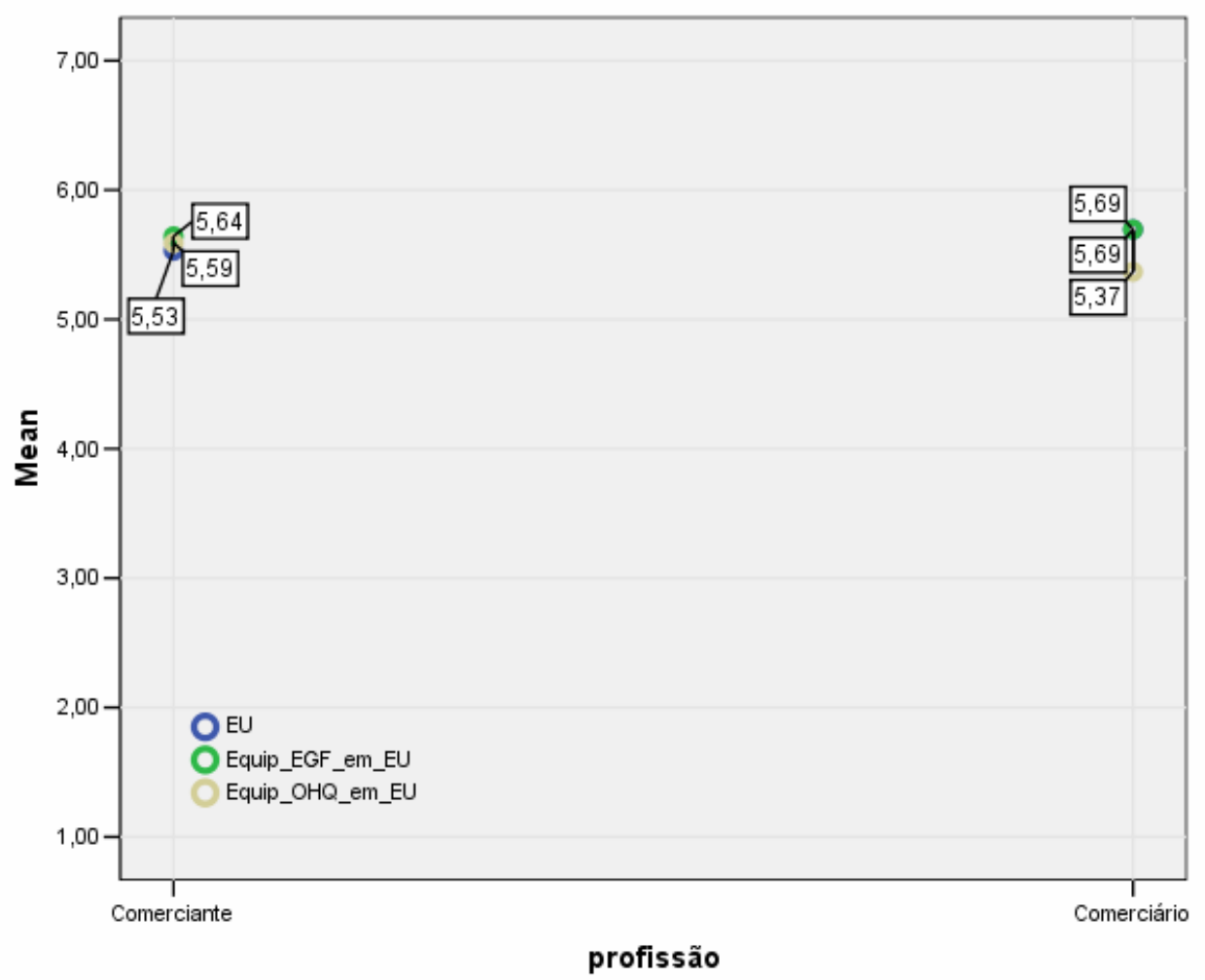

Gráfico 31- Escores médios equiparados nas escalas entre comerciantes e comerciários

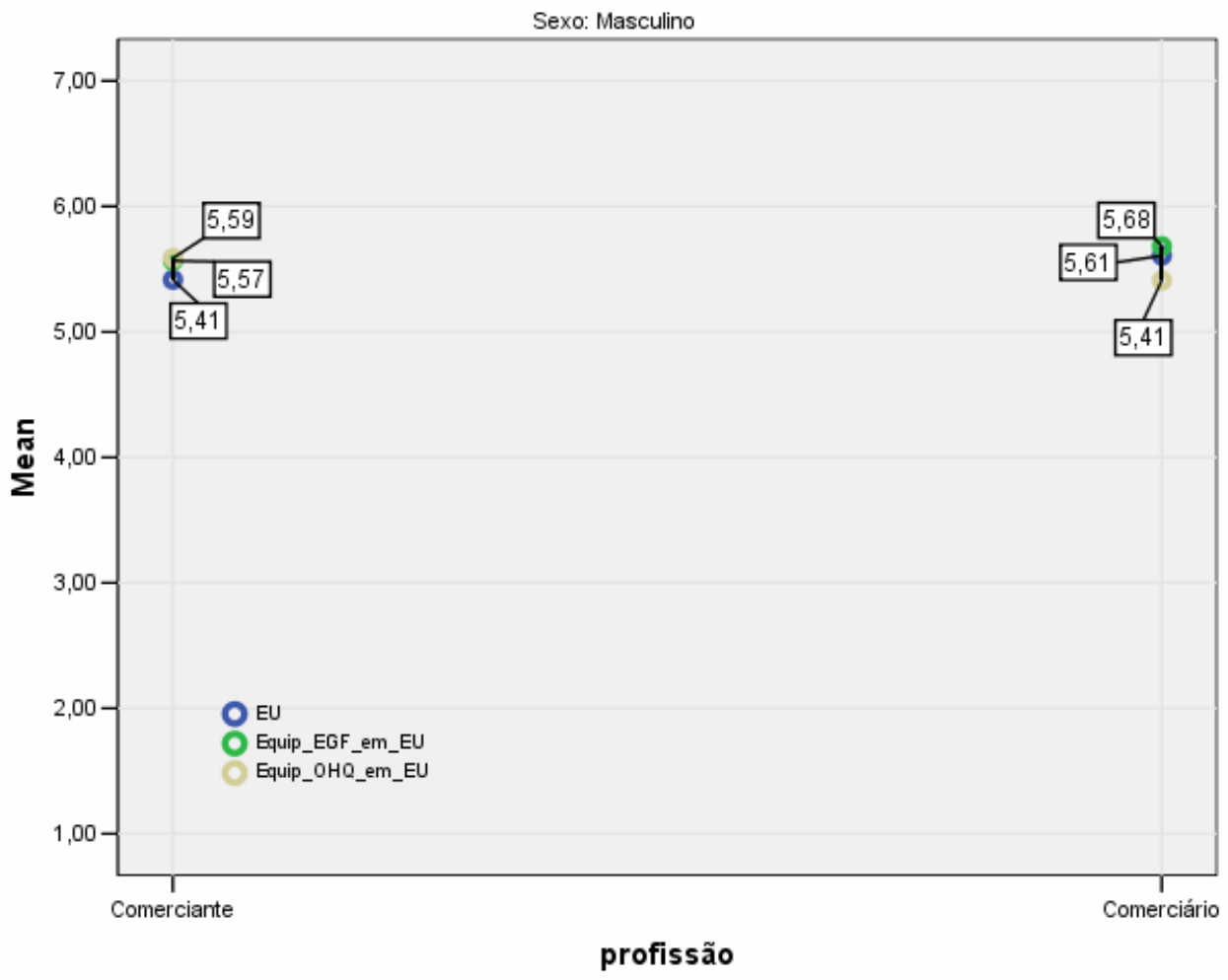

Gráfico 32- Escores médios equiparados nas escalas entre comerciantes e comerciários - homens 


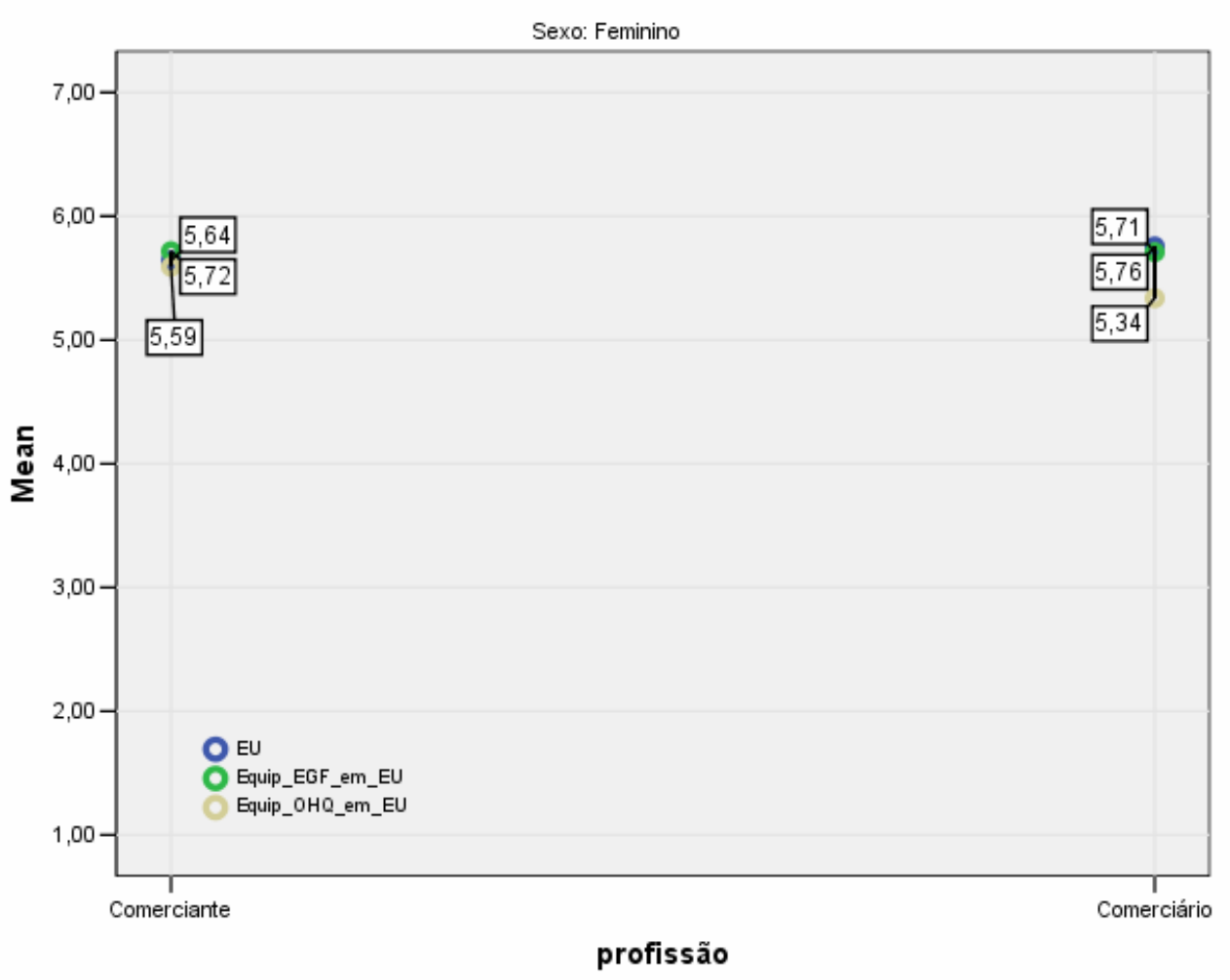

Gráfico 33- Escores médios equiparados nas escalas entre comerciantes e comerciários- mulheres

Com o propósito de avaliar se existem relações entre a posse de negócio próprio e o BES, foram realizadas regressões (Tabelas 150 a 152) que mostram a ausência de relação entre as duas variáveis Lykken (1999) apresenta estudos, comparando funcionários de supermercados e seus patrões, onde uns são tão felizes quanto os outros e ele advoga que a origem da felicidade no trabalho está na realização de uma atividade produtiva, com o qual o indivíduo se identifique e tenha satisfação em exercer.

\subsection{COMPARAÇÃO ENTRE EMPREGO EFETIVO E TEMPORÁRIO}

Frey e Stutzer (2002) mostram que o desemprego possui fortes marcas nas pessoas. No indivíduo, ainda que retorne ao mercado de trabalho, o período de desemprego permanece como uma cicatriz. O delineamento da pesquisa não focou a análise, junto aos desempregados, contudo, o comércio admite trabalhadores temporários, que não possuem relação trabalhista estável, como os demais funcionários. Podemos considerar dessa forma 
que não estão totalmente empregados, pois, findo o contrato temporário, poderão voltar à condição de desempregados. O Gráfico 34 mostra as médias obtidas para estes dois grupos.

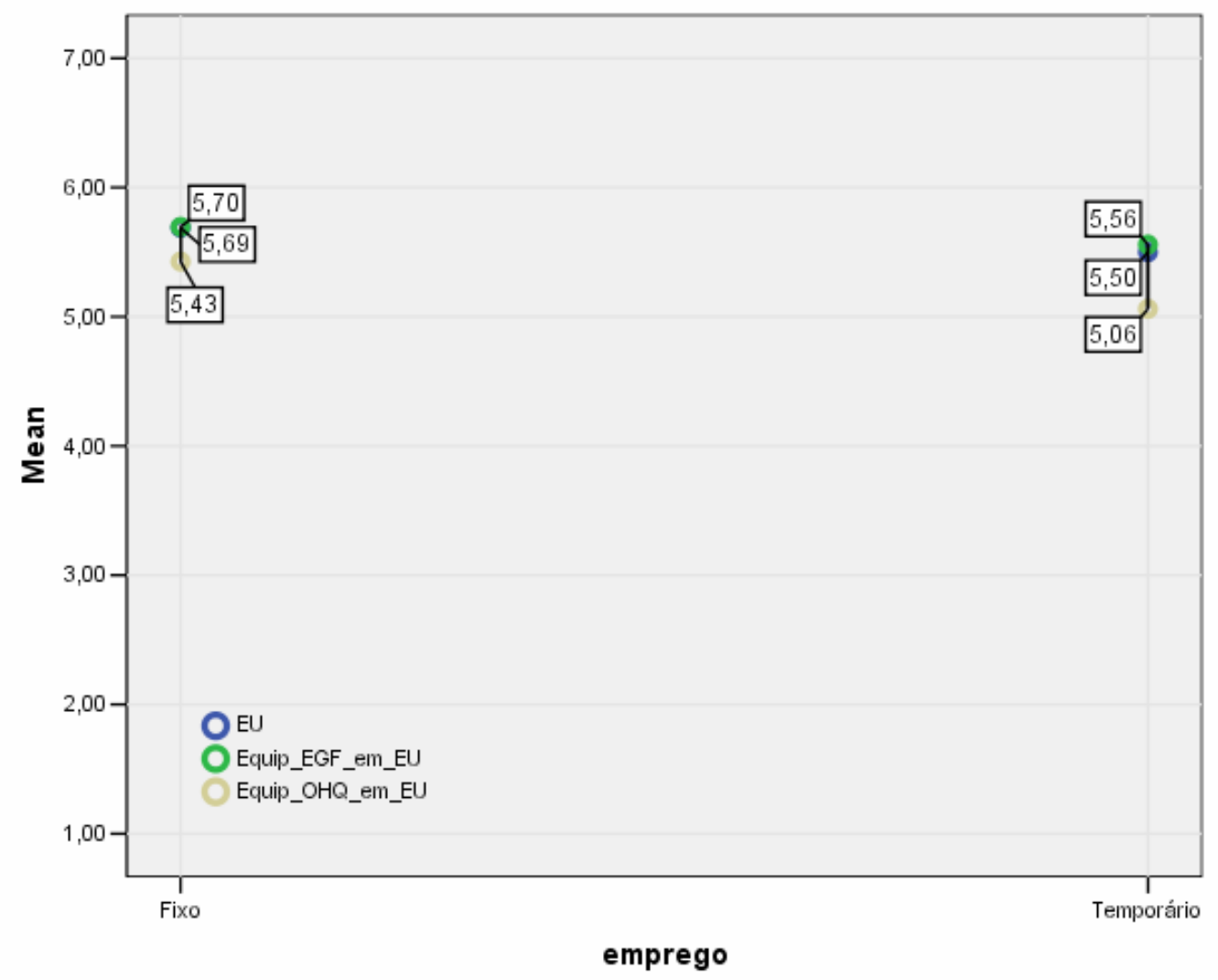

Gráfico 34- Escores médios equiparados entre funcionários fixos e temporários

Realizado o teste de homogeneidade de variâncias, o resultado apresentou diferenças para a escala EU (Tabela 153), tendo então de se fazer teste não paramétrico. Apesar de que, quem possui emprego fixo, tenha apresentado maiores escores do que aqueles que possuem emprego temporário, o teste não paramétrico (Tabela 154) e paramétrico (Tabela 155) não mostrou diferenças. Procurou-se estabelecer uma relação através da regressão (Tabelas 156 a 158), porém em nenhum momento isto se apresentou significância estatística.

Assim, não há indícios de relações entre felicidade e emprego temporário. Qualquer outro tipo de investigação torna-se limitado devido à baixa quantidade de pesquisados com este perfil. 


\subsection{RENDA}

Nas sociedades Ocidentais prevalecem os princípios utilitaristas nos quais as riquezas geradas causam impactos de forma incisiva no bem-estar dos indivíduos; se aceita e reconhece-se que o aumento de riquezas oferece maior nível de felicidade. Diversos pesquisadores, como Maslow, mostraram que os indivíduos buscam suprir níveis de subsistência e necessitam de recursos para isso (Kingwell, 2006), mas à medida que a renda sobre progressivamente, o ganho de felicidade derivado deste crescimento é cada vez menor (Stutzer \& Frey, 2003). Assim, o intuito do estudo que segue é investigar a relação entre níveis de riqueza das pessoas, suas características individuais e o desempenho de felicidade obtido nas três escalas utilizadas.

O Gráfico 35 mostra os escores obtidos e a Tabela 159 (Apêndices) os resultados do teste de médias para as escalas entre os grupos de renda, onde o OHQ obteve significância estatística. Isto fornece indícios, para esta escala, para afirmar que os pesquisados em nossa amostra com renda familiar, abaixo de 500 reais e entre 501 e 1.000 reais, possuem níveis menores de BES, conforme o Gráfico 35. Com referência ao desempenho das escalas dentro das categorias, existe uma correlação forte entre as médias das escalas (Tabela 160). O OHQ mostrou ter escore diferente apenas ao EGF para as três primeiras categorias de renda (Tabela 161). Esta Tabela possui o primeiro campo, onde não há especificação de renda, e é referente a 6 pesquisados que não responderam quanto à classificação de sua renda familiar. 


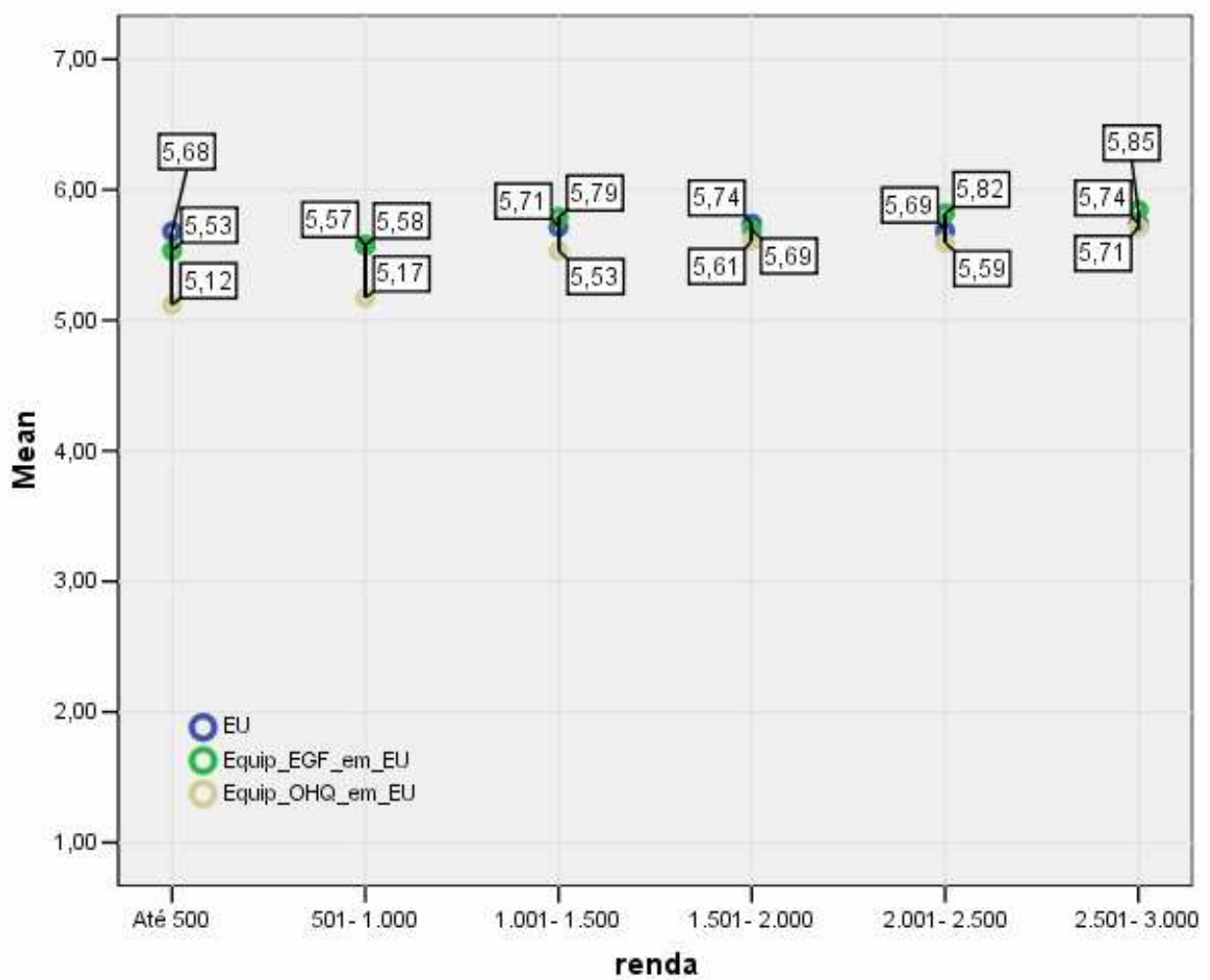

Gráfico 35- Escores médios equiparados de felicidade para níveis de renda.

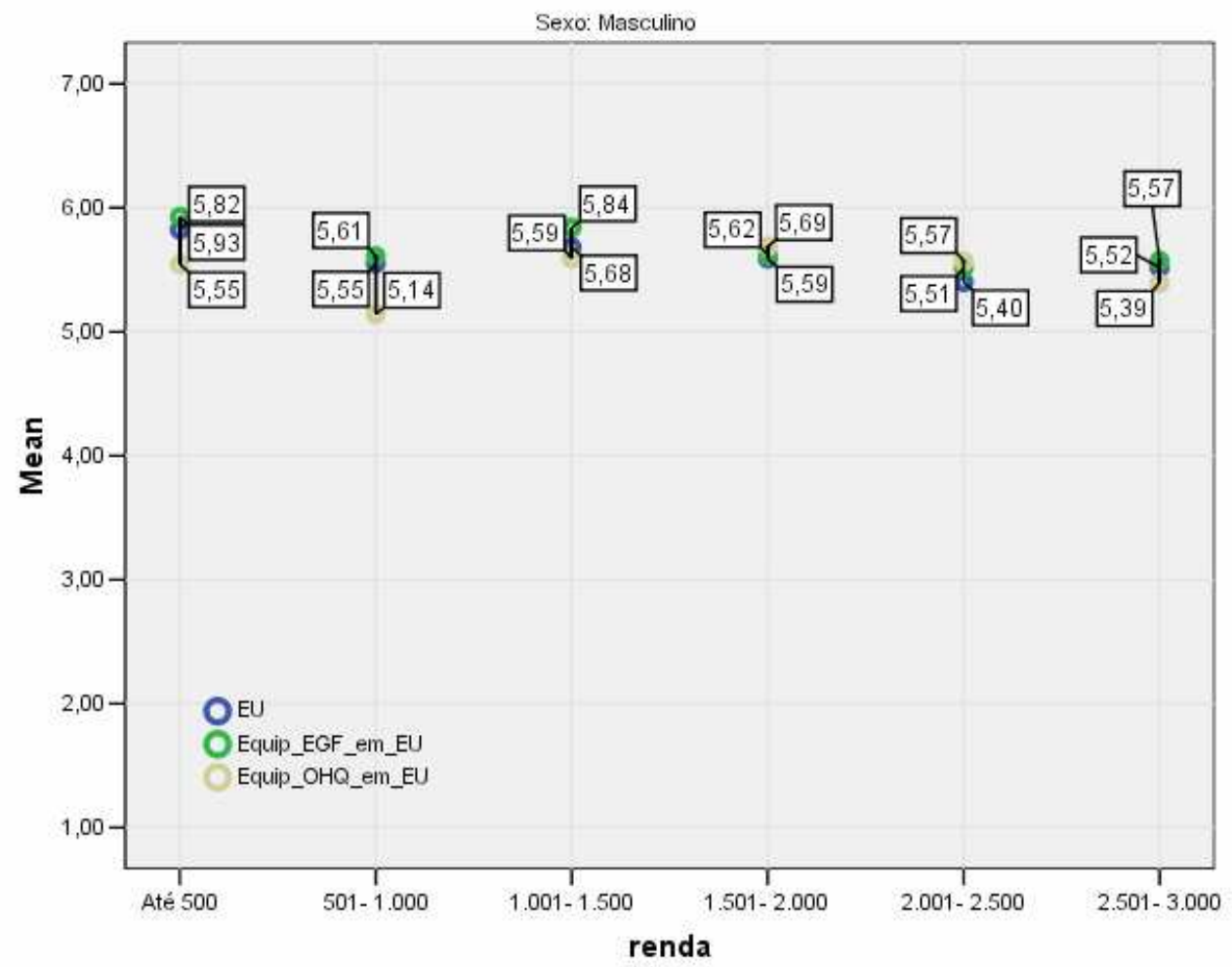

Gráfico 36- Escores médio equiparados de felicidade para níveis de renda - homens 


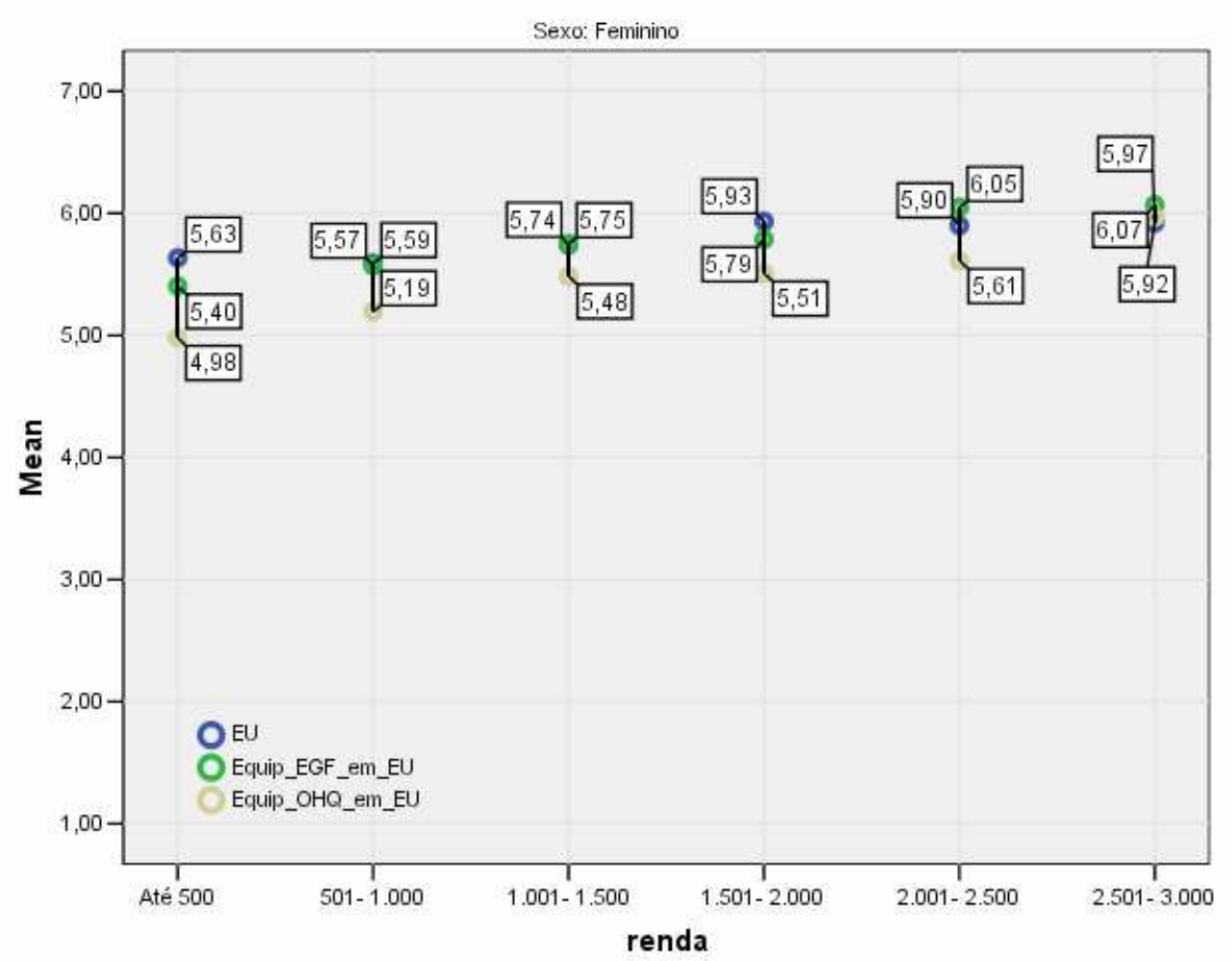

Gráfico 37- Escores médio equiparados de felicidade para níveis de renda- mulheres

Através da imprensa escrita e falada, é notória a diferença salarial entre homens e mulheres no Brasil, nos dias de hoje, o que pode causar impacto no nível de satisfação dos indivíduos. Os Gráficos 36 e 37 apresentam os escores para homens e mulheres, em cada nível de renda, e a Tabela 162 (Apêndices) mostra que para os homens não existe diferença entre os escores apresentados, porém para as mulheres há significância na escala OHQ, onde os níveis inferiores de renda apresentam menor escore de felicidade. Ao avaliarmos o desempenho das três escalas, dentro das categorias (Tabela 163), houve diferença entre o OHQ e a EGF entre os homens, com renda familiar até 500,00. Essa mesma diferença foi registrada para mulheres com renda familiar até 500, entre 501 e 1.000 e 2.001 e 2.500 reais. Nestes casos, pode-se verificar, no Gráfico 37 que os escores equiparados para o OHQ estão em níveis menores.

Existe correlação significativa entre nível de renda e escolaridade, tanto apontada pela literatura quanto encontrado neste trabalho $(r=0,304)$. Isto mostra a importância em 
investigar o desempenho do BES, considerando o impacto que o nível de escolaridade possui no BES, segmentado pelas as faixas de renda. Isto porque, nesta pesquisa, temos pessoas com baixa escolaridade, com salários mais elevados e pessoas com nível superior, com baixos salários, devendo-se compreender a importância destas diferenças na felicidade registrada. Contudo a amostra de que dispomos não oferece uma distribuição conveniente (Tabela 165), pois existem várias categorias que possuem poucos respondentes, o que faz com que o intervalo de confiança se eleve a ponto de não oferecer significância estatística.

Frey \& Stutzer (2002) afirmam que, tanto através da regressão simples como múltipla, se obteve significância estatística para renda, considerando uma escala de um único item, mas com baixa explicação da variância. Ao se elevarem faixas de renda, os ganhos obtidos de felicidade são cada vez menores (Frey \& Stutzer, 2002). As pessoas com maiores rendas possuem melhores oportunidades de adquirir bens e serviços, além de terem maior status na sociedade, o que influencia a auto-estima (Frey \& Stutzer, 2002).

Para avaliar a relação entre as categorias de renda e o BES, regressões foram feitas para as escalas EU, EGF e OHQ (Tabela s 166 a 171), sendo as variáveis independentes o nível de renda, transformadas em dummies e o grupo critério a faixa salarial de até 500 reais. Somente o OHQ apresentou significância estatística em várias categorias de renda: entre 1.001 e 1.500 reais $(\beta=0,423)$, entre 1.501 e 2.000 reais $(\beta=0,502)$ e entre 2.501 e 3.00 reais $(\beta=0,602)$. Observa-se que em rendas maiores, o escore da regressão também se eleva, com explicação da variância de 3,2\%.

Frey e Stutzer (2002) afirmam que a renda possui correlação com a educação. E isto para este trabalho amostra foi obtido. A correlação entre renda e escolaridade foi de 0,30. Esta correlação exprime praticamente a mesma força existente filhos e estado civil $(-0,326)$ e há também relação direta entre renda e número de filhos $(0,109)$. Apesar de se esperar uma relação inversa, face às despesas domiciliares, esta relação não está no poder de compra, mas 
relaciona-se com a renda absoluta, pois, o aumento de número de filhos pode não somente representar despesas, mas excedente de mão de obra que reforça o orçamento doméstico.

\subsection{RELIGIÃO}

Myers (1992) afirma que as pessoas religiosas são mais felizes do que as não religiosas, independentemente de qual religião pratiquem, contudo Argyle (1987) sustenta ser este relacionamento fraco. As análises que seguem buscam identificar estas diferenças.

Nesta pesquisa foi avaliada a prática ou não de uma religião junto aos pesquisados, e procurou-se identificar qual religião seria o pesquisado adepto. Inicialmente, investigaram-se as diferenças entre aqueles que possuem, ou não, religião. Entre os pesquisados, $78,1 \%$ afirmam praticar alguma religião, enquanto $21,9 \%$ não o fazem. O Gráfico 38 mostra os escores para as escalas consideradas, e a Tabela 172 (Apêndices) apresenta o teste de médias. A escala EGF apresentou diferenças entre os seus escores, o que leva a considerar que aqueles que não são praticantes de alguma religião, possuem menor nível de felicidade, nesta escala.

Quanto ao desempenho das escalas, nestas categorias, a EU e EGF apresentaram igualdade para os dois casos, porém o escore no OHQ mostrou ser diferente das duas escalas para os praticantes de religião e diferente apenas da EGF, para os não praticantes. Isto representa que, na primeira categoria, a escala apresenta escore menor do que as outras duas (Tabela s 173 e 174, em Apêndices). 


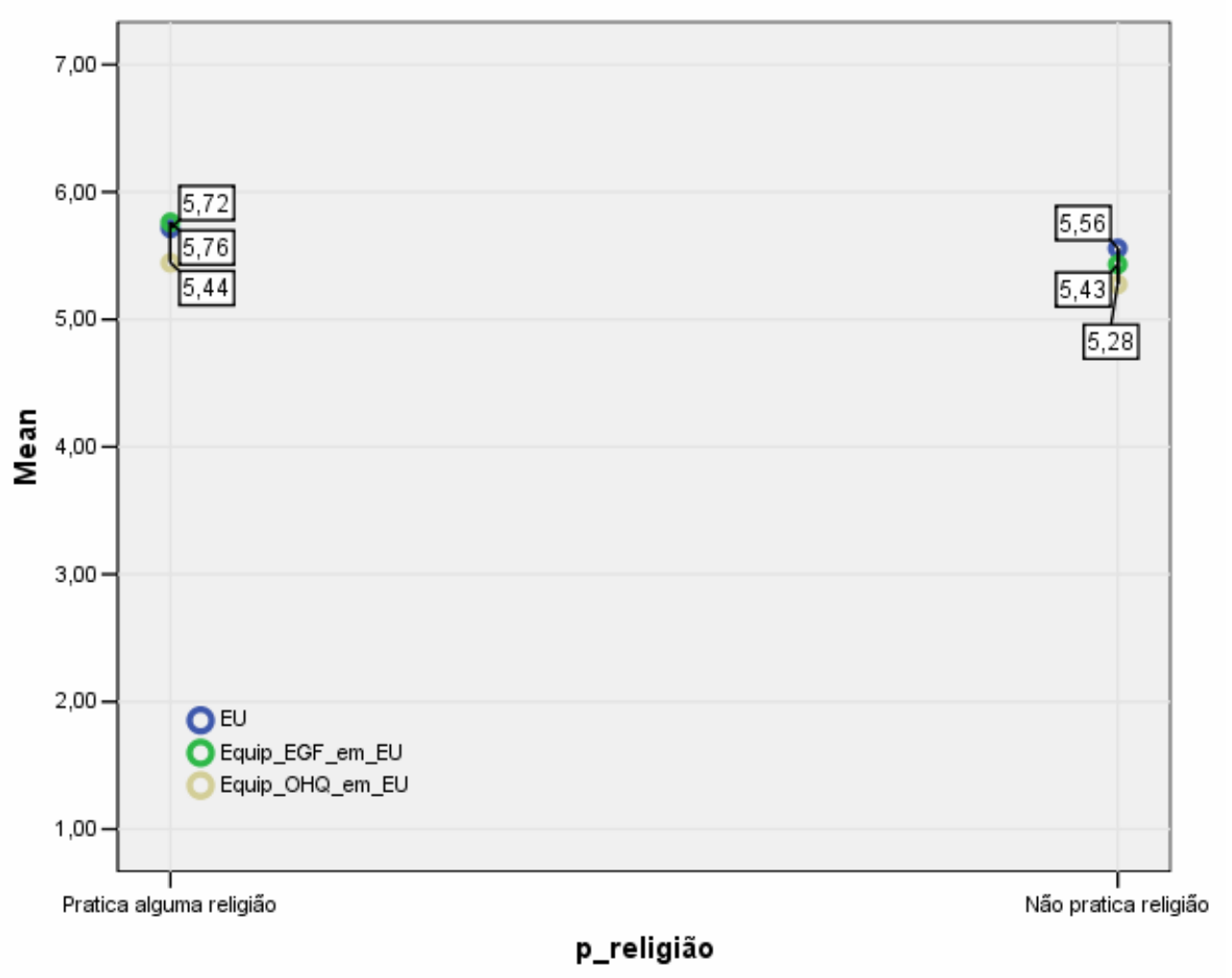

Gráfico 38- Escores médios equiparados de os praticantes e não praticantes de religião

Para Frey e Stutzer (2002), a crença religiosa e felicidade são positivamente relacionadas, porém não de maneira tão extensa. Considerando que o afeto positivo é um importante integrante do bem-estar subjetivo, Fredrickson (2003) afirma que o afeto positivo leva à gratidão, portanto, podemos concluir que pessoas felizes são mais gratas, inclusive a Deus. Para investigar esta relação causal entre a prática religiosa, regressões foram realizadas tendo como variável dependente os escores médio equiparados das escalas e independente as duas categorias de prática ou não de atividade religiosa, transformadas em variáveis dummies, sendo o critério adotado para os praticantes de religião (Tabelas 175 a 180, em Apêndices). Entre as análises feitas, somente para a EGF houve significância estatística e mostrou que a não-prática de religião $(\beta=-0,348)$ leva a menor nível de $\mathrm{BES}$, porem esta relação é muito pequena $\left(R^{2}=0,011\right)$, e, pesar da pouca explicação, o resultado mostra convergência com a literatura, considerada a escala OHQ. 
O tipo de religião faz alguma diferença? Ser católico oferece uma possibilidade maior de ser feliz do que ser espírita? O Gráfico 39 mostra os escores obtidos para os tipos de religiões considerados na pesquisa, que representam variações de uma média similar (Tabela 181, Apêndices). Portanto, não há diferenças entre níveis de BES entre as denominações religiosas da amostra.

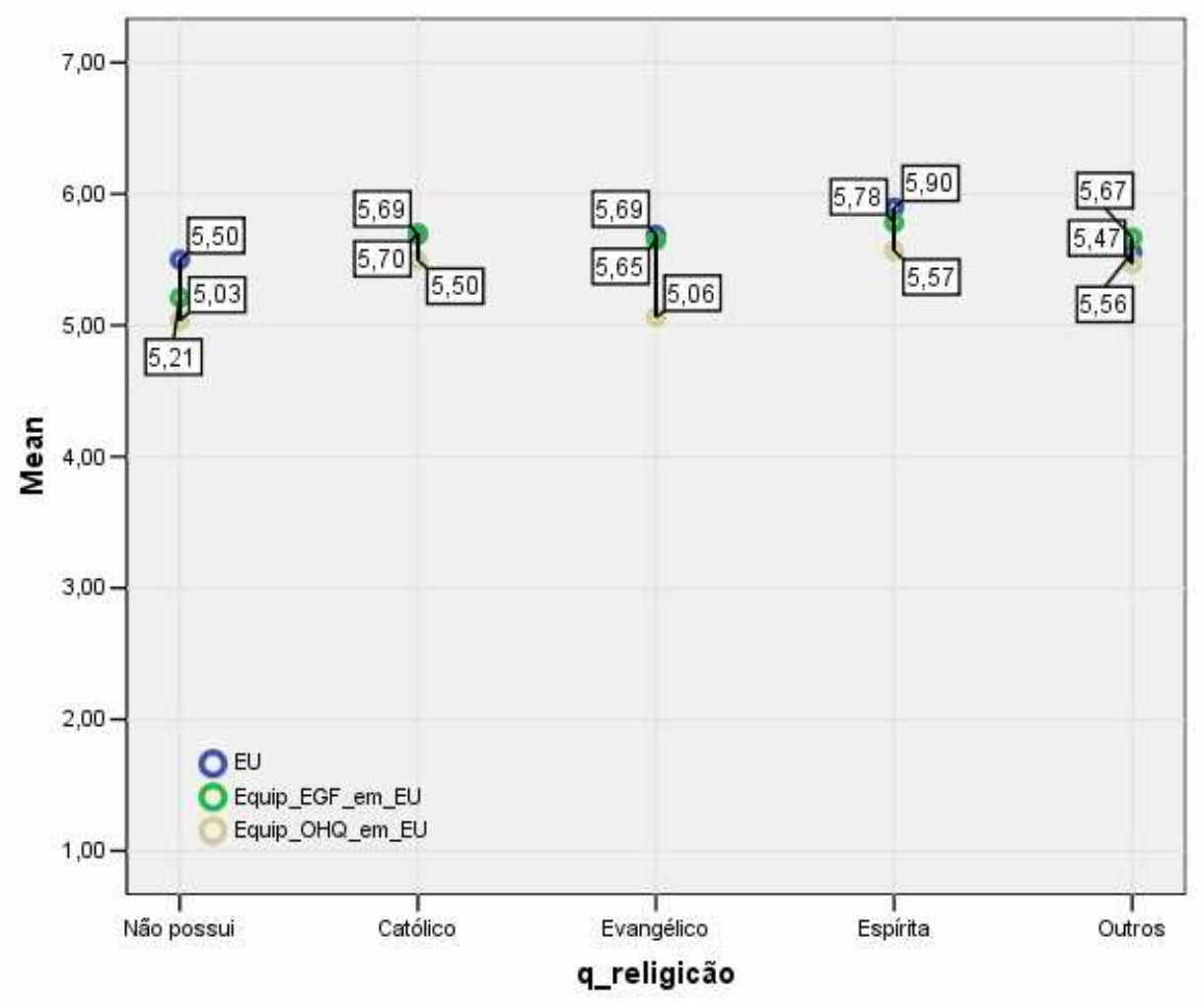

Gráfico 39- Escores médios equiparados para tipos de religião

O sexo possui diferenciação entre o bem-estar gerado pela prática religiosa? As pessoas mais idosas encontram na religião melhor BES? Para os homens na escala EGF foi obtida a significância estatística (Tabela 182) e no Gráfico 40 mostra que aqueles que não praticam algum tipo de religião, possuem menor BES. Quanto às mulheres, elas não apresentaram diferenças em seus escores.

Para a análise das faixas etárias, o teste de homogeneidade da variância foi significativo para a escala EU (Tabela 183), sendo feito o teste não paramétrico para análise das médias. Como resultado, tanto da ANOVA como o do Kruskal-Wallis apresentou-se igualdade de médias. 


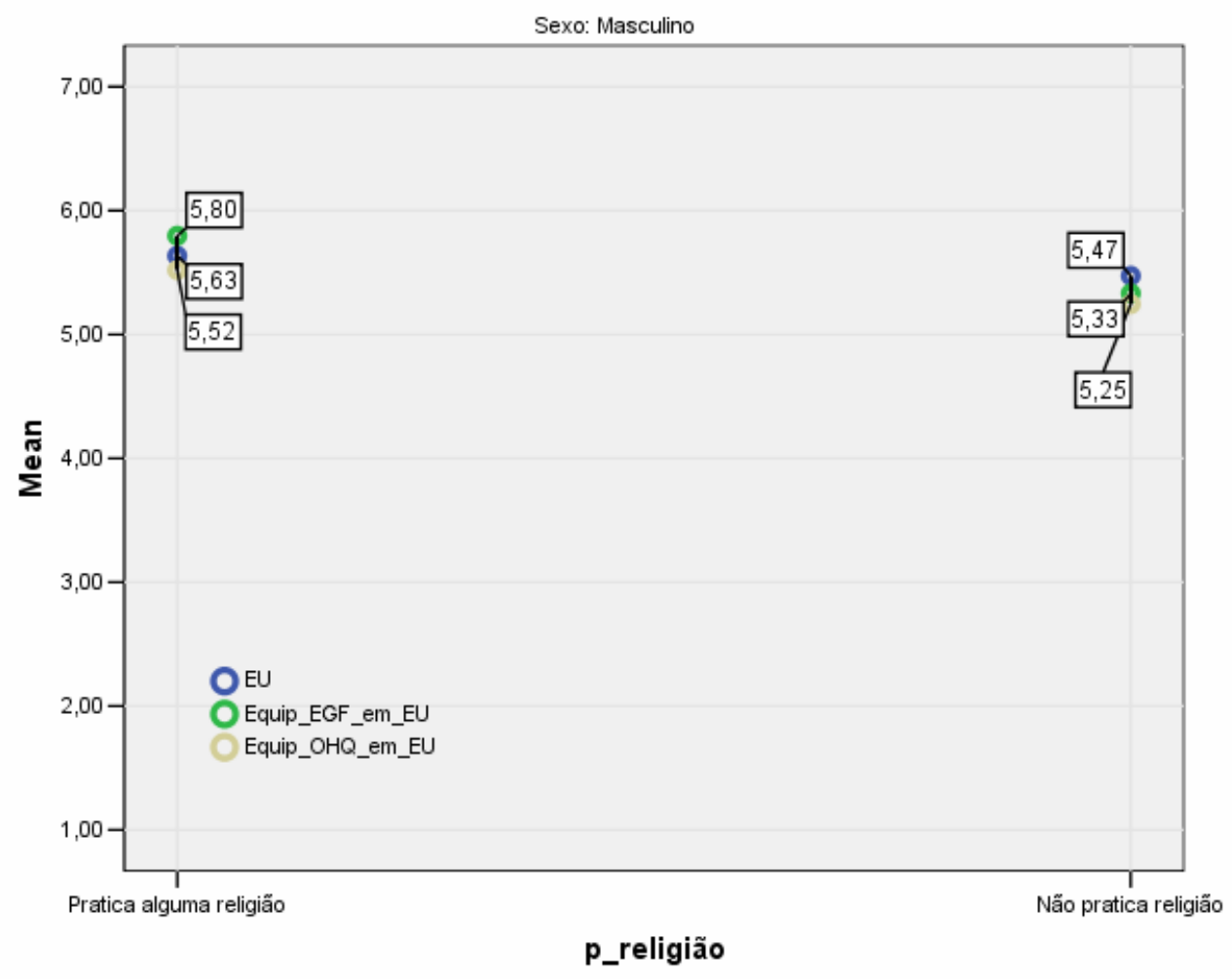

Gráfico 40- Escores médios equiparados praticantes e não praticantes de religião - homens

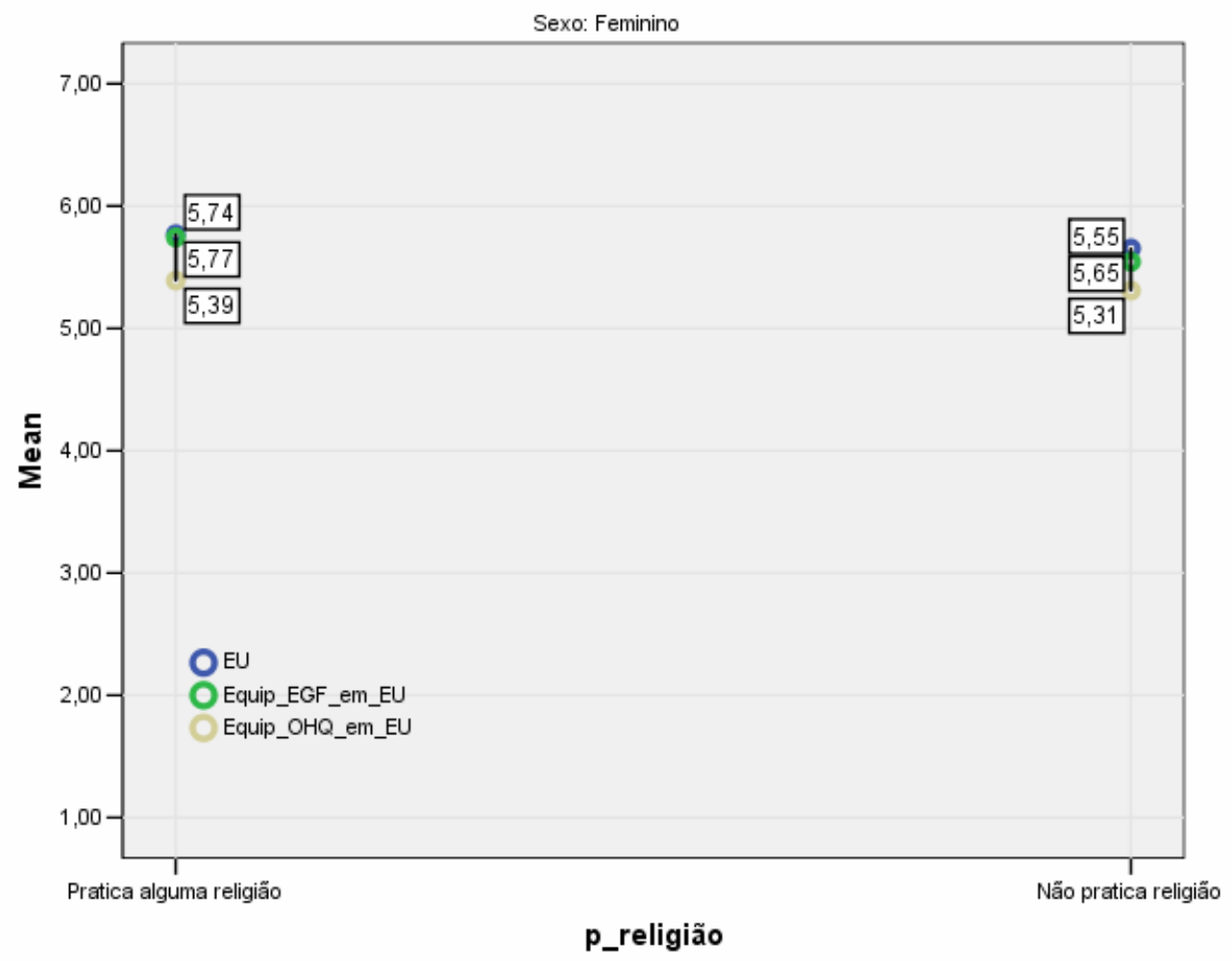

Gráfico 41- Escores médios equiparados praticantes e não praticantes de religião - mulheres 


\subsection{ATIVIDADE SÓCIO POLÍTICA}

As variáveis econômicas, como o desemprego e a inflação, relacionam-se com a saúde mental e o bem-estar geral das pessoas (Frey \& Stutzer, 2000). Frey \& Stutzer (2004) afirmam que a participação no processo político, através da atividade democrática, fornece ao indivíduo a percepção de estar contribuindo ao contexto político. A distribuição de renda causa impacto na igualdade social e econômica, o que conduz a percepção de uma sociedade mais justa e leva as pessoas a terem maior satisfação com suas vidas (O’Connell, 2003). Neste contexto, em que o melhor desempenho político, econômico e social proporciona melhores condições de vida às pessoas, esta consciência pode motivar os indivíduos a atuarem em organizações sócio-políticas, quer seja através de mecanismos partidários, ou instituições nãogovernamentais, e daí obterem níveis diferenciados de satisfação.

Do total dos respondentes, 17 indivíduos apenas responderam exercerem alguma atividade sócio política. Isto significa 3,6\% da amostra, em que grande parte está acima do terceiro grau (Tabela 187). Em uma consideração particular, esta pequena atuação dos pesquisados (considerando-se a amostra e não sendo realizados os cálculos para inferência populacional) pode indicar o caminho da raiz de alguns problemas sociais e políticos, fundamentados em uma omissão junto ao cotidiano, das decisões políticas, além da distância de trabalhos sociais de poderiam minimizar condições adversas em, uma sociedade distorcida como a nossa.

Nos escores apresentados na figura a seguir (Gráfico 42), as médias para os praticantes de atividades sócio políticas são maiores do que os que não atuam em nenhum campo, porém quando consideramos as diferenças entre as médias no teste estatístico (Tabela 186), não existem diferenças entre os sujeitos avaliados. 


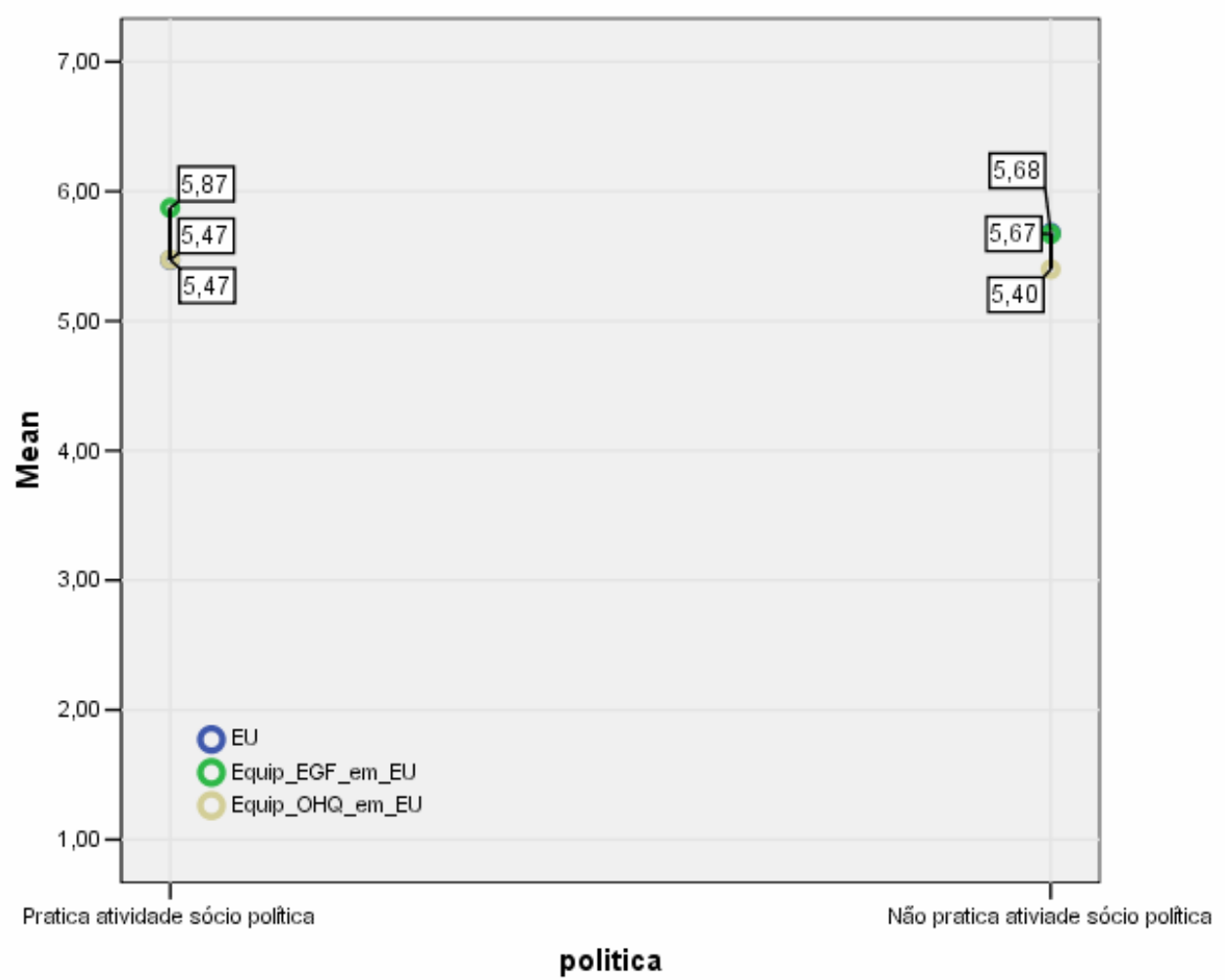

Gráfico 42- Escores médios equiparados para praticantes e não praticantes de atividades sócio políticas

\subsection{SAÚDE}

As auto-avaliações de saúde e felicidade estão bem correlacionadas (Frey \& Stutzer, 2002). Diversos estudos citados em Diener \& Seligman (2004) mostram que, ante a doença, as pessoas não conseguem invariavelmente adaptar-se e indivíduos, com problemas sérios de saúde, como doenças do coração, possuem seu nível de BES diminuído em 1 ano. Portanto, este é um importante fator a ser considerado no estudo.

O questionário possui, em sua parte inicial, diversos tipos de classificação de doenças, na qual o pesquisado se classifica como portador ou não de determinado mal. A partir daí, foi criada uma variável com duas categorias, na qual aqueles que responderam possuir ao menos um problema de saúde foram classificados na categoria Apresentam algum problema de saúde; enquanto que aqueles que não se avaliaram como doentes integram a categoria Boa saúde. Na amostra, 15,5\% dos pesquisados manifestaram possuir algum problema de saúde. 


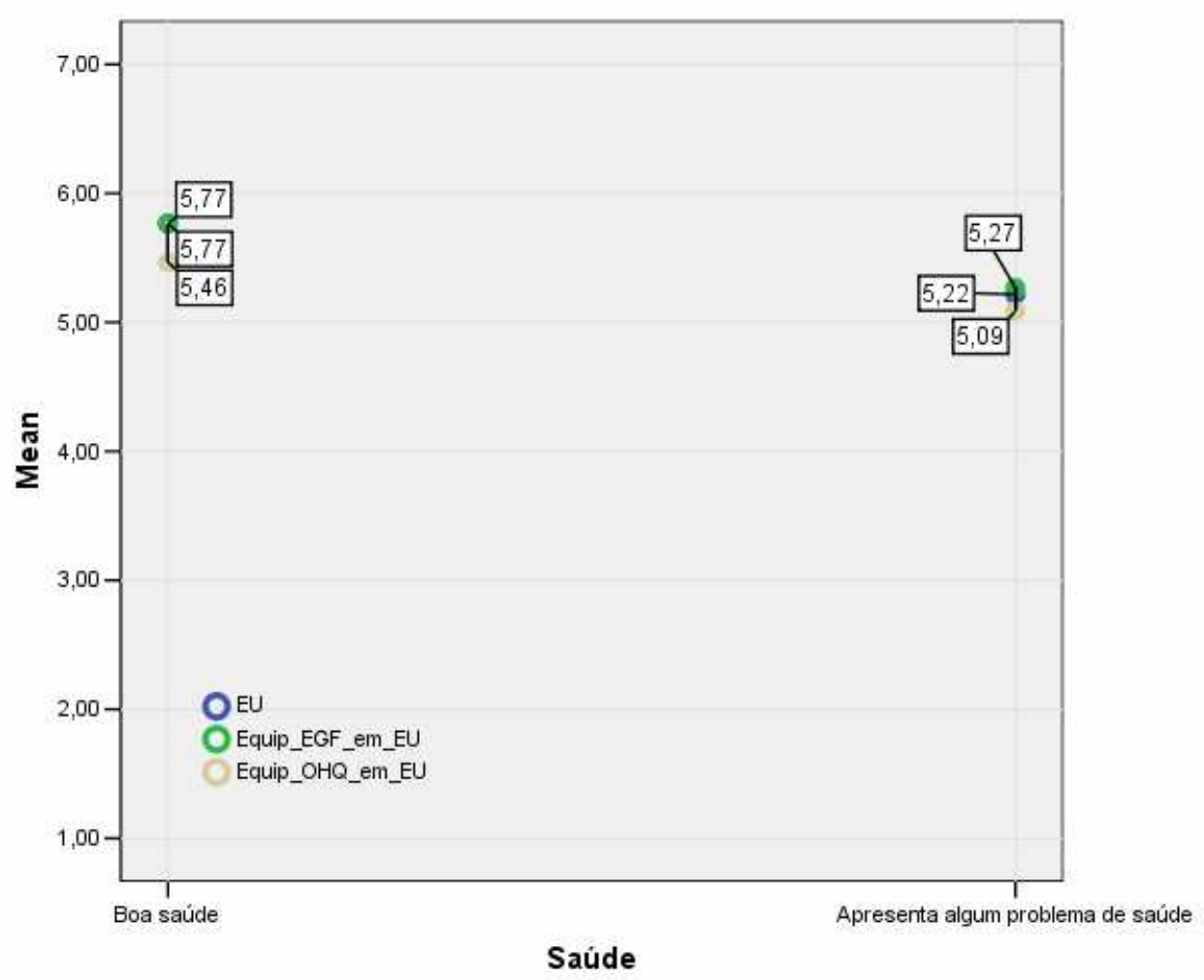

Gráfico 43- Escores médios equiparados para saúde

Considerando os escores de pessoas com boa saúde e pessoas com algum problema, para as três escalas, houve significância estatística quanto à diferença de médias (Tabela 188). Isto quer dizer que, nas três medidas, aqueles que possuem problemas de saúde são menos felizes do que os que não apresentam.

Para melhor compreensão desta relação, a variável descrita com duas categorias foi transformada em dicotômica para ser submetida à regressão como variável independente, sendo o critério adotado a categoria em que os indivíduos apresentam algum problema de saúde. As Tabelas 189 a 194 (Apêndices) mostraram esta relação para todas as escalas, cujos escores são mostrados para os indivíduos com saúde; para a $\mathrm{EU}, \beta=0,553$ e $R^{2}=0,022$, para a EGF, $\beta=0,524$ e $R^{2}=0,020$ e para o OHQ, $\beta=0,391$ e $R^{2}=0,012$. 


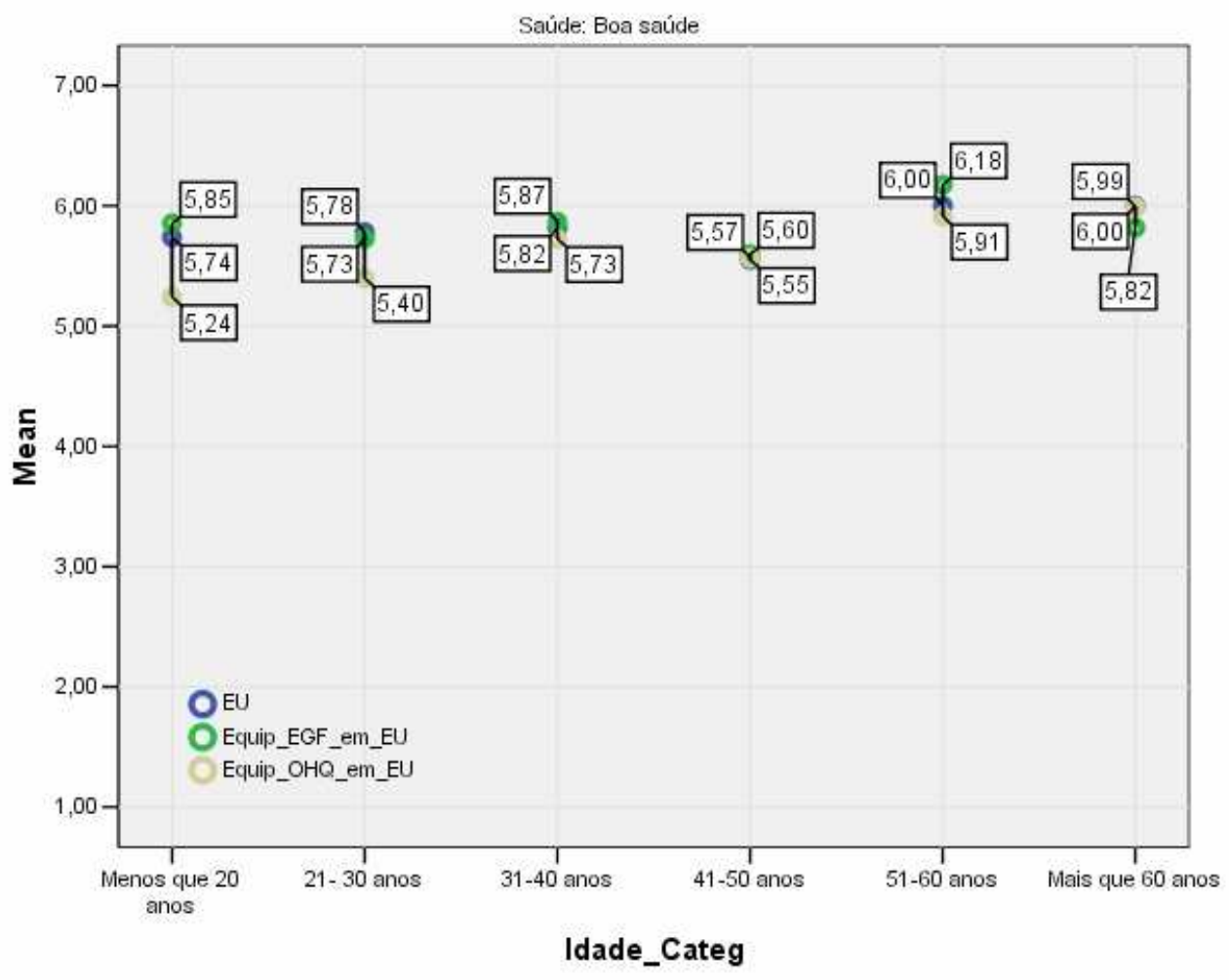

Gráfico 44- Escores médios equiparados indivíduos boa saúde separados por idades

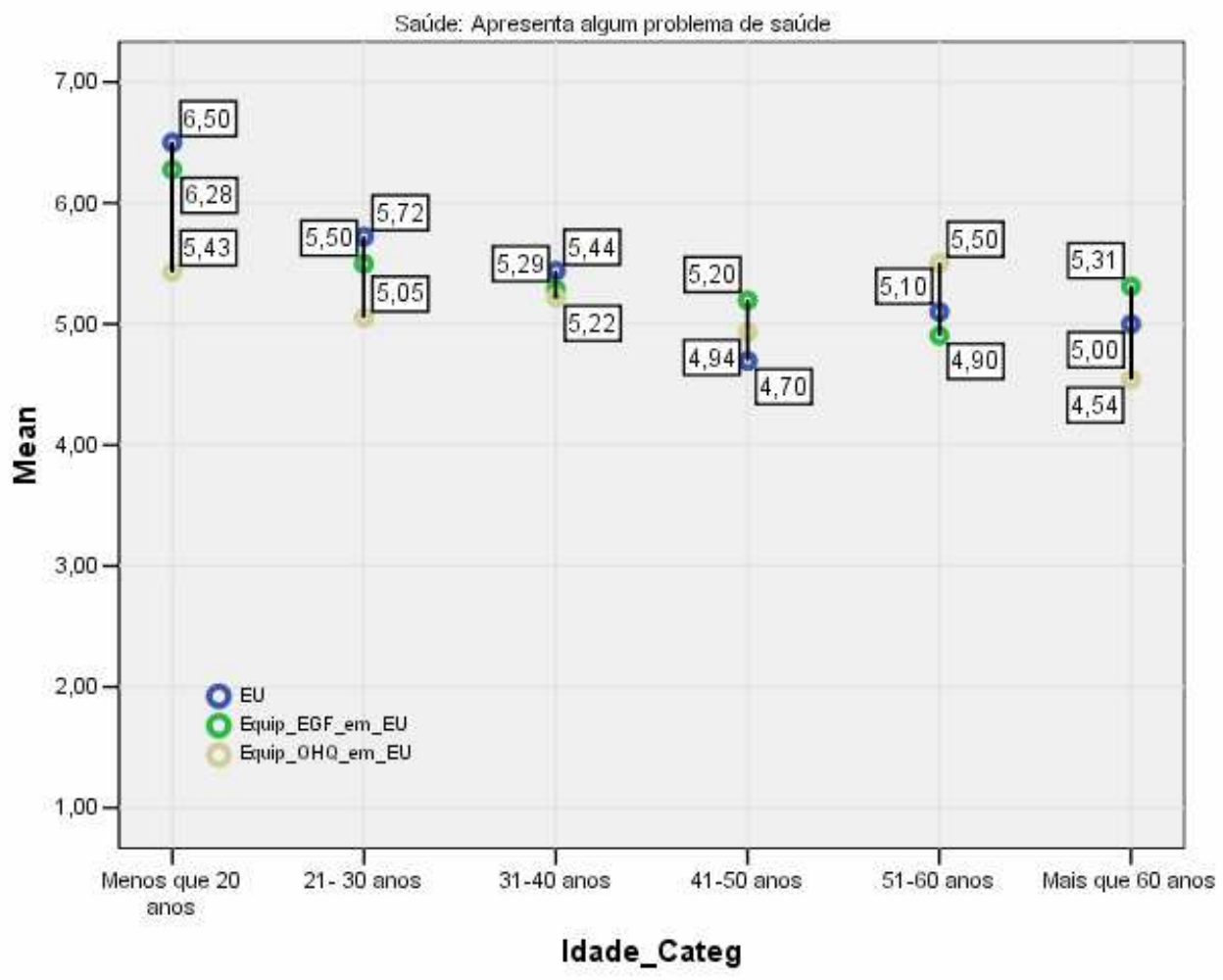

Gráfico 45- Escores médios equiparados indivíduos que apresentam algum problema de saúde separado por idades 
Para Argyle (1984), esta relação é, particularmente, mais forte em pessoas idosas. Ao compararmos os Gráficos 44 e 45, o segundo, que representa as médias para pessoas que não se classificaram com boa saúde, mostra nas faixas etárias mais elevadas menores escores de BES.

Apesar das diferenças visuais, o resultado mostrou a não existência de diferenças entre as médias (Tabela 195). Esta, porém, é uma tentativa de avaliar a convergência dos dados obtidos com a teoria, mas as limitações do trabalho devem ser observadas, pois as faixas etárias mais elevadas, cujos indivíduos possuem mais de 60 anos, há poucos pesquisados: apenas 4 representantes para os saudáveis e 3 para aqueles que apresentam algum problema de saúde.

A definição de saúde, empregada por Argyle (1987), proveniente da Organização Mundial de Saúde, é "um estado de bem-estar físico, social, e mental e não apenas a ausência de doenças" (pg. 177). Assim, atitudes saudáveis como práticas desportivas podem ter relações com o BES.

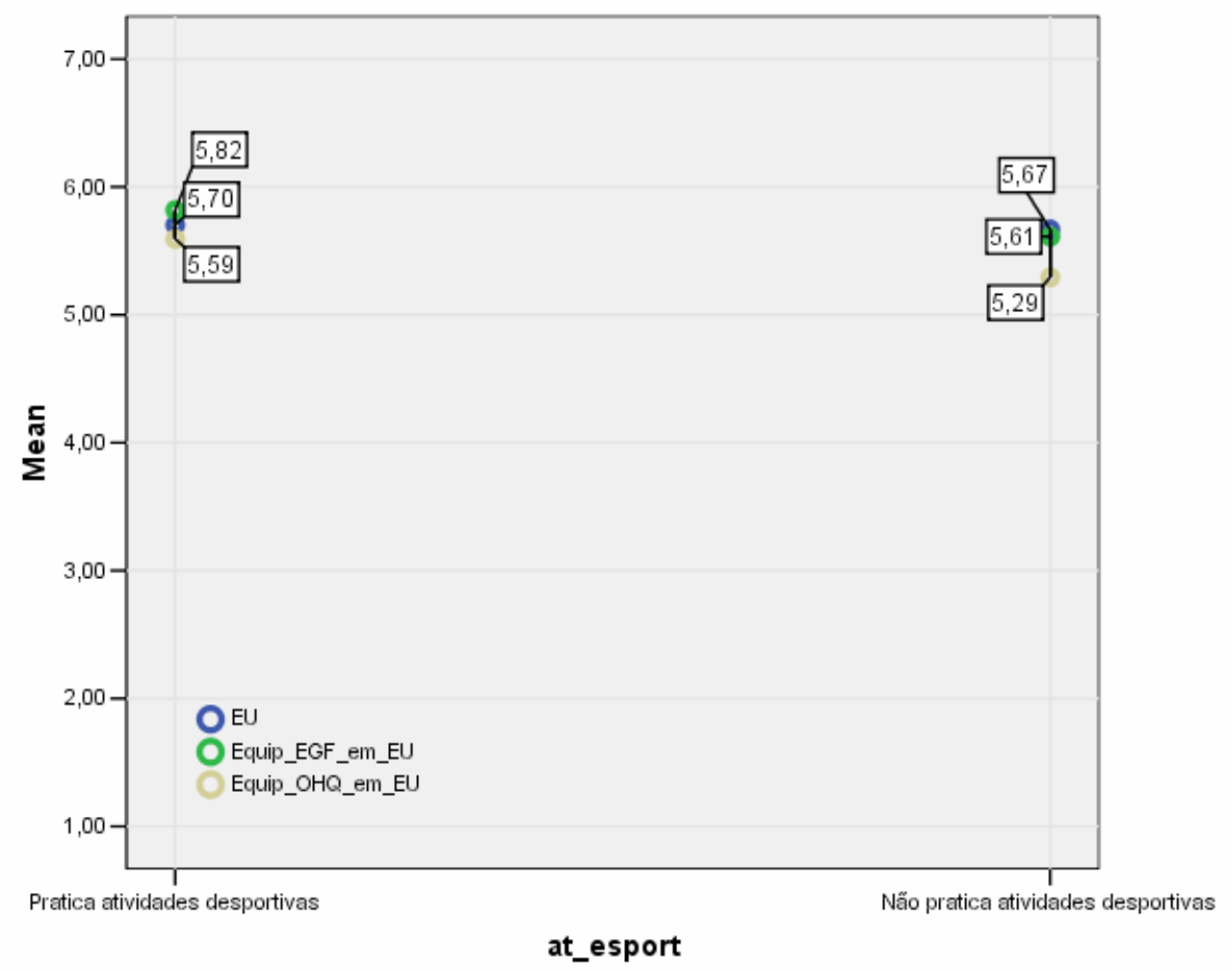

Gráfico 46- Escores médios equiparados separado por práticas desportivas 
Entre as escalas avaliadas, o questionário OHQ apresentou diferenças em seus escores (Tabela 197), através do teste de médias entre os praticantes e não praticantes de atividades físicas, onde estes últimos possuem níveis inferiores de BES. Quanto à prática ou não do tabagismo, entre os pesquisados não houve diferença nos escores médios de BES (Tabela 198, Apêndice). 


\section{1- AS PESQUISAS SOBRE BES NO BRASIL}

O tema Felicidade, como estudo científico, no escopo fornecido pela psicologia positiva é algo novo no país. Nos indexadores de periódicos, não houve grande número de pesquisas publicadas sobre o assunto, porém, se nos voltarmos para a maravilha que a rede mundial tem oferecido à comunidade científica, através da diminuição das distâncias e do volume de informações, já existem sites em comunidade de relacionamento, especificamente no Orkut, nos quais a psicologia positiva já possui adeptos em várias áreas, quer seja da psicologia, administração, sociologia, educação física, entre outros. Este é um relato informal, de contatos com outros pesquisadores que desenvolvem trabalhos, em diversas universidades espalhadas pelo país. Caso se confirme toda esta produção, em um futuro próximo, poderemos contar com um volume muito maior de trabalhos publicados. Entre os trabalhos encontrados, seguem alguns exemplos do que está sendo produzido no país em relação ao tema.

Queiroz \& Néri (2005) se fundamentam na diferenciação de bem-estar subjetivo e bem-estar psicológico, como construtos relacionados, mas empiricamente separados, e realizam um trabalho comparativo deste último com inteligência emocional. As escalas utilizadas consistem no instrumento de avaliação de inteligência emocional desenvolvido por Siqueira, Barbosa e Alves (1999), citado no artigo referido anteriormente, e a escala de Desenvolvimento Pessoal, construída por Neri (1995), também referenciada neste mesmo artigo. O trabalho não encontrou correlação entre os dois construtos, porém houve relação entre alguns de seus fatores.

Dela Coleta \& Dela Coleta (2005) desenvolveram o trabalho de avaliação do BES com dois tipos de análise: a primeira, através de escalas derivadas de alguns instrumentos de mensuração de BES e informações de dados pessoais do entrevistado, seus hábitos, preferências e expectativas; e o segundo tipo foi a utilização de uma pergunta aberta: "Para 
você, o que é uma vida boa?” (pg. 536). Entre outras análises, através desta resposta espontânea, foi possível realizar um ordenamento de importância do que os pesquisados entendem por uma vida boa e como resultado, a saúde, harmonia / paz e amizade tiveram as maiores freqüências.

No esteio de estudos internacionais, Corbi e Menezes Filho (2006) realizaram investigação alinhada ao enfoque econômico do bem-estar subjetivo, ou felicidade, a partir dos dados disponíveis na Pesquisa Mundial de Valores (World Value Survey), que consiste em uma pesquisa mundial, quanto a mudanças sócio-culturais, políticas e econômicas, sobre as convicções e valores dos indivíduos, realizadas em 65 países e com amostras acima de 1.000 pessoas. São utilizados os resultados dessas pesquisas no Brasil, comparativamente com dados de outros países, para investigar os correlatos econômicos com a felicidade nacional.

Em nosso estudo, verificamos que a ausência de saúde impacta negativamente no bem-estar subjetivo das pessoas. Seligman (2002) apresenta a relação entre a recuperação de pessoas portadoras de males cardíacos, com níveis elevados de BES. Rabelo \& Néri (2005) mostram que acidentes vasculares (AVC) trazem seqüelas que levam à dificuldade de reenquadramento dos indivíduos às suas atividades corriqueiras, decorrendo daí quadros de depressão e problemas de relacionamento social e abordam a importância do bem-estar subjetivo, neste processo de recuperação, e as poucas pesquisas relacionando os dois aspectos.

Jonathan (2005) conduziu um estudo com certa similaridade a este. Foi realizado na cidade do Rio de Janeiro pesquisa junto a 49 empresárias com o objetivo de relacionar o empreendedorismo feminino com avaliação de qualidade de vida. O método utilizado foi entrevista semi-estruturada e a aplicação do Inventário de Qualidade de Vida de Frisch (1992), citado no referido artigo. Concluiu-se que, a experiência empreendedora proporciona impacto na satisfação com a vida, pois deriva de um sentimento de auto-realização, que por sua vez possui impacto em sua auto-estima. 
Albuquerque \& Tróccoli (2004) realizaram a construção de uma escala de BES, motivados pela diversidade teórica e cultural existente na avaliação do construto, de maneira a buscar criar uma escala mais apropriada de mensuração, focada nas três dimensões conceituais: afeto positivo, afeto negativo e satisfação/ insatisfação com a vida. Esta escala apresenta 62 questões, sendo 47 de avaliação do balanço afetivo e 15 voltadas à satisfação com a vida. No artigo descrito, a análise fatorial resultou nos 3 fatores teóricos que compõem o BES e explicação da variância de $44 \%$. 


\section{2- CONCLUSÃO}

O trabalho realizado mostra a importância do BES, enquanto característica individual, que oferece uma medida de desempenho social e profissional das pessoas; e também como uma característica coletiva, que de forma agregada está inserida no que recentes pesquisadores denominam de capital psicológico (Luthans e colaboradores, 2007). Dito de outra forma, o quão bem as pessoas se sentem irá influenciar em condutas e relacionamentos, construindo a qualidade deste tecido social.

Em uma visão geral do trabalho, os dois objetivos que constituem o propósito da pesquisa, limitados ao contexto da amostra, foram delineados ao longo do texto, descritos e agora sintetizados nos aspectos mais relevantes e observados em suas particularidades.

O OHQ apresentou quantidade de correlações dois a dois entre os itens menores do que seria necessário para apresentar uma estrutura fatorial robusta e estável, de forma a manter-se mais íntegra no arranjo das variáveis, ante as filtragens realizadas, porém a quantidade de fatores manteve-se relativamente estável. A capacidade de mensuração desta escala foi atestada, pois se mostrou eficaz em discriminar grupos, mediante teste de médias feito $^{7}$, contudo estas medidas se mostraram diferenciado em alguns aspectos das outras duas escalas utilizadas, observado o teste de médias junto aos escores equiparados. Kashdan (2004) menciona que a estrutura da escala está mais voltada à mensuração de aspectos de alto-estima e senso de propósito, e, tendo em vista as significâncias obtidas em avaliações de renda, que, por sua vez, possuem correlações teóricas com auto-estima (Cummins, 2000), esta observação do autor, por uma relação indireta, pode se enquadrar neste trabalho. Na maioria das análises, o OHQ mostrou acompanhar os resultados das duas outras escalas, mas, em algumas situações (como renda), apresentou poder discriminar indivíduos onde os outros dois testes não conseguiram. Isto pode não ser um aspecto muito positivo, pois, conforme Kashdan

\footnotetext{
${ }^{7}$ Considerado o a juste realizado na escala, que foi a eliminação do item 25 .
} 
(2004) menciona, é possível originarem-se correlações espúrias. Portanto, os resultados quanto às diferenças individuais, a seguir sintetizados, podem estar mais carregados na avaliação de determinados aspectos do bem-estar subjetivo, no que tange ao OHQ, que leva à necessidade de melhor compreensão das relações encontradas. Em contrapartida, diversos aspectos encontram lastro em pesquisas internacionais, conforme demonstrado.

A EGF é também rapidamente avaliada em Kashdan (2004), que, em estudo de multicolineariedade, mostra menor correlação com auto-estima e senso de propósito do que a escala OHQ. Porém, esta escala também possui fragilidades, como a baixa consistência interna do questionário e o valor de comunalidade próximo ao limite de corte. Certamente estes pontos de melhorias serão observados em trabalhos futuros, mas apesar deles, foi um questionário capaz de identificar grupos distintos e, conforme mencionado para o OHQ, alinhado com parte dos resultados obtidos nas análises sócio demográficas, a ponto de encontrar apoio na literatura internacional, em alguns de seus achados.

Em termos comparativos, as três escalas mostraram-se relativamente semelhantes nas conduções das mensurações, porém, em alguns casos, para determinadas categorias, houve diferenças entre as medidas apresentadas pelas três escalas. Na maioria das vezes era o OHQ que se diferenciava das outras duas, o que leva a crer que a EGF está mais próxima a EU em termos de mensuração do que ao OHQ. Apesar de as três escalas terem boas correlações, a literatura mostra que as correlações de instrumentos de múltiplos itens (ex: EGF e OHQ) com instrumentos de item único (ex: EU), estão entre 0,73 a 0,89 (Diener e colaboradores, 1997), valores maiores do que aqueles obtidos por esta pesquisa, que foram de 0,556 e 0,635, sendo o menor valor para o OHQ.

Não existe um sistema-padrão de mensuração de BES e diferentes escalas são construídas sobre diferentes conceitos (Argyle, 1989) e a operacionalização, em termos de medida dos conceitos do BES, é ainda confusa e deturpada (Albuquerque \& Tróccoli 2004). 
As análises sócio-demográficas realizadas podem ser sintetizadas no quadro a seguir, onde estão relacionadas todas as características que se mostraram significativas nas regressões feitas.

Tabela 33 - Síntese dos resultados

\begin{tabular}{|c|c|c|c|c|}
\hline Característica & $\begin{array}{c}\text { Escala de } \\
\text { Significância }\end{array}$ & $\begin{array}{l}\text { Coeficiente de } \\
\text { regressão }\end{array}$ & $R^{2}$ & $\begin{array}{l}\text { Explicação da } \\
\text { Variância }\end{array}$ \\
\hline Idade entre 41 e 50 anos & EU & $-0,480$ & 0,015 & $1,50 \%$ \\
\hline Homens entre 41 e 50 anos & EU & $-0,848$ & 0,023 & $2,30 \%$ \\
\hline Mulheres entre 21 a 30 anos & \multirow{2}{*}{$\mathrm{OHQ}$} & 0,448 & \multirow{2}{*}{0,027} & \multirow{2}{*}{$2,70 \%$} \\
\hline Mulheres entre 51 a 60 anos & & 1,019 & & \\
\hline Mulheres brancas & EU & 0,295 & 0,012 & $1,20 \%$ \\
\hline Mulheres negras & EGF & $-1,565$ & 0,371 & $37,10 \%$ \\
\hline Brancos entre 41 e 50 anos & EU & $-0,698$ & 0,038 & $3,80 \%$ \\
\hline Pardos entre 21 e 30 anos & \multirow{3}{*}{$\mathrm{OHQ}$} & 0,820 & \multirow{3}{*}{0,10} & \multirow{3}{*}{$10,00 \%$} \\
\hline Pardos entre 31 e 40 anos & & 1,022 & & \\
\hline Pardos entre 41 e 50 anos & & 1,052 & & \\
\hline Pardos com renda entre 1.5001 e 2.000 & \multirow{2}{*}{$\mathrm{OHQ}$} & 1,252 & 0,143 & $14,30 \%$ \\
\hline Brancos com renda entre 2.501 e 3.000 & & 0,570 & 0,010 & $1,00 \%$ \\
\hline Homem viúvo & \multirow{2}{*}{ EU } & $-1,663$ & 0,036 & $3,60 \%$ \\
\hline Mulher viúva & & $-1,325$ & 0,056 & $5,60 \%$ \\
\hline \multirow{3}{*}{ Mulheres casadas } & EU & 0,439 & 0,056 & $5,60 \%$ \\
\hline & EGF & 0,446 & 0,037 & $3,70 \%$ \\
\hline & $\mathrm{OHQ}$ & 0,453 & 0,035 & $3,50 \%$ \\
\hline Casados entre 41 a 50 anos & EU & $-0,671$ & 0,057 & $5,7 \%$ \\
\hline Casados abaixo de 20 anos & EGF & 1.117 & 0,06 & $6,0 \%$ \\
\hline Segundo grau completo & \multirow{3}{*}{$\mathrm{OHQ}$} & 0,691 & \multirow{3}{*}{0,032} & \multirow{3}{*}{$3,20 \%$} \\
\hline Terceiro grau incompleto & & 0,893 & & \\
\hline Terceiro grau completo & & 0,895 & & \\
\hline Mulheres com terceiro grau completo & EU & 0,709 & 0,021 & $2,10 \%$ \\
\hline Mulheres com o segundo grau completo & \multirow{3}{*}{$\mathrm{OHQ}$} & 0,761 & \multirow{3}{*}{0,065} & \multirow{3}{*}{$6,50 \%$} \\
\hline Mulheres com o terceiro grau incompleto & & 1,029 & & \\
\hline Mulheres com terceiro grau completo & & 0,916 & & \\
\hline Renda entre 1.001 e 1.500 reais & \multirow{3}{*}{$\mathrm{OHQ}$} & 0,423 & \multirow{3}{*}{0,032} & \multirow{3}{*}{$3,20 \%$} \\
\hline Renda entre 1.501 e 2.000 reais & & 0,502 & & \\
\hline Renda entre 2.501 e 3.000 reais & & 0.602 & & \\
\hline Não pratica de religião & $\mathrm{OHQ}$ & $-0,348$ & 0,011 & $1,10 \%$ \\
\hline Brancos com Segundo Grau Completo & \multirow{3}{*}{$\mathrm{OHQ}$} & 0,732 & \multirow{3}{*}{0,029} & \multirow{3}{*}{$2,9 \%$} \\
\hline Brancos com Terceiro Grau Incompleto & & 0,975 & & \\
\hline Brancos com Terceiro Grau Completo & & 0,846 & & \\
\hline \multirow{3}{*}{ Boa saúde } & EU & 0,553 & 0,022 & $2,20 \%$ \\
\hline & EGF & 0,524 & 0,020 & $2,00 \%$ \\
\hline & $\mathrm{OHQ}$ & 0,391 & 0,012 & $1,20 \%$ \\
\hline
\end{tabular}


As mulheres mostram poder extrair BES ligeiramente maior, em algumas situações, como o casamento e níveis com maiores níveis de educação. Em relação ao casamento, este foi uma das duas únicas características avaliadas em que as três escalas manifestaram-se significantes de forma uníssona. A segunda foi boa saúde. Estas características estão mais sob o nosso domínio, assim como a prática de uma atividade religiosa. Mesmo que os escores de explicação da variância sejam baixos, podemos refletir que uma vida saudável, com boa educação escolar e um casamento realizador pode vir elevar os níveis de felicidade a um patamar que, segundo pesquisas citadas anteriormente, é estável e para onde caminha o indivíduo, após um período de adaptação. Em outras palavras, teríamos pequenos ganhos reais de felicidade.

Algumas dessas características estão fora de nosso controle, como o avançar da idade, etnia, viuvez e até mesmo renda, pois valores maiores de remuneração estão ligados a inúmeras variáveis que estão muito além da particular compreensão deste trabalho, desde fatores macro e microeconômicos até características inerentes ao indivíduo. Em algumas circunstâncias, foram detectados impactos negativos destas características no BES, como para a idade, em particular entre os pesquisados de 41 a 50 anos, quer seja na análise considerando a amostra total, ou nos cortes realizadas por sexo e etnia.

É importante frisar que estas conclusões às vezes se traduzem por especulações, pois os resultados devem ser observados dentro das limitações da pesquisa, com relação à composição de seus respondentes. Todos esses achados devem ser mais bem compreendidos, sobretudo os que mostram níveis inferiores de BES para as mulheres negras, com uma grande explicação da variância. Estamos nos referindo a 7 mulheres contra 11 homens, quantia muito pequena para uma análise crível, mas a relevância dos resultados aponta o sentido para outros trabalhos, a fim de investigar a coerência desta informação. 
A renda mostrou ser importante para dois grupos étnicos, pardos e brancos, com rendas altas, os primeiros entre 1.501 e 2.000 e o segundo, 2.501 e 3.000, somente para o questionário OHQ. Para os brancos a explicação da variância é muito pequena, porém para os pardos o valor de $14,3 \%$ deve ser melhor compreendida, uma vez que é expressivo. Esta categoria possui apenas 8 respondentes aleatoriamente escolhidos e, em uma pesquisa delineada com melhores propósitos de investigação, deve-se verificar se esta informação é capaz de resistir a ela.

A personalidade é um grande influenciador da satisfação com a vida, de acordo com Diener (1984), que também sustenta que as diversas variáveis demográficas contam com uma baixa explicação da variância do bem-estar subjetivo, não conseguindo explicar mais do que $15 \%$ da mesma. Isto está planamente condizente com o estudo conduzido neste trabalho, dados os valores apresentados de $\boldsymbol{R}^{2}$.

Conclusivamente, esta pesquisa procurou fornecer caminhos para a investigação quanto a diferenças individuais e o impacto que estas possuem no nível de BES dos indivíduos. Certamente uma quantidade maior de dúvidas despertou, porém elas estarão semeadas para que, em situações futuras, possam ser resolvidas através de trabalhos que ofereçam um melhor conhecimento sobre felicidade e as características particulares que possuímos. 


\section{3- BIBLIOGRAFIA}

Albuquerque, A.S. \& Tróccoli, B.T. (2004). Desenvolvimento de Uma Escala de Bem-Estar Subjetivo. Psicologia: Teoria e Pesquisa, 20(2):153-164

Almeida, D. M (2005). Resilience and vulnerability to daily stressors assessed via diary methods. Current Directions in Psychological Science, 14(5), 64-68

Anastasi, A.(1965). Testes Psicológicos . São Paulo: Herder.

Argyle, M. \& Handerson, M.(1985) . The anatomy of relationships . Londres: Penguin Books Argyle, M. (1987). The psychology of happiness . Londres : Routledge.

Arthaud-Day, M.L. \& Near, J.P. (2005). The wealth of nations and the happiness of nations: Are they related? Social Indicators Research.

Artes, R. (1998). Aspectos estatísticos da análise fatorial de escalas de avaliação. Revista de Psiquiatria Clínica 25(5), 223-228

Baker, L. A.; Cahalin, L. P.; Gerst, K. \& Burr, J. A. (2005). Productive activities and subjective well being among older adults: the influence of number of activities and time commitment. Social Indicators Research, 73, 431-458

Berry, D. S. \& Willingham, J. K. (1997). Affective traits, responses to conflict, and satisfaction in romantic relationships. Journal of Research in Personality, 31, 564-576.

Beck, T.; Ward, C. H. \& Mendelson, M. \& Hock, J., \& Erbaugh, J. (1961). An inventory for measuring depression. Archives of General Psychiatry, 7, 158-216.

Blanchflower, D.G. \& Oswald, A. J. (2004). Money, sex and happiness: an empirical study. Scandinavian Journal of Economics, 106 (3), 393-415.

Bradburn, N. M. (1969). The structure of psychological well-being. Chicago: Aldine.

Bunchaft, G. \& Cavas, C.S.T (2002). Sob Medida. São Paulo: Vetor,

Buss, D. M. (2000). The evolution of happiness. American Psychologist, 55 (1), 15-23

Cameron, K. S. \& Caza, A. (2004). Contributions to the discipline of Positive Organizational Scholarship. American Behavioral Scientist, 47 (6) February, 1-9

Campbell, A. (1976). Subjective measures of well being. American Psychologist, February, $117-124$

Campbell, A., (1981). The sense of well-being in America. New York: McGraw Hill.

Clark, A. E.; Oswald, A. J. (2002). Well being in panels. Working Paper December 
Christopher, A.; Kuo, S.V.; Abraham, K.M.; Noel, L.W. \& Linz, H.E. (2004)- Materialism and affective well-being: the role of social support. Personality and Individual Differences- in press

Clark, A. E. \& Oswald, A. J. (2002b). A simple statistical method for measuring how life events affect happiness. International Journal of Epidemealogy, 31, 1139-1144

Cooper, H., Okamura, L. \& Gurka, V. (1992). Social activity and subjective well-being. Personality and Individual Differences, 13, 573-583.

Corbi, R.B. \& Menezes -Filho, N.A. (2006). Os determinantes empíricos da felicidade no Brasil. Revista de Economia Politica, 26, 4 (104), 518-536

Crow, S. M. \& Hartman , S. J.(1995). Can't get no satisfaction. Leadership \& Organization Development Journal, 16 (4), 34-38

Cropanzano, R. \& Wright, T. A. (1999). A 5-year study of change in the relationship between well-being and job performance. Consulting Psychology Journal, 51, 252-265.

Csikszentmihalyi \& Csikszentmihalyi (1988). Optimal experience: Psychological studies of flow in consciousness. Cambridge: Cambridge University Press

Cummins, R. A. (2000). Personal income and subjective well being . Journal of Happiness Studies , 1, 133-158

Da Silva, J. A. (2005). Inteligência: resultado da genética, do ambiente ou de ambos. São Paulo: Editora Lovise.

Dalgas-Pelish, P. L. (1993). The impact of the first child on marital happiness. Journal of Advanced Nursing, 18, 437-441

Dela Coleta, J.A. \& Dela Coleta M.F. (2006). Felicidade, bem-estar subjetivo e comportamento acadêmico de estudantes universitários. Psicologia em Estudo, 11 (3), 533539

DeLuga, R. J. \& Mason, S. (2000). Relationship of resident assistant conscientiousness, extraversion, and positive affect with rated performance. Journal of Research in Personality, $34,225-235$.

Diener, E. (1984). Subjective well being. Psychological Bulletin, 95 (3), 542-575

Diener, E. \& Larsen, R. J. (1984). Temporal stability and cross-situational consistency of affective, behavioral, and cognitive responses. Journal of Personality and Social Psychology, 47, 871-883.

Diener, E. \& Suh, E. (1997). Measuring quality of life: economic, social and subjective indicators. Social Indicators Research , 40, 189-216

Diener, E.; Suh, E. \& Oishi, S. (1997). Recent findings on subjective well-being. Indian Journal of Clinical Psychology, 24(1), 25-41. 
Diener, E. (2000). Subjective Well Being: The science of happiness and a proposal of a national index. American Psychologist, 55(1), 34-43

Diener, E. \& Lucas, R. (2000). Exploring differences in societal levels of happiness: relatives standards, need fulfillment culture and evaluation theory. Journal of Happiness Studies, 1, 4178

Diener, E. \& Seligman, M. E. P. (2002). Very happy people. Psychological Science, 13, 8184.

Diener, E.; Scollon, C. N. \& Lucas, R. E. (2003) . The evolving concept of subjective well being: the multifaceted nature of happiness. Advances in Cell Aging and Gerontology $15,187-219$

Diener, E. \& Seligman, M. (2004). Beyond money: toward an economy of well-being. Psychological Science in the Public Interest -5, 1-32

DiTellla, R. \& MaCculloch, R. (2005) . Partisan social happiness . Review of Economic Studies 72, 367-393

Easterlin, R. A. (1974). "Does Economic Growth Improve the Human Lot?" Nations and Households in Economic Editores Paul A. David and Melvin W., Nova York: Academic Press, Inc.

Easterlin, R. A. (2001) . Income and happiness towards a unified theory . The Economic Journal, July, 465-484

Easterlin, R. A. (2003) . Bulding a better theory of well being . Discussion Paper $n^{\circ} 742$, March 2003

Easterlin, R. A. (2004). Life cycle happiness and its sources . Working Paper October 26

Foster, J. B.; Hebl, M. R.; West, M. \& Dawson, J. (2004). Setting the tone for organizational success: The impact of CEO affect on organizational climate and firm-level outcomes. Artigo apresentado no $17^{\circ}$ Encontro da Sociedade para Psicologia Organizacional e Industrial em Toronto, Canadá.

Fordyce, M. W. (1983). A program to increase happiness: Further Studies. Journal of Counseling Psychology - 30(4), 483-498

Francis, L. J. (1999). Happiness is a thing called stable extraversion - a further examination of the relationship between the Oxford Happiness Inventory and Eysenck's dimensional model of personality and gender. Personality and Individual Differences, 26, 5-11

Francis, L. J.; Ziebertz, H. \& Lewis ,C. A. (2003). The relationship between religion and happiness among German students. Pastoral Psychology- 51(4), 273-281

Frank, R. H. (1997). The frame of reference as a public good .The Economic Journal, 107, 1832- 1847 
Fredrickson, B. L. \& Kahneman, D. (1993). Duration neglect in retrospective evaluations of affective episodes'. Journal of Personality and Social Psychology, 65,45:55.

Fredrickson, B. L. (2003). The value of positive emotions. American Scientist, 91, 330- 335

Fredrickson, B. L. (2004). The broaden-and-build theory of positive emotions.

Philosophical Transactions: Biological Sciences 359, 1367-1377.

Frey, B. S. \& Stutzer, A. (2000). Happiness and Economics: How the Economy and Institutions Affect Human Well-Being. Nova Jersey: Princeton University Press

Frey, B. S. \& Stutzer, A. (2002). What can economists learn from happiness research? Journal of Economic Literature, 40, 402-435.

Frey, B. S. \& Stutzer, A. (2004). Beyond outcomes: measuring procedural utility. Oxford Economic Papers- no prelo

Fry, L.W. (2005) Toward a theory of ethical and spiritual well-being, and corporate social responsibility through spiritual leadership. Em R.A Giacalone, C. L. Jurkiewicz, \& C.Dunn, (Eds), Positive psychology in bussiness and corporate responsibility. Connecticut:

Information Age Publishing

Fuentes, N. \& Rojas, M. (2001) - Economy theory and subjective well being: Mexico Social Indicators Research (53), 289- 314

George, J. M. (1995). Leader positive mood and group performance: The case of customer service. Journal of Applied Social Psychology, 25, 778-795.

Giannetti, E. (2002). Felicidade. São Paulo: Companhia das letras.

Gladow, N. W., \& Ray, M. P. (1986). The impact of informal support systems on the wellbeing of low income single parents. Family Relations: Journal of Applied Family and Child Studies, 35, 113-123.

Hair Jr., J.F; Anderson R.E.; Tatham, R.L. \& Black, W. C. (2005) Análise de dados multivariados. Porto Alegre: Bookman

Hamermesh, D.S. (2004) - Subjective outcomes in economics - Southern Economic Journal $-71(1), 2-11$

Harter, J. K; Schmidt, F. L. \& Keyes, C. L.M. (2003). Well being in the work place and its relationship to business outcome. Em C.L.M Keyes \& J. Haidt,. (Eds). Flourishing : the positive person and the good life.. American Psychological Association

Hayo, B. \& Seifert, W. (2003) . Subjective well being in Eastern Europe . Journal of Economic Psychology -24, 329-348

Headey, B., Veenhoven, R. \& Wearing, A. (1991). Top-down versus bottom-up theories of subjective well-being. Social Indicators Research, 24, 81-100. 
Helliwell, J. (2003) . How's life? Combining individual e national variables to explain SWB. Economic Modeling- 20, 331-360

Hills, P. \& Argyle, M. (2001). Emotional stability as a major dimension of happiness . Personality and Individual Differences - 31, 1357- 1364

Hills, P. \& Argyle, M. (2002) . The Oxford Happiness Questionnaire: a compact scale for the measurement of psychological well being . Personality and Individual Differences- 3,10731082

Ho, L. S. (2005) . Happiness and Public Policy - Trabalho apresentado na conferência internacional "Progresso, felicidade e políticas públicas", organizado pelo Instituto de Ciências Sociais da Universidade de Lingan e a Sociedade para Qualidade de Vida de Hong Kong.

Jonathan, E. G. (2005). Mulheres empreendedoras: medos, conquistas e qualidade de vida. Psicologia em Estudo, 10( 3), 373-382,

Kashdan, T. B (2004). The assessment of subjective well-being (issues raised by the Oxford Happiness Questionnaire). Personality and Individual Differences 36 : 1225-1232

Kashdan, T. B. \& Roberts, J. E. (2004). Trait and state curiosity in the genesis of intimacy: Differentiation from related constructs. Journal of Social and Clinical Psychology, 23, 792816.

Kasser, T. \& Ryan, R.M. (1996). Further Examining the American Dream: Differential Correlates of Intrinsic and Extrinsic Goals. Personality and Social Psychology Bulletin, 22, 280-87.

Kasser, T. (2000). Two versions of the American dream: Which goals and values make for a high quality of life? In E. Diener \& D. Rahtz, (Eds.) Advances in quality of life theory and research. Dordrecht, Netherlands: Kluwer.

Kenny, C. (2005) . Does development make you happy? Subjective well being and economic growth in developing countries . Social Indicators Research -73, 199-219

Keyes, C. L. M.; Hysom, S. J. \& Lupo, K. L. (2000). The Positive Organization: leadership legitimacy, employee well-being, and the bottom line .The Psychologist Manager Journal-4, (2), 143-153

Kilbourne, W. \& Gühagen, M. (2005). Across cultural examination of relationship between materialism and individual values. Journal of Economic Psychology - no prelo

Kim, H. K. \& McKenry , P. C. (2003). The relationship between marriage and psychological well-being. Journal of Family Issues- 23 (8), 885-911

Kim, J. \& Mueller, C. W. (1978). Introduction to factor analysis: what is and how to do it. Sage University Paper Series on Quantitative Applications in the Social Sciences, vol 13. California: Sage 
Kim, J. \& Mueller, C. W. (1978b). Factor analysis: statistical methods and pratical issues. Sage University Paper Series on Quantitative Applications in the Social Sciences, vol 14. California: Sage

Kingwell, M. (2006) - Aprendendo felicidade. Rio de Janeiro: Relume Dumará

Layard, R.(2003). Lionel Robbins Memorial Lectures - palestra proferida em 3,4,5 de Março - London Scholl of Economics

Lee, G. R. \& Ishii-Kuntz, M. (1987). Social interaction, loneliness, and emotional well-being among the elderly. Research on Aging, 9, 459-482.

Lucas, R. E.; Diener, E. \& Suh, E. M. (1996). Discriminant validity of well-being measures. Journal of Personality and Social Psychology, 71, 616-628.

Lucas, R. E.; Diener, E.; Grob, A.; Suh, E. M.; \& Shao, L. (2000). Cross-cultural evidence for the fundamental features of extraversion. Jornal of Personality and Social Psychology, 79, $452-468$.

Lucas, R. E.; Clark. A. E.; Georgellis, Y. \& Diener , E. (2003) . Reexamining adaptation and the set point model of happiness: reactions to changes in marital status. Journal of Personality and Social Psychology - 84(3), 527-539

Lucas, R. E.; Clark, A. E.; Georgellis, Y. \& Diener, E. (2004). Unemployment alters the set point for live satisfaction. Psychological Science - 15(1), 8-13

Luthans, F.; Youssef, C.M. \& Avolio, B.J. (2007). Psychological capital: developing the human competitive edge. Nova York: Oxford University Press

Lyubomirsky, S., \& Ross, L. (1997). Hedonic consequences of social comparison: A contrast of happy and unhappy people. Journal of Personality and Social Psychology, 73, 1141-1157.

Lyubomirsky, S., \& Tucker, K. L. (1998). Implications of individual differences in subjective happiness for perceiving, interpreting, and thinking about life events. Motivation and Emotion, 22, 155-186.

Lyubomirsky, S. \& Lepper, H. S. (1999). A measure of subjective happiness: preliminary reliability and construct validation. Social Indicators Research-46, 137- 155

Lyubomirsky, S. (2001). Why are some people happier than others. American Psychologist, 56(3), 239-249

Lyubomirsky, S.; Sheldon, K. M. \& Schkade, D. (2005). Pursuing happiness: the architecture of sustainable change. Review of General Psychology 9(2), 111-131.

Lounsbury ,J. W.; Loveland , J. M.; Sundstrom, E. D.; Gibson, L. W.; Drost, A.W. \& Hamrick, F. L. (2003). An investigation of personality traits in relation to career satisfaction . Journal of Career Assessment - 11(3), 287-307 
Lykken, D. \& Bouchard Jr., T.J. \& Mcgue, M. \& Tellegen, A. (1990) . The Minnesota twin registry: some initial findings . Acta Geneticae et Gemmellologiae - 39, 35-70

Lykken, D. \& Tellegen, A. (1996) . Happiness is a stochastic phenomenon. Psychological Science- 7, 186-189

Lykken, D. (1999). Felicidade. Rio de Janeiro, Editora Objetiva.

Maltby, J.; Day, L. \& Barber, L. (2005). Forgiveness and happiness: the differing on texts of forgiveness using the distinctions between hedonic and eudaimonic happiness. Journal of Happiness Studies- 6, 1-13

Magen, Z., \& Aharoni, R. (1991). Adolescents' contributing toward others: Relationship to positive experiences and transpersonal commitment. Journal of Humanistic Psychology, 31, 126-143.

Myers, D. (1992). The pursuit of happiness. Nova York: Avon Books

Michalos, A. C (1985) . Multiple discrepancies theory. Social Indicators Research - 16: 347413

Mongrain, M., \& Zuroff, D. C. (1995). Motivational and affective correlates of dependency and self-criticism. Personality and Individual Differences, 18, 347-354.

$\mathrm{Ng}, \mathrm{Y}$. (1997). A case for happiness, cardinalism and interpessoal comparability . The Economic Journal-107, (November), 1848-1858

$\mathrm{Ng}$, S. \& Ng, Y. (2000). Welfare- reducing growth despite individual and government optimization. Social Choice and Welfare- 18, 497- 506

Nickerson, C.; Schwarz, N.; Diener, E. \& Kahneman, D. (2003) . Zeroing in the dark side of American dream .Psychological Science - 14 (6), 531-536

O'Conell, M. (2003). Fairly satisfied: economic equality wealth and satisfaction . Journal of Economic Psychology - no prelo

Oishi, S.; Diener, E.; Suh, E. \& Lucas, R. (1999). Value as a moderator in SWB. Journal of Personality, 67(1),,157-184

Oswald, A. J. (1997). Happiness and economic performance . The Economic Journal, 107, November, 1815- 1831

Ott, J. (2001). Did the market depress happiness in USA? Journal of Happiness Studies- 2, 433-443

Pasquali, L. (2003). Psicometria: teoria dos testes na psicologia e na educação. Petrópolis: Vozes.

Queiroz, N.C. \& Neri, A.L. (2005). Bem-estar psicológico e inteligência emocional entre homens e mulheres na meia idade e na velhice. Psicologia: Reflexão e Crítica, 18(2), 292-299 
Quick, J. C. \& Quick, J. D. (2004). Healthy, happy, productive work: a leadership challenge. Organizational Dynamics, 33(4), 329-337

Rabelo, D.F. \& Nério, A.L. (2005). Bem-estar subjetivo e senso de ajustamento psicológico em idosos que sofreram acidente vascular cerebral: uma revisão. Estudos de Psicologia, 11(2), 169-177

Ryff, C. D. (1989). Happiness is everything, or is it? Explorations on the meaning of psychological well-being. Journal of Personality and Social Psychology 57(6), 1069-1081

Sckade, D. A. \& Kahnemann, D. (1998). Does living in California make people happy? A focusing illusion in judgments of life satisfaction. Psychological Science - 9(5), 340-346

Seligman, M. E. P. \& Csikszentmihalyi, M. (2000). Positive psychology: an introduction . American Psychology- 55(1), 5-14

Seligman, M. E. P (2002). Felicidade autêntica. Rio de Janeiro: Objetiva

Siegrist, J. (2003). Subjective well being: new conceptual and methodological developments in health - related social sciences - ESF SCSS Exploratory Workshop on "Income, Interactions and Subjective Well Being" - Paris, 25-26 September 2003

Smith, D. M.; Langa, K. M.; Kabeto, M. U. \& Ubel, P. A. (2005) . Health, wealth and happiness . Psychological Science- 6 (9), 663-666

Spreitzer, E \& Snyder, E.E. (1974) . Correlates of life satisfaction among the age .Journal of Gerontology, Vol. 29, 454-458

Sousa, L \& Lyubomirsky, S. (2001). Life satisfaction. In J. Worell (Ed.), Encyclopedia of women and gender, Sex similarities and differences and the impact of society on gender (Vol. 2, pp. 667-676). San Diego: CA,Academic Press.

Staw, B. M., \& Barsade, S. G. (1993). Affect and managerial performance: a test of the sadder-but-wiser vs. happier-and-smarter hypothesis. Administrative Science Quarterly, 38, 304-331.

Steele, G. R. (2004). Understanding economic man: psychology, rationality, and values. The American Journal of Economics and Sociology, Vol. 63, No. 5 ,1021-1055

Stutzer, A. \& Frey, B. S. (2002). Happiness Research: State and Prospects . Review of Social Economy - 62, (2), 207-228.

Stutzer, A. \& Frey, B. S.. (2003). Reported SWB: a challenge for economic theory and economic policy . Schmollers Jahrbuch -124(2), 191-231.

Stutzer, A. \& Frey, B. S. (2004). Does marriage make people happy, or do happy people get married ? Journal of Socio- Economics, 35 (2), 326-347

Stutzer, A. (2004). The role of income aspirations in individual happiness . Journal of Economic Behavior - 54, 89-109 
Sund, L. \& Smyrnios, K. X. (2005). Striving for happiness and its impact on family stability: an exploration of the Aristotelian conception of happiness. Family Business Review, 18(2), $155-170$

Tatzel, M. (2001). "Money worlds" and well being: an integration of money dispositions, materialism and price related behavior . Journal of Economic Psychology, 23, 103-126

Tellegen A.; Lykken D.T.; Bouchard T.J.Jr.; Wilcox K.J.; Segal N.L.\& Rich S. (1988). Personality similarity in twins reared apart and together. Journal of personality and social psychology, 54 (6),1031-9

Urry, H. L; Nitschke, J. B., Dolski, I.; Jackson, D. C.; Dalton, Kim M. ; Mueller, C. J. ; Rosenkranz, M. A.; Ryff, C. D.; Singer, B. H. \& Davidson, R. J. (2004) - Make a life worth of living: neural correlates of well being . Psychological Science ,15(6), 367-372

Weiss, H. M.; Nicholas, J. P. \& Daus, C. S. (1999). An examination of the joint effects of effective experiences and job beliefs on job satisfaction and variations in affective experiences over time. Organizational Behavior and Human Decision Processes, 78, 1-24.

Wilson, W. (1967). Correlates of avowed happiness. Psychological Bulletin, 67, 249-306

Wright, T. A. \& Cropanzano, R. (2004). The role of psychological well-being in job performance: a fresh look at an age-old quest . Organizational Dynamics 33 , Issue 4 , December, 338-351

Wright, T. A.; Cropanzano, R. \& Meyer, D. G. (2004). State and trait correlations of job performance: a tale of two perspectives. Journal of Business and Psychology -1(3), 365-383

Wood, W.; Rhodes, N. \& Whelan, M. (1989). Sex differences in positive well-being: a consideration of emotional style and marital status. Psychological Bulletin 1 106(2), September, 249-264

Wrzesniewski, A.; McCauley, C.; Rozin, P. \& Schwartz, B. (1997). Jobs, careers, and callings: people"s relations to their work. Journal of Research in Personality, 31, 21-33

Van Praag, B.M.S (2003) . The anatomy of subjective well being . Journal of Economic Behavior and Organizations, 51, 29-49

Veenhoven, R. (1991). Is happiness relative? Social Indicators Research - 24, 1-34

Veenhoven, R. (1994). Is happiness a trait? Social Indicators Research - 32, 101- 160

Veenhoven, R. (1994b). El studio de la satisfaction con la vida . Intervención Psicosocial - 3, $87-116$

Veenhoven, R. (2000). Well Being in welfare state . Journal of Comparative Policy Analysis $2,91-125$

Veenhoven, R. (2002). Why social policy needs subjective indicators . Social Indicators Research- 58, 33-45 
Veenhoven, R. (2004). The greatest happiness principle. Em A. Linley. \& S. Joseph, (Eds), Positive Psychology in Practice. Nova Jersey: John Wiley \& Sons.

Veenhoven, R, (2005). Apparent quality of life in nations: how long e happy people live. Social Indicators Research 71, 61-86

Veenhoven, R, (2006). Happiness in hardship. Em Bruni, L. \& Porta (Eds). Economics and happiness : Framing the analysis, Nova York: Oxford University Press 


\section{4- APÊNDICES}


Tabela 1- Teste t para o OHQ

\begin{tabular}{|c|c|c|c|c|c|c|c|c|c|c|}
\hline \multicolumn{11}{|c|}{ Independent Samples Test } \\
\hline & & \multicolumn{2}{|c|}{$\begin{array}{l}\text { Levene's Test } \\
\text { for Equality of } \\
\text { Variances }\end{array}$} & \multicolumn{7}{|c|}{ t-test for Equality of Means } \\
\hline & & \multirow[b]{2}{*}{$\mathrm{F}$} & \multirow[b]{2}{*}{ Sig. } & \multirow[b]{2}{*}{$t$} & \multirow[b]{2}{*}{ df } & \multirow{2}{*}{$\begin{array}{c}\text { Sig. } \\
\text { (2-tailed) }\end{array}$} & \multirow{2}{*}{$\begin{array}{c}\text { Mean } \\
\text { Difference }\end{array}$} & \multirow{2}{*}{$\begin{array}{l}\text { Std. Error } \\
\text { Difference }\end{array}$} & \multicolumn{2}{|c|}{$\begin{array}{l}95 \% \text { Confidence } \\
\text { Interval of the } \\
\text { Difference }\end{array}$} \\
\hline & & & & & & & & & Lower & Upper \\
\hline \multirow{2}{*}{$\begin{array}{l}\text { Setimento calorosos com } \\
\text { quase todos }\end{array}$} & Equal variances assumed & 14,322 &, 000 & 4,740 & 482 &, 000 &, 67279 &, 14195 & ,39388 & ,95171 \\
\hline & Equal variances not assumed & & & 4,699 & 451,3 &, 000 & ,67279 & 14317 & ,39143 & ,95415 \\
\hline \multirow[t]{2}{*}{ Possui muita energia } & Equal variances assumed & 47,847 & ,000 & 7,332 & 482 & ,000 & ,77214 & ,10531 &, 56523 & 97906 \\
\hline & Equal variances not assumed & & & 7,137 & 371,0 &, 000 &, 77214 & , 10819 &, 55940 & ,98489 \\
\hline Tenho memória felizes do & Equal variances assumed & 34,304 & ,000 & 7,042 & 482 & ,000 & 1,09200 & ,15508 & ,78728 & 1,397 \\
\hline passado & Equal variances not assumed & & & 6,964 & 442,2 &, 000 & 1,09200 &, 15680 & ,78383 & 1,400 \\
\hline Sou feliz & Equal variances assumed & 100,7 &, 000 & 11,316 & 482 & ,000 & 1,04496 & ,09234 & ,86352 & 1,226 \\
\hline & Equal variances not assumed & & & 10,849 & 301,1 &, 000 & 1,04496 &, 09632 & ,85541 & 1,235 \\
\hline Estou controle de minha & Equal variances assumed & ,376 & ,540 & 9,009 & 482 & ,000 & 1,41141 & ,15666 & 1,1036 & 1,719 \\
\hline vida & Equal variances not assumed & & & 9,023 & 477,2 &, 000 & 1,41141 & ,15643 & 1,1040 & 1,719 \\
\hline sou interessado em & Equal variances assumed & 8,398 & ,004 & 5,375 & 482 &, 000 &, 86270 & ,16050 & ,54734 & 1,178 \\
\hline outras pessoa & Equal variances not assumed & & & 5,356 & 466,6 &, 000 &, 86270 &, 16107 &, 54618 & 1,179 \\
\hline Me sinto satisfeito com a & Equal variances assumed & 12,579 & ,000 & 8,674 & 482 & ,000 & 1,32688 & ,15297 & 1,0263 & 1,627 \\
\hline amenira que sou & Equal variances not assumed & & & 8,632 & 463,1 &, 000 & 1,32688 & ,15371 & 1,0248 & 1,629 \\
\hline Sinto-me satisfeito com a & Equal variances assumed & 100,9 & ,000 & 10,113 & 482 &, 000 & 1,30030 & ,12858 & 1,0477 & 1,553 \\
\hline vida & Equal variances not assumed & & & 9,864 & 381,1 &, 000 & 1,30030 &, 13182 & 1,0411 & 1,559 \\
\hline Sinto-me alegre e & Equal variances assumed & 56,371 & ,000 & 8,731 & 482 & ,000 & 1,07645 & ,12329 & ,83420 & 1,319 \\
\hline exaltado & Equal variances not assumed & & & 8,566 & 408,3 &, 000 & 1,07645 &, 12566 & ,82943 & 1,323 \\
\hline Tenho senso de & Equal variances assumed & 22,376 & ,000 & 5,984 & 481 & ,000 & 1,65254 & ,27618 & 1,1099 & 2,195 \\
\hline significado e propósito & Equal variances not assumed & & & 5,647 & 245,7 &, 000 & 1,65254 & ,29266 & 1,0761 & 2,229 \\
\hline Tenho influencia boa nos & Equal variances assumed & 5,323 & ,021 & 5,026 & 482 &, 000 & ,61412 & ,12218 & ,37405 & ,85419 \\
\hline acontecimentos & Equal variances not assumed & & & 4,996 & 459,3 &, 000 & ,61412 & ,12293 & ,37254 & ,85569 \\
\hline Sou otimista sobre $o$ & Equal variances assumed & 104,0 & 000 & 10,353 & 481 &, 000 & 1,44701 & ,13976 & 1,1724 & 1,722 \\
\hline futuro & Equal variances not assumed & & & 10,111 & 388,3 &, 000 & 1,44701 &, 14312 & 1,1656 & 1,728 \\
\hline A vida é boa & Equal variances assumed & 112,6 & ,000 & 7,563 & 482 &, 000 &, 59847 & 07913 & ,44298 & ,75396 \\
\hline & Equal variances not assumed & & & 7,259 & 306,7 &, 000 &, 59847 & 08244 & ,43624 & ,76069 \\
\hline Sempre contagio de & Equal variances assumed & 70,665 & ,000 & 7,355 & 482 &, 000 & ,76813 & ,10443 &, 56293 & ,97333 \\
\hline alegria outras pessoas & Equal variances not assumed & & & 7,159 & 370,7 &, 000 & ,76813 & ,10730 &, 55714 & ,97912 \\
\hline Sinto minha mente alerta & Equal variances assumed & 54,791 & ,000 & 6,742 & 482 & ,000 & ,75006 & ,11126 & ,53145 & ,96868 \\
\hline & Equal variances not assumed & & & 6,584 & 386,7 &, 000 &, 75006 & ,11393 &, 52607 & ,97406 \\
\hline Sinto a vida & Equal variances assumed & 59,019 & 000 & 8,697 & 482 & ,000 & 1,02590 & ,11796 & ,79413 & 1,258 \\
\hline recompensada & Equal variances not assumed & & & 8,477 & 377,3 &, 000 & 1,02590 &, 12103 & ,78793 & 1,264 \\
\hline Frequentemente sinto-me & Equal variances assumed & 1,951 & ,163 & 5,531 & 482 &, 000 & ,85912 & ,15532 & ,55392 & 1,164 \\
\hline descansado & Equal variances not assumed & & & 5,543 & 478,0 &, 000 & 85912 & , 15500 &, 55455 & 1,164 \\
\hline Faço o que gosto & Equal variances assumed & 14,629 & ,000 & 8,073 & 482 & ,000 & 1,26492 & ,15668 & ,95705 & 1,573 \\
\hline & Equal variances not assumed & & & 8,114 & 481,1 &, 000 & 1,26492 &, 15590 & ,95858 & 1,571 \\
\hline Acho fácil tomar decisões & Equal variances assumed & 12,541 & ,000 & 8,002 & 482 & ,000 & 1,28304 & ,16034 & ,96798 & 1,598 \\
\hline & Equal variances not assumed & & & 8,051 & 481,7 &, 000 & 1,28304 & ,15936 & ,96990 & 1,596 \\
\hline Sinto-me particularmente & Equal variances assumed & 99,908 & ,000 & 7,968 & 482 &, 000 & 1,16826 & ,14661 & ,88018 & 1,456 \\
\hline saudável & Equal variances not assumed & & & 7,803 & 399,4 &, 000 & 1,16826 & ,14972 & ,87391 & 1,463 \\
\hline Acho a maioria das & Equal variances assumed & 35,993 &, 000 & 9,180 & 482 &, 000 & 1,03685 & ,11295 & ,81492 & 1,259 \\
\hline coisas agradáveis & Equal variances not assumed & & & 9,026 & 417,8 &, 000 & 1,03685 &, 11488 & 81104 & 1,263 \\
\hline Acho que o mundo é um & Equal variances assumed & 89,355 & ,000 & 8,682 & 482 &, 000 & 1,30408 & ,15020 & 1,0089 & 1,599 \\
\hline bom lugar & Equal variances not assumed & & & 8,502 & 399,7 &, 000 & 1,30408 &, 15338 & 1,0026 & 1,606 \\
\hline Sempre me saio bem em & Equal variances assumed & 25,314 & ,000 & 9,915 & 482 &, 000 & 1,22330 & ,12338 & ,98086 & 1,466 \\
\hline tudo o que quero & Equal variances not assumed & & & 9,819 & 447,2 &, 000 & 1,22330 & ,12459 & ,97845 & 1,468 \\
\hline Me acho atraente & Equal variances assumed & 18,224 & ,000 & 7,092 & 482 &, 000 & 1,03629 & ,14613 & ,74916 & 1,323 \\
\hline & Equal variances not assumed & & & 7,026 & 448,5 &, 000 & 1,03629 &, 14750 &, 74641 & 1,326 \\
\hline Encontro beleza em & Equal variances assumed & 107 & ,743 & 1,199 & 482 & ,231 & , 16286 & ,13588 &,- 10414 & ,42985 \\
\hline algumas coisas & Equal variances not assumed & & & 1,203 & 479,7 & ,230 & ,16286 & ,13541 &,- 10322 & ,42893 \\
\hline Sorrio muito & Equal variances assumed & 62,574 & ,000 & 7,882 & 482 &, 000 & ,87816 & ,11141 & ,65925 & 1,097 \\
\hline & Equal variances not assumed & & & 7,651 & 358,0 &, 000 &, 87816 &, 11478 & 65244 & 1,104 \\
\hline Sinto-me capaz de & Equal variances assumed & 62,222 &, 000 & 8,162 & 482 &, 000 & 1,02737 & ,12587 &, 78005 & 1,275 \\
\hline conseguir qualquer coisa & Equal variances not assumed & & & 7,978 & 390,8 &, 000 & 1,02737 & ,12878 & ,77419 & 1,281 \\
\hline Me divirto com outras & Equal variances assumed & 55,766 & ,000 & 6,797 & 482 &, 000 & ,92009 & ,13537 & 65410 & 1,186 \\
\hline & Equal variances not assumed & & & 6,676 & 413,5 &, 000 & ,92009 &, 13781 & ,64919 & 1,191 \\
\hline Estou envolvido e & Equal variances assumed & 6,526 & 011 & 4,858 & 482 &, 000 & ,74203 & ,15273 & ,44193 & 1,042 \\
\hline comprometido. & Equal variances not assumed & & & 4,831 & 460,9 &, 000 & ,74203 & ,15358 & ,44021 & 1,044 \\
\hline
\end{tabular}


Tabela 4-Fatores obtidos na análise rotação ortogonal - Oxford Happiness Questionnaire

\begin{tabular}{|c|c|c|c|c|c|c|c|c|}
\hline \multicolumn{9}{|c|}{ Rotated Component Matrix ${ }^{a}$} \\
\hline & \multicolumn{8}{|c|}{ Component } \\
\hline & 1 & 2 & 3 & 4 & 5 & 6 & 7 & 8 \\
\hline A vida é boa & ,661 & & & ,155 & &,- 135 & ,220 & \\
\hline Eu sinto que a vida é muito recompensada &, 596 & & ,249 & ,188 & & & & \\
\hline Eu sou muito feliz &, 578 & & ,290 & ,217 &, 112 & ,125 & ,222 & \\
\hline Estou muito satisfeito com tudo em minha vida &, 535 & ,248 & ,474 & & & & & ,116 \\
\hline Eu acho a maioria das coisas agradáveis &, 527 &, 106 & & & ,277 & ,271 &,- 167 & \\
\hline Eu acho que o mundo que o mundo é um bom lugar & ,382 & ,206 & & ,348 & & &,- 117 & ,350 \\
\hline Existe uma diferença entre o que gostaria de fazer e o que faço & & ,670 & 141 & & &,- 118 &,- 136 & \\
\hline Não é fácil tomar decisões &,- 304 &, 577 & ,274 &, 138 &, 132 & & ,235 & 160 \\
\hline Sinto que não estou, sobretudo, no controle de minha vida & ,274 &, 575 & & &,- 113 & ,250 &, 174 & \\
\hline Eu raramente me sinto descansado & &, 525 &,- 325 & ,259 & & & & \\
\hline Não me sinto particularmente satisfeito com a maneira que sou & ,295 & ,448 &, 118 & & &,- 119 & ,265 & \\
\hline Sinto-me alegre e exaltado & ,293 &, 170 & ,692 & & &, 117 & &,- 123 \\
\hline Sinto minha mente completamente alerta &, 164 &,- 101 & ,465 & ,124 & ,293 & & & \\
\hline Sinto que possuo muita energia & & & ,423 &, 121 & ,136 & ,348 & ,419 & \\
\hline Eu não me acho atraente & &, 170 & & ,629 &, 131 & & & , 168 \\
\hline Não me divirto com outras pessoas & ,166 & & &, 576 &,- 277 & ,213 & ,270 & \\
\hline Sempre contagio de alegria outras pessoas & ,202 & & ,445 &, 549 & ,123 & & &,- 291 \\
\hline Eu sorrio muito & ,295 & & ,196 &, 542 & & 173 & &,- 253 \\
\hline Estou sempre comprometido e envolvido & & & & & ,746 & & & \\
\hline Sinto-me capaz de conseguir qualquer coisa &, 106 & ,116 & ,165 & ,324 &, 582 & & ,155 &,- 206 \\
\hline Sempre me saio bem em tudo o que quero & ,219 & ,183 & ,307 & &, 511 &, 104 & ,123 &,- 147 \\
\hline Eu tenho sentimentos calorosos com quas todos & & & & & & ,767 & &,- 203 \\
\hline Eu sou intensamente interessado em outras pessoas & & & &, 195 &, 169 & ,705 &,- 143 &, 109 \\
\hline $\begin{array}{l}\text { Não tenho particularmente senso de significado e propósito } \\
\text { para minha vida }\end{array}$ & & & & & &,- 100 & ,689 & \\
\hline Eu particularmente não sou otimista sobre o futuro & , 198 & ,132 & & ,351 & ,253 & & ,404 &, 168 \\
\hline Sempre tenho boas influencias nos acontecimentos &, 196 &, 160 & ,202 & & ,133 & ,189 &, 108 &,- 631 \\
\hline Não me sinto particularmente saudável & & ,281 & ,343 &, 110 & & &, 117 &, 570 \\
\hline Não tenho particularmente memórias felizes do passado & ,338 & ,236 &,- 114 &,- 123 & ,133 & ,165 & ,354 & ,367 \\
\hline
\end{tabular}

Extraction Method: Principal Component Analysis.

Rotation Method: Varimax with Kaiser Normalization.

a. Rotation converged in 10 iterations. 
Tabela 5- Comunalidade fatoração ortogonal - Oxford Happiness Questionnaire

Communalities

\begin{tabular}{|l|r|}
\hline & Extraction \\
\hline Eu tenho sentimentos calorosos com quas todos &, 653 \\
Sinto que possuo muita energia &, 519 \\
Não tenho particularmente memórias felizes do passado &, 504 \\
Eu sou muito feliz &, 552 \\
Sinto que não estou, sobretudo, no controle de minha vida &, 526 \\
Eu sou intensamente interessado em outras pessoas &, 603 \\
Não me sinto particularmente satisfeito com a maneira que sou &, 394 \\
Estou muito satisfeito com tudo em minha vida &, 604 \\
Sinto-me alegre e exaltado &, 631 \\
Não tenho particularmente senso de significado e propósito para minha vida &, 498 \\
Sempre tenho boas influencias nos acontecimentos &, 569 \\
Eu particularmente não sou otimista sobre o futuro &, 445 \\
A vida é boa &, 541 \\
Sempre contagio de alegria outras pessoas &, 643 \\
Sinto minha mente completamente alerta &, 362 \\
Eu sinto que a vida é muito recompensada &, 471 \\
Eu raramente me sinto descansado &, 462 \\
Existe uma diferença entre o que gostaria de fazer e o que faço &, 511 \\
Não é fácil tomar decisões &, 619 \\
Não me sinto particularmente saudável &, 556 \\
Eu acho a maioria das coisas agradáveis &, 474 \\
Eu acho que o mundo que o mundo é um bom lugar &, 454 \\
Sempre me saio bem em tudo o que quero &, 486 \\
Eu não me acho atraente &, 471 \\
Eu sorrio muito &, 518 \\
Sinto-me capaz de conseguir qualquer coisa &, 564 \\
Não me divirto com outras pessoas &, 561 \\
Estou sempre comprometido e envolvido &, 583 \\
\hline Extraction Method: Principal Component Analysis. & \\
\end{tabular}

Tabela 6- Fatores obtidos na análise rotação oblíqua - Oxford Happiness Questionnaire

\begin{tabular}{|c|c|c|c|c|c|c|c|c|}
\hline \multicolumn{9}{|c|}{ Structure Matrix } \\
\hline & \multicolumn{8}{|c|}{ Component } \\
\hline & 1 & 2 & 3 & 4 & 5 & 6 & 7 & 8 \\
\hline Eu sou muito feliz & ,691 &, 310 &, 359 & 290 &,- 321 & & ,322 &,- 240 \\
\hline A vida é boa & 679 & 157 & & 168 &,- 199 & & 288 & \\
\hline Eu sinto que a vida é muito recompensada & 649 & ,241 & 213 & ,234 &,- 292 & & &,- 201 \\
\hline Estou muito satisfeito com tudo em minha vida &, 596 & ,405 & ,226 & ,267 & &,- 112 & &,- 465 \\
\hline Eu acho a maioria das coisas agradáveis &, 556 & ,219 & 403 & ,369 &,- 115 & & & \\
\hline Existe uma diferença entre o que gostaria de fazer e o que faço &, 130 &, 660 & & , 120 &,- 131 &,- 141 & & -124 \\
\hline Não é fácil tomar decisões &,- 109 &, 595 & 119 & ,211 &,- 192 &,- 289 & ,322 &,- 262 \\
\hline Sinto que não estou, sobretudo, no controle de minha vida & ,357 &, 590 & ,336 & & & & ,258 & \\
\hline Não me sinto particularmente satisfeito com a maneira que sou & ,386 &, 530 & & &,- 122 &,- 115 & ,359 &,- 102 \\
\hline Eu raramente me sinto descansado & ,167 &, 517 & 105, & &,- 175 &,- 196 & 124, & ,365 \\
\hline Eu tenho sentimentos calorosos com quase todos & 197 & & ,742 & & & ,197 & & \\
\hline Eu sou intensamente interessado em outras pessoas & & & ,703 & 267 &,- 207 &,- 153 & & \\
\hline Sinto que possuo muita energia & 238, & 117, & ,459 & ,284 &,- 223 & & 454, & -,401 \\
\hline Estou sempre comprometido e envolvido & 119, & & 177, & 720, & & & & \\
\hline Sinto-me capaz de conseguir qualquer coisa & ,262 & ,246 & ,159 & ,639 &,- 444 & & ,223 &,- 143 \\
\hline Sempre me saio bem em tudo o que quero & ,341 & ,296 & ,258 &, 597 &,- 135 & 105, & , 170 &,- 330 \\
\hline Sempre contagio de alegria outras pessoas & ,357 & ,151 & , 175 & ,290 &,- 699 & ,143 & &,- 351 \\
\hline Eu sorrio muito & ,436 & ,197 & ,360 & ,213 &,- 619 & & , 104 & \\
\hline Eu não me acho atraente & ,152 & ,289 & , 194 & ,220 &,- 593 & -,357 & 130 & \\
\hline Não me divirto com outras pessoas & ,298 & ,192 & ,348 &,- 152 &,- 502 &,- 217 & ,369 & 141, \\
\hline Não me sinto particularmente saudável & ,189 & ,399 & , 122 &, 117 &,- 124 &,- 610 & ,207 &,- 305 \\
\hline Sempre tenho boas influencias nos acontecimentos & ,299 & ,211 & ,275 & ,208 &,- 185 &, 566 & 144 &,- 207 \\
\hline Eu acho que o mundo que o mundo é um bom lugar & ,433 & ,334 & ,246 & &,- 297 &,- 447 & & ,106 \\
\hline $\begin{array}{l}\text { Não tenho particularmente senso de significado e propósito } \\
\text { para minha vida }\end{array}$ & 102, & 122, & & & & & 681, & \\
\hline Eu particularmente não sou otimista sobre o futuro & 352, & ,300 & 266, & 348, &,- 359 & -,294 & ,486 & \\
\hline Não tenho particularmente memórias felizes do passado & ,380 & ,323 & ,273 & , 179 &, 171 &,- 370 & ,393 & \\
\hline Sinto-me alegre e exaltado & ,429 & ,333 & ,280 & ,239 &,- 302 & & &,- 656 \\
\hline Sinto minha mente completamente alerta & ,250 & & , 156 & ,416 &,- 268 & & &,- 442 \\
\hline
\end{tabular}

Extraction Method: Principal Component Analysis.

Rotation Method: Oblimin with Kaiser Normalization. 
Tabela 7- Comunalidade fatoração oblíqua - Oxford Happiness Questionnaire

Communalities

\begin{tabular}{|l|r|}
\hline & Extraction \\
\hline Eu tenho sentimentos calorosos com quase todos &, 653 \\
Sinto que possuo muita energia &, 519 \\
Não tenho particularmente memórias felizes do passado &, 504 \\
Eu sou muito feliz &, 552 \\
Sinto que não estou, sobretudo, no controle de minha vida &, 526 \\
Eu sou intensamente interessado em outras pessoas &, 603 \\
Não me sinto particularmente satisfeito com a maneira que sou &, 394 \\
Estou muito satisfeito com tudo em minha vida &, 604 \\
Sinto-me alegre e exaltado &, 631 \\
Não tenho particularmente senso de significado e propósito para minha vida &, 498 \\
Sempre tenho boas influencias nos acontecimentos &, 569 \\
Eu particularmente não sou otimista sobre o futuro &, 445 \\
A vida é boa &, 541 \\
Sempre contagio de alegria outras pessoas &, 643 \\
Sinto minha mente completamente alerta &, 362 \\
Eu sinto que a vida é muito recompensada &, 471 \\
Eu raramente me sinto descansado &, 462 \\
Existe uma diferença entre o que gostaria de fazer e o que faço &, 511 \\
Não é fácil tomar decisões &, 619 \\
Não me sinto particularmente saudável &, 556 \\
Eu acho a maioria das coisas agradáveis &, 474 \\
Eu acho que o mundo que o mundo é um bom lugar &, 454 \\
Sempre me saio bem em tudo o que quero &, 486 \\
Eu não me acho atraente &, 471 \\
Eu sorrio muito &, 518 \\
Sinto-me capaz de conseguir qualquer coisa &, 564 \\
Não me divirto com outras pessoas &, 561 \\
Estou sempre comprometido e envolvido &, 583 \\
\hline Extraction Method: Principal Component Analysis. & \\
\end{tabular}

Tabela 8- Fatores obtidos na fatoração dos oito fatores - Oxford Happiness Questionnaire Structure Matrix

\begin{tabular}{|ll|r|r|}
\hline & \multicolumn{2}{|c|}{ Component } \\
\cline { 3 - 4 } & \multicolumn{1}{|c|}{1} & \multicolumn{1}{|c|}{2} \\
\hline REGR factor score 1 for analysis 1 &, 701 & \\
REGR factor score & 2 for analysis 1 &, 659 &, 287 \\
REGR factor score & 3 for analysis 1 &, 636 & \\
REGR factor score & 4 for analysis 1 &, 588 &,- 369 \\
REGR factor score & 5 for analysis 1 &,- 562 & \\
REGR factor score & 7 for analysis 1 &, 451 &, 356 \\
REGR factor score & 8 for analysis 1 &,- 281 &, 664 \\
REGR factor score & 6 for analysis 1 &,- 292 &,- 615 \\
\hline
\end{tabular}

Extraction Method: Principal Component Analysis.

Rotation Method: Oblimin with Kaiser Normalization. 
Tabela 9- Análise fatorial com a metade da amostra. - Oxford Happiness Questionnaire

\begin{tabular}{|c|c|c|c|c|c|c|c|}
\hline \multicolumn{8}{|c|}{ Structure Matrix } \\
\hline & \multicolumn{7}{|c|}{ Component } \\
\hline & 1 & 2 & 3 & 4 & 5 & 6 & 7 \\
\hline Sorrio muito & ,766 & ,210 &, 188 &,- 172 & &, 157 & ,138 \\
\hline $\begin{array}{l}\text { Sempre contagio de alegria outras } \\
\text { pessoas }\end{array}$ & ,718 & & &,- 141 & & ,249 & ,383 \\
\hline $\begin{array}{l}\text { Setimento calorosos com quase } \\
\text { todos }\end{array}$ & & ,821 & &,- 121 & & & \\
\hline sou interessado em outras pessoa & ,163 &, 598 & ,379 & ,104 & & 313 & ,123 \\
\hline Possui muita energia & 261 & ,478 & &,- 468 & 290 & ,217 & \\
\hline Me acho atraente & 149 & & 660 &,- 107 & ,281 & & , 166 \\
\hline Acho que o mundo é um bom lugar & 140 & & 634 &,- 160 &,- 150 & 176 & ,382 \\
\hline Me divirto com outras pessoas & ,426 & ,126 &, 555 &,- 262 & ,192 &,- 108 & \\
\hline Sinto-me particularmente saudável & &,- 330 & ,466 &,- 272 & 291 & ,257 & , 196 \\
\hline $\begin{array}{l}\text { Tenho influencia boa nos } \\
\text { acontecimentos }\end{array}$ & ,362 & ,315 &,- 375 & & ,266 & ,202 & 319 \\
\hline A vida é boa & ,329 & & &,- 721 & & & ,312 \\
\hline Tenho memória felizes do passado &,- 179 & &, 178 &,- 668 & ,181 & & ,141 \\
\hline Sinto a vida recompensada & ,386 & &, 159 &,- 512 & & ,250 & ,454 \\
\hline Acho fácil tomar decisões & & & 107 & & ,755 & & ,232 \\
\hline Sou otimista sobre o futuro & 224 & & ,332 &,- 450 & ,496 & ,375 & 127 \\
\hline $\begin{array}{l}\text { Me sinto satisfeito com a amenira que } \\
\text { sou }\end{array}$ & ,264 &,- 277 & &,- 302 & ,433 & 274 & ,327 \\
\hline Estou envolvido e comprometido. & ,106 & & & & & ,735 & \\
\hline $\begin{array}{l}\text { Sinto-me capaz de conseguir } \\
\text { qualquer coisa }\end{array}$ & ,477 & & & & ,430 &, 529 & ,228 \\
\hline Acho a maioria das coisas agradáveis & ,221 & &, 104 &,- 389 & &, 510 & ,283 \\
\hline $\begin{array}{l}\text { Sempre me saio bem em tudo o que } \\
\text { quero }\end{array}$ & & ,152 & &,- 275 & ,315 & ,471 & ,413 \\
\hline Sinto-me satisfeito com a vida & ,220 & &, 151 &,- 341 & ,108 & ,314 & ,733 \\
\hline Sinto-me alegre e exaltado & ,490 & ,136 & &,- 127 & ,195 & ,273 & ,709 \\
\hline Faço o que gosto & & & 179 &,- 194 & ,241 & & 652 \\
\hline Sou feliz & ,419 & 171 & 200 &,- 544 & 146 & ,273 &, 548 \\
\hline
\end{tabular}

Extraction Method: Principal Component Analysis.

Rotation Method: Oblimin with Kaiser Normalization.

Tabela 10- Análise Discriminante - Escala reduzida obtida por nossa análise

Canonical Discriminant Function Coefficients

\begin{tabular}{|l|r|}
\hline & Function \\
\cline { 2 - 2 } & \multicolumn{1}{|c|}{1} \\
\hline Eu tenho sentimentos calorosos com quase todos &, 134 \\
Não tenho particularmente memórias felizes do passado &, 098 \\
Eu sou muito feliz &, 209 \\
Sinto que não estou, sobretudo, no controle de minha vida &, 163 \\
Eu não me sinto particularmente satisfeito com a maneira &, 103 \\
que sou &, 142 \\
Estou muito satisfeito com tudo em minha vida &, 104 \\
Não tenho particularmente senso de significado e propósito &, 193 \\
para minha vida &, 182 \\
Eu particularmente não sou otimista sobre o futuro &, 210 \\
Sinto minha mente completamente alerta &, 110 \\
Existe uma distância entre o que eu gostaria de fazer e o &, 237 \\
que faço &, 172 \\
Não me sinto particularmente saudável &, 131 \\
Eu acho a maioria das coisas agradáveis &, 190 \\
Sempre me saio bem em tudo o que quero & $-10,602$ \\
Eu não me acho atraente & \\
Não me divirto com outras pessoas & (Constant)
\end{tabular}

Unstandardized coefficients 
Tabela 11- Comunalidades escala reduzida - OHQ

\begin{tabular}{|c|c|c|}
\hline \multicolumn{3}{|l|}{ Communalities } \\
\hline & Initial & Extraction \\
\hline Eu tenho sentimentos calorosos com quase todos & 1,000 & ,687 \\
\hline Eu sou muito feliz & 1,000 & ,499 \\
\hline Sinto que não estou, sobretudo, no controle de minha vida & 1,000 &, 566 \\
\hline $\begin{array}{l}\text { Eu não me sinto particularmente satisfeito com a maneira } \\
\text { que sou }\end{array}$ & 1,000 & ,432 \\
\hline Estou muito satisfeito com tudo em minha vida & 1,000 &, 520 \\
\hline $\begin{array}{l}\text { Não tenho particularmente senso de significado e propósito } \\
\text { para minha vida }\end{array}$ & 1,000 & ,136 \\
\hline Eu particularmente não sou otimista sobre o futuro & 1,000 & ,424 \\
\hline Sinto minha mente completamente alerta & 1,000 &, 527 \\
\hline $\begin{array}{l}\text { Existe uma distância entre o que eu gostaria de fazer e o } \\
\text { que faço }\end{array}$ & 1,000 & ,375 \\
\hline Não me sinto particularmente saudável & 1,000 & ,389 \\
\hline Eu acho a maioria das coisas agradáveis & 1,000 & ,450 \\
\hline Sempre me saio bem em tudo o que quero & 1,000 & ,493 \\
\hline Eu não me acho atraente & 1,000 & ,480 \\
\hline Não me divirto com outras pessoas & 1,000 & ,630 \\
\hline
\end{tabular}

Extraction Method: Principal Component Analysis.

Tabela 12- Estrutura fatorial escala reduzida $\mathrm{OHQ}$

\begin{tabular}{|c|c|c|c|c|}
\hline \multicolumn{5}{|l|}{ Structure Matrix } \\
\hline & \multicolumn{4}{|c|}{ Component } \\
\hline & 1 & 2 & 3 & 4 \\
\hline Sinto que não estou, sobretudo, no controle de minha vida & 643 &,- 395 & ,162 & \\
\hline $\begin{array}{l}\text { Eu não me sinto particularmente satisfeito com a maneira } \\
\text { que sou }\end{array}$ & ,639 & & ,298 &,- 176 \\
\hline $\begin{array}{l}\text { Existe uma distância entre o que eu gostaria de fazer e o que } \\
\text { faço }\end{array}$ &, 591 & ,110 & & \\
\hline Estou muito satisfeito com tudo em minha vida &, 551 &,- 184 & &,- 533 \\
\hline Não me sinto particularmente saudável &, 509 & ,234 & ,324 &,- 223 \\
\hline Eu tenho sentimentos calorosos com quase todos & &,- 806 & &,- 135 \\
\hline Não me divirto com outras pessoas &, 161 &,- 250 & ,734 & \\
\hline Eu não me acho atraente & & ,101 & 671 &,- 171 \\
\hline Eu particularmente não sou otimista sobre o futuro & ,271 & &, 571 &,- 372 \\
\hline $\begin{array}{l}\text { Não tenho particularmente senso de significado e propósito } \\
\text { para minha vida }\end{array}$ & ,257 & & ,306 & \\
\hline Sempre me saio bem em tudo o que quero & ,197 &,- 189 & &,- 688 \\
\hline Sinto minha mente completamente alerta & &, 110 & ,117 &,- 685 \\
\hline Eu sou muito feliz & ,382 &,- 292 & ,397 &,- 540 \\
\hline Eu acho a maioria das coisas agradáveis & ,202 &,- 455 & &,- 518 \\
\hline
\end{tabular}

Extraction Method: Principal Component Analysis.

Rotation Method: Oblimin with Kaiser Normalization.

Tabela 13- Tabela de correlações - Escala Geral de Felicidade

\begin{tabular}{|rl|r|r|r|r|}
\multicolumn{7}{|c|}{ Correlation Matrix } \\
\hline Correlation & ef1 & \multicolumn{1}{|c|}{ ef1 } & \multicolumn{1}{|c|}{ ef2 } & \multicolumn{1}{c|}{ ef3 } & \multicolumn{1}{c|}{ ef4 } \\
& ef2 &, 000 &, 681 &, 433 &, 331 \\
& ef3 &, 431 & 1,000 &, 397 &, 283 \\
& ef4 &, 331 &, 397 & 1,000 &, 246 \\
&, 283 &, 246 & 1,000 \\
\hline
\end{tabular}


Tabela 14- Análise de médias - Escala Geral de Felicidade.

Independent Samples Test

\begin{tabular}{|c|c|c|c|c|c|c|c|c|c|c|}
\hline & & \multicolumn{2}{|c|}{$\begin{array}{l}\text { Levene's Test for } \\
\text { Equality of Variances }\end{array}$} & \multicolumn{7}{|c|}{ t-test for Equality of Means } \\
\hline & & \multirow[b]{2}{*}{$\mathrm{F}$} & \multirow[b]{2}{*}{ Sig. } & \multirow[b]{2}{*}{$t$} & \multirow[b]{2}{*}{$\mathrm{df}$} & \multirow[b]{2}{*}{ Sig. (2-tailed) } & \multirow{2}{*}{$\begin{array}{c}\text { Mean } \\
\text { Difference }\end{array}$} & \multirow{2}{*}{$\begin{array}{l}\text { Std. Error } \\
\text { Difference }\end{array}$} & \multicolumn{2}{|c|}{$\begin{array}{l}95 \% \text { Confidence } \\
\text { Interval of the } \\
\text { Difference }\end{array}$} \\
\hline & & & & & & & & & Lower & Upper \\
\hline ef1 & $\begin{array}{l}\text { Equal variances } \\
\text { assumed } \\
\text { Equal variances } \\
\text { not assumed }\end{array}$ & 49,091 &, 000 & $\begin{array}{l}-19,789 \\
-18,893\end{array}$ & $\begin{array}{r}480 \\
317,016\end{array}$ & $\begin{array}{l}, 000 \\
, 000\end{array}$ & $\begin{array}{r}-1,74775 \\
-1,74775\end{array}$ & $\begin{array}{l}, 08832 \\
, 09251\end{array}$ & $\begin{array}{l}-1,92129 \\
-1,92976\end{array}$ & $\begin{array}{l}-1,57421 \\
-1,56574\end{array}$ \\
\hline ef2 & $\begin{array}{l}\text { Equal variances } \\
\text { assumed } \\
\text { Equal variances } \\
\text { not assumed }\end{array}$ & 50,938 &, 000 & $\begin{array}{l}-16,198 \\
-15,406\end{array}$ & $\begin{array}{r}480 \\
304,240\end{array}$ & $\begin{array}{l}, 000 \\
, 000\end{array}$ & $\begin{array}{l}-1,55911 \\
-1,55911\end{array}$ & $\begin{array}{l}, 09626 \\
, 10120\end{array}$ & $\begin{array}{l}-1,74825 \\
-1,75826\end{array}$ & $\begin{array}{l}-1,36998 \\
-1,35997\end{array}$ \\
\hline ef3 & $\begin{array}{l}\text { Equal variances } \\
\text { assumed } \\
\text { Equal variances } \\
\text { not assumed }\end{array}$ & 9,563 & ,002 & $\begin{array}{l}-13,825 \\
-13,585\end{array}$ & $\begin{array}{r}480 \\
420,729\end{array}$ & $\begin{array}{l}, 000 \\
, 000\end{array}$ & $\begin{array}{r}-1,70003 \\
-1,70003\end{array}$ & $\begin{array}{l}\text {,12297 } \\
\text {,12514 }\end{array}$ & $\begin{array}{l}-1,94166 \\
-1,94601\end{array}$ & $\begin{array}{l}-1,45841 \\
-1,45406\end{array}$ \\
\hline
\end{tabular}

Tabela 15- Análise Fatorial- Escala Geral de Felicidade

\section{Component Matrix}

\begin{tabular}{|l|r|}
\hline & $\begin{array}{c}\text { Compone } \\
\text { nt }\end{array}$ \\
\cline { 2 - 2 } & \multicolumn{1}{|c|}{$\begin{array}{l}\text {,860 } \\
\text { Em geral me considero }\end{array}$} \\
Comparando com a maioria de meus amigos, eu me considero &, 832 \\
Algumas pessoas geralmente são muito felizes &, 688 \\
Algumas pessoas geralmente não são muito felizes &, 563 \\
\hline
\end{tabular}

Extraction Method: Principal Component Analysis.

a. 1 components extracted.

Tabela 16- Comunalidades Escala Geral de Felicidade

Communalities

\begin{tabular}{|l|r|r|}
\hline & \multicolumn{1}{|c|}{ Initial } & Extraction \\
\hline Em geral me considero & 1,000 &, 739 \\
Comparando com a maioria de meus amigos, eu & 1,000 &, 693 \\
me considero & 1,000 &, 474 \\
Algumas pessoas geralmente são muito felizes &, 317 \\
Algumas pessoas geralmente não são muito felizes & 1,000 &, \\
\hline
\end{tabular}

Extraction Method: Principal Component Analysis. 
Tabela 17- Análise Fatorial Idades - Faixa etária 1-OHQ

\begin{tabular}{|c|c|c|c|c|c|c|c|c|}
\hline \multicolumn{9}{|c|}{ Structure Matrix } \\
\hline & \multicolumn{8}{|c|}{ Component } \\
\hline & 1 & 2 & 3 & 4 & 5 & 6 & 7 & 8 \\
\hline Sempre tenho boas influencias nos acontecimentos & 7,742 & & 209 &,- 237 &,- 147 & &,- 234 & ,118 \\
\hline Sinto-me alegre e exaltado & ,711 & ,233 & &,- 264 &,- 113 & 157 & &,- 195 \\
\hline Sempre me saio bem em tudo o que quero & ,581 & ,136 & ,113 &,- 284 & & ,327 & & ,465 \\
\hline Sinto que possuo muita energia &, 554 & ,204 & ,283 & & & ,185 &,- 213 & ,224 \\
\hline Eu sou muito feliz & ,527 & 203 & 141 &,- 507 &,- 237 & 177 &,- 185 & ,280 \\
\hline Não me sinto particularmente saudável & & 679 & &,- 229 & & & &,- 105 \\
\hline Não tenho particularmente memórias felizes do passado & & 645 & 184 & & & 193 & & ,247 \\
\hline Não acho fácil tomar decisões & ,132 & ,642 & & ,135 & ,251 &,- 140 &,- 299 & ,325 \\
\hline $\begin{array}{l}\text { Eu não me sinto particularmente satisfeito com a maneira que } \\
\text { sou }\end{array}$ & ,287 &, 507 &,- 114 &,- 235 & &,- 176 & & \\
\hline Eu tenho sentimentos calorosos com quase todos & 205 & & ,721 & &,- 142 & & & \\
\hline Eu sou intensamente interessado em outras pessoas & & & ,721 & & & 154 &,- 251 & \\
\hline Sinto que não estou, sobretudo, no controle de minha vida & 148 & ,381 & ,417 &,- 343 & , 180 &,- 190 & ,389 & \\
\hline Eu não acho que o mundo que o mundo é um bom lugar & & ,303 & &,- 675 & &,- 201 &,- 123 & \\
\hline Eu acho a maioria das coisas agradáveis & ,262 & & ,272 &,- 667 & &, 174 & & \\
\hline Eu sinto que a vida é muito recompensada & ,498 & & 112 &,- 610 & & &,- 358 & ,145 \\
\hline Estou muito satisfeito com tudo em minha vida & ,372 & ,372 &,- 102 &,- 591 & & ,340 & &,- 132 \\
\hline A vida é boa & ,357 & ,278 &,- 187 &,- 541 &,- 413 & &,- 152 & ,282 \\
\hline $\begin{array}{l}\text { Existe uma distância entre o que eu gostaria de fazer e o que } \\
\text { faço }\end{array}$ & ,276 & ,283 &, 130 &,- 309 & ,646 &,- 120 & & \\
\hline Eu sorrio muito & ,438 &, 127 & ,306 &,- 404 &,- 550 & & & \\
\hline Não me divirto com outras pessoas & ,169 & ,179 & ,350 & &,- 517 &,- 382 &,- 303 & 171 \\
\hline Estou sempre comprometido e envolvido & ,133 & & ,105 & & &, 772 & & \\
\hline Sinto-me capaz de conseguir qualquer coisa & ,411 & ,129 & ,126 &,- 144 &,- 343 &, 557 &,- 239 & ,359 \\
\hline Sempre contagio de alegria outras pessoas & ,470 & & &,- 273 &,- 118 & &,- 695 &,- 107 \\
\hline Eu não me acho atraente & & ,364 & ,380 &,- 283 & & 112 &,- 654 & ,107 \\
\hline $\begin{array}{l}\text { Não tenho particularmente senso de significado e propósito } \\
\text { para minha vida }\end{array}$ & & &,- 141 & & & &, 111 & ,633 \\
\hline Eu particularmente não sou otimista sobre o futuro & 223 & ,333 & ,242 &,- 243 &,- 241 & &,- 329 & 563, \\
\hline
\end{tabular}

Extraction Method: Principal Component Analysis.

Rotation Method: Oblimin with Kaiser Normalization. 
Tabela 18-Comunalidades Idades - Faixa etária 1-OHQ

Communalities

\begin{tabular}{|l|c|c|}
\hline & Initial & $\begin{array}{c}\text { Extrac } \\
\text { tion }\end{array}$ \\
\hline Eu tenho sentimentos calorosos com quase todos & 1,000 &, 572 \\
Sinto que possuo muita energia & 1,000 &, 441 \\
Não tenho particularmente memórias felizes do passado & 1,000 &, 535 \\
Eu sou muito feliz & 1,000 &, 513 \\
Sinto que não estou, sobretudo, no controle de minha vida & 1,000 &, 676 \\
Eu sou intensamente interessado em outras pessoas & 1,000 &, 568 \\
Eu não me sinto particularmente satisfeito com a maneira que & 1,000 &, 385 \\
sou & 1,000 &, 641 \\
Estou muito satisfeito com tudo em minha vida & 1,000 &, 621 \\
Sinto-me alegre e exaltado & 1,000 &, 606 \\
Sempre tenho boas influencias nos acontecimentos & 1,000 &, 543 \\
Eu particularmente não sou otimista sobre o futuro & 1,000 &, 640 \\
A vida é boa & 1,000 &, 684 \\
Sempre contagio de alegria outras pessoas & 1,000 &, 606 \\
Eu sinto que a vida é muito recompensada & 1,000 &, 692 \\
Não acho fácil tomar decisões & 1,000 &, 519 \\
Não me sinto particularmente saudável & 1,000 &, 551 \\
Eu acho a maioria das coisas agradáveis & 1,000 &, 625 \\
Eu não acho que o mundo que o mundo é um bom lugar & 1,000 &, 615 \\
Sempre me saio bem em tudo o que quero & 1,000 &, 683 \\
Eu não me acho atraente & 1,000 &, 588 \\
Eu sorrio muito & 1,000 &, 621 \\
Sinto-me capaz de conseguir qualquer coisa & 1,000 &, 644 \\
Não me divirto com outras pessoas & 1,000 &, 608 \\
Estou sempre comprometido e envolvido & 1,000 &, 669 \\
Existe uma distância entre o que eu gostaria de fazer e o que & 1,000 &, 476 \\
faço & & \\
Não tenho particularmente senso de significado e propósito & & \\
para minha vida & & \\
\hline Extraction Method: Principal Component Analysis. & & \\
\hline
\end{tabular}

Extraction Method: Principal Component Analysis. 
Tabela 19- Comparação análise fatorial questionário total $x$ idades menores que 24 anos

Fatores obtidos no questionário total

FATOR 1- Satisfaç̃o com a vida 9,45\%

A vida é boa

Estou muito satisfeito com tudo em minha vida

Eu acho a maioria das coisas agradáveis

FATOR 1- Satisfação com a vida $9,45 \%$

Eu sinto que a vida é muito recompensada

Eu sou muito feliz

\section{FATOR 2 - Controle - 7,26\%}

Eu raramente me sinto descansado

Existe uma diferença entre o que gostaria de fazer e o que faço

Não acho fácil tomar decisões

Eu não me sinto particularmente satisfeito com a maneira que sou

Sinto que não estou, sobretudo, no controle de minha vida

FATOR 3 - Relacão positiva com outros - 7,22\%

Eu sou intensamente interessado em outras pessoas Eu tenho sentimentos calorosos com quase todos

Sinto que possuo muita energia

\section{FATOR 4 - Autonomia- $7,14 \%$}

Estou sempre comprometido e envolvido

Sempre me saio bem em tudo o que quero

Sinto-me capaz de conseguir qualquer coisa

FATOR 5 - Superioridade ambiental $-5,88 \%$

Eu não me acho atraente

Não me divirto com outras pessoas

Sempre contagio de alegria outras pessoas

Eu sorrio muito

FATOR 6 - Aceitação -5,73\%

Sempre tenho boas influencias nos acontecimentos

Não me sinto particularmente saudável

Eu não acho que o mundo é um bom lugar

$$
\text { FATOR } 7 \text { - Propósito-5,07\% }
$$

Não tenho particularmente senso de significado e propósito para minha vida

Eu particularmente não sou otimista sobre o futuro Não tenho particularmente memórias felizes do passado

FATOR 8 - Disposição mental- 5,01\%

Sinto-me alegre e exaltado

Sinto minha mente completamente alerta
Fatores obtidos idades até 24 anos

FATOR 4- 6,03\%

A vida é boa

Estou muito satisfeito com tudo em minha vida

Eu acho a maioria das coisas agradáveis

$$
\text { FATOR 4- 6,03\% }
$$

Eu sinto que a vida é muito recompensada

Eu não acho que o mundo que o mundo é um bom lugar FATOR 2- 8,06\%

Não me sinto particularmente saudável

Não tenho particularmente memórias felizes do passado Não acho fácil tomar decisões

Eu não me sinto particularmente satisfeito com a maneira que sou

\section{FATOR 3- 6,66\%}

Eu sou intensamente interessado em outras pessoas Eu tenho sentimentos calorosos com quase todos Sinto que não estou, sobretudo, no controle de minha vida

\section{FATOR 6- 4,51\%}

Estou sempre comprometido e envolvido

Sinto-me capaz de conseguir qualquer coisa

$$
\text { FATOR 5- 5,41\% }
$$

Existe uma distância entre o que eu gostaria de fazer e o que faço

Não me divirto com outras pessoas

Eu sorrio muito

FATOR $7-4,34 \%$

Sempre contagio de alegria outras pessoas

Eu não me acho atraente

\section{FATOR 8- 4,08\%}

Não tenho particularmente senso de significado e propósito para minha vida

Eu particularmente não sou otimista sobre o futuro

\section{FATOR 1- 19,83\%}

Sempre tenho boas influencias nos acontecimentos

Sinto-me alegre e exaltado

Sempre me saio bem em tudo o que quero

Sinto que possuo muita energia

Eu sou muito feliz 
Tabela 20 - Análise Fatorial Idades - Faixa etária 2-OHQ

Structure Matrix

\begin{tabular}{|c|c|c|c|c|c|c|c|}
\hline & \multicolumn{7}{|c|}{ Component } \\
\hline & 1 & 2 & 3 & 4 & 5 & 6 & 7 \\
\hline Sempre contagio de alegria outras pessoas & ,788 & ,108 &,- 131 &,- 266 & ,365 & 152 & \\
\hline Sinto minha mente completamente alerta & ,717 & &,- 103 &,- 170 & & 268 & , 165 \\
\hline Eu sorrio muito & 682 & &,- 322 &,- 260 & ,460 & 179 & 164 \\
\hline Eu sou muito feliz &, 546 & 122 &,- 528 &,- 437 & ,401 & ,242 & ,242 \\
\hline Não acho fácil tomar decisões & & ,748 & & & & ,129 & \\
\hline Não me sinto particularmente saudável & & ,692 &,- 184 &,- 248 & & & 277 \\
\hline Eu particularmente não sou otimista sobre o futuro & 364 &, 538 &,- 270 & & ,241 & ,181 & ,377 \\
\hline Não tenho particularmente memórias felizes do passado & & &,- 719 &,- 108 & , 138 & ,210 & \\
\hline $\begin{array}{l}\text { Não tenho particularmente senso de significado e propósito } \\
\text { para minha vida }\end{array}$ & 217 & ,288 &,- 684 &,- 169 & & & 281 \\
\hline A vida é boa & 374 &,- 155 &,- 635 &,- 140 & 120 & & \\
\hline Sinto que não estou, sobretudo, no controle de minha vida & & , 180 &,- 568 &,- 382 & & 279 & 178 \\
\hline $\begin{array}{l}\text { Eu não me sinto particularmente satisfeito com a maneira que } \\
\text { sou }\end{array}$ & 266 & ,441 &,- 521 &,- 280 &,- 196 & & ,238 \\
\hline Eu raramente me sinto descansado & ,133 & ,294 &,- 475 & ,258 & & , 171 & ,324 \\
\hline Estou muito satisfeito com tudo em minha vida & , 162 & , 130 &,- 269 &,- 813 & 175 & ,256 & 149 \\
\hline Sinto-me alegre e exaltado & ,346 & ,295 &,- 193 &,- 682 & ,381 & ,113 & \\
\hline Eu sinto que a vida é muito recompensada & ,375 & &,- 282 &,- 655 & & ,302 & ,415 \\
\hline Sempre tenho boas influencias nos acontecimentos & ,271 & &,- 195 &,- 392 & 287 & ,234 &,- 265 \\
\hline Eu tenho sentimentos calorosos com quase todos & , 155 &,- 120 &,- 132 &,- 107 & ,753 & ,210 & \\
\hline Eu sou intensamente interessado em outras pessoas & , 173 & & &,- 184 & ,675 & & 164 \\
\hline Sinto que possuo muita energia & ,386 & ,406 &,- 231 &,- 110 &, 501 & ,214 & \\
\hline Sinto-me capaz de conseguir qualquer coisa & ,289 & ,175 &,- 231 &,- 116 & & ,789 & ,121 \\
\hline Eu acho a maioria das coisas agradáveis & , 109 & &,- 293 &,- 316 & 406 &, 573 & 127 \\
\hline Sempre me saio bem em tudo o que quero & ,260 & ,308 & &,- 404 & , 145 &, 534 & \\
\hline Eu não acho que o mundo que o mundo é um bom lugar & & ,277 &,- 164 &,- 192 & ,283 &, 165 & ,710 \\
\hline Não me divirto com outras pessoas & 312 & ,122 &,- 323 &,- 244 & ,295 &,- 199 &, 557 \\
\hline Eu não me acho atraente & ,444 & ,168 & & & & ,303 & ,554 \\
\hline
\end{tabular}

Extraction Method: Principal Component Analysis.

Rotation Method: Oblimin with Kaiser Normalization.

Tabela 21- Comunalidades- - Faixa etária 2-OHQ

\begin{tabular}{|c|c|c|}
\hline \multicolumn{3}{|l|}{ Communalities } \\
\hline & Initial & $\begin{array}{c}\text { Extrac } \\
\text { tion }\end{array}$ \\
\hline Eu tenho sentimentos calorosos com quase todos & 1,000 & ,608 \\
\hline Sinto que possuo muita energia & 1,000 &, 545 \\
\hline Não tenho particularmente memórias felizes do passado & 1,000 & ,624 \\
\hline Eu sou muito feliz & 1,000 & ,630 \\
\hline Sinto que não estou, sobretudo, no controle de minha vida & 1,000 &, 507 \\
\hline Eu sou intensamente interessado em outras pessoas & 1,000 &, 518 \\
\hline $\begin{array}{l}\text { Eu não me sinto particularmente satisfeito com a maneira que } \\
\text { sou }\end{array}$ & 1,000 &, 581 \\
\hline Estou muito satisfeito com tudo em minha vida & 1,000 & 697 \\
\hline Sinto-me alegre e exaltado & 1,000 & 642 \\
\hline Sempre tenho boas influencias nos acontecimentos & 1,000 & ,379 \\
\hline Eu particularmente não sou otimista sobre o futuro & 1,000 &, 521 \\
\hline A vida é boa & 1,000 &, 546 \\
\hline Sempre contagio de alegria outras pessoas & 1,000 & ,695 \\
\hline Eu sinto que a vida é muito recompensada & 1,000 & ,683 \\
\hline Não acho fácil tomar decisões & 1,000 &, 592 \\
\hline Não me sinto particularmente saudável & 1,000 &, 583 \\
\hline Eu acho a maioria das coisas agradáveis & 1,000 &, 526 \\
\hline Eu não acho que o mundo que o mundo é um bom lugar & 1,000 & ,640 \\
\hline Sempre me saio bem em tudo o que quero & 1,000 & ,476 \\
\hline Eu não me acho atraente & 1,000 &, 532 \\
\hline Eu sorrio muito & 1,000 & ,613 \\
\hline Sinto-me capaz de conseguir qualquer coisa & 1,000 & 669 \\
\hline Não me divirto com outras pessoas & 1,000 &, 576 \\
\hline $\begin{array}{l}\text { Não tenho particularmente senso de significado e propósito para } \\
\text { minha vida }\end{array}$ & 1,000 &, 539 \\
\hline Sinto minha mente completamente alerta & 1,000 &, 577 \\
\hline Eu raramente me sinto descansado & 1,000 & , 478 \\
\hline
\end{tabular}

Extraction Method: Principal Component Analysis. 
Tabela 22- Comparação análise fatorial questionário completo x faixa etária 25 - 32 anos

Fatores obtidos no questionário total

FATOR 1- Satisfacão com a vida 9,45\%

A vida é boa

Estou muito satisfeito com tudo em minha vida

Eu acho a maioria das coisas agradáveis

Eu sinto que a vida é muito recompensada

Eu sou muito feliz

FATOR 2 - Controle - 7,26\%

Eu raramente me sinto descansado

Existe uma diferença entre o que gostaria de fazer e o que faço

Não acho fácil tomar decisões

Eu não me sinto particularmente satisfeito com a maneira que sou

Sinto que não estou, sobretudo, no controle de minha vida

FATOR 3 - Relacão positiva com outros - 7,22\%

Eu sou intensamente interessado em outras pessoas

Eu tenho sentimentos calorosos com quase todos

Sinto que possuo muita energia

FATOR 4 - Autonomia- 7,14\%

Estou sempre comprometido e envolvido

Sempre me saio bem em tudo o que quero

Sinto-me capaz de conseguir qualquer coisa

FATOR 5 - Superioridade ambiental $-5,88 \%$

Eu não me acho atraente

Não me divirto com outras pessoas

Sempre contagio de alegria outras pessoas

Eu sorrio muito

FATOR 6 - Aceitacão -5,73\%

Sempre tenho boas influencias nos acontecimentos

Não me sinto particularmente saudável

Eu não acho que o mundo é um bom lugar

$$
\text { FATOR } 7 \text { - Propósito-5,07\% }
$$

Não tenho particularmente senso de significado e propósito para minha vida

Eu particularmente não sou otimista sobre o futuro

Não tenho particularmente memórias felizes do passado

FATOR 8 - Disposicão mental- 5,01\%

Sinto-me alegre e exaltado

Sinto minha mente completamente alerta

Fatores obtidos idades entre 25 e 32 anos

FATOR 4- 5,70\%

Sempre tenho boas influencias nos acontecimentos

Estou muito satisfeito com tudo em minha vida

Sinto-me alegre e exaltado

Eu sinto que a vida é muito recompensada

\section{FATOR 3- 6,36\%}

Eu raramente me sinto descansado

Não tenho particularmente memórias felizes do passado Não tenho particularmente senso de significado e propósito para minha vida

Eu não me sinto particularmente satisfeito com a maneira que sou

Sinto que não estou, sobretudo, no controle de minha vida

A vida é boa

\section{FATOR 5- 5,15\%}

Eu sou intensamente interessado em outras pessoas Eu tenho sentimentos calorosos com quase todos

Sinto que possuo muita energia

$$
\text { FATOR 6- } 4,70 \%
$$

Eu acho a maioria das coisas agradáveis Sempre me saio bem em tudo o que quero Sinto-me capaz de conseguir qualquer coisa FATOR 1-22,82\%

Eu sou muito feliz

Sinto minha mente completamente alerta Sempre contagio de alegria outras pessoas Eu sorrio muito

\section{FATOR $7-4,20 \%$}

Eu não acho que o mundo que o mundo é um bom lugar Não me divirto com outras pessoas

Eu não me acho atraente

\section{FATOR 2- 8,67\%}

Não acho fácil tomar decisões

Não me sinto particularmente saudável

Eu particularmente não sou otimista sobre o futuro 
Tabela 23- Análise Fatorial Idades - Faixa etária 3-OHQ

\begin{tabular}{|c|c|c|c|c|c|c|c|c|}
\hline \multicolumn{9}{|c|}{ Structure Matrix } \\
\hline & \multicolumn{8}{|c|}{ Component } \\
\hline & 1 & 2 & 3 & 4 & 5 & 6 & 7 & 8 \\
\hline Estou muito satisfeito com tudo em minha vida & ,804 & ,277 & &,- 147 & ,122 & & 211 & ,288 \\
\hline Eu sou muito feliz & ,761 & ,288 & &,- 221 & ,310 &,- 265 & & ,264 \\
\hline Sinto-me alegre e exaltado & ,743 & & &,- 344 & ,278 &,- 109 & ,308 & 178 \\
\hline A vida é boa &, 595 & ,320 & &,- 465 & & &,- 195 & ,388 \\
\hline $\begin{array}{l}\text { Eu não me sinto particularmente satisfeito com a maneira que } \\
\text { sou }\end{array}$ &, 521 & ,472 & ,396 &,- 249 & &,- 141 & ,159 & \\
\hline Eu acho a maioria das coisas agradáveis & ,481 & ,199 & 157 &,- 234 & & ,220 & ,192 &, 101 \\
\hline $\begin{array}{l}\text { Existe uma distância entre o que eu gostaria de fazer e o que } \\
\text { faço }\end{array}$ & ,463 & ,221 &,- 110 &,- 312 &,- 148 &,- 373 &, 171 & ,199 \\
\hline Eu raramente me sinto descansado & & ,711 &,- 160 &,- 208 & &,- 222 & & \\
\hline Sinto que não estou, sobretudo, no controle de minha vida & , 191 & ,689 & ,191 & & &,- 113 & ,318 &,- 132 \\
\hline Não tenho particularmente memórias felizes do passado & ,379 & ,609 & & ,306 &, 124 &,- 140 & & , 199 \\
\hline Eu sinto que a vida é muito recompensada & ,298 & ,464 &,- 259 &,- 433 & , 108 & &,- 165 & ,423 \\
\hline Eu particularmente não sou otimista sobre o futuro & ,426 & ,451 & &,- 228 & &,- 147 &, 141 & ,376 \\
\hline Sempre tenho boas influencias nos acontecimentos & 180 & & ,730 &,- 193 & ,245 & & 254 & 102 \\
\hline Não me sinto particularmente saudável & ,324 & ,285 &,- 574 &,- 192 & ,229 &,- 162 & ,266 &,- 143 \\
\hline Sempre contagio de alegria outras pessoas & ,383 &, 167 & &,- 792 & , 187 &,- 112 &, 127 & ,260 \\
\hline Eu sorrio muito & ,229 & ,213 & &,- 741 & &,- 182 & , 167 & \\
\hline Sinto minha mente completamente alerta & ,200 & &,- 233 &,- 435 & ,374 & ,308 & ,301 & ,387 \\
\hline Eu tenho sentimentos calorosos com quase todos &, 115 & & ,152 & & ,772 & ,128 & &, 119 \\
\hline Sinto que possuo muita energia & ,215 & &,- 172 &,- 167 & ,712 &,- 225 & & ,255 \\
\hline Não me divirto com outras pessoas & 158 & ,242 & &,- 226 & ,249 &,- 738 & & \\
\hline Eu não me acho atraente & ,128 &, 144 & &,- 105 &,- 131 &,- 659 & ,329 &, 118 \\
\hline Não acho fácil tomar decisões & ,257 & ,205 & &,- 202 & &,- 140 & ,692 & ,139 \\
\hline Sinto-me capaz de conseguir qualquer coisa & ,292 & ,139 & &,- 522 & ,218 & &, 526 & ,418 \\
\hline $\begin{array}{l}\text { Não tenho particularmente senso de significado e propósito } \\
\text { para minha vida }\end{array}$ & ,262 & ,419 &, 115 &,- 176 & ,347 &,- 441 & ,482 & \\
\hline Estou sempre comprometido e envolvido & ,122 & & &,- 162 & ,171 & & & ,739 \\
\hline Sempre me saio bem em tudo o que quero & ,428 & & & & ,248 & & ,317 & 614 \\
\hline
\end{tabular}

Extraction Method: Principal Component Analysis.

Rotation Method: Oblimin with Kaiser Normalization. 
Tabela 24- Comunalidades Idades - Faixa etária 3-OHQ

\section{Communalities}

\begin{tabular}{|c|c|c|}
\hline & Initial & $\begin{array}{c}\text { Extrac } \\
\text { tion }\end{array}$ \\
\hline Eu tenho sentimentos calorosos com quase todos & 1,000 &, 639 \\
\hline Sinto que possuo muita energia & 1,000 & ,628 \\
\hline Não tenho particularmente memórias felizes do passado & 1,000 & ,685 \\
\hline Eu sou muito feliz & 1,000 & ,717 \\
\hline Sinto que não estou, sobretudo, no controle de minha vida & 1,000 & ,614 \\
\hline $\begin{array}{l}\text { Eu não me sinto particularmente satisfeito com a maneira que } \\
\text { sou }\end{array}$ & 1,000 & ,605 \\
\hline Estou muito satisfeito com tudo em minha vida & 1,000 & 677 \\
\hline Sinto-me alegre e exaltado & 1,000 & 679 \\
\hline Sempre tenho boas influencias nos acontecimentos & 1,000 & ,661 \\
\hline Eu particularmente não sou otimista sobre o futuro & 1,000 & ,393 \\
\hline A vida é boa & 1,000 & ,647 \\
\hline Sempre contagio de alegria outras pessoas & 1,000 & ,681 \\
\hline Eu sinto que a vida é muito recompensada & 1,000 &, 581 \\
\hline Não acho fácil tomar decisões & 1,000 &, 546 \\
\hline Não me sinto particularmente saudável & 1,000 & ,658 \\
\hline Eu acho a maioria das coisas agradáveis & 1,000 & ,361 \\
\hline Sempre me saio bem em tudo o que quero & 1,000 &, 583 \\
\hline Eu não me acho atraente & 1,000 &, 556 \\
\hline Eu sorrio muito & 1,000 &, 579 \\
\hline Sinto-me capaz de conseguir qualquer coisa & 1,000 &, 593 \\
\hline Não me divirto com outras pessoas & 1,000 & ,657 \\
\hline $\begin{array}{l}\text { Não tenho particularmente senso de significado e propósito } \\
\text { para minha vida }\end{array}$ & 1,000 & ,604 \\
\hline Sinto minha mente completamente alerta & 1,000 & ,609 \\
\hline Eu raramente me sinto descansado & 1,000 &, 573 \\
\hline $\begin{array}{l}\text { Existe uma distância entre o que eu gostaria de fazer e o que } \\
\text { faço }\end{array}$ & 1,000 & ,431 \\
\hline Estou sempre comprometido e envolvido & 1,000 &, 568 \\
\hline
\end{tabular}

Extraction Method: Principal Component Analysis. 
Tabela 25- Comparação análise fatorial questionário completo $x$ faixa etária acima de 33 anos

Fatores obtidos no questionário total FATOR 1- Satisfação com a vida $9,45 \%$

A vida é boa

Estou muito satisfeito com tudo em minha vida

Eu acho a maioria das coisas agradáveis

Eu sinto que a vida é muito recompensada

Eu sou muito feliz

\section{FATOR 2 - Controle - $7,26 \%$}

Eu raramente me sinto descansado

Existe uma diferença entre o que gostaria de fazer e o que faço

Não acho fácil tomar decisões

Eu não me sinto particularmente satisfeito com a maneira que sou

Sinto que não estou, sobretudo, no controle de minha vida

FATOR 3 - Relação positiva com outros - 7,22\%

Eu sou intensamente interessado em outras pessoas

Eu tenho sentimentos calorosos com quase todos

Sinto que possuo muita energia

FATOR 4 - Autonomia- $7,14 \%$

Estou sempre comprometido e envolvido

Sempre me saio bem em tudo o que quero

Sinto-me capaz de conseguir qualquer coisa

FATOR 5 - Superioridade ambiental $-5,88 \%$

Eu não me acho atraente

Não me divirto com outras pessoas

Sempre contagio de alegria outras pessoas

Eu sorrio muito

FATOR 6 - Aceitação -5,73\%

Sempre tenho boas influencias nos acontecimentos Não me sinto particularmente saudável

Eu não acho que o mundo é um bom lugar

$$
\text { FATOR } 7 \text { - Propósito-5, 07\% }
$$

Não tenho particularmente senso de significado e propósito para minha vida

Eu particularmente não sou otimista sobre o futuro

Não tenho particularmente memórias felizes do passado

$$
\text { FATOR } 8 \text { - Disposição mental- 5,01\% }
$$

Sinto-me alegre e exaltado

Sinto minha mente completamente alerta
Fatores obtidos idades maior 33 anos

FATOR 1- 22,27\%

A vida é boa

Estou muito satisfeito com tudo em minha vida

Eu acho a maioria das coisas agradáveis

Eu não me sinto particularmente satisfeito com a maneira

que sou

Eu sou muito feliz

Sinto-me alegre e exaltado

Existe uma distância entre o que eu gostaria de fazer e o que faço

FATOR 2- 7,80\%

Eu raramente me sinto descansado

Eu sinto que a vida é muito recompensada

Não tenho particularmente memórias felizes do passado

Eu particularmente não sou otimista sobre o futuro

Sinto que não estou, sobretudo, no controle de minha vida

\section{FATOR 5- 5,30\%}

Eu tenho sentimentos calorosos com quase todos

Sinto que possuo muita energia

FATOR 8-3,98\%

Estou sempre comprometido e envolvido

Sempre me saio bem em tudo o que quero

\section{FATOR 6- 4,37\%}

Eu não me acho atraente

Não me divirto com outras pessoas

\section{FATOR 3- 6,16\%}

Sempre tenho boas influencias nos acontecimentos

Não me sinto particularmente saudável

\section{FATOR 7- 4,31\%}

Não tenho particularmente senso de significado e propósito para minha vida

Não acho fácil tomar decisões

Sinto-me capaz de conseguir qualquer coisa

\section{FATOR 4- 5,51\%}

Sempre contagio de alegria outras pessoas

Eu sorrio muito

Sinto minha mente completamente alerta

Tabela 26- Análise de variância para categorias etárias

\section{ANOVA}

\begin{tabular}{|ll|r|r|r|r|r|}
\hline & & \multicolumn{1}{c|}{$\begin{array}{c}\text { Sum of } \\
\text { Squares }\end{array}$} & df & Mean Square & \multicolumn{1}{c|}{ F } & Sig. \\
\hline EU & Between Groups & 15,490 & 5 & 3,098 & 1,706 &, 132 \\
& Within Groups & 837,238 & 461 & 1,816 & & \\
& Total & 852,728 & 466 & & & \\
\hline Equip_EGF_em_EU & Between Groups & 6,126 & 5 & 1,225 &, 662 &, 653 \\
& Within Groups & 855,576 & 462 & 1,852 & & \\
& Total & 861,702 & 467 & & & \\
\hline Equip_OHQ_em_EU & Between Groups & 8,136 & 5 & 1,627 &, 941 &, 454 \\
& Within Groups & 800,920 & 463 & 1,730 & & \\
& Total & 809,056 & 468 & & & \\
\hline
\end{tabular}


Tabela 27- Teste de médias equiparadas para das categorias etárias

\begin{tabular}{|c|c|c|c|c|c|c|c|c|c|c|}
\hline \multicolumn{11}{|c|}{ Paired Samples Test } \\
\hline \multirow[b]{3}{*}{ Idade_Categ } & & & \multicolumn{5}{|c|}{ Paired Differences } & \multirow[b]{3}{*}{$t$} & \multirow[b]{3}{*}{ df } & \multirow{3}{*}{$\begin{array}{c}\text { Sig. } \\
\text { (2-tailed) }\end{array}$} \\
\hline & & & \multirow[b]{2}{*}{ Mean } & \multirow[b]{2}{*}{ Std. Deviation } & \multirow{2}{*}{$\begin{array}{l}\text { Std. Error } \\
\text { Mean }\end{array}$} & \multicolumn{2}{|c|}{$\begin{array}{l}95 \% \text { Confidence } \\
\text { Interval of the } \\
\text { Difference }\end{array}$} & & & \\
\hline & & & & & & Lower & Upper & & & \\
\hline & Pair 1 & EU - Equip_EGF_em_EU & ,23147 & 1,12896 & ,30173 &,- 42037 & ,88331 & ,767 & 13 & ,457 \\
\hline & Pair 2 & EU - Equip_OHQ_em_EU & ,44207 & 1,53666 & ,39676 &,- 40891 & 1,29304 & 1,114 & 14 & 284 \\
\hline & Pair 3 & Equip_EGF_em_EU - Equip_OHQ_em_EU & ,28953 & 1,16044 & ,31014 &,- 38049 &, 95955 &, 934 & 13 & 368 \\
\hline Menos que 20 anos & Pair 1 & EU - Equip_EGF_em_EU &,- 10592 & 1,33319 & 16797 &,- 44168 & 22983 &,- 631 & 62 & ,531 \\
\hline & Pair 2 & EU - Equip_OHQ_em_EU &, 51490 & 1,45216 & ,18296 & ,14918 & ,88063 & 2,814 & 62 & ,007 \\
\hline & Pair 3 & Equip_EGF_em_EU - Equip_OHQ_em_EU & ,62083 & 1,17617 & ,14818 & ,32461 & ,91704 & 4,190 & 62 &, 000 \\
\hline $21-30$ anos & Pair 1 & EU - Equip_EGF_em_EU & 06691 & 1,20515 & 08144 &,- 09359 & 22742 & ,822 & 218 &, 412 \\
\hline & Pair 2 & EU - Equip_OHQ_em_EU & ,40838 & 1,14697 &, 07751 & ,25562 &, 56113 & 5,269 & 218 &, 000 \\
\hline & Pair 3 & Equip_EGF_em_EU - Equip_OHQ_em_EU & ,34127 & 1,07432 & ,07243 & ,19852 & 48402 & 4,712 & 219 &, 000 \\
\hline $31-40$ anos & Pair 1 & EU - Equip_EGF_em_EU &,- 01634 & ,94846 & ,09888 &,- 21276 & ,18008 &,- 165 & 91 & ,869 \\
\hline & Pair 2 & EU - Equip_OHQ_em_EU & ,13356 & 1,20862 & ,12533 &,- 11535 & ,38247 & 1,066 & 92 & ,289 \\
\hline & Pair 3 & Equip_EGF_em_EU - Equip_OHQ_em_EU & 11921 & 1,17760 & 12211 &,- 12331 & ,36174 & ,976 & 92 & ,331 \\
\hline $41-50$ anos & Pair 1 & EU - Equip_EGF_em_EU & $\begin{array}{l}-21325 \\
\end{array}$ & 1,11295 & 14022 &,- 49354 & 06704 & $-1,521$ & 62 & ,133 \\
\hline & Pair 2 & EU - Equip_OHQ_em_EU &,- 09805 & 1,40812 & 17741 &,- 45268 & 25658 &,- 553 & 62 & ,582 \\
\hline & Pair 3 & Equip_EGF_em_EU - Equip_OHQ_em_EU & ,11520 & 1,25946 & ,15868 &,- 20199 & ,43239 &, 726 & 62 & ,471 \\
\hline $51-60$ anos & Pair 1 & EU - Equip_EGF_em_EU &,- 00660 & 1,05038 & ,22394 &,- 47231 & ,45911 &,- 029 & 21 & ,977 \\
\hline & Pair 2 & EU - Equip_OHQ_em_EU &,- 13464 & 1,20093 & ,25604 &,- 66710 & ,39783 &,- 526 & 21 & ,605 \\
\hline & Pair 3 & Equip_EGF_em_EU - Equip_OHQ_em_EU &,- 12804 & 1,12985 & ,24088 &,- 62898 & ,37291 &,- 532 & 21 & ,601 \\
\hline Mais que 60 anos & Pair 1 & EU - Equip_EGF_em_EU &,- 03004 & 1,46919 &, 55530 & $-1,38881$ & 1,32873 &,- 054 & 6 & 959 \\
\hline & Pair 2 & EU - Equip_OHQ_em_EU & ,20214 &, 85064 & ,32151 &,- 58457 & ,98886 & ,629 & 6 &, 553 \\
\hline & Pair 3 & Equip_EGF_em_EU - Equip_OHQ_em_EU & ,23219 & 1,00687 & ,38056 &,- 69901 & 1,16338 & ,610 & 6 &, 564 \\
\hline
\end{tabular}

Tabela 28- Regressão idades EGF

Coefficients $^{\mathrm{a}}$

\begin{tabular}{|ll|r|r|r|r|r|}
\hline \multirow{2}{*}{ Model } & \multicolumn{2}{|c|}{$\begin{array}{c}\text { Unstandardized } \\
\text { Coefficients }\end{array}$} & \multicolumn{2}{c|}{$\begin{array}{c}\text { Standardized } \\
\text { Coefficients }\end{array}$} & & \\
\cline { 3 - 5 } & \multicolumn{1}{|c|}{$\mathrm{B}$} & Std. Error & \multicolumn{1}{|c|}{ Beta } & \multicolumn{1}{c|}{$\mathrm{t}$} & \multicolumn{1}{c|}{ Sig. } \\
\hline 1 & (Constant) & 22,286 &, 634 & & 35,165 &, 000 \\
& Idade &,- 022 &, 019 &,- 054 & $-1,158$ &, 248 \\
\hline
\end{tabular}

a. Dependent Variable: TOTAL_EGF

Tabela 29- Regressão idades OHQ

Coefficients ${ }^{\mathrm{a}}$

\begin{tabular}{|rl|r|r|r|r|r|}
\hline \multirow{2}{*}{ Model } & \multicolumn{2}{|c|}{$\begin{array}{c}\text { Unstandardized } \\
\text { Coefficients }\end{array}$} & \multicolumn{2}{c|}{$\begin{array}{c}\text { Standardized } \\
\text { Coefficients }\end{array}$} & \\
\cline { 2 - 5 } & \multicolumn{1}{|c|}{$\mathrm{B}$} & Std. Error & \multicolumn{1}{|c|}{ Beta } & \multicolumn{1}{c|}{$\mathrm{t}$} & \multicolumn{1}{c|}{ Sig. } \\
\hline 1 & (Constant) & 121,337 & 2,598 & & 46,712 &, 000 \\
& Idade &, 110 &, 080 &, 064 & 1,378 &, 169 \\
\hline
\end{tabular}

a. Dependent Variable: Total_OHQ

Tabela 30- Regressão idades EU

Coefficients $^{\mathrm{a}}$

\begin{tabular}{|ll|r|r|r|r|r|}
\hline \multirow{2}{*}{ Model } & \multicolumn{2}{|c|}{$\begin{array}{c}\text { Unstandardized } \\
\text { Coefficients }\end{array}$} & \multicolumn{2}{c|}{$\begin{array}{c}\text { Standardized } \\
\text { Coefficients }\end{array}$} & \\
\cline { 2 - 5 } & \multicolumn{1}{|c|}{$\mathrm{B}$} & Std. Error & \multicolumn{1}{c|}{ Beta } & \multicolumn{1}{c|}{$\mathrm{t}$} & Sig. \\
\hline 1 & (Constant) & 6,084 &, 192 & & 31,676 &, 000 \\
& Idade &,- 013 &, 006 &,- 101 & $-2,196$ &, 029 \\
\hline
\end{tabular}

a. Dependent Variable: EU 
Tabela 31- Regressão dummy idades- EGF

Coefficients $^{\mathrm{a}}$

\begin{tabular}{|c|c|c|c|c|c|c|}
\hline \multirow{2}{*}{\multicolumn{2}{|c|}{ Model }} & \multicolumn{2}{|c|}{$\begin{array}{c}\text { Unstandardized } \\
\text { Coefficients }\end{array}$} & \multirow{2}{*}{$\begin{array}{c}\text { Standardized } \\
\text { Coefficients }\end{array}$} & \multirow[b]{2}{*}{$t$} & \multirow[b]{2}{*}{ Sig. } \\
\hline & & $\mathrm{B}$ & Std. Error & & & \\
\hline \multirow[t]{6}{*}{1} & (Constant) & 21,403 &, 566 & & 37,789 &, 000 \\
\hline & Dummy_ldade_2 & ,366 & ,642 & ,041 &, 570 &, 569 \\
\hline & Dummy_Idade_3 & ,307 & ,721 & ,028 & ,426 & ,671 \\
\hline & Dummy_Idade_4 &,- 523 & ,786 &,- 041 &,- 665 &, 506 \\
\hline & Dummy_Idade_5 & ,025 & 1,015 & ,001 & ,025 & ,980 \\
\hline & Dummy_Idade_6 &,- 153 & 1,675 &,- 004 &,- 091 & ,927 \\
\hline
\end{tabular}

a. Dependent Variable: TOTAL_EGF

Tabela 32- Regressão dummy idades - OHQ

Coefficients $^{\mathrm{a}}$

\begin{tabular}{|c|c|c|c|c|c|c|}
\hline \multirow{2}{*}{\multicolumn{2}{|c|}{ Model }} & \multicolumn{2}{|c|}{$\begin{array}{l}\text { Unstandardized } \\
\text { Coefficients }\end{array}$} & \multirow{2}{*}{$\begin{array}{c}\text { Standardized } \\
\text { Coefficients } \\
\text { Beta }\end{array}$} & \multirow[b]{2}{*}{$t$} & \multirow[b]{2}{*}{ Sig. } \\
\hline & & $\mathrm{B}$ & Std. Error & & & \\
\hline \multirow[t]{6}{*}{1} & (Constant) & 5,135 &, 166 & & 30,980 &, 000 \\
\hline & Dummy_Idade_2 & ,264 & , 188 & , 100 & 1,403 & , 161 \\
\hline & Dummy_Idade_3 & ,391 & 211 & ,121 & 1,850 & ,065 \\
\hline & Dummy_Idade_4 & ,218 & 231 & ,057 & ,942 & 347 \\
\hline & Dummy_Idade_5 &, 584 & 299 & ,104 & 1,954 & 051 \\
\hline & Dummy_Idade_6 & ,386 & ,494 & ,037 & ,782 & ,435 \\
\hline
\end{tabular}

a. Dependent Variable: Equip_OHQ_em_EU

Tabela 33- Análise fatorial - Homens -OHQ

\begin{tabular}{|c|c|c|c|c|c|c|c|c|}
\hline \multicolumn{9}{|c|}{ Structure Matrix } \\
\hline & \multicolumn{8}{|c|}{ Component } \\
\hline & 1 & 2 & 3 & 4 & 5 & 6 & 7 & 8 \\
\hline Eu sou muito feliz & ,741 & ,194 & ,287 &,- 348 & ,239 & & $\overline{-, 334}$ &,- 125 \\
\hline Eu sinto que a vida é muito recompensada & ,726 & & ,222 &,- 294 & &,- 259 &,- 187 & \\
\hline Estou muito satisfeito com tudo em minha vida & ,685 & ,313 & ,184 & & ,263 &,- 245 & &,- 372 \\
\hline A vida é boa & ,654 & ,331 & ,158 &,- 237 & ,103 &,- 187 &,- 256 & \\
\hline Sinto-me alegre e exaltado & ,614 & ,107 & ,361 &,- 178 & ,334 &,- 300 &,- 157 &,- 203 \\
\hline Não tenho particularmente memórias felizes do passado & ,123 & 677 & & & & &,- 184 & \\
\hline $\begin{array}{l}\text { Não tenho particularmente senso de significado e propósito } \\
\text { para minha vida }\end{array}$ & ,213 & ,653 & &,- 331 & ,240 &,- 152 &,- 285 & \\
\hline Sinto que não estou, sobretudo, no controle de minha vida & & ,643 & ,176 &,- 233 & ,154 &,- 155 & &,- 414 \\
\hline $\begin{array}{l}\text { Eu não me sinto particularmente satisfeito com a maneira que } \\
\text { sou }\end{array}$ & ,278 & ,606 & &,- 253 & ,228 & & &,- 163 \\
\hline Eu raramente me sinto descansado & &, 520 & &,- 191 & ,333 & ,378 & & ,359 \\
\hline Eu sou intensamente interessado em outras pessoas & & ,108 & 729, &,- 179 & ,115 & &,- 242 & \\
\hline Eu tenho sentimentos calorosos com quase todos &, 128 & & ,700 & &,- 207 &,- 273 &,- 175 & \\
\hline Eu acho a maioria das coisas agradáveis & ,407 & & 674 &,- 157 & &,- 162 & &,- 142 \\
\hline Eu não me acho atraente & & ,215 & &,- 719 & &,- 120 &,- 119 &,- 217 \\
\hline Sempre contagio de alegria outras pessoas &, 508 & & ,328 &,- 621 & ,241 &,- 242 &,- 219 &, 115 \\
\hline Eu sorrio muito & ,357 & & ,471 &,- 614 & ,324 & & & \\
\hline Sinto-me capaz de conseguir qualquer coisa & 291 & & ,266 &,- 566 & 259 &,- 416 & &,- 152 \\
\hline Não me divirto com outras pessoas & 130 & ,294 & &,- 543 & &, 134 &,- 393 &,- 132 \\
\hline $\begin{array}{l}\text { Existe uma distância entre o que eu gostaria de fazer e o que } \\
\text { faço }\end{array}$ &, 134 & , 100 & & & ,804 & & & \\
\hline Não acho fácil tomar decisões &,- 262 & ,333 & &,- 200 &, 568 &,- 226 &,- 319 &,- 239 \\
\hline Sempre tenho boas influencias nos acontecimentos & ,267 & 197 & ,184 &,- 134 & &,- 670 & & \\
\hline Sinto minha mente completamente alerta & ,296 & & ,227 &,- 280 & &,- 543 &,- 235 & ,192 \\
\hline Sempre me saio bem em tudo o que quero & 188 & & ,408 &,- 152 & ,358 &,- 494 &,- 323 &,- 110 \\
\hline Sinto que possuo muita energia & ,279 & & ,264 &,- 108 & &,- 221 &,- 766 & \\
\hline Eu particularmente não sou otimista sobre o futuro &, 300 & ,362 & ,267 &,- 291 & ,291 & &,- 516 &,- 142 \\
\hline Eu não acho que o mundo que o mundo é um bom lugar & ,322 & 177 & ,173 &,- 391 & ,203 &, 111 &,- 121 &,- 650 \\
\hline Não me sinto particularmente saudável &, 114 & ,264 & &,- 197 & ,355 & ,162 &,- 335 &,- 456 \\
\hline
\end{tabular}

Extraction Method: Principal Component Analysis.

Rotation Method: Oblimin with Kaiser Normalization. 
Tabela 34- Comunalidades Análise fatorial - Homens -OHQ

Communalities

\begin{tabular}{|c|c|c|}
\hline & Initial & $\begin{array}{c}\text { Extrac } \\
\text { tion }\end{array}$ \\
\hline Eu tenho sentimentos calorosos com quase todos & 1,000 &, 609 \\
\hline Sinto que possuo muita energia & 1,000 & 673 \\
\hline Não tenho particularmente memórias felizes do passado & 1,000 &, 520 \\
\hline Eu sou muito feliz & 1,000 & 659 \\
\hline Sinto que não estou, sobretudo, no controle de minha vida & 1,000 & ,601 \\
\hline Eu sou intensamente interessado em outras pessoas & 1,000 & ,596 \\
\hline $\begin{array}{l}\text { Eu não me sinto particularmente satisfeito com a maneira que } \\
\text { sou }\end{array}$ & 1,000 & ,465 \\
\hline Estou muito satisfeito com tudo em minha vida & 1,000 & 670 \\
\hline Sinto-me alegre e exaltado & 1,000 & ,532 \\
\hline $\begin{array}{l}\text { Não tenho particularmente senso de significado e propósito } \\
\text { para minha vida }\end{array}$ & 1,000 &, 543 \\
\hline Sempre tenho boas influencias nos acontecimentos & 1,000 &, 516 \\
\hline Eu particularmente não sou otimista sobre o futuro & 1,000 & ,468 \\
\hline A vida é boa & 1,000 & ,543 \\
\hline Sempre contagio de alegria outras pessoas & 1,000 & ,664 \\
\hline Sinto minha mente completamente alerta & 1,000 & ,471 \\
\hline Eu sinto que a vida é muito recompensada & 1,000 &, 577 \\
\hline Eu raramente me sinto descansado & 1,000 & ,694 \\
\hline $\begin{array}{l}\text { Existe uma distância entre o que eu gostaria de fazer e o que } \\
\text { faço }\end{array}$ & 1,000 & ,685 \\
\hline Não acho fácil tomar decisões & 1,000 & ,692 \\
\hline Não me sinto particularmente saudável & 1,000 & ,444 \\
\hline Eu acho a maioria das coisas agradáveis & 1,000 & ,562 \\
\hline Eu não acho que o mundo que o mundo é um bom lugar & 1,000 & 629 \\
\hline Sempre me saio bem em tudo o que quero & 1,000 &, 503 \\
\hline Eu não me acho atraente & 1,000 &, 577 \\
\hline Eu sorrio muito & 1,000 & ,614 \\
\hline Sinto-me capaz de conseguir qualquer coisa & 1,000 & ,536 \\
\hline Não me divirto com outras pessoas & 1,000 & ,487 \\
\hline
\end{tabular}

Extraction Method: Principal Component Analysis. 
Tabela 35- Comparação análise fatorial questionário completo x homens

\section{Fatores obtidos no questionário $\quad$ Fatores análise sexo masculino total}

\section{FATOR 1- Satisfação com a vida 9,45\%}

A vida é boa

Estou muito satisfeito com tudo em minha vida

Eu acho a maioria das coisas agradáveis

Eu sinto que a vida é muito recompensada

Eu sou muito feliz

\section{FATOR 2 - Controle - 7,26\%}

Eu raramente me sinto descansado

Existe uma diferença entre o que gostaria de

fazer e o que faço

Não acho fácil tomar decisões

Eu não me sinto particularmente satisfeito com a maneira que sou

Sinto que não estou, sobretudo, no controle de minha vida

\section{FATOR 3 - Relacão positiva com outros -}

$$
7,22 \%
$$

Eu sou intensamente interessado em outras pessoas

Eu tenho sentimentos calorosos com quase todos

Sinto que possuo muita energia

FATOR 4 - Autonomia- $7,14 \%$

Estou sempre comprometido e envolvido

Sempre me saio bem em tudo o que quero

Sinto-me capaz de conseguir qualquer coisa

FATOR 5 - Superioridade ambiental $-5,88 \%$

Eu não me acho atraente

Não me divirto com outras pessoas

Sempre contagio de alegria outras pessoas

Eu sorrio muito

FATOR 6 - Aceitação -5,73\%

Sempre tenho boas influencias nos acontecimentos

Não me sinto particularmente saudável

Eu não acho que o mundo é um bom lugar

\section{FATOR 7 - Propósito-5,07\%}

Não tenho particularmente senso de significado e propósito para minha vida

Eu particularmente não sou otimista sobre o futuro

Não tenho particularmente memórias felizes do passado

FATOR 8 - Disposicão mental- 5,01\%

Sinto-me alegre e exaltado

Sinto minha mente completamente alerta

\section{FATOR 1- 21,69\%}

A vida é boa

Estou muito satisfeito com tudo em minha vida

Eu sinto que a vida é muito recompensada

Eu sou muito feliz

Sinto-me alegre e exaltado

\section{FATOR 2- 8,80\%}

Eu raramente me sinto descansado

Não tenho particularmente senso de significado e propósito para minha vida

Não tenho particularmente memórias felizes do passado

Eu não me sinto particularmente satisfeito com a maneira que sou

Sinto que não estou, sobretudo, no controle de minha vida

\section{FATOR 3- 5,25\%}

Eu sou intensamente interessado em outras pessoas

Eu tenho sentimentos calorosos com quase todos

Eu acho a maioria das coisas agradáveis

$$
\text { FATOR 6- 4,37\% }
$$

Sempre tenho boas influencias nos acontecimentos

Sempre me saio bem em tudo o que quero

Sinto minha mente completamente alerta

\section{FATOR 4- 5,08\%}

Sinto-me capaz de conseguir qualquer coisa

Não me divirto com outras pessoas

Sempre contagio de alegria outras pessoas

Eu sorrio muito

Eu não me acho atraente

FATOR 8- 3,80\%

Não me sinto particularmente saudável Eu não acho que o mundo que o mundo é um bom lugar

\section{FATOR 5- 4,41\%}

Existe uma distância entre o que eu gostaria de fazer e o que faço

Não acho fácil tomar decisões

FATOR 7- 4,12\%

Sinto que possuo muita energia

Eu particularmente não sou otimista sobre 0 futuro 
Tabela 36- Análise fatorial - Mulheres -OHQ

\begin{tabular}{|c|c|c|c|c|c|c|c|c|}
\hline \multicolumn{9}{|c|}{ Structure Matrix } \\
\hline & \multicolumn{8}{|c|}{ Component } \\
\hline & 1 & 2 & 3 & 4 & 5 & 6 & 7 & 8 \\
\hline Eu sorrio muito & ,659 & & 256 & ,229 & ,194 &,- 263 & ,293 &, 111 \\
\hline A vida é boa & ,653 & &,- 199 & , 108 & ,375 & ,101 & , 185 & \\
\hline Eu sou muito feliz & 608 & 295, & 232 & ,423 & ,423 & & ,219 & \\
\hline Não me divirto com outras pessoas & ,605 &, 154 & ,308 & & & & & ,384 \\
\hline $\begin{array}{l}\text { Existe uma distância entre o que eu gostaria de fazer e o que } \\
\text { faço }\end{array}$ & & ,693 & & & ,149 & & , 199 & ,139 \\
\hline Eu raramente me sinto descansado &, 113 & 601 & & & & & & ,351 \\
\hline Sinto que não estou, sobretudo, no controle de minha vida & 127 &, 588 & ,250 & 105, & 266 & , 174 & &,- 165 \\
\hline $\begin{array}{l}\text { Eu não me sinto particularmente satisfeito com a maneira que } \\
\text { sou }\end{array}$ & ,397 &, 525 &,- 108 & ,163 & & 102 & ,304 & \\
\hline Não acho fácil tomar decisões & &, 509 & &, 168 &,- 226 &, 139 & ,441 & ,259 \\
\hline Eu tenho sentimentos calorosos com quase todos & ,219 &, 126 & ,771 & & & & & \\
\hline Eu sou intensamente interessado em outras pessoas & & & ,739 & & & & , 143 & 186, \\
\hline Sinto-me capaz de conseguir qualquer coisa & 169 &, 159 & & ,734 & &,- 172 & ,258 & ,151 \\
\hline Estou sempre comprometido e envolvido & &,- 143 & , 126 & ,683 & & & & \\
\hline Sempre me saio bem em tudo o que quero & & ,224 & &, 557 &, 521 &,- 140 & ,321 & \\
\hline Sinto que possuo muita energia & ,411 & ,213 & ,396 & ,450 & & & ,328 & \\
\hline Eu acho a maioria das coisas agradáveis & ,226 & ,134 & , 127 & ,216 & ,640 & & ,205 & \\
\hline Eu sinto que a vida é muito recompensada & ,366 & ,326 & &, 118 &, 528 &,- 163 & ,310 & ,131 \\
\hline Não tenho particularmente memórias felizes do passado & ,331 & ,273 & & ,258 & ,173 &, 593 & & \\
\hline Sempre tenho boas influencias nos acontecimentos & ,292 & ,209 & 261 & ,361 & ,252 &,- 549 & &,- 186 \\
\hline Sempre contagio de alegria outras pessoas & ,429 & & & ,203 & &,- 529 &, 505 & ,196 \\
\hline Sinto-me alegre e exaltado & ,324 & ,187 & , 191 & ,253 & ,233 &,- 184 & ,689 &,- 107 \\
\hline Sinto minha mente completamente alerta & & & & ,216 & ,293 &,- 167 &, 574 & ,208 \\
\hline Não me sinto particularmente saudável & , 149 & ,254 & & & & ,492 &, 549 & ,205 \\
\hline Estou muito satisfeito com tudo em minha vida & ,260 & ,242 & , 136 & ,265 &, 506 & ,162 &, 549 &,- 134 \\
\hline Eu não me acho atraente & , 145 &, 172 & , 133 &, 142 & & &, 131 & ,698 \\
\hline Eu não acho que o mundo que o mundo é um bom lugar & ,212 & ,206 & ,128 &,- 142 & ,423 & ,220 & &, 504 \\
\hline Eu particularmente não sou otimista sobre o futuro & ,337 & ,222 & & ,446 & & & ,241 & ,451 \\
\hline
\end{tabular}

Rotation Method: Oblimin with Kaiser Normalization.

Tabela 37- Comunalidades Análise fatorial - Mulheres -OHQ

\begin{tabular}{|c|c|c|}
\hline \multicolumn{3}{|l|}{ Communalities } \\
\hline & Initial & $\begin{array}{c}\text { Extrac } \\
\text { tion }\end{array}$ \\
\hline Eu tenho sentimentos calorosos com quase todos & 1,000 &, 634 \\
\hline Sinto que possuo muita energia & 1,000 &, 520 \\
\hline Não tenho particularmente memórias felizes do passado & 1,000 &, 553 \\
\hline Eu sou muito feliz & 1,000 &, 581 \\
\hline Sinto que não estou, sobretudo, no controle de minha vida & 1,000 &, 513 \\
\hline Eu sou intensamente interessado em outras pessoas & 1,000 & 648 \\
\hline Eu não me sinto particularmente satisfeito com a maneira que sou & 1,000 & ,445 \\
\hline Estou muito satisfeito com tudo em minha vida & 1,000 &, 593 \\
\hline Sinto-me alegre e exaltado & 1,000 & 609 \\
\hline Sempre tenho boas influencias nos acontecimentos & 1,000 & 600 \\
\hline Eu particularmente não sou otimista sobre o futuro & 1,000 & ,480 \\
\hline A vida é boa & 1,000 & ,600 \\
\hline Sempre contagio de alegria outras pessoas & 1,000 & 652 \\
\hline Sinto minha mente completamente alerta & 1,000 & ,453 \\
\hline Eu sinto que a vida é muito recompensada & 1,000 & ,467 \\
\hline Eu raramente me sinto descansado & 1,000 & ,483 \\
\hline Existe uma distância entre o que eu gostaria de fazer e o que faço & 1,000 &, 523 \\
\hline Não acho fácil tomar decisões & 1,000 &, 561 \\
\hline Não me sinto particularmente saudável & 1,000 &, 597 \\
\hline Eu acho a maioria das coisas agradáveis & 1,000 & ,447 \\
\hline Eu não acho que o mundo que o mundo é um bom lugar & 1,000 &, 549 \\
\hline Sempre me saio bem em tudo o que quero & 1,000 &, 580 \\
\hline Eu não me acho atraente & 1,000 &, 524 \\
\hline Eu sorrio muito & 1,000 &, 570 \\
\hline Sinto-me capaz de conseguir qualquer coisa & 1,000 &, 597 \\
\hline Não me divirto com outras pessoas & 1,000 &, 581 \\
\hline Estou sempre comprometido e envolvido & 1,000 &, 555 \\
\hline
\end{tabular}


Tabela 38- Comparação análise fatorial questionário completo $\mathrm{x}$ mulheres

\section{Fatores obtidos no questionário total}

\section{FATOR 1- Satisfacão com a vida 9,45\%}

A vida é boa

Estou muito satisfeito com tudo em minha vida

Eu acho a maioria das coisas agradáveis

Eu sinto que a vida é muito recompensada

Eu sou muito feliz

\section{FATOR 2 - Controle - 7,26\%}

Eu raramente me sinto descansado

Existe uma diferença entre o que gostaria de fazer e o que faço

Não acho fácil tomar decisões

Eu não me sinto particularmente satisfeito com a maneira que sou

Sinto que não estou, sobretudo, no controle de minha vida

FATOR 3 - Relação positiva com outros - 7,22\%

Eu sou intensamente interessado em outras pessoas

Eu tenho sentimentos calorosos com quase todos

Sinto que possuo muita energia

\section{FATOR 4 - Autonomia- 7,14\%}

Estou sempre comprometido e envolvido

Sempre me saio bem em tudo o que quero

Sinto-me capaz de conseguir qualquer coisa

\section{FATOR 5 - Superioridade ambiental $-5,88 \%$}

Eu não me acho atraente

Não me divirto com outras pessoas

Sempre contagio de alegria outras pessoas

Eu sorrio muito

FATOR 6 - Aceitacão - $5,73 \%$

Sempre tenho boas influencias nos acontecimentos

Não me sinto particularmente saudável

Eu não acho que o mundo é um bom lugar

$$
\text { FATOR } 7 \text { - Propósito-5,07\% }
$$

Não tenho particularmente senso de significado $e$ propósito para minha vida

Eu particularmente não sou otimista sobre o futuro

Não tenho particularmente memórias felizes do passado

$$
\text { FATOR } 8 \text { - Disposição mental- 5,01\% }
$$

Sinto-me alegre e exaltado

Sinto minha mente completamente alerta
Fatores análise sexo feminino

\section{FATOR 1- 19.10\%}

A vida é boa

Eu sorrio muito

Não me divirto com outras pessoas

Eu sou muito feliz

\section{FATOR 2- 7,62\%}

Eu raramente me sinto descansado

Existe uma distância entre o que eu gostaria de fazer e o que faço

Não acho fácil tomar decisões

Eu não me sinto particularmente satisfeito com a maneira que sou

Sinto que não estou, sobretudo, no controle de minha vida

\section{FATOR 3- 5,89}

Eu sou intensamente interessado em outras pessoas Eu tenho sentimentos calorosos com quase todos

\section{FATOR 4- 5,06\%}

Estou sempre comprometido e envolvido Sempre me saio bem em tudo o que quero Sinto-me capaz de conseguir qualquer coisa Sinto que possuo muita energia

\section{FATOR 8- 3,78\%}

Eu não me acho atraente

Eu não acho que o mundo que o mundo é um bom lugar

Eu particularmente não sou otimista sobre o futuro

\section{FATOR 6- 4,52\%}

Não tenho particularmente memórias felizes do passado Sempre tenho boas influencias nos acontecimentos Sempre contagio de alegria outras pessoas

\section{FATOR 5- 4,99\%}

Eu acho a maioria das coisas agradáveis

Eu sinto que a vida é muito recompensada

\section{FATOR 7- 4,29\%}

Sinto-me alegre e exaltado

Sinto minha mente completamente alerta

Não me sinto particularmente saudável

Estou muito satisfeito com tudo em minha vida 
Tabela 39- - Teste de médias homens x mulheres

ANOVA

\begin{tabular}{|ll|r|r|r|r|r|}
\hline & & \multicolumn{1}{c|}{$\begin{array}{c}\text { Sum of } \\
\text { Squares }\end{array}$} & df & Mean Square & F & Sig. \\
\hline EU & Between Groups & 2,629 & 1 & 2,629 & 1,426 &, 233 \\
& Within Groups & 883,337 & 479 & 1,844 & & \\
& Total & 885,967 & 480 & & &, 852 \\
& Between Groups &, 065 & 1 &, 065 &, 035 & \\
& Within Groups & 883,513 & 479 & 1,844 & &, 507 \\
& Total & 883,577 & 480 & &, 440 & \\
\hline Equip_OHQ_em_EU & Between Groups &, 765 & 1 &, 765 & & \\
& Within Groups & 835,676 & 481 & 1,737 & & \\
& Total & 836,441 & 482 & & & \\
\end{tabular}

Tabela 40- Correlação de médias equiparadas entre escalas - Gênero

Paired Samples Correlations

\begin{tabular}{|lll|r|r|c|}
\hline Sexo & & N & Correlation & Sig. \\
\hline Masculino & Pair 1 & EU \& Equip_EGF_em_EU & 208 &, 681 &, 000 \\
& Pair 2 & EU \& Equip_OHQ_em_EU & 210 &, 601 &, 000 \\
& Pair 3 & Equip_EGF_em_EU \& Equip_OHQ_em_EU & 208 &, 617 &, 000 \\
\hline Feminino & Pair 1 & EU \& Equip_EGF_em_EU & 271 &, 601 &, 000 \\
& Pair 2 & EU \& Equip_OHQ_em_EU & 271 &, 524 &, 000 \\
& Pair 3 & Equip_EGF_em_EU \& Equip_OHQ_em_EU & 273 &, 647 &, 000 \\
\hline
\end{tabular}

a. No statistics are computed for one or more split files

Tabela 41- Teste médias equiparadas - gênero

\begin{tabular}{|c|c|c|c|c|c|c|c|c|c|c|}
\hline \multicolumn{11}{|c|}{ Paired Samples Tese } \\
\hline \multirow[b]{3}{*}{ Sexo } & & & \multicolumn{5}{|c|}{ Paired Differences } & \multirow[b]{3}{*}{$\mathrm{t}$} & \multirow[b]{3}{*}{ df } & \multirow{3}{*}{$\begin{array}{c}\text { Sig. } \\
\text { (2-tailed) }\end{array}$} \\
\hline & & & \multirow[b]{2}{*}{ Mean } & \multirow{2}{*}{$\begin{array}{c}\text { Std. } \\
\text { Deviation }\end{array}$} & \multirow{2}{*}{$\begin{array}{l}\text { Std. Error } \\
\text { Mean }\end{array}$} & \multicolumn{2}{|c|}{$\begin{array}{l}95 \% \text { Confidence } \\
\text { Interval of the } \\
\text { Difference }\end{array}$} & & & \\
\hline & & & & & & Lower & Upper & & & \\
\hline Masculino & Pair 1 & EU - Equip_EGF_em_EU &,- 08284 & 1,10554 &, 07666 &,- 23396 &, 06829 & $-1,081$ & 207 & 281 \\
\hline & Pair 2 & EU - Equip_OHQ_em_EU & 14911 & 1,21014 & 08351 &,- 01551 & ,31374 & 1,786 & 209 & ,076 \\
\hline & Pair 3 & Equip_EGF_em_EU - Equip_OHQ_em_EU & ,22657 & 1,18578 & ,08222 & ,06447 & ,38866 & 2,756 & 207 &, 006 \\
\hline Feminino & Pair 1 & EU - Equip_EGF_em_EU & 04226 & 1,19517 & 07260 &,- 10068 & , 18520 &, 582 & 270 &, 561 \\
\hline & Pair 2 & EU - Equip_OHQ_em_EU & ,37334 & 1,29476 & 07865 & ,21849 &, 52819 & 4,747 & 270 &, 000 \\
\hline & Pair 3 & Equip_EGF_em_EU - Equip_OHQ_em_EU & ,32698 & 1,11296 & 06736 & 19437 & ,45959 & 4,854 & 272 &, 000 \\
\hline
\end{tabular}

a. No statistics are computed for one or more split files

Tabela 42- Teste de homogeneidade da variância- faixas etárias com controle em sexo

Test of Homogeneity of Variances

\begin{tabular}{|c|c|c|c|c|c|}
\hline Sexo & & $\begin{array}{l}\text { Levene } \\
\text { Statistic }\end{array}$ & df1 & df2 & Sig. \\
\hline \multirow[t]{3}{*}{ Masculino } & EU &, 735 & 5 & 201 &, 598 \\
\hline & Equip_EGF_em_EU &, 501 & 5 & 200 & ,775 \\
\hline & Equip_OHQ_em_EU &, 512 & 5 & 201 & ,767 \\
\hline \multirow[t]{3}{*}{ Feminino } & $\mathrm{EU}$ & 3,325 & 4 & 254 & 011 \\
\hline & Equip_EGF_em_EU & 1,338 & 4 & 256 & ,256 \\
\hline & Equip_OHQ_em_EU &, 905 & 4 & 256 & ,461 \\
\hline
\end{tabular}


Tabela 43- Análise variância faixas etárias com controle em sexo- EGF e OHQ

\begin{tabular}{|c|c|c|c|c|c|c|c|}
\hline \multicolumn{8}{|c|}{ ANOVA } \\
\hline \multicolumn{3}{|l|}{ Sexo } & $\begin{array}{l}\text { Sum of } \\
\text { Squares }\end{array}$ & df & Mean Square & $\mathrm{F}$ & Sig. \\
\hline \multirow[t]{6}{*}{ Masculino } & \multirow[t]{3}{*}{ Equip_EGF_em_EU } & Between Groups & 6,990 & 5 & 1,398 & \multirow[t]{3}{*}{, 728} & \multirow[t]{3}{*}{, 603} \\
\hline & & Within Groups & 384,293 & 200 & 1,921 & & \\
\hline & & Total & 391,283 & 205 & & & \\
\hline & \multirow[t]{3}{*}{ Equip_OHQ_em_EU } & Between Groups & 4,485 & 5 & 897 - - & \multirow[t]{3}{*}{, 503} & \multirow[t]{3}{*}{,774 } \\
\hline & & Within Groups & 358,532 & 201 & 1,784 & & \\
\hline & & Total & 363,017 & 206 & & & \\
\hline \multirow[t]{6}{*}{ Feminino } & \multirow[t]{3}{*}{ Equip_EGF_em_EU } & Between Groups & 2,179 & 5 & ,436 & \multirow[t]{3}{*}{,238 } & \multirow[t]{3}{*}{,945 } \\
\hline & & Within Groups & 468,035 & 256 & 1,828 & & \\
\hline & & Total & 470,214 & 261 & & & \\
\hline & \multirow[t]{3}{*}{ Equip_OHQ_em_EU } & Between Groups & 8,476 & 5 & 1,695 & \multirow[t]{3}{*}{,993 } & \multirow[t]{3}{*}{,423 } \\
\hline & & Within Groups & 437,213 & 256 & 1,708 & & \\
\hline & & Total & 445,690 & 261 & & & \\
\hline
\end{tabular}

Tabela 44- Teste não paramétrico para EU - idades analisadas por sexo

\begin{tabular}{|ll|r|}
\hline \multicolumn{3}{|c|}{ Test Statistics, } \\
\hline Sexo & & \multicolumn{1}{|c|}{ EU } \\
\hline Masculino & Chi-Square & 5,332 \\
& df & 5 \\
& Asymp. Sig. &, 377 \\
\hline Feminino & Chi-Square & 4,086 \\
& df & 5 \\
& Asymp. Sig. &, 537 \\
\hline
\end{tabular}

a. Kruskal Wallis Test

b. Grouping Variable: Idade_Categ 
Tabela 45- Correlação entre as escalas para idades separadas por sexo

Paired Samples Correlations ${ }^{\mathrm{a}}$

\begin{tabular}{|c|c|c|c|c|c|c|}
\hline Sexo & \multicolumn{3}{|l|}{ Idade_Categ } & $\mathrm{N}$ & Correlation & Sig. \\
\hline \multirow{21}{*}{ Masculino } & & Pair 1 & EU \& Equip_EGF_em_EU & 2 & 1,000 &, 000 \\
\hline & & Pair 2 & EU \& Equip_OHQ_em_EU & 3 &, 737 & ,472 \\
\hline & & Pair 3 & Equip_EGF_em_EU \& Equip_OHQ_em_EU & 2 & 1,000 &, 000 \\
\hline & \multirow[t]{3}{*}{ Menos que 20 anos } & Pair 1 & EU \& Equip_EGF_em_EU & 23 & ,301 & ,162 \\
\hline & & Pair 2 & EU \& Equip_OHQ_em_EU & 23 & 158 & ,472 \\
\hline & & Pair 3 & Equip_EGF_em_EU \& Equip_OHQ_em_EU & 23 &, 582 & 004 \\
\hline & \multirow[t]{3}{*}{$21-30$ anos } & Pair 1 & EU \& Equip_EGF_em_EU & 96 & ,657 &, 000 \\
\hline & & Pair 2 & EU \& Equip_OHQ_em_EU & 96 & ,666 & 000 \\
\hline & & Pair 3 & Equip_EGF_em_EU \& Equip_OHQ_em_EU & 96 & ,632 &, 000 \\
\hline & \multirow[t]{3}{*}{$31-40$ anos } & Pair 1 & EU \& Equip_EGF_em_EU & 40 & ,848 &, 000 \\
\hline & & Pair 2 & EU \& Equip_OHQ_em_EU & 41 &, 547 &, 000 \\
\hline & & Pair 3 & Equip_EGF_em_EU \& Equip_OHQ_em_EU & 40 & ,495 & 001 \\
\hline & \multirow[t]{3}{*}{$41-50$ anos } & Pair 1 & EU \& Equip_EGF_em_EU & 27 & ,749 &, 000 \\
\hline & & Pair 2 & EU \& Equip_OHQ_em_EU & 27 & ,700 & 000 \\
\hline & & Pair 3 & Equip_EGF_em_EU \& Equip_OHQ_em_EU & 27 & ,689 & 000 \\
\hline & \multirow[t]{3}{*}{$51-60$ anos } & Pair 1 & EU \& Equip_EGF_em_EU & 14 & ,798 &, 001 \\
\hline & & Pair 2 & EU \& Equip_OHQ_em_EU & 14 & ,716 & 004 \\
\hline & & Pair 3 & Equip_EGF_em_EU \& Equip_OHQ_em_EU & 14 &, 772 & 001 \\
\hline & \multirow[t]{3}{*}{ Mais que 60 anos } & Pair 1 & EU \& Equip_EGF_em_EU & 6 & ,375 & ,464 \\
\hline & & Pair 2 & EU \& Equip_OHQ_em_EU & 6 & ,805 & 053 \\
\hline & & Pair 3 & Equip_EGF_em_EU \& Equip_OHQ_em_EU & 6 & ,779 & 068 \\
\hline \multirow[t]{18}{*}{ Feminino } & \multirow[t]{3}{*}{. } & Pair 1 & EU \& Equip_EGF_em_EU & 11 & ,708 & 015 \\
\hline & & Pair 2 & EU \& Equip_OHQ_em_EU & 11 & ,378 & ,252 \\
\hline & & Pair 3 & Equip_EGF_em_EU \& Equip_OHQ_em_EU & 11 & ,648 & 031 \\
\hline & \multirow[t]{3}{*}{ Menos que 20 anos } & Pair 1 & EU \& Equip_EGF_em_EU & 40 & ,699 & 000 \\
\hline & & Pair 2 & EU \& Equip_OHQ_em_EU & 40 &, 537 &, 000 \\
\hline & & Pair 3 & Equip_EGF_em_EU \& Equip_OHQ_em_EU & 40 & ,635 & 000 \\
\hline & \multirow[t]{3}{*}{$21-30$ anos } & Pair 1 & EU \& Equip_EGF_em_EU & 123 & ,497 &, 000 \\
\hline & & Pair 2 & EU \& Equip_OHQ_em_EU & 123 &, 574 & 000 \\
\hline & & Pair 3 & Equip_EGF_em_EU \& Equip_OHQ_em_EU & 124 & ,706 &, 000 \\
\hline & \multirow[t]{3}{*}{$31-40$ anos } & Pair 1 & EU \& Equip_EGF_em_EU & 52 &, 567 & 000 \\
\hline & & Pair 2 & EU \& Equip_OHQ_em_EU & 52 &, 518 & 000 \\
\hline & & Pair 3 & Equip_EGF_em_EU \& Equip_OHQ_em_EU & 53 & 638 &, 000 \\
\hline & \multirow[t]{3}{*}{$41-50$ anos } & Pair 1 & EU \& Equip_EGF_em_EU & 36 & ,717 &, 000 \\
\hline & & Pair 2 & EU \& Equip_OHQ_em_EU & 36 & ,464 & 004 \\
\hline & & Pair 3 & Equip_EGF_em_EU \& Equip_OHQ_em_EU & 36 &, 564 & 000 \\
\hline & \multirow[t]{3}{*}{$51-60$ anos } & Pair 1 & EU \& Equip_EGF_em_EU & 8 & ,786 & 021 \\
\hline & & Pair 2 & EU \& Equip_OHQ_em_EU & 8 &, 567 & 143 \\
\hline & & Pair 3 & Equip_EGF_em_EU \& Equip_OHQ_em_EU & 8 &, 654 & 079 \\
\hline
\end{tabular}

a. No statistics are computed for one or more split files 
Tabela 46- Teste de médias para idades separada por sexo

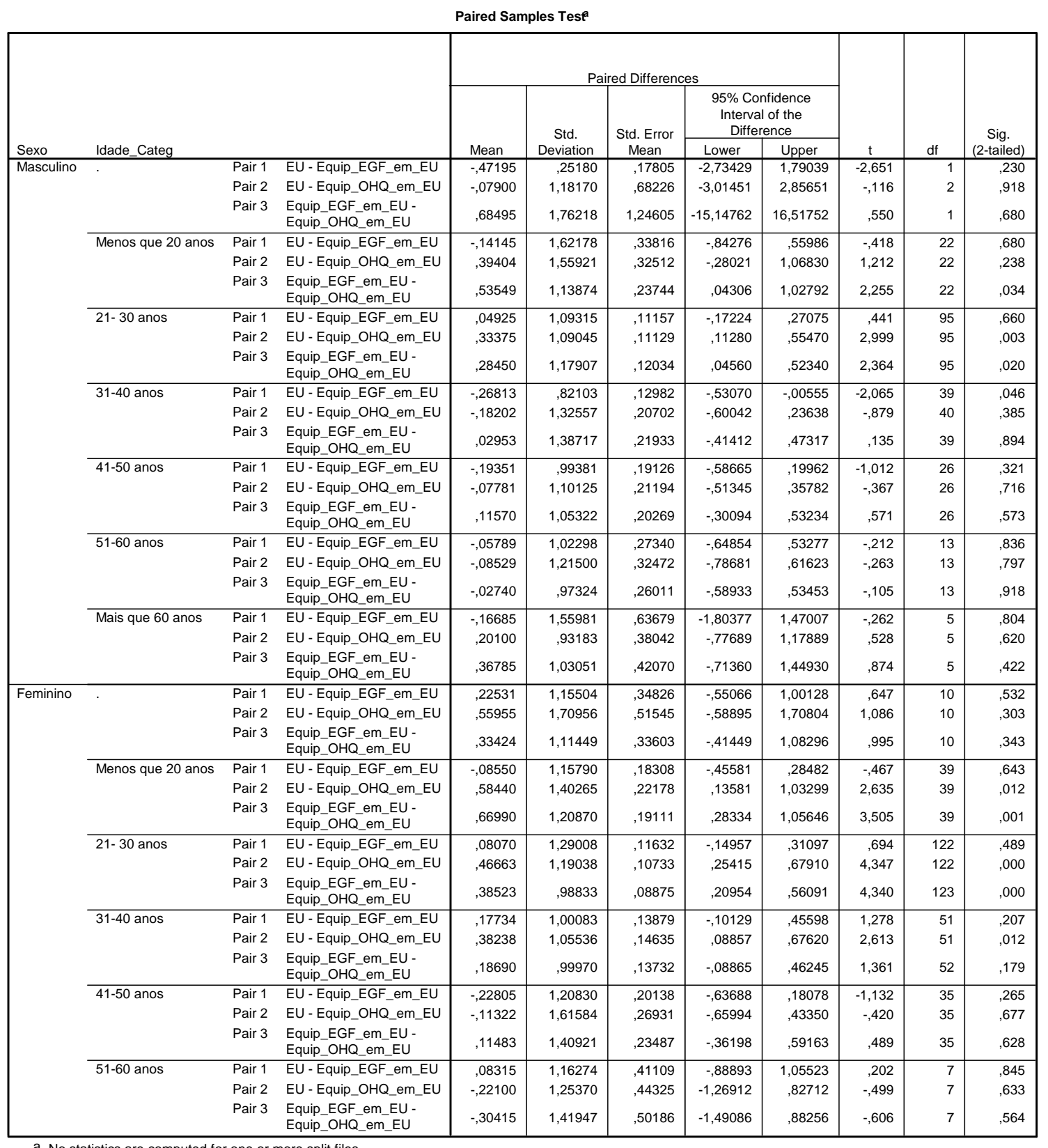

a. No statistics are computed for one or more split files

Tabela 47- Coeficientes de determinação de idades separado por sexo -EU

Model Summary

\begin{tabular}{|ll|r|r|r|r|}
\hline Sexo & Model & \multicolumn{1}{|c|}{ R } & R Square & $\begin{array}{c}\text { Adjusted } \\
\text { R Square }\end{array}$ & $\begin{array}{c}\text { Std. Error of } \\
\text { the Estimate }\end{array}$ \\
\hline Masculino & 1 &, $158^{\mathrm{a}}$ &, 025 &, 001 & 1,37996 \\
\hline Feminino 1 &, $150^{\mathrm{a}}$ &, 023 &, 004 & 1,33741 \\
\hline
\end{tabular}

a. Predictors: (Constant), Dummy_Idade_6, Dummy_Idade_5,

Dummy_Idade 4, Dummy Idade 3, Dummy Idade 2 
Tabela 48- Coeficientes de regressão idades separado por sexo - EU

\begin{tabular}{|c|c|c|c|c|c|c|c|}
\hline \multicolumn{8}{|c|}{ Coefficients $^{a}$} \\
\hline \multirow[b]{2}{*}{ Sexo } & \multirow[b]{2}{*}{ Model } & & \multicolumn{2}{|c|}{$\begin{array}{l}\text { Unstandardized } \\
\text { Coefficients }\end{array}$} & \multirow{2}{*}{$\begin{array}{c}\begin{array}{c}\text { Standardized } \\
\text { Coefficients }\end{array} \\
\text { Beta }\end{array}$} & \multirow[b]{2}{*}{$t$} & \multirow[b]{2}{*}{ Sig. } \\
\hline & & & $\mathrm{B}$ & Std. Error & & & \\
\hline \multirow[t]{6}{*}{ Masculino } & 1 & (Constant) & 6,158 &, 317 & & 19,451 &, 000 \\
\hline & & Dummy_ldade_2 &,- 491 & ,347 &,- 177 & $-1,414$ & ,159 \\
\hline & & Dummy_Idade_3 &,- 647 & ,378 &,- 193 & $-1,713$ & ,088 \\
\hline & & Dummy_ldade_4 &,- 848 & ,407 &,- 212 & $-2,081$ & ,039 \\
\hline & & Dummy_ldade_5 &,- 746 & ,461 &,- 148 & $-1,620$ & , 107 \\
\hline & & Dummy_Idade_6 &,- 729 & 610 &,- 095 & $-1,195$ & 233 \\
\hline \multirow[t]{6}{*}{ Feminino } & 1 & (Constant) & 5,628 & 204 & & 27,594 & ,000 \\
\hline & & Dummy_Idade_2 & ,234 & 237 & ,087 & ,987 & ,324 \\
\hline & & Dummy_Idade_3 & ,281 & 272 & ,085 & 1,033 & ,303 \\
\hline & & Dummy_Idade_4 &,- 312 & 298 &,- 081 & $-1,048$ & 296 \\
\hline & & Dummy_ldade_5 & ,008 & ,452 &, 001 & ,019 & ,985 \\
\hline & & Dummy_Idade_6 & ,372 & 1,353 &, 017 & 275 & ,784 \\
\hline
\end{tabular}

a. Dependent Variable: EU

Tabela 49- Coeficientes de determinação de idades separado por sexo -EGF

\begin{tabular}{|ll|r|r|r|r|}
\multicolumn{1}{|c|}{ Model Summary } \\
Sexo & Model & \multicolumn{1}{|c|}{ R } & R Square & $\begin{array}{c}\text { Adjusted } \\
\text { R Square }\end{array}$ & $\begin{array}{r}\text { Std. Error of } \\
\text { the Estimate }\end{array}$ \\
\hline Masculino & 1 &, $086^{\mathrm{a}}$ &, 007 &,- 017 & 1,39687 \\
\hline Feminino & 1 &, $107^{\mathrm{a}}$ &, 011 &,- 007 & 1,34206 \\
\hline
\end{tabular}

a. Predictors: (Constant), Dummy_Idade_6, Dummy_Idade_5,

Dummy_Idade_4, Dummy_Idade_3, Dummy_Idade_2

Tabela 50- Coeficientes de regressão idades separado por sexo - EGF

Coefficients ${ }^{\mathrm{a}}$

\begin{tabular}{|c|c|c|c|c|c|c|c|}
\hline \multirow[b]{2}{*}{ Sexo } & \multirow[b]{2}{*}{ Model } & & \multicolumn{2}{|c|}{$\begin{array}{l}\text { Unstandardized } \\
\text { Coefficients }\end{array}$} & \multirow{2}{*}{$\begin{array}{c}\text { Standardized } \\
\text { Coefficients } \\
\text { Beta }\end{array}$} & \multirow[b]{2}{*}{$t$} & \multirow[b]{2}{*}{ Sig. } \\
\hline & & & $\mathrm{B}$ & Std. Error & & & \\
\hline \multirow[t]{6}{*}{ Masculino } & 1 & (Constant) & 5,972 & ,329 & & 18,138 &, 000 \\
\hline & & Dummy_ldade_2 &,- 287 & ,360 &,- 103 &,- 798 & ,426 \\
\hline & & Dummy_Idade_3 &,- 263 & ,391 &,- 078 &,- 674 &, 501 \\
\hline & & Dummy_Idade_4 &,- 458 & ,419 &,- 115 & $-1,092$ & ,276 \\
\hline & & Dummy_Idade_5 &,- 476 & ,472 &,- 094 & $-1,007$ & ,315 \\
\hline & & Dummy_Idade_6 &,- 327 & ,622 &,- 043 &,- 525 & ,600 \\
\hline \multirow[t]{6}{*}{ Feminino } & 1 & (Constant) & 5,528 & ,205 & & 27,013 &, 000 \\
\hline & & Dummy_Idade_2 & ,269 & ,238 & , 100 & 1,132 & ,259 \\
\hline & & Dummy_ldade_3 & 220 & ,272 & ,067 & ,809 & ,419 \\
\hline & & Dummy_Idade_4 &,- 078 & ,299 &,- 020 &,- 262 & ,793 \\
\hline & & Dummy_Idade_5 & ,346 & ,453 & ,051 & ,764 & ,446 \\
\hline & & Dummy_Idade_6 &,- 319 & 1,358 &,- 014 &,- 235 & ,814 \\
\hline
\end{tabular}

a. Dependent Variable: Equip_EGF_em_EU

Tabela 51- Coeficientes de determinação de idades separado por sexo --OHQ

\begin{tabular}{|ll|r|r|r|r|}
\multicolumn{1}{|c|}{ Model Summary } \\
Sexo & Model & \multicolumn{1}{c|}{$\mathrm{R}$} & $\mathrm{R}$ Square & $\begin{array}{c}\text { Adjusted } \\
\text { R Square }\end{array}$ & $\begin{array}{r}\text { Std. Error of } \\
\text { the Estimate }\end{array}$ \\
\hline Masculino & 1 &, $070^{\mathrm{a}}$ &, 005 &,- 019 & 1,34041 \\
\hline Feminino & 1 &, $165^{\mathrm{a}}$ &, 027 &, 009 & 1,30481 \\
\hline
\end{tabular}

a. Predictors: (Constant), Dummy_Idade_6, Dummy_Idade_5,

Dummy_Idade_4, Dummy_Idade_3, Dummy_Idade_2 
Tabela 52- Coeficientes de regressão idades separado por sexo - OHQ

\begin{tabular}{|c|c|c|c|c|c|c|c|}
\hline \multicolumn{8}{|c|}{ Coefficients $^{a}$} \\
\hline \multirow[b]{2}{*}{ Sexo } & \multirow[b]{2}{*}{ Model } & & \multicolumn{2}{|c|}{$\begin{array}{c}\text { Unstandardized } \\
\text { Coefficients }\end{array}$} & \multirow{2}{*}{$\begin{array}{c}\begin{array}{c}\text { Standardized } \\
\text { Coefficients }\end{array} \\
\text { Beta }\end{array}$} & \multirow[b]{2}{*}{$\mathrm{t}$} & \multirow[b]{2}{*}{ Sig. } \\
\hline & & & $\mathrm{B}$ & Std. Error & & & \\
\hline \multirow[t]{6}{*}{ Masculino } & 1 & (Constant) & 5,548 & ,308 & & 18,043 &, 000 \\
\hline & & Dummy_Idade_2 &,- 146 & ,337 &,- 055 &,- 433 & ,665 \\
\hline & & Dummy_Idade_3 &, 014 & ,367 &, 004 & ,037 & ,970 \\
\hline & & Dummy_Idade_4 &,- 249 & ,396 &,- 065 &,- 630 &, 530 \\
\hline & & Dummy_Idade_5 & ,010 & ,447 &, 002 &, 021 & 983 \\
\hline & & Dummy_Idade_6 &,- 066 &, 593 &,- 009 &,- 111 & ,911 \\
\hline \multirow[t]{6}{*}{ Feminino } & 1 & (Constant) & 4,949 & ,199 & & 24,870 & ,000 \\
\hline & & Dummy_Idade_2 & ,448 & ,231 & , 170 & 1,940 & ,053 \\
\hline & & Dummy_Idade_3 &, 548 & ,265 & , 169 & 2,071 & 039 \\
\hline & & Dummy_Idade_4 & ,444 & ,291 & ,118 & 1,529 & ,127 \\
\hline & & Dummy_Idade_5 & 1,019 & ,441 & , 153 & 2,311 & 022 \\
\hline & & Dummy_Idade_6 & ,842 & 1,320 & ,039 & ,638 &, 524 \\
\hline
\end{tabular}

a. Dependent Variable: Equip_OHQ_em_EU

Tabela 53- Coeficiente de determinação para idades separado por sexo e existência de filhos- EU Model Summary

\begin{tabular}{|lll|r|r|r|r|}
\hline \multirow{2}{*}{ Sexo } & Filhos_Categ & Model & \multicolumn{1}{|c|}{ R } & R Square & $\begin{array}{c}\text { Adjusted } \\
\text { R Square }\end{array}$ & $\begin{array}{r}\text { Std. Error of } \\
\text { the Estimate }\end{array}$ \\
\hline Masculino & Com filhos & 1 &, $193^{\mathrm{a}}$ &, 037 &,- 018 & 1,46910 \\
\cline { 2 - 8 } & Sem filhos & 1 &, $194^{\mathrm{b}}$ &, 037 &,- 006 & 1,31590 \\
\hline \multirow{2}{*}{ Feminino } & Com filhos & 1 &, $136^{\mathrm{a}}$ &, 019 &,- 031 & 1,32385 \\
\cline { 2 - 8 } & Sem filhos & 1 &, $195^{\mathrm{c}}$ &, 038 &, 014 & 1,35598 \\
\hline
\end{tabular}

a. Predictors: (Constant), Dummy_Idade_6, Dummy_Idade_1, Dummy_Idade_5, Dummy_Idade_4, Dummy_Idade_3

b. Predictors: (Constant), Dummy_Idade_6, Dummy_Idade_5, Dummy_Idade_4, Dummy_Idade_3, Dummy_Idade_1

c. Predictors: (Constant), Dummy_Idade_5, Dummy_Idade_4, Dummy_Idade_3, Dummy_Idade_1 
Tabela 54- Coeficientes de regressão para faixas etárias, separadas por filhos e controladas por sexo- EU

\begin{tabular}{|c|c|c|c|c|c|c|c|c|}
\hline \multicolumn{9}{|c|}{ Coefficients $^{a}$} \\
\hline \multirow[b]{2}{*}{ Sexo } & \multirow[b]{2}{*}{ Filhos_Categ } & \multirow[b]{2}{*}{ Model } & & \multicolumn{2}{|c|}{$\begin{array}{c}\text { Unstandardized } \\
\text { Coefficients }\end{array}$} & \multirow{2}{*}{$\begin{array}{c}\begin{array}{c}\text { Standardized } \\
\text { Coefficients }\end{array} \\
\text { Beta }\end{array}$} & \multirow[b]{2}{*}{$\mathrm{t}$} & \multirow[b]{2}{*}{ Sig. } \\
\hline & & & & $\mathrm{B}$ & Std. Error & & & \\
\hline \multirow[t]{12}{*}{ Masculino } & Com filhos & 1 & (Constant) & 5,500 & ,288 & & 19,090 &, 000 \\
\hline & & & Dummy_Idade_1 & 1,500 & 1,497 & , 107 & 1,002 & ,319 \\
\hline & & & Dummy_Idade_3 & ,130 & ,404 &, 041 & ,321 & ,749 \\
\hline & & & Dummy_Idade_4 &,- 326 & ,421 &,- 097 &,- 775 & ,440 \\
\hline & & & Dummy_ldade_5 &,- 333 &, 513 &,- 077 &,- 650 &, 517 \\
\hline & & & Dummy_Idade_6 &, 500 & ,789 &, 070 & ,634 &, 528 \\
\hline & Sem filhos & 1 & (Constant) & 5,778 & , 166 & & 34,850 &, 000 \\
\hline & & & Dummy_Idade_1 & ,131 & ,326 &, 039 & ,403 & ,688 \\
\hline & & & Dummy_Idade_3 &,- 444 & ,352 &,- 123 & $-1,264$ & 209 \\
\hline & & & Dummy_Idade_4 &, 056 &, 562 &, 009 & ,099 & ,921 \\
\hline & & & Dummy_Idade_5 & ,222 & ,611 & 034 & ,363 & ,717 \\
\hline & & & Dummy_Idade_6 & $-1,111$ & ,778 &,- 134 & $-1,429$ & ,156 \\
\hline \multirow[t]{11}{*}{ Feminino } & Com filhos & 1 & (Constant) & 5,816 & ,215 & & 27,081 &, 000 \\
\hline & & & Dummy_Idade_1 & ,184 & ,794 & ,024 & ,232 & ,817 \\
\hline & & & Dummy_Idade_3 & ,184 & ,326 &, 063 & ,564 &, 574 \\
\hline & & & Dummy_Idade_4 &,- 296 & ,341 &,- 097 &,- 868 & ,388 \\
\hline & & & Dummy_Idade_5 &,- 038 & ,491 &,- 008 &,- 077 & ,938 \\
\hline & & & Dummy_Idade_6 & ,184 & 1,341 &, 014 & ,137 & ,891 \\
\hline & Sem filhos & 1 & (Constant) & 5,864 & , 145 & & 40,565 &, 000 \\
\hline & & & Dummy_Idade_1 &,- 242 & ,266 &,- 074 &,- 911 & ,364 \\
\hline & & & Dummy_Idade_3 &,- 056 & ,303 &,- 015 &,- 185 & 854 \\
\hline & & & Dummy_Idade_4 &,- 941 & ,403 &,- 186 & $-2,334$ & ,021 \\
\hline & & & Dummy_ldade_5 &,- 864 & ,970 &,- 069 &,- 891 & ,374 \\
\hline
\end{tabular}

a. Dependent Variable: EU

Tabela 55- Coeficiente de determinação para idades separado por sexo e existência de filhos- EGF

Model Summary

\begin{tabular}{|lll|r|r|r|r|}
\hline Sexo & Filhos_Categ & Model & $\mathrm{R}$ & R Square & $\begin{array}{c}\text { Adjusted } \\
\text { R Square }\end{array}$ & $\begin{array}{r}\text { Std. Error of } \\
\text { the Estimate }\end{array}$ \\
\hline Masculino & Com filhos & 1 &, $180^{\mathrm{a}}$ &, 032 &,- 025 & 1,37981 \\
\cline { 2 - 7 } & Sem filhos & 1 &, $145^{\mathrm{b}}$ &, 021 &,- 023 & 1,42348 \\
\hline Feminino & Com filhos & 1 &, $119^{\mathrm{a}}$ &, 014 &,- 036 & 1,32794 \\
\cline { 2 - 7 } & Sem filhos & 1 &, $090^{\mathrm{c}}$ &, 008 &,- 016 & 1,37010 \\
\hline
\end{tabular}

a. Predictors: (Constant), Dummy_Idade_6, Dummy_Idade_1, Dummy_Idade_5,

Dummy_Idade_4, Dummy_Idade_3

b. Predictors: (Constant), Dummy_Idade_6, Dummy_Idade_5, Dummy_Idade_4,

Dummy_Idade_3, Dummy_Idade_1

c. Predictors: (Constant), Dummy_Idade_5, Dummy_Idade_4, Dummy_Idade_3, Dummy_Idade_1 
Tabela 56- Coeficientes de regressão para faixas etárias, separadas por filhos e controladas por sexoEGF

\begin{tabular}{|c|c|c|c|c|c|c|c|c|}
\hline \multicolumn{9}{|c|}{ Coefficients $^{a}$} \\
\hline \multirow[b]{2}{*}{ Sexo } & \multirow[b]{2}{*}{ Filhos Categ } & \multirow[b]{2}{*}{ Model } & & \multicolumn{2}{|c|}{$\begin{array}{l}\text { Unstandardized } \\
\text { Coefficients }\end{array}$} & \multirow{2}{*}{$\begin{array}{c}\begin{array}{c}\text { Standardized } \\
\text { Coefficients }\end{array} \\
\text { Beta }\end{array}$} & \multirow[b]{2}{*}{$t$} & \multirow[b]{2}{*}{ Sig. } \\
\hline & & & & $\mathrm{B}$ & Std. Error & & & \\
\hline \multirow[t]{12}{*}{ Masculino } & Com filhos & 1 & (Constant) & 5,527 & ,276 & & 20,026 &, 000 \\
\hline & & & Dummy_ldade_1 & 1,513 & 1,407 & ,116 & 1,075 & 285 \\
\hline & & & Dummy_Idade_3 & ,410 & ,386 & ,137 & 1,061 & ,291 \\
\hline & & & Dummy_ldade_4 &,- 025 & ,399 &,- 008 &,- 064 & ,949 \\
\hline & & & Dummy_ldade_5 &,- 063 & ,485 &,- 016 &,- 130 & ,897 \\
\hline & & & Dummy_Idade_6 &, 064 & ,743 &, 010 & ,086 & ,931 \\
\hline & Sem filhos & 1 & (Constant) & 5,679 & ,179 & & 31,666 & ,000 \\
\hline & & & Dummy_ldade_1 & ,376 & ,353 & ,105 & 1,067 & ,288 \\
\hline & & & Dummy_Idade_3 &,- 300 & ,380 &,- 077 &,- 789 & ,432 \\
\hline & & & Dummy_ldade_4 &,- 114 & ,608 &,- 018 &,- 187 & ,852 \\
\hline & & & Dummy_ldade_5 &,- 104 & ,661 &,- 015 &,- 157 & ,876 \\
\hline & & & Dummy_Idade_6 & ,039 & ,841 & ,004 & ,046 & ,963 \\
\hline \multirow[t]{11}{*}{ Feminino } & Com filhos & 1 & (Constant) & 5,819 & ,215 & & 27,014 &, 000 \\
\hline & & & Dummy_Idade_1 & ,102 & ,796 &, 013 & ,128 & ,899 \\
\hline & & & Dummy_Idade_3 &, 011 & ,327 & 004 & ,032 & ,974 \\
\hline & & & Dummy_ldade_4 &,- 281 & ,342 &,- 092 &,- 821 & ,414 \\
\hline & & & Dummy_ldade_5 & ,203 & ,492 & ,044 & ,413 & ,680 \\
\hline & & & Dummy_ldade_6 &,- 610 & 1,345 &,- 046 &,- 454 & 651 \\
\hline & Sem filhos & 1 & (Constant) & 5,686 &, 145 & & 39,150 &, 000 \\
\hline & & & Dummy_ldade_1 & ,035 & ,268 & 011 & ,130 & ,897 \\
\hline & & & Dummy_ldade_3 &,- 025 & ,301 &,- 007 &,- 081 & ,935 \\
\hline & & & Dummy_Idade_4 &,- 406 & ,407 &,- 080 &,- 998 & ,320 \\
\hline & & & Dummy_ldade_5 &,- 477 & 980 &,- 038 &,- 486 & 627 \\
\hline
\end{tabular}

a. Dependent Variable: Equip_EGF_em_EU

Tabela 57- Coeficientes de regressão para faixas etárias, separadas por filhos e controladas por sexoOHQ

Model Summary

\begin{tabular}{|lll|r|r|r|r|}
\hline \multirow{2}{*}{ Sexo } & Filhos_Categ & Model & $\mathrm{R}$ & R Square & $\begin{array}{c}\text { Adjusted } \\
\text { R Square }\end{array}$ & $\begin{array}{r}\text { Std. Error of } \\
\text { the Estimate }\end{array}$ \\
\hline \multirow{2}{*}{ Masculino } & Com filhos & 1 &, $174^{\mathrm{a}}$ &, 030 &,- 025 & 1,39371 \\
\cline { 2 - 7 } & Sem filhos & 1 &, $097^{\mathrm{b}}$ &, 009 &,- 035 & 1,31178 \\
\hline \multirow{2}{*}{ Feminino } & Com filhos & 1 &, $195^{\mathrm{a}}$ &, 038 &,- 011 & 1,36998 \\
\cline { 2 - 8 } & Sem filhos & 1 &, $160^{\mathrm{c}}$ &, 026 &, 002 & 1,27746 \\
\hline
\end{tabular}

a. Predictors: (Constant), Dummy Idade 6, Dummy Idade 1, Dummy Idade 5,

Dummy_Idade_4, Dummy_Idade_3

b. Predictors: (Constant), Dummy_Idade_6, Dummy Idade 5, Dummy Idade 4,

Dummy_Idade_3, Dummy_Idade_1

c. Predictors: (Constant), Dummy_Idade_5, Dummy Idade_4, Dummy Idade_3,

Dummy_Idade_1 
Tabela 58- Coeficientes de regressão para faixas etárias, separadas por filhos e controladas por sexoOHQ

\begin{tabular}{|c|c|c|c|c|c|c|c|c|}
\hline \multicolumn{9}{|c|}{ Coefficients $^{a}$} \\
\hline \multirow[b]{2}{*}{ Sexo } & \multirow[b]{2}{*}{ Filhos Categ } & \multirow[b]{2}{*}{ Model } & & \multicolumn{2}{|c|}{$\begin{array}{c}\text { Unstandardized } \\
\text { Coefficients }\end{array}$} & \multirow{2}{*}{$\begin{array}{c}\begin{array}{c}\text { Standardized } \\
\text { Coefficients }\end{array} \\
\text { Beta }\end{array}$} & \multirow[b]{2}{*}{$t$} & \multirow[b]{2}{*}{ Sig. } \\
\hline & & & & $\mathrm{B}$ & Std. Error & & & \\
\hline \multirow[t]{12}{*}{ Masculino } & Com filhos & 1 & (Constant) & 5,262 & ,273 & & 19,252 &, 000 \\
\hline & & & Dummy_Idade_1 & 1,969 & 1,420 & 148 & 1,386 & , 169 \\
\hline & & & Dummy_Idade_3 & ,246 & ,383 &, 082 & ,643 &, 522 \\
\hline & & & Dummy_Idade_4 &,- 088 & ,399 &,- 028 &,- 220 & ,826 \\
\hline & & & Dummy_ldade_5 & ,151 & ,486 & ,037 & ,310 & ,757 \\
\hline & & & Dummy_Idade_6 & ,259 & ,749 & ,038 & ,346 & ,730 \\
\hline & Sem filhos & 1 & (Constant) & 5,446 & 165 & & 32,952 &, 000 \\
\hline & & & Dummy_Idade_1 &, 041 & ,325 & ,012 & ,126 & ,900 \\
\hline & & & Dummy_Idade_3 & ,197 & ,351 &, 055 &, 562 &, 575 \\
\hline & & & Dummy_ldade_4 & ,333 &, 560 & 057 &, 594 &, 553 \\
\hline & & & Dummy_ldade_5 & ,460 & ,609 & 073 & ,755 & ,452 \\
\hline & & & Dummy_Idade_6 &,- 015 & ,775 &,- 002 &,- 019 & ,985 \\
\hline \multirow[t]{11}{*}{ Feminino } & Com filhos & 1 & (Constant) & 5,224 & 222 & & 23,508 & ,000 \\
\hline & & & Dummy_Idade_1 &,- 153 & ,822 &,- 019 &,- 187 & ,852 \\
\hline & & & Dummy_Idade_3 & ,194 & ,338 & ,064 &, 575 &, 567 \\
\hline & & & Dummy_Idade_4 & ,417 & ,353 & 131 & 1,181 & ,240 \\
\hline & & & Dummy_ldade_5 & ,887 &, 508 & ,183 & 1,746 & ,084 \\
\hline & & & Dummy_Idade_6 &, 567 & 1,388 & 041 & ,408 & ,684 \\
\hline & Sem filhos & 1 & (Constant) & 5,403 & ,135 & & 39,898 & 000 \\
\hline & & & Dummy_ldade_1 &,- 338 & ,250 &,- 110 & $-1,351$ & ,179 \\
\hline & & & Dummy_Idade_3 & ,178 & 281 &, 051 & ,633 & ,528 \\
\hline & & & Dummy_ldade_4 &,- 487 & 379 &,- 102 & $-1,283$ & 201 \\
\hline & & & Dummy_Idade_5 &,- 080 & 913 &,- 007 &,- 087 & ,931 \\
\hline
\end{tabular}

a. Dependent Variable: Equip_OHQ_em_EU

Tabela 59- Análise variância médias das escalas - etnia

ANOVA

\begin{tabular}{|ll|r|r|r|r|r|}
\hline & & \multicolumn{1}{|c|}{$\begin{array}{c}\text { Sum of } \\
\text { Squares }\end{array}$} & df & Mean Square & F & Sig. \\
\hline EU & Between Groups & 8,355 & 3 & 2,785 & 1,513 &, 210 \\
& Within Groups & 874,133 & 475 & 1,840 & & \\
& Total & 882,489 & 478 & & &, 403 \\
\hline Equip_EGF_em_EU & Between Groups & 5,411 & 3 & 1,804 &, 978 & \\
& Within Groups & 876,187 & 475 & 1,845 & & \\
& Total & 881,598 & 478 & & &, 184 \\
& Between Groups & 8,397 & 3 & 2,799 & 1,618 & \\
& Within Groups & 824,996 & 477 & 1,730 & & \\
& Total & 833,394 & 480 & & & \\
\hline
\end{tabular}


Tabela 60- Correlação entre médias equiparadas - etnias

\begin{tabular}{|c|c|c|c|c|c|}
\hline \multicolumn{6}{|c|}{ Paired Samples Correlations } \\
\hline \multicolumn{3}{|l|}{ etnia } & $\mathrm{N}$ & Correlation & Sig. \\
\hline & Pair 1 & EU \& Equip_EGF_em_EU & 3 &, 610 &, 582 \\
\hline & Pair 2 & EU \& Equip_OHQ_em_EU & 3 & ,993 & 076 \\
\hline & Pair 3 & Equip_EGF_em_EU \& Equip_OHQ_em_EU & 3 &, 512 & ,658 \\
\hline \multirow[t]{3}{*}{ Negro } & Pair 1 & EU \& Equip_EGF_em_EU & 18 & ,191 & ,447 \\
\hline & Pair 2 & EU \& Equip_OHQ_em_EU & 18 & ,302 & ,223 \\
\hline & Pair 3 & Equip_EGF_em_EU \& Equip_OHQ_em_EU & 18 & ,492 & 038 \\
\hline \multirow[t]{3}{*}{ Pardo } & Pair 1 & EU \& Equip_EGF_em_EU & 79 &, 590 & 000 \\
\hline & Pair 2 & EU \& Equip_OHQ_em_EU & 79 &, 559 & 000 \\
\hline & Pair 3 & Equip_EGF_em_EU \& Equip_OHQ_em_EU & 79 &, 588 &, 000 \\
\hline \multirow[t]{3}{*}{ Branco } & Pair 1 & EU \& Equip_EGF_em_EU & 377 & ,673 & 000 \\
\hline & Pair 2 & EU \& Equip_OHQ_em_EU & 379 &, 572 &, 000 \\
\hline & Pair 3 & Equip_EGF_em_EU \& Equip_OHQ_em_EU & 379 & ,647 &, 000 \\
\hline \multirow[t]{3}{*}{ Índio } & Pair 1 & EU \& Equip_EGF_em_EU & 3 & 945 & ,212 \\
\hline & Pair 2 & EU \& Equip_OHQ_em_EU & 3 & ,711 & , 497 \\
\hline & Pair 3 & Equip_EGF_em_EU \& Equip_OHQ_em_EU & 3 & 902 & ,284 \\
\hline
\end{tabular}

Tabela 61- Teste médias equiparadas - etnias

\begin{tabular}{|c|c|c|c|c|c|c|c|c|c|c|}
\hline \multicolumn{11}{|c|}{ Paired Samples Test } \\
\hline \multirow[b]{3}{*}{ etnia } & & & \multicolumn{5}{|c|}{ Paired Differences } & \multirow[b]{3}{*}{ t } & \multirow[b]{3}{*}{ df } & \multirow{3}{*}{$\begin{array}{c}\text { Sig. } \\
\text { (2-tailed) }\end{array}$} \\
\hline & & & \multirow[b]{2}{*}{ Mean } & \multirow{2}{*}{$\begin{array}{c}\text { Std. } \\
\text { Deviation }\end{array}$} & \multirow{2}{*}{$\begin{array}{l}\text { Std. } \\
\text { Error } \\
\text { Mean }\end{array}$} & \multicolumn{2}{|c|}{$\begin{array}{c}95 \% \text { Confidence } \\
\text { Interval of the } \\
\text { Difference }\end{array}$} & & & \\
\hline & & & & & & Lower & Upper & & & \\
\hline . & Pair 1 & EU - Equip_EGF_em_EU & 33877 & ,92410 & 5,53353 & $-1,957$ & 2,63437 & 635 & 2 &, 590 \\
\hline & Pair 2 & EU - Equip_OHQ_em_EU & 1,06767 & 64445 & ,37207 &,- 53324 & 2,66857 & 2,870 & 2 & 103 \\
\hline & Pair 3 & Equip_EGF_em_EU - Equip_OHQ_em_EU &, 72890 & 1,17176 &, 67652 & $-2,182$ & 3,63972 & 1,077 & 2 & ,394 \\
\hline Negro & Pair 1 & EU - Equip_EGF_em_EU &,- 54349 & 2,00178 & ,47182 & $-1,539$ & ,45197 & $-1,152$ & 17 & ,265 \\
\hline & Pair 2 & EU - Equip_OHQ_em_EU &,- 17944 & 1,86652 & ,43994 & $-1,108$ & ,74876 &,- 408 & 17 & 688 \\
\hline & Pair 3 & Equip_EGF_em_EU - Equip_OHQ_em_EU & ,36405 & 1,29611 & ,30550 &,- 28049 & 1,00859 & 1,192 & 17 & ,250 \\
\hline Pardo & Pair 1 & EU - Equip_EGF_em_EU & 04695 & 1,20752 & ,13586 &,- 22352 & ,31742 & ,346 & 78 & 731 \\
\hline & Pair 2 & EU - Equip_OHQ_em_EU & ,46915 & 1,24105 & ,13963 & 19117 & ,74713 & 3,360 & 78 & 001 \\
\hline & Pair 3 & Equip_EGF_em_EU - Equip_OHQ_em_EU & ,42220 & 1,21590 & 13680 & 14985 & 69455 & 3,086 & 78 &, 003 \\
\hline Branco & Pair 1 & EU - Equip_EGF_em_EU & ,00927 & 1,09440 & 05636 &,- 10156 & ,12010 &, 164 & 376 & ,869 \\
\hline & Pair 2 & EU - Equip_OHQ_em_EU & ,25360 & 1,22946 & 06315 & 12943 & 37778 & 4,016 & 378 &, 000 \\
\hline & Pair 3 & Equip_EGF_em_EU - Equip_OHQ_em_EU & ,23943 & 1,12633 & ,05786 &, 12567 & ,35319 & 4,138 & 378 &, 000 \\
\hline Índio & Pair 1 & EU - Equip_EGF_em_EU &,- 83640 & ,90432 &, 52211 & $-3,083$ & 1,41007 & $-1,602$ & 2 & ,250 \\
\hline & Pair 2 & EU - Equip_OHQ_em_EU &, 01700 & 1,46956 & ,84845 & $-3,634$ & 3,66760 &, 020 & 2 & ,986 \\
\hline & Pair 3 & Equip_EGF_em_EU - Equip_OHQ_em_EU & ,85340 &, 59001 & ,34064 &,- 61227 & 2,31907 & 2,505 & 2 &, 129 \\
\hline
\end{tabular}

Tabela 62-Regressão idades dummy para EU para etnia

\begin{tabular}{|l|r|r|r|r|}
\hline Model & $\mathrm{R}$ & $\mathrm{R}$ Square & $\begin{array}{c}\text { Adjusted } \\
\text { R Square }\end{array}$ & $\begin{array}{c}\text { Std. Error of } \\
\text { the Estimate }\end{array}$ \\
\hline 1 &, $095^{\mathrm{a}}$ &, 009 &, 003 & 1,35533 \\
\hline
\end{tabular}

Tabela 63- Coeficientes regressão etnia dummy para EU

Coefficients $^{a}$

\begin{tabular}{|rl|r|r|r|r|r|}
\hline \multirow{2}{*}{ Model } & \multicolumn{2}{|c|}{$\begin{array}{c}\text { Unstandardized } \\
\text { Coefficients }\end{array}$} & \multicolumn{2}{c|}{$\begin{array}{c}\text { Standardized } \\
\text { Coefficients }\end{array}$} & \\
\cline { 3 - 5 } & & \multicolumn{1}{|c|}{ B } & Std. Error & \multicolumn{1}{|c|}{ Beta } & \multicolumn{1}{c|}{ Sig. } \\
\hline 1 & (Constant) & 5,646 &, 150 & & 37,725 &, 000 \\
& Dummy_Negro &,- 591 &, 353 &,- 083 & $-1,675$ &, 095 \\
& Dummy_Branco &, 074 &, 165 &, 022 &, 448 &, 654 \\
& Dummy_Índio &, 354 &, 797 &, 021 &, 444 &, 657 \\
\hline
\end{tabular}

a. Dependent Variable: EU 
Tabela 64-Regressão idades dummy para OHQ para etnia

\begin{tabular}{|l|r|r|r|r|}
\multicolumn{7}{c|}{ Model Summary } \\
\hline Model & $\mathrm{R}$ & R Square & $\begin{array}{c}\text { Adjusted } \\
\text { R Square }\end{array}$ & $\begin{array}{c}\text { Std. Error of } \\
\text { the Estimate }\end{array}$ \\
\hline 1 &, $097^{\mathrm{a}}$ &, 009 &, 003 & 18,24770 \\
\hline
\end{tabular}

a. Predictors: (Constant), Dummy_Índio, Dummy_Negro,

Dummy_Branco

Tabela 65- Coeficientes regressão etnia dummy para OHQ

Coefficients $^{a}$

\begin{tabular}{|rl|r|r|r|r|r|}
\hline \multirow{2}{*}{ Model } & \multicolumn{2}{|c|}{$\begin{array}{c}\text { Unstandardized } \\
\text { Coefficients }\end{array}$} & \multicolumn{2}{c|}{$\begin{array}{c}\text { Standardized } \\
\text { Coefficients }\end{array}$} & & \\
\cline { 3 - 5 } & & \multicolumn{1}{|c|}{$\mathrm{B}$} & Std. Error & Beta & $\mathrm{t}$ & \multirow{2}{*}{ Sig. } \\
\cline { 3 - 7 } & (Constant) & 121,171 & 2,015 & & 60,131 &, 000 \\
& Dummy_Negro & 1,107 & 4,750 &, 011 &, 233 &, 816 \\
& Dummy_Branco & 4,268 & 2,221 &, 096 & 1,921 &, 055 \\
& Dummy_Índio & 11,496 & 10,726 &, 049 & 1,072 &, 284 \\
\hline
\end{tabular}

a. Dependent Variable: Total_OHQ

Tabela 66-Regressão idades dummy para EGF para etnia

\begin{tabular}{|l|r|r|r|r|}
\multicolumn{7}{|c|}{ Model Summary } \\
\hline Model & R & R Square & $\begin{array}{l}\text { Adjusted } \\
\text { R Square }\end{array}$ & $\begin{array}{r}\text { Std. Error of } \\
\text { the Estimate }\end{array}$ \\
\hline 1 &, $075^{\mathrm{a}}$ &, 006 &,- 001 & 4,44859 \\
\hline
\end{tabular}

a. Predictors: (Constant), Dummy_Índio, Dummy_Negro,

Dummy_Branco

Tabela 67- Coeficientes regressão etnia dummy para EGF

Coefficients $^{\mathrm{a}}$

\begin{tabular}{|rl|r|r|r|r|r|}
\hline \multirow{2}{*}{ Model } & \multicolumn{2}{|c|}{$\begin{array}{c}\text { Unstandardized } \\
\text { Coefficients }\end{array}$} & $\begin{array}{c}\text { Standardized } \\
\text { Coefficients }\end{array}$ & \\
\cline { 3 - 5 } & \multicolumn{1}{|c|}{$\mathrm{B}$} & Std. Error & \multicolumn{1}{|c|}{ Beta } & \multicolumn{1}{c|}{ t } & \multicolumn{1}{c|}{ Sig. } \\
\hline 1 & (Constant) & 21,244 &, 491 & & 43,243 &, 000 \\
& Dummy_Negro &, 034 & 1,158 &, 001 &, 029 &, 977 \\
& Dummy_Branco &, 366 &, 542 &, 034 &, 675 &, 500 \\
& Dummy_Índio & 4,089 & 2,615 &, 072 & 1,564 &, 119 \\
\hline
\end{tabular}

a. Dependent Variable: TOTAL_EGF 
Tabela 68- Análise de variância para sexo separado por etnia

\begin{tabular}{|c|c|c|c|c|c|c|c|}
\hline \multicolumn{8}{|c|}{ ANOVA } \\
\hline \multicolumn{3}{|l|}{ etnia } & $\begin{array}{c}\text { Sum of } \\
\text { Squares }\end{array}$ & $d f$ & Mean Square & & \\
\hline & \multirow[t]{3}{*}{$\mathrm{EU}$} & Between Groups &, 167 & 1 & \multirow{3}{*}{$\begin{array}{r}, 167 \\
, 500\end{array}$} & \multirow{3}{*}{$\frac{\mathrm{F}}{, 333}$} & \multirow{3}{*}{$\frac{\text { Sig. }}{, 667}$} \\
\hline & & Within Groups &, 500 & 1 & & & \\
\hline & & Total &, 667 & 2 & & & \\
\hline & \multirow[t]{3}{*}{ Equip_EGF_em_EU } & Between Groups & ,388 & 1 & ,388 & \multirow[t]{3}{*}{170} & \multirow[t]{3}{*}{,751 } \\
\hline & & Within Groups & 2,281 & 1 & 2,281 & & \\
\hline & & Total & 2,668 & 2 & & & \\
\hline & \multirow[t]{3}{*}{ Equip_OHQ_em_EU } & Between Groups & 1,058 & 1 & 1,058 & \multirow[t]{3}{*}{, 560} & \multirow[t]{3}{*}{,591 } \\
\hline & & Within Groups & 1,890 & 1 & 1,890 & & \\
\hline & & Total & 2,948 & 2 & & & \\
\hline \multirow[t]{9}{*}{ Negro } & \multirow[t]{3}{*}{ EU } & Between Groups & 1,334 & 1 & 1,334 & \multirow[t]{3}{*}{,398 } & \multirow[t]{3}{*}{,537 } \\
\hline & & Within Groups & 53,610 & 16 & 3,351 & & \\
\hline & & Total & 54,944 & 17 & & & \\
\hline & \multirow[t]{3}{*}{ Equip_EGF_em_EU } & Between Groups & 10,479 & 1 & 10,479 & \multirow[t]{3}{*}{9,428} & \multirow[t]{3}{*}{,007 } \\
\hline & & Within Groups & 17,783 & 16 & 1,111 & & \\
\hline & & Total & 28,262 & 17 & & & \\
\hline & \multirow[t]{3}{*}{ Equip_OHQ_em_EU } & Between Groups & 2,340 & 1 & 2,340 & \multirow[t]{3}{*}{1,459} & ,245 \\
\hline & & Within Groups & 25,662 & 16 & 1,604 & & \\
\hline & & Total & 28,002 & 17 & & & \\
\hline Pardo & EU & Between Groups & 2,659 & 1 & 2,659 & 1,531 & ,220 \\
\hline & & Within Groups & 132,020 & 76 & 1,737 & & \\
\hline & & Total & 134,679 & 77 & & & \\
\hline & Equip_EGF_em_EU & Between Groups & 1,808 & 1 & 1,808 & ,990 & ,323 \\
\hline & & Within Groups & 138,819 & 76 & 1,827 & & \\
\hline & & Total & 140,627 & 77 & & & \\
\hline & Equip_OHQ_em_EU & Between Groups & 4,117 & 1 & 4,117 & 2,348 & , 130 \\
\hline & & Within Groups & 133,230 & 76 & 1,753 & & \\
\hline & & Total & 137,347 & 77 & & & \\
\hline Branco & EU & Between Groups & 8,088 & 1 & 8,088 & 4,549 & ,034 \\
\hline & & Within Groups & 670,265 & 377 & 1,778 & & \\
\hline & & Total & 678,354 & 378 & & & \\
\hline & Equip_EGF_em_EU & Between Groups & 2,837 & 1 & 2,837 & 1,526 & ,218 \\
\hline & & Within Groups & 701,098 & 377 & 1,860 & & \\
\hline & & Total & 703,936 & 378 & & & \\
\hline & Equip_OHQ_em_EU & Between Groups & ,136 & 1 & ,136 & ,078 & ,780 \\
\hline & & Within Groups & 659,154 & 379 & 1,739 & & \\
\hline & & Total & 659,290 & 380 & & & \\
\hline Índio & EU & Between Groups & 6,000 & 1 & 6,000 & . & . \\
\hline & & Within Groups &, 000 & 1 &, 000 & & \\
\hline & & Total & 6,000 & 2 & & & \\
\hline & Equip_EGF_em_EU & Between Groups & 1,551 & 1 & 1,551 & 8,333 & ,212 \\
\hline & & Within Groups & ,186 & 1 & ,186 & & \\
\hline & & Total & 1,738 & 2 & & & \\
\hline & Equip_OHQ_em_EU & Between Groups & ,169 & 1 & , 169 & 1,021 & ,497 \\
\hline & & Within Groups & , 166 & 1 & ,166 & & \\
\hline & & Total & ,335 & 2 & & & \\
\hline
\end{tabular}

Tabela 69- Coeficientes de determinação regressão etnia avaliada por sexo - EU

\begin{tabular}{|ll|r|r|r|r|}
\multicolumn{7}{|c|}{ Model Summary } \\
\hline etnia & Model & \multicolumn{1}{c|}{$\mathrm{R}$} & \multicolumn{1}{c|}{ R Square } & $\begin{array}{c}\text { Adjusted } \\
\text { R Square }\end{array}$ & $\begin{array}{c}\text { Std. Error of } \\
\text { the Estimate }\end{array}$ \\
\hline & 1 &, $500^{\mathrm{a}}$ &, 250 &,- 500 &, 70711 \\
\hline Negro & 1 &, $156^{\mathrm{a}}$ &, 024 &,- 037 & 1,83048 \\
\hline Pardo & 1 &, $144^{\mathrm{a}}$ &, 021 &, 008 & 1,30957 \\
\hline Branco & 1 &, $109^{\mathrm{a}}$ &, 012 &, 009 & 1,33338 \\
\hline Índio & 1 & $1,000^{\mathrm{a}}$ & 1,000 & 1,000 &, 00000 \\
\hline
\end{tabular}

a. Predictors: (Constant), Dummy_Mulher 
Tabela 70- Coeficientes de regressão etnia avaliada por sexo - EU

Coefficients ${ }^{\mathrm{a}}$

\begin{tabular}{|c|c|c|c|c|c|c|c|}
\hline \multirow[b]{2}{*}{ etnia } & \multirow[b]{2}{*}{ Model } & & \multicolumn{2}{|c|}{$\begin{array}{c}\text { Unstandardized } \\
\text { Coefficients }\end{array}$} & \multirow{2}{*}{$\begin{array}{l}\text { Standardized } \\
\text { Coefficients } \\
\text { Beta }\end{array}$} & \multirow[b]{2}{*}{$t$} & \multirow[b]{2}{*}{ Sig. } \\
\hline & & & B & Std. Error & & & \\
\hline & 1 & (Constant) & 7,000 & ,707 & & 9,899 &, 064 \\
\hline & & Dummy_Mulher &,- 500 & ,866 &,- 500 &,- 577 & ,667 \\
\hline \multirow[t]{2}{*}{ Negro } & 1 & (Constant) & 5,273 & ,552 & & 9,554 & ,000 \\
\hline & & Dummy_Mulher &,- 558 & ,885 &,- 156 &,- 631 & ,537 \\
\hline \multirow[t]{2}{*}{ Pardo } & 1 & (Constant) & 5,824 & ,225 & & 25,930 &, 000 \\
\hline & & Dummy_Mulher &,- 379 & ,298 &,- 144 & $-1,274$ & , 207 \\
\hline \multirow[t]{2}{*}{ Branco } & 1 & (Constant) & 5,552 & ,104 & & 53,162 & ,000 \\
\hline & & Dummy_Mulher & 295 & , 138 & 109 & 2,133 & 034 \\
\hline \multirow[t]{2}{*}{ Índio } & 1 & (Constant) & 7,000 & ,000 & & . & . \\
\hline & & Dummy_Mulher & $-3,000$ & ,000 & $-1,000$ & . & \\
\hline
\end{tabular}

a. Dependent Variable: EU

Tabela 71- Coeficientes de determinação regressão etnia avaliada por sexo - EGF

Model Summary

\begin{tabular}{|ll|r|r|r|r|}
\hline etnia & Model & \multicolumn{1}{|c|}{$\mathrm{R}$} & R Square & $\begin{array}{c}\text { Adjusted } \\
\text { R Square }\end{array}$ & $\begin{array}{c}\text { Std. Error of } \\
\text { the Estimate }\end{array}$ \\
\hline$\cdot$ & 1 &, $381^{\mathrm{a}}$ &, 145 &,- 709 & 1,51017 \\
\hline Negro & 1 &, $609^{\mathrm{a}}$ &, 371 &, 331 & 1,05425 \\
\hline Pardo & 1 &, $098^{\mathrm{a}}$ &, 010 &,- 003 & 1,35268 \\
\hline Branco & 1 &, $063^{\mathrm{a}}$ &, 004 &, 001 & 1,36370 \\
\hline Índio & 1 &, $945^{\mathrm{a}}$ &, 893 &, 786 &, 43148 \\
\hline
\end{tabular}

a. Predictors: (Constant), Dummy_Mulher

Tabela 72- Coeficientes de regressão etnia avaliada por sexo - -EGF

Coefficients ${ }^{\mathrm{a}}$

\begin{tabular}{|c|c|c|c|c|c|c|c|}
\hline \multirow[b]{2}{*}{ etnia } & \multirow[b]{2}{*}{ Model } & & \multicolumn{2}{|c|}{$\begin{array}{c}\text { Unstandardized } \\
\text { Coefficients }\end{array}$} & \multirow{2}{*}{$\begin{array}{c}\text { Standardized } \\
\text { Coefficients } \\
\text { Beta }\end{array}$} & \multirow[b]{2}{*}{$t$} & \multirow[b]{2}{*}{ Sig. } \\
\hline & & & $\mathrm{B}$ & Std. Error & & & \\
\hline & 1 & (Constant) & 5,819 & 1,510 & & 3,853 &, 162 \\
\hline & & Dummy_Mulher & ,763 & 1,850 & ,381 & ,412 & 751 \\
\hline \multirow[t]{2}{*}{ Negro } & 1 & (Constant) & 6,208 & ,318 & & 19,529 & 000 \\
\hline & & Dummy_Mulher & $-1,565$ &, 510 &,- 609 & $-3,071$ & ,007 \\
\hline \multirow[t]{2}{*}{ Pardo } & 1 & (Constant) & 5,712 & ,232 & & 24,621 & ,000 \\
\hline & & Dummy_Mulher &,- 265 & 307 & -,098 &,- 863 & ,391 \\
\hline \multirow[t]{2}{*}{ Branco } & 1 & (Constant) & 5,600 & ,107 & & 52,101 & ,000 \\
\hline & & Dummy_Mulher & ,175 & ,142 & ,063 & 1,235 & ,218 \\
\hline \multirow[t]{2}{*}{ Índio } & 1 & (Constant) & 7,345 & ,305 & & 24,074 & ,026 \\
\hline & & Dummy_Mulher & $-1,526$ & ,528 &,- 945 & $-2,887$ & ,212 \\
\hline
\end{tabular}

a. Dependent Variable: Equip_EGF_em_EU 
Tabela 73- Coeficientes de determinação regressão etnia avaliada por sexo - - OHQ

\begin{tabular}{|ll|r|r|r|r|}
\multicolumn{7}{|c|}{ Model Summary } \\
\hline etnia & Model & \multicolumn{1}{c|}{$\mathrm{R}$} & \multicolumn{1}{c|}{ R Square } & $\begin{array}{r}\text { Adjusted } \\
\text { R Square }\end{array}$ & $\begin{array}{r}\text { Std. Error of } \\
\text { the Estimate }\end{array}$ \\
\hline$\cdot$ & 1 &, $599^{\mathrm{a}}$ &, 359 &,- 282 & 1,37462 \\
\hline Negro & 1 &, $289^{\mathrm{a}}$ &, 084 &, 026 & 1,26644 \\
\hline Pardo & 1 &, $173^{\mathrm{a}}$ &, 030 &, 017 & 1,31546 \\
\hline Branco & 1 &, $014^{\mathrm{a}}$ &, 000 &,- 002 & 1,31878 \\
\hline Índio & 1 &, $711^{\mathrm{a}}$ &, 505 &, 010 &, 40729 \\
\hline
\end{tabular}

a. Predictors: (Constant), Dummy_Mulher

Tabela 74- Coeficientes de regressão etnia avaliada por sexo - -OHQ

Coefficients $^{\mathrm{a}}$

\begin{tabular}{|c|c|c|c|c|c|c|c|}
\hline \multirow[b]{2}{*}{ etnia } & \multirow[b]{2}{*}{ Model } & & \multicolumn{2}{|c|}{$\begin{array}{c}\text { Unstandardized } \\
\text { Coefficients }\end{array}$} & \multirow{2}{*}{$\begin{array}{c}\text { Standardized } \\
\text { Coefficients }\end{array}$} & \multirow[b]{2}{*}{$t$} & \multirow[b]{2}{*}{ Sig. } \\
\hline & & & $\mathrm{B}$ & Std. Error & & & \\
\hline \multirow[t]{2}{*}{ 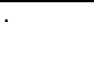 } & 1 & (Constant) & 6,439 & 1,375 & & 4,684 &, 134 \\
\hline & & Dummy_Mulher & $-1,260$ & 1,684 &,- 599 &,- 748 & ,591 \\
\hline \multirow[t]{2}{*}{ Negro } & 1 & (Constant) & 5,523 & ,382 & & 14,463 & ,000 \\
\hline & & Dummy_Mulher &,- 740 & ,612 &,- 289 & $-1,208$ & ,245 \\
\hline \multirow[t]{2}{*}{ Pardo } & 1 & (Constant) & 5,401 & ,226 & & 23,942 & ,000 \\
\hline & & Dummy_Mulher &,- 462 & 299 &,- 173 & $-1,544$ & ,127 \\
\hline \multirow[t]{2}{*}{ Branco } & 1 & (Constant) & 5,441 & ,103 & & 52,672 & ,000 \\
\hline & & Dummy_Mulher & ,038 & ,137 & ,014 & ,280 & ,780 \\
\hline \multirow[t]{2}{*}{ Índio } & 1 & (Constant) & 6,151 & ,288 & & 21,358 & ,030 \\
\hline & & Dummy_Mulher &,- 504 & ,499 &,- 711 & $-1,010$ & ,497 \\
\hline
\end{tabular}

a. Dependent Variable: Equip_OHQ_em_EU

Tabela 75- Grupos étnicos $x$ distribuição de renda etnia * renda Crosstabulation

\begin{tabular}{|c|c|c|c|c|c|c|c|c|}
\hline & & \multicolumn{6}{|c|}{ renda } & \multirow[b]{2}{*}{ Total } \\
\hline & & Até 500 & $501-1.000$ & $1.001-1.500$ & $1.501-2.000$ & $2.001-2.500$ & $2.501-3.000$ & \\
\hline \multirow[t]{4}{*}{ etnia } & Negro & 3 & 10 & 3 & 1 & 0 & 1 & 18 \\
\hline & Pardo & 18 & 23 & 14 & 8 & 3 & 12 & 78 \\
\hline & Branco & 47 & 100 & 79 & 60 & 34 & 56 & 376 \\
\hline & Índio & 1 & 1 & 1 & 0 & 0 & 0 & 3 \\
\hline Total & & 69 & 134 & 97 & 69 & 37 & 69 & 475 \\
\hline
\end{tabular}

Tabela 76- Coeficientes de determinação regressão idades separados por etnia EU

\begin{tabular}{|ll|r|r|r|r|}
\multicolumn{7}{|c|}{ Model Summary } \\
\hline etnia & Model & \multicolumn{1}{c|}{$\mathrm{R}$} & R Square & $\begin{array}{c}\text { Adjusted } \\
\text { R Square }\end{array}$ & $\begin{array}{c}\text { Std. Error of } \\
\text { the Estimate }\end{array}$ \\
\hline & 1 &, $500^{\mathrm{a}}$ &, 250 &,- 500 &, 70711 \\
\hline Negro & 1 &, $236^{\mathrm{b}}$ &, 056 &,- 070 & 1,85978 \\
\hline Pardo & 1 &, $169^{\mathrm{c}}$ &, 028 &,- 024 & 1,33053 \\
\hline Branco & 1 &, $194^{\mathrm{d}}$ &, 038 &, 025 & 1,32302 \\
\hline Índio & 1 & $1,000^{\mathrm{b}}$ & 1,000 & & \\
\hline
\end{tabular}

a. Predictors: (Constant), Dummy_Idade_5

b. Predictors: (Constant), Dummy_Idade_3, Dummy_Idade_2

c. Predictors: (Constant), Dummy_Idade_5, Dummy_Idade_4,

Dummy_Idade_3, Dummy_Idade_2

d. Predictors: (Constant), Dummy_Idade_6, Dummy_Idade_5,

Dummy_Idade_4, Dummy_Idade_3, Dummy_Idade_2 
Tabela 77- Coeficientes de regressão idades separados por etnia EU

\begin{tabular}{|c|c|c|c|c|c|c|c|}
\hline \multirow[b]{3}{*}{ etnia } & \multicolumn{7}{|c|}{ Coefficients $^{\mathrm{a}}$} \\
\hline & & & \multicolumn{2}{|c|}{$\begin{array}{c}\text { Unstandardized } \\
\text { Coefficients }\end{array}$} & \multirow{2}{*}{$\begin{array}{c}\begin{array}{c}\text { Standardized } \\
\text { Coefficients }\end{array} \\
\text { Beta }\end{array}$} & \multirow[b]{2}{*}{$t$} & \multirow[b]{2}{*}{ Sig. } \\
\hline & & Model & $\mathrm{B}$ & $\begin{array}{l}\text { Std. } \\
\text { Error }\end{array}$ & & & \\
\hline \multirow[t]{2}{*}{ 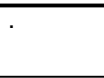 } & 1 & (Constant) & 6,500 &, 500 & & 13,000 &, 049 \\
\hline & & Dummy_Idade_5 &, 500 & ,866 & ,500 &, 577 & ,667 \\
\hline \multirow[t]{3}{*}{ Negro } & 1 & (Constant) & 5,500 & 1,315 & & 4,182 &, 001 \\
\hline & & Dummy_Idade_2 &,- 773 & 1,430 &,- 216 &,- 541 &, 597 \\
\hline & & Dummy_Idade_3 &, 100 & 1,556 &, 026 &, 064 & ,950 \\
\hline \multirow[t]{5}{*}{ Pardo } & 1 & (Constant) & 5,500 & ,314 & & 17,538 & ,000 \\
\hline & & Dummy_Idade_5 & 1,500 & 1,367 & 128 & 1,097 & ,276 \\
\hline & & Dummy_Idade_2 &, 075 & ,378 & ,029 & ,199 & ,843 \\
\hline & & Dummy_Idade_3 &,- 045 &, 509 &,- 012 &,- 089 & ,929 \\
\hline & & Dummy_Idade_4 &, 500 &, 543 & ,122 & ,920 & ,360 \\
\hline \multirow[t]{6}{*}{ Branco } & 1 & (Constant) & 5,905 & 204 & & 28,924 &, 000 \\
\hline & & Dummy_Idade_5 &,- 520 & ,330 &,- 098 & $-1,575$ & 116 \\
\hline & & Dummy_Idade_2 &,- 004 & 229 &,- 001 &,- 015 & ,988 \\
\hline & & Dummy_Idade_3 &,- 146 & ,251 &,- 045 &,- 582 &, 561 \\
\hline & & Dummy_Idade_4 &,- 698 & 268 &,- 188 & $-2,603$ &, 010 \\
\hline & & Dummy_Idade_6 &,- 405 &, 510 &,- 043 &,- 793 & ,428 \\
\hline \multirow[t]{3}{*}{ Índio } & 1 & (Constant) & 7,000 & 000 & & & \\
\hline & & Dummy_Idade_2 & $-3,000$ &, 000 & $-1,000$ & & \\
\hline & & Dummy_Idade_3 &, 000 & ,000 &, 000 & & \\
\hline
\end{tabular}

a. Dependent Variable: EU

Tabela 78- Coeficientes de determinação regressão idades separados por etnia -EGF

Model Summary

\begin{tabular}{|ll|r|r|r|r|}
\hline etnia & Model & \multicolumn{1}{c|}{$\mathrm{R}$} & $\mathrm{R}$ Square & $\begin{array}{c}\text { Adjusted } \\
\text { R Square }\end{array}$ & $\begin{array}{c}\text { Std. Error of } \\
\text { the Estimate }\end{array}$ \\
\hline$\cdot$ & 1 &, $381^{\mathrm{a}}$ &, 145 &,- 709 & 1,51017 \\
\hline Negro & 1 &, $170^{\mathrm{b}}$ &, 029 &,- 101 & 1,35266 \\
\hline Pardo & 1 &, $271^{\mathrm{c}}$ &, 073 &, 023 & 1,33458 \\
\hline Branco & 1 &, $110^{\mathrm{d}}$ &, 012 &,- 001 & 1,36549 \\
\hline Índio & 1 & $1,000^{\mathrm{b}}$ & 1,000 & & \\
\hline
\end{tabular}

a. Predictors: (Constant), Dummy_Idade_5

b. Predictors: (Constant), Dummy_Idade_3, Dummy_Idade_2

c. Predictors: (Constant), Dummy_Idade_5, Dummy_Idade_4, Dummy_Idade_3, Dummy_Idade_2

d. Predictors: (Constant), Dummy_Idade_6, Dummy_Idade_5, Dummy_Idade_4, Dummy_Idade_3, Dummy_Idade_2 
Tabela 79- Coeficientes de regressão idades separados por etnia -EGF

\begin{tabular}{|c|c|c|c|c|c|c|c|}
\hline \multicolumn{8}{|c|}{ Coefficients $^{a}$} \\
\hline \multirow[b]{2}{*}{ etnia } & \multirow[b]{2}{*}{ Model } & & \multicolumn{2}{|c|}{$\begin{array}{c}\text { Unstandardized } \\
\text { Coefficients }\end{array}$} & \multirow{2}{*}{$\begin{array}{c}\begin{array}{c}\text { Standardized } \\
\text { Coefficients }\end{array} \\
\text { Beta }\end{array}$} & \multirow[b]{2}{*}{$t$} & \multirow[b]{2}{*}{ Sig. } \\
\hline & & & B & $\begin{array}{l}\text { Std. } \\
\text { Error }\end{array}$ & & & \\
\hline \multirow[t]{2}{*}{. } & 1 & (Constant) & 6,582 & 1,068 & & 6,164 &, 102 \\
\hline & & Dummy_ldade_5 &,- 763 & 1,850 &,- 381 &,- 412 & ,751 \\
\hline \multirow[t]{3}{*}{ Negro } & 1 & (Constant) & 6,125 & ,956 & & 6,403 & ,000 \\
\hline & & Dummy_Idade_2 &,- 666 & 1,040 &,- 259 &,- 640 & ,532 \\
\hline & & Dummy_Idade_3 &,- 427 & 1,132 &,- 153 &,- 377 & ,711 \\
\hline \multirow[t]{5}{*}{ Pardo } & 1 & (Constant) & 4,972 & ,315 & & 15,806 & ,000 \\
\hline & & Dummy_Idade_5 &,- 068 & 1,371 &,- 006 &,- 049 & ,961 \\
\hline & & Dummy_Idade_2 &, 680 & ,379 & ,253 & 1,794 & 077 \\
\hline & & Dummy_Idade_3 & ,820 &, 511 & ,211 & 1,605 & ,113 \\
\hline & & Dummy_ldade_4 & 1,153 &, 545 & ,273 & 2,115 & ,038 \\
\hline \multirow[t]{6}{*}{ Branco } & 1 & (Constant) & 5,871 & ,213 & & 27,533 &, 000 \\
\hline & & Dummy_Idade_5 &,- 205 & ,342 &,- 038 &,- 598 &, 550 \\
\hline & & Dummy_Idade_2 &,- 090 & ,239 &,- 033 &,- 375 & ,708 \\
\hline & & Dummy_ldade_3 &,- 170 & ,261 &,- 052 &,- 651 &, 515 \\
\hline & & Dummy_Idade_4 &,- 494 & ,279 &,- 130 & $-1,773$ & 077 \\
\hline & & Dummy_Idade_6 &,- 281 &, 528 &,- 030 &,- 532 &, 595 \\
\hline \multirow[t]{3}{*}{ Índio } & 1 & (Constant) & 7,040 & 000 & & . & . \\
\hline & & Dummy_Idade_2 & $-1,220$ &, 000 &,- 756 & . & . \\
\hline & & Dummy_Idade_3 & ,610 &, 000 & ,378 & . & . \\
\hline
\end{tabular}

a. Dependent Variable: Equip_EGF_em_EU

Tabela 80- Coeficientes de determinação regressão idades separados por etnia -OHQ

Model Summary

\begin{tabular}{|ll|r|r|r|r|}
\hline etnia & Model & \multicolumn{1}{|c|}{$\mathrm{R}$} & \multicolumn{1}{c|}{ R Square } & $\begin{array}{c}\text { Adjusted } \\
\text { R Square }\end{array}$ & $\begin{array}{c}\text { Std. Error of } \\
\text { the Estimate }\end{array}$ \\
\hline$\cdot$ & 1 &, $599^{\mathrm{a}}$ &, 359 &,- 282 & 1,37462 \\
\hline Negro & 1 &, $395^{\mathrm{b}}$ &, 156 &, 044 & 1,25510 \\
\hline Pardo & 1 &, $314^{\mathrm{c}}$ &, 099 &, 050 & 1,29358 \\
\hline Branco & 1 &, $059^{\mathrm{d}}$ &, 003 &,- 010 & 1,32362 \\
\hline Índio & 1 & $1,000^{\mathrm{b}}$ & 1,000 & & \\
\hline
\end{tabular}

a. Predictors: (Constant), Dummy_Idade_5

b. Predictors: (Constant), Dummy_Idade_3, Dummy_Idade_2

c. Predictors: (Constant), Dummy_Idade_5, Dummy_Idade_4,

Dummy_Idade_3, Dummy_Idade_2

d. Predictors: (Constant), Dummy_Idade_6, Dummy_Idade_5,

Dummy_Idade_4, Dummy_Idade_3, Dummy_Idade_2 
Tabela 81- Coeficientes de regressão idades separados por etnia OHQ

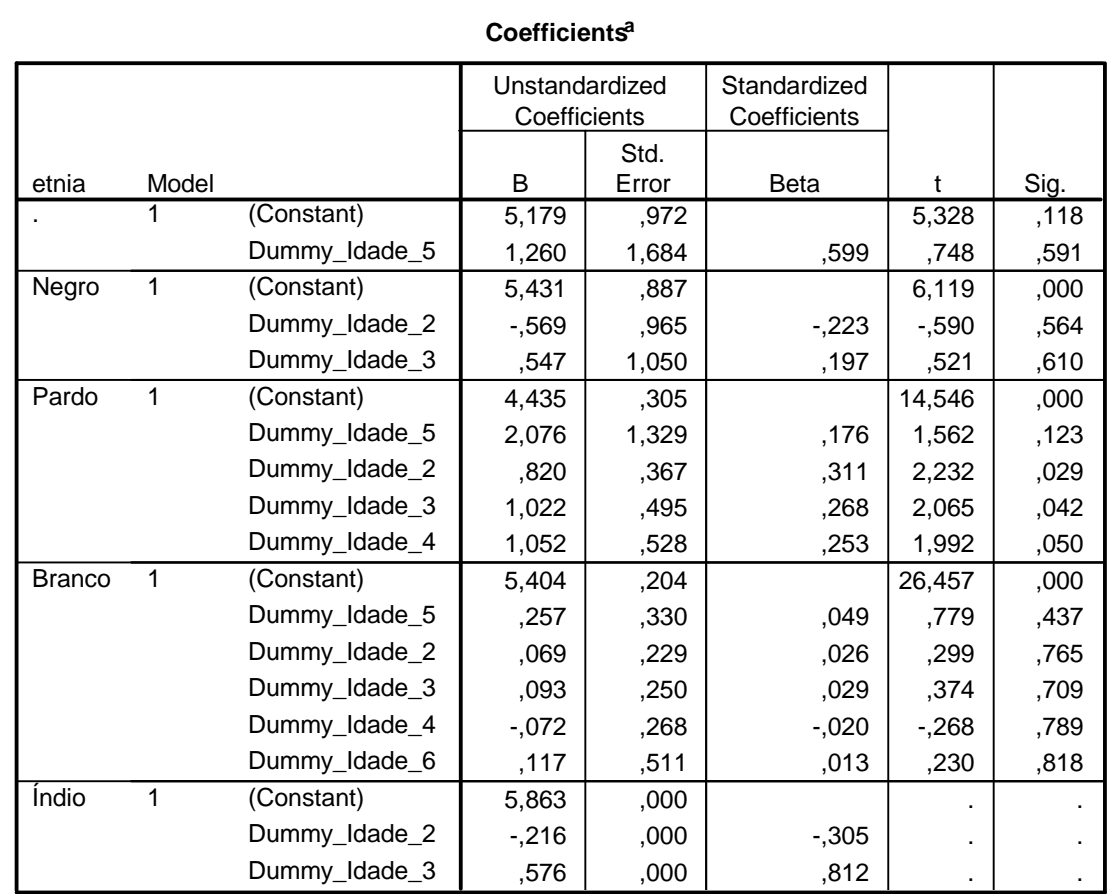

a. Dependent Variable: Equip_OHQ_em_EU

Tabela 82- Coeficientes de determinação regressão renda separado por etnia- EU

Model Summary

\begin{tabular}{|ll|r|r|r|r|}
\hline etnia & Model & \multicolumn{1}{c|}{$\mathrm{R}$} & $\mathrm{R}$ Square & $\begin{array}{c}\text { Adjusted } \\
\text { R Square }\end{array}$ & $\begin{array}{c}\text { Std. Error of } \\
\text { the Estimate }\end{array}$ \\
\hline$\cdot$ & 1 & $1,000^{\mathrm{a}}$ & 1,000 & $\cdot$ & $\cdot$ \\
\hline Negro & 1 &, $452^{\mathrm{b}}$ &, 204 &,- 041 & 1,83415 \\
\hline Pardo & 1 &, $222^{\mathrm{c}}$ &, 049 &,- 016 & 1,32504 \\
\hline Branco & 1 &, $049^{\mathrm{c}}$ &, 002 &,- 011 & 1,34695 \\
\hline Índio & 1 & $1,000^{\mathrm{a}}$ & 1,000 & & \\
\hline
\end{tabular}

a. Predictors: (Constant), Dummy_Renda_3, Dummy_Renda_2

b. Predictors: (Constant), Dummy_Renda_6, Dummy_Renda_4, Dummy_Renda_3, Dummy_Renda_2

c. Predictors: (Constant), Dummy_Renda_6, Dummy_Renda_5, Dummy_Renda_4, Dummy_Renda_3, Dummy_Renda_2 
Tabela 83- Coeficientes de regressão renda separado por etnia-EU

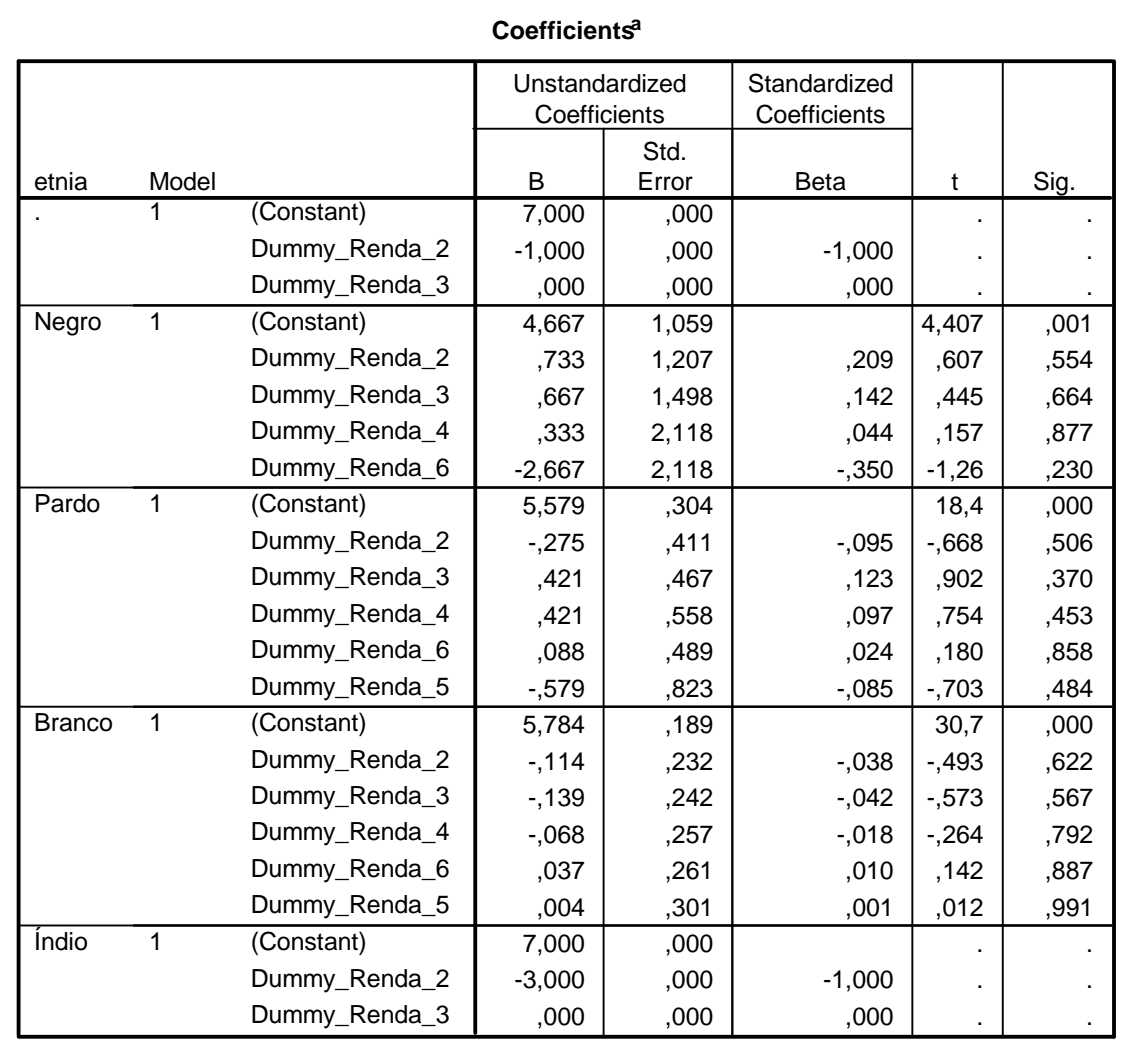

a. Dependent Variable: EU

Tabela 84- Coeficientes de determinação regressão renda separado por etnia- EGF

Model Summary

\begin{tabular}{|ll|r|r|r|r|}
\hline etnia & Model & \multicolumn{1}{|c|}{$\mathrm{R}$} & \multicolumn{1}{c|}{ R Square } & $\begin{array}{c}\text { Adjusted } \\
\text { R Square }\end{array}$ & $\begin{array}{r}\text { Std. Error of } \\
\text { the Estimate }\end{array}$ \\
\hline$\cdot$ & 1 & $1,000^{\mathrm{a}}$ & 1,000 & $\cdot$ & $\cdot$ \\
\hline Negro & 1 &, $466^{\mathrm{b}}$ &, 218 &,- 023 & 1,30426 \\
\hline Pardo & 1 &, $339^{\mathrm{c}}$ &, 115 &, 054 & 1,31351 \\
\hline Branco & 1 &, $069^{\mathrm{c}}$ &, 005 &,- 009 & 1,37046 \\
\hline Índio & 1 & $1,000^{\mathrm{a}}$ & 1,000 & & \\
\hline
\end{tabular}

a. Predictors: (Constant), Dummy_Renda_3, Dummy_Renda_2

b. Predictors: (Constant), Dummy_Renda_6, Dummy_Renda_4, Dummy_Renda_3, Dummy_Renda_2

c. Predictors: (Constant), Dummy_Renda_6, Dummy_Renda_5, Dummy_Renda_4, Dummy_Renda_3, Dummy_Renda_2 
Tabela 85- Coeficientes de regressão renda separado por etnia- EGF

\begin{tabular}{|c|c|c|c|c|c|c|c|}
\hline \multicolumn{8}{|c|}{ Coefficients $^{a}$} \\
\hline \multirow[b]{2}{*}{ etnia } & \multirow[b]{2}{*}{ Model } & & \multicolumn{2}{|c|}{$\begin{array}{c}\text { Unstandardized } \\
\text { Coefficients }\end{array}$} & \multirow{2}{*}{$\begin{array}{c}\text { Standardized } \\
\text { Coefficients } \\
\text { Beta }\end{array}$} & \multirow[b]{2}{*}{$t$} & \multirow[b]{2}{*}{ Sig. } \\
\hline & & & B & $\begin{array}{l}\text { Std. } \\
\text { Error }\end{array}$ & & & \\
\hline \multirow[t]{3}{*}{.} & 1 & (Constant) & 5,819 &, 000 & & . & \\
\hline & & Dummy_Renda_2 &,- 305 & ,000 &,- 152 & . & . \\
\hline & & Dummy_Renda_3 & 1,831 & ,000 & ,915 & . & \\
\hline \multirow[t]{5}{*}{ Negro } & 1 & (Constant) & 4,904 & ,753 & & 6,513 & ,000 \\
\hline & & Dummy_Renda_2 & ,641 & ,859 & ,254 & ,746 & ,469 \\
\hline & & Dummy_Renda_3 & 1,424 & 1,065 & ,423 & 1,337 & ,204 \\
\hline & & Dummy_Renda_4 &,- 305 & 1,506 &,- 056 &,- 203 & ,843 \\
\hline & & Dummy_Renda_6 & 2,136 & 1,506 & ,390 & 1,418 & ,180 \\
\hline \multirow[t]{6}{*}{ Pardo } & 1 & (Constant) & 5,546 & ,301 & & 18,406 &, 000 \\
\hline & & Dummy_Renda_2 &,- 576 & ,407 &,- 195 & $-1,414$ & ,161 \\
\hline & & Dummy_Renda_3 & ,665 & ,463 & ,189 & 1,438 & , 155 \\
\hline & & Dummy_Renda_4 &, 540 &, 554 &, 121 &, 975 & ,333 \\
\hline & & Dummy_Renda_6 &, 095 & ,484 &, 025 & ,196 & ,845 \\
\hline & & Dummy_Renda_5 &,- 134 & ,816 &,- 019 &,- 164 & ,870 \\
\hline \multirow[t]{6}{*}{ Branco } & 1 & (Constant) & 5,544 & 190 & & 29,170 &, 000 \\
\hline & & Dummy_Renda_2 &, 177 & ,235 & ,057 &, 755 & ,451 \\
\hline & & Dummy_Renda_3 &, 114 & ,245 & ,034 & ,464 & ,643 \\
\hline & & Dummy_Renda_4 &, 113 & ,260 & ,030 & ,435 & ,664 \\
\hline & & Dummy_Renda_6 & ,325 & ,264 & ,085 & 1,231 & ,219 \\
\hline & & Dummy_Renda_5 & ,239 & ,305 & 049 & ,783 & ,434 \\
\hline \multirow[t]{3}{*}{ Índio } & 1 & (Constant) & 7,650 &, 000 & & . & . \\
\hline & & Dummy_Renda_2 & $-1,831$ & ,000 & $-1,134$ & . & . \\
\hline & & Dummy_Renda_3 &,- 610 &, 000 &,- 378 & & \\
\hline
\end{tabular}

a. Dependent Variable: Equip_EGF_em_EU

Tabela 86- - Coeficientes de determinação regressão renda separado por etnia- OHQ

Model Summary

\begin{tabular}{|ll|r|r|r|r|}
\hline etnia & Model & \multicolumn{1}{c|}{$\mathrm{R}$} & \multicolumn{1}{c|}{ R Square } & $\begin{array}{c}\text { Adjusted } \\
\text { R Square }\end{array}$ & $\begin{array}{r}\text { Std. Error of } \\
\text { the Estimate }\end{array}$ \\
\hline$\cdot$ & 1 & $1,000^{\mathrm{a}}$ & 1,000 &. &. \\
\hline Negro & 1 &, $423^{\mathrm{b}}$ &, 179 &,- 074 & 1,32989 \\
\hline Pardo & 1 &, $378^{\mathrm{c}}$ &, 143 &, 084 & 1,26987 \\
\hline Branco & 1 &, $153^{\mathrm{c}}$ &, 023 &, 010 & 1,31039 \\
\hline Índio & 1 & $1,000^{\mathrm{a}}$ & 1,000 & & \\
\hline
\end{tabular}

a. Predictors: (Constant), Dummy_Renda_3, Dummy_Renda_2

b. Predictors: (Constant), Dummy_Renda_6, Dummy_Renda_4, Dummy_Renda_3, Dummy_Renda_2

c. Predictors: (Constant), Dummy_Renda_6, Dummy_Renda_5, Dummy_Renda_4, Dummy_Renda_3, Dummy_Renda_2 
Tabela 87- Coeficientes de regressão renda separado por etnia- OHQ

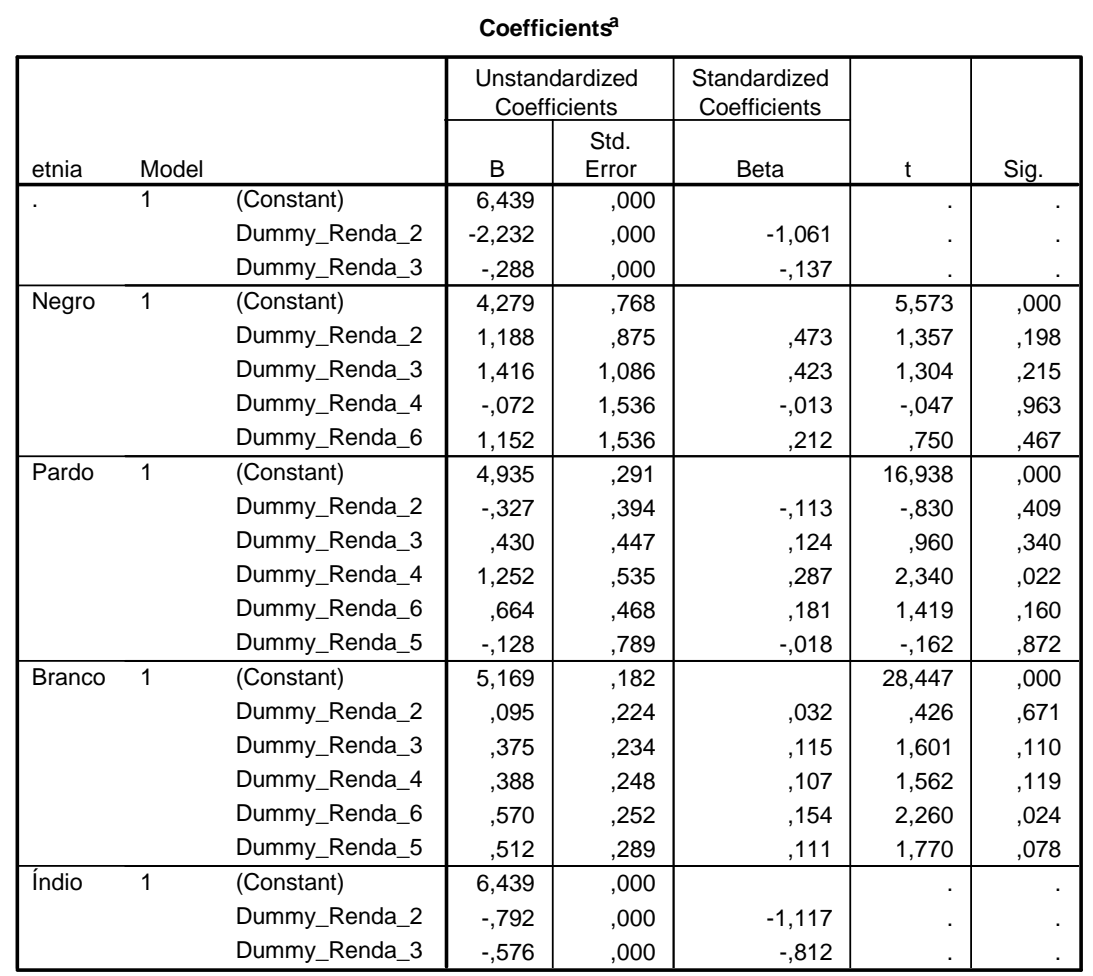

a. Dependent Variable: Equip_OHQ_em_EU

Tabela 88- Análise fatorial casados

\begin{tabular}{|c|c|c|c|c|c|c|c|c|c|}
\hline \multicolumn{10}{|c|}{ Structure Matrix } \\
\hline & \multicolumn{9}{|c|}{ Component } \\
\hline & 1 & 2 & 3 & 4 & 5 & 6 & 7 & 8 & 9 \\
\hline A vida é boa & ,735 & &,- 126 & ,155 & & &,- 157 & & \\
\hline Sempre contagio de alegria outras pessoas & ,608 & &, 100 &,- 218 & ,257 &,- 360 &,- 286 &,- 243 & ,343 \\
\hline Sinto minha mente completamente alerta & ,605 & ,225 & & & ,367 &,- 142 &,- 158 & & ,152 \\
\hline Eu sinto que a vida é muito recompensada & ,603 & &,- 131 & ,263 & ,148 &, 172 &,- 337 &,- 302 & ,305 \\
\hline Eu acho a maioria das coisas agradáveis & ,496 &,- 163 & ,371 & ,241 &, 160 & &,- 303 &,- 176 & \\
\hline Eu sorrio muito & ,492 & & ,382 & &, 148 &,- 227 &,- 344 &,- 311 & ,173 \\
\hline Não me sinto particularmente saudável & ,128 & ,651 & & 108 & ,133 &, 123 &,- 314 & & ,217 \\
\hline Não acho fácil tomar decisões & & ,604 & ,184 & & ,107 &,- 373 & &,- 292 & \\
\hline Eu raramente me sinto descansado & &, 501 & & ,266 &,- 208 & & ,232 &,- 271 & 125 \\
\hline Eu particularmente não sou otimista sobre o futuro & ,302 & ,429 & & ,157 & ,152 &,- 154 &,- 314 &,- 352 & ,356 \\
\hline Eu sou intensamente interessado em outras pessoas & &, 107 & ,797 & & & & & & \\
\hline Eu tenho sentimentos calorosos com quase todos & &,- 332 & ,619 & ,143 & ,199 & & & & ,407 \\
\hline Não tenho particularmente memórias felizes do passado & ,261 &, 131 & & ,756 & & &,- 115 & & ,102 \\
\hline Sinto que não estou, sobretudo, no controle de minha vida & & &, 130 & ,715 & &,- 323 &,- 156 &,- 253 & \\
\hline Estou sempre comprometido e envolvido & & &, 141 & & ,737 & & &, 154 & \\
\hline Sinto-me capaz de conseguir qualquer coisa & ,144 & & & & 673 &,- 130 &,- 326 &,- 449 & \\
\hline Sempre me saio bem em tudo o que quero & ,406 & &, 156 & ,248 & ,602 & &,- 339 &,- 190 & ,120 \\
\hline Sempre tenho boas influencias nos acontecimentos & 145 &,- 384 & ,228 & & 155 &,- 626 &,- 282 & & \\
\hline Eu não me sinto particularmente satisfeito com a maneira que sou & ,186 & ,415 &,- 140 & ,344 & &,- 505 &,- 182 &,- 161 & , 180 \\
\hline $\begin{array}{l}\text { Não tenho particularmente senso de significado e propósito para } \\
\text { minha vida }\end{array}$ & 121 & ,220 &,- 195 & ,369 & ,244 &,- 492 &,- 168 &,- 259 & ,358 \\
\hline Estou muito satisfeito com tudo em minha vida & ,216 & & & ,348 & ,256 & &,- 789 &,- 177 & \\
\hline Eu sou muito feliz & ,319 & &, 136 &, 140 & ,146 &,- 108 &,- 702 &,- 202 & ,458 \\
\hline Sinto-me alegre e exaltado & ,338 & ,188 & ,185 &,- 107 & &,- 292 &,- 702 &,- 107 & ,213 \\
\hline Eu não me acho atraente & &, 127 & & & &,- 106 & &,- 818 & ,128 \\
\hline Eu não acho que o mundo que o mundo é um bom lugar &, 130 & ,215 & , 199 & 179 & & ,309 &,- 422 &,- 577 & ,123 \\
\hline Sinto que possuo muita energia & ,156 & &, 184 & &, 165 & &,- 168 & & ,787 \\
\hline Não me divirto com outras pessoas & & ,202 & & 213 &,- 225 & &,- 195 &,- 437 & ,611 \\
\hline
\end{tabular}

Extraction Method: Principal Component Analysis.

Rotation Method: Oblimin with Kaiser Normalization. 
Tabela 89- Comunalidades análise fatorial casados

Communalities

\begin{tabular}{|l|r|r|}
\hline & & Extrac \\
& Initial & tion \\
\hline Eu tenho sentimentos calorosos com quase todos & 1,000 &, 691 \\
Sinto que possuo muita energia & 1,000 &, 682 \\
Não tenho particularmente memórias felizes do passado & 1,000 &, 647 \\
Eu sou muito feliz & 1,000 &, 633 \\
Sinto que não estou, sobretudo, no controle de minha vida & 1,000 &, 690 \\
Eu sou intensamente interessado em outras pessoas & 1,000 &, 680 \\
Eu não me sinto particularmente satisfeito com a maneira que sou & 1,000 &, 533 \\
Estou muito satisfeito com tudo em minha vida & 1,000 &, 723 \\
Sinto-me alegre e exaltado & 1,000 &, 665 \\
Não tenho particularmente senso de significado e propósito para minha vida & 1,000 &, 577 \\
Sempre tenho boas influencias nos acontecimentos & 1,000 &, 667 \\
Eu particularmente não sou otimista sobre o futuro & 1,000 &, 435 \\
A vida é boa & 1,000 &, 597 \\
Sempre contagio de alegria outras pessoas & 1,000 &, 649 \\
Sinto minha mente completamente alerta & 1,000 &, 496 \\
Eu sinto que a vida é muito recompensada & 1,000 &, 600 \\
Eu raramente me sinto descansado & 1,000 &, 481 \\
Não acho fácil tomar decisões & 1,000 &, 595 \\
Não me sinto particularmente saudável & 1,000 &, 576 \\
Eu acho a maioria das coisas agradáveis & 1,000 &, 504 \\
Eu não acho que o mundo que o mundo é um bom lugar & 1,000 &, 626 \\
Sempre me saio bem em tudo o que quero & 1,000 &, 557 \\
Eu não me acho atraente & 1,000 &, 699 \\
Eu sorrio muito & 1,000 &, 487 \\
Sinto-me capaz de conseguir qualquer coisa & 1,000 &, 689 \\
Não me divirto com outras pessoas & 1,000 &, 604 \\
Estou sempre comprometido e envolvido & 1,000 &, 608 \\
\hline Extraction Men
\end{tabular}

Extraction Method: Principal Component Analysis. 
Tabela 90- Comparação análise fatorial original $x$ analise fatorial casados

Fatores obtidos no questionário total $\quad$ Fatores análise casados

FATOR 1- Satisfaç̃o com a vida $9,45 \%$

A vida é boa

Estou muito satisfeito com tudo em minha vida

Eu acho a maioria das coisas agradáveis

Eu sinto que a vida é muito recompensada

Eu sou muito feliz

\section{FATOR 2 - Controle - 7,26\%}

Eu raramente me sinto descansado

Existe uma diferença entre o que gostaria de fazer e o que faço

Não acho fácil tomar decisões

Eu não me sinto particularmente satisfeito com a maneira que sou

Sinto que não estou, sobretudo, no controle de minha vida FATOR 3 - Relação positiva com outros - 7,22\%

Eu sou intensamente interessado em outras pessoas

Eu tenho sentimentos calorosos com quase todos

Sinto que possuo muita energia

\section{FATOR 4 - Autonomia- 7,14\%}

Estou sempre comprometido e envolvido

Sempre me saio bem em tudo o que quero

Sinto-me capaz de conseguir qualquer coisa

\section{FATOR 5 - Superioridade ambiental $-5,88 \%$}

\section{Eu não me acho atraente}

Não me divirto com outras pessoas

Sempre contagio de alegria outras pessoas

Eu sorrio muito

\section{FATOR 6 - Aceitação -5,73\%}

Sempre tenho boas influencias nos acontecimentos

Não me sinto particularmente saudável

Eu não acho que o mundo é um bom lugar

\section{FATOR 7 - Propósito-5,07\%}

Não tenho particularmente senso de significado e propósito para minha vida

Eu particularmente não sou otimista sobre o futuro Não tenho particularmente memórias felizes do passado FATOR 8 - Disposicão mental- 5,01\%

Sinto-me alegre e exaltado

Sinto minha mente completamente alerta

FATOR 1- 18,67\%

A vida é boa

Sempre contagio de alegria outras pessoas

Eu acho a maioria das coisas agradáveis

Eu sinto que a vida é muito recompensada

Eu sorrio muito

Sinto minha mente completamente alerta

FATOR 2- 8,036\%

Eu raramente me sinto descansado

Não me sinto particularmente saudável

Não acho fácil tomar decisões

Eu particularmente não sou otimista sobre o futuro

\section{FATOR 3- 5,94\%}

Eu sou intensamente interessado em outras pessoas

Eu tenho sentimentos calorosos com quase todos

\section{FATOR 5- 5,22\%}

Estou sempre comprometido e envolvido

Sempre me saio bem em tudo o que quero

Sinto-me capaz de conseguir qualquer coisa

Eu não me acho atraente

$$
\text { FATOR } 8-4,06 \%
$$

Eu não acho que o mundo que o mundo é um bom lugar

\section{FATOR $6-4,89 \%$}

Sempre tenho boas influencias nos acontecimentos

Eu não me sinto particularmente satisfeito com a maneira que sou

Não tenho particularmente senso de significado e propósito para minha vida

\section{FATOR 4 - 5,72\%}

Não tenho particularmente memórias felizes do passado

Sinto que não estou, sobretudo, no controle de minha vida

\section{FATOR 7- 4,21\%}

Estou muito satisfeito com tudo em minha vida

Eu sou muito feliz

Sinto-me alegre e exaltado

FATOR 9 - 3,95\%

Sinto que possuo muita energia

Não me divirto com outras pessoas 
Tabela 91- Análise fatorial não casados

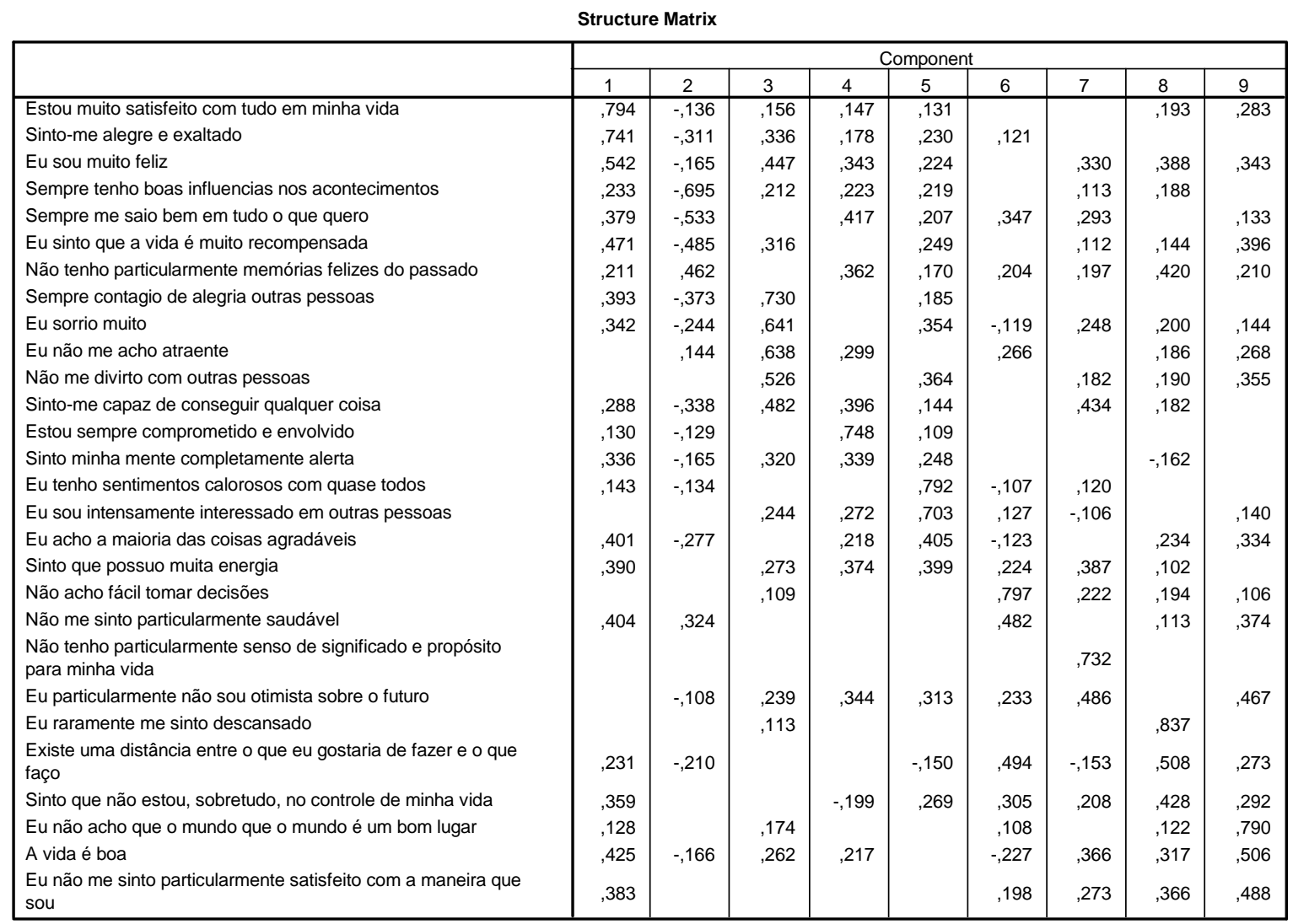

Extraction Method: Principal Component Analysis.

Rotation Method: Oblimin with Kaiser Normalization.

Tabela 92- Comunalidades análise fatorial não casados

\begin{tabular}{|c|c|c|}
\hline \multicolumn{3}{|l|}{ Communalities } \\
\hline & Initial & $\begin{array}{c}\text { Extrac } \\
\text { tion }\end{array}$ \\
\hline Eu tenho sentimentos calorosos com quase todos & 1,000 & ,683 \\
\hline Sinto que possuo muita energia & 1,000 & ,496 \\
\hline Não tenho particularmente memórias felizes do passado & 1,000 & 623 \\
\hline Eu sou muito feliz & 1,000 & ,627 \\
\hline Sinto que não estou, sobretudo, no controle de minha vida & 1,000 & ,477 \\
\hline Eu sou intensamente interessado em outras pessoas & 1,000 & 610 \\
\hline Eu não me sinto particularmente satisfeito com a maneira que sou & 1,000 & ,430 \\
\hline Estou muito satisfeito com tudo em minha vida & 1,000 & ,649 \\
\hline Sinto-me alegre e exaltado & 1,000 & ,631 \\
\hline Não tenho particularmente senso de significado e propósito para minha vida & 1,000 &, 598 \\
\hline Sempre tenho boas influencias nos acontecimentos & 1,000 &, 558 \\
\hline Eu particularmente não sou otimista sobre o futuro & 1,000 &, 584 \\
\hline A vida é boa & 1,000 & 610 \\
\hline Sempre contagio de alegria outras pessoas & 1,000 & 677 \\
\hline Sinto minha mente completamente alerta & 1,000 & ,335 \\
\hline Eu sinto que a vida é muito recompensada & 1,000 &, 519 \\
\hline Eu raramente me sinto descansado & 1,000 & ,738 \\
\hline Existe uma distância entre o que eu gostaria de fazer e o que faço & 1,000 & ,630 \\
\hline Não acho fácil tomar decisões & 1,000 & ,673 \\
\hline Não me sinto particularmente saudável & 1,000 &, 578 \\
\hline Eu acho a maioria das coisas agradáveis & 1,000 & ,437 \\
\hline Eu não acho que o mundo que o mundo é um bom lugar & 1,000 & ,642 \\
\hline Sempre me saio bem em tudo o que quero & 1,000 & ,651 \\
\hline Eu não me acho atraente & 1,000 & ,613 \\
\hline Eu sorrio muito & 1,000 & ,619 \\
\hline Sinto-me capaz de conseguir qualquer coisa & 1,000 &, 579 \\
\hline Não me divirto com outras pessoas & 1,000 &, 535 \\
\hline Estou sempre comprometido e envolvido & 1,000 &, 577 \\
\hline
\end{tabular}

Extraction Method: Principal Component Analysis. 
Tabela 93- Comparação análise fatorial original $x$ analise fatorial não casados

Fatores obtidos no questionário total

FATOR 1- Satisfação com a vida $9,45 \%$

A vida é boa

Estou muito satisfeito com tudo em minha vida

Eu acho a maioria das coisas agradáveis

Eu sinto que a vida é muito recompensada

Eu sou muito feliz

\section{FATOR 2 - Controle - 7,26\%}

Eu raramente me sinto descansado

Existe uma diferença entre o que gostaria de fazer e o

que faço

Não acho fácil tomar decisões

Eu não me sinto particularmente satisfeito com a maneira que sou

Sinto que não estou, sobretudo, no controle de minha vida

FATOR 3 - Relacão positiva com outros - 7,22\%

Eu sou intensamente interessado em outras pessoas

Eu tenho sentimentos calorosos com quase todos

Sinto que possuo muita energia

FATOR 4 - Autonomia- 7,14\%

Estou sempre comprometido e envolvido

Sempre me saio bem em tudo o que quero

Sinto-me capaz de conseguir qualquer coisa

FATOR 5 - Superioridade ambiental $-5,88 \%$

Eu não me acho atraente

Não me divirto com outras pessoas

Sempre contagio de alegria outras pessoas

Eu sorrio muito

FATOR 6 - Aceitação $-5,73 \%$

Sempre tenho boas influencias nos acontecimentos

Não me sinto particularmente saudáve

Eu não acho que o mundo é um bom lugar

\section{FATOR 7 - Propósito-5,07\%}

Não tenho particularmente senso de significado e propósito para minha vida

Eu particularmente não sou otimista sobre o futuro Não tenho particularmente memórias felizes do passado

$$
\text { FATOR } 8 \text { - Disposicão mental- 5,01\% }
$$

Sinto-me alegre e exaltado

Sinto minha mente completamente alerta

Fatores análise não casados

FATOR 1- 20,29\%

Estou muito satisfeito com tudo em minha vida Sinto-me alegre e exaltado

Eu sou muito feliz

\section{FATOR 8- 3,85\%}

Eu raramente me sinto descansado

Existe uma distância entre o que eu gostaria de fazer e o que faço

Sinto que não estou, sobretudo, no controle de minha vida

$$
\text { FATOR 5- 4,37\% }
$$

Eu sou intensamente interessado em outras pessoas Eu tenho sentimentos calorosos com quase todos Eu acho a maioria das coisas agradáveis Sinto que possuo muita energia

$$
\text { FATOR 4- 5,07\% }
$$

Estou sempre comprometido e envolvido

Sinto minha mente completamente alerta

$$
\text { FATOR 3- 5,37\% }
$$

Eu não me acho atraente

Não me divirto com outras pessoas

Sempre contagio de alegria outras pessoas

Eu sorrio muito

Sinto-me capaz de conseguir qualquer coisa

$$
\text { FATOR 2- 7,51\% }
$$

Eu sinto que a vida é muito recompensada

Sempre me saio bem em tudo o que quero

Sempre tenho boas influencias nos acontecimentos

Não tenho particularmente memórias felizes do passado

$$
\text { FATOR } 7-4,13 \%
$$

Não tenho particularmente senso de significado e propósito para minha vida

Eu particularmente não sou otimista sobre o futuro

\section{FATOR 6- 4,32\%}

Não acho fácil tomar decisões

Não me sinto particularmente saudável

\section{FATOR 9- 3,59\%}

Eu não acho que o mundo que o mundo é um bom lugar

\begin{tabular}{|c|c|c|c|c|}
\hline & $\begin{array}{l}\text { Levene } \\
\text { Statistic }\end{array}$ & df1 & $\mathrm{df} 2$ & Sig. \\
\hline$E U$ & 2,861 & 4 & 477 &, 023 \\
\hline Equip_EGF_em_EU & 3,364 & 4 & 477 &, 010 \\
\hline Equip_OHQ_em_EU & 1,685 & 4 & 479 & ,152 \\
\hline
\end{tabular}
A vida é boa

Eu não me sinto particularmente satisfeito com a maneira que sou

Tabela 94- Teste de homogeneidade das variâncias - estado civil

Test of Homogeneity of Variances 
Tabela 95- Teste não paramétrico estado civil - EU e EGF

Test Statistics ${ }^{a, b}$

\begin{tabular}{|l|r|r|}
\hline & \multicolumn{1}{|c|}{ EU } & $\begin{array}{c}\text { Equip_EGF_ } \\
\text { em_EU }\end{array}$ \\
\hline Chi-Square & 11,476 & 7,347 \\
df & 4 & 4 \\
Asymp. Sig. &, 022 &, 119 \\
\hline
\end{tabular}

a. Kruskal Wallis Test

b. Grouping Variable: est_cívil

Tabela 96 - Análise de variância estado civil - OHQ

ANOVA

Equip_OHQ_em_EU
\begin{tabular}{|l|r|r|r|r|r|}
\hline & Sum of & df & Mean Square & \multicolumn{1}{c|}{ F } & Sig. \\
\hline Between Groups & 12,444 & 4 & 3,111 & 1,808 &, 126 \\
Within Groups & 824,011 & 479 & 1,720 & & \\
Total & 836,455 & 483 & & & \\
\hline
\end{tabular}

Tabela 97- Correlação entre médias equiparadas -estado civil

\begin{tabular}{|lll|r|r|c|}
\multicolumn{7}{l}{ Paired Samples Correlations } \\
\hline est_cívil & & N & Correlation & Sig. \\
\hline Casado & Pair 1 & EU \& Equip_EGF_em_EU & 206 &, 662 &, 000 \\
& Pair 2 & EU \& Equip_OHQ_em_EU & 208 &, 577 &, 000 \\
& Pair 3 & Equip_EGF_em_EU \& Equip_OHQ_em_EU & 206 &, 596 &, 000 \\
\hline Solteiro & Pair 1 & EU \& Equip_EGF_em_EU & 225 &, 600 &, 000 \\
& Pair 2 & EU \& Equip_OHQ_em_EU & 225 &, 513 &, 000 \\
& Pair 3 & Equip_EGF_em_EU \& Equip_OHQ_em_EU & 227 &, 643 &, 000 \\
\hline Divorciado & Pair 1 & EU \& Equip_EGF_em_EU & 22 &, 450 &, 036 \\
& Pair 2 & EU \& Equip_OHQ_em_EU & 22 &, 778 &, 000 \\
& Pair 3 & Equip_EGF_em_EU \& Equip_OHQ_em_EU & 22 &, 615 &, 002 \\
\hline Viúvo & Pair 1 & EU \& Equip_EGF_em_EU & 10 &, 883 &, 001 \\
& Pair 2 & EU \& Equip_OHQ_em_EU & 10 &, 710 &, 021 \\
& Pair 3 & Equip_EGF_em_EU \& Equip_OHQ_em_EU & 10 &, 870 &, 001 \\
\hline Outros & Pair 1 & EU \& Equip_EGF_em_EU & 17 &, 456 &, 066 \\
& Pair 2 & EU \& Equip_OHQ_em_EU & 17 &, 519 &, 033 \\
& Pair 3 & Equip_EGF_em_EU \& Equip_OHQ_em_EU & 17 &, 689 &, 002 \\
\hline
\end{tabular}


Tabela 98- Teste $t$ de médias equiparadas - estado civil

Paired Samples Test

\begin{tabular}{|c|c|c|c|c|c|c|c|c|c|c|}
\hline \multirow[b]{3}{*}{ est cívil } & & & \multicolumn{5}{|c|}{ Paired Differences } & \multirow[b]{3}{*}{$\mathrm{t}$} & \multirow[b]{3}{*}{ df } & \multirow{3}{*}{$\begin{array}{c}\text { Sig. } \\
\text { (2-tailed) }\end{array}$} \\
\hline & & & \multirow[b]{2}{*}{ Mean } & \multirow{2}{*}{$\begin{array}{c}\text { Std. } \\
\text { Deviation }\end{array}$} & \multirow{2}{*}{$\begin{array}{l}\text { Std. } \\
\text { Error } \\
\text { Mean }\end{array}$} & \multicolumn{2}{|c|}{$\begin{array}{l}95 \% \text { Confidence } \\
\text { Interval of the } \\
\text { Difference }\end{array}$} & & & \\
\hline & & & & & & Lower & Upper & & & \\
\hline \multirow[t]{3}{*}{ Casado } & Pair 1 & EU - Equip_EGF_em_EU &,- 03349 & 1,05492 & ,07350 &,- 17840 &, 11142 & $\overline{-, 456}$ & 205 &, 649 \\
\hline & Pair 2 & EU - Equip_OHQ_em_EU & ,25612 & 1,12482 & 07799 & ,10235 & ,40988 & 3,284 & 207 & 001 \\
\hline & Pair 3 & Equip_EGF_em_EU - Equip_OHQ_em_EU & ,28521 & 1,14468 & 07975 & ,12796 & ,44245 & 3,576 & 205 & 000 \\
\hline \multirow[t]{3}{*}{ Solteiro } & Pair 1 & EU - Equip_EGF_em_EU &, 04088 & 1,25299 & 08353 &,- 12373 & ,20548 & ,489 & 224 & ,625 \\
\hline & Pair 2 & EU - Equip_OHQ_em_EU & ,35051 & 1,36814 & 09121 & ,17077 &, 53025 & 3,843 & 224 & 000 \\
\hline & Pair 3 & Equip_EGF_em_EU - Equip_OHQ_em_EU & ,30489 & 1,14551 & 07603 & ,15508 & ,45471 & 4,010 & 226 & 000 \\
\hline \multirow[t]{3}{*}{ Divorciado } & Pair 1 & EU - Equip_EGF_em_EU &,- 09519 & 1,17554 & ,25063 &,- 61640 & ,42601 &,- 380 & 21 & ,708 \\
\hline & Pair 2 & EU - Equip_OHQ_em_EU &,- 19173 & 1,00937 & ,21520 &,- 63926 & ,25580 &,- 891 & 21 & ,383 \\
\hline & Pair 3 & Equip_EGF_em_EU - Equip_OHQ_em_EU &,- 09654 & 1,26596 & ,26990 &,- 65783 & ,46476 &,- 358 & 21 & ,724 \\
\hline \multirow[t]{3}{*}{ Viúvo } & Pair 1 & EU - Equip_EGF_em_EU &,- 58206 & 1,02507 & ,32415 & $-1,31535$ & ,15123 & $-1,796$ & 9 & ,106 \\
\hline & Pair 2 & EU - Equip_OHQ_em_EU &,- 71260 & 1,45670 & ,46065 & $-1,75466$ & ,32946 & $-1,547$ & 9 & , 156 \\
\hline & Pair 3 & Equip_EGF_em_EU - Equip_OHQ_em_EU &,- 13054 & 1,07661 & ,34045 &,- 90070 & ,63962 &,- 383 & 9 & ,710 \\
\hline \multirow[t]{3}{*}{ Outros } & Pair 1 & EU - Equip_EGF_em_EU & 09086 & 1,14240 & ,27707 &,- 49651 & 67823 & 328 & 16 & ,747 \\
\hline & Pair 2 & EU - Equip_OHQ_em_EU & ,72994 & 1,21816 & ,29545 & ,10362 & 1,35626 & 2,471 & 16 & 025 \\
\hline & Pair 3 & Equip_EGF_em_EU - Equip_OHQ_em_EU & 63908 & ,94871 & 23010 &, 15130 & 1,12686 & 2,777 & 16 &, 013 \\
\hline
\end{tabular}

Tabela 99- Teste de homogeneidade de variâncias estado civil separado por sexo

Test of Homogeneity of Variances

\begin{tabular}{|ll|r|r|r|r|}
\hline \multirow{2}{*}{ Sexo } & & \multicolumn{1}{|c|}{$\begin{array}{l}\text { Levene } \\
\text { Statistic }\end{array}$} & \multicolumn{1}{|c|}{ df1 } & \multicolumn{1}{c|}{ df2 } & \multicolumn{1}{c|}{ Sig. } \\
\hline Masculino & EU &, 802 & 4 & 205 &, 525 \\
& Equip_EGF_em_EU & 1,782 & 4 & 203 &, 134 \\
& Equip_OHQ_em_EU &, 796 & 4 & 205 &, 529 \\
\hline Feminino & EU & 6,382 & 4 & 266 &, 000 \\
& Equip_EGF_em_EU & 2,239 & 4 & 268 &, 065 \\
& Equip_OHQ_em_EU & 2,179 & 4 & 268 &, 072 \\
\hline
\end{tabular}

Tabela 100 - Teste não paramétrico estado civil em relação ao sexo

\begin{tabular}{|ll|r|}
\multicolumn{3}{|c|}{ Test Statistics } \\
\begin{tabular}{|ll|r|}
\hline Sexo & & \multicolumn{1}{|c|}{ EU } \\
\hline Masculino & Chi-Square & 6,393 \\
& df & 4 \\
& Asymp. Sig. &, 172 \\
\hline Feminino & Chi-Square & 8,843 \\
& df & 4 \\
& Asymp. Sig. &, 065 \\
\hline
\end{tabular}
\end{tabular}

a. Kruskal Wallis Test

b. Grouping Variable: est_cívil 
Tabela 101- Análise de médias estado civil separado por sexo - OHQ e EGF

\begin{tabular}{|c|c|c|c|c|c|c|c|}
\hline \multicolumn{8}{|c|}{ ANOVA } \\
\hline \multicolumn{3}{|l|}{ Sexo } & $\begin{array}{l}\text { Sum of } \\
\text { Squares }\end{array}$ & df & Mean Square & $\mathrm{F}$ & Sig. \\
\hline \multirow[t]{6}{*}{ Masculino } & \multirow[t]{3}{*}{ Equip_EGF_em_EU } & Between Groups & 4,706 & 4 & 1,177 & \multirow[t]{3}{*}{,609 } & \multirow[t]{3}{*}{, 657} \\
\hline & & Within Groups & 392,388 & 203 & 1,933 & & \\
\hline & & Total & 397,094 & 207 & & & \\
\hline & \multirow[t]{3}{*}{ Equip_OHQ_em_EU } & Between Groups & 5,399 & 4 & 1,350 & \multirow[t]{3}{*}{,762 } & \multirow[t]{3}{*}{, 551} \\
\hline & & Within Groups & 362,955 & 205 & 1,771 & & \\
\hline & & Total & 368,354 & 209 & & & \\
\hline \multirow[t]{6}{*}{ Feminino } & \multirow[t]{3}{*}{ Equip_EGF_em_EU } & Between Groups & 17,891 & 4 & 4,473 & \multirow[t]{3}{*}{2,558} & \multirow[t]{3}{*}{,039 } \\
\hline & & Within Groups & 468,528 & 268 & 1,748 & & \\
\hline & & Total & 486,419 & 272 & & & \\
\hline & \multirow[t]{3}{*}{ Equip_OHQ_em_EU } & Between Groups & 16,286 & 4 & 4,072 & \multirow[t]{3}{*}{2,419} & \multirow[t]{3}{*}{,049 } \\
\hline & & Within Groups & 451,035 & 268 & 1,683 & & \\
\hline & & Total & 467,322 & 272 & & & \\
\hline
\end{tabular}

Tabela 102- Correlação entre médias equiparadas estado civil separadas por sexo

Paired Samples Correlations ${ }^{\mathrm{a}}$

\begin{tabular}{|c|c|c|c|c|c|c|}
\hline Sexo & est_cívil & & & $\mathrm{N}$ & Correlation & Sig. \\
\hline \multirow[t]{15}{*}{ Masculino } & \multirow[t]{3}{*}{ Casado } & Pair 1 & EU \& Equip_EGF_em_EU & 104 & ,729 &, 000 \\
\hline & & Pair 2 & EU \& Equip_OHQ_em_EU & 106 &, 584 &, 000 \\
\hline & & Pair 3 & Equip_EGF_em_EU \& Equip_OHQ_em_EU & 104 &, 592 &, 000 \\
\hline & \multirow[t]{3}{*}{ Solteiro } & Pair 1 & EU \& Equip_EGF_em_EU & 89 & ,620 & ,000 \\
\hline & & Pair 2 & EU \& Equip_OHQ_em_EU & 89 &, 550 &, 000 \\
\hline & & Pair 3 & Equip_EGF_em_EU \& Equip_OHQ_em_EU & 89 & ,628 &, 000 \\
\hline & \multirow[t]{3}{*}{ Divorciado } & Pair 1 & EU \& Equip_EGF_em_EU & 8 &, 562 & , 148 \\
\hline & & Pair 2 & EU \& Equip_OHQ_em_EU & 8 & ,919 & ,001 \\
\hline & & Pair 3 & Equip_EGF_em_EU \& Equip_OHQ_em_EU & 8 & ,633 &, 092 \\
\hline & \multirow[t]{3}{*}{ Viúvo } & Pair 1 & EU \& Equip_EGF_em_EU & 3 & ,993 & ,073 \\
\hline & & Pair 2 & EU \& Equip_OHQ_em_EU & 3 & ,985 & ,109 \\
\hline & & Pair 3 & Equip_EGF_em_EU \& Equip_OHQ_em_EU & 3 & ,960 & , 182 \\
\hline & \multirow[t]{3}{*}{ Outros } & Pair 1 & EU \& Equip_EGF_em_EU & 4 & ,485 & ,515 \\
\hline & & Pair 2 & EU \& Equip_OHQ_em_EU & 4 & ,704 & ,296 \\
\hline & & Pair 3 & Equip_EGF_em_EU \& Equip_OHQ_em_EU & 4 &, 951 &, 049 \\
\hline \multirow[t]{15}{*}{ Feminino } & \multirow[t]{3}{*}{ Casado } & Pair 1 & EU \& Equip_EGF_em_EU & 101 & ,567 & ,000 \\
\hline & & Pair 2 & EU \& Equip_OHQ_em_EU & 101 &, 579 & ,000 \\
\hline & & Pair 3 & Equip_EGF_em_EU \& Equip_OHQ_em_EU & 101 &, 599 &, 000 \\
\hline & \multirow[t]{3}{*}{ Solteiro } & Pair 1 & EU \& Equip_EGF_em_EU & 136 & ,591 & ,000 \\
\hline & & Pair 2 & EU \& Equip_OHQ_em_EU & 136 & ,494 &, 000 \\
\hline & & Pair 3 & Equip_EGF_em_EU \& Equip_OHQ_em_EU & 138 & ,653 &, 000 \\
\hline & \multirow[t]{3}{*}{ Divorciado } & Pair 1 & EU \& Equip_EGF_em_EU & 14 & ,478 & ,084 \\
\hline & & Pair 2 & EU \& Equip_OHQ_em_EU & 14 & ,633 & ,015 \\
\hline & & Pair 3 & Equip_EGF_em_EU \& Equip_OHQ_em_EU & 14 & ,667 &, 009 \\
\hline & \multirow[t]{3}{*}{ Viúvo } & Pair 1 & EU \& Equip_EGF_em_EU & 7 & 847 & ,016 \\
\hline & & Pair 2 & EU \& Equip_OHQ_em_EU & 7 & ,615 & ,142 \\
\hline & & Pair 3 & Equip_EGF_em_EU \& Equip_OHQ_em_EU & 7 & 844 &, 017 \\
\hline & \multirow[t]{3}{*}{ Outros } & Pair 1 & EU \& Equip_EGF_em_EU & 13 & ,462 & ,112 \\
\hline & & Pair 2 & EU \& Equip_OHQ_em_EU & 13 & ,466 & ,109 \\
\hline & & Pair 3 & Equip_EGF_em_EU \& Equip_OHQ_em_EU & 13 & ,693 & ,009 \\
\hline
\end{tabular}

a. No statistics are computed for one or more split files 
Tabela 103- Teste de médias entre médias equiparadas estado civil separadas por sexo

\begin{tabular}{|c|c|c|c|c|c|c|c|c|c|c|c|}
\hline \multicolumn{12}{|c|}{ Paired Samples Tes? } \\
\hline \multirow[b]{3}{*}{ Sexo } & \multirow[b]{3}{*}{ est cívil } & & & \multicolumn{5}{|c|}{ Paired Differences } & \multirow[b]{3}{*}{$t$} & \multirow[b]{3}{*}{$d f$} & \multirow{3}{*}{$\begin{array}{c}\text { Sig. } \\
\text { (2-tailed) }\end{array}$} \\
\hline & & & & \multirow[b]{2}{*}{ Mean } & \multirow{2}{*}{$\begin{array}{c}\text { Std. } \\
\text { Deviation }\end{array}$} & \multirow{2}{*}{$\begin{array}{l}\text { Std. } \\
\text { Error } \\
\text { Mean }\end{array}$} & \multicolumn{2}{|c|}{$\begin{array}{l}95 \% \text { Confidence } \\
\text { Interval of the } \\
\text { Difference }\end{array}$} & & & \\
\hline & & & & & & & Lower & Upper & & & \\
\hline \multirow[t]{15}{*}{ Masculino } & Casado & Pair 1 & EU - Equip_EGF_em_EU &,- 14779 & 1,03238 &, 10123 &,- 34856 &, 05299 & $-1,460$ & 103 & , 147 \\
\hline & & Pair 2 & EU - Equip_OHQ_em_EU & 09874 & 1,23052 & ,11952 &,- 13825 & ,33572 &, 826 & 105 & ,411 \\
\hline & & Pair 3 & Equip_EGF_em_EU - Equip_OHQ_em_EU & ,23479 & 1,20630 &, 11829 &, 00019 & 46938 & 1,985 & 103 &, 050 \\
\hline & Solteiro & Pair 1 & EU - Equip_EGF_em_EU &, 01493 & 1,19553 & ,12673 &,- 23692 & ,26677 & , 118 & 88 & ,907 \\
\hline & & Pair 2 & EU - Equip_OHQ_em_EU &, 24001 & 1,25659 &, 13320 &,- 02469 &, 50472 & 1,802 & 88 & ,075 \\
\hline & & Pair 3 & Equip_EGF_em_EU - Equip_OHQ_em_EU & ,22509 & 1,19074 & ,12622 &,- 02575 & ,47592 & 1,783 & 88 & ,078 \\
\hline & Divorciado & Pair 1 & EU - Equip_EGF_em_EU &,- 43803 & 1,26411 & ,44693 & $-1,49485$ & 61880 &,- 980 & 7 & 360 \\
\hline & & Pair 2 & EU - Equip_OHQ_em_EU &,- 14300 &, 71804 & 25387 &,- 74330 & ,45730 &,- 563 & 7 &, 591 \\
\hline & & Pair 3 & Equip_EGF_em_EU - Equip_OHQ_em_EU & 29503 & 1,46323 &, 51733 &,- 92827 & 1,51832 &, 570 & 7 &, 586 \\
\hline & Viúvo & Pair 1 & EU - Equip_EGF_em_EU &,- 59900 & ,39103 & ,22576 & $-1,57037$ &, 37237 & $-2,653$ & 2 &, 118 \\
\hline & & Pair 2 & EU - Equip_OHQ_em_EU &,- 44700 & ,35714 & ,20620 & $-1,33420$ & 44020 & $-2,168$ & 2 & 162 \\
\hline & & Pair 3 & Equip_EGF_em_EU - Equip_OHQ_em_EU &, 15200 &, 66121 & ,38175 & $-1,49054$ & 1,79454 & ,398 & 2 &, 729 \\
\hline & Outros & Pair 1 & EU - Equip_EGF_em_EU &, 52805 & ,67381 & ,33691 &,- 54413 & 1,60023 & 1,567 & 3 & ,215 \\
\hline & & Pair 2 & EU - Equip_OHQ_em_EU &, 49300 &, 58790 & ,29395 &,- 44247 & 1,42847 & 1,677 & 3 & ,192 \\
\hline & & Pair 3 & Equip_EGF_em_EU - Equip_OHQ_em_EU &,- 03505 & ,26359 &, 13180 &,- 45448 &, 38438 &,- 266 & 3 & 808 \\
\hline \multirow[t]{15}{*}{ Feminino } & Casado & Pair 1 & EU - Equip_EGF_em_EU & 06698 & 1,06279 &, 10575 &,- 14283 & 27679 & ,633 & 100 & ,528 \\
\hline & & Pair 2 & EU - Equip_OHQ_em_EU &, 41676 & ,98727 & ,09824 & ,22186 & ,61166 & 4,242 & 100 & ,000 \\
\hline & & Pair 3 & Equip_EGF_em_EU - Equip_OHQ_em_EU & ,34978 & 1,07894 & ,10736 & ,13678 & ,56278 & 3,258 & 100 & ,002 \\
\hline & Solteiro & Pair 1 & EU - Equip_EGF_em_EU &, 05786 & 1,29328 &, 11090 &,- 16147 & 27718 &, 522 & 135 &, 603 \\
\hline & & Pair 2 & EU - Equip_OHQ_em_EU & ,42282 & 1,43639 & ,12317 & 17923 & 66641 & 3,433 & 135 & ,001 \\
\hline & & Pair 3 & Equip_EGF_em_EU - Equip_OHQ_em_EU &, 35637 & 1,11672 & 09506 & ,16839 &, 54434 & 3,749 & 137 &, 000 \\
\hline & Divorciado & Pair 1 & EU - Equip_EGF_em_EU & , 10071 & 1,12169 & ,29978 &,- 54693 &, 74836 & ,336 & 13 &, 742 \\
\hline & & Pair 2 & EU - Equip_OHQ_em_EU &,- 21957 & 1,16872 &, 31235 &,- 89437 &, 45522 &,- 703 & 13 &, 494 \\
\hline & & Pair 3 & Equip_EGF_em_EU - Equip_OHQ_em_EU &,- 32029 & 1,13481 & ,30329 &,- 97550 & ,33493 & $-1,056$ & 13 &, 310 \\
\hline & Viúvo & Pair 1 & EU - Equip_EGF_em_EU &,- 57480 & 1,23490 &, 46675 & $-1,71689$ &, 56729 & $-1,232$ & 6 & 264 \\
\hline & & Pair 2 & EU - Equip_OHQ_em_EU &,- 82643 & 1,75785 & 66441 & $-2,45217$ & ,79931 & $-1,244$ & 6 & 260 \\
\hline & & Pair 3 & Equip_EGF_em_EU - Equip_OHQ_em_EU &,- 25163 & 1,23931 & ,46841 & $-1,39780$ & ,89454 &,- 537 & 6 & 610 \\
\hline & Outros & Pair 1 & EU - Equip_EGF_em_EU &,- 04365 & 1,24230 & ,34455 &,- 79437 & ,70706 &,- 127 & 12 &, 901 \\
\hline & & Pair 2 & EU - Equip_OHQ_em_EU & ,80285 & 1,36663 & ,37904 &,- 02300 & 1,62869 & 2,118 & 12 & 056 \\
\hline & & Pair 3 & Equip_EGF_em_EU - Equip_OHQ_em_EU &, 84650 & ,99227 & ,27521 & ,24688 & 1,44612 & 3,076 & 12 & 010 \\
\hline
\end{tabular}

a. No statistics are computed for one or more split files

Tabela 104- Coeficientes de determinação regressão para estado civil com separação em sexo - EU

Model Summary

\begin{tabular}{|ll|r|r|r|r|}
\hline Sexo & Model & \multicolumn{1}{|c|}{$\mathrm{R}$} & R Square & $\begin{array}{c}\text { Adjusted } \\
\text { R Square }\end{array}$ & $\begin{array}{c}\text { Std. Error of } \\
\text { the Estimate }\end{array}$ \\
\hline Masculino & 1 &, $188^{\mathrm{a}}$ &, 036 &, 017 & 1,36908 \\
\hline Feminino 1 &, $237^{\mathrm{a}}$ &, 056 &, 042 & 1,31167 \\
\hline
\end{tabular}

a. Predictors: (Constant), Dummy_EC_Outros, Dummy_EC_Viúvo,

Dummy_EC_Divorciado, Dummy_EC_Casado

Tabela 105- Coeficientes de regressão para estado civil com separação em sexo - EU

Coefficients $^{\mathrm{a}}$

\begin{tabular}{|c|c|c|c|c|c|c|c|}
\hline \multirow[b]{2}{*}{ Sexo } & \multirow[b]{2}{*}{ Model } & & \multicolumn{2}{|c|}{$\begin{array}{c}\text { Unstandardized } \\
\text { Coefficients }\end{array}$} & \multirow{2}{*}{$\begin{array}{c}\begin{array}{c}\text { Standardized } \\
\text { Coefficients }\end{array} \\
\text { Beta }\end{array}$} & \multirow[b]{2}{*}{$\mathrm{t}$} & \multirow[b]{2}{*}{ Sig. } \\
\hline & & & $\mathrm{B}$ & Std. Error & & & \\
\hline \multirow[t]{5}{*}{ Masculino } & 1 & (Constant) & 5,663 &, 145 & & 39,022 &, 000 \\
\hline & & Dummy_EC_Casado &,- 059 & ,197 &,- 021 &,- 300 & ,764 \\
\hline & & Dummy_EC_Divorciado &,- 663 &, 505 &,- 092 & $-1,312$ & , 191 \\
\hline & & Dummy_EC_Viúvo & $-1,663$ & ,804 &,- 143 & $-2,069$ & 040 \\
\hline & & Dummy_EC_Outros & ,837 & ,700 & 083 & 1,196 & ,233 \\
\hline \multirow[t]{5}{*}{ Feminino } & 1 & (Constant) & 5,610 & ,112 & & 49,880 & ,000 \\
\hline & & Dummy_EC_Casado & ,439 & ,172 & ,159 & 2,549 & ,011 \\
\hline & & Dummy_EC_Divorciado &,- 039 & ,368 &,- 006 &,- 106 & ,916 \\
\hline & & Dummy_EC_Viúvo & $-1,325$ &, 508 &,- 157 & $-2,606$ &, 010 \\
\hline & & Dummy_EC_Outros & ,236 & ,381 & ,038 & ,619 &, 536 \\
\hline
\end{tabular}

a. Dependent Variable: EU 
Tabela 106- Coeficientes de determinação regressão para estado civil com separação em sexo- EGF

Model Summary

\begin{tabular}{|ll|r|r|r|r|}
\hline Sexo & Model & \multicolumn{1}{|c|}{ R } & R Square & $\begin{array}{c}\text { Adjusted } \\
\text { R Square }\end{array}$ & $\begin{array}{c}\text { Std. Error of } \\
\text { the Estimate }\end{array}$ \\
\hline Masculino & 1 &, $109^{\mathrm{a}}$ &, 012 &,- 008 & 1,39030 \\
\hline Feminino 1 &, $192^{\mathrm{a}}$ &, 037 &, 022 & 1,32221 \\
\hline
\end{tabular}

a. Predictors: (Constant), Dummy_EC_Outros, Dummy_EC_Viúvo, Dummy_EC_Divorciado, Dummy_EC_Casado

Tabela 107-- Coeficientes de regressão para estado civil com separação em sexo - EGF Coefficients $^{\mathrm{a}}$

\begin{tabular}{|c|c|c|c|c|c|c|c|}
\hline \multirow[b]{2}{*}{ Sexo } & \multirow[b]{2}{*}{ Model } & & \multicolumn{2}{|c|}{$\begin{array}{l}\text { Unstandardized } \\
\text { Coefficients }\end{array}$} & \multirow{2}{*}{$\begin{array}{c}\begin{array}{c}\text { Standardized } \\
\text { Coefficients }\end{array} \\
\text { Beta }\end{array}$} & \multirow[b]{2}{*}{$\mathrm{t}$} & \multirow[b]{2}{*}{ Sig. } \\
\hline & & & $\mathrm{B}$ & Std. Error & & & \\
\hline \multirow[t]{5}{*}{ Masculino } & 1 & (Constant) & 5,648 &, 147 & & 38,325 &, 000 \\
\hline & & Dummy_EC_Casado & ,086 & 201 & ,031 & ,430 & ,668 \\
\hline & & Dummy_EC_Divorciado &,- 210 &, 513 &,- 029 &,- 409 & ,683 \\
\hline & & Dummy_EC_Viúvo & $-1,049$ & ,816 &,- 091 & $-1,285$ & 200 \\
\hline & & Dummy_EC_Outros & ,324 & ,711 & ,032 & ,456 & 649 \\
\hline \multirow[t]{5}{*}{ Feminino } & 1 & (Constant) & 5,536 & ,113 & & 49,189 & ,000 \\
\hline & & Dummy_EC_Casado & ,446 & ,173 &, 161 & 2,577 & ,011 \\
\hline & & Dummy_EC_Divorciado &,- 066 & ,371 &,- 011 &,- 177 & ,860 \\
\hline & & Dummy_EC_Viúvo &,- 676 &, 512 &,- 080 & $-1,319$ & , 188 \\
\hline & & Dummy_EC_Outros & ,353 & ,384 & ,056 & ,921 & ,358 \\
\hline
\end{tabular}

a. Dependent Variable: Equip_EGF_em_EU

Tabela 108-Coeficientes de determinação regressão para estado civil com separação em sexo OHQ

Model Summary

\begin{tabular}{|ll|r|r|r|r|}
\hline Sexo & Model & R & R Square & $\begin{array}{c}\text { Adjusted } \\
\text { R Square }\end{array}$ & $\begin{array}{r}\text { Std. Error of } \\
\text { the Estimate }\end{array}$ \\
\hline Masculino & 1 &, $121^{\mathrm{a}}$ &, 015 &,- 005 & 1,33061 \\
\hline Feminino 1 &, $187^{\mathrm{a}}$ &, 035 &, 020 & 1,29729 \\
\hline
\end{tabular}

a. Predictors: (Constant), Dummy_EC_Outros, Dummy_EC_Viúvo, Dummy_EC_Divorciado, Dummy_EC_Casado

Tabela 109- Coeficientes de regressão para estado civil com separação em sexo OHQ

\begin{tabular}{|c|c|c|c|c|c|c|c|}
\hline \multicolumn{8}{|c|}{ Coefficients $^{a}$} \\
\hline \multirow[b]{2}{*}{ Sexo } & \multirow[b]{2}{*}{ Model } & & \multicolumn{2}{|c|}{$\begin{array}{l}\text { Unstandardized } \\
\text { Coefficients }\end{array}$} & \multirow{2}{*}{$\begin{array}{c}\begin{array}{c}\text { Standardized } \\
\text { Coefficients }\end{array} \\
\text { Beta }\end{array}$} & \multirow[b]{2}{*}{$t$} & \multirow[b]{2}{*}{ Sig. } \\
\hline & & & $\mathrm{B}$ & Std. Error & & & \\
\hline \multirow[t]{5}{*}{ Masculino } & 1 & (Constant) & 5,423 &, 141 & & 38,448 &, 000 \\
\hline & & Dummy_EC_Casado & ,082 & ,191 & ,031 & ,429 & ,668 \\
\hline & & Dummy_EC_Divorciado &,- 280 & ,491 &,- 040 &,- 570 &, 569 \\
\hline & & Dummy_EC_Viúvo &,- 976 & ,781 &,- 087 & $-1,249$ & ,213 \\
\hline & & Dummy_EC_Outros &, 584 &, 680 &, 060 & ,859 & ,391 \\
\hline \multirow[t]{5}{*}{ Feminino } & 1 & (Constant) & 5,180 & ,110 & & 46,907 &, 000 \\
\hline & & Dummy_EC_Casado & ,453 & ,170 & ,167 & 2,665 & ,008 \\
\hline & & Dummy_EC_Divorciado & ,611 & ,364 & ,103 & 1,679 & ,094 \\
\hline & & Dummy_EC_Viúvo &,- 068 &, 503 &,- 008 &,- 135 & ,893 \\
\hline & & Dummy_EC_Outros &,- 137 & ,376 &,- 022 &,- 363 &, 717 \\
\hline
\end{tabular}

a. Dependent Variable: Equip_OHQ_em_EU 
Tabela 110- Coeficientes de determinação para idades separação por estado civil - EU

Model Summary

\begin{tabular}{|ll|r|r|r|r|}
\hline est_cívil & Model & \multicolumn{1}{|c|}{$\mathrm{R}$} & \multicolumn{1}{c|}{ R Square } & $\begin{array}{c}\text { Adjusted } \\
\text { R Square }\end{array}$ & $\begin{array}{r}\text { Std. Error of } \\
\text { the Estimate }\end{array}$ \\
\hline Casado & 1 &, $239^{\mathrm{a}}$ &, 057 &, 034 & 1,20767 \\
\hline Solteiro & 1 &, $074^{\mathrm{b}}$ &, 005 &,- 013 & 1,43634 \\
\hline Divorciado & 1 &, $246^{\mathrm{c}}$ &, 061 &,- 096 & 1,27385 \\
\hline Viúvo & 1 &, $655^{\mathrm{c}}$ &, 429 &, 143 & 1,78885 \\
\hline Outros & 1 &, $342^{\mathrm{d}}$ &, 117 &,- 087 & 1,22233 \\
\hline
\end{tabular}

a. Predictors: (Constant), Dummy Idade 6, Dummy Idade 1,

Dummy_Idade_5, Dummy_Idade_4, Dummy_Idade_3

b. Predictors: (Constant), Dummy_Idade_5, Dummy_Idade_4, Dummy_Idade_3, Dummy_Idade_1

c. Predictors: (Constant), Dummy_Idade_5, Dummy_Idade_3, Dummy_Idade_4

d. Predictors: (Constant), Dummy_Idade_4, Dummy_Idade_1, Dummy_Idade_3

Tabela 111- Regressão para idades separação por estado civil - EU

Coefficients $^{\mathrm{a}}$

\begin{tabular}{|c|c|c|c|c|c|c|c|}
\hline \multirow[b]{2}{*}{ est_cívil } & \multirow[b]{2}{*}{ Model } & & \multicolumn{2}{|c|}{$\begin{array}{l}\text { Unstandardized } \\
\text { Coefficients }\end{array}$} & \multirow{2}{*}{$\begin{array}{c}\begin{array}{c}\text { Standardized } \\
\text { Coefficients }\end{array} \\
\text { Beta }\end{array}$} & \multirow[b]{2}{*}{$t$} & \multirow[b]{2}{*}{ Sig. } \\
\hline & & & $\mathrm{B}$ & Std. Error & & & \\
\hline \multirow[t]{6}{*}{ Casado } & 1 & (Constant) & 6,013 & ,137 & & 43,972 &, 000 \\
\hline & & Dummy_Idade_1 & ,416 & ,476 & ,061 & ,873 & ,384 \\
\hline & & Dummy_Idade_3 &,- 077 & 205 &,- 029 &,- 376 & ,707 \\
\hline & & Dummy_Idade_4 &,- 671 & ,233 &,- 218 & $-2,882$ & ,004 \\
\hline & & Dummy_Idade_5 &,- 551 & ,362 &,- 109 & $-1,524$ & ,129 \\
\hline & & Dummy_Idade_6 &,- 441 & ,476 &,- 065 &,- 926 & ,355 \\
\hline \multirow[t]{5}{*}{ Solteiro } & 1 & (Constant) & 5,669 & ,123 & & 46,029 & ,000 \\
\hline & & Dummy_Idade_1 &,- 015 & ,230 &,- 004 &,- 063 & ,949 \\
\hline & & Dummy_Idade_3 &,- 124 & ,330 &,- 026 &,- 375 & ,708 \\
\hline & & Dummy_Idade_4 &,- 544 &, 523 &,- 071 & $-1,041$ & 299 \\
\hline & & Dummy_Idade_5 &,- 169 & ,729 &,- 016 &,- 232 & ,817 \\
\hline \multirow[t]{4}{*}{ Divorciado } & 1 & (Constant) & 5,000 & ,570 & & 8,777 & ,000 \\
\hline & & Dummy_Idade_3 & ,333 & ,771 & ,125 & ,432 & 671 \\
\hline & & Dummy_Idade_4 & ,375 & ,726 & , 152 &, 516 & ,612 \\
\hline & & Dummy_Idade_5 & 1,000 & ,930 & ,289 & 1,075 & ,297 \\
\hline \multirow[t]{4}{*}{ Viúvo } & 1 & (Constant) & 3,000 & 1,265 & & 2,372 & ,055 \\
\hline & & Dummy_Idade_3 & $-1,000$ & 2,191 &,- 164 &,- 456 & ,664 \\
\hline & & Dummy_Idade_4 & 1,400 & 1,497 & ,382 & ,935 & ,386 \\
\hline & & Dummy_Idade_5 & 3,000 & 1,789 & ,655 & 1,677 & ,145 \\
\hline \multirow[t]{4}{*}{ Outros } & 1 & (Constant) & 6,077 & ,339 & & 17,925 & ,000 \\
\hline & & Dummy_Idade_1 & ,923 & 1,268 & ,191 & ,728 & ,480 \\
\hline & & Dummy_Idade_3 &,- 577 & ,928 &,- 163 &,- 621 &, 545 \\
\hline & & Dummy_Idade_4 & $-1,077$ & 1,268 &,- 223 &,- 849 & ,411 \\
\hline
\end{tabular}

a. Dependent Variable: EU 
Tabela 112- Coeficientes de determinação regressão para estado civil com separação idades EGF

Model Summary

\begin{tabular}{|ll|r|r|r|r|}
\hline est_cívil & Model & \multicolumn{1}{c|}{$\mathrm{R}$} & $\mathrm{R}$ Square & $\begin{array}{c}\text { Adjusted } \\
\text { R Square }\end{array}$ & $\begin{array}{c}\text { Std. Error of } \\
\text { the Estimate }\end{array}$ \\
\hline Casado & 1 &, $245^{\mathrm{a}}$ &, 060 &, 037 & 1,30286 \\
\hline Solteiro & 1 &, $061^{\mathrm{b}}$ &, 004 &,- 014 & 1,38354 \\
\hline Divorciado & 1 &, $254^{\mathrm{c}}$ &, 064 &,- 092 & 1,03940 \\
\hline Viúvo & 1 &, $711^{\mathrm{c}}$ &, 505 &, 258 & 1,87952 \\
\hline Outros & 1 &, $629^{\mathrm{d}}$ &, 395 &, 256 &, 86184 \\
\hline
\end{tabular}

a. Predictors: (Constant), Dummy_Idade_6, Dummy_Idade_1, Dummy_Idade_5, Dummy_Idade_4, Dummy_Idade_3

b. Predictors: (Constant), Dummy_Idade_5, Dummy_Idade_4, Dummy_Idade_3, Dummy_Idade_1

c. Predictors: (Constant), Dummy_Idade_5, Dummy_Idade_3, Dummy_Idade_4

d. Predictors: (Constant), Dummy_Idade_4, Dummy_Idade_1, Dummy_Idade_3

Tabela 113- Regressão para idades separação por estado civil - EGF

Coefficients $^{\mathrm{a}}$

\begin{tabular}{|c|c|c|c|c|c|c|c|}
\hline \multirow[b]{2}{*}{ est_cívil } & \multirow[b]{2}{*}{ Model } & & \multicolumn{2}{|c|}{$\begin{array}{l}\text { Unstandardized } \\
\text { Coefficients }\end{array}$} & \multirow{2}{*}{$\begin{array}{c}\text { Standardized } \\
\text { Coefficients } \\
\text { Beta }\end{array}$} & \multirow[b]{2}{*}{$\mathrm{t}$} & \multirow[b]{2}{*}{ Sig. } \\
\hline & & & $\mathrm{B}$ & Std. Error & & & \\
\hline \multirow[t]{6}{*}{ Casado } & 1 & (Constant) & 5,922 &, 148 & & 39,888 &, 000 \\
\hline & & Dummy_Idade_1 & 1,117 & ,514 & , 153 & 2,172 & ,031 \\
\hline & & Dummy_Idade_3 & ,092 & ,223 & ,032 & ,412 & ,681 \\
\hline & & Dummy_Idade_4 &,- 490 & ,252 &,- 148 & $-1,945$ & ,053 \\
\hline & & Dummy_Idade_5 &,- 479 & ,391 &,- 088 & $-1,225$ & ,222 \\
\hline & & Dummy_Idade_6 &,- 321 &, 514 &,- 044 &,- 624 &, 533 \\
\hline \multirow[t]{5}{*}{ Solteiro } & 1 & (Constant) & 5,570 & ,118 & & 47,122 & ,000 \\
\hline & & Dummy_ldade_1 & ,127 & ,221 &, 040 &, 577 &, 565 \\
\hline & & Dummy_ldade_3 &,- 175 & 312 &,- 039 &,- 562 &, 575 \\
\hline & & Dummy_Idade_4 &,- 056 & ,503 &,- 007 &,- 111 & ,912 \\
\hline & & Dummy_Idade_5 &,- 056 & ,702 &,- 005 &,- 079 & 937 \\
\hline \multirow[t]{4}{*}{ Divorciado } & 1 & (Constant) & 5,331 & ,465 & & 11,469 &, 000 \\
\hline & & Dummy_Idade_3 &,- 071 & 629 &,- 033 &,- 113 & ,911 \\
\hline & & Dummy_Idade_4 & ,450 & ,593 & ,223 &, 759 & ,457 \\
\hline & & Dummy_ldade_5 &,- 122 &, 759 &,- 043 &,- 161 & ,874 \\
\hline \multirow[t]{4}{*}{ Viúvo } & 1 & (Constant) & 3,531 & 1,329 & & 2,657 & ,038 \\
\hline & & Dummy_Idade_3 & $-1,068$ & 2,302 &,- 155 &,- 464 & ,659 \\
\hline & & Dummy_Idade_4 & 1,190 & 1,573 & ,287 & ,757 & ,478 \\
\hline & & Dummy_Idade_5 & 3,814 & 1,880 & ,737 & 2,029 & ,089 \\
\hline \multirow[t]{4}{*}{ Outros } & 1 & (Constant) & 5,984 & ,239 & & 25,033 & ,000 \\
\hline & & Dummy_ldade_1 & 1,056 & ,894 & ,256 & 1,181 & ,259 \\
\hline & & Dummy_ldade_3 & $-1,537$ & ,655 &,- 511 & $-2,348$ & ,035 \\
\hline & & Dummy_Idade_4 &, 751 & ,894 & ,182 & ,840 & ,416 \\
\hline
\end{tabular}

a. Dependent Variable: Equip_EGF_em_EU 
Tabela 114- Coeficiente de determinação para idades separação por estado civil - OHQ

Model Summary

\begin{tabular}{|ll|r|r|r|r|}
\hline est_cívil & Model & \multicolumn{1}{|c|}{ R } & R Square & $\begin{array}{c}\text { Adjusted } \\
\text { R Square }\end{array}$ & $\begin{array}{c}\text { Std. Error of } \\
\text { the Estimate }\end{array}$ \\
\hline Casado & 1 &, $127^{\mathrm{a}}$ &, 016 &,- 008 & 1,22128 \\
\hline Solteiro & 1 &, $068^{\mathrm{b}}$ &, 005 &,- 013 & 1,34645 \\
\hline Divorciado & 1 &, $332^{\mathrm{c}}$ &, 110 &,- 038 & 1,63579 \\
\hline Viúvo & 1 &, $706^{\mathrm{c}}$ &, 499 &, 248 & 1,64009 \\
\hline Outros & 1 &, $767^{\mathrm{d}}$ &, 589 &, 494 &, 92577 \\
\hline
\end{tabular}

a. Predictors: (Constant), Dummy_Idade_6, Dummy_Idade_1, Dummy_Idade_5, Dummy_Idade_4, Dummy_Idade_3

b. Predictors: (Constant), Dummy_Idade_5, Dummy_Idade_4, Dummy_Idade_3, Dummy_Idade_1

c. Predictors: (Constant), Dummy_Idade_5, Dummy_Idade_3, Dummy_Idade_4

d. Predictors: (Constant), Dummy_Idade_4, Dummy_Idade_1, Dummy_Idade_3

Tabela 115- Regressão para idades separação por estado civil - OHQ

Coefficients $^{\mathrm{a}}$

\begin{tabular}{|c|c|c|c|c|c|c|c|}
\hline \multirow[b]{2}{*}{ est cívil } & \multirow[b]{2}{*}{ Model } & & \multicolumn{2}{|c|}{$\begin{array}{c}\text { Unstandardized } \\
\text { Coefficients }\end{array}$} & \multirow{2}{*}{$\begin{array}{c}\begin{array}{c}\text { Standardized } \\
\text { Coefficients }\end{array} \\
\text { Beta }\end{array}$} & \multirow[b]{2}{*}{$\mathrm{t}$} & \multirow[b]{2}{*}{ Sig. } \\
\hline & & & $\mathrm{B}$ & Std. Error & & & \\
\hline \multirow[t]{6}{*}{ Casado } & 1 & (Constant) & 5,468 &, 138 & & 39,542 &, 000 \\
\hline & & Dummy_Idade_1 & ,364 & ,482 & 054 & ,756 & ,451 \\
\hline & & Dummy_Idade_3 & ,309 & 208 & ,117 & 1,488 & ,138 \\
\hline & & Dummy_Idade_4 &,- 005 & ,236 &,- 002 &,- 023 & ,982 \\
\hline & & Dummy_Idade_5 &,- 031 & ,366 &,- 006 &,- 086 & ,932 \\
\hline & & Dummy_Idade_6 &,- 099 & ,482 &,- 015 &,- 205 & ,838 \\
\hline \multirow[t]{5}{*}{ Solteiro } & 1 & (Constant) & 5,297 &, 115 & & 46,047 &, 000 \\
\hline & & Dummy_Idade_1 &,- 161 & ,215 &,- 052 &,- 747 & ,456 \\
\hline & & Dummy_Idade_3 &, 156 & ,303 & ,035 &, 514 & ,608 \\
\hline & & Dummy_Idade_4 &,- 001 & ,490 &, 000 &,- 002 & ,998 \\
\hline & & Dummy_Idade_5 &, 080 &, 683 & ,008 &, 117 & ,907 \\
\hline \multirow[t]{4}{*}{ Divorciado } & 1 & (Constant) & 5,013 & ,732 & & 6,853 &, 000 \\
\hline & & Dummy_Idade_3 & ,814 & ,991 & 231 & ,821 & ,422 \\
\hline & & Dummy_Idade_4 & ,274 & ,933 & ,084 & 293 & ,773 \\
\hline & & Dummy_Idade_5 & 1,618 & 1,195 & ,354 & 1,354 & ,192 \\
\hline \multirow[t]{4}{*}{ Viúvo } & 1 & (Constant) & 4,963 & 1,160 & & 4,279 & 005 \\
\hline & & Dummy_Idade_3 & $-2,772$ & 2,009 &,- 463 & $-1,380$ & ,217 \\
\hline & & Dummy_Idade_4 &,- 338 & 1,372 &,- 094 &,- 247 & 813 \\
\hline & & Dummy_ldade_5 & 1,980 & 1,640 & ,441 & 1,207 & ,273 \\
\hline \multirow[t]{4}{*}{ Outros } & 1 & (Constant) & 5,536 & ,257 & & 21,562 &, 000 \\
\hline & & Dummy_Idade_1 & 1,695 & ,961 & ,316 & 1,764 & ,101 \\
\hline & & Dummy_Idade_3 & $-2,553$ & ,703 &,- 652 & $-3,631$ &, 003 \\
\hline & & Dummy_Idade_4 & $-1,113$ &, 961 &,- 208 & $-1,159$ & ,267 \\
\hline
\end{tabular}

a. Dependent Variable: Equip_OHQ_em_EU 
Tabela 116- Análise de médias para níveis educacionais

\section{ANOVA}

\begin{tabular}{|ll|r|r|r|r|r|}
\hline & & \multicolumn{1}{c|}{$\begin{array}{c}\text { Sum of } \\
\text { Squares }\end{array}$} & df & Mean Square & \multicolumn{1}{c|}{ F } & Sig. \\
\hline EU & Between Groups & 9,371 & 5 & 1,874 & 1,017 &, 407 \\
& Within Groups & 873,221 & 474 & 1,842 & & \\
& Total & 882,592 & 479 & & &, 266 \\
\hline Equip_EGF_em_EU & Between Groups & 11,896 & 5 & 2,379 & 1,291 & \\
& Within Groups & 873,573 & 474 & 1,843 & & \\
& Total & 885,468 & 479 & & & \\
\hline Equip_OHQ_em_EU & Between Groups & 27,905 & 5 & 5,581 & 3,307 & \\
& Within Groups & 803,293 & 476 & 1,688 & & \\
& Total & 831,198 & 481 & & & \\
\hline
\end{tabular}

Tabela 117- Correlação entre os escores - nível educacional

Paired Samples Correlations

\begin{tabular}{|c|c|c|c|c|c|}
\hline \multicolumn{3}{|l|}{ escolar } & $\mathrm{N}$ & Correlation & Sig. \\
\hline \multirow[t]{3}{*}{. } & Pair 1 & EU \& Equip_EGF_em_EU & 2 & . & \\
\hline & Pair 2 & EU \& Equip_OHQ_em_EU & 2 & . & \\
\hline & Pair 3 & Equip_EGF_em_EU \& Equip_OHQ_em_EU & 2 & $-1,000$ &, 000 \\
\hline \multirow[t]{3}{*}{ Primeiro Grau Incompleto } & Pair 1 & EU \& Equip_EGF_em_EU & 35 &, 578 & ,000 \\
\hline & Pair 2 & EU \& Equip_OHQ_em_EU & 35 & ,420 & ,012 \\
\hline & Pair 3 & Equip_EGF_em_EU \& Equip_OHQ_em_EU & 35 & ,405 &, 016 \\
\hline \multirow[t]{3}{*}{ Primeiro Grau Completo } & Pair 1 & EU \& Equip_EGF_em_EU & 18 & ,701 & ,001 \\
\hline & Pair 2 & EU \& Equip_OHQ_em_EU & 18 &, 532 & 023 \\
\hline & Pair 3 & Equip_EGF_em_EU \& Equip_OHQ_em_EU & 18 & ,701 & 001 \\
\hline \multirow{3}{*}{$\begin{array}{l}\text { Segundo Grau } \\
\text { Incompleto }\end{array}$} & Pair 1 & EU \& Equip_EGF_em_EU & 60 & ,514 & ,000 \\
\hline & Pair 2 & EU \& Equip_OHQ_em_EU & 61 & ,494 & ,000 \\
\hline & Pair 3 & Equip_EGF_em_EU \& Equip_OHQ_em_EU & 61 &, 506 &, 000 \\
\hline \multirow[t]{3}{*}{ Segundo Grau Completo } & Pair 1 & EU \& Equip_EGF_em_EU & 227 & ,674 & ,000 \\
\hline & Pair 2 & EU \& Equip_OHQ_em_EU & 228 &, 579 &, 000 \\
\hline & Pair 3 & Equip_EGF_em_EU \& Equip_OHQ_em_EU & 228 & ,628 &, 000 \\
\hline \multirow{3}{*}{$\begin{array}{l}\text { Ensino Superior } \\
\text { Incompleto }\end{array}$} & Pair 1 & EU \& Equip_EGF_em_EU & 74 & ,643 &, 000 \\
\hline & Pair 2 & EU \& Equip_OHQ_em_EU & 74 & ,606 &, 000 \\
\hline & Pair 3 & Equip_EGF_em_EU \& Equip_OHQ_em_EU & 74 & ,735 &, 000 \\
\hline \multirow{3}{*}{$\begin{array}{l}\text { Ensino Superior } \\
\text { completo }\end{array}$} & Pair 1 & EU \& Equip_EGF_em_EU & 64 & ,638 & ,000 \\
\hline & Pair 2 & EU \& Equip_OHQ_em_EU & 64 &, 554 & ,000 \\
\hline & Pair 3 & Equip_EGF_em_EU \& Equip_OHQ_em_EU & 64 & ,742 & ,000 \\
\hline
\end{tabular}


Tabela 116 Análise média escores nas categoria educacionais

\begin{tabular}{|c|c|c|c|c|c|c|c|c|c|c|}
\hline \multicolumn{11}{|c|}{ Paired Samples Test } \\
\hline \multirow[b]{3}{*}{ escolar } & & & \multicolumn{5}{|c|}{ Paired Differences } & \multirow[b]{3}{*}{$t$} & \multirow[b]{3}{*}{ df } & \multirow{3}{*}{$\begin{array}{c}\text { Sig. } \\
\text { (2-tailed) }\end{array}$} \\
\hline & & & \multirow[b]{2}{*}{ Mean } & \multirow{2}{*}{$\begin{array}{c}\text { Std. } \\
\text { Deviation }\end{array}$} & \multirow{2}{*}{$\begin{array}{l}\text { Std. Error } \\
\text { Mean }\end{array}$} & \multicolumn{2}{|c|}{$\begin{array}{l}95 \% \text { Confidence } \\
\text { Interval of the } \\
\text { Difference }\end{array}$} & & & \\
\hline & & & & & & Lower & Upper & & & \\
\hline & Pair 1 & EU - Equip_EGF_em_EU & 1,33315 &, 21574 & ,15255 &,- 60518 & 3,27148 & 8,739 & 1 &, 073 \\
\hline & Pair 2 & EU - Equip_OHQ_em_EU & 1,53300 & 2,29103 & 1,62000 & $-19,05105$ & 22,11705 &, 946 & 1 &, 518 \\
\hline & Pair 3 & $\begin{array}{l}\text { Equip_EGF_em_EU - } \\
\text { Equip_OHQ_em_EU }\end{array}$ & , 19985 & 2,50676 & 1,77255 & $-22,32253$ & 22,72223 &, 113 & 1 & ,929 \\
\hline Primeiro Grau Incompleto & Pair 1 & EU - Equip_EGF_em_EU &,- 06780 & 1,31804 & ,22279 &,- 52056 & ,38496 &,- 304 & 34 & ,763 \\
\hline & Pair 2 & EU - Equip_OHQ_em_EU &, 50729 & 1,45661 & ,24621 &, 00692 & 1,00765 & 2,060 & 34 &, 047 \\
\hline & Pair 3 & $\begin{array}{l}\text { Equip_EGF_em_EU - } \\
\text { Equip_OHQ_em_EU }\end{array}$ &, 57509 & 1,41483 & 23915 &, 08907 & 1,06110 & 2,405 & 34 & 022 \\
\hline Primeiro Grau Completo & Pair 1 & EU - Equip_EGF_em_EU &,- 18380 & 1,11214 & ,26213 &,- 73686 & ,36926 &,- 701 & 17 & ,493 \\
\hline & Pair 2 & EU - Equip_OHQ_em_EU &, 47300 & 1,39385 & ,32853 &,- 22014 & 1,16614 & 1,440 & 17 & , 168 \\
\hline & Pair 3 & $\begin{array}{l}\text { Equip_EGF_em_EU - } \\
\text { Equip_OHQ_em_EU }\end{array}$ & ,65680 & ,98853 & ,23300 & , 16521 & 1,14839 & 2,819 & 17 &, 012 \\
\hline Segundo Grau & Pair 1 & EU - Equip_EGF_em_EU & ,20830 & 1,37155 & ,17707 &,- 14601 & ,56261 & 1,176 & 59 & ,244 \\
\hline Incompleto & Pair 2 & EU - Equip_OHQ_em_EU & ,41582 & 1,32093 & 16913 & 07751 &, 75413 & 2,459 & 60 &, 017 \\
\hline & Pair 3 & $\begin{array}{l}\text { Equip_EGF_em_EU - } \\
\text { Equip_OHQ_em_EU }\end{array}$ & , 16442 & 1,37305 & , 17580 &,- 18724 &, 51607 & ,935 & 60 & ,353 \\
\hline Segundo Grau Completo & Pair 1 & EU - Equip_EGF_em_EU &,- 05527 & 1,08493 & 07201 &,- 19716 & ,08663 &,- 768 & 226 & ,444 \\
\hline & Pair 2 & EU - Equip_OHQ_em_EU & ,27402 & 1,21417 & 08041 &, 11557 & ,43246 & 3,408 & 227 & 001 \\
\hline & Pair 3 & $\begin{array}{l}\text { Equip_EGF_em_EU - } \\
\text { Equip_OHQ_em_EU }\end{array}$ & ,33326 & 1,10158 & ,07295 & , 18951 & ,47702 & 4,568 & 227 &, 000 \\
\hline Ensino Superior & Pair 1 & EU - Equip_EGF_em_EU &,- 05714 & 1,20235 & ,13977 &,- 33570 & ,22142 &,- 409 & 73 & ,684 \\
\hline Incompleto & Pair 2 & EU - Equip_OHQ_em_EU & ,02089 & 1,25723 & 14615 &,- 27038 & ,31217 & ,143 & 73 & ,887 \\
\hline & Pair 3 & $\begin{array}{l}\text { Equip_EGF_em_EU - } \\
\text { Equip_OHQ_em_EU }\end{array}$ & ,07803 & 1,07716 & ,12522 &,- 17152 & ,32759 & ,623 & 73 &, 535 \\
\hline Ensino Superior & Pair 1 & EU - Equip_EGF_em_EU & ,05031 & 1,07496 & ,13437 &,- 21821 & ,31882 & ,374 & 63 & ,709 \\
\hline completo & Pair 2 & EU - Equip_OHQ_em_EU & ,22625 & 1,18056 & 14757 &,- 06865 &, 52115 & 1,533 & 63 & 130 \\
\hline & Pair 3 & $\begin{array}{l}\text { Equip_EGF_em_EU - } \\
\text { Equip_OHQ_em_EU }\end{array}$ & , 17594 & ,94092 & ,11762 &,- 05909 & ,41098 & 1,496 & 63 & 140 \\
\hline
\end{tabular}

Tabela 118- Coeficientes de determinação EU para nível escolaridade

\begin{tabular}{|l|r|r|r|r|}
\multicolumn{7}{c|}{ Model Summary } \\
\hline Model & $\mathrm{R}$ & R Square & $\begin{array}{c}\text { Adjusted } \\
\text { R Square }\end{array}$ & $\begin{array}{r}\text { Std. Error of } \\
\text { the Estimate }\end{array}$ \\
\hline 1 &, $088^{\mathrm{a}}$ &, 008 &,- 003 & 1,35903 \\
\hline
\end{tabular}

a. Predictors: (Constant), Terceiro_G_Completo_Dmy,

Primeiro_G_Completo_Dmy, Segundo_G

Incompleto_Dmy, Terceiro_G_Incompleto_Dmy,

Segundo_G_Completo_Dmy

Tabela 119- Coeficientes de regressão EU para nível escolaridade

Coefficients $^{\mathrm{a}}$

\begin{tabular}{|ll|r|r|r|r|r|}
\hline \multirow{2}{*}{ Model } & \multicolumn{2}{|c|}{$\begin{array}{c}\text { Unstandardized } \\
\text { Coefficients }\end{array}$} & \multicolumn{2}{c|}{$\begin{array}{c}\text { Standardized } \\
\text { Coefficients }\end{array}$} & \\
\cline { 3 - 5 } & & \multicolumn{1}{|c|}{ B } & Std. Error & \multicolumn{2}{c|}{ Beta } & \multicolumn{1}{c|}{ Sig. } \\
\hline 1 & (Constant) & 5,324 &, 223 & & 23,831 &, 000 \\
& Primeiro_G_Completo_Dmy &, 176 &, 391 &, 025 &, 450 &, 653 \\
& Segundo_G_Incompleto_Dmy &, 348 &, 283 &, 085 & 1,228 &, 220 \\
& Segundo_G_Completo_Dmy &, 404 &, 241 &, 149 & 1,676 &, 094 \\
& Terceiro_G_Incompleto_Dmy &, 351 &, 274 &, 093 & 1,284 &, 200 \\
& Terceiro_G_Completo_Dmy &, 488 &, 281 &, 122 & 1,739 &, 083 \\
\hline
\end{tabular}

a. Dependent Variable: EU 
Tabela 120- Coeficientes de determinação EGF para nível escolaridade

\begin{tabular}{|c|r|r|r|r|}
\hline Model & R & R Square & $\begin{array}{l}\text { Adjusted } \\
\text { R Square }\end{array}$ & $\begin{array}{c}\text { Std. Error of } \\
\text { the Estimate }\end{array}$ \\
\hline 1 &, $115^{\mathrm{a}}$ &, 013 &, 003 & 1,35495 \\
\hline
\end{tabular}

Tabela 121- Coeficientes de regressão EGF para nível escolaridade

Coefficients $^{\mathrm{a}}$

\begin{tabular}{|c|c|c|c|c|c|c|}
\hline \multirow[b]{2}{*}{ Mode } & & \multicolumn{2}{|c|}{$\begin{array}{l}\text { Unstandardized } \\
\text { Coefficients }\end{array}$} & \multirow{2}{*}{$\begin{array}{c}\begin{array}{c}\text { Standardized } \\
\text { Coefficients }\end{array} \\
\text { Beta }\end{array}$} & \multirow[b]{2}{*}{$t$} & \multirow[b]{2}{*}{ Sig. } \\
\hline & & $\mathrm{B}$ & Std. Error & & & \\
\hline & (Constant) & 5,316 & ,223 & & 23,867 &, 000 \\
\hline & Primeiro_G_Completo_Dmy & ,367 & ,389 & 051 & ,944 & 346 \\
\hline & Segundo_G_Incompleto_Dmy & 108 & ,282 & 026 & ,382 & ,703 \\
\hline & Segundo_G_Completo_Dmy & ,460 & ,240 & 170 & 1,916 & ,056 \\
\hline & Terceiro_G_Incompleto_Dmy & ,416 & ,273 & ,111 & 1,526 & ,128 \\
\hline & Terceiro_G_Completo_Dmy & ,446 & ,280 &, 112 & 1,593 &, 112 \\
\hline
\end{tabular}

a. Dependent Variable: Equip_EGF_em_EU

Tabela 122- Coeficientes de determinação OHQ para nível escolaridade

\begin{tabular}{|l|r|r|r|r|}
\multicolumn{7}{c|}{ Model Summary } \\
\hline Model & R & R Square & $\begin{array}{l}\text { Adjusted } \\
\text { R Square }\end{array}$ & $\begin{array}{r}\text { Std. Error of } \\
\text { the Estimate }\end{array}$ \\
\hline 1 &, $179^{\mathrm{a}}$ &, 032 &, 022 & 1,30143 \\
\hline
\end{tabular}

a. Predictors: (Constant), Terceiro_G_Completo_Dmy,

Primeiro_G_Completo_Dmy, Segundo_G_

Incompleto_Dmy, Terceiro_G_Incompleto_Dmy,

Segundo_G_Completo_Dmy

Tabela 123- Coeficientes de regressão OHQ para nível escolaridade

\begin{tabular}{|c|c|c|c|c|c|c|}
\hline \multicolumn{7}{|c|}{ Coefficients $^{a}$} \\
\hline \multirow[b]{2}{*}{ Mod } & & \multicolumn{2}{|c|}{$\begin{array}{c}\text { Unstandardized } \\
\text { Coefficients }\end{array}$} & \multirow{2}{*}{$\begin{array}{c}\begin{array}{c}\text { Standardized } \\
\text { Coefficients }\end{array} \\
\text { Beta }\end{array}$} & \multirow[b]{2}{*}{$t$} & \multirow[b]{2}{*}{ Sig. } \\
\hline & & $\mathrm{B}$ & Std. Error & & & \\
\hline & (Constant) & 4,762 & ,214 & & 22,255 &, 000 \\
\hline & Primeiro_G_Completo_Dmy & ,265 & ,374 & ,038 & ,710 & ,478 \\
\hline & Segundo_G_Incompleto_Dmy & ,477 & ,270 & ,121 & 1,763 & ,079 \\
\hline & Segundo_G_Completo_Dmy & ,691 & ,231 & ,263 & 2,998 & ,003 \\
\hline & Terceiro_G_Incompleto_Dmy & ,893 & ,262 & ,245 & 3,409 &, 001 \\
\hline & Terceiro_G_Completo_Dmy & ,825 & ,269 & ,212 & 3,068 & ,002 \\
\hline
\end{tabular}

a. Dependent Variable: Equip_OHQ_em_EU

Tabela 124- Coeficientes de determinação para nível escolaridade separado por sexo EU

\begin{tabular}{|ll|r|r|r|r|}
\multicolumn{1}{|c|}{ Model Summary } \\
\hline Sexo & Model & \multicolumn{1}{|c|}{ R } & R Square & $\begin{array}{r}\text { Adjusted } \\
\text { R Square }\end{array}$ & $\begin{array}{r}\text { Std. Error of } \\
\text { the Estimate }\end{array}$ \\
\hline Masculino & 1 &, $047^{\mathrm{a}}$ &, 002 &,- 022 & 1,39594 \\
\hline Feminino & 1 &, $147^{\mathrm{a}}$ &, 021 &, 003 & 1,33814 \\
\hline
\end{tabular}

a. Predictors: (Constant), Terceiro_G_Completo_Dmy, Primeiro_G_

Completo_Dmy, Segundo_G_Incompleto_Dmy, Terceiro_G_

Incompleto_Dmy, Segundo_G_Completo_Dmy 
Tabela 125- Coeficientes de regressão para nível escolaridade separado por sexo EU

\begin{tabular}{|c|c|c|c|c|c|c|c|}
\hline \multicolumn{8}{|c|}{ Coefficients $^{a}$} \\
\hline \multirow[b]{2}{*}{ Sexo } & \multirow[b]{2}{*}{ Model } & & \multicolumn{2}{|c|}{$\begin{array}{l}\text { Unstandardized } \\
\text { Coefficients }\end{array}$} & \multirow{2}{*}{$\begin{array}{c}\text { Standardized } \\
\text { Coefficients } \\
\text { Beta }\end{array}$} & \multirow[b]{2}{*}{$\mathrm{t}$} & \multirow[b]{2}{*}{ Sig. } \\
\hline & & & $\mathrm{B}$ & Std. Error & & & \\
\hline \multirow[t]{6}{*}{ Masculino } & 1 & (Constant) & 5,500 & ,373 & & 14,742 &, 000 \\
\hline & & Primeiro_G_Completo_Dmy & ,167 &, 596 & ,025 & ,279 & ,780 \\
\hline & & Segundo_G_Incompleto_Dmy & ,177 & ,449 & ,046 & ,395 & ,693 \\
\hline & & Segundo_G_Completo_Dmy &, 122 & ,399 & 044 & 307 & ,759 \\
\hline & & Terceiro_G_Incompleto_Dmy &,- 014 & ,441 &,- 004 &,- 032 & ,974 \\
\hline & & Terceiro_G_Completo_Dmy & ,109 & ,473 & ,025 & ,230 & 819 \\
\hline \multirow[t]{6}{*}{ Feminino } & 1 & (Constant) & 5,217 & ,279 & & 18,699 & ,000 \\
\hline & & Primeiro_G_Completo_Dmy & ,116 &, 526 & ,016 & ,220 & ,826 \\
\hline & & Segundo_G_Incompleto_Dmy & ,438 & ,374 & ,101 & 1,172 & ,242 \\
\hline & & Segundo_G_Completo_Dmy &, 590 & 303 & ,220 & 1,950 & 052 \\
\hline & & Terceiro_G_Incompleto_Dmy & ,629 & ,352 & , 165 & 1,787 & ,075 \\
\hline & & Terceiro_G_Completo_Dmy & ,709 & ,349 & 190 & 2,035 &, 043 \\
\hline
\end{tabular}

a. Dependent Variable: EU

Tabela 126- Coeficientes de determinação para nível escolaridade separado por sexo EGF

\begin{tabular}{|c|c|c|c|c|c|}
\hline \multicolumn{6}{|c|}{ Model Summary } \\
\hline Sexo & Model & $\mathrm{R}$ & R Square & $\begin{array}{l}\text { Adjusted } \\
\text { R Square }\end{array}$ & $\begin{array}{l}\text { Std. Error of } \\
\text { the Estimate }\end{array}$ \\
\hline Masculino & 1 &, $158^{\mathrm{a}}$ & , 025 & ,001 & 1,38445 \\
\hline Feminino & 1 & $137^{a}$ & 019 & 000 & 1,33699 \\
\hline
\end{tabular}

Tabela 127- Coeficientes de regressão para nível escolaridade separado por sexo EGF

\begin{tabular}{|c|c|c|c|c|c|c|c|}
\hline \multicolumn{8}{|c|}{ Coefficients $^{a}$} \\
\hline \multirow[b]{2}{*}{ Sexo } & \multirow[b]{2}{*}{ Model } & & \multicolumn{2}{|c|}{$\begin{array}{c}\text { Unstandardized } \\
\text { Coefficients }\end{array}$} & \multirow{2}{*}{$\begin{array}{c}\begin{array}{c}\text { Standardized } \\
\text { Coefficients }\end{array} \\
\text { Beta }\end{array}$} & \multirow[b]{2}{*}{$t$} & \multirow[b]{2}{*}{ Sig. } \\
\hline & & & $\mathrm{B}$ & Std. Error & & & \\
\hline \multirow[t]{6}{*}{ Masculino } & 1 & (Constant) & 5,296 & ,370 & & 14,314 &, 000 \\
\hline & & Primeiro_G_Completo_Dmy & ,862 &, 592 & 127 & 1,457 & 147 \\
\hline & & Segundo_G_Incompleto_Dmy & ,086 & ,448 & ,022 & ,191 & ,848 \\
\hline & & Segundo_G_Completo_Dmy &, 532 & ,396 & ,192 & 1,345 & 180 \\
\hline & & Terceiro_G_Incompleto_Dmy & ,357 & ,438 & ,097 & ,816 & ,415 \\
\hline & & Terceiro_G_Completo_Dmy & 178 & ,469 &, 040 & ,380 & ,705 \\
\hline \multirow[t]{6}{*}{ Feminino } & 1 & (Constant) & 5,329 & ,279 & & 19,114 & ,000 \\
\hline & & Primeiro_G_Completo_Dmy &,- 119 &, 526 &,- 016 &,- 227 & ,821 \\
\hline & & Segundo_G_Incompleto_Dmy & , 176 & ,371 &, 041 & ,474 & ,636 \\
\hline & & Segundo_G_Completo_Dmy & ,409 & ,302 & ,153 & 1,354 & ,177 \\
\hline & & Terceiro_G_Incompleto_Dmy & ,475 & ,352 & ,125 & 1,352 & , 178 \\
\hline & & Terceiro_G_Completo_Dmy &, 595 & ,348 & 159 & 1,708 & ,089 \\
\hline
\end{tabular}

a. Dependent Variable: Equip_EGF_em_EU

Tabela 128- Coeficientes de determinação para nível escolaridade separado por sexo OHQ

Model Summary

\begin{tabular}{|ll|r|r|r|r|}
\hline Sexo & Model & \multicolumn{1}{|c|}{$\mathrm{R}$} & R Square & $\begin{array}{c}\text { Adjusted } \\
\text { R Square }\end{array}$ & $\begin{array}{c}\text { Std. Error of } \\
\text { the Estimate }\end{array}$ \\
\hline Masculino & 1 &, $126^{\mathrm{a}}$ &, 016 &,- 008 & 1,33307 \\
\hline Feminino 1 &, $255^{\mathrm{a}}$ &, 065 &, 047 & 1,27927 \\
\hline
\end{tabular}

a. Predictors: (Constant), Terceiro_G_Completo_Dmy, Primeiro_G_

Completo_Dmy, Segundo_G_Incompleto_Dmy, Terceiro_G_

Incompleto_Dmy, Segundo_G_Completo_Dmy 
Tabela 129- Coeficientes de regressão para nível escolaridade separado por sexo OHQ

\begin{tabular}{|c|c|c|c|c|c|c|c|}
\hline \multicolumn{8}{|c|}{ Coefficients $^{a}$} \\
\hline \multirow[b]{2}{*}{ Sexo } & \multirow[b]{2}{*}{ Model } & & \multicolumn{2}{|c|}{$\begin{array}{l}\text { Unstandardized } \\
\text { Coefficients }\end{array}$} & \multirow{2}{*}{$\begin{array}{c}\begin{array}{c}\text { Standardized } \\
\text { Coefficients }\end{array} \\
\text { Beta }\end{array}$} & \multirow[b]{2}{*}{$t$} & \multirow[b]{2}{*}{ Sig. } \\
\hline & & & $\mathrm{B}$ & Std. Error & & & \\
\hline \multirow[t]{6}{*}{ Masculino } & 1 & (Constant) & 4,876 &, 356 & & 13,685 &, 000 \\
\hline & & Primeiro_G_Completo_Dmy & ,779 &, 570 & 119, & 1,368 & 173 \\
\hline & & Segundo_G_Incompleto_Dmy &, 553 & ,429 & ,148 & 1,289 &, 199 \\
\hline & & Segundo_G_Completo_Dmy &, 577 & ,381 & ,217 & 1,514 &, 132 \\
\hline & & Terceiro_G_Incompleto_Dmy & ,706 & ,422 & ,199 & 1,674 & ,096 \\
\hline & & Terceiro_G_Completo_Dmy & ,671 & ,452 & , 158 & 1,485 &, 139 \\
\hline \multirow[t]{6}{*}{ Feminino } & 1 & (Constant) & 4,692 & ,267 & & 17,591 & 000 \\
\hline & & Primeiro_G_Completo_Dmy &,- 293 &, 503 &,- 040 &,- 583 &, 560 \\
\hline & & Segundo_G_Incompleto_Dmy & ,348 & ,355 &, 083 & ,980 & ,328 \\
\hline & & Segundo_G_Completo_Dmy & ,761 & ,289 & ,291 & 2,632 & ,009 \\
\hline & & Terceiro_G_Incompleto_Dmy & 1,029 & ,336 & ,275 & 3,058 & ,002 \\
\hline & & Terceiro_G_Completo_Dmy & ,916 & ,333 & ,250 & 2,749 & ,006 \\
\hline
\end{tabular}

a. Dependent Variable: Equip_OHQ_em_EU

Tabela 130- Coeficientes de determinação para nível escolaridade separado por etnia- EU

Model Summary

\begin{tabular}{|ll|r|r|r|r|}
\hline etnia & Model & \multicolumn{1}{|c|}{$\mathrm{R}$} & R Square & $\begin{array}{c}\text { Adjusted } \\
\text { R Square }\end{array}$ & $\begin{array}{r}\text { Std. Error of } \\
\text { the Estimate }\end{array}$ \\
\hline$\cdot$ & 1 &, $500^{\mathrm{a}}$ &, 250 &,- 500 &, 70711 \\
\hline Negro & 1 &, $651^{\mathrm{b}}$ &, 424 &, 184 & 1,62447 \\
\hline Pardo & 1 &, $193^{\mathrm{c}}$ &, 037 &,- 029 & 1,33355 \\
\hline Branco & 1 &, $094^{\mathrm{d}}$ &, 009 &,- 004 & 1,34258 \\
\hline Índio & 1 &, $500^{\mathrm{a}}$ &, 250 &,- 500 & 2,12132 \\
\hline
\end{tabular}

a. Predictors: (Constant), Terceiro_G_Incompleto_Dmy

b. Predictors: (Constant), Terceiro_G_Completo_Dmy, Terceiro_G_ Incompleto_Dmy, Primeiro_G_Completo_Dmy, Segundo_G_ Incompleto_Dmy, Segundo_G_Completo_Dmy

c. Predictors: (Constant), Terceiro_G_Completo_Dmy, Primeiro_G_ Completo_Dmy, Terceiro_G_Incompleto_Dmy, Segundo_G_ Incompleto_Dmy, Segundo_G_Completo_Dmy

d. Predictors: (Constant), Terceiro_G_Completo_Dmy, Primeiro_G_ Completo_Dmy, Segundo_G_Incompleto_Dmy, Terceiro_G_ Incompleto_Dmy, Segundo_G_Completo_Dmy 
Tabela 131- Coeficientes de regressão para nível escolaridade separado por etnia- EU

Coefficients $^{\mathrm{a}}$

\begin{tabular}{|c|c|c|c|c|c|c|c|}
\hline \multirow[b]{2}{*}{ etnia } & & & \multicolumn{2}{|c|}{$\begin{array}{l}\text { Unstandardized } \\
\text { Coefficients }\end{array}$} & \multirow{2}{*}{$\begin{array}{c}\begin{array}{c}\text { Standardized } \\
\text { Coefficients }\end{array} \\
\text { Beta }\end{array}$} & \multirow[b]{2}{*}{$t$} & \multirow[b]{2}{*}{ Sig. } \\
\hline & & Model & $\mathrm{B}$ & $\begin{array}{l}\text { Std. } \\
\text { Error }\end{array}$ & & & \\
\hline \multirow[t]{2}{*}{$\cdot$} & 1 & (Constant) & 6,500 &, 500 & & 13,000 &, 049 \\
\hline & & Terceiro_G_Incompleto_Dmy &, 500 & ,866 &, 500 &, 577 & ,667 \\
\hline \multirow[t]{6}{*}{ Negro } & 1 & (Constant) & 5,000 & 1,624 & & 3,078 & ,010 \\
\hline & & Terceiro_G_Incompleto_Dmy & 2,000 & 2,297 & ,262 & ,871 & ,401 \\
\hline & & Primeiro_G_Completo_Dmy & $-4,000$ & 2,297 &,- 524 & $-1,741$ & , 107 \\
\hline & & Segundo_G_Incompleto_Dmy & 1,000 & 1,990 &, 180 &, 503 & ,624 \\
\hline & & Segundo_G_Completo_Dmy &, 167 & 1,691 & ,045 & ,099 & ,923 \\
\hline & & Terceiro_G_Completo_Dmy & $-1,000$ & 2,297 &,- 131 &,- 435 & ,671 \\
\hline \multirow[t]{6}{*}{ Pardo } & 1 & (Constant) & 5,200 & ,422 & & 12,331 &, 000 \\
\hline & & Terceiro_G_Incompleto_Dmy &, 550 & ,633 & ,127 & ,869 & ,387 \\
\hline & & Primeiro_G_Completo_Dmy &,- 200 & ,878 &,- 029 &,- 228 & ,820 \\
\hline & & Segundo_G_Incompleto_Dmy &, 537 &, 521 &, 176 & 1,030 & ,306 \\
\hline & & Segundo_G_Completo_Dmy & ,388 & ,480 & ,147 & ,809 & ,421 \\
\hline & & Terceiro_G_Completo_Dmy & 1,000 & ,730 & , 186 & 1,369 &, 175 \\
\hline \multirow[t]{6}{*}{ Branco } & 1 & (Constant) & 5,385 & ,263 & & 20,450 & ,000 \\
\hline & & Terceiro_G_Incompleto_Dmy & ,219 & ,313 & 061 & ,698 & ,485 \\
\hline & & Primeiro_G_Completo_Dmy &, 544 & ,445 & 077 & 1,222 & ,222 \\
\hline & & Segundo_G_Incompleto_Dmy & ,240 & ,338 & ,055 &, 711 & ,478 \\
\hline & & Segundo_G_Completo_Dmy & ,402 & ,282 & , 150 & 1,426 & ,155 \\
\hline & & Terceiro_G_Completo_Dmy & ,426 & ,317 &, 115 & 1,344 & , 180 \\
\hline \multirow[t]{2}{*}{ İndio } & 1 & (Constant) & 5,500 & 1,500 & & 3,667 & ,170 \\
\hline & & Terceiro_G_Incompleto_Dmy & 1,500 & 2,598 & ,500 &, 577 & ,667 \\
\hline
\end{tabular}

a. Dependent Variable: EU

Tabela 132- Coeficientes de determinação para nível escolaridade separado por etnia-EGF

Model Summary

\begin{tabular}{|ll|r|r|r|r|}
\hline etnia & Model & \multicolumn{1}{|c|}{$\mathrm{R}$} & \multicolumn{1}{c|}{ R Square } & $\begin{array}{c}\text { Adjusted } \\
\text { R Square }\end{array}$ & $\begin{array}{c}\text { Std. Error of } \\
\text { the Estimate }\end{array}$ \\
\hline$\cdot$ & 1 &, $381^{\mathrm{a}}$ &, 145 &,- 709 & 1,51017 \\
\hline Negro & 1 &, $501^{\mathrm{b}}$ &, 251 &,- 061 & 1,32820 \\
\hline Pardo & 1 &, $198^{\mathrm{c}}$ &, 039 &,- 027 & 1,36831 \\
\hline Branco & 1 &, $100^{\mathrm{d}}$ &, 010 &,- 003 & 1,36692 \\
\hline Índio & 1 &, $756^{\mathrm{a}}$ &, 571 &, 143 &, 86295 \\
\hline
\end{tabular}

a. Predictors: (Constant), Terceiro_G_Incompleto_Dmy

b. Predictors: (Constant), Terceiro_G_Completo_Dmy, Terceiro_G_ Incompleto_Dmy, Primeiro_G_Completo_Dmy, Segundo_G_ Incompleto_Dmy, Segundo_G_Completo_Dmy

c. Predictors: (Constant), Terceiro_G_Completo_Dmy, Primeiro_G_ Completo_Dmy, Terceiro_G_Incompleto_Dmy, Segundo_G_ Incompleto_Dmy, Segundo_G_Completo_Dmy

d. Predictors: (Constant), Terceiro_G_Completo_Dmy, Primeiro_G_ Completo_Dmy, Segundo_G_Incompleto_Dmy, Terceiro_G_ Incompleto_Dmy, Segundo_G_Completo_Dmy 
Tabela 133-- Coeficientes de regressão para nível escolaridade separado por etnia- EGF

\begin{tabular}{|c|c|c|c|c|c|c|c|}
\hline \multicolumn{8}{|c|}{ Coefficients $^{a}$} \\
\hline \multirow[b]{2}{*}{ etnia } & \multirow[b]{2}{*}{ Model } & & \multicolumn{2}{|c|}{$\begin{array}{c}\text { Unstandardized } \\
\text { Coefficients }\end{array}$} & \multirow{2}{*}{$\begin{array}{c}\text { Standardized } \\
\text { Coefficients }\end{array}$} & \multirow[b]{2}{*}{$t$} & \multirow[b]{2}{*}{ Sig. } \\
\hline & & & $\mathrm{B}$ & Std. Error & & & \\
\hline \multirow[t]{2}{*}{. } & 1 & (Constant) & 6,582 & 1,068 & & 6,164 &, 102 \\
\hline & & Terceiro_G_Incompleto_Dmy &,- 763 & 1,850 &,- 381 &,- 412 & ,751 \\
\hline \multirow[t]{6}{*}{ Negro } & 1 & (Constant) & 6,735 & 1,328 & & 5,071 & ,000 \\
\hline & & Terceiro_G_Incompleto_Dmy & $-2,746$ & 1,878 &,- 502 & $-1,462$ & ,169 \\
\hline & & Primeiro_G_Completo_Dmy & $-2,746$ & 1,878 &,- 502 & $-1,462$ & ,169 \\
\hline & & Segundo_G_Incompleto_Dmy & $-1,373$ & 1,627 &,- 344 &,- 844 & ,415 \\
\hline & & Segundo_G_Completo_Dmy &,- 941 & 1,382 &,- 354 &,- 680 &, 509 \\
\hline & & Terceiro_G_Completo_Dmy &,- 915 & 1,878 &,- 167 &,- 487 & ,635 \\
\hline \multirow[t]{6}{*}{ Pardo } & 1 & (Constant) & 5,240 & ,433 & & 12,109 & ,000 \\
\hline & & Terceiro_G_Incompleto_Dmy & ,427 & ,649 & ,096 & ,658 &, 513 \\
\hline & & Primeiro_G_Completo_Dmy &, 173 & ,901 & ,025 & ,192 & ,848 \\
\hline & & Segundo_G_Incompleto_Dmy & ,002 &, 535 & 001 &, 003 & ,998 \\
\hline & & Segundo_G_Completo_Dmy &, 508 & ,492 & ,187 & 1,032 & ,306 \\
\hline & & Terceiro_G_Completo_Dmy & ,824 & ,749 &, 149 & 1,099 & ,275 \\
\hline \multirow[t]{6}{*}{ Branco } & 1 & (Constant) & 5,291 & 268 & & 19,738 & ,000 \\
\hline & & Terceiro_G_Incompleto_Dmy & ,446 & ,319 & ,122 & 1,399 & ,163 \\
\hline & & Primeiro_G_Completo_Dmy &, 572 & ,453 & 079 & 1,262 & 208 \\
\hline & & Segundo_G_Incompleto_Dmy & ,223 & ,344 & ,050 & ,647 &, 518 \\
\hline & & Segundo_G_Completo_Dmy & ,473 & ,287 & ,173 & 1,649 & ,100 \\
\hline & & Terceiro_G_Completo_Dmy & ,444 & ,323 &, 117 & 1,376 &, 170 \\
\hline \multirow[t]{2}{*}{ Índio } & 1 & (Constant) & 6,430 & 610 & & 10,537 & ,060 \\
\hline & & Terceiro_G_Incompleto_Dmy & 1,220 & 1,057 & ,756 & 1,155 & ,454 \\
\hline
\end{tabular}

a. Dependent Variable: Equip_EGF_em_EU

Tabela 134- - Coeficientes de determinação para nível escolaridade separado por etnia-OHQ

Model Summary

\begin{tabular}{|ll|r|r|r|r|}
\hline etnia & Model & \multicolumn{1}{|c|}{$\mathrm{R}$} & \multicolumn{1}{c|}{ R Square } & $\begin{array}{c}\text { Adjusted } \\
\text { R Square }\end{array}$ & $\begin{array}{c}\text { Std. Error of } \\
\text { the Estimate }\end{array}$ \\
\hline$\cdot$ & 1 &, $599^{\mathrm{a}}$ &, 359 &,- 282 & 1,37462 \\
\hline Negro & 1 &, $473^{\mathrm{b}}$ &, 224 &,- 100 & 1,34594 \\
\hline Pardo & 1 &, $281^{\mathrm{c}}$ &, 079 &, 016 & 1,31633 \\
\hline Branco & 1 &, $170^{\mathrm{d}}$ &, 029 &, 016 & 1,30667 \\
\hline Índio & 1 &, $965^{\mathrm{a}}$ &, 930 &, 861 &, 15274 \\
\hline
\end{tabular}

a. Predictors: (Constant), Terceiro_G_Incompleto_Dmy

b. Predictors: (Constant), Terceiro_G_Completo_Dmy, Terceiro_G_ Incompleto_Dmy, Primeiro_G_Completo_Dmy, Segundo_G_ Incompleto_Dmy, Segundo_G_Completo_Dmy

c. Predictors: (Constant), Terceiro_G_Completo_Dmy, Primeiro_G_ Completo_Dmy, Terceiro_G_Incompleto_Dmy, Segundo_G_ Incompleto_Dmy, Segundo_G_Completo_Dmy

d. Predictors: (Constant), Terceiro_G_Completo_Dmy, Primeiro_G_ Completo_Dmy, Segundo_G_Incompleto_Dmy, Terceiro_G_ Incompleto_Dmy, Segundo_G_Completo_Dmy 
Tabela 135- Coeficientes de regressão para nível escolaridade separado por etnia OHQ

Coefficients $^{\mathrm{a}}$

\begin{tabular}{|c|c|c|c|c|c|c|c|}
\hline \multirow[b]{2}{*}{ etnia } & \multirow[b]{2}{*}{ Model } & & \multicolumn{2}{|c|}{$\begin{array}{c}\text { Unstandardized } \\
\text { Coefficients }\end{array}$} & \multirow{2}{*}{$\begin{array}{c}\begin{array}{c}\text { Standardized } \\
\text { Coefficients }\end{array} \\
\text { Beta } \\
\end{array}$} & \multirow[b]{2}{*}{$t$} & \multirow[b]{2}{*}{ Sig. } \\
\hline & & & $\mathrm{B}$ & Std. Error & & & \\
\hline \multirow[t]{2}{*}{ 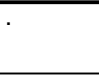 } & 1 & (Constant) & 5,179 & ,972 & & 5,328 & ,118 \\
\hline & & Terceiro_G_Incompleto_Dmy & 1,260 & 1,684 & ,599 & ,748 &, 591 \\
\hline \multirow[t]{6}{*}{ Negro } & 1 & (Constant) & 6,223 & 1,346 & & 4,624 & 001 \\
\hline & & Terceiro_G_Incompleto_Dmy & $-1,224$ & 1,903 &,- 225 &,- 643 &, 532 \\
\hline & & Primeiro_G_Completo_Dmy & $-3,168$ & 1,903 &,- 582 & $-1,664$ & ,122 \\
\hline & & Segundo_G_Incompleto_Dmy &,- 756 & 1,648 &,- 190 &,- 459 & ,655 \\
\hline & & Segundo_G_Completo_Dmy &,- 870 & 1,401 &,- 329 &,- 621 &, 546 \\
\hline & & Terceiro_G_Completo_Dmy & $-1,440$ & 1,903 &,- 264 &,- 757 & ,464 \\
\hline \multirow[t]{6}{*}{ Pardo } & 1 & (Constant) & 4,675 & ,416 & & 11,231 & ,000 \\
\hline & & Terceiro_G_Incompleto_Dmy & ,405 & ,624 & ,093 & ,649 &, 519 \\
\hline & & Primeiro_G_Completo_Dmy &,- 684 & ,867 &,- 099 &,- 789 & ,432 \\
\hline & & Segundo_G_Incompleto_Dmy & ,290 &, 514 & ,094 &, 564 &, 575 \\
\hline & & Segundo_G_Completo_Dmy & ,720 & ,474 & ,270 & 1,520 & ,133 \\
\hline & & Terceiro_G_Completo_Dmy & 1,087 & ,721 & 201 & 1,508 & ,136 \\
\hline \multirow[t]{6}{*}{ Branco } & 1 & (Constant) & 4,739 & ,256 & & 18,492 &, 000 \\
\hline & & Terceiro_G_Incompleto_Dmy & ,975 & ,305 & ,275 & 3,200 &, 001 \\
\hline & & Primeiro_G_Completo_Dmy &, 651 & ,433 & ,093 & 1,503 & ,134 \\
\hline & & Segundo_G_Incompleto_Dmy &, 615 & ,328 &, 145 & 1,877 & ,061 \\
\hline & & Segundo_G_Completo_Dmy & ,732 & ,274 & ,278 & 2,668 & ,008 \\
\hline & & Terceiro_G_Completo_Dmy & ,846 & ,308 & ,231 & 2,744 & ,006 \\
\hline \multirow[t]{2}{*}{ Índio } & 1 & (Constant) & 5,755 & ,108 & & 53,287 & ,012 \\
\hline & & Terceiro_G_Incompleto_Dmy & ,684 & ,187 & ,965 & 3,657 &, 170 \\
\hline
\end{tabular}

a. Dependent Variable: Equip_OHQ_em_EU

Tabela 136- Análise de médias para número de filhos

ANOVA

\begin{tabular}{|c|c|c|c|c|c|c|}
\hline & & $\begin{array}{l}\text { Sum of } \\
\text { Squares }\end{array}$ & $\mathrm{df}$ & Mean Square & $\mathrm{F}$ & Sig. \\
\hline \multirow[t]{3}{*}{ EU } & Between Groups & 4,264 & 4 & 1,066 & \multirow[t]{3}{*}{, 577} & \multirow[t]{3}{*}{, 680} \\
\hline & Within Groups & 880,069 & 476 & 1,849 & & \\
\hline & Total & 884,333 & 480 & & & \\
\hline \multirow[t]{3}{*}{ Equip_EGF_em_EU } & Between Groups & 1,170 & 4 & ,293 & \multirow[t]{3}{*}{,157 } & \multirow[t]{3}{*}{,960 } \\
\hline & Within Groups & 884,327 & 476 & 1,858 & & \\
\hline & Total & 885,497 & 480 & & & \\
\hline \multirow[t]{3}{*}{ Equip_OHQ_em_EU } & Between Groups & ,164 & 4 & ,041 & \multirow[t]{3}{*}{,023 } & \multirow[t]{3}{*}{,999 } \\
\hline & Within Groups & 833,858 & 478 & 1,744 & & \\
\hline & Total & 834,022 & 482 & & & \\
\hline
\end{tabular}


Tabela 137- Correlação entre as escalas nas categorias filhos

Paired Samples Correlations ${ }^{\mathrm{a}}$

\begin{tabular}{|lll|r|r|r|}
\hline filhos & & N & Correlation & Sig. \\
\hline Sem filhos & Pair 1 & EU \& Equip_EGF_em_EU & 282 &, 620 &, 000 \\
& Pair 2 & EU \& Equip_OHQ_em_EU & 282 &, 479 &, 000 \\
& Pair 3 & Equip_EGF_em_EU \& Equip_OHQ_em_EU & 284 &, 629 &, 000 \\
\hline 1 filho & Pair 1 & EU \& Equip_EGF_em_EU & 83 &, 573 &, 000 \\
& Pair 2 & EU \& Equip_OHQ_em_EU & 83 &, 653 &, 000 \\
& Pair 3 & Equip_EGF_em_EU \& Equip_OHQ_em_EU & 83 &, 609 &, 000 \\
\hline 2 filhos & Pair 1 & EU \& Equip_EGF_em_EU & 72 &, 695 &, 000 \\
& Pair 2 & EU \& Equip_OHQ_em_EU & 74 &, 671 &, 000 \\
& Pair 3 & Equip_EGF_em_EU \& Equip_OHQ_em_EU & 72 &, 639 &, 000 \\
\hline 3 filhos & Pair 1 & EU \& Equip_EGF_em_EU & 31 &, 824 &, 000 \\
& Pair 2 & EU \& Equip_OHQ_em_EU & 31 &, 658 &, 000 \\
& Pair 3 & Equip_EGF_em_EU \& Equip_OHQ_em_EU & 31 &, 744 &, 000 \\
\hline 4 ou mais filhos & Pair 1 & EU \& Equip_EGF_em_EU & 11 &, 707 &, 015 \\
& Pair 2 & EU \& Equip_OHQ_em_EU & 11 &, 788 &, 004 \\
& Pair 3 & Equip_EGF_em_EU \& Equip_OHQ_em_EU & 11 &, 636 \\
\hline
\end{tabular}

a. No statistics are computed for one or more split files

Tabela 138- Análise de média entre escalas nas categorias de quantidade de filhos

Paired Samples Tes

\begin{tabular}{|c|c|c|c|c|c|c|c|c|c|c|}
\hline \multirow[b]{3}{*}{ filhos } & & & \multicolumn{5}{|c|}{ Paired Differences } & \multirow[b]{3}{*}{$\mathrm{t}$} & \multirow[b]{3}{*}{$\mathrm{df}$} & \multirow{3}{*}{$\begin{array}{c}\text { Sig. } \\
\text { (2-tailed) }\end{array}$} \\
\hline & & & \multirow[b]{2}{*}{ Mean } & \multirow{2}{*}{$\begin{array}{c}\text { Std. } \\
\text { Deviation }\end{array}$} & \multirow{2}{*}{$\begin{array}{l}\text { Std. } \\
\text { Error } \\
\text { Mean }\end{array}$} & \multicolumn{2}{|c|}{$\begin{array}{l}95 \% \text { Confidence } \\
\text { Interval of the } \\
\text { Difference }\end{array}$} & & & \\
\hline & & & & & & Lower & Upper & & & \\
\hline \multirow[t]{3}{*}{ Sem filhos } & Pair 1 & EU - Equip_EGF_em_EU &, 03510 & 1,18527 &, 07058 &,- 10384 &, 17403 & ,497 & 281 &, 619 \\
\hline & Pair 2 & EU - Equip_OHQ_em_EU & ,30091 & 1,34181 & ,07990 & ,14363 & 45820 & 3,766 & 281 &, 000 \\
\hline & Pair 3 & Equip_EGF_em_EU - Equip_OHQ_em_EU & ,26234 & 1,14932 &, 06820 & ,12809 & ,39658 & 3,847 & 283 &, 000 \\
\hline \multirow[t]{3}{*}{1 filho } & Pair 1 & EU - Equip_EGF_em_EU &,- 05076 & 1,22512 & ,13447 &,- 31827 & ,21675 &,- 377 & 82 & ,707 \\
\hline & Pair 2 & EU - Equip_OHQ_em_EU & ,25478 & 1,09753 & 12047 &, 01513 & 49444 & 2,115 & 82 & 037 \\
\hline & Pair 3 & Equip_EGF_em_EU - Equip_OHQ_em_EU & ,30555 & 1,11981 & ,12291 & ,06103 &, 55006 & 2,486 & 82 &, 015 \\
\hline \multirow[t]{3}{*}{2 filhos } & Pair 1 & EU - Equip_EGF_em_EU &,- 01478 & 1,06590 & , 12562 &,- 26525 & ,23569 &,- 118 & 71 & ,907 \\
\hline & Pair 2 & EU - Equip_OHQ_em_EU & ,32414 & 1,05420 & ,12255 & ,07990 & ,56837 & 2,645 & 73 & 010 \\
\hline & Pair 3 & Equip_EGF_em_EU - Equip_OHQ_em_EU & ,32823 & 1,14151 & ,13453 & ,05998 &, 59647 & 2,440 & 71 & 017 \\
\hline \multirow[t]{3}{*}{3 filhos } & Pair 1 & EU - Equip_EGF_em_EU &,- 32677 & ,88558 & 15906 &,- 65161 &,- 00194 & $-2,054$ & 30 & 049 \\
\hline & Pair 2 & EU - Equip_OHQ_em_EU &,- 02971 & 1,35864 & ,24402 &,- 52806 & ,46864 &,- 122 & 30 & ,904 \\
\hline & Pair 3 & Equip_EGF_em_EU - Equip_OHQ_em_EU & ,29706 & 1,17949 & ,21184 &,- 13558 & ,72971 & 1,402 & 30 & 171 \\
\hline \multirow[t]{3}{*}{4 ou mais filhos } & Pair 1 & EU - Equip_EGF_em_EU & 02345 & 1,27176 & ,38345 &,- 83093 & 87784 & ,061 & 10 & ,952 \\
\hline & Pair 2 & EU - Equip_OHQ_em_EU & ,08900 & 1,08137 & ,32605 &,- 63748 & ,81548 & 273 & 10 & ,790 \\
\hline & Pair 3 & Equip_EGF_em_EU - Equip_OHQ_em_EU & ,06555 & 1,27291 &, 38380 &,- 78961 & 92070 & ,171 & 10 &, 868 \\
\hline
\end{tabular}

a. No statistics are computed for one or more split files 
Tabela 139- Coeficientes de determinação para idades separada por número de filhos EU

\begin{tabular}{|c|c|c|c|c|c|}
\hline \multicolumn{6}{|c|}{ Model Summary } \\
\hline \multirow[b]{2}{*}{ filhos } & \multirow[b]{2}{*}{ Model } & $\mathrm{R}$ & \multirow[b]{2}{*}{ R Square } & \multirow[b]{2}{*}{$\begin{array}{l}\text { Adjusted } \\
\text { R Square }\end{array}$} & \multirow[b]{2}{*}{$\begin{array}{l}\text { Std. Error of } \\
\text { the Estimate }\end{array}$} \\
\hline & & $\begin{array}{c}\text { est_cívil = } \\
\text { Casado } \\
\text { (Selected) }\end{array}$ & & & \\
\hline Sem filhos & 1 &, $304^{\mathrm{a}}$ &, 092 &, 017 & 1,14639 \\
\hline 1 filho & 1 &, $155^{\mathrm{b}}$ & ,024 &,- 057 & 1,06628 \\
\hline 2 filhos & 1 & ,292c & 085 &,- 001 & 1,27465 \\
\hline 3 filhos & 1 &, $275^{d}$ & 076 &,- 130 & 1,65440 \\
\hline 4 ou mais filhos & 1 &, $577^{\mathrm{e}}$ & ,333 &,- 333 & 1,49071 \\
\hline \multicolumn{6}{|c|}{$\begin{array}{l}\text { a. Predictors: (Constant), Dummy_Idade_6, Dummy_Idade_5, Dummy_ } \\
\text { Idade_1, Dummy_Idade_4, Dummy_Idade_3 }\end{array}$} \\
\hline \multicolumn{6}{|c|}{$\begin{array}{l}\text { b. Predictors: (Constant), Dummy_Idade_5, Dummy_Idade_1, Dummy_ } \\
\text { Idade_4, Dummy_Idade_3 }\end{array}$} \\
\hline \multicolumn{6}{|c|}{$\begin{array}{l}\text { c. Predictors: (Constant), Dummy_Idade_6, Dummy_Idade_1, Dummy_ } \\
\text { Idade_5, Dummy_Idade_3, Dummy_Idade_4 }\end{array}$} \\
\hline \multicolumn{6}{|c|}{$\begin{array}{l}\text { d. Predictors: (Constant), Dummy_Idade_6, Dummy_Idade_3, Dummy_ } \\
\text { Idade_5, Dummy_Idade_4 }\end{array}$} \\
\hline \multicolumn{6}{|c|}{$\begin{array}{l}\text { e. Predictors: (Constant), Dummy_Idade_5, Dummy_Idade_4, Dummy_ } \\
\text { Idade_3 }\end{array}$} \\
\hline \multicolumn{6}{|c|}{$\begin{array}{l}\text { f. There are no valid cases in one or more split files. Statistics cannot be } \\
\text { computed. }\end{array}$} \\
\hline
\end{tabular}

Tabela 140- Coeficientes de regressão para idades separado por número de filhos EU

Coefficients $\mathbf{s}^{\mathrm{a}, \mathrm{b}, \mathrm{c}}$

\begin{tabular}{|c|c|c|c|c|c|c|c|}
\hline \multirow[b]{2}{*}{ filhos } & \multirow[b]{2}{*}{ Model } & & \multicolumn{2}{|c|}{$\begin{array}{c}\text { Unstandardized } \\
\text { Coefficients }\end{array}$} & \multirow{2}{*}{$\begin{array}{c}\begin{array}{c}\text { Standardized } \\
\text { Coefficients }\end{array} \\
\text { Beta }\end{array}$} & \multirow[b]{2}{*}{$\mathrm{t}$} & \multirow[b]{2}{*}{ Sig. } \\
\hline & & & $\mathrm{B}$ & Std. Error & & & \\
\hline \multirow[t]{6}{*}{ Sem filhos } & 1 & (Constant) & 6,167 & ,209 & & 29,463 &, 000 \\
\hline & & Dummy_Idade_1 & ,233 & ,554 & ,054 & ,421 & ,675 \\
\hline & & Dummy_Idade_3 &,- 389 & ,342 &,- 151 & $-1,138$ & ,260 \\
\hline & & Dummy_Idade_4 &,- 542 & ,456 &,- 154 & $-1,187$ & 240 \\
\hline & & Dummy_Idade_5 &,- 167 & ,694 &,- 030 &,- 240 & ,811 \\
\hline & & Dummy_Idade_6 & $-1,667$ & ,837 &,- 249 & $-1,991$ & 051 \\
\hline \multirow[t]{5}{*}{1 filho } & 1 & (Constant) & 5,955 & ,227 & & 26,193 & ,000 \\
\hline & & Dummy_Idade_1 & 1,045 & 1,090 & ,138 & ,959 & ,342 \\
\hline & & Dummy_Idade_3 &,- 002 & ,325 &,- 001 &,- 007 & ,995 \\
\hline & & Dummy_Idade_4 &, 045 & ,491 &, 014 & ,093 & ,927 \\
\hline & & Dummy_Idade_5 &,- 288 & ,656 &,- 065 &,- 439 & ,663 \\
\hline \multirow[t]{6}{*}{2 filhos } & 1 & (Constant) & 6,000 & ,368 & & 16,306 & ,000 \\
\hline & & Dummy_Idade_1 & $6,35 \mathrm{E}-017$ & 1,327 & ,000 & ,000 & 1,000 \\
\hline & & Dummy_Idade_3 & ,111 & ,475 & 041 & ,234 & ,816 \\
\hline & & Dummy_Idade_4 &,- 667 & ,461 &,- 253 & $-1,445$ & , 154 \\
\hline & & Dummy_Idade_5 &,- 500 & ,736 &,- 100 &,- 679 &, 500 \\
\hline & & Dummy_Idade_6 & ,333 & ,823 & ,058 & ,405 & ,687 \\
\hline \multirow[t]{5}{*}{3 filhos } & 1 & (Constant) & 5,333 & ,955 & & 5,584 & ,000 \\
\hline & & Dummy_Idade_3 & ,667 & 1,351 & ,147 & ,494 & ,628 \\
\hline & & Dummy_Idade_4 &,- 233 & 1,089 &,- 076 &,- 214 & ,833 \\
\hline & & Dummy_ldade_5 &,- 733 & 1,208 &,- 199 &,- 607 &, 551 \\
\hline & & Dummy_Idade_6 &, 167 & 1,510 & ,031 & , 110 & ,913 \\
\hline \multirow[t]{4}{*}{4 ou mais filhos } & 1 & (Constant) & 7,000 & 1,491 & & 4,696 & ,018 \\
\hline & & Dummy_Idade_3 & $-1,667$ & 1,721 &,- 690 &,- 968 & ,404 \\
\hline & & Dummy_Idade_4 & $-3,7 E-016$ & 2,108 &, 000 & ,000 & 1,000 \\
\hline & & Dummy_Idade_5 & $-1,000$ & 1,826 &,- 378 &,- 548 & ,622 \\
\hline
\end{tabular}

a. There are no valid cases in one or more split files. Statistics cannot be computed.

b. Dependent Variable: EU

c. Selecting only cases for which est_cívil = Casado 
Tabela 141- Coeficientes de determinação para idades separado por número de filhos EGF

Model Summary

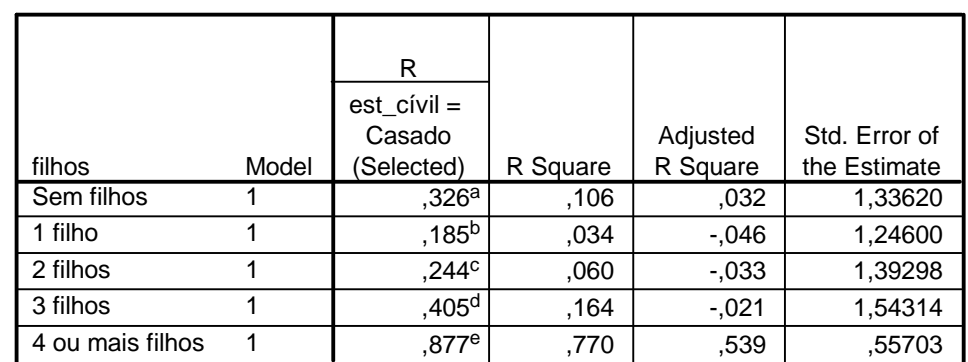

a. Predictors: (Constant), Dummy_Idade_6, Dummy_Idade_5, Dummy_ Idade_1, Dummy_Idade_4, Dummy_Idade_3

b. Predictors: (Constant), Dummy_Idade_5, Dummy_Idade_1, Dummy_ Idade_4, Dummy_Idade_3

c. Predictors: (Constant), Dummy_Idade_6, Dummy_Idade_1, Dummy_ Idade_5, Dummy_Idade_3, Dummy_Idade_4

d. Predictors: (Constant), Dummy_Idade_6, Dummy_Idade_3, Dummy_ Idade_5, Dummy_Idade_4

e. Predictors: (Constant), Dummy_Idade_5, Dummy_Idade_4, Dummy_ Idade_3

f. There are no valid cases in one or more split files. Statistics cannot be computed.

Tabela 142- Coeficientes de regressão para idades separado por número de filhos EGF

Coefficients $\mathbf{s}^{\mathrm{a}, \mathrm{b}, \mathrm{c}}$

\begin{tabular}{|c|c|c|c|c|c|c|c|}
\hline \multirow[b]{2}{*}{ filhos } & \multirow[b]{2}{*}{ Model } & & \multicolumn{2}{|c|}{$\begin{array}{l}\text { Unstandardized } \\
\text { Coefficients }\end{array}$} & \multirow{2}{*}{$\begin{array}{c}\text { Standardized } \\
\text { Coefficients } \\
\text { Beta }\end{array}$} & \multirow[b]{2}{*}{$\mathrm{t}$} & \multirow[b]{2}{*}{ Sig. } \\
\hline & & & B & Std. Error & & & \\
\hline \multirow[t]{6}{*}{ Sem filhos } & 1 & (Constant) & 5,992 & ,244 & & 24,563 &, 000 \\
\hline & & Dummy_Idade_1 & 1,109 & ,645 & ,218 & 1,717 & ,091 \\
\hline & & Dummy_Idade_3 &,- 105 & ,398 &,- 035 &,- 264 & ,793 \\
\hline & & Dummy_Idade_4 &,- 821 &, 532 &,- 199 & $-1,545$ & 128 \\
\hline & & Dummy_Idade_5 &,- 681 & ,809 &,- 105 &,- 842 & ,403 \\
\hline & & Dummy_Idade_6 &,- 173 & ,976 &,- 022 &,- 177 & ,860 \\
\hline \multirow[t]{5}{*}{1 filho } & 1 & (Constant) & 5,916 & ,266 & & 22,272 &, 000 \\
\hline & & Dummy_Idade_1 & 1,428 & 1,274 & ,161 & 1,121 & ,268 \\
\hline & & Dummy_Idade_3 &,- 010 &, 380 &,- 004 &,- 026 & ,979 \\
\hline & & Dummy_Idade_4 &,- 148 &, 574 &,- 039 &,- 258 & ,798 \\
\hline & & Dummy_Idade_5 & ,411 & ,767 & ,079 &, 537 &, 594 \\
\hline \multirow[t]{6}{*}{2 filhos } & 1 & (Constant) & 5,847 &, 420 & & 13,922 &, 000 \\
\hline & & Dummy_Idade_1 &, 582 & 1,455 & ,056 &, 400 & 691 \\
\hline & & Dummy_Idade_3 & ,439 &, 539 & ,148 & ,814 & ,419 \\
\hline & & Dummy_Idade_4 &,- 347 &, 518 &,- 123 &,- 670 &, 506 \\
\hline & & Dummy_Idade_5 &,- 180 & ,813 &,- 034 &,- 222 & 825 \\
\hline & & Dummy_Idade_6 &,- 028 & ,907 &,- 005 &,- 031 & ,976 \\
\hline \multirow[t]{5}{*}{3 filhos } & 1 & (Constant) & 5,006 & ,891 & & 5,619 &, 000 \\
\hline & & Dummy_Idade_3 & 2,034 & 1,260 & 459 & 1,614 & 124 \\
\hline & & Dummy_Idade_4 & ,417 & 1,016 & ,138 & ,410 & 686 \\
\hline & & Dummy_Idade_5 & ,325 & 1,127 & 090 & 289 & ,776 \\
\hline & & Dummy_Idade_6 & 051 & 1,409 &, 010 & ,036 & ,972 \\
\hline \multirow[t]{4}{*}{4 ou mais filhos } & 1 & (Constant) & 6,125 &, 557 & & 10,995 & ,002 \\
\hline & & Dummy_Idade_3 &,- 915 &, 643 &,- 596 & $-1,423$ & ,250 \\
\hline & & Dummy_Idade_4 & ,915 & ,788 & ,421 & 1,162 & 329 \\
\hline & & Dummy_Idade_5 &,- 915 & ,682 &,- 544 & $-1,342$ & ,272 \\
\hline
\end{tabular}

a. There are no valid cases in one or more split files. Statistics cannot be computed.

b. Dependent Variable: Equip_EGF_em_EU

c. Selecting only cases for which est_cívil = Casado 
Tabela 143- Coeficientes de determinação para idades separado por número de filhos OHQ

Model Summary

\begin{tabular}{|c|c|c|c|c|c|}
\hline & & $\mathrm{R}$ & & & \\
\hline filhos & Model & $\begin{array}{c}\text { est_cívil = } \\
\text { Casado } \\
\text { (Selected) }\end{array}$ & R Square & $\begin{array}{l}\text { Adjusted } \\
\text { R Square } \\
\end{array}$ & $\begin{array}{l}\text { Std. Error of } \\
\text { the Estimate }\end{array}$ \\
\hline Sem filhos & 1 &, $195^{\mathrm{a}}$ & ,038 &,- 042 & 1,19932 \\
\hline 1 filho & 1 &, $181^{b}$ & ,033 &,- 048 &, 92109 \\
\hline 2 filhos & 1 &, $158^{\mathrm{C}}$ & ,025 &,- 067 & 1,34619 \\
\hline 3 filhos & 1 &, $369^{d}$ & , 136 &,- 056 & 1,73210 \\
\hline 4 ou mais filhos & 1 &, $828^{e}$ & ,686 & ,372 & ,74670 \\
\hline
\end{tabular}

a. Predictors: (Constant), Dummy_Idade_6, Dummy_Idade_5, Dummy_ Idade_1, Dummy_Idade_4, Dummy_Idade_3

b. Predictors: (Constant), Dummy_Idade_5, Dummy_Idade_1, Dummy_ Idade_4, Dummy_Idade_3

c. Predictors: (Constant), Dummy_Idade_6, Dummy_Idade_1, Dummy_ Idade_5, Dummy_Idade_3, Dummy_Idade_4

d. Predictors: (Constant), Dummy_Idade_6, Dummy_Idade_3, Dummy_ Idade_5, Dummy_Idade_4

e. Predictors: (Constant), Dummy_Idade_5, Dummy_Idade_4, Dummy Idade_3

f. There are no valid cases in one or more split files. Statistics cannot be computed.

Tabela 144- Coeficientes de regressão para idades separado por número de filhos OHQ

Coefficients $\mathrm{s}^{\mathrm{a}, \mathrm{b}, \mathrm{c}}$

\begin{tabular}{|c|c|c|c|c|c|c|c|}
\hline \multirow[b]{2}{*}{ filhos } & \multirow[b]{2}{*}{ Model } & & \multicolumn{2}{|c|}{$\begin{array}{l}\text { Unstandardized } \\
\text { Coefficients }\end{array}$} & \multirow{2}{*}{$\begin{array}{c}\text { Standardized } \\
\text { Coefficients } \\
\text { Beta }\end{array}$} & \multirow[b]{2}{*}{$t$} & \multirow[b]{2}{*}{ Sig. } \\
\hline & & & B & Std. Error & & & \\
\hline \multirow[t]{6}{*}{ Sem filhos } & 1 & (Constant) & 5,597 & ,219 & & 25,559 &, 000 \\
\hline & & Dummy_Idade_1 & ,497 &, 579 & ,113 & ,858 & ,395 \\
\hline & & Dummy_Idade_3 & ,322 & ,358 & ,123 & ,902 & ,371 \\
\hline & & Dummy_Idade_4 & 059 & ,477 &, 017 & ,124 & 901 \\
\hline & & Dummy_Idade_5 & 146 & ,726 & 026 & ,202 & 841 \\
\hline & & Dummy_Idade_6 &,- 742 & ,876 &,- 109 &,- 847 & ,401 \\
\hline \multirow[t]{5}{*}{1 filho } & 1 & (Constant) & 5,601 & ,196 & & 28,523 &, 000 \\
\hline & & Dummy_Idade_1 &,- 026 & 942 &,- 004 &,- 028 & ,978 \\
\hline & & Dummy_Idade_3 & 001 & ,281 &, 001 &, 004 & ,996 \\
\hline & & Dummy_Idade_4 & 442 & ,424 & 157 & 1,041 & ,303 \\
\hline & & Dummy_Idade_5 & ,406 &, 567 & , 105 & ,716 & ,478 \\
\hline \multirow[t]{6}{*}{2 filhos } & 1 & (Constant) & 5,359 & ,389 & & 13,790 &, 000 \\
\hline & & Dummy_Idade_1 &,- 576 & 1,401 &,- 058 &,- 411 & 683 \\
\hline & & Dummy_Idade_3 & ,272 &, 502 & ,097 &, 542 &, 590 \\
\hline & & Dummy_Idade_4 &,- 141 & ,487 &,- 052 &,- 289 & ,774 \\
\hline & & Dummy_Idade_5 &, 036 & ,777 &, 007 &, 046 & ,963 \\
\hline & & Dummy_Idade_6 & ,408 & 869 &, 069 & ,470 & 641 \\
\hline \multirow[t]{5}{*}{3 filhos } & 1 & (Constant) & 3,631 & 1,000 & & 3,631 & ,002 \\
\hline & & Dummy_Idade_3 & 2,016 & 1,414 & ,412 & 1,425 & 171 \\
\hline & & Dummy_Idade_4 & 1,764 & 1,140 &, 530 & 1,547 & 139 \\
\hline & & Dummy_Idade_5 & 1,742 & 1,265 & ,436 & 1,377 & 185 \\
\hline & & Dummy_Idade_6 & 1,656 & 1,581 & ,283 & 1,047 & ,309 \\
\hline \multirow[t]{4}{*}{4 ou mais filhos } & 1 & (Constant) & 6,583 & ,747 & & 8,816 &, 003 \\
\hline & & Dummy_Idade_3 & $-1,272$ & 862 &,- 722 & $-1,475$ & ,237 \\
\hline & & Dummy_Idade_4 & ,792 & 1,056 & ,318 &, 750 &, 508 \\
\hline & & Dummy_Idade_5 &,- 648 & ,915 &,- 336 &,- 709 &, 530 \\
\hline
\end{tabular}

a. There are no valid cases in one or more split files. Statistics cannot be computed.

b. Dependent Variable: Equip_OHQ_em_EU

c. Selecting only cases for which est_cívil = Casado 
Tabela 145- Correlação entre números de filhos e escolaridade

\begin{tabular}{|ll|r|r|}
\multicolumn{4}{|c|}{ Correlations } \\
\hline \multicolumn{1}{|c|}{} & \multicolumn{1}{|c|}{ filhos } & \multicolumn{1}{c|}{ escolar } \\
\hline filhos & Pearson Correlation & 1 &,$- 147^{\star *}$ \\
& Sig. (2-tailed) & &, 001 \\
& $\mathrm{~N}$ & 483 & 482 \\
\hline escolar & Pearson Correlation &,$- 147^{* \star}$ & 1 \\
& Sig. (2-tailed) &, 001 & \\
& $\mathrm{~N}$ & 482 & 482 \\
\hline
\end{tabular}

${ }^{\star *}$. Correlation is significant at the 0.01 level

Tabela 146- Teste de médias para comerciantes e comerciários

ANOVA

\begin{tabular}{|ll|r|r|r|r|r|}
\hline & & \multicolumn{1}{|c|}{$\begin{array}{c}\text { Sum of } \\
\text { Squares }\end{array}$} & df & Mean Square & \multicolumn{1}{c|}{ F } & \multicolumn{1}{c|}{ Sig. } \\
\hline EU & Between Groups & 1,858 & 1 & 1,858 & 1,002 &, 317 \\
& Within Groups & 873,364 & 471 & 1,854 & & \\
& Total & 875,222 & 472 & & &, 634 \\
\hline Equip_EGF_em_EU & Between Groups &, 423 & 1 &, 423 &, 227 & \\
& Within Groups & 878,827 & 472 & 1,862 & & \\
& Total & 879,250 & 473 & & &, 188 \\
\hline Equip_OHQ_em_EU & Between Groups & 3,005 & 1 & 3,005 & 1,736 & \\
& Within Groups & 818,875 & 473 & 1,731 & & \\
& Total & 821,880 & 474 & & & \\
\end{tabular}

Tabela 147- Correlação entre escalas categorias comerciantes e comerciários

Paired Samples Correlations

\begin{tabular}{|lll|r|r|r|}
\hline profissão & & \multicolumn{1}{c|}{ N } & Correlation & Sig. \\
\hline & Pair 1 & EU \& Equip_EGF_em_EU & 8 &, 197 &, 640 \\
& Pair 2 & EU \& Equip_OHQ_em_EU & 9 &, 023 &, 954 \\
& Pair 3 & Equip_EGF_em_EU \& Equip_OHQ_em_EU & 8 &, 601 &, 115 \\
\hline Comerciante & Pair 1 & EU \& Equip_EGF_em_EU & 83 &, 722 &, 000 \\
& Pair 2 & EU \& Equip_OHQ_em_EU & 83 &, 458 &, 000 \\
& Pair 3 & Equip_EGF_em_EU \& Equip_OHQ_em_EU & 84 &, 576 &, 000 \\
\hline Comerciário & Pair 1 & EU \& Equip_EGF_em_EU & 389 &, 622 &, 000 \\
& Pair 2 & EU \& Equip_OHQ_em_EU & 390 &, 587 &, 000 \\
& Pair 3 & Equip_EGF_em_EU \& Equip_OHQ_em_EU & 390 &, 649 &, 000 \\
\hline
\end{tabular}

Tabela 148- Análise de média nas categorias comerciante e comerciário

\begin{tabular}{|c|c|c|c|c|c|c|c|c|c|c|}
\hline \multicolumn{11}{|c|}{ Paired Samples Test } \\
\hline \multirow[b]{3}{*}{ profissão } & & & \multicolumn{5}{|c|}{ Paired Differences } & \multirow[b]{3}{*}{$\mathrm{t}$} & \multirow[b]{3}{*}{ df } & \multirow{3}{*}{$\begin{array}{c}\text { Sig. } \\
\text { (2-tailed) }\end{array}$} \\
\hline & & & \multirow[b]{2}{*}{ Mean } & \multirow{2}{*}{$\begin{array}{c}\text { Std. } \\
\text { Deviation }\end{array}$} & \multirow{2}{*}{$\begin{array}{l}\text { Std. } \\
\text { Error } \\
\text { Mean }\end{array}$} & \multicolumn{2}{|c|}{$\begin{array}{l}95 \% \text { Confidence } \\
\text { Interval of the } \\
\text { Difference }\end{array}$} & & & \\
\hline & & & & & & Lower & Upper & & & \\
\hline \multirow{3}{*}{ protissao } & Pair 1 & EU - Equip_EGF_em_EU &, 69119 &, 95154 & ,33642 &,- 10432 & 1,48670 & 2,055 & 7 &, 079 \\
\hline & Pair 2 & EU - Equip_OHQ_em_EU & 1,02767 & 1,40686 & ,46895 &,- 05374 & 2,10907 & 2,191 & 8 &, 060 \\
\hline & Pair 3 & Equip_EGF_em_EU - Equip_OHQ_em_EU &, 54781 & ,95287 & ,33689 &,- 24881 & 1,34443 & 1,626 & 7 & 148 \\
\hline \multirow[t]{3}{*}{ Comerciante } & Pair 1 & EU - Equip_EGF_em_EU &,- 11284 & ,99287 & ,10898 &,- 32964 & , 10396 & $-1,035$ & 82 & ,304 \\
\hline & Pair 2 & EU - Equip_OHQ_em_EU &,- 05963 & 1,33157 & , 14616 &,- 35038 & ,23113 &,- 408 & 82 & ,684 \\
\hline & Pair 3 & Equip_EGF_em_EU - Equip_OHQ_em_EU & ,04357 & 1,23586 & ,13484 &,- 22463 & ,31177 & ,323 & 83 & ,747 \\
\hline \multirow[t]{3}{*}{ Comerciário } & Pair 1 & EU - Equip_EGF_em_EU &,- 00061 & 1,19217 &, 06045 &,- 11945 &, 11824 &,- 010 & 388 & ,992 \\
\hline & Pair 2 & EU - Equip_OHQ_em_EU & ,33052 & 1,22948 & ,06226 & ,20812 & ,45292 & 5,309 & 389 &, 000 \\
\hline & Pair 3 & Equip_EGF_em_EU - Equip_OHQ_em_EU & ,32655 & 1,12412 & 05692 & ,21464 & ,43847 & 5,737 & 389 &, 000 \\
\hline
\end{tabular}


Tabela 149- Análise de médias comerciantes e comerciários segmentado por sexo

\begin{tabular}{|c|c|c|c|c|c|c|c|}
\hline \multicolumn{8}{|c|}{ ANOVA } \\
\hline \multicolumn{3}{|l|}{ Sexo } & $\begin{array}{l}\text { Sum of } \\
\text { Squares }\end{array}$ & $\mathrm{df}$ & Mean Square & $\mathrm{F}$ & Sig. \\
\hline \multirow[t]{9}{*}{ Masculino } & \multirow[t]{3}{*}{ EU } & Between Groups & 1,249 & 1 & 1,249 & \multirow[t]{3}{*}{,652 } & \multirow[t]{3}{*}{, 420} \\
\hline & & Within Groups & 388,976 & 203 & 1,916 & & \\
\hline & & Total & 390,224 & 204 & & & \\
\hline & \multirow[t]{3}{*}{ Equip_EGF_em_EU } & Between Groups &, 444 & 1 & ,444 & \multirow[t]{3}{*}{,227 } & \multirow[t]{3}{*}{,634 } \\
\hline & & Within Groups & 393,950 & 202 & 1,950 & & \\
\hline & & Total & 394,394 & 203 & & & \\
\hline & \multirow[t]{3}{*}{ Equip_OHQ_em_EU } & Between Groups & 1,142 & 1 & 1,142 & \multirow[t]{3}{*}{,646 } & \multirow[t]{3}{*}{,423 } \\
\hline & & Within Groups & 358,866 & 203 & 1,768 & & \\
\hline & & Total & 360,008 & 204 & & & \\
\hline \multirow[t]{9}{*}{ Feminino } & \multirow[t]{3}{*}{ EU } & Between Groups & ,450 & 1 & ,450 & \multirow[t]{3}{*}{,248 } & \multirow[t]{3}{*}{,619 } \\
\hline & & Within Groups & 481,198 & 265 & 1,816 & & \\
\hline & & Total & 481,648 & 266 & & & \\
\hline & \multirow[t]{3}{*}{ Equip_EGF_em_EU } & Between Groups & ,074 & 1 & ,074 & \multirow[t]{3}{*}{, 041} & \multirow[t]{3}{*}{,839 } \\
\hline & & Within Groups & 482,650 & 267 & 1,808 & & \\
\hline & & Total & 482,725 & 268 & & & \\
\hline & \multirow[t]{3}{*}{ Equip_OHQ_em_EU } & Between Groups & 1,758 & 1 & 1,758 & \multirow[t]{3}{*}{1,021} & \multirow[t]{3}{*}{,313 } \\
\hline & & Within Groups & 459,607 & 267 & 1,721 & & \\
\hline & & Total & 461,365 & 268 & & & \\
\hline
\end{tabular}

Tabela 150- Comparação médias nas categorias

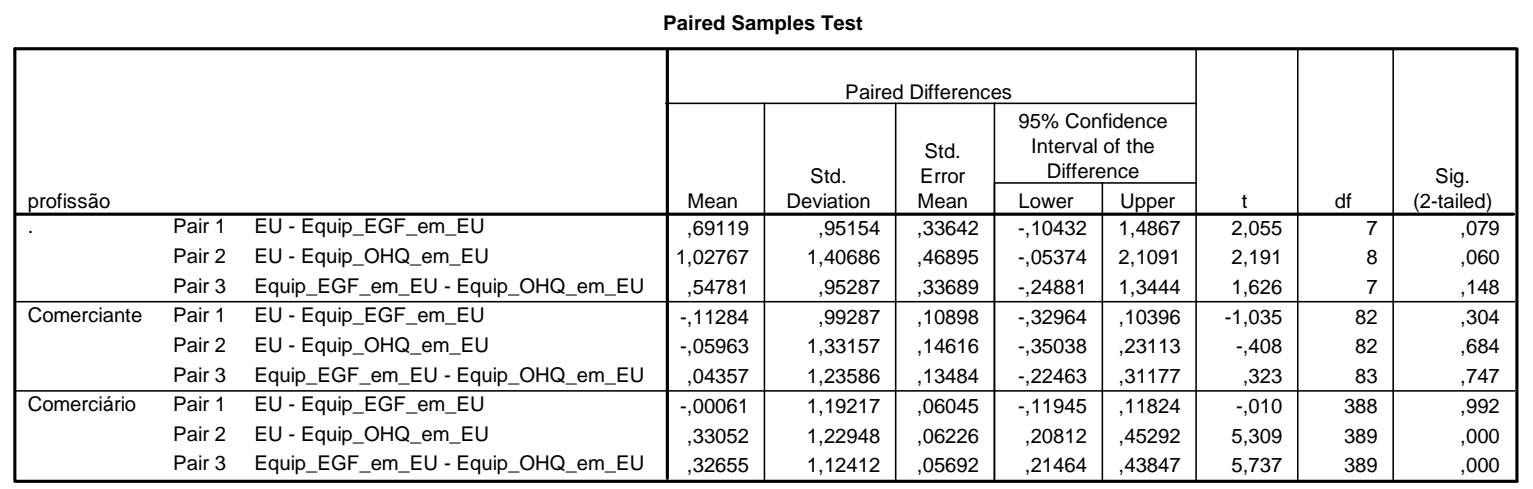

Tabela 151- Regressão profissão - EU

Coefficients $^{\mathrm{a}}$

\begin{tabular}{|c|c|c|c|c|c|c|}
\hline \multirow{2}{*}{\multicolumn{2}{|c|}{ Model }} & \multicolumn{2}{|c|}{$\begin{array}{l}\text { Unstandardized } \\
\text { Coefficients }\end{array}$} & \multirow{2}{*}{$\begin{array}{c}\text { Standardized } \\
\text { Coefficients }\end{array}$} & \multirow[b]{2}{*}{$\mathrm{t}$} & \multirow[b]{2}{*}{ Sig. } \\
\hline & & $\mathrm{B}$ & Std. Error & & & \\
\hline & (Constant) & 5,717 & ,068 & & 84,162 &, 000 \\
\hline & Comerciante_Dmy &,- 187 & ,164 &,- 052 & $-1,140$ & 255 \\
\hline
\end{tabular}

a. Dependent Variable: EU

Tabela 152- Regressão profissão - EGF

Coefficients $^{\mathrm{a}}$

\begin{tabular}{|c|c|c|c|c|c|c|}
\hline \multirow[b]{2}{*}{ Model } & & \multicolumn{2}{|c|}{$\begin{array}{l}\text { Unstandardized } \\
\text { Coefficients }\end{array}$} & \multirow{2}{*}{$\begin{array}{l}\text { Standardized } \\
\text { Coefficients } \\
\text { Beta }\end{array}$} & \multirow[b]{2}{*}{$\mathrm{t}$} & \multirow[b]{2}{*}{ Sig. } \\
\hline & & $\mathrm{B}$ & Std. Error & & & \\
\hline & (Constant) & 5,699 & ,068 & & 83,730 &, 000 \\
\hline & Comerciante_Dmy &,- 083 & , 163 &,- 023 &,- 509 & 611 \\
\hline
\end{tabular}

a. Dependent Variable: Equip_EGF_em_EU 
Tabela 153- Regressão profissão - OHQ

Coefficients $^{\mathrm{a}}$

\begin{tabular}{|c|c|c|c|c|c|c|}
\hline \multirow[b]{2}{*}{ Model } & & \multicolumn{2}{|c|}{$\begin{array}{l}\text { Unstandardized } \\
\text { Coefficients }\end{array}$} & \multirow{2}{*}{$\begin{array}{c}\text { Standardized } \\
\text { Coefficients } \\
\text { Beta }\end{array}$} & \multirow[b]{2}{*}{$\mathrm{t}$} & \multirow[b]{2}{*}{ Sig. } \\
\hline & & B & Std. Error & & & \\
\hline & (Constant) & 5,370 & ,066 & & 81,669 &, 000 \\
\hline & Comerciante_Dmy & ,202 & , 158 & ,058 & 1,281 & 201 \\
\hline
\end{tabular}

a. Dependent Variable: Equip_OHQ_em_EU

Tabela 154- Teste de homeogeneidade de variâncias para tipo de emprego

Test of Homogeneity of Variances

\begin{tabular}{|l|r|r|r|r|}
\hline & \multicolumn{1}{|c|}{$\begin{array}{c}\text { Levene } \\
\text { Statistic }\end{array}$} & df1 & \multicolumn{1}{c|}{ df2 } & \multicolumn{1}{c|}{ Sig. } \\
\hline EU & 4,088 & 1 & 477 &, 044 \\
Equip_EGF_em_EU &, 283 & 1 & 477 &, 595 \\
Equip_OHQ_em_EU &, 311 & 1 & 479 &, 577 \\
\hline
\end{tabular}

Tabela 155- Teste não paramétrico para a EU

Test Statistics ${ }^{\mathrm{a}, \mathrm{b}}$

\begin{tabular}{|l|r|}
\hline & \multicolumn{1}{|c|}{ EU } \\
\hline Chi-Square &, 044 \\
df & 1 \\
Asymp. Sig. &, 834 \\
\hline
\end{tabular}

a. Kruskal Wallis Test

b. Grouping Variable: emprego

Tabela 156- Análise de médias tipo de emprego

ANOVA

\begin{tabular}{|ll|r|r|r|r|r|}
\hline & & $\begin{array}{c}\text { Sum of } \\
\text { Squares }\end{array}$ & df & Mean Square & F & Sig. \\
\hline Equip_EGF_em_EU & Between Groups &, 491 & 1 &, 491 &, 265 &, 607 \\
& Within Groups & 883,873 & 477 & 1,853 & & \\
& Total & 884,363 & 478 & & & \\
\hline Equip_OHQ_em_EU & Between Groups & 3,510 & 1 & 3,510 & 2,028 &, 155 \\
& Within Groups & 829,215 & 479 & 1,731 & & \\
& Total & 832,726 & 480 & & & \\
\hline
\end{tabular}

Tabela 157- Regressão emprego EU

Coefficients $^{\mathrm{a}}$

\begin{tabular}{|c|c|c|c|c|c|c|}
\hline \multirow{2}{*}{\multicolumn{2}{|c|}{ Model }} & \multicolumn{2}{|c|}{$\begin{array}{c}\text { Unstandardized } \\
\text { Coefficients }\end{array}$} & \multirow{2}{*}{$\begin{array}{c}\begin{array}{c}\text { Standardized } \\
\text { Coefficients }\end{array} \\
\text { Beta }\end{array}$} & \multirow[b]{2}{*}{$t$} & \multirow[b]{2}{*}{ Sig. } \\
\hline & & $\mathrm{B}$ & Std. Error & & & \\
\hline & (Constant) & 5,581 & ,244 & & 22,874 &, 000 \\
\hline & Tempor_Dmy & ,111 & ,252 & ,020 & ,441 & ,660 \\
\hline
\end{tabular}

a. Dependent Variable: EU

Tabela 158- Regressão emprego - EGF

Coefficients $^{\mathrm{a}}$

\begin{tabular}{|c|c|c|c|c|c|c|}
\hline \multirow[b]{2}{*}{ Model } & & \multicolumn{2}{|c|}{$\begin{array}{c}\text { Unstandardized } \\
\text { Coefficients }\end{array}$} & \multirow{2}{*}{$\begin{array}{c}\begin{array}{c}\text { Standardized } \\
\text { Coefficients }\end{array} \\
\text { Beta }\end{array}$} & \multirow[b]{2}{*}{$\mathrm{t}$} & \multirow[b]{2}{*}{ Sig. } \\
\hline & & $\mathrm{B}$ & Std. Error & & & \\
\hline & (Constant) & 5,600 & ,240 & & 23,327 &, 000 \\
\hline & Tempor_Dmy &, 090 & 248 & ,017 & ,364 & ,716 \\
\hline
\end{tabular}

a. Dependent Variable: Equip_EGF_em_EU 
Tabela 159- Regressão emprego OHQ

Coefficients $^{\mathrm{a}}$

\begin{tabular}{|c|c|c|c|c|c|c|}
\hline \multirow{2}{*}{\multicolumn{2}{|c|}{ Model }} & \multicolumn{2}{|c|}{$\begin{array}{l}\text { Unstandardized } \\
\text { Coefficients }\end{array}$} & \multirow{2}{*}{$\begin{array}{c}\text { Standardized } \\
\text { Coefficients }\end{array}$} & \multirow[b]{2}{*}{$t$} & \multirow[b]{2}{*}{ Sig. } \\
\hline & & $B$ & Std. Error & & & \\
\hline & (Constant) & 5,127 & ,233 & & 22,052 &, 000 \\
\hline & Tempor_Dmy & ,298 & 241 & ,056 & 1,237 & ,217 \\
\hline
\end{tabular}

a. Dependent Variable: Equip_OHQ_em_EU

Tabela 160- Teste de média das escalas para renda

ANOVA

\begin{tabular}{|ll|r|r|r|r|r|}
\hline & & \multicolumn{1}{|c|}{$\begin{array}{c}\text { Sum of } \\
\text { Squares }\end{array}$} & df & Mean Square & \multicolumn{1}{c|}{ F } & \multicolumn{1}{c|}{ Sig. } \\
\hline EU & Between Groups & 2,072 & 5 &, 414 &, 223 &, 953 \\
& Within Groups & 873,750 & 470 & 1,859 & & \\
& Total & 875,821 & 475 & & & \\
\hline Equip_EGF_em_EU & Between Groups & 6,206 & 5 & 1,241 &, 664 &, 651 \\
& Within Groups & 876,740 & 469 & 1,869 & & \\
& Total & 882,946 & 474 & & & \\
\hline Equip_OHQ_em_EU & Between Groups & 26,013 & 5 & 5,203 & 3,056 &, 010 \\
& Within Groups & 801,711 & 471 & 1,702 & & \\
& Total & 827,724 & 476 & & & \\
\hline
\end{tabular}

Tabela 161- Correlação entre os escores médios equiparados em cada categoria de renda

Paired Samples Correlations

\begin{tabular}{|c|c|c|c|c|c|}
\hline renda & & & $\mathrm{N}$ & Correlation & Sig. \\
\hline \multirow[t]{3}{*}{. } & Pair 1 & EU \& Equip_EGF_em_EU & 6 &, 530 & ,279 \\
\hline & Pair 2 & EU \& Equip_EGF_em_EU & 6 &, 530 & ,279 \\
\hline & Pair 3 & Equip_EGF_em_EU \& Equip_OHQ_em_EU & 7 & ,485 & ,270 \\
\hline \multirow[t]{3}{*}{ Até 500} & Pair 1 & EU \& Equip_EGF_em_EU & 69 & ,509 & 000 \\
\hline & Pair 2 & EU \& Equip_EGF_em_EU & 69 &, 509 &, 000 \\
\hline & Pair 3 & Equip_EGF_em_EU \& Equip_OHQ_em_EU & 69 & ,711 & ,000 \\
\hline \multirow[t]{3}{*}{$501-1.000$} & Pair 1 & EU \& Equip_EGF_em_EU & 134 & ,579 & ,000 \\
\hline & Pair 2 & EU \& Equip_EGF_em_EU & 134 &, 579 & ,000 \\
\hline & Pair 3 & Equip_EGF_em_EU \& Equip_OHQ_em_EU & 134 & 619 & ,000 \\
\hline \multirow[t]{3}{*}{$1.001-1.500$} & Pair 1 & EU \& Equip_EGF_em_EU & 98 & ,719 & 000 \\
\hline & Pair 2 & EU \& Equip_EGF_em_EU & 98 & ,719 & ,000 \\
\hline & Pair 3 & Equip_EGF_em_EU \& Equip_OHQ_em_EU & 98 &, 515 &, 000 \\
\hline \multirow[t]{3}{*}{$1.501-2.000$} & Pair 1 & EU \& Equip_EGF_em_EU & 69 & ,660 & ,000 \\
\hline & Pair 2 & EU \& Equip_EGF_em_EU & 69 & ,660 & ,000 \\
\hline & Pair 3 & Equip_EGF_em_EU \& Equip_OHQ_em_EU & 69 & ,620 & ,000 \\
\hline \multirow[t]{3}{*}{$2.001-2.500$} & Pair 1 & EU \& Equip_EGF_em_EU & 35 & ,845 & 000 \\
\hline & Pair 2 & EU \& Equip_EGF_em_EU & 35 & ,845 & 000 \\
\hline & Pair 3 & Equip_EGF_em_EU \& Equip_OHQ_em_EU & 36 & ,696 & ,000 \\
\hline \multirow[t]{3}{*}{$2.501-3.000$} & Pair 1 & EU \& Equip_EGF_em_EU & 69 & ,681 &, 000 \\
\hline & Pair 2 & EU \& Equip_EGF_em_EU & 69 & ,681 &, 000 \\
\hline & Pair 3 & Equip_EGF_em_EU \& Equip_OHQ_em_EU & 69 & ,721 & ,000 \\
\hline
\end{tabular}


Tabela 162- Teste de média para as escalas em cada categoria de renda

\begin{tabular}{|c|c|c|c|c|c|c|c|c|c|c|}
\hline \multicolumn{11}{|c|}{ Paired Samples Test } \\
\hline \multirow[b]{3}{*}{ renda } & & & \multicolumn{5}{|c|}{ Paired Differences } & \multirow[b]{3}{*}{$t$} & \multirow[b]{3}{*}{ df } & \multirow{3}{*}{$\begin{array}{c}\text { Sig. } \\
\text { (2-tailed) }\end{array}$} \\
\hline & & & \multirow[b]{2}{*}{ Mean } & \multirow{2}{*}{$\begin{array}{c}\text { Std. } \\
\text { Deviation }\end{array}$} & \multirow{2}{*}{$\begin{array}{l}\text { Std. } \\
\text { Error } \\
\text { Mean }\end{array}$} & \multicolumn{2}{|c|}{$\begin{array}{l}95 \% \text { Confidence } \\
\text { Interval of the } \\
\text { Difference }\end{array}$} & & & \\
\hline & & & & & & Lower & Upper & & & \\
\hline & Pair 1 & EU - Equip_EGF_em_EU & ,39812 & 1,12675 & ,45999 &,- 78434 & 1,58057 & 865 & 5 &, 426 \\
\hline & Pair 2 & EU - Equip_EGF_em_EU & ,39812 & 1,12675 & ,45999 &,- 78434 & 1,58057 & 865 & 5 & ,426 \\
\hline & Pair 3 & Equip_EGF_em_EU - Equip_OHQ_em_EU &, 73323 & ,98741 & ,37321 &,- 17997 & 1,64643 & 1,965 & 6 & ,097 \\
\hline Até 500 & Pair 1 & EU - Equip_EGF_em_EU & ,14917 & 1,32577 & ,15960 &,- 16931 & ,46766 & ,935 & 68 &, 353 \\
\hline & Pair 2 & EU - Equip_EGF_em_EU & 14917 & 1,32577 & 15960 &,- 16931 & ,46766 & ,935 & 68 & ,353 \\
\hline & Pair 3 & Equip_EGF_em_EU - Equip_OHQ_em_EU & ,41194 & 1,03727 & ,12487 & ,16276 &, 66112 & 3,299 & 68 & ,002 \\
\hline $501-1.000$ & Pair 1 & EU - Equip_EGF_em_EU &,- 00343 & 1,36554 & ,11797 & 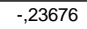 & ,22991 &,- 029 & 133 & ,977 \\
\hline & Pair 2 & EU - Equip_EGF_em_EU &,- 00343 & 1,36554 & ,11797 &,- 23676 & 22991 &,- 029 & 133 & ,977 \\
\hline & Pair 3 & Equip_EGF_em_EU - Equip_OHQ_em_EU &, 40604 & 1,23272 & , 10649 & , 19540 &, 61667 & 3,813 & 133 &, 000 \\
\hline $1.001-1.500$ & Pair 1 & EU - Equip_EGF_em_EU &,- 07709 & ,98612 & ,09961 &,- 27480 & ,12061 &,- 774 & 97 & ,441 \\
\hline & Pair 2 & EU - Equip_EGF_em_EU &,- 07709 & 98612 & 09961 &,- 27480 & 12061 &,- 774 & 97 & ,441 \\
\hline & Pair 3 & Equip_EGF_em_EU - Equip_OHQ_em_EU & ,25899 & 1,25603 & ,12688 &, 00718 &, 51081 & 2,041 & 97 & ,044 \\
\hline $1.501-2.000$ & Pair 1 & EU - Equip_EGF_em_EU &, 04796 & 1,01527 &, 12222 &,- 19593 & ,29186 & ,392 & 68 & ,696 \\
\hline & Pair 2 & EU - Equip_EGF_em_EU & ,04796 & 1,01527 & 12222 &,- 19593 & 29186 & ,392 & 68 & ,696 \\
\hline & Pair 3 & Equip_EGF_em_EU - Equip_OHQ_em_EU &, 08069 & 1,07049 & ,12887 &,- 17647 & ,33785 & ,626 & 68 &, 533 \\
\hline $2.001-2.500$ & Pair 1 & EU - Equip_EGF_em_EU &,- 13369 & ,70951 & ,11993 &,- 37741 &, 11004 & $-1,115$ & 34 & ,273 \\
\hline & Pair 2 & EU - Equip_EGF_em_EU &,- 13369 & 70951 & 11993 &,- 37741 & ,11004 & $-1,115$ & 34 & 273 \\
\hline & Pair 3 & Equip_EGF_em_EU - Equip_OHQ_em_EU & 19860 & 1,04429 & ,17405 &,- 15474 & ,55194 & 1,141 & 35 & 262 \\
\hline $2.501-3.000$ & Pair 1 & EU - Equip_EGF_em_EU &,- 10680 & 1,10778 & ,13336 &,- 37292 & ,15932 &,- 801 & 68 & ,426 \\
\hline & Pair 2 & EU - Equip_EGF_em_EU &,- 10680 & 1,10778 & ,13336 &,- 37292 & 15932 & -801 & 68 & ,426 \\
\hline & Pair 3 & Equip_EGF_em_EU - Equip_OHQ_em_EU & ,13528 & 1,02412 &, 12329 &,- 11074 &, 38130 & 1,097 & 68 & 276 \\
\hline
\end{tabular}

Tabela 163- Comparação médias níveis de renda para sexos

ANOVA

\begin{tabular}{|c|c|c|c|c|c|c|c|}
\hline \multicolumn{3}{|l|}{ Sexo } & $\begin{array}{c}\text { Sum of } \\
\text { Squares }\end{array}$ & df & Mean Square & $\mathrm{F}$ & Sig. \\
\hline \multirow{9}{*}{ Masculino } & \multirow[t]{3}{*}{ EU } & Between Groups & 1,637 & 5 & ,327 & \multirow{3}{*}{, 169 } & \multirow{3}{*}{, 974} \\
\hline & & Within Groups & 392,243 & 202 & 1,942 & & \\
\hline & & Total & 393,880 & 207 & & & \\
\hline & \multirow[t]{3}{*}{ TOTAL_EGF } & Between Groups & 36,212 & 5 & 7,242 & \multirow[t]{3}{*}{,342 } & \multirow[t]{3}{*}{ 887 } \\
\hline & & Within Groups & 4229,167 & 200 & 21,146 & & \\
\hline & & Total & 4265,379 & 205 & & & \\
\hline & \multirow[t]{3}{*}{ Total_OHQ } & Between Groups & 2102,638 & 5 & 420,528 & \multirow[t]{3}{*}{1,236} & \multirow[t]{3}{*}{ 294 } \\
\hline & & Within Groups & 68746,285 & 202 & 340,328 & & \\
\hline & & Total & 70848,923 & 207 & & & \\
\hline \multirow[t]{9}{*}{ Feminino } & \multirow[t]{3}{*}{$\overline{E U}$} & Between Groups & 5,119 & 5 & 1,024 & \multirow[t]{3}{*}{,563 } & \multirow[t]{3}{*}{,728 } \\
\hline & & Within Groups & 474,529 & 261 & 1,818 & & \\
\hline & & Total & 479,648 & 266 & & & \\
\hline & \multirow[t]{3}{*}{ TOTAL_EGF } & Between Groups & 133,324 & 5 & 26,665 & \multirow[t]{3}{*}{1,379} & \multirow[t]{3}{*}{,232 } \\
\hline & & Within Groups & 5065,153 & 262 & 19,333 & & \\
\hline & & Total & 5198,478 & 267 & & & \\
\hline & \multirow[t]{3}{*}{ Total_OHQ } & Between Groups & 4938,443 & 5 & 987,689 & \multirow[t]{3}{*}{3,089} & \multirow[t]{3}{*}{,010 } \\
\hline & & Within Groups & 83785,658 & 262 & 319,793 & & \\
\hline & & Total & 88724,101 & 267 & & & \\
\hline
\end{tabular}


Tabela 164- Teste de médias entre as escalas para renda segmentada por sexo

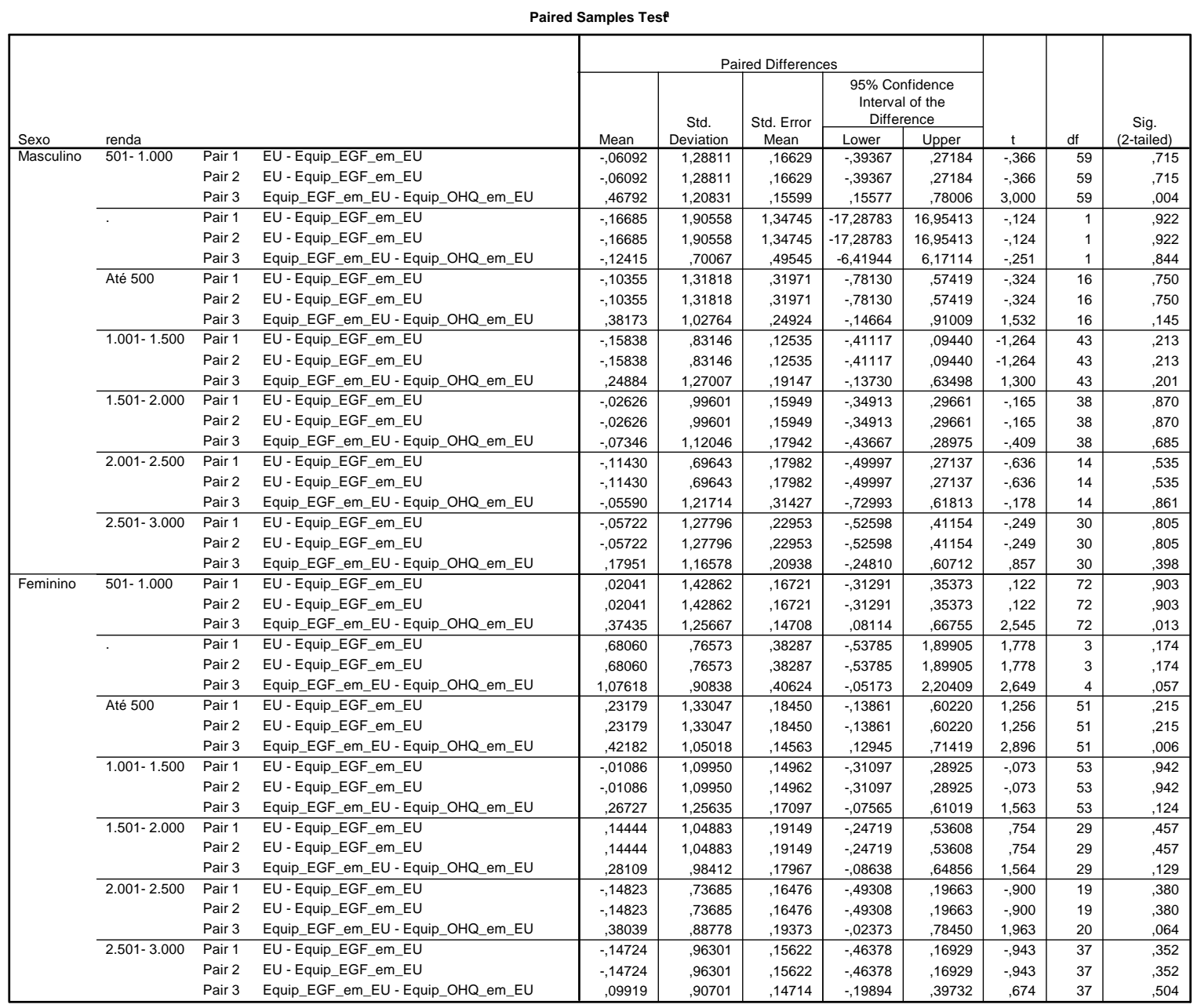

a. No statistics are computed for one or more split files

Tabela 165- Correlação entre renda e escolaridade

Correlations

\begin{tabular}{|ll|r|r|}
\hline & & \multicolumn{1}{c|}{ renda } & \multicolumn{1}{c|}{ escolar } \\
\hline renda & Pearson Correlation & 1 &, $304^{\star *}$ \\
& Sig. (2-tailed) & &, 000 \\
& $\mathrm{~N}$ & 477 & 476 \\
\hline escolar & Pearson Correlation &, $304^{\star *}$ & 1 \\
& Sig. (2-tailed) &, 000 & \\
& $\mathrm{~N}$ & 476 & 482 \\
\hline
\end{tabular}

${ }^{\star \star}$. Correlation is significant at the 0.01 level 
Tabela 166- Distribuição dos níveis de renda entre as escolaridades

escolar * renda Crosstabulation

\begin{tabular}{|c|c|c|c|c|c|c|c|c|}
\hline & & \multicolumn{6}{|c|}{ renda } & \multirow[b]{2}{*}{ Total } \\
\hline & & Até 500 & $501-1.000$ & $1.001-1.500$ & $1.501-2.000$ & $2.001-2.500$ & $2.501-3.000$ & \\
\hline \multirow[t]{6}{*}{ escolar } & Primeiro Grau Incompleto & 11 & 13 & 6 & 3 & 1 & 1 & 35 \\
\hline & Primeiro Grau Completo & 3 & 6 & 3 & 2 & 4 & 0 & 18 \\
\hline & $\begin{array}{l}\text { Segundo Grau } \\
\text { Incompleto }\end{array}$ & 12 & 22 & 10 & 6 & 5 & 7 & 62 \\
\hline & Segundo Grau Completo & 32 & 71 & 55 & 35 & 10 & 24 & 227 \\
\hline & $\begin{array}{l}\text { Ensino Superior } \\
\text { Incompleto }\end{array}$ & 6 & 14 & 17 & 11 & 10 & 12 & 70 \\
\hline & $\begin{array}{l}\text { Ensino Superior } \\
\text { completo }\end{array}$ & 5 & 9 & 7 & 11 & 7 & 25 & 64 \\
\hline Total & & 69 & 135 & 98 & 68 & 37 & 69 & 476 \\
\hline
\end{tabular}

Tabela 167- Coeficiente de determinação regressão renda EU

\begin{tabular}{|c|r|r|r|r|}
\hline \multicolumn{7}{|c|}{ Model Summary } \\
\hline Model & R & R Square & $\begin{array}{l}\text { Adjusted } \\
\text { R Square }\end{array}$ & $\begin{array}{c}\text { Std. Error of } \\
\text { the Estimate }\end{array}$ \\
\hline 1 &, $050^{\mathrm{a}}$ &, 002 &,- 008 & 1,36268 \\
\hline
\end{tabular}

Tabela 168- Coeficientes de regressão renda EU

Coefficients ${ }^{\mathrm{a}}$

\begin{tabular}{|c|c|c|c|c|c|c|}
\hline \multirow{2}{*}{\multicolumn{2}{|c|}{ Model }} & \multicolumn{2}{|c|}{$\begin{array}{l}\text { Unstandardized } \\
\text { Coefficients }\end{array}$} & \multirow{2}{*}{$\begin{array}{c}\text { Standardized } \\
\text { Coefficients }\end{array}$} & \multirow[b]{2}{*}{$t$} & \multirow[b]{2}{*}{ Sig. } \\
\hline & & $\mathrm{B}$ & Std. Error & & & \\
\hline & (Constant) & 5,720 & ,157 & & 36,352 &, 000 \\
\hline & Dummy_Renda_2 &,- 142 & , 196 &,- 047 &,- 725 & ,469 \\
\hline & Dummy_Renda_3 &,- 006 & 209 &,- 002 &,- 027 & ,978 \\
\hline & Dummy_Renda_4 & ,019 & 227 &, 005 & ,084 & ,933 \\
\hline & Dummy_Renda_5 & ,002 & 276 & ,000 & ,008 & ,994 \\
\hline & Dummy_Renda_6 & ,019 & ,227 & ,005 & ,084 & ,933 \\
\hline
\end{tabular}

a. Dependent Variable: EU

Tabela 169- Coeficiente de determinação regressão renda EGF

\begin{tabular}{|c|c|c|c|c|}
\hline \multicolumn{5}{|c|}{ Model Summary } \\
\hline Model & $\mathrm{R}$ & R Square & $\begin{array}{l}\text { Adjusted } \\
\text { R Square }\end{array}$ & $\begin{array}{l}\text { Std. Error of } \\
\text { the Estimate }\end{array}$ \\
\hline 1 &, $082^{\mathrm{a}}$ &, 007 &,- 004 & 1,35933 \\
\hline
\end{tabular}

Tabela 170- Coeficiente de regressão renda EGF

Coefficients $^{a}$

\begin{tabular}{|c|c|c|c|c|c|c|}
\hline \multirow{2}{*}{\multicolumn{2}{|c|}{ Model }} & \multicolumn{2}{|c|}{$\begin{array}{l}\text { Unstandardized } \\
\text { Coefficients }\end{array}$} & \multirow{2}{*}{$\begin{array}{c}\begin{array}{c}\text { Standardized } \\
\text { Coefficients }\end{array} \\
\text { Beta }\end{array}$} & \multirow[b]{2}{*}{$t$} & \multirow[b]{2}{*}{ Sig. } \\
\hline & & B & Std. Error & & & \\
\hline \multirow[t]{6}{*}{1} & (Constant) & 5,550 & , 156 & & 35,596 &, 000 \\
\hline & Dummy_Renda_2 & ,028 & ,195 & ,009 & ,142 & ,888 \\
\hline & Dummy_Renda_3 & ,241 & 208 & ,072 & 1,160 & ,247 \\
\hline & Dummy_Renda_4 & ,141 & ,226 & ,036 & ,623 &, 534 \\
\hline & Dummy_Renda_5 & ,201 & 275 & ,039 & ,731 & ,465 \\
\hline & Dummy_Renda_6 & ,296 & ,226 & ,076 & 1,307 & , 192 \\
\hline
\end{tabular}

a. Dependent Variable: Equip_EGF_em_EU 
Tabela 171- Coeficiente de determinação regressão renda OHQ

\begin{tabular}{|c|c|c|c|c|}
\hline \multicolumn{5}{|c|}{ Model Summary } \\
\hline Model & $\mathrm{R}$ & R Square & $\begin{array}{l}\text { Adjusted } \\
\text { R Square }\end{array}$ & $\begin{array}{l}\text { Std. Error of } \\
\text { the Estimate }\end{array}$ \\
\hline 1 &, $180^{\mathrm{a}}$ &, 032 &, 022 & 1,30124 \\
\hline
\end{tabular}

Tabela 172- Coeficiente de determinação regressão renda OHQ

Coefficients $^{\mathrm{a}}$

\begin{tabular}{|c|c|c|c|c|c|c|}
\hline \multirow{2}{*}{\multicolumn{2}{|c|}{ Model }} & \multicolumn{2}{|c|}{$\begin{array}{c}\text { Unstandardized } \\
\text { Coefficients }\end{array}$} & \multirow{2}{*}{$\begin{array}{c}\begin{array}{c}\text { Standardized } \\
\text { Coefficients }\end{array} \\
\text { Beta }\end{array}$} & \multirow[b]{2}{*}{$t$} & \multirow[b]{2}{*}{ Sig. } \\
\hline & & $\mathrm{B}$ & Std. Error & & & \\
\hline & (Constant) & 5,109 &, 149 & & 34,228 &, 000 \\
\hline & Dummy_Renda_2 & ,054 & , 187 & ,018 & ,289 & ,773 \\
\hline & Dummy_Renda_3 & ,423 & , 199 & ,129 & 2,129 & ,034 \\
\hline & Dummy_Renda_4 &, 502 & ,216 & ,133 & 2,318 & ,021 \\
\hline & Dummy_Renda_5 &, 501 & ,261 & ,101 & 1,921 & 055 \\
\hline & Dummy_Renda_6 & ,602 & ,216 & , 160 & 2,781 &, 006 \\
\hline
\end{tabular}

a. Dependent Variable: Equip_OHQ_em_EU

Tabela 173- Análise de médias entre praticantes e não praticantes de religião

ANOVA

\begin{tabular}{|ll|r|r|r|r|r|}
\hline & & \multicolumn{1}{|c|}{$\begin{array}{c}\text { Sum of } \\
\text { Squares }\end{array}$} & df & Mean Square & \multicolumn{1}{c|}{ F } & \multicolumn{1}{c|}{ Sig. } \\
\hline EU & Between Groups & 1,934 & 1 & 1,934 & 1,050 &, 306 \\
& Within Groups & 882,398 & 479 & 1,842 & & \\
& Total & 884,333 & 480 & & &, 020 \\
\hline Equip_EGF_em_EU & Between Groups & 9,930 & 1 & 9,930 & 5,444 & \\
& Within Groups & 875,585 & 480 & 1,824 & &, 187 \\
& Total & 885,515 & 481 & & & \\
\hline Equip_OHQ_em_EU & Between Groups & 3,011 & 1 & 3,011 & 1,749 & \\
& Within Groups & 828,336 & 481 & 1,722 & & \\
& Total & 831,347 & 482 & & & \\
\end{tabular}

Tabela 174- Correlação entre as escalas para as categorias praticante religião

Paired Samples Correlations

\begin{tabular}{|lll|r|r|r|}
\hline p_religião & & N & Correlation & Sig. \\
\hline Pratica alguma religião & Pair 1 & EU \& Equip_EGF_em_EU & 376 &, 633 &, 000 \\
& Pair 2 & EU \& Equip_OHQ_em_EU & 376 &, 526 &, 000 \\
& Pair 3 & Equip_EGF_em_EU \& Equip_OHQ_em_EU & 377 &, 645 &, 000 \\
\hline Não pratica religião & Pair 1 & EU \& Equip_EGF_em_EU & 104 &, 643 &, 000 \\
& Pair 2 & EU \& Equip_OHQ_em_EU & 105 &, 653 &, 000 \\
& Pair 3 & Equip_EGF_em_EU \& Equip_OHQ_em_EU & 105 &, 588 &, 000 \\
\hline
\end{tabular}

a. No statistics are computed for one or more split files

Tabela 175-Teste de médias entre as escalas para as categorias praticante religião

\begin{tabular}{|c|c|c|c|c|c|c|c|c|c|c|}
\hline \multicolumn{11}{|c|}{ Paired Samples Test } \\
\hline \multirow[b]{3}{*}{ p religião } & & & \multicolumn{5}{|c|}{ Paired Differences } & \multirow[b]{3}{*}{$t$} & \multirow[b]{3}{*}{ df } & \multirow[b]{3}{*}{ Sig. (2-tailed) } \\
\hline & & & \multirow[b]{2}{*}{ Mean } & \multirow[b]{2}{*}{ Std. Deviation } & \multirow{2}{*}{$\begin{array}{l}\text { Std. Error } \\
\text { Mean }\end{array}$} & \multicolumn{2}{|c|}{$\begin{array}{l}95 \% \text { Confidence } \\
\text { Interval of the } \\
\text { Difference }\end{array}$} & & & \\
\hline & & & & & & Lower & Upper & & & \\
\hline \multirow[t]{3}{*}{ Pratica alguma religião } & Pair 1 & EU - Equip_EGF_em_EU &,- 04555 & 1,14966 &, 05929 &,- 16213 &, 07103 &,- 768 & 375 &, 443 \\
\hline & Pair 2 & EU - Equip_OHQ_em_EU & ,27236 & 1,30400 & ,06725 & ,14013 & ,40459 & 4,050 & 375 & ,000 \\
\hline & Pair 3 & Equip_EGF_em_EU - Equip_OHQ_em_EU & ,31786 & 1,10978 & ,05716 & ,20548 & ,43025 & 5,561 & 376 &, 000 \\
\hline \multirow[t]{3}{*}{ Não pratica religião } & Pair 1 & EU - Equip_EGF_em_EU & ,12553 & 1,18827 & $\frac{11652}{, 1162}$ &,- 10555 & ,35662 & 1,077 & 103 & ,284 \\
\hline & Pair 2 & EU - Equip_OHQ_em_EU & 29959 & 1,10175 & 10752 & 08638 & ,51281 & 2,786 & 104 & ,006 \\
\hline & Pair 3 & Equip_EGF_em_EU - Equip_OHQ_em_EU &, 14823 & 1,26091 &, 12305 &,- 09579 & 39225 & 1,205 & 104 &, 231 \\
\hline
\end{tabular}


Tabela 176- Coeficientes de determinação regressão religião- EU

\begin{tabular}{|l|r|r|r|r|}
\multicolumn{7}{|c}{ Model Summary } \\
\hline Model & $\mathrm{R}$ & R Square & $\begin{array}{c}\text { Adjusted } \\
\text { R Square }\end{array}$ & $\begin{array}{r}\text { Std. Error of } \\
\text { the Estimate }\end{array}$ \\
\hline 1 &, $048^{\mathrm{a}}$ &, 002 &, 000 & 1,35711 \\
\hline
\end{tabular}

a. Predictors: (Constant), Relig_N_Prat_Dmy

Tabela 177- Coeficientes de regressão religião- EU

\begin{tabular}{|c|c|c|c|c|c|}
\hline \multicolumn{6}{|c|}{ Coefficients $^{a}$} \\
\hline \multirow[b]{2}{*}{ Model } & \multicolumn{2}{|c|}{$\begin{array}{c}\text { Unstandardized } \\
\text { Coefficients }\end{array}$} & $\begin{array}{c}\text { Standardized } \\
\text { Coefficients }\end{array}$ & \multirow[b]{2}{*}{$\mathrm{t}$} & \multirow[b]{2}{*}{ Sig. } \\
\hline & B & Std. Error & Beta & & \\
\hline (Constant) & 5,719 & ,070 & & 81,820 &, 000 \\
\hline Relig_N_Prat_Dmy &,- 157 & , 150 &,- 048 & $-1,048$ & ,295 \\
\hline
\end{tabular}

a. Dependent Variable: EU

Tabela 178- Coeficientes de determinação regressão religião- EGF

\begin{tabular}{|l|r|r|r|r|}
\multicolumn{7}{c|}{ Model Summary } \\
\hline Model & R & R Square & $\begin{array}{c}\text { Adjusted } \\
\text { R Square }\end{array}$ & $\begin{array}{r}\text { Std. Error of } \\
\text { the Estimate }\end{array}$ \\
\hline 1 &, $106^{\mathrm{a}}$ &, 011 &, 009 & 1,35061 \\
\hline
\end{tabular}

a. Predictors: (Constant), Relig_N_Prat_Dmy

Tabela 179- Coeficientes de regressão religião- EGF

Coefficients $^{\mathrm{a}}$

\begin{tabular}{|c|c|c|c|c|c|c|}
\hline \multirow[b]{2}{*}{ Model } & & \multicolumn{2}{|c|}{$\begin{array}{c}\text { Unstandardized } \\
\text { Coefficients }\end{array}$} & \multirow{2}{*}{$\begin{array}{c}\text { Standardized } \\
\text { Coefficients }\end{array}$} & \multirow[b]{2}{*}{$t$} & \multirow[b]{2}{*}{ Sig. } \\
\hline & & $\mathrm{B}$ & Std. Error & & & \\
\hline & (Constant) & 5,760 & ,070 & & 82,811 &, 000 \\
\hline & Relig_N_Prat_Dmy &,- 348 & ,149 &,- 106 & $-2,333$ & 020 \\
\hline
\end{tabular}

a. Dependent Variable: Equip_EGF_em_EU

Tabela 180- Coeficientes de determinação regressão religião- OHQ

\begin{tabular}{|l|r|r|r|r|}
\multicolumn{7}{|c|}{ Model Summary } \\
\hline Model & $R$ & R Square & $\begin{array}{l}\text { Adjusted } \\
\text { R Square }\end{array}$ & $\begin{array}{r}\text { Std. Error of } \\
\text { the Estimate }\end{array}$ \\
\hline 1 &, $062^{\mathrm{a}}$ &, 004 &, 002 & 1,31482 \\
\hline
\end{tabular}

a. Predictors: (Constant), Relig_N_Prat_Dmy

Tabela 181- Coeficientes de regressão religião- OHQ

Coefficients $^{\mathrm{a}}$

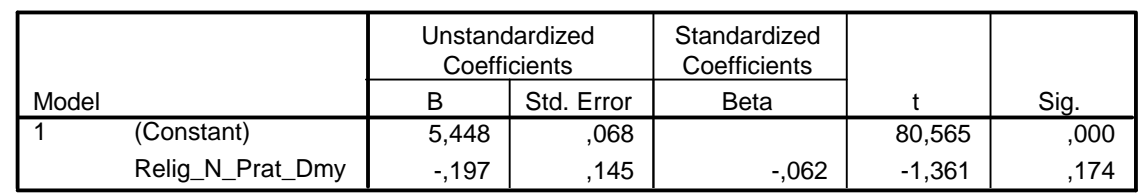

a. Dependent Variable: Equip_OHQ_em_EU 
Tabela 182- Comparação de médias tipos de religião

ANOVA

\begin{tabular}{|c|c|c|c|c|c|c|}
\hline & & $\begin{array}{l}\text { Sum of } \\
\text { Squares }\end{array}$ & $\mathrm{df}$ & Mean Square & $\mathrm{F}$ & Sig. \\
\hline \multirow[t]{3}{*}{ EU } & Between Groups & 2,627 & 4 & ,657 & \multirow[t]{3}{*}{,355 } & \multirow[t]{3}{*}{, 841} \\
\hline & Within Groups & 877,260 & 474 & 1,851 & & \\
\hline & Total & 879,887 & 478 & & & \\
\hline \multirow[t]{3}{*}{ Equip_EGF_em_EU } & Between Groups & 1,005 & 4 & ,251 & \multirow[t]{3}{*}{, 135 } & \multirow[t]{3}{*}{,970 } \\
\hline & Within Groups & 884,027 & 474 & 1,865 & & \\
\hline & Total & 885,032 & 478 & & & \\
\hline \multirow[t]{3}{*}{ Equip_OHQ_em_EU } & Between Groups & 14,850 & 4 & 3,712 & \multirow[t]{3}{*}{2,155} & \multirow[t]{3}{*}{,073 } \\
\hline & Within Groups & 819,951 & 476 & 1,723 & & \\
\hline & Total & 834,801 & 480 & & & \\
\hline
\end{tabular}

Tabela 183- Comparação de médias praticantes e não praticantes religião separados por sexo

\begin{tabular}{|c|c|c|c|c|c|c|c|}
\hline \multicolumn{8}{|c|}{ ANOVA } \\
\hline \multicolumn{3}{|l|}{ Sexo } & $\begin{array}{l}\text { Sum of } \\
\text { Squares }\end{array}$ & df & Mean Square & $\mathrm{F}$ & Sig. \\
\hline \multirow[t]{9}{*}{ Masculino } & \multirow[t]{3}{*}{ EU } & Between Groups & ,945 & 1 & ,945 & \multirow[t]{3}{*}{, 495} & \multirow[t]{3}{*}{, 483} \\
\hline & & Within Groups & 395,485 & 207 & 1,911 & & \\
\hline & & Total & 396,431 & 208 & & & \\
\hline & \multirow[t]{3}{*}{ Equip_EGF_em_EU } & Between Groups & 8,794 & 1 & 8,794 & \multirow[t]{3}{*}{4,665} & \multirow[t]{3}{*}{, 032} \\
\hline & & Within Groups & 388,300 & 206 & 1,885 & & \\
\hline & & Total & 397,094 & 207 & & & \\
\hline & \multirow[t]{3}{*}{ Equip_OHQ_em_EU } & Between Groups & 3,665 & 1 & 3,665 & \multirow[t]{3}{*}{2,108} & \multirow[t]{3}{*}{,148 } \\
\hline & & Within Groups & 359,773 & 207 & 1,738 & & \\
\hline & & Total & 363,437 & 208 & & & \\
\hline \multirow[t]{9}{*}{ Feminino } & \multirow[t]{3}{*}{ EU } & Between Groups &, 551 & 1 &, 551 & \multirow[t]{3}{*}{,306 } & \multirow[t]{3}{*}{, 580} \\
\hline & & Within Groups & 484,386 & 269 & 1,801 & & \\
\hline & & Total & 484,937 & 270 & & & \\
\hline & \multirow[t]{3}{*}{ Equip_EGF_em_EU } & Between Groups & 2,339 & 1 & 2,339 & \multirow[t]{3}{*}{1,310} & \multirow[t]{3}{*}{,253 } \\
\hline & & Within Groups & 484,080 & 271 & 1,786 & & \\
\hline & & Total & 486,419 & 272 & & & \\
\hline & \multirow[t]{3}{*}{ Equip_OHQ_em_EU } & Between Groups & ,443 & 1 & ,443 & \multirow[t]{3}{*}{,257 } & \multirow[t]{3}{*}{,613 } \\
\hline & & Within Groups & 466,879 & 271 & 1,723 & & \\
\hline & & Total & 467,322 & 272 & & & \\
\hline
\end{tabular}

Tabela 184- Teste de homogeneidade das variâncias para idades separadas por prática / não-prática de religião

\begin{tabular}{|c|c|c|c|c|c|}
\hline p_religião & & $\begin{array}{l}\text { Levene } \\
\text { Statistic }\end{array}$ & df1 & df2 & Sig. \\
\hline \multirow{3}{*}{ Pratica alguma religião } & $\mathrm{EU}$ & 2,586 & 5 & 356 &, 026 \\
\hline & Equip_EGF_em_EU & ,453 & 5 & 357 & ,811 \\
\hline & Equip_OHQ_em_EU & ,665 & 5 & 357 & ,650 \\
\hline \multirow[t]{3}{*}{ Não pratica religião } & $\mathrm{EU}$ & 3,615 & 5 & 99 & ,005 \\
\hline & Equip_EGF_em_EU & ,736 & 5 & 99 &, 598 \\
\hline & Equip_OHQ_em_EU & 1,841 & 5 & 100 & ,112 \\
\hline
\end{tabular}


Tabela 185- Teste não paramétrico prática de religião separado por idades

\begin{tabular}{|ll|r|r|}
\hline \multicolumn{4}{|c|}{ Test Statistics } \\
\hline Idade_Categ & & EU & $\begin{array}{r}\text { Equip_OHQ_ } \\
\text { em_EU }\end{array}$ \\
\hline Menos que 20 anos & Chi-Square &, 453 &, 314 \\
& df & 1 & 1 \\
& Asymp. Sig. &, 501 &, 575 \\
\hline 21-30 anos & Chi-Square & 2,247 & 1,542 \\
& df & 1 & 1 \\
& Asymp. Sig. &, 134 &, 214 \\
\hline 31-40 anos & Chi-Square &, 188 &, 639 \\
& df & 1 & 1 \\
& Asymp. Sig. &, 665 &, 424 \\
\hline $41-50$ anos & Chi-Square &, 350 &, 246 \\
& df & 1 & 1 \\
& Asymp. Sig. &, 554 &, 620 \\
\hline $51-60$ anos & Chi-Square &, 133 & 1,614 \\
& df & 1 & 1 \\
& Asymp. Sig. &, 715 &, 204 \\
\hline Mais que 60 anos & Chi-Square &, 659 &, 150 \\
& df & 1 & 1 \\
& Asymp. Sig. &, 417 &, 699 \\
\hline
\end{tabular}

a. Kruskal Wallis Test

b. Grouping Variable: p_religião

Tabela 186- Análise de variâncias de idades separado por prática / não-prática de religião

ANOVA

\begin{tabular}{|c|c|c|c|c|c|c|c|}
\hline p_religião & & & $\begin{array}{c}\text { Sum of } \\
\text { Squares }\end{array}$ & df & Mean Square & $\mathrm{F}$ & Sig. \\
\hline \multirow[t]{9}{*}{ Pratica alguma religião } & \multirow[t]{3}{*}{ EU } & Between Groups & 15,249 & 5 & 3,050 & \multirow[t]{3}{*}{1,677} & \multirow[t]{3}{*}{, 139} \\
\hline & & Within Groups & 647,571 & 356 & 1,819 & & \\
\hline & & Total & 662,820 & 361 & & & \\
\hline & \multirow[t]{3}{*}{ Equip_EGF_em_EU } & Between Groups & 8,530 & 5 & 1,706 & \multirow[t]{3}{*}{ 981 } & \multirow[t]{3}{*}{,429 } \\
\hline & & Within Groups & 620,716 & 357 & 1,739 & & \\
\hline & & Total & 629,246 & 362 & & & \\
\hline & \multirow[t]{3}{*}{ Equip_OHQ_em_EU } & Between Groups & 8,526 & 5 & 1,705 & \multirow[t]{3}{*}{,982 } & \multirow[t]{3}{*}{,429 } \\
\hline & & Within Groups & 619,913 & 357 & 1,736 & & \\
\hline & & Total & 628,438 & 362 & & & \\
\hline \multirow[t]{9}{*}{ Não pratica religião } & \multirow[t]{3}{*}{ EU } & Between Groups & 7,083 & 5 & 1,417 & \multirow[t]{3}{*}{ 776 } & \multirow[t]{3}{*}{, 569} \\
\hline & & Within Groups & 180,764 & 99 & 1,826 & & \\
\hline & & Total & 187,848 & 104 & & & \\
\hline & \multirow[t]{3}{*}{ Equip_EGF_em_EU } & Between Groups & 3,492 & 5 & 698 & \multirow[t]{3}{*}{,317 } & \multirow[t]{3}{*}{ 902 } \\
\hline & & Within Groups & 218,177 & 99 & 2,204 & & \\
\hline & & Total & 221,669 & 104 & & & \\
\hline & \multirow[t]{3}{*}{ Equip_OHQ_em_EU } & Between Groups & 2,368 & 5 & ,474 & \multirow[t]{3}{*}{,271 } & \multirow[t]{3}{*}{,928 } \\
\hline & & Within Groups & 174,772 & 100 & 1,748 & & \\
\hline & & Total & 177,140 & 105 & & & \\
\hline
\end{tabular}


Tabela 187- Análise de médias para praticantes e não praticantes de atividades sócio políticas ANOVA

\begin{tabular}{|c|c|c|c|c|c|c|}
\hline & & $\begin{array}{c}\text { Sum of } \\
\text { Squares }\end{array}$ & $\mathrm{df}$ & Mean Square & $\mathrm{F}$ & Sig. \\
\hline \multirow[t]{3}{*}{$\mathrm{EU}$} & Between Groups & ,727 & 1 & ,727 & \multirow[t]{3}{*}{,392 } & \multirow[t]{3}{*}{, 532} \\
\hline & Within Groups & 877,694 & 473 & 1,856 & & \\
\hline & Total & 878,421 & 474 & & & \\
\hline \multirow[t]{3}{*}{ Equip_EGF_em_EU } & Between Groups & ,663 & 1 & ,663 & \multirow[t]{3}{*}{,361 } & \multirow[t]{3}{*}{,548 } \\
\hline & Within Groups & 868,756 & 473 & 1,837 & & \\
\hline & Total & 869,419 & 474 & & & \\
\hline \multirow[t]{3}{*}{ Equip_OHQ_em_EU } & Between Groups & ,088 & 1 & ,088 & \multirow[t]{3}{*}{,051 } & \multirow[t]{3}{*}{,822 } \\
\hline & Within Groups & 823,066 & 473 & 1,740 & & \\
\hline & Total & 823,154 & 474 & & & \\
\hline
\end{tabular}

Tabela 188- Cruzamento entre nível de escolaridade e atividade política escolar * politica Crosstabulation

\begin{tabular}{|c|c|c|c|c|}
\hline & & \multicolumn{2}{|c|}{ politica } & \multirow[b]{2}{*}{ Total } \\
\hline & & $\begin{array}{c}\text { Pratica } \\
\text { atividade } \\
\text { sócio política }\end{array}$ & $\begin{array}{l}\text { Não pratica } \\
\text { ativiade sócio } \\
\text { política }\end{array}$ & \\
\hline \multirow[t]{6}{*}{ escolar } & Primeiro Grau Incompleto & 1 & 34 & 35 \\
\hline & Primeiro Grau Completo & 0 & 18 & 18 \\
\hline & Segundo Grau Incompleto & 2 & 60 & 62 \\
\hline & Segundo Grau Completo & 4 & 220 & 224 \\
\hline & Ensino Superior Incompleto & 4 & 70 & 74 \\
\hline & Ensino Superior completo & 6 & 58 & 64 \\
\hline Total & & 17 & 460 & 477 \\
\hline
\end{tabular}

Tabela 189- Análise de médias saúde

ANOVA

\begin{tabular}{|ll|r|r|r|r|r|}
\hline & & \multicolumn{1}{|c|}{$\begin{array}{c}\text { Sum of } \\
\text { Squares }\end{array}$} & df & Mean Square & \multicolumn{1}{c|}{ F } & Sig. \\
\hline & Between Groups & 19,183 & 1 & 19,183 & 10,622 &, 001 \\
& Within Groups & 866,884 & 480 & 1,806 & & \\
& Total & 886,066 & 481 & & & \\
\hline Equip_EGF_em_EU & Between Groups & 17,418 & 1 & 17,418 & 9,631 &, 002 \\
& Within Groups & 868,098 & 480 & 1,809 & & \\
& Total & 885,515 & 481 & & & \\
\hline Equip_OHQ_em_EU & Between Groups & 9,690 & 1 & 9,690 & 5,649 &, 018 \\
& Within Groups & 826,765 & 482 & 1,715 & & \\
& Total & 836,455 & 483 & & & \\
\hline
\end{tabular}

Tabela 190- Coeficiente determinação regressão saúde EU

Model Summary

\begin{tabular}{|l|r|r|r|r|}
\hline Model & $\mathrm{R}$ & R Square & $\begin{array}{c}\text { Adjusted } \\
\text { R Square }\end{array}$ & $\begin{array}{r}\text { Std. Error of } \\
\text { the Estimate }\end{array}$ \\
\hline 1 &, $147^{\mathrm{a}}$ &, 022 &, 020 & 1,34388 \\
\hline
\end{tabular}

a. Predictors: (Constant), Saúde_Dmy 
Tabela 191- Coeficiente regressão saúde EU

\section{Coefficients $^{\mathrm{a}}$}

\begin{tabular}{|c|c|c|c|c|c|c|}
\hline \multirow{2}{*}{\multicolumn{2}{|c|}{ Model }} & \multicolumn{2}{|c|}{$\begin{array}{c}\text { Unstandardized } \\
\text { Coefficients }\end{array}$} & \multirow{2}{*}{$\begin{array}{c}\text { Standardized } \\
\text { Coefficients } \\
\text { Beta }\end{array}$} & \multirow[b]{2}{*}{$t$} & \multirow[b]{2}{*}{ Sig. } \\
\hline & & $\mathrm{B}$ & Std. Error & & & \\
\hline & (Constant) & 5,216 &, 156 & & 33,390 &, 000 \\
\hline & Saúde_Dmy &, 553 & , 170 & , 147 & 3,259 & 001 \\
\hline
\end{tabular}

a. Dependent Variable: EU

Tabela 192- Coeficiente determinação regressão saúde EGF

Model Summary

\begin{tabular}{|l|r|r|r|r|}
\hline Model & \multicolumn{1}{|c|}{$\mathrm{R}$} & R Square & $\begin{array}{c}\text { Adjusted } \\
\text { R Square }\end{array}$ & $\begin{array}{r}\text { Std. Error of } \\
\text { the Estimate }\end{array}$ \\
\hline 1 &, $140^{\mathrm{a}}$ &, 020 &, 018 & 1,34482 \\
\hline
\end{tabular}

a. Predictors: (Constant), Saúde_Dmy

Tabela 193- Coeficiente regressão saúde EGF

Coefficients $^{\mathrm{a}}$

\begin{tabular}{|rl|r|r|r|r|r|}
\hline \multirow{2}{*}{ Model } & \multicolumn{2}{|c|}{$\begin{array}{c}\text { Unstandardized } \\
\text { Coefficients }\end{array}$} & \multicolumn{2}{c|}{$\begin{array}{c}\text { Standardized } \\
\text { Coefficients }\end{array}$} & & \\
\cline { 3 - 5 } & \multicolumn{1}{|c|}{$\mathrm{B}$} & Std. Error & \multicolumn{1}{|c|}{ Beta } & \multicolumn{1}{c|}{$\mathrm{t}$} & Sig. \\
\hline 1 & (Constant) & 5,242 &, 155 & & 33,755 &, 000 \\
& Saúde_Dmy &, 524 &, 169 &, 140 & 3,103 &, 002 \\
\hline
\end{tabular}

a. Dependent Variable: Equip_EGF_em_EU

Tabela 194- Coeficiente determinação regressão saúde OHQ

Model Summary

\begin{tabular}{|l|r|r|r|r|}
\hline Model & \multicolumn{1}{|c|}{$\mathrm{R}$} & R Square & $\begin{array}{c}\text { Adjusted } \\
\text { R Square }\end{array}$ & $\begin{array}{r}\text { Std. Error of } \\
\text { the Estimate }\end{array}$ \\
\hline 1 &, $108^{\mathrm{a}}$ &, 012 &, 010 & 1,30969 \\
\hline
\end{tabular}

a. Predictors: (Constant), Saúde_Dmy

Tabela 195- Coeficiente regressão saúde OHQ

Coefficients $^{a}$

\begin{tabular}{|c|c|c|c|c|c|c|}
\hline \multirow{2}{*}{\multicolumn{2}{|c|}{ Model }} & \multicolumn{2}{|c|}{$\begin{array}{l}\text { Unstandardized } \\
\text { Coefficients }\end{array}$} & \multirow{2}{*}{$\begin{array}{c}\text { Standardized } \\
\text { Coefficients } \\
\text { Beta }\end{array}$} & \multirow[b]{2}{*}{$t$} & \multirow[b]{2}{*}{ Sig. } \\
\hline & & $\mathrm{B}$ & Std. Error & & & \\
\hline \multirow[t]{2}{*}{1} & (Constant) & 5,075 &, 151 & & 33,557 &, 000 \\
\hline & Saúde_Dmy & ,391 & , 165 & , 108 & 2,377 & ,018 \\
\hline
\end{tabular}

a. Dependent Variable: Equip_OHQ_em_EU 
Tabela 196- Teste de médias para idades separado por saúde

\begin{tabular}{|c|c|c|c|c|c|c|c|}
\hline \multicolumn{8}{|c|}{ ANOVA } \\
\hline \multicolumn{3}{|l|}{ Saúde } & $\begin{array}{l}\text { Sum of } \\
\text { Squares }\end{array}$ & df & Mean Square & $\mathrm{F}$ & Sig. \\
\hline \multirow[t]{9}{*}{ Boa saúde } & \multirow[t]{3}{*}{ EU } & Between Groups & 3,046 & 5 & ,609 & \multirow[t]{3}{*}{,358 } & \multirow[t]{3}{*}{877} \\
\hline & & Within Groups & 661,526 & 389 & 1,701 & & \\
\hline & & Total & 664,572 & 394 & & & \\
\hline & \multirow[t]{3}{*}{ Equip_EGF_em_EU } & Between Groups & 4,678 & 5 & 936 & \multirow[t]{3}{*}{,517 } & \multirow[t]{3}{*}{,763 } \\
\hline & & Within Groups & 703,965 & 389 & 1,810 & & \\
\hline & & Total & 708,643 & 394 & & & \\
\hline & \multirow[t]{3}{*}{ Equip_OHQ_em_EU } & Between Groups & 12,256 & 5 & 2,451 & \multirow[t]{3}{*}{1,434} & \multirow[t]{3}{*}{,211 } \\
\hline & & Within Groups & 666,466 & 390 & 1,709 & & \\
\hline & & Total & 678,722 & 395 & & & \\
\hline \multirow{9}{*}{$\begin{array}{l}\text { Apresenta algum } \\
\text { problema de saúde }\end{array}$} & \multirow[t]{3}{*}{ EU } & Between Groups & 15,168 & 5 & 3,034 & \multirow[t]{3}{*}{1,285} & \multirow[t]{3}{*}{,281 } \\
\hline & & Within Groups & 155,818 & 66 & 2,361 & & \\
\hline & & Total & 170,986 & 71 & & & \\
\hline & \multirow[t]{3}{*}{ Equip_EGF_em_EU } & Between Groups & 4,579 & 5 & 916 & \multirow[t]{3}{*}{,465 } & \multirow[t]{3}{*}{,801 } \\
\hline & & Within Groups & 132,073 & 67 & 1,971 & & \\
\hline & & Total & 136,653 & 72 & & & \\
\hline & \multirow[t]{3}{*}{ Equip_OHQ_em_EU } & Between Groups & 3,479 & 5 & ,696 & \multirow[t]{3}{*}{,395 } & \multirow[t]{3}{*}{,850 } \\
\hline & & Within Groups & 117,985 & 67 & 1,761 & & \\
\hline & & Total & 121,464 & 72 & & & \\
\hline
\end{tabular}

Tabela 197- Tabela cruzada idades $x$ saúde

Idade_Categ * Saúde Crosstabulation

\begin{tabular}{|c|c|c|c|c|}
\hline & & \multicolumn{2}{|c|}{ Saúde } & \multirow[b]{2}{*}{ Total } \\
\hline & & Boa saúde & $\begin{array}{c}\text { Apresenta } \\
\text { algum } \\
\text { problema } \\
\text { de saúde }\end{array}$ & \\
\hline \multirow[t]{6}{*}{ Idade_Categ } & Menos que 20 anos & 61 & 2 & 63 \\
\hline & $21-30$ anos & 202 & 18 & 220 \\
\hline & $31-40$ anos & 77 & 17 & 94 \\
\hline & $41-50$ anos & 40 & 23 & 63 \\
\hline & $51-60$ anos & 12 & 10 & 22 \\
\hline & Mais que 60 anos & 4 & 3 & 7 \\
\hline Total & & 396 & 73 & 469 \\
\hline
\end{tabular}

Tabela 198- Teste de médias para prática desportiva

ANOVA

\begin{tabular}{|c|c|c|c|c|c|c|}
\hline & & $\begin{array}{c}\text { Sum of } \\
\text { Squares }\end{array}$ & $\mathrm{df}$ & Mean Square & $\mathrm{F}$ & Sig. \\
\hline \multirow[t]{3}{*}{ EU } & Between Groups & ,222 & 1 & ,222 & \multirow[t]{3}{*}{, 120} & \multirow[t]{3}{*}{, 729} \\
\hline & Within Groups & 885,844 & 480 & 1,846 & & \\
\hline & Total & 886,066 & 481 & & & \\
\hline \multirow[t]{3}{*}{ Equip_EGF_em_EU } & Between Groups & 5,184 & 1 & 5,184 & \multirow[t]{3}{*}{2,827} & \multirow[t]{3}{*}{,093 } \\
\hline & Within Groups & 880,331 & 480 & 1,834 & & \\
\hline & Total & 885,515 & 481 & & & \\
\hline \multirow[t]{3}{*}{ Equip_OHQ_em_EU } & Between Groups & 10,682 & 1 & 10,682 & \multirow[t]{3}{*}{6,235} & \multirow[t]{3}{*}{,013 } \\
\hline & Within Groups & 825,773 & 482 & 1,713 & & \\
\hline & Total & 836,455 & 483 & & & \\
\hline
\end{tabular}


Tabela 199- Teste de médias para fumantes e não fumantes

ANOVA

\begin{tabular}{|ll|r|r|r|r|r|}
\hline & & \multicolumn{1}{|c|}{$\begin{array}{c}\text { Sum of } \\
\text { Squares }\end{array}$} & df & Mean Square & F & Sig. \\
\hline EU & Between Groups & 4,266 & 2 & 2,133 & 1,151 &, 317 \\
& Within Groups & 874,366 & 472 & 1,852 & & \\
& Total & 878,632 & 474 & & &, 447 \\
\hline Equip_EGF_em_EU & Between Groups & 2,969 & 2 & 1,484 &, 807 & \\
& Within Groups & 868,041 & 472 & 1,839 & &, 365 \\
& Total & 871,010 & 474 & & & \\
\hline Equip_OHQ_em_EU & Between Groups & 3,476 & 2 & 1,738 & 1,010 & \\
& Within Groups & 815,474 & 474 & 1,720 & & \\
& Total & 818,949 & 476 & & & \\
\end{tabular}


Tabela 200- Valores de mediana do OHQ

Statistics

\begin{tabular}{|c|c|c|c|c|c|}
\hline & \multicolumn{2}{|c|}{$\mathrm{N}$} & \multirow[b]{2}{*}{ Median } & \multirow[b]{2}{*}{ Std. Deviation } & \multirow[b]{2}{*}{ Variance } \\
\hline & Valid & Missing & & & \\
\hline $\begin{array}{l}\text { Eu tenho sentimentos calorosos com } \\
\text { quase todos }\end{array}$ & 484 & 0 & 5,0000 & 1,59268 & 2,537 \\
\hline Sinto que possuo muita energia & 484 & 0 & 5,0000 & 1,21766 & 1,483 \\
\hline $\begin{array}{l}\text { Não tenho particularmente memórias } \\
\text { felizes do passado }\end{array}$ & 484 & 0 & 5,0000 & 1,78617 & 3,190 \\
\hline Eu sou muito feliz & 484 & 0 & 5,0000 & 1,13936 & 1,298 \\
\hline $\begin{array}{l}\text { Sinto que não estou, sobretudo, no } \\
\text { controle de minha vida }\end{array}$ & 484 & 0 & 4,0000 & 1,85720 & 3,449 \\
\hline $\begin{array}{l}\text { Eu sou intensamente interessado em } \\
\text { outras pessoas }\end{array}$ & 484 & 0 & 4,0000 & 1,81224 & 3,284 \\
\hline $\begin{array}{l}\text { Eu não me sinto particularmente } \\
\text { satisfeito com a maneira que sou }\end{array}$ & 484 & 0 & 5,0000 & 1,80388 & 3,254 \\
\hline $\begin{array}{l}\text { Estou muito satisfeito com tudo em } \\
\text { minha vida }\end{array}$ & 484 & 0 & 5,0000 & 1,55259 & 2,411 \\
\hline Sinto-me alegre e exaltado & 484 & 0 & 5,0000 & 1,45516 & 2,117 \\
\hline $\begin{array}{l}\text { Não tenho particularmente senso de } \\
\text { significado e propósito para minha } \\
\text { vida }\end{array}$ & 483 & 1 & 6,0000 & 3,13597 & 9,834 \\
\hline $\begin{array}{l}\text { Sempre tenho boas influencias nos } \\
\text { acontecimentos }\end{array}$ & 484 & 0 & 5,0000 & 1,37468 & 1,890 \\
\hline $\begin{array}{l}\text { Eu particularmente não sou otimista } \\
\text { sobre o futuro }\end{array}$ & 483 & 1 & 6,0000 & 1,69305 & 2,866 \\
\hline A vida é boa & 484 & 0 & 6,0000 & ,91796 & ,843 \\
\hline $\begin{array}{l}\text { Sempre contagio de alegria outras } \\
\text { pessoas }\end{array}$ & 484 & 0 & 5,0000 & 1,20793 & 1,459 \\
\hline $\begin{array}{l}\text { Sinto minha mente completamente } \\
\text { alerta }\end{array}$ & 484 & 0 & 5,0000 & 1,27648 & 1,629 \\
\hline $\begin{array}{l}\text { Eu sinto que a vida é muito } \\
\text { recompensada }\end{array}$ & 484 & 0 & 5,0000 & 1,39151 & 1,936 \\
\hline Eu raramente me sinto descansado & 484 & 0 & 3,0000 & 1,75674 & 3,086 \\
\hline $\begin{array}{l}\text { Existe uma distância entre o que eu } \\
\text { gostaria de fazer e o que faço }\end{array}$ & 484 & 0 & 3,0000 & 1,83092 & 3,352 \\
\hline Não acho fácil tomar decisões & 484 & 0 & 3,0000 & 1,87171 & 3,503 \\
\hline $\begin{array}{l}\text { Não me sinto particularmente } \\
\text { saudável }\end{array}$ & 484 & 0 & 6,0000 & 1,71061 & 2,926 \\
\hline $\begin{array}{l}\text { Eu acho a maioria das coisas } \\
\text { agradáveis }\end{array}$ & 484 & 0 & 5,0000 & 1,34268 & 1,803 \\
\hline $\begin{array}{l}\text { Eu não acho que o mundo que o } \\
\text { mundo é um bom lugar }\end{array}$ & 484 & 0 & 6,0000 & 1,77149 & 3,138 \\
\hline $\begin{array}{l}\text { Sempre me saio bem em tudo o que } \\
\text { quero }\end{array}$ & 484 & 0 & 5,0000 & 1,48480 & 2,205 \\
\hline Eu não me acho atraente & 484 & 0 & 5,0000 & 1,68417 & 2,836 \\
\hline Eu sorrio muito & 484 & 0 & 5,0000 & 1,29826 & 1,685 \\
\hline $\begin{array}{l}\text { Sinto-me capaz de conseguir } \\
\text { qualquer coisa }\end{array}$ & 484 & 0 & 5,0000 & 1,47282 & 2,169 \\
\hline Não me divirto com outras pessoas & 484 & 0 & 6,0000 & 1,55416 & 2,415 \\
\hline $\begin{array}{l}\text { Estou sempre comprometido e } \\
\text { envolvido }\end{array}$ & 484 & 0 & 5,0000 & 1,71556 & 2,943 \\
\hline
\end{tabular}


15- INSTRUMENTO DE PESQUISA 


\section{INSTRUÇÕES GERAIS}

A pesquisa que segue é composta por questionários que visam mensurar como você sente-se com relação a determinados fatores de bem-estar, além de conter algumas informações pessoais básicas. Nosso objetivo é estar sabendo como as pessoas se sentem e avaliam suas vidas em termos gerais. Sua participação é totalmente optativa. Os dados estão sendo coletados entre comerciantes e comerciários de Ribeirão Preto Região em seus locais de trabalho, a fim de atingir o público alvo da pesquisa. Todavia, não será solicitado em momento algum informações privativas ou sigilosas a respeito de sua empresa. Este material é de uso restrito para pesquisa em questão e por este termo assinado por ambas as partes fica assegurado o uso exclusivo das informações nesta pesquisa e a possibilidade de interrupção da participação em qualquer momento que você achar conveniente, além de estar concordando espontaneamente na participação da mesma. Você poderá preencher este questionário agora, que levará um tempo de cerca de 15 minutos, ou em qualquer horário que tenha disponibilidade e retornarei em 4 dias para coletá-lo de volta, preenchido ou não, conforme seu desejo de participação. Os resultados de forma coletiva serão publicados e divulgados. Estarei disponível a qualquer momento para esclarecimento de dúvidas que se faça necessário, considerando abaixo as formas de contato para isso. Cordialmente agradeço

Entrevistado

Assinatura

Endereço

Pesquisador:

Airton Rodrigues

Rua Rui Barbosa, 169 - Centro, Jardinópolis-SP. CEP 14.680-000 airton@pg.ffclrp.usp.br / 016.3663-4586

Orientador: Prof. Dr. José Aparecido da Silva 


\section{Dados Pessoais}

\begin{tabular}{|c|c|}
\hline Nome: (Iniciais) & \\
\hline Idade: & Sexo: ( )Masculino \\
\hline Raça/ etnia: ( )negro ( )pardo ( )branco ( )indio & \\
\hline $\begin{array}{l}\text { Estado Civil:( )casado ( )solteiro ( )divorciado, se d } \\
\begin{array}{ll}\text { ( )viúvo } & (\text { )outros }\end{array}\end{array}$ & ivorciado, quantas vezes ( ) \\
\hline Caso tenha filhos, quantos: ( )1 ( )2 ( )3 ( )ma & s que três \\
\hline $\begin{array}{l}\text { Grau de escolaridade: ( )primeiro grau incompleto } \\
\text { ( ) } \text { )segundo grau incompleto } \\
\text { ( ) ensino superior incompleto }\end{array}$ & $\begin{array}{l}\text { ( ) primeiro grau completo } \\
\text { ( ) segundo grau completo } \\
\text { ( ) ensino superior completo }\end{array}$ \\
\hline
\end{tabular}

\section{Dados econômicos, situacionais e de contexto social}

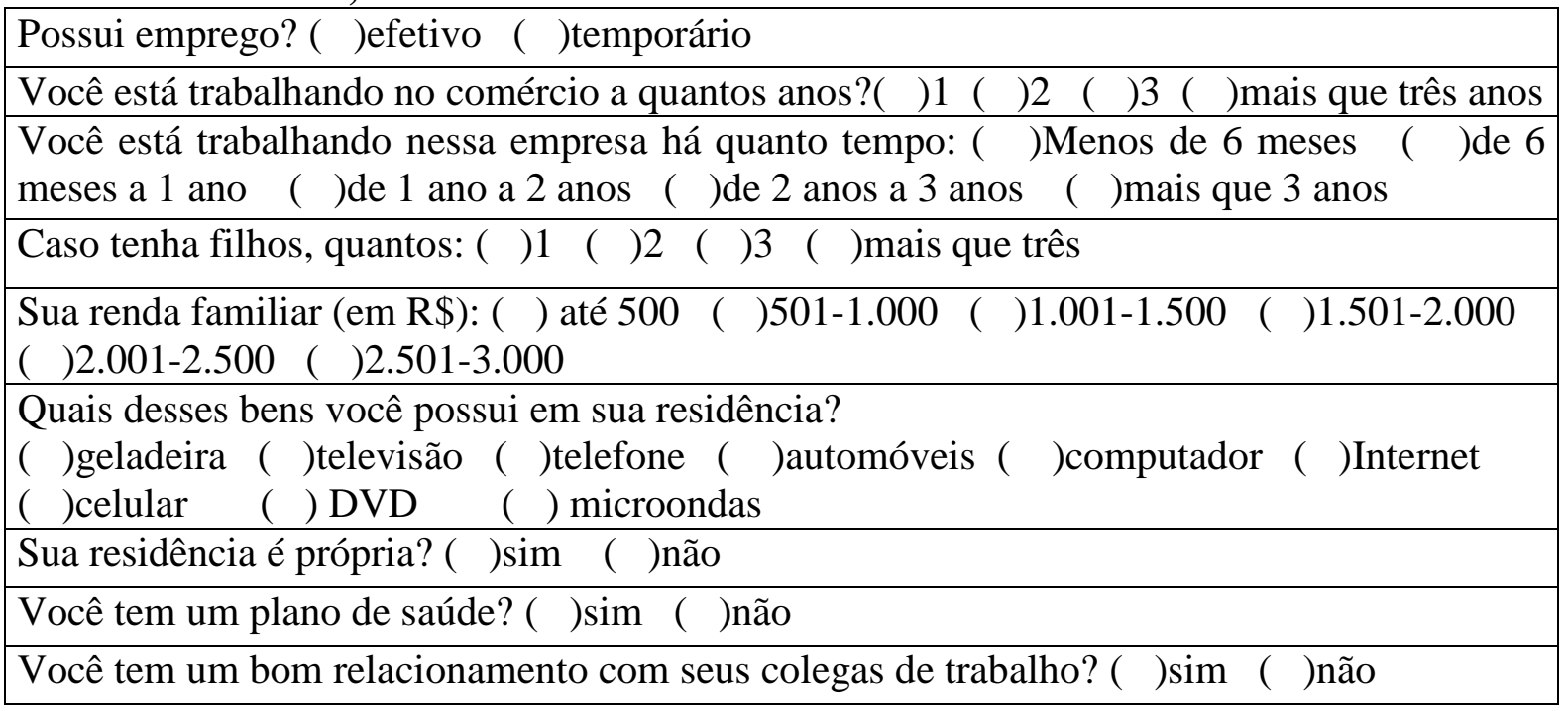

\section{Dados de sua saúde}

Você pratica alguma atividade esportiva? ( )sim ( )não

Entre os problemas de saúde, qual ou quais você apresenta?

( )hipertensão ( )diabetes ( )baixa acuidade ou perda de visão ( )baixa acuidade ou perda de audição ( ) doença terminal ( )sofrimento ou indicativo de distúrbio psicológico

Você apresenta alguma deficiência física? ( )sim （ )não

\section{Dados institucionais}

\begin{tabular}{|l|}
\hline Você pratica alguma religião? ( )sim ( ) não \\
\hline Qual a sua religião? ( )católico ( )evangélico ( )espírita ( )outros \\
\hline Você pratica alguma atividade sócio- política? ( )sim ( )não \\
\hline
\end{tabular}

Houve algum evento marcante nas ultimas duas semanas de vida? （ )sim （ )não 


\section{ESCALA GERAL DE FELICIDADE}

Para cada uma das seguintes afirmações e/ou perguntas, circule a categoria de resposta (de 1 a 7) que considera apropriada a você.

1.Em geral, me considero:

Uma pessoa não muito feliz $\left|\begin{array}{l|l|l|l|l|l|l|l} & 1 & 2 & 3 & 4 & 5 & 6 & \end{array}\right|$ Uma pessoa muito feliz

2.Comparando com a maioria dos meus amigos, eu me considero:

Uma pessoa não muito feliz $|1| 2|3| 4|5| 6|7|$ | 1 | 4 ma pessoa muito feliz

3. Algumas pessoas são geralmente muito felizes. Elas aproveitam a vida, aconteça o que acontecer, procurando obter o máximo. Em que grau essa descrição se aplica a você?

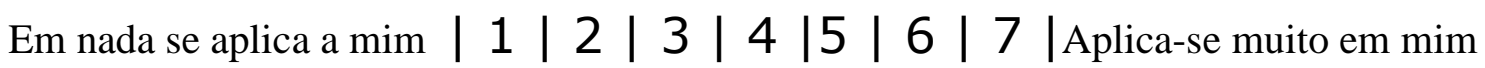

4. Algumas pessoas geralmente não são tão felizes. Embora não estejam deprimidas, nunca parece tão felizes quanto poderiam ser. Em que grau essa descrição se aplica a você?

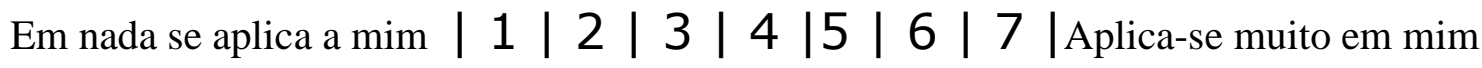




\section{QUESTIONÁRIO DE FELICIDADE}

\section{INSTRUÇÕES}

Abaixo estão afirmações sobre felicidade. Por favor, indique o quanto concorda ou discorda com cada , completando um numero de acordo com a escala baixo:

1- $\quad$ Discorda profundamente

2- $\quad$ Discorda moderadamente

3- $\quad$ Discorda minimamente

4- $\quad$ Concorda minimamente

5- $\quad$ Concorda moderadamente

6- Concorda profundamente

Você deve ler as afirmações cuidadosamente porque algumas são expressas positivamente e outras negativamente.Não se demore muito em uma questão específica: não há respostas certas ou erradas, nem pegadinhas.A primeira reposta que vir a sua mente provavelmente será a melhor resposta.Se achar alguma questão difícil, por favor, dê a resposta que é verdadeira para você em geral ou com frequiência, entende ser a verdadeira.

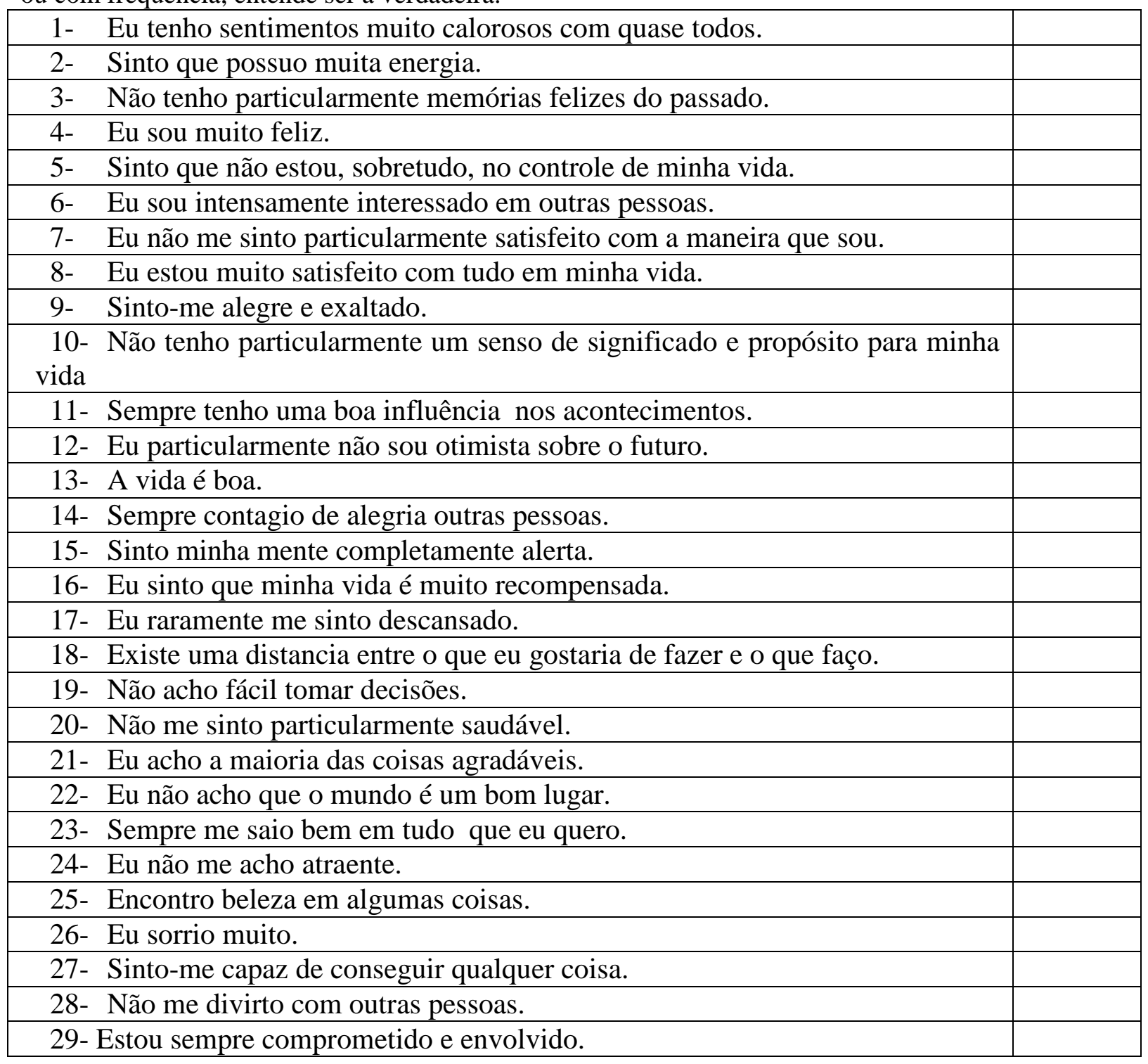


Para a pergunta apresentada abaixo, circule a categoria de resposta (de 1 a 7 ) que considera mais apropriada para você.

Considerando todas as coisas, o quão feliz você está nos dias atuais?

Não muito feliz $|1| 2|3| 4|5| 6|7|$ Muito feliz 